UNIVERSIDADE FEDERAL DO RIO GRANDE DO SUL INSTITUTO DE GEOCIÊNCIAS

PROGRAMA DE PÓS-GRADUAÇÃO EM GEOGRAFIA

TESE DE DOUTORADO

\title{
GEOGRAFIA(S) DA PESCA ARTESANAL BRASILEIRA
}

CRISTIANO QUARESMA DE PAULA

Dirce Maria Antunes Suertegaray (Orientadora) 
CIP - Catalogação na Publicação

Quaresma de Paula, Cristiano

Geografia(s) da Pesca Artesanal Brasileira/

Cristiano Quaresma de Paula. -- 2018.

451 f.

Orientadora: Dirce Maria Antunes Suergaray.

Tese (Doutorado) -- Universidade Federal do Rio Grande do Sul, Instituto de Geociências, Programa de Pós-Graduação em Geografia, Porto Alegre, BR-RS, 2018.

1. Pesca Artesanal. 2. Território Tradicional. 3. Território de Luta. 4. Geografia das Ausências. 5. Geografia das Emergências. I. Antunes Suergaray, Dirce Maria, orient. II. Título.

Elaborada pelo Sistema de Geraçāo Automática de Ficha Catalográfica da UFRGS com os dados fornecidos pelo(a) autor(a) 


\title{
CRISTIANO QUARESMA DE PAULA
}

\section{GEOGRAFIA(S) DA PESCA ARTESANAL BRASILEIRA}

\author{
Tese apresentada ao Programa de Pós- \\ graduação em Geografia como requisito \\ para obtenção do título de Doutor em \\ Geografia. \\ Área de Concentração: Ambiente, Ensino e \\ Território.
}

\section{Tese Aprovada com Louvor.}

Banca Examinadora:

Profa. Dra. Dirce Maria Antunes Suertegaray (Presidente)

Profa. Dra. Catia Antonia da Silva (FFP - UERJ)

Prof. Dr. Marcelo Argenta Câmara (Dep. Geografia UFRGS)

Profa. Dra. Cláudia Luísa Zeferino Pires (POSGea UFRGS)

Pescador Nilmar Conceição (MPP)

PORTO ALEGRE 
Ao meu pai, Suedi Simini de Paula, grande mestre do (a)mar. 


\section{Agradecimentos}

Nesses quatro anos do doutorado, muitas pessoas me deram suporte com palavras de incentivo, acolhimento e abraços. Desta forma, mesmo correndo o risco de não mencionar pessoas que foram importantes, expresso meu agradecimento a todos que de alguma forma se fizeram presentes nesse período.

Aos meus familiares que compreenderam a minha ausência, e sempre se fizeram presentes, mesmo que à distância. A minha mãe, Jacqueline Quaresma de Paula, minha maior incentivadora. Ao meu pai Suedi Simini de Paula que nunca precisou falar muito para expressar tudo o que sente. E a minha irmã Sophia Quaresma de Paula que é uma grande companheira.

Ao carinho e mimo da minha madrinha Luciana Monte Quaresma e, ao esforço por estarem presentes, das minhas primas Stefani Quaresma San Martins e Letícia Quaresma San Martins. Igualmente, agradeço a Doralina da Silva Ávila, a Francine da Silva Ávila e ao Wolney Ávila, que não são meus parentes de sangue, mas de coração, e sempre me incentivaram nos estudos.

Aos meus amigos e amigas que perto ou longe sempre estão comigo. Aos sempre presentes Andrei Rosca, Cibele Dias, Marília Lopes, Natália Viana, Raquel Duarte, Renan Juliano, Sibele Lemos, Tânia da Luz, Tiago Collares, Maristel San Matin e Carmen Castanheira. Aos Friends Bianca Cunha, Daniel Pinto, Giovana Valente, Juliana Saraçol, Kellen Avencurt, Marcelo Furtado, Maurício Legemann, Pedro Leivas e Rafaele Araújo. Também agradeço aos amigos que ganhei nesse período do doutorado e tornaram meus dias mais felizes: Fabiana Garcia, Alini Ferreira, Alessa Flores, André Flores, Daniela Huber, Katia Huber, Angela Hendler, Viviane Tavares, Rafael Cortes, Carol Kolinski e toda a galera do Caravana. E aos pequenos Vitória, Cadu, Pedro, Clarinha, Maria, Joana, Olivia e Isabelly.

À parceria dos amigos da UFRGS, em especial aos do Núcleo de Estudos Geografia \& Ambiente (NEGA): Cláudia Pires, Mateus Oliveira, Evelin Biondo, Cleder Fontana, Sinthia Batista, Maíra Suertegaray, Dilermando da Silveira, Eder Rodrigues, Karine Wenndy e Antonia Evangelista. Aos amigos e colegas do POSGEA Helena Bonetto, Lucimar Vieira, Aline Goulart, Perla Couto, Keli Ruas, Letícia Celise e Laura Rudzewicz.

Agradeço aos movimentos sociais de pescadores artesanais que possibilitaram essa pesquisa, em especial ao Movimento dos Pescadores e Pescadoras Artesanais (MPP), à Articulação Sudeste-Sul do MPP, ao Conselho Pastoral dos Pescadores - CPP, e ao Fórum Delta do Jacuí. Agradeço especialmente aos pescadores artesanais Cinelande (Cilanda) Borges 
in memorian, Nilmar Conceição, Viviane Machado, Isac Oliveira, Claudio Nunes, Manoel Santos, Paulo Denilto, Deraldo Oliveira, Noemi Brum e Latifeh Aziz. E aos companheiros de luta pela pesca artesanal Luís Ramos, Warna Frühauf, Cida Ramos, Jenifer Meirelles e Cristiane Santos.

Aos geógrafos que estão envolvidos na proposta de constituição da Rede de Geografias da Pesca e que estão presentes nessa pesquisa a partir de suas dissertações e teses e através dos questionários respondidos. Em especial, agradeço à Catia Antonia da Silva, Catherine Prost, Guiomar Germani, Christian Silva, Rodrigo Euzébio, Felipe Rainha, Kássia Rios, Taíse Alves, Cristina Gross e Suana Silva.

Também desejo expor minha gratidão ao Programa de Pós-Graduação em Geografia da UFRGS pelo suporte que foi dado a essa pesquisa. Em particular reconheço o trabalho e dedicação dos coordenadores Roberto Verdum e Cláudia Pires. Extendo o agradecimento à equipe da secretaria, em especial à Alynni Avila, que sempre busca nos atender da melhor forma. Através dos professores Roberto Verdum, Nelson Rego, Álvaro Hedrich e Cláudia Pires, agradeço a todo o corpo docente do POSGEA.

À Coordenação de Aperfeiçoamento de Pessoal de Nível Superior - CAPES pela bolsa de pesquisa de doutorado.

Por fim, gostaria de agradecer a minha orientadora professora Dirce Maria Antunes Suertegaray. Durante o doutorado tive oportunidade de trabalhar próximo dela, para além da tese, e acredito que nossa parceria resultou em bons frutos. Contudo, para mim, nunca serão esquecidos os momentos de diálogos e aconselhamentos sobre a Geografia e a vida. Sou orgulhoso de ter sido seu orientado, mas muito mais feliz por ter conquistado o seu respeito e amizade. 


\section{Prólogo}

Já na etapa final de redação da tese "Geografias da pesca artesanal brasileira" participei do seminário "Sentipensar con la tierra - Territorialidade e cosmovivência: língua, pensamento, política e decolonialidade na América/Abya Yala", ministrado pelo mestre José Ángel Quitero Weir. Após essa atividade, a avaliação proposta consistiu na construção de um texto "autoral" onde fosse possível expressar os sentimentos que estão presentes na nossa forma de pensar, logo, que integram a ciência que fazemos. De fato, aí há uma ruptura, pois o fazer ciência "tradicional/moderna" implica em separar o sujeito do objeto, com isso, apartar o sentir do pensar.

Essa ruptura se justifica quando se entende o lugar do sujeito. No caso de Quintero, o objeto está no lugar onde o sujeito se encontra, ou se encontrou em parte da sua vida. $\mathrm{O}$ afastamento do lugar do objeto modifica a visão do sujeito (pesquisador), o qual passa a se ver como de fora e se sentir pertencente a uma outra cultura. Contudo, nem sempre os membros dessa outra cultura o reconhecem como um dos seus, e assim o sujeito fica sem lugar. Chega então o momento de voltar ao seu lugar, a sua cultura, e assim reconhecer-se como sujeito/objeto, que entende porque sente.

Começo essa reflexão dia 22 de dezembro 2017 a partir de um lugar, da casa dos meus pais, onde fui passar o recesso de final de ano e vivi do meu nascimento aos 25 anos. A mãe me esperou com um burriquete ensopado e, assim que almocei com a família, fiquei um pouco no quintal de casa vendo a minha irmã brincar. Meu pai fazia a manutenção do seu caíco, do qual há pouco havia trocado o fundo. Preparava essa embarcação para a safra do camarão que começa em 1 de fevereiro, logo após a festa de Iemanjá. Me disse que a safra será melhor nesse ano, porque a água salgou cedo, e que os guris já tinham encontrado camarão na laguna. Nesse dia ele também me mostrou seu novo motor de poupa, encantado com a praticidade. Dizia que já cansava muito remando nos dias de vento na Laguna dos Patos (...)

Tenho trabalhado na construção de uma tese de doutorado sobre a pesca artesanal brasileira, a partir do diálogo estabelecido entre geógrafos e movimentos sociais de pescadores artesanais. Para dar sustentação à tese, construí bancos de dados, diversas análises de conteúdo, dezenas de mapas temáticos, etc. Há um empenho no sentido de situar a Geografia como campo científico que dá, ou pode dar, respostas à sociedade e de evidenciar que os pescadores artesanais apresentam elementos de compreensão do espaço geográfico que integram sociedade/natureza, ambiente/território. Não se tem o intuito de propor outra racionalidade 
científica - isso já está proposto por Leff, Morin, Boaventura Santos, entre muitos outros - mas de aproximar visões sobre o espaço, que em diálogo, podem dar respostas à complexidade do real.

Para sentipensar a tese talvez fosse necessário responder a pergunta "Mas por que o Cristiano busca isso?”. Contudo, vou adiar a resposta a essa pergunta e tentar sentipensar "Quem é o Cristiano?".

Difícil responder, mas vou começar pelo princípio. Sou filho de Jacqueline Quaresma de Paula e Suedi Simini de Paula, ambos pescadores. Meu pai aprendeu com o meu avô, que aprendeu com mestres anteriores. E minha mãe, ao casar-se com um pescador, assumiu diversas tarefas como cuidar de apetrechos, beneficiar peixe, camarão e siri - o que é muito comum entre as mulheres da minha comunidade.

Quando criança, ser pescador também era uma possibilidade para mim, uma das "brincadeiras" da infância era acompanhar meu pai nas pescarias noturnas de camarão, que ocorriam no verão. Minha tia Neli, costureira, fez para mim os trajes de pescador artesanal. Eu ficava sentado na poupa do barco observando os procedimentos da pescaria. Tudo fazia sentido. A posição das redes (horizontal e verticalmente), o número de redes e lampiões, a intensidade da luz, etc. Vez ou outra, algum pescador próximo gritava alguma coisa, dando alguma dica. Um desses pescadores que era vizinho de andaina (área de pesca adotada na região), era também nosso vizinho de quintal - o Tataco-. Quando ele sabia que eu havia ido "pescar", ia no barco conversar conosco. Outros vizinhos nossos de rua também eram vizinhos de mar (mesmos sendo uma Laguna, todos a chamavam de mar), entre eles o Mano e o Izair, que eram pais de minhas amigas. Após a pesca, meu pai desembarcava na prainha, que ficava próxima a uma das vias principais do bairro. Ali mesmo ele, como outros pescadores, costumava comercializar o pescado. Quando não era possível, comercializavam para “compradores” (eram proprietários de pequenas fabricas de pescado da cidade).

Também ajudava minha mãe e avó no beneficiamento do pescado no dia-a-dia. A principal atividade das mulheres e crianças na pesca, nesse período do ano, era o beneficiamento do siri. Minha avó materna quando ficou viúva, com ajuda da minha tia mais nova, ficou por cinco anos vivendo exclusivamente da renda do siri. A rotina sempre foi pesada, começando com a chegada do meu pai na praia. Após separar o camarão do siri, minha avó recolhia todo o material em caixas e carregava de carrinho-de-mão até sua casa. Em grandes panelas de água fervente o siri era cozido. Então, o casco e patas eram removidos e o siri era lavado e acondicionado. Geralmente a manhã inteira era reservada para esse pré-preparo, para que então, 
à tarde, a carne fosse retirada. Nesses momentos, as mulheres vizinhas costumavam se juntar para trabalhar e conversar. As crianças menores costumaram partir e tirar carne das garras do siri, que também era comercializada. As mulheres trabalhadoras do siri tinham total conhecimento sobre a biologia da espécie, sabiam sobre o sexo, estágio reprodutivo, estrutura óssea, etc. Conforme as crianças cresciam, iam também aprendendo isso para trabalhar na atividade.

Dependendo da pescaria vivia-se um ciclo de vida, que se renovava a cada dia. O início/fim era quando ao entardecer de cada dia de verão eu a minha mãe acompanhávamos meu pai, ajudando a carregar os apetrechos de pesca, até a prainha onde seu caíco ficava ancorado e ele partia. Sentia meu coração estufar com um misto de orgulho e medo, porque o mar sempre era algo a ser respeitado. Eu a minha mãe, às vezes, ficávamos na beira da praia até ver de longe meu pai ascendendo as luzes dos lampiões que serviam de atrativo para a entrada dos camarões nas redes. A volta para casa sempre era silenciosa. E nos dias de tempo ruim, ficávamos a noite em claro esperando amanhecer e ele chegar bem.

Retomei essas duas atividades que sempre foram fundamentais para a sobrevivência da minha família principalmente na infância e adolescência. Contudo, mais do que a atividade fonte de renda, sempre foram importantes na nossa sociabilidade. Por mais cansativas que fossem, sempre havia espaço para conversas, brincadeiras, aconselhamentos, etc. Contudo o contexto de vida e trabalho com poucas condições de salubridade também tornava essas atividades muito sofridas, se envelhecia cedo e adoecia bastante. Admito que trazer em mente essas memórias não é fácil, minha avó, em função do excesso de esforço e condições de trabalho no beneficiamento do siri, adquiriu uma doença pulmonar grave e veio a falecer aos 61 anos.

Com quatorze anos foi a última vez que fui para o mar com o meu pai. Acabava de terminar o ensino fundamental e começaria o ensino médio em uma outra escola. Essa é a idade que os rapazes que vão ser pescadores costumam assumir a atividade de forma mais efetiva, mesmo trabalhando junto com o pai ou outro mestre teria redes suas, e logo buscaria ter seu barco, na época um primo meu começou esse processo. A rotina de estudos e a influência do novo contexto social em que me inseria (ao contrário da escola de ensino fundamental que ficava no bairro a de ensino médio era no centro da cidade e com estudantes de classe média) me afastaram da pesca. Foi um período difícil, onde não conseguia me incluir nos grupos pela inserção de valores que não correspondiam ao meu meio social (competitividade entre alunos, padrão de consumo). Por outro lado, o interesse pelos estudos de uma forma mais pronunciada do que pela dinâmica da minha comunidade, foi aos poucos me afastando, e inclusive, 
modificando a forma como era visto pelos meus vizinhos e amigos. Consequentemente negava totalmente a possibilidade de ser pescador. Meus pais concordavam com isso, porque entendiam que ser pescador não era "futuro" para mim. Apesar de ser uma cidade onde a atividade pesqueira é importante, o pescador é um sujeito bastante marginalizado nos discursos da sociedade e as comunidades acabam interiorizando tais falas. $\mathrm{O}$ sentimento que tinha nesse período era de não ter chão, pois ao mesmo tempo que me afastava da vida em comunidade, não me sentia confortável no novo contexto social. Foi o sentimento de não pertencer a nenhum lugar.

No ensino médio, em reação ao meu desinteresse nas ciências exatas (onde estimulavam a competividade entre os alunos), descobri minha vocação para as ciências humanas e sociais, especialmente Geografia e Sociologia. Quando fiz dezenove anos fui aprovado no vestibular para o curso de Geografia na universidade federal. Aí começa a se constituir um sujeito mais próximo daquele que escreve a tese (embora esteja sempre em transformação). Logo que ingresso no curso, passo a ter contato com inúmeras pesquisas, não só da Geografia que tratam da pesca artesanal. Muitas me causavam repulsa por apresentarem os pescadores como predadores do ambiente. Contudo, um horizonte vai sendo aberto a partir do momento que vislumbro os pescadores sendo abordados no âmbito dos povos tradicionais. Então as problemáticas da pesca artesanal passam a ganhar meu interesse nos estudos da Geografia. Muitos conceitos apresentados faziam sentido na minha vivência, outros me incomodavam. Os métodos expostos me causavam interesse na medida em que dialogavam com o vivido.

Para me manter na universidade trabalhei em bolsas e estágios durante todo o curso. Fui estimulado por um professor, para atender a demanda de uma bolsa de trabalho que recebia, a escrever um resumo para apresentar na MPU - Mostra de Produção Universitária. Foi meu primeiro trabalho acadêmico onde abordei um conceito recém aprendido - Lugar. $\mathrm{O}$ trabalho foi chamado "A pesca artesanal na prainha do pôr-do-sol". Esse pequeno trabalho me ajudou a lembrar que a prainha do pôr-do-sol não tem só água e sol se pondo, ela tem meu pai remando em direção ao mar até que eu pudesse identificar só um ponto no horizonte. Então entendi que o lugar expressa sentimento, e que aquele era meu lugar no mundo. Assim, a Geografia inaugura um novo momento na minha vida, onde eu tenho a possibilidade de pensar sobre e a partir daquilo que eu sinto.

Ainda na graduação levava cada aprendizado para meu contexto de vida, buscando aquilo que poderia ser meu caminho de pesquisa. Transitei por diversas abordagens, até que lendo um texto entendi a importância da gestão dos recursos pelas comunidades. Essa relação 
entre sociedade e natureza se expressava na episteme Ambiente, ou Meio Ambiente. Compreender essa relação me ajudou a conceber a distinção entre pescadores artesanais e outros povos tradicionais da sociedade em geral. Mas no caso do ambiente de pesca o território também se evidenciava como uma episteme fundamental. No caso das andainas dos pescadores da minha comunidade havia um contexto de respeito ao uso. Raramente um pescador invadia a andaina do outro e, quando isso ocorria, havia mediação de outros membros da comunidade e, em casos mais graves, da própria justiça (as normas da pesca da região, com o tempo, passaram a incluir o registro de andaina). Assim, fui entendendo que na gestão dos recursos do ambiente o estabelecimento de territórios corresponde a projetos de desenvolvimento. Um dos resultados desse processo de aprendizado é meu trabalho de conclusão de curso "Territórios e Territorialidades na Pesca Artesanal do Estuário da Lagoa dos Patos: contribuições para iniciativas de ecodesenvolvimento". Nesse trabalho dei destaque a pesca do siri, a qual fazia tanto sentido no meio em que me constitui como pessoa.

Ainda sobre a graduação, cabe destacar a presença de uma professora que era especialista em pesca artesanal no âmbito acadêmico e diplomático. Ela se interessou pelo meu perfil, especialmente por vir de uma comunidade de pescadores, e passou a me inserir em projetos de pesquisa relacionados a pesca artesanal. Entre eles, fizemos um censo da pesca artesanal no Estuário da Laguna dos Patos. Esse estudo entrevistou mais de quatro mil pescadores artesanais. Eu coordenei os trabalhos de campo, pela facilidade de acesso que tinha nas comunidades. Não me causava estranheza chegar em uma comunidade diferente e conversar com uma família de pescadores. Me era muito familiar aquele contexto, me sentia à vontade e me comunicava bem. Sentia como se estive falando com pessoas da minha própria família. Sempre que percebia dificuldade dos pescadores no acesso às políticas públicas para a pesca artesanal, dedicava um tempo para explicar o caminho dessa conquista. Me sentia também responsável e me dediquei a esse trabalho do censo porque compreendia que seria um instrumento para os pescadores artesanais da região lutarem por direitos.

Nas cerca de 700 horas de entrevista que realizei, aprendi muito. Aprendi sobre relaçõos sociais que se estabelecem e dão sustentação ao território. Apreendi também sobre o Saber que envolve usar o ambiente sem o seu colapso, mesmo que as necessidades da comunidade ainda não tenham sido supridas. Aprendi sobre artes, locais e tempos de pesca. Sentia que os pescadores também confiavam em mim para transmitir aquelas informações e que um novo vinculo era constituído. 
Concorri a um edital, ainda na graduação, e passei um semestre fora do país, fazendo intercâmbio em Portugal. Foi a primeira vez que residi fora da minha comunidade. Lá descobri muitas coisas, me sentia feliz de ver e viver experiências que até então faziam parte do meu imaginário construído através de livros e televisão. Conheci lugares lindos, pessoas incríveis, vivi intensamente esse momento que de alguma forma me transformou. Contudo, ao mesmo tempo que sentia que alargava minha visão de mundo, se afirmava meu sentimento de pertença ao meu lugar. Quando passavam os momentos de agito e euforia, eu me transportava em pensamento para a prainha do pôr-do-sol, sentia falta dos sons e cheiros da casa dos meus pais. Os diálogos na Europa sempre eram insuficientes frente a falta de presença dos meus pais e amigos, embora muitas vezes essa presença fosse silenciosa. Do outro lado do Atlântico, eu tive a certeza de qual era o meu lugar no mundo. Era o lugar que orientava a forma de me relacionar em sociedade, de me relacionar com a natureza, a forma de sentir e pensar. Contudo, a consciência daquela falta me ajudava a entender quem eu sou, de onde vim e o que quero para a vida. Dali em diante, onde quer que estivesse, saberia meu lugar no mundo.

Ao longo da graduação me chamava atenção a apatia de alguns colegas quanto aos povos tradicionais. Aquela importância enorme que me ocupava parecia para muitos ser descabida, pois estavam mais interessados em técnicas de geoprocessamento, topografia, ou qualquer outra que lhes daria maior retorno financeiro depois de formados. Também no curso, salvo algumas exceções, os professores não costumavam sensibilizar os alunos para essas problemática. Vislumbrando meu futuro profissional, sentia que seria mais útil sendo professor, para que algumas das ideias e princípios que me orientavam, fossem transmitidos a outros. Sentia o compromisso de socializar tudo aquilo que aprendi nos livros e na vivência em comunidade.

Decidi então cursar mestrado em uma outra instituição. Foi nesse momento que mudei de cidade e fiquei cerca de $380 \mathrm{~km}$ apartado da convivência com a minha família e comunidade. Apesar da distância, não me sentia infeliz, pois sabia que tinha um lugar para voltar, o que sempre fiz com frequência. No mestrado, tive acesso a novas leituras de teorias e métodos que ampliavam as possibilidades de respostas para aquelas problemáticas relacionadas à pesca artesanal, que sempre me acompanhavam. Nesse período, comecei a trabalhar com um coletivo de pescadores da região, um fórum de pesca. A partir do diálogo continuo com os pescadores, visitando diversas comunidades, ia se confirmando a relação indissociável de ambiente e território na pesca artesanal. Entendia que os pescadores teriam condições de fazer o manejo dos recursos presentes no território, mas eram impedidos por impactos ambientais provocados por outras atividades econômicas que tinham o domínio do capital e por isso a prerrogativa de 
uso do território. Nesse contexto se mantinha a minha familiaridade com as comunidades de pescadores, mas o principal espaço de pertencimento era o fórum, era a discussão coletiva e política. A partir das minhas experiências dialogava com os pescadores em uma troca de saberes que gerava ressignificações tanto naquilo que eu estudava, quanto naquilo que era vivido e compartilhado entre todos. Nesse momento eu não me via como comunitário, não pertencia ao contexto social vivido por aquelas comunidades, mas me via com geógrafo em diálogo. Como geógrafo não abandonava toda a minha bagagem de vivências em comunidade, mas colocava a serviço daquele grupo aquilo que aprendi no meio acadêmico. Na dissertação de mestrado estudei “Gestão Compartilhada dos Territórios da Pesca Artesanal: Fórum Delta do Jacuí". Esse trabalho é um instrumento de luta dos pescadores da região.

Pensando no doutorado como continuidade da minha formação, prestei seleção no mesmo programa de pós-graduação onde cursei o mestrado. $\mathrm{Na}$ primeira tentativa fui reprovado. Isso para mim foi uma ruptura em um processo que parecia fluir, então me senti mal, desestimulado, e decidi voltar para casa para passar um período. Antes de retornar para a casa dos meus pais, fui participar da reunião do fórum de pesca, pois eles também tinham expectativa que eu fosse aprovado para que continuasse próximo auxiliando. Com um sentimento de tristeza expliquei para um dos pescadores o meu insucesso. Daquele dia em diante ele passou a me chamar de doutor, dizia que para eles -os pescadores - eu era o doutor que os entendia. Mais uma vez o sentir e o pensar estavam associados, eu sempre tentava entender porque me sentia parte.

O período que passei na casa dos meus pais (um semestre) foi de me reencontrar, como filho, irmão, vizinho, amigo. Passava muito tempo com a minha família, compartilhava tarefas, inclusive relacionadas à pesca. Ia com o meu pai na praia ver o caíco ancorado, ajuda a mãe no siri, estudava para a prova do doutorado. Criei o hábito de correr na prainha todos os dias no pôr-do-sol, queria aproveitar ao máximo aquilo que me fazia bem. Com o tempo, aquele retorno que incialmente havia me provocado tristeza teve um sentido de reconstrução. Eu me sentia renovado e disposto para começar algo novo. Lembrava das palavras da minha orientadora quando nos despedimos "Cristiano, vamos dar tempo ao tempo". E eu me dei esse tempo para sentir antes de pensar.

Na seleção seguinte fui aprovado e comecei um novo ciclo da minha formação - que deve se encerrar nessa tese. Como o contexto de discussão coletiva ganhou destaque no mestrado, busquei ampliar a escala para nacional para tratar da pesca artesanal brasileira. Para isso, utilizei o melhor de mim, que é capacidade diálogo e união que aprendi a partir da vivência 
comunitária. Esse diálogo se dá em duas frentes, uma é constituída pelos geógrafos, que, como eu, estão empenhados em buscar respostas à pesca artesanal. Passamos a agregar esses pesquisadores em rede, na Rede de Geografias da Pesca. Esse coletivo vem se constituindo e permite pensar a pesca artesanal brasileira em seu todo e nas suas particularidades a partir dos diálogos de saberes entre geógrafos e pescadores artesanais de diversas regiões brasileiras.

A segunda frente foi o diálogo com os movimentos sociais de pescadores artesanais. Em especial, pretendia ampliar o diálogo com o MPP - Movimento dos Pescadores e Pescadoras Artesanais - que desde 2012 deu início a uma campanha para a construção de uma lei de iniciativa popular que regularize os territórios de comunidades tradicionais de pescadores artesanais. Mas o diálogo inicialmente não foi possível. Escrevi diversas vezes, me dispondo a ajudar, mas não obtinha resposta. Falava com pescadores que participavam do movimento, de outros Estados, e me diziam que o MPP não costumava se abrir para pesquisadores que não conheciam. Como a coordenação do movimento estava no Nordeste e eu no Sul, realmente não tinham referências que pudessem esclarecer sobre as minhas intencionalidades. No âmbito da pesca, foi a primeira vez que me vi como o outro, pois até então entre os pescadores sempre tive acesso livre. Certamente, esse é um mecanismo de defesa dos movimentos sociais, então resolvi respeitar essa dinâmica e dar seguimento a tese sem o envolvimento do MPP.

Para a minha surpresa em 2016, logo após apresentar meu projeto de qualificação de doutorado, recebo o convite para participar da II Assembleia Nacional do MPP, na praia do Batoque - CE. Priorizei essa atividade como trabalho de campo de doutorado e fui participar. Foi uma semana inserido na vida do movimento, compartilhando espaços de discussão, recreação, alojamento, alimentação, etc. Me senti acolhido pelos pescadores de diversos estados brasileiros, compreendi as principais bandeiras de luta, prioridades, e o caminho que persistiam. Participando daquelas discussões, me sentia corresponsável. Nas lutas do movimento, o território tinha destaque e a relação com o ambiente aparecia com vinculo que justificava a permanência do coletivo no território tradicional. Além disso, o território era mar, praia, mangue e espaço de moradia e vivência das comunidades. Apesar de minha comunidade hoje estar em uma área urbana esse contínuo sempre existiu, então tudo aquilo fazia sentido e me provocava a pensar no âmbito da Geografia.

A partir dessa reunião fui convidado a participar e a construir outras atividades do MPP, em especial na articulação Sudeste-Sul, da qual me tornei apoiador. Esse contato com o movimento social influenciou de forma significativa a tese, ampliando a sua complexidade. $\mathrm{O}$ compromisso não é exclusivo com a área da Geografia, mas também de corresponder às 
demandas do movimento social. Assim, o caminho tem sido abordar Brasil, mas trazendo experiências que rementem ao lugar de vida e luta, onde as comunidades resistem ao avanço de outras atividades econômicas (modernas) sobre o seu território tradicional. Logo, o novo contexto de pesquisa é dado no âmbito de uma luta comum dos pescadores artesanais brasileiros, o direito de permanecer no território tradicional. Essa pertença que deve ser transformada em direito é sentida por todos, também por mim. Mas o pensar nessa garantia de território, pode integrar contribuições da Geografia. Essa Geografia não é neutra, corresponde também aos sentimentos do pesquisador que é sujeito/objeto. Contudo, no âmbito da tese de doutorado essa postura do pesquisador também encontra espaço em teorias e métodos.

Do ponto de vista do método, o caminho adotado é de uma abordagem que distingue, mas não separa. $\mathrm{O}$ pesquisador tem uma trajetória que lhe distingue dos demais membros da sua comunidade de origem, mas não o aparta da história de vida comunitária nem das lutas dos pescadores artesanais brasileiros. Isso encontra alento no âmbito do pensamento complexo, onde a dialógica se coloca como princípio para a compreensão do real. Assim, ganha espaço na pesquisa o Diálogo de Saberes, que implica nos diálogos dos diversos conhecimentos que se constituem em sentipensar. Isso implica em reconhecer os pescadores artesanais também como produtores de conhecimento válido e eficaz para a gestão do ambiente e do território.

Agradeço ao mestre José Ángel Quintero Wier por essa provocação. Admito que sentipensar traz para a consciência recortes da memória que não são possíveis de serem escritos nessas poucas páginas, mas o exercício traz um mar de emoções que são muito bem-vindas nesse momento duro que é a escrita da tese. Obrigado por nos provocar a sentipensar, obrigado por inspirar.

Cristiano Quaresma de Paula. 


\section{Resumo}

A tese busca compreender a expressão da pesca artesanal na Geografia brasileira, em que medida essas pesquisas geram significações no pensamento geográfico e quais as possibilidades de corresponderem às problemáticas apresentadas pelas comunidades e movimentos sociais de pescadores. Para isso, foram tomados aportes teóricos que expõem o movimento de renovação da Geografia e a expansão da pós-graduação; compreensões sobre a ecogênese territorial, territórios e territorialidades; crítica ao moderno, modernização e modernidade; e propostas de diálogos de saberes por meio da tradução intercultural e visibilidade dos Novos Movimentos Sociais. No campo metodológico, segue-se a proposta do pensamento complexo, por meio dos princípios da dialógica, recursivo organizacional, e hologramático. Em relação às inúmeras técnicas de pesquisa adotadas, destaca-se as análises de conteúdo e representações cartográficas. Foi possível mapear as áreas de pesquisa, bem como as instituições em que as mesmas foram realizadas e as que os pesquisadores estão vinculados. Observou-se a expansão de tais pesquisas a partir de 2005, em um movimento que acompanha a Política Nacional de Pós-Graduação. Isso permitiu a realização de pesquisas em diversas regiões, bem como em instituições que estão situadas fora das capitais, dando visibilidade a sujeitos (pesquisadores e pescadores) e problemáticas que até então eram marginalizados na pesquisa geográfica. A análise das abordagens teóricas, metodológicas e problemáticas, permitiram compreender que os geógrafos abordam prioritariamente a resistências das comunidades frente ao avanço de outras atividades econômicas. Para isso, associam os conceitos de ambiente e território, cuja relação pode ser compreendida em três perspectivas: Impactos Ambientais, Disputas no Território e Conflitos por Território. Partindo dessas propostas de análise da Geografia, abriuse diálogo com os movimentos sociais, especialmente com as denúncias apresentadas pelo Movimento dos Pescadores e Pescadoras Artesanais (MPP). Nessa análise, observou-se que o movimento social denuncia a expressão das faces da modernização sobre os territórios tradicionais que evidenciam: Degradação, Sobre-exploração e Restrição ao Acesso, e Expropriação da Terra. Desta forma, a pesquisa permite compreender as Geografias da Pesca Artesanal Brasileira, suas tendências de expansão e diálogo intraregional, assim como lacunas devido ao desconhecimento sobre tais pesquisas. Acredita-se que a constituição de uma rede de pesquisadores favoreceria tais estudos. A pesquisa também permitiu discutir os conceitos território e territorialidade, no contexto analisado, e sob essa perspectiva ressignificar as noções de pesca artesanal, pescadores artesanais, saberes e comunidades tradicionais. Assim como 
discutir a gestão comunitária e compartilhada evidenciando instrumentos como Acordos de Pesca, Comitês Permanentes de Gestão (CPG), Reservas Extrativistas (RESEX), Termos de Autorização de Uso Sustentável (TAUS), e o projeto de Lei de Iniciativa Popular pelo Território Pesqueiro. Desta forma, a tese discute através das Geografias da Pesca, o pensamento geográfico crítico brasileiro no século XXI, que busca superar invisibilidade e promover Novos Movimentos Sociais, com a discussão das Geografias da Ausências e Geografias das Emergências, no âmbito da construção de outra Racionalidade Ambiental e na constituição de Epistemologias do Sul.

Palavras-Chave: Pesca Artesanal. Território Tradicional. Território de Luta. Geografia das Ausências. Geografia das Emergências. 


\section{Resumen}

La tesis busca comprender la expresión de la pesca artesanal en la Geografía brasileña, en qué medida esas investigaciones generan significaciones en el pensamiento geográfico y cuáles son las posibilidades de corresponder a las problemáticas presentadas por las comunidades y movimientos sociales de los pescadores. Para ello, se tomaron aportes teóricos que exponen el movimiento de renovación de la geografía y la expansión del postgrado; comprensiones sobre la ecogénesis territorial, territorios y territorialidades; crítica al moderno, modernización y modernidad; y propuestas de diálogos de saber por medio de la traducción intercultural y la visibilidad de los Nuevos Movimientos Sociales. En el campo metodológico se sigue la propuesta del pensamiento complejo, por medio de los principios de la dialógica, recursivo organizacional, y hologramático. En relación a las innumerables técnicas de investigación adoptadas se destaca el análisis de contenido y representaciones cartográficas. Fue posible mapear las áreas de investigación, así como las instituciones en que las mismas fueron realizadas y las que los investigadores están vinculados. Se observó la expansión de tales investigaciones a partir de 2005, en un movimiento que acompaña la Política Nacional de Postgrado. Esto permitió la realización de investigaciones en diversas regiones, así como instituciones que están situadas fuera de las capitales, dando visibilidad a sujetos (investigadores y pescadores) y problemáticas que hasta entonces eran marginados en la investigación geográfica. El análisis de los enfoques teóricos, metodológicos y problemáticas, permitieron comprender que los geógrafos abordan con prioridad las resistencias de las comunidades frente al avance de otras actividades económicas. Para ello, asocian los conceptos de ambiente y territorio, cuya relación puede ser comprendida en tres perspectivas: Impactos Ambientales, Disputas en el Territorio y Conflictos por Territorio. A partir de esas propuestas de análisis de la Geografía, se abrió diálogo con los movimientos sociales, especialmente con las denuncias presentadas por el Movimiento de los Pescadores y Pescadoras Artesanales (MPP). En ese análisis se observó que el movimiento social denuncia la expresión de las caras de la modernización sobre los territorios tradicionales, que evidencian: Degradación, Sobreexplotación y Restricción al acceso, y Expropiación de la Tierra. De esta forma la investigación permite comprender las Geografías de la Pesca Artesanal Brasileña, sus tendencias de expansión y diálogo intraregional, así como lagunas debido al desconocimiento sobre tales investigaciones. Se cree que la constitución de una red de investigadores favorecería tales estudios. La investigación también permitió discutir los conceptos territorio y 
territorialidad, en el contexto analizado, y bajo esa perspectiva resignificar las nociones de pesca artesanal, pescadores artesanales, saberes y comunidades tradicionales. Así como discutir la gestión comunitaria y compartida evidenciando instrumentos como Acuerdos de Pesca, Comités Permanentes de Gestión (CPG), Reservas Extractivas (RESEX), Términos de Autorización de Uso Sostenible (TAUS), y el proyecto de Ley de Iniciativa Popular por el Territorio Pesquero. De este modo la tesis discute a través de las Geografías de la Pesca, el pensamiento geográfico crítico brasileño en el siglo XXI, que busca superar invisibilidad y promover Nuevos Movimientos Sociales, con la discusión de las Geografías de las Ausencias y Geografías de las Emergencias, en el ámbito de la construcción de otra Racionalidad Ambiental y la constitución de Epistemologías del Sur.

Palabras-Clave: Pesca Artesanal. Territorio Tradicional. Territorio de Lucha. Geografía de las Ausencias. Geografía de las Emergencias. 


\section{Sumário}

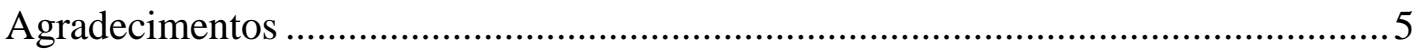

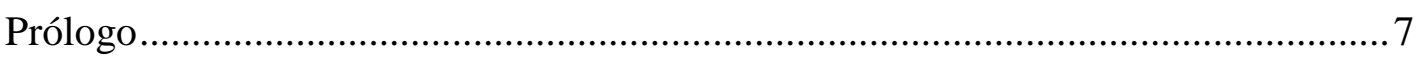

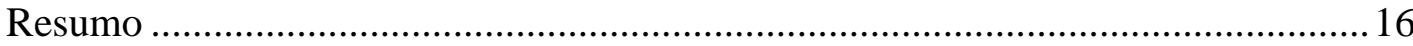

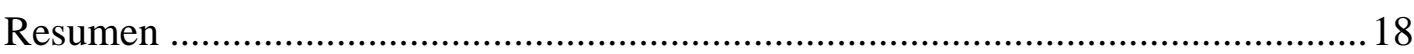

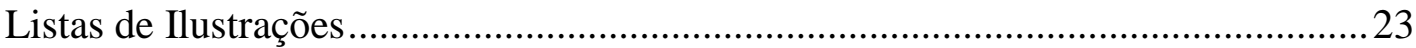

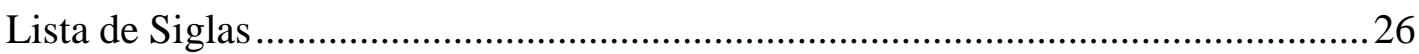

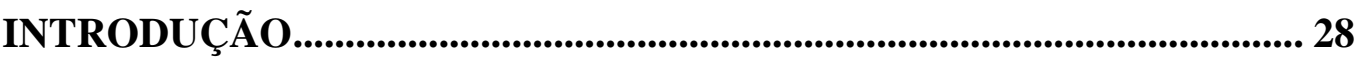

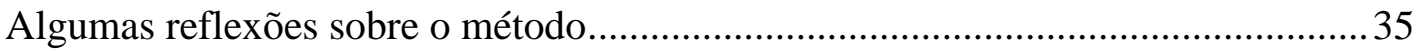

1. A EXPRESSÃO DA PESCA ARTESANAL NA GEOGRAFIA BRASILEIRA

1.1 Pressupostos Teóricos: Renovação da Geografia e Expansão da PósGraduação em Geografia no Brasil ...........................................................................40

1.2 Caminho Metodológico .........................................................................................................50

1.3 Instituições onde Foram Realizadas as Pesquisas...........................................55

1.3.1 Motivação para pesquisar a pesca artesanal .............................................63

1.4 Pesquisadores e instituições que abordam a pesca artesanal ........................69

1.4.1 A pesquisa sobre pesca artesanal na Geografia brasileira .........................98

1.5 Análise das Pesquisas considerando as Áreas de Estudo ............................103

1.5.1 Principais abordagens conceituais ..................................................... 109

1.5.2 Principais abordagens metodológicas ................................................. 125

1.5.3 Instituições/entidades de pescadores artesanais..................................... 128

1.5.4 Principais problemáticas de pesquisa ................................................. 130

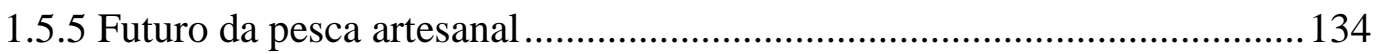

2. IMPACTOS AMBIENTAIS, DISPUTAS NO TERRITÓRIO E CONFLITOS POR TERRITÓRIO NA PESCA ARTESANAL BRASILEIRA ............................ 141

2.1 Pressupostos Teóricos: Território e Territorialidade .................................143

2.2 Caminho metodológico ...........................................................................................161 
2.3 Impactos Ambientais, Disputas no Território e Conflitos por Território.163

2.4 Impactos Ambientais

2.5 Disputas no Território

2.6 Conflitos por Território 202

3. AS TRÊS FACES DA MODERNIZAÇÃO NA PESCA ARTESANAL BRASILEIRA- UM DIÁLOGO COM O MOVIMENTO SOCIAL 230

3.1 Pressupostos Teóricos: Moderno, Modernização e Modernidade .232

3.2 Caminho Metodológico ........................................................................248

3.3 As Três Faces da Modernização ..............................................................256

3.4 Primeira Face da Modernização: a degradação ........................................258

3.5 Segunda Face da Modernização: Sobre-exploração e restrição do acesso 271

3.6 Terceira Face da Modernização: a expropriação da terra ...........................291

3.7 O Estado como Promotor da Modernização ...............................................305

3.8 Modernização e Pesca artesanal .............................................................315

4. GEOGRAFIAS DA PESCA ARTESANAL BRASILEIRA .................... 318

4.1 Pressupostos Teóricos: Diálogos de Saberes e Movimentos Sociais.............320

4.2 Caminho Metodológico .......................................................................332

4.3 Da pesquisa do Geógrafo à Rede de Geógrafos: desafios para a construção de Geografias da Pesca................................................................................................................335

4.3.1 Limites e possibilidades para a Geografia, no tempo presente ...................336

4.3.2 Tendências de diálogos entre teorias e métodos........................................341

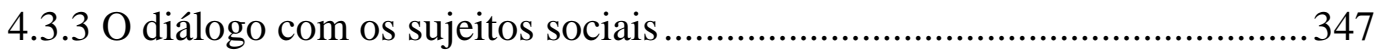

4.3.4 Possibilidades de diálogos na Geografia e com as Ciências Humanas .....349

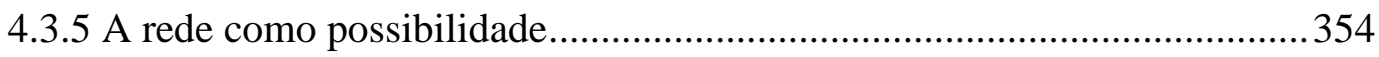

4.4 Da Territorialidade Tradicional ao Território de Luta das Comunidades Tradicionais de Pescadores Artesanais.............................................................................359

4.4.1 Territórios e Territorialidades na Pesca Artesanal....................................360

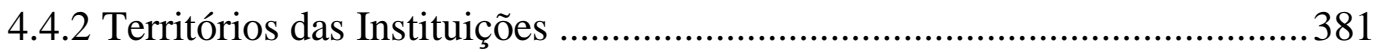

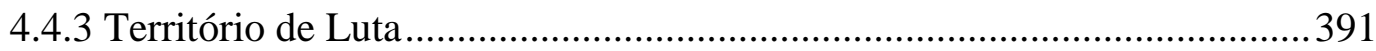


4.5 Das Geografias das Ausências, às Geografias das Emergências da Pesca Artesanal Brasileira.....................................................................................................405

4.5.1 A expressão do/no Território das Ausências e Emergências ......................406

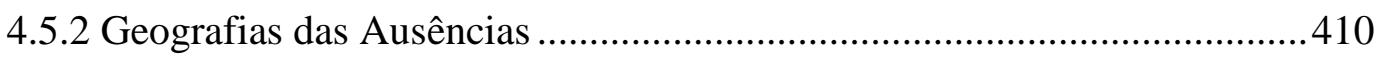

4.5.3 Geografias das Emergências ............................................................ 417

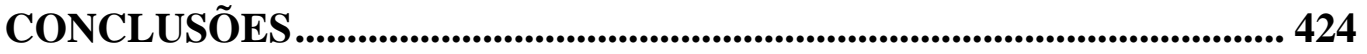

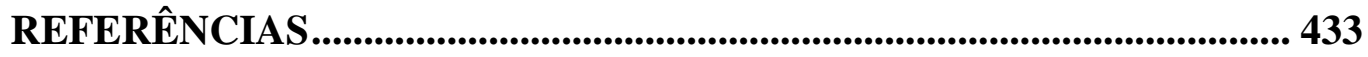

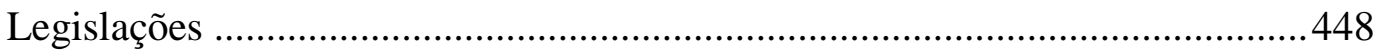




\section{Listas de Ilustrações}

\section{Figuras}

Figura 1: Diagrama de Organização do Banco de Dados do Questionário, questões objetivas.... 51

Figura 2: Diagrama de organização do Banco de Dados do Questionário, questões abertas........ 52

Figura 3: Diagrama da organização do Banco de Dados da Análise de Dissertações e Teses...... 53

Figura 4: Mapa de Densidade de Programas de Pós-Graduação onde Foram Realizadas as

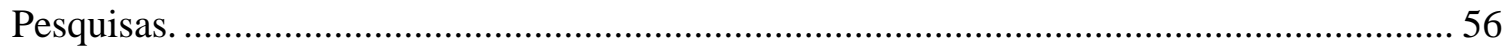

Figura 5: Mapa da Periodização das Pesquisas por Instituição de Ensino Superior. ...................... 58

Figura 6: Mapa da Periodização das Pesquisas por Unidade da Federação................................... 59

Figura 7: Nuvem de Palavras, Linhas de Pesquisa dos PPGs (Geografia) da região Norte.......... 60

Figura 8: Nuvem de Palavras, Linhas de Pesquisa dos PPGs (Geografia) da região Nordeste .... 61

Figura 9: Nuvem de Palavras, Linhas de Pesquisa dos PPGs (Geografia) da região Centro-Oeste

Figura 10: Nuvem de Palavras, Linhas de Pesquisa dos PPGs (Geografia) da região Sudeste .... 62

Figura 11: Nuvem de Palavras, Linhas de Pesquisa dos PPGs (Geografia) da região Sul............ 62

Figura 12: Nuvem de Palavras "Motivação para pesquisar a pesca artesanal na Geografia" ....... 63

Figura 13: Mapa de Questionários Respondidos, por Instituição............................................... 70

Figura 14: Mapa de Questionários Respondidos por Unidade da Federação............................... 71

Figura 15: Mapa de Densidade de Questionários Respondidos por Instituição ............................ 73

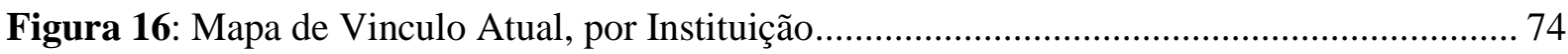

Figura 17: Mapa de Vinculo Atual, por Unidade da Federação................................................. 75

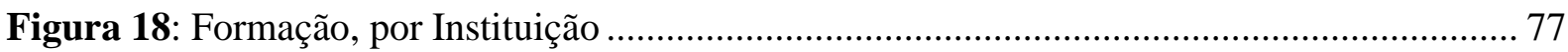

Figura 19: Formação, por Unidade da Federação ...................................................................... 78

Figura 20: Participação em Grupo de Pesquisa, por Instituição................................................... 80

Figura 21: Participação em Grupo de Pesquisa, por Unidade da Federação................................... 81

Figura 22: Mapa de Participação em Projeto de Pesquisa, por Instituição ..................................... 83

Figura 23: Mapa de Participação em Projeto de Pesquisa, por Unidade da Federação................. 84

Figura 24: Mapa de Projetos de Extensão por Instituição ............................................................ 87

Figura 25: Mapa de Projetos de Extensão por Unidade da Federação ........................................... 88

Figura 26: Mapa de Professores Universitário,s por Instituição ................................................. 90

Figura 27: Mapa de Professores Universitários, por Unidade da Federação ................................ 91

Figura 28: Mapa de Atuação como Professor Universitário, por Instituição ................................ 93

Figura 29: Mapa de Atuação como Professor Universitário, por Unidade da Federação ............. 94 
Figura 30: Mapa de Atividades Desenvolvidas no Magistério Superior, por Instituição 96

Figura 31: Mapa de Atividades Desenvolvidas no Magistério Superior, por Unidade da Federação

Figura 32: Nuvem de Palavras "Pesquisas sobre a pesca artesanal na Geografia brasileira" 99

Figura 33: Mapa de Trabalhos Analisados, por Unidade da Federação 104

Figura 34: Mapa de Densidade de Pesquisas Analisadas. 105

Figura 35: Mapa de Trabalhos Analisados (Dissertações e Teses), por Unidade da Federação. 106

Figura 36: Mapa de Densidade de Trabalhos (Dissertações de Mestrado). 107

Figura 37: Mapa de Densidade de Trabalhos (Teses de Doutorado) 108

Figura 38: Mapa de Principais Abordagens Conceituais, por Unidade da Federação. 110

Figura 39: Mapa de Densidade de Trabalhos que Abordam o Conceito de Território 112

Figura 40: Mapa de Densidade de Trabalhos que Abordam o Conceito de Espaço 115

Figura 41: Mapa de Densidade de Trabalhos que Abordam o Conceito de Ambiente 119

Figura 42: Mapa de Métodos Utilizados por Unidade da Federação 126

Figura 43: Entidades de Pescadores que Participaram das Pesquisas, por Unidade da Federação

Figura 44: Principais Problemáticas Estudadas, por Unidade da Federação 131

Figura 45: Nuvem de Palavras "Futuro da Pesca Artesanal" 135

Figura 46: Diagrama de Análise das Dissertações e Teses 162

Figura 47: Mapa de Impactos Ambientais, por Região 166

Figura 48: Mapa de Atividades Causadoras de Impactos Ambientais, por Região 167

Figura 49: Mapa de Densidade de Impactos 175

Figura 50: Mapa de Disputas no Território, por Região 178

Figura 51: Mapa de Atividades que Disputam Territórios, por Região 179

Figura 52: Mapa de Densidade de Disputas no Território 200

Figura 53: Mapa de Conflitos por Território, por Região 204

Figura 54: Mapa de Atividades entram em Conflitos por Território, por Região 205

Figura 55: Mapa de Densidade de Conflitos por Território 226

Figura 56: Nuvem de Palavras - Denúncias do Blog Pelo Território Pesqueiro 249

Figura 57: Diagrama de Análise das Denúncias 250

Figura 58: Nuvem de Palavras - Relatório "Conflitos Socioambientais e Violações de Direitos Humanos em Comunidades Tradicionais Pesqueiras no Brasil” 251

Figura 59: Diagrama de Análise das Dissertações e Teses 251

Figura 60: Diagrama de Análise de Correlação entre as Dissertações e Teses e as Denúncias do Blog Pelo Território Pesqueiro. 252 
Figura 61: Nuvem de Palavras - Rede Social do Movimento dos Pescadores e Pescadoras Artesanais

Figura 62: Mapa da Primeira Face da Modernização: degradação dos ecossistemas 259

Figura 63: Mapa da Segunda Face da Modernização: sobre-exploração e restrição ao acesso .. 272

Figura 64: Mapa da Terceira Face da Modernização: a expropriação da terra 292

Figura 65: Mapa de Relação entre Programas de Pós-Graduação e Áreas de Estudo, por Região e Período.

Figura 66: Mapa da Expressão Regional das Referências nos Trabalhos aos Pesquisadores que Responderam os Questionários 350

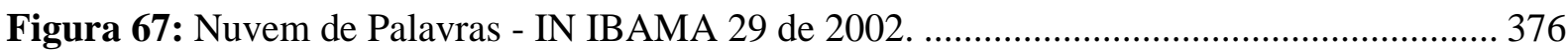

Figura 68: Nuvem de Palavras - Portaria MPA MMA No5 de 2015 …....................................... 384

Figura 69: Nuvem de Palavras - Sistema Nacional de Unidades de Conservação (SNUC) ....... 387

Figura 70: Nuvem de Palavras - Lei № 89 de 2010 ...................................................................... 394

Figura 71: Nuvem de Palavras - Projeto de Lei de Iniciativa Popular ....................................... 401

\section{Gráficos}

Gráfico 1:Respostas aos Questionários por Unidade da Federação e Região ......................... 72

Gráfico 2: Formação dos Pesquisadores, por Região ........................................................... 76

Gráfico 3: Participação em Grupo de Pesquisa, por Região................................................. 82

Gráfico 4: Financiamento dos Projetos de Pesquisa por Região …........................................ 85

Gráfico 5: Financiamento dos Projetos de Extensão por Região .......................................... 89

Gráfico 6: Professores Universitários por Instituição..........................................................92

Gráfico 7: Principais Problemáticas Estudadas, por Região ............................................. 130

Gráfico 8: Relação entre principais problemáticas e principais abordagens conceituais .......342

Gráfico 9: Relação entre principais problemáticas e principais abordagens metodológicas.344

Gráfico 10: Desejo dos pesquisadores de participarem da Rede de Geografias da Pesca..... 356

\section{Quadro}

Quadro 1: Invariantes territoriais 


\section{Lista de Siglas}

AGB - Associação de Geógrafos Brasileiros

APAPG - Associação de Pescadores e Aquicultores da Pedra de Guaratiba

CAPES - Coordenação de Aperfeiçoamento de Pessoal de Nível Superior

CBG - Congresso Brasileiro de Geógrafos

CNPQ - Conselho Nacional de Desenvolvimento Científico e Tecnológico

CONFREM - Comissão Nacional de Fortalecimento das Reservas Extrativistas Costeiras e Marinhas

CPG - Comitê Permanente de Gestão

CPP - Conselho Pastoral dos Pescadores

CPT - Comissão Pastoral da Terra

CTPG - Comissão Técnica da Gestão Compartilhada dos Recursos Pesqueiros

ENANPEGE - Encontro Nacional da ANPEGE

ENG - Encontro Nacional de Geógrafos

FAO - Organização das Nações Unidas para a Alimentação e a Agricultura

FLONA - Floresta Nacional

GAPTA - Grupo Acadêmico Produção do Território e Meio Ambiente na Amazônia

GEOGRAFAR - Geografia dos Assentamentos na Área Rural

GEOPLAN - Grupo de Pesquisa em Geoecologia e Planejamento Territorial

GEPPAM - Grupo de Estudo Paisagem e Planejamento Ambiental

IBAMA - Instituto Brasileiro de Meio Ambiente

IBGE - Instituto Brasileiro de Geografia e Estatística

INCRA - Instituto Nacional de Colonização e Reforma Agrária

MCT - Ministério de Ciência e Tecnologia

MDIC - Ministério da Indústria, Comércio Exterior e Serviços 
MEC - Ministério da Educação

MMA - Ministério do Meio Ambiente

MONAPE -Movimento Nacional dos Pescadores

MOPEAR - Movimento Paranaense de Pescadores Artesanais

MPA - Ministério da Pesca e Aquicultura

MPP - Movimento dos Pescadores e Pescadoras Artesanais

NEGA - Núcleo de Estudos Geografia \& Ambiente

NUTEMC - Núcleo de Pesquisa e Extensão: Urbano, Território e Mudanças Contemporâneas

OIT - Organização Internacional do Trabalho

PNPG - Política Nacional de Pós-Graduação

PPG - Programa de Pós-Graduação

PROEXT - Programa de Extensão Universitária

RGP - Registro Geral de Pesca

SEAP - Secretaria Especial da Aquicultura e Pesca

SINGREH - Sistema Nacional de Gerenciamento dos Recursos Hídricos

SISNAMA - Sistema Nacional do Meio Ambiente

SNUC - Sistema Nacional de Unidades de Conservação

SPU - Secretaria do Patrimônio da União

SUDEP - Superintendência de Desenvolvimento da Pesca

TAUS- Termo de Autorização de Uso Sustentável

TUCUM - Rede Cearense de Turismo Comunitário

UC - Unidade de Conservação

ZEE - Zona Econômica Exclusiva 


\section{INTRODUÇÃo}

No Brasil, o choque entre a racionalidade econômica e a racionalidade ambiental se evidencia na pesca artesanal, resultando em inúmeras problemáticas. Essas racionalidades disputam territórios, recursos, bem como o domínio do conhecimento e projetos de futuro. Nesse contexto, ao mesmo tempo em que veem o território tradicional e os recursos ambientais perecerem pelo avanço da modernização, os pescadores artesanais são considerados dentro da lógica dominante (moderna), como incultos, e entraves para o desenvolvimento. Nesse processo se evidenciam conflitos entre os agentes do capital e os pescadores artesanais, que reivindicam direito ao território tradicional, bem como o reconhecimento dos seus saberes constituídos ao longo de gerações, por meio da relação com o ambiente e das relações sociais estabelecidas no território.

Ao mesmo tempo em que as comunidades tradicionais se veem atacadas no seu direito de permanecer e realizar a gestão do território, vive-se uma crise ambiental planetária sem precedentes, resultante do padrão de produção e consumo inerentes ao modo de produção capitalista, e do desconhecimento das consequências do conhecimento científico moderno. Desta forma, valorizar o conhecimento tradicional, reconhecer os povos tradicionais como peritos na gestão ambiental, e garantir a eles o direito de uso do território tradicional são ações necessárias, no campo político, científico e social. Isto, trará benefícios para toda a sociedade, seja pela qualidade ambiental decorrente da gestão comunitária e compartilhada do território, seja pelo oferecimento de alimento, proporcionando, principalmente às populações mais pobres, segurança alimentar.

Acredita-se que é relevante compreender a pesca artesanal brasileira através da Geografia. Isso porque, em todo o Brasil, inúmeros geógrafos abordam em artigos, livros, monografias, dissertações, teses e livros as problemáticas da pesca artesanal. Desta forma, a pesquisa contribui na sumarização e análise desses estudos (dissertações e teses). Isto favorece estabelecer diálogos entre pesquisas, para discutir a pesca artesanal em escala nacional. Logo, auxilia na proposição de respostas às problemáticas dos pescadores artesanais e evidencia tendências na produção acadêmica da Geografia brasileira, principalmente evidenciando o diálogo de saberes entre pescadores e geógrafos.

Também é relevante compreender essas pesquisas no momento atual da Geografia brasileira, tanto no tocante ao estágio do pensamento Geográfico, quanto no processo de institucionalização da Geografia, por meio da expansão e consolidação da pós-graduação. Isso 
tem visibilizado sujeitos sociais até então marginalizados e proporcionado a realização de pesquisas em diversas regiões e localidades. Destaca-se que a existência de grupos de pesquisa que abordam os pescadores artesanais em seus estudos também se põe com possibilidade de compreender a pesquisa brasileira sobre a pesca artesanal. Diante da necessidade de articulação é importante frisar a iniciativa de construção de um trabalho em rede, como é o caso da Rede de Geografias da Pesca.

Os diálogos de saberes se colocam como um meio de (re)significar os conceitos geográficos de ambiente e território, para que os mesmos correspondam a uma melhor leitura da realidade estudada e sejam operacionais e apropriados pelos sujeitos da pesquisa. $\mathrm{O}$ reconhecimento dos saberes tradicionais dos pescadores, em sua dimensão territorial, parece superar a lacuna conceitual do conteúdo da "tradição" do conhecimento. Ainda contribui para o estabelecimento de políticas públicas para a pesca artesanal brasileira, congruentes com as particularidades dos diversos territórios tradicionais das comunidades de pescadores artesanais.

A partir desse diálogo, as compreensões geradas podem ser melhor explicadas por meio da relação território e ambiente. Nesse caso, destaca-se o processo de discussão sobre territórios tradicionais desencadeado pela "Campanha Nacional pela Regularização do Território das Comunidades Tradicionais Pesqueiras" promovida pelo Movimento dos Pescadores e Pescadoras Artesanais - MPP.

A tese, evidentemente, não contempla todo o contexto vivido pelas comunidades tradicionais de pescadores artesanais do Brasil. Contudo, a contribuição permeia a resposta da questão norteadora:

Qual a compreensão da Geografia brasileira sobre a dinâmica dos territórios tradicionais dos pescadores artesanais? Em que medida seus conceitos, métodos e abordagens dialogam com o conhecimento tradicional dos pescadores artesanais em situações em que as comunidades são desterritorializadas? Em que medida a compreensão desse processo pode contribuir com a Geografia brasileira, com a gestão comunitária da pesca artesanal e com contextos de luta por políticas públicas enfocadas no território das comunidades de pescadores?

Para responder a essas questões, a pesquisa foi dividida em três eixos:

O Eixo 1 pretende responder a questão "Qual a compreensão da Geografia brasileira sobre a dinâmica dos territórios tradicionais dos pescadores artesanais? Entendeu-se que a resposta permeia a análise da produção acadêmica da Geografia brasileira sobre a pesca artesanal. Assim, foram analisadas as dissertações de mestrado e teses de doutorado 
desenvolvidas por geógrafos que abordam a pesca artesanal no Brasil. Interessou compreender principais problemáticas, teorias, métodos e técnicas de pesquisa. Ainda a espacialização desses trabalhos (representação cartográfica) permitiu pensar a pesca e pensar a própria Geografia brasileira. Esta se configurou em uma análise panorâmica (de sobrevoo) que permitiu identificar, relacionar e perceber possibilidades de interpretação da Geografia quanto às problemáticas da pesca artesanal. Ainda contribui na identificação dos geógrafos envolvidos, no contexto institucional em que atuam, para inferir probabilidades de articulação em um trabalho em rede.

O Eixo I busca atender os seguintes objetivos específicos da tese: identificar abordagens, sobre a pesca artesanal na produção acadêmica da Geografia brasileira (Dissertações e Teses); analisar e espacializar o conteúdo das discussões sobre a pesca artesanal, na Geografia brasileira; identificar pesquisadores, grupos e núcleos de pesquisa, que priorizam em suas abordagens a pesca artesanal; e identificar lacunas e perspectivas no estágio atual da Geografia da pesca do Brasil.

Como resultado desse processo foi elaborado o Capítulo I.

O Capítulo I "A Expressão da Pesca Artesanal na Geografia Brasileira” busca na Geografia brasileira pesquisas que tratem da pesca artesanal. Esse processo se concretizou na análise de dissertações e teses, bem como das respostas dos pesquisadores a um questionário. Para essa análise foi fundamental estabelecer um horizonte teórico/histórico que situa o momento atual do pensamento geográfico brasileiro na perspectiva crítica, bem como apresenta o processo recente de institucionalização da Geografia Brasileira, por meio da pesquisa em pósgraduação. Isso foi fundamental para compreender o holograma que situa cada um dos trabalhos em um todo que expõe a tendência ao pensamento crítico que visibiliza os sujeitos sociais até então marginalizados, bem como a possibilidade de realização de pesquisa em áreas até então pouco estudadas do território nacional e abrindo espaço para sujeitos pesquisadores estritamente relacionados com a realidade vivida pelos pescadores artesanais.

Decorrente desse processo de análise verificou-se a forte tendência das pesquisas em abordarem o conceito de território e ambiente, na compreensão do espaço geográfico. Esses conceitos estão relacionados a inúmeras problemáticas, entre as quais se evidencia o predomínio dos contextos de resistência das comunidades de pescadores frente a modernização que avança sobre os seus territórios tradicionais.

O Eixo 2 está empenhado em responder a questão: Qual a compreensão da Geografia brasileira sobre a dinâmica dos territórios tradicionais dos pescadores artesanais, e em que 
medida seus conceitos, métodos e abordagens dialogam com o conhecimento tradicional dos pescadores artesanais em situações em que as comunidades são desterritorializadas?

A partir da referida visão panorâmica dos estudos sobre pesca artesanal na Geografia brasileira, foi identificado um recorte analítico que enfatiza a relação entre ambiente e território. Desta forma se analisa as atividades econômicas que embatem com a pesca artesanal sob essa ótica. Tais contextos foram elencados para que tal compreensão abranja a diversidade de territórios pesqueiros presentes no Brasil e problemáticas associadas a eles. Assim, existe o desafio de que as compreensões geradas correspondam às demandas dos pescadores artesanais, dentro das suas estratégias de luta.

Propõe-se que, com base nessa análise, será possível discutir os territórios tradicionais das comunidades tradicionais de pescadores artesanais com o movimento social. Para tal discussão, se estabelece a relação entre esses contextos em que geógrafos desenvolvem pesquisas e ações junto aos pescadores e as problemáticas apresentadas por meio de denúncias pelo Movimento dos Pescadores e Pescadoras Artesanais - MPP. Neste sentido, põe-se em relação as propostas analíticas de compreensão de ambiente/território com a expressão da modernização, principal opositor do movimento social que defende o território tradicional.

Para atender ao Eixo II, seguiu-se os seguintes objetivos específicos: evidenciar a partir das dissertações e teses dos geógrafos as principais problemáticas relativas aos territórios da pesca artesanal brasileira; estabelecer uma proposta analítica sobre os territórios pesqueiros no Brasil considerando os diálogos entre pescadores e geógrafos no âmbito da pesquisa geográfica, reconhecer as principais problemáticas debatidas pelos pescadores artesanais organizados em movimento social, no tempo presente; analisar a modernização que avança sobre os territórios tradicionais de pescadores artesanais no Brasil a partir do movimento social em diálogo com concepções da Geografia.

Como resultado do Eixo II, apresentam-se os Capítulo II e III:

No Capítulo II “Impactos Ambientais, Disputas no Território e Conflitos por Território na Pesca Artesanal Brasileira" o empenho está em compreender na análise de dissertações e teses distinções desse contínuo que se expressa entre o território da natureza e a natureza do território. Isso quer dizer, que se busca propor uma análise que trata de território e ambiente de forma associada, mas que distingue a prevalência de um ou outro. Tal distinção se deve a abordagem relacional do território tradicional. De um lado, território e ambiente se encontram, pois prevalece a relação entre sociedade e natureza, mas as regras inerentes a esse uso e os limites estabelecidos evidenciam a dinâmica territorial. De outro, o território se delimita, 
principalmente a partir das relações sociais, multidimensionais, onde o poder de apropriação $e$ domínio se expressa de forma mais evidente. A noção da ecogênese territorial e da semiotização do espaço inerente à territorialização são fundamentais para compreender os processos de desterritorialização sofrido pelas comunidades tradicionais de pescadores, que no momento atual estão sujeitos aos desígnios de redes globais de tecnologia e informação, que propõe/impõe outros usos ao território.

Desta maneira, se evidencia três tendências a processos na pesca artesanal brasileira. $\mathrm{O}$ primeiro trata de Impactos Ambientais, que atingem os recursos e, pela queda na produtividade da pesca, desterritorializa os pescadores. O segundo trata de Disputas no Território, entre pescadores e agentes de outras atividades econômica que desejam se impor no território, seja para explorar os pesqueiros tradicionais, seja para o uso do sitio para a promoção de suas atividades. O terceiro processo é um cenário geralmente decorrente dos outros que expressa Conflitos por Território, nesse contexto prevalecem as relações de poder e já não é mais possível multiterritorialidade. Tais conflitos se evidenciam na ação direta ou por meio de processos judiciais. Ressalta-se que nesse processo o domínio das redes de informação auxilia essas atividades econômicas a apresentarem perspectivas de futuro vinculadas ao desenvolvimento e progresso, e ao mesmo tempo desqualificam as comunidades tradicionais. Soma-se a isso o apoio do Estado, ou de agentes de governo, interessados nas divisas financeiras decorrentes dessas atividades econômicas.

No Capítulo III “As Três Faces da Modernização na Pesca Artesanal Brasileira- um diálogo com o movimento social" a análise apresentada no Capítulo II entra em diálogo com o movimento social. Nesse sentido agrega à discussão as denúncias, principalmente, do MPP. Ressalta-se que já no Capítulo I se evidenciou que as principais problemáticas relativas à pesca artesanal brasileira diziam respeito a resistência das comunidades à modernização. As análises das denúncias do MPP evidenciaram esse contexto, mas permitiu também estabelecer distinções que são fundamentais para pensar as estratégias de defesa do território tradicional das comunidades de pescadores artesanais. Na perspectiva teórica, é fundamental compreender que esses contextos explicitados decorrem da geração intencional de ausências, que invisibiliza e marginaliza sujeitos sociais. Ao contrário, destacar tais lutas insere a pesquisa na proposta da sociologia das emergências, processo fundamental para enfrentar a modernização. Entre as propostas dessa perspectiva teórica pressupõe-se a superação da monocultura do saber por uma ecologia dos saberes, dessa forma o conhecimento geográfico e a proposta analítica do Capítulo 
anterior não se anulam, mas se unem na resistência à modernização e na construção de um cosmopolitismo subalterno.

Nessa proposta dialógica se apresenta a possibilidade de leitura da modernização a partir de três faces, que se expõem no território. A primeira face diz respeito a degradação do ambiente. Essa face age sobre os ecossistemas que são fundamentais para a presença dos recursos pesqueiros, por isso gera impactos ambientais, disputas no território e conflitos por território com a urbanização, industrialização e agronegócio. A segunda face da modernização se expressa no pesqueiro tradicional como sobre-exploração do pescado ou na restrição ao acesso e expõe, principalmente, disputas no território e conflitos por território com o hidronegócio e pesca industrial. A terceira face da modernização se apresenta na expropriação da terra. Essa diz respeito principalmente ao território de moradia e vivência das comunidades tradicionais de pescadores e destaca prioritariamente conflitos por território com o turismo, "proprietários de terras" (fundiários), e especuladores imobiliários.

O Eixo III busca responder a pergunta: Em que medida a compreensão desse processo pode contribuir com a Geografia brasileira, com a gestão comunitária da pesca artesanal e com contextos de luta por políticas públicas enfocadas no território das comunidades de pescadores?

A partir dos resultados dos Eixos I e II essa etapa da pesquisa revisitou as principais compreensões destacadas na pesquisa propondo ressignificações. Retomando os resultados do Eixo I apresenta-se lacunas e tendências nos estudos da Geografia brasileira sobre a pesca artesanal, enfatizando possibilidades de diálogo entre as regiões e propondo a articulação do trabalho em rede, de forma que as pesquisas correspondam às demandas do movimento social. Desta forma há uma discussão que prevalece no campo da institucionalização da Geografia e tendências do pensamento Geográfico. Retomando os resultados do Eixo II e integrando outras concepções, busca-se revisar alguns conceitos geográficos e conceitos relacionados à pesca artesanal. Assim, procura-se discutir concepções de pesca, pescador, comunidade, conhecimento, a partir de autores de outras ciências, concepções do movimento social, diretrizes do governo e, compreendendo a Geografia como uma ciência do espaço, ressignificálas a partir dos conceitos de território e ambiente. De outro lado, com base no diálogo com o movimento social e das análises decorrentes do diálogo entre pescadores e geógrafos, considera-se fundamental ressignificar os conceitos de ambiente e território a partir da pesca artesanal brasileira. Por fim, retoma-se a discussão sobre a própria Geografia, enquanto ciência que dialoga com os sujeitos sociais em superação das invisibilidades decorrentes da sociedade 
atual e que evidencia situações de conflito que podem auxiliar os sujeitos sociais a terem reconhecidos seus direitos fundamentais como permanecer no território.

Para o Eixo III estabeleceu-se os objetivos específico: Reconhecer a importância das comunidades tradicionais para pensar os conceitos e métodos da Geografia e a gestão da pesca no Brasil; apontar potencialidades e desafios na gestão da pesca artesanal brasileira e na pesquisa em Geografias da pesca; e destacar possíveis articulações entre os geógrafos que pesquisam a pesca artesanal, e a possibilidade do trabalho em rede.

Como resultado desse Eixo, apresenta-se o Capítulo IV.

No Capítulo IV a tese se depara com o desafio de, a partir das discussões estabelecidas, pensar geograficamente a pesca artesanal brasileira, bem como discutir as Geografias da Pesca. Neste momento, propõe-se a discussão em níveis teórico e epistemológico. Teórico, pois se pretende que os conceitos discutidos e propostos permitam leituras das realidades vividas pelos pescadores artesanais brasileiros e o debate teórico na Geografia. Epistemológico, pois é fundamental situar a compreensão sobre o sujeito da pesquisa e a concepção de ciência em que ela se insere. Para tanto, as elaborações conceituais apresentadas seguem duas principais correntes de pensamento. De um lado, se situa na produção de uma racionalidade ambiental alternativa à racionalidade econômica dominante. De outro, se percebe na constituição de epistemologias do Sul, logo, na construção de conhecimentos contra-hegemônicos como alternativa à colonialidade do saber. Sob essas duas influências, todas as propostas apresentadas decorrem de um amplo processo dialógico com demais pesquisadores e com movimentos sociais, por meio de diálogos de saberes e tradução (hermenêutica diapótica).

O Capítulo foi pensado em três etapas que evidenciam o movimento de reconstrução das compreensões a partir da tese. O primeiro movimento vai da pesquisa do geógrafo para rede pesquisadores geógrafos e apresenta desafios para a construção de Geografias da pesca. Essa discussão vai na perspectiva de apresentar tendências e lacunas (institucionais e teóricas/metodológicas) nas Geografias da Pesca, abordar, mesmo que de forma sucinta, a proposta de um trabalho em rede. $\mathrm{O}$ segundo, parte da territorialidade tradicional para $o$ território de luta das comunidades tradicionais de pescadores artesanais. Isso significa discutir os conceitos de pescador artesanal, comunidade tradicional, conhecimento tradicional, território tradicional a partir da perspectiva da tese (relação território e ambiente) e em diálogo com outras concepções acadêmicas, da gestão e do movimento social. O terceiro avança das Geografias das ausências para as Geografias das emergências da pesca artesanal brasileira. Trata-se de estabelecer a leitura das ausências e emergências a partir da Geografia, por meio da expressão 
das epistemes e métodos, de forma a dar maior visibilidade às comunidades tradicionais e provocar reflexões sobre o pensamento geográfico.

Diante do exposto, apresenta-se o objetivo geral que sustenta o argumento de tese

Entender, a partir da Geografia brasileira, a dinâmica dos territórios tradicionais da pesca artesanal, apontando o diálogo entre seus conceitos, métodos e abordagens com o conhecimento tradicional dos pescadores artesanais, em situações em que as comunidades são desterritorializadas, para compreender a própria Geografia brasileira e suas contribuições com a gestão comunitária da pesca artesanal e com contextos de luta por políticas públicas territoriais das comunidades de pescadores.

Desde o princípio não se propõe a estabelecer uma Geografia da Pesca, mas reconhecer a pluralidade de conceitos, métodos, problemáticas, etc. Apresentar, a partir da Geografia brasileira, em diálogo com o movimento social, a possibilidade de compreender a relação entre território e ambiente, no âmbito das comunidades tradicionais de pescadores artesanais, que por sua vez estão sujeitos à impactos, disputas e conflitos, que expressam as faces da modernização. Assim, pretende-se discutir a pesca artesanal brasileira e as Geografias da Pesca, que buscam superar a Geografia das Ausências para promover a Geografia das Emergências.

Deste modo a tese trata da relação dialógica entre Geografia e pesca artesanal brasileira. Entende que o pensamento geográfico pode contribuir nas discussões sobre a pesca artesanal e ao mesmo tempo é influenciado, nos diálogos de saberes, pelas comunidades de pescadores e movimentos sociais. Assim, ao passo que a Geografia potencializa a discussão sobre os territórios das comunidades tradicionais pesqueiras, também se renova na perspectiva crítica. A superação das Geografias das Ausências e a promoção das Geografias das Emergências expõem essa mútua influência, quando evidenciam a constituição do território de luta das comunidades, ao mesmo tempo em que busca superar as invisibilidades promovidas na ciência geográfica.

\section{Algumas reflexões sobre o método}

Parafraseando o poeta António Machado (1999) “o caminho se faz ao caminhar”, assim serão apresentadas dos princípios que guiaram o trajeto que foi percorrido na pesquisa. Para isso serão expostos alguns elementos teóricos e metodológicos de um longo processo de reflexão, sobre a teoria do pensamento complexo e suas possíveis implicações.

O contexto de crise decorrente dos efeitos nocivos da ciência moderna, que começam a se expor no século XX (MORIN, 1990, p. p.17) e descobertas científicas, relativamente 
recentes, como os sistemas abertos, princípio da entropia, cibernética e etc. tem promovido questionamentos sobre as formas de fazer ciência (MORIN, 1997, 2002). O que se discute são as possibilidades de atingir o real em sua complexidade, pois como destaca Morin (1990) o real sempre foi complexo.

Morin (1990) exalta que os limites das interpretações, na ciência moderna, devem-se principalmente ao paradigma da simplificação que se expressa pelo conjunto de princípios da disjunção, redução e abstração. Estes implicam em análises baseadas em separar ou reduzir elementos da realidade. Assim, provoca-se para a riqueza de reconhecer o fenômeno de autoeco-organização extraordinariamente complexo que produz autonomia. Desta forma pode-se reintegrar o homem entre os seres naturais para o distinguir deles, mas não para reduzir a essa situação.

No entanto, não se pretende confundir holismo com complexidade. A aspiração à complexidade traz nela a busca pela completude, uma vez que se sabe que tudo é solidário e que tudo é multidimensional. Entretanto a consciência da complexidade leva a "reconhecer que não poderemos nunca escapar á incerteza e, por isso, não teremos um saber total”. Nessa perspectiva, a totalidade é a não verdade (MORIN, 1990, p.100).

Esse horizonte de pensamento não trabalha com a análise de variáveis isoladas, logo, é capaz de apreender o todo e as partes nas suas relações com o todo. Assim, Morin (1990, p. 123-124) propõe que a complexidade integra três etapas. Primeiramente busca-se reconhecer que os conhecimentos que se tem são simples, e insuficientes para conhecer as propriedades do conjunto "um todo é mais do que a soma das partes que o constituem". Na sequência, busca-se conceber que as partes estão inibidas ou virtualizadas, ou seja, "o todo é então menor que a soma das partes". Finalmente, pretende-se romper com a estrutura mental e superar as dificuldades do entendimento, para pressupor que "o todo é simultaneamente mais e menos do que a soma das partes".

Em síntese, Morin (1990, p. 22) propõe substituir os princípios da disjunção/redução, pelo da distinção/conjunção, que permite distinguir sem separar, associar sem identificar ou reduzir e, assim, elaborar conhecimentos fundados na complexidade. Esta última pode ser concebida como um "tecido de acontecimentos, ações, interações, retroações, determinações, acasos, que constituem o nosso mundo fenomenal".

Em sua extensa obra sobre a teoria do pensamento complexo Morin tem apresentado alguns princípios para promover a complexidade. Entre eles destaca-se o dialógico, o recursivo organizacional e o hologramático. 
O princípio metodológico da dialógica não se opõe à dialética, ou às contribuições de outros métodos. Acrescenta-se que para além da discussão teórica e metodológica a dialógica é um princípio que norteia o diálogo transdisciplinar, ou seja, que transcende os limites da ciência moderna (MORIN, 1990).

É importante destacar que em contexto de pensamento complexo a dialógica pressupõe a relação de ideias que são ao mesmo tempo complementares e antagônicas. Nessa perspectiva se entende que na unidade gerada persiste também a dualidade inicial. Destaca-se que alguns críticos ao pensamento complexo pressupõem que o resultado da dialógica seria a conformação de um consenso permanente, de acordo. Contudo, é importante refletir sobre a expressão do princípio dialógico à luz de diferentes métodos. Nesta compreensão os consensos são provisórios e só são possíveis em um contexto de mútua influência que resulta nele. No âmbito de um consenso diversos dissensos se suprimem, mas não deixam de existir, e a partir deles a dialógica continua. Logo, a dialógica é um princípio que orienta a compreensão dos processos e não se detém aos produtos destes.

Na complexidade o princípio recursivo organizacional favorece conceber que o produto e os efeitos são ao mesmo tempo causa e produtores daquilo que os produziu. Morin (1990) apresenta três causalidades que podem ser entendidas por ângulos distintos. O primeiro ângulo é a causalidade linear que propõe que tal causa produz tais efeitos (seria o ângulo mais empregado nas pesquisas dominadas pelo simplismo e reducionismo). O segundo ângulo propõe que a causalidade é circular retroativa. $O$ terceiro ângulo trata da causalidade recursiva, na qual o produto é produtor daquilo que produz. O autor frisa que essas três causaliades encontram-se em todos os níveis de organização complexos. Isto faz-se num circuito espiral através da evolução histórica (p.125-126).

Parte-se da relação entre o principio hologramático e o recursivo organizacional, pois na lógica recursiva sabe-se que o adquirido com o conhecimento das partes regressa sobre o todo (MORIN, 1990, p.108-109). Assim, a auto-eco-organização pode ser compreendida como de caráter hologramático. Na qualidade da imagem hologramática cada ponto possui a quasetotalidade da informação do todo, assim, de uma certa maneira, "o todo enquanto todo de que fazemos parte, está presente no nosso espírito" ( p.128). No horizonte do pensamento complexo é o principio hologramático que permite supor que não apenas a parte está no todo, como o todo também está na parte. Assim cumpre-se com o objetivo de superar o reducionismo que só considera a parte e o holismo que busca compreender o todo. 
Tendo situado a pesquisa no horizonte do pensamento complexo, destaca-se que em cada Capítulo haverá uma breve exposição dos princípios do pensamento complexo, propostos por Morin (1990) e serão detalhadas as técnicas de pesquisas que foram adotadas. 


\section{Capítulo I}

\section{A Expressão da Pesca Artesanal na Geografia Brasileira}

No rio e no mar: pescador na luta!

Milton Santos (2006) entende que existem tantas Geografias quanto geógrafos. Sem querer estabelecer uma leitura literal, compreende-se que o autor considera a diversidade de problemáticas e a pluralidade de possibilidades de interpretação teóricas e metodológicas presentes na Geografia brasileira. Diante das problemáticas da pesca artesanal, esse Capítulo situa a produção geográfica no tempo presente. Assim, apresentam-se pesquisadores e instituições envolvidas, abordagens teóricas e metodológicas, problemáticas, etc. Esse passo é fundamental para compreender as Geografia(s) da Pesca Artesanal Brasileira, que não é entendida como um campo ou especialização do conhecimento geográfico, mas um horizonte de compreensão do espaço que visibiliza os pescadores artesanais como atores sociais e sujeitos de direito.

A análise que segue, revela a constituição do saber geográfico dentro das possibilidades presentes na Geografia brasileira. Essas possibilidades devem ser vistas, no mínimo, sob duas perspectivas. A primeira se refere a situação institucional em que as pesquisas e a atuação profissional dos geógrafos se apresentam. Isso quer dizer que, em certa medida, o conhecimento é gerado dentro de determinadas condições materiais e imateriais, e que isso se expressa na pesquisa geográfica. A segunda, se refere ao momento do pensamento geográfico que se vive, em que vislumbra como viáveis determinadas análises, sem considerá-las menores ou irrelevantes. Nesse sentido, a pluralidade de possibilidades existe dentro de determinado contexto científico que se expressa na história do pensamento geográfico.

Ressalta-se que esse Capítulo está implicado em apresentar um panorama da Geografia que se expõe nessa tese. Esse panorama se apresenta no conteúdo das dissertações e teses, mas também na espacialização desses trabalhos e das respostas dos geógrafos a um questionário. Desta forma, há o interesse explicito de iniciar uma discussão sobre a produção acadêmica da Geografia sobre a pesca artesanal brasileira, expondo no mapa as distinções que se evidenciam. Disso depende as leituras dos Capítulos posteriores, para que sejam contextualizadas dentro do processo de construção do conhecimento científico. 
Para além disso, é fundamental conceber esse Capítulo como um momento da pesquisa geográfica sobre a pesca artesanal. Sendo assim, apresenta algumas respostas que estão situadas no tempo e no espaço e, por isso, estão em constantes transformações. Contudo, dialoga com um contexto acadêmico e social em que um grupo de pesquisadores geógrafos buscam a construção de uma rede de cooperação científica, em diálogo com os movimentos sociais. Sendo assim, essa sumarização de trabalhos e, pesquisadores envolvidos, contribuem para pensar a própria rede.

No campo teórico, esse Capítulo propõe pensar o pensamento geográfico constituído, principalmente, a partir de movimento de renovação que rompe com a lógica da Geografia "tradicional ou clássica" e abre a discussão para a perspectiva crítica, onde se visibiliza atores sociais até então deixados à margem da pesquisa geográfica. Sendo assim, a tese se situa no âmbito do pensamento geográfico crítico, e entende os trabalhos analisados nessa perspectiva, considerando a diversidade de possibilidades. Contudo, o Capítulo também exige esclarecer o movimento de institucionalização da Geografia brasileira, onde, pela característica do material analisado, serão apresentadas informações referentes a expansão dos programas de pósgraduação.

Do ponto de vista metodológico, a teoria do pensamento complexo em que se situa a tese, pressupõe a relação entre os métodos e o emprego de técnicas de investigação que melhor correspondam à problemática estudada. Desta forma, a presente análise é quali-quantitativa, para estabelecer uma visão panorâmica sobre o contexto de produção da Geografia brasileira sobre a pesca artesanal e, assim, dar suporte aos Capítulos posteriores.

Diante do exposto, esse Capítulo está comprometido em: Identificar abordagens sobre a pesca artesanal na produção acadêmica da Geografia brasileira (Dissertações e Teses); analisar e espacializar o conteúdo das discussões sobre a pesca artesanal na Geografia brasileira; e identificar pesquisadores, grupos e núcleos de pesquisa, que priorizam em suas abordagens a pesca artesanal.

\subsection{Pressupostos Teóricos: Renovação da Geografia e Expansão da Pós-Graduação em Geografia no Brasil}

Nesse momento, alguns pressupostos teóricos situam as Geografias da Pesca Artesanal no contexto da História do Pensamento Geográfico brasileiro. Para tanto, se apresentará o contexto de ruptura com a Geografia Tradicional e o Movimento de Renovação da Geografia 
com ênfase na Geografia Crítica (PORTO-GONÇALVES, 1978'; ANDRADE, 1999; MORAES, 2005). Na sequência, se apresentará o contexto atual em que os sujeitos pescadores têm maior visibilidade (SILVA, 2017). Ainda será exposto o processo de expansão da pósgraduação em Geografia no Brasil, que servirá de base para compreender o avanço recente em número e áreas de estudo (em diversas regiões) (SUERTEGARAY, 2003, 2007; MENDONÇA, 2005; SILVA E DANTAS, 2005; SPÓSITO, 2016).

Ressalta-se que, a compreensão da história do pensamento geográfico aqui apresentada, não está comprometida em estabelecer fases ou periodizações bem determinadas. Andrade (1999) destaca que essas fases se interpenetram umas nas outras. Contudo, pretende-se destacar o período de "rupturas, as mudanças, as revoluções e contrarrevoluções" (PORTOGONÇALVES, 1978) que abriu espaço para a perspectiva de pesquisa em que se encontra a tese. Como destaca Porto-Gonçalves (1978):

Qualquer esforço no sentido de desvendar a natureza da crise de um determinado segmento do espaço do saber deve, portanto, partir da premissa de que o trabalho intelectual, embora possuindo uma dinâmica específica, sofre influência do próprio contexto histórico que constitui a materialidade do trabalho científico. Neste ensaio, o que pretendemos fazer é exatamente lançar ao debate algumas ideias acerca de natureza da crise da Geografia, tomando por base a prática dos geógrafos pensada historicamente.

Moraes (2005) destacava em $1982^{2}$ o movimento de renovação que a Geografia se encontrava em decorrência do rompimento com a perspectiva tradicional. A crise na Geografia Tradicional ensejou a busca "de novos caminhos, de nova linguagem, de novas respostas, enfim, de uma liberdade maior de reflexão e criação" (p.103). Assim, as certezas se diluíram em detrimento da busca constante do objeto, método e significado da Geografia.

Andrade (1999) ressalta que a Geografia Tradicional (considerada nos anos 1940 como a Geografia Científica) no Brasil, surgiu da necessidade de conhecimento e de mapeamento do território nacional, em um período após a Revolução de 1930, que se vivia inquietações em todos os setores do conhecimento. Nesse período de institucionalização da Geografia Brasileira destaca-se:

Essa década foi marcada pela fundação das universidades de São Paulo e do Distrito Federal (Rio de Janeiro), depois chamada do Brasil, quando a Geografia passou a ser ministrada em curso próprio, de nível superior. A essas universidades seguiu-se a fundação do Instituto Brasileiro de Geografia e Estatística, que recrutou geógrafos formados por essas universidades e

\footnotetext{
${ }^{1}$ Fala proferida no $3^{\circ}$ Congresso de Geógrafos, em Fortaleza (1978).

${ }^{2}$ Lançamento da primeira edição de Geografia Pequena História Crítica em 1982.
} 
especialistas diplomados em outras áreas e que vinham trabalhando com Geografia, estatística e com cartografia (ANDRADE, 1999, p.28).

Na perspectiva da Geografia Tradicional, Andrade (1999) destaca que nos anos 1940 e 1950 foram elaborados ensaios da maior importância. Entre eles vale ressaltar a tese fundadora da cátedra de Geografia Humana da Universidade de São Paulo - A ilha de São Sebastião: estudo de Geografia humana - de Ary França (1951). O autor relaciona quadros naturais e humanos, ocupação, uso e transformação da paisagem da ilha de São Sebastião. O autor evidencia os "caiçaras" e aborda, entre as atividades econômicas, a pesca (comercial e de subsistência). Contudo, apesar de ter sido o registro mais antigo encontrado, na Geografia brasileira, de estudo que aborda a pesca artesanal, prevalece a visão de que os pescadores/agricultores são primitivos, pobres, e que estabelecem técnicas de uso da natureza arcaicas, que provocam degradação. Em França (1951), o caminho apresentado é a superação dessas atividades "tradicionais":

Aos caiçaras das gerações atuais, coube, contudo, participação muito pequena
nas transformações da paisagem, embora, como cultivadores e pescadores
costeiros, não tenham menor aptidões do que os seus antepassados para a
destruição do patrimônio natural, com o uso das mesmas técnicas rotineiras
das derrubadas e queimadas para a formação das roças (p.180).
Da pesca comercial pouco se poderá esperar para melhoria das condições de
vida dos habitantes locais, diante dos novos processos que a estão libertando
de bases em portos locais e já determinam a sua decadência na ilha. Nos
quadros de uma nova economia, com bases comerciais que se impõem, serão
necessários transportes marítimos e terrestres eficientes, adaptados às
condições regionais e aos produtos. Neles residirá o aproveitamento de uma
das maiores vantagens dessa ilha e fachadas litorâneas: a situação geográfica
(p.182).

Moraes (2005) enaltece que a crise da Geografia Tradicional e o movimento de renovação começam a se evidenciar já em meados dos anos 1950. A década de 1960 é marcada por incertezas e os questionamentos difundidos por vários pontos até que, a partir de 1970, considera-se que "a Geografia Tradicional está definitivamente enterrada". Contudo, o autor ressalta que "manifestações dessa data em diante vão soar como sobrevivências, resquícios de um passado já superado" (p.103).

Como destaca Porto-Gonçalves (1978) "as crises de hegemonia são provenientes da não-resposta de uma dada "visão" a uma realidade historicamente determinada e, portanto, não satisfatoriamente explicada, segundo as necessidades daqueles que controlam as instituições”. Desta forma, uma "nova visão" somente será válida, enquanto satisfazer a expectativa dos que a tornaram hegemônica, garantindo seu status de "científica". 
O movimento de renovação da Geografia estabelece um tempo de críticas e de propostas no âmbito dessa disciplina. “Os geógrafos vão abrir-se para novas discussões e buscar caminhos metodológicos até então não trilhados”. Moraes (2005) entende que esta crise é benéfica, uma vez que introduz um pensamento crítico, "frente ao passado dessa disciplina e seus horizontes futuros" (p. 103). Assim, os geógrafos insurgem contra a Geografia Tradicional, muito descritiva e preocupada com a nomenclatura (ANDRADE, 1999, p.28).

Moraes (2005) apresenta três campos de forças que levaram à crise da Geografia brasileira: a alteração na base social em decorrência do desenvolvimento do Modo de Produção Capitalista (monopolista); a linguagem e métodos da Geografia não davam suporte à interpretação da realidade cada vez mais complexa; a ruina do pensamento filosófico no qual a Geografia se assentava (positivismo).

Como consequência da primeira força (mudança no contexto social), o planejamento econômico estava estabelecido como uma arma de intervenção do Estado. "E com ele, o planejamento territorial, como proposta de intervenção deliberada na organização do espaço". Desta forma o contexto social solicitava uma nova função para as ciências humanas, "a necessidade de gerar um instrumental de intervenção, enfim, uma função mais tecnológica" ao contrário do que pressupunha a Geografia Tradicional (MORAES, 2005, p. 104).

A segunda força (necessidade de linguagem e métodos adequados a nova realidade) se deve à intensificação da urbanização, mudanças no quadro agrário - industrialização e mecanização -, a mudança nos centros de decisão, a globalização nos fluxos e relações econômicas. Nesse período se entende que as comunidades locais tendiam a desaparecer, ou se tornar "meros" elos da sociedade globalizada.

Isto defasou o instrumental de pesquisa da Geografia, implicando numa crise das técnicas tradicionais de análise. Estas já não davam mais conta nem da descrição e representação dos fenômenos da superfície terrestre. Criadas para explicar situações simples, quadros locais fechados não conseguiam compreender a complexidade da organização atual do espaço. O instrumental elaborado para explicar comunidades locais não conseguiam apreender o espaço da economia localizada (MORAES, 2005, p. 105).

Tais mudanças provocaram a terceira força (crise no pensamento filosófico que sustentava a Geografia), na medida que a Geografia Tradicional "permanecia como talvez o último baluarte do positivismo clássico".

O desenvolvimento das ciências e do pensamento filosófico ultrapassara em muito os postulados positivistas, que apareciam agora como por demais simplistas. Assim, mesmo ao nível desse pensamento, ocorrera uma 
renovação, à qual a Geografia permanecera alheia. A própria complexidade da realidade e dos instrumentos de pesquisa havia envelhecido as formulações do positivismo clássico. A crise desse foi também uma das razões da crise da Geografia, que nele se fundamentava (MORAES, 2005, p. 105).

Moraes (2005) apresenta um "mosaico da Geografia renovada" que é bastante diversificado, abrangendo um amplo leque de concepções, mas que podem ser agrupados de acordo com os seus propósitos e posicionamentos políticos em dois grupos: "um pode ser denominado Geografia Pragmática e outro Geografia Crítica” (MORAES, 2005, p. 107).

Andrade (1999) enaltece que o momento político da época acabou favorecendo uma ou outra abordagem. $\mathrm{O}$ autor entende que "a partir do golpe de 64, estimulado pelo governo militar, surgiu no estudo das ciências sociais uma tendência quantitativa com grande repercussão no campo da Geografia. Nascia assim, a chamada Geografia quantitativa ou teorética”. Essa renovação interessava ao governo militar por que os trabalhos estavam "baseados exclusivamente em estatísticas, projetavam o crescimento econômico, deixando à margem as implicações sociais e ecológicas desse crescimento" (ANDRADE,1999, p.29).

Em sua crítica, Porto-Gonçalves (1978) enfatiza que sem romper com os "fundamentos teóricos e filosóficos da Geografia tradicional", a chamada "nova Geografia" se comprometeu em precisar (matematicamente) as formulações da Geografia tradicional e, assim, facilitar a identificação dos seus problemas. Contudo, a Geografia nova exerce um papel significativo no pensamento geográfico, que se reflete na dinâmica da sociedade:

Muitos investimentos passaram a ser feitos para criação de "polos de desenvolvimento", para "difusão de inovações" atendendo aos interesses dos capitais disponíveis nos centros hegemônicos do capitalismo. A hegemonia que a chamada "visão espacial" começava a exercer, através das teorias de localidades centrais ou de outros nomes como a teoria dos polos de desenvolvimento ou a teoria de difusão de inovações, não se deveu ao fato de ter apreendido o movimento real que governa a natureza do espaço, mas porque atendia aos novos interesses de um modo de produção incapaz historicamente de superar os problemas que criou.

Nesse sentido, pode-se dizer que a "nova Geografia" não produziu um novo conhecimento, mas sim um novo desconhecimento, capaz de fazer sobreviver por mais tempo algo que a história já condenou. Portanto, trata-se de uma nova contrarrevolução no pensamento geográfico, tal e qual tivemos às vésperas das duas guerras mundiais. Ao subordinar o espaço aos interesses do capital, produziu esse espaço-prisão, planejado pelos Estados que cada vez mais se tornam capitalistas.

Nesse momento será destacada a Geografia Crítica, onde a perspectiva da tese se insere. Andrade (1999) contextualiza que a "abertura política e a possibilidade de discussão maior dos temas científicos nas universidades, surgiram várias correntes, que são chamadas geralmente 
de Geografica Crítica” (p.29). O autor destaca que dentro dessa abordagem encontram-se várias perspectivas que devem ser devidamente compreendidas para não serem tomadas como iguais.

A denominação "Geografia Crítica" ressalta "uma postura radical, frente à Geografia existente (seja tradicional ou pragmática), a qual será levada ao nível de ruptura com o pensamento anterior” (MORAES, 2005, p.119). O autor complementa que:

Porém, o designativo da crítica diz respeito, principalmente, a uma postura frente à realidade, frente à ordem constituída. São os autores que se posicionam por uma transformação da realidade social, pensando o seu saber como uma arma desse processo. São, assim, os que assumem o conteúdo político de conhecimento científico, propondo uma Geografia militante, que lutam por uma sociedade mais justa (MORAES, 2005, p. 119).

A atuação da Geografia Crítica também questiona a estrutura acadêmica, "que possibilitou a repetição dos equívocos: "mandarinato", o apego às velhas teorias, o cerceamento da criatividade dos pesquisadores, o isolamento dos geógrafos, a má formação filosófica, etc.”. Ainda, o autor destaca a "despolitização ideológica do discurso geográfico, que afastava do âmbito dessa disciplina a discussão das questões sociais”. (MORAES, 2005, p. 120).

Moraes (2005) aponta que no âmbito da Geografia Crítica, obedecendo seus objetivos e princípios, convivem propostas díspares. Logo, não se trata de um conjunto monolítico, mas, um conjunto de argumentos de perspectivas diferenciadas.

A unidade da Geografia Crítica manifesta-se na postura de oposição a uma realidade sócias e espacial contraditória e injusta, fazendo-se do conhecimento geográfico uma arma de combate a situação existente. É uma unidade de propósitos dada pelo posicionamento social, pela concepção de ciência como momento das práxis, por uma aceitação plena e explícita do conjunto político do discurso geográfico. Enfim, é uma unidade ética. Entretanto, esses objetivos unitários objetivam-se através de fundamentos metodológicos diversificados, no âmbito da Geografia Crítica. Esta apresenta um mosaico de orientações metodológicas bastante variado: estruturalistas, existencialistas, analíticos, marxistas (em suas várias nuances), ecléticos, etc. Aqui a unidade se esvanece, mantendo-se como único traço comum, o discurso crítico (MORAES, 2005, 131).

Desta forma há "uma unidade ética, substantivada numa diversidade epistemológica". Tal diversidade estimula o debate, gera polêmicas e faz avançar colocações. "Onde há discussões há vida, onde há debate aflora o pensamento crítico, onde há polêmica há espaço para o novo, para a criação". A Geografia na atualidade questiona "verdades" fossilizadas, busca novos caminhos e questiona velhas concepções (MORAES, 2005, p.131).

Ressalta-se que é fundamental compreender que a Geografia brasileira não está construída, "não concluiu ainda o seu processo evolutivo, ela segue um processo de construção 
que nunca terá fim, à proporção que vai sendo construida, vai descortinando novos desafios que precisam ser respondidos". Este devenir não se encerra, uma vez que a construção implica em uma permanente reconstrução. “A solução de problemas vai sempre provocando o surgimento de novos problemas, em vista das transformações que a sociedade vai realizando" (ANDRADE, 1999, p.32).

Silva (2017) enaltece que em um primeiro momento "as lutas sociais dos sujeitos e de suas comunidades tradicionais não aparecem nos estudos geográficos". Assim a produção de invisibilidade nas representações geográficas resulta na leitura do espaço geográfico como "espaço econômico" pautado pelas lógicas das empresas e da localização industrial (p.253). Segundo a autora, avanços ocorrem a partir da década de 1980:

\begin{abstract}
Assim, nos avanços dos anos 1980, com a apropriação do marxismo, a leitura da resistência ainda vai trabalhar a totalidade do conceito de sujeito social: o trabalhador (operário) em confronto com os ideais da burguesia. Desse modo, nos estudos geográficos, assim como na Sociologia e na História predominam abordagens sobre os agentes sociais e da classe trabalhadora como pelos trabalhadores urbanos, camponeses ou pequenos agricultores (RIBEIRO, 2005). Temas emergentes como os conflitos dos extrativistas na Amazônia, os extrativistas (PORTO-GONÇALVES, 2006), já apontava nessa década para os estudos sobre novos sujeitos necessitariam entrar na cena intelectual da análise da Teoria socioespacial crítica, reconhecendo nas lutas sociais a identidade e a diversidade cultural dos sujeitos (p.253).
\end{abstract}

Já nos anos 2000 há intensificação de correntes geográficas que apontam para a dimensão das desigualdades sociais resultantes da modernização excludente. Nesse período se evidenciam trabalhos de pesquisa, de ensino e de extensão sobre a multiculturalidade, a multidimensionalidade do sujeito que produzem o espaço. Então a diversidade e a identidade de sujeitos sociais e individuais são pautadas, valorizando sua territorialidade (espacialidade) e as historicidades (cultura). Estes estudos estão articulados pela análise da pobreza, criminalização e conflitos territoriais no Brasil, e em várias partes do mundo. Isso ajuda a pensar o fazer geográfico no tempo presente, indicando novas possibilidades teóricas, metodológicas, epistemológicas e repensando as teorias sobre os sujeitos sociais e suas geograficidades (SILVA, 2017, p.253).

Como destaca Silva (2017) a partir dos anos 2000 se evidenciam avanços na produção acadêmica da Geografia brasileira, no sentido de inserir novos atores sociais nas análises e (re)discutir conceitos e métodos. Do ponto de vista institucional isso dialoga com o processo de expansão da pós-graduação, dentro do Sistema CAPES, no Brasil. 
Há a confluência entre o período de renovação da Geografia Brasileira e a criação e expansão dos programas de pós-graduação que são bastante reveladores na análise proposta na tese. Suertegaray (2003, 2007), Mendonça (2005) Silva e Dantas, (2005) e Spósito (2016) analisaram a distribuição dos Programas de Pós-graduação em Geografia no território nacional, atentando para distribuição regional e para o movimento em direção ao "interior". Ressalta-se que aqui estão sendo considerados programas no contexto do Sistema Nacional de PósGraduação $^{3}$, logo tal expansão está articulada com políticas nacionais de fomento ao ensino de pós-graduação.

Quando às décadas de 1970 e 1980 (SUERTEGARAY, 2007, p.11) enfatiza que "os primeiros cursos de pós-graduação em Geografia a integrarem o Sistema Nacional de PósGraduação foram os de Geografia Humana e de Geografia Física da Universidade de São Paulo, criados em 1971”. Na sequência, foi criado o curso de Pós-Graduação em Geografia da Universidade Federal do Rio de Janeiro (1972), Universidade Estadual Paulista - Rio Claro (1977). Na década de 1980 foram criados os cursos de Pós-Graduação na Universidade Federal de Santa Catarina (1985), Universidade Federal do Sergipe (1985), Universidade Estadual Paulista - Presidente Prudente (1988) e Universidade Federal de Minas Gerais (1988). Totalizaram oito cursos implantados, cinco deles na região Sudeste, dois no Nordeste e um na região Sul (SUERTEGARAY, 2003, 2007; SILVA e DANTAS, 2005 e SPÓSITO, 2016).

\begin{abstract}
A instituição da Geografia como ciência foi marcada por forte influência das universidades estaduais paulistas, especificamente as detentoras da modalidade de doutorado. A USP (Programas de Geografia Física e Geografia Humana), seguida pela UNESP/RC, influenciaram na construção da Escola Geográfica Brasileira, gestada nos moldes da Escola Francesa, voltada para o entendimento da realidade brasileira e como reflexo da política de modernização empreendida. A ruptura dessa lógica somente se inicia nos anos 1990, e tem continuidade nos 2000 e 2010, guardando, cada um dos períodos, suas especificidades (BRASIL, 2016, p. 2).
\end{abstract}

De 1990 a 1999, a Pós-Graduação em Geografia atinge 19 cursos. Na década de 1990, há indicação do princípio do movimento de expansão. Amplia-se o número de cursos de no próprio Sudeste, além do eixo das universidades estaduais paulistas, sendo a maioria deles em instituições situadas em capitais. Foram criados três cursos no Sudeste, três no Sul, dois no Nordeste e dois no Centro-Oeste (SUERTEGARAY, 2003, 2007; SILVA e DANTAS, 2005 e SPÓSITO, 2015).

Suertegaray (2007) aponta que até 2005:

\footnotetext{
${ }^{3}$ Sistema Nacional de Pós-Graduação foi orientado pelo Parecer CFE nº 977/65.
} 
Em termos totais a área contava com 32 cursos de mestrado e 15 de doutorado. Estes dados indicam que área tende manter a expansão e, para o futuro próximo prevê-se um incremento de novos cursos de doutorado e uma tendência à interiorização dos cursos de mestrado. Além desta expansão em relação à solicitação de novos mestrados, a demanda cresce a partir das regiões Norte e Nordeste, que ainda apresentam carência de cursos de pós-graduação em Geografia (p.13).

Considerando o processo de deslocamento de profissionais do interior para os programas de pós-graduação, Mendonça (2005) enaltece que:

Tem sido mais fácil o sistema promover o deslocamento de um considerável número de pessoas do "Brasil profundo" (ou hinterland) em direção aos "grandes centros", que criar e implementar programas piloto de formação e pesquisa nas chamadas "áreas (geográficas) carentes". Críticos afoitos concebem este tipo de ação como sendo um novo tipo de "colonialismo interno", nominação fácil que perpetua a geopolítica concentradora e deslocacional. Este processo mais antigo de um tipo particular de colonialismo, parece importante assinalar, não passa somente na reprodução muitas vezes acrítica do "conhecimento" conduzido nas malas em intermináveis viagens e na mente exausta, ele tem que ser permanentemente repetido até às mais distantes fronteiras administrativas e imateriais do território nacional, vangloriado e reificado. Geográfico de primeira grandeza ele torna-se, surpreendentemente, muito mais importante que o próprio lugar (p.9).

Cabe destacar que em 2005 entra em vigor o Plano Nacional de Pós-Graduação (20052010). O diagnóstico que baseia esse documento destaca que:

Ainda que de certa forma os três planos anteriores tenham manifestado preocupações com as mesmas, inclusive com sugestões de políticas direcionadas, a realidade mostra que seus executores não conseguiram implementá-las em sua plenitude. O sistema continua concentrado na região sudeste". Independentemente de políticas direcionadas, nos últimos anos a Região Sul vem encontrando estratégias desenvolvimentistas e consolidando seus programas, de sorte a ocupar hoje lugar de visibilidade no Sistema. O Nordeste alcançou algum destaque, porém, ainda apresenta assimetrias entre os seus estados. No Centro-Oeste o quadro de assimetrias é ainda mais acentuado, uma vez que a pós-graduação concentra-se em Brasília. E no Norte, região de extrema importância nacional pela sua dimensão e diversidade, encontra-se uma pós-graduação incipiente, com concentração em dois estados de uma região de dimensão continental (BRASIL, 2005, p.45).

Desta forma o PNPG (2005-2010) está concentrado na redução de assimetrias regionais da distribuição da pós-graduação no Brasil. Para garantir o "crescimento harmônico" o plano define que as regiões Norte, Nordeste e Centro-Oeste em políticas de fomento à pós-graduação. Também pretendia-se diminuir as assimetrias intra-regionais (p.89). 
Consequentemente no decênio 2000-2009, a Pós-Graduação em Geografia atinge o número de 41 cursos. Nesse período é possível vislumbrar processo de expansão em dimensão nacional. Foram criados seis programas no Centro-Oeste, seis Sul, dois Nordeste, três no Norte e cinco no Sudeste. Esse período é marcado para a expansão de cursos de doutorado (18 cursos) (BRASIL, 2016).

No campo da política da Pós-Graduação, em 2011 entrou em vigor o Plano Nacional de Pós-Graduação (2011-2020). Neste plano foi diagnosticado que as assimetrias entre grandes regiões foram reduzidas, contudo o plano apresenta assimetrias no âmbito das mesorregiões, ou seja, dentro das unidades da federação:

Porém, a mesma análise permite verificar que assimetrias, ele está em grande parte atingido. Porém, a mesma análise permite verificar que todas as unidades da federação possuem mesorregiões com significativas assimetrias nos todas as unidades da federação possuem mesorregiões com significativas assimetrias nos mesmos indicadores, sugerindo que as políticas de indução à redução dessas assimetrias mesmos indicadores, sugerindo que as políticas de indução à redução dessas assimetrias devem contemplar a análise dos indicadores nacionais por mesorregiões brasileiras (BRASIL, 2011).

Desta forma o PNPG (2011-2020), em suas recomendações, propõe a redução de assimetrias em nível mesoregional:

Nos Planos anteriores, a questão das assimetrias foi focalizada tomando-se como parâmetro as regiões e as unidades da federação. No Plano 2011-2020 será adotada a distribuição geográfica por mesorregião. A incorporação desse indicador agrega precisão ao diagnóstico. Com isso, torna-se possível identificar diferentes graus de consolidação na formação de recursos humanos em nível de pós-graduação, desde a incipiência até a excelência, independentemente da unidade da federação ou macrorregião (BRASIL, 2011, p.297).

Assim, se observa o avanço na criação de programas de pós-graduação rumo ao interior, fora das capitais dos estados, bem como em instituições estaduais. De 2010 a 2016 a PósGraduação em Geografia no Brasil envolve 64 cursos. A região Norte apresenta a lacuna de falta de programas no Amapá e Acre, são criados dois cursos novos (UFRR e UFT). Nas demais regiões o movimento de expansão prossegue com a criação de programas de pós-graduação no Nordeste (7), Sul (2), Centro Oeste (3) e Sudeste (7). Ressalta-se também para o aumento do número de cursos de doutorado (35) e para a criação de programas de mestrado profissional (4).

O encontro entre a movimento de renovação da Geografia brasileira e o processo de expansão da pós-graduação em Geografia são de grande importância na compreensão da pesquisa em Geografia no tempo presente. Esse suporte teórico/histórico/institucional permite 
compreender o contexto em que são estabelecidas Geografias da pesca artesanal brasileira. Se de um lado inserem-se atores e contextos sociais que estavam invisibilizados nas análises, por outro lado, a expansão da pós-graduação abre a possibilidade para outros sujeitos se inserirem como pesquisadores e, assim, apresentarem o Brasil a partir da análise de contextos em que estão implicados.

\subsection{Caminho Metodológico}

Na perspectiva do pensamento complexo (MORIN, 1990, 1996, 2008) o método é concebido por meio dos princípios da dialógica, recursão organizacional e holograma. A dialógica é pressuposta no contexto de diálogo, entre pescadores e geógrafos, no qual as pesquisas ocorreram. Também se pressupõe a dialógica entre teorias, métodos e problemáticas comuns. O princípio recursivo se estabelece na medida em que cada etapa da pesquisa incita etapas posteriores. Logo, as categorias dos conteúdos analisados são (re)concebidas a partir do movimento do processo da pesquisa. O princípio hologramático permite pensar o que se chama de "Geografias da pesca", a partir de cada estudo desenvolvido por geógrafos sobre a pesca artesanal. Também a partir de ideias de conjunto da análise é possível estabelecer leituras e propostas analíticas sobre as singularidades dos trabalhos.

As análises desse Capítulo se deram principalmente sobre duas fontes de informação. Os trabalhos realizados pela Geografia brasileira sobre pesca artesanal e as respostas de geógrafos, que pesquisam a pesca artesanal, a um questionário.

\section{Questionários com geógrafos que pesquisam a pesca artesanal}

Para compreender o perfil dos pesquisadores, pesquisas e acessar um maior número de trabalhos realizados (considerando que muitos não estão disponíveis online) foram respondidos questionários pelos pesquisadores vinculados à Geografia, que abordam a pesca artesanal.

Para os questionários utilizou-se uma plataforma online, disponibilizada pelo Google Docs. - Sheets. Dos 96 pesquisadores que foram identificados como autores ou orientadores de trabalhos sobre pesca artesanal ${ }^{4}$ na Geografia, 82 responderam os questionários, destes, 74 foram mapeados. Os questionários foram respondidos de maio a novembro de 2015.

${ }^{4}$ Soube-se posteriormente ao período de respostas dos questionários de outros pesquisadores envolvidos com as problemáticas da pesca artesanal, contudo pode-se inferir que os pesquisadores identificados chegam a $90 \%$ do total existente até 2015. 
Todas as informações respondidas pelos pesquisadores no Google Docs.-Sheets foram automaticamente tabuladas em uma planilha editável no Excel®. As figuras 1 e 2 expõem o diagrama de organização dos questionários.

Ressalta-se que para a análise das questões abertas (figura 2) a exploração material se deu com auxílio do software Nvivo®, que permitiu identificar as questões emergentes (BARDIN, 2007) e a representação através de nuvens de palavras. A partir delas se deu a análise do conjunto das respostas.

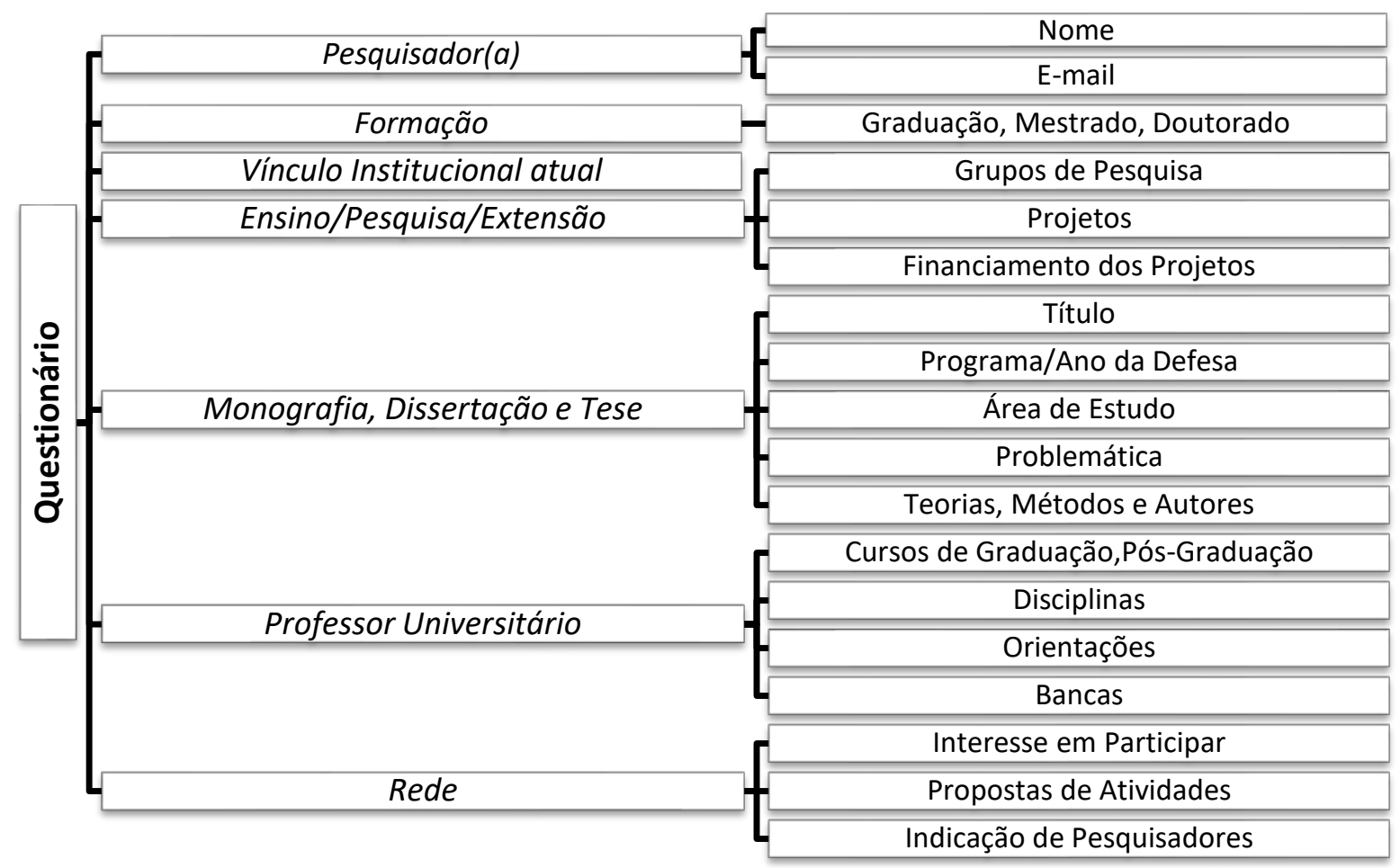

Figura 1: Diagrama de Organização do Banco de Dados do Questionário, questões objetivas Fonte: Elaborado por De Paula (2018). 


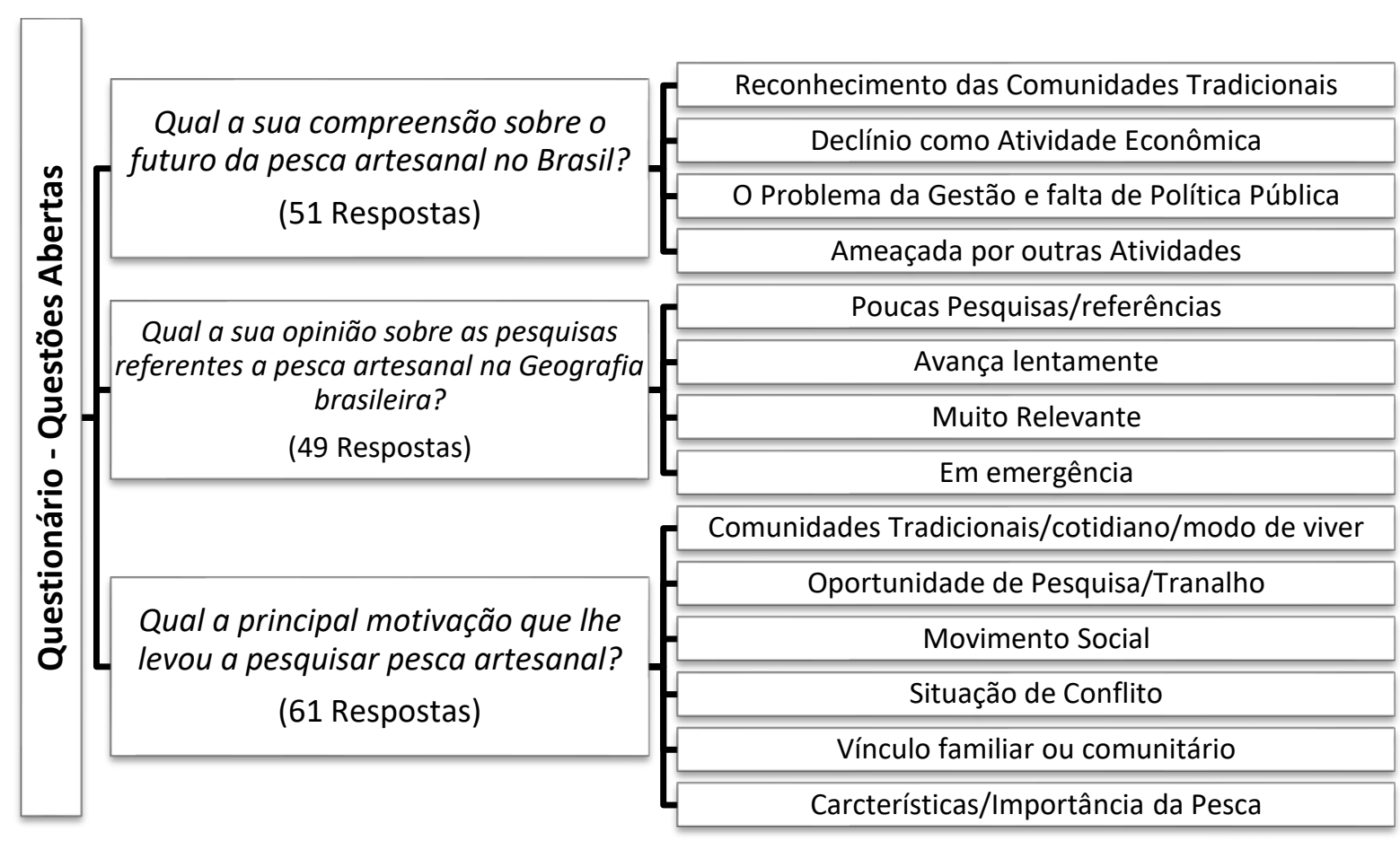

Figura 2: Diagrama de organização do Banco de Dados do Questionário, questões abertas. Fonte: Elaborado por De Paula (2018).

\section{Análise dos trabalhos (dissertações e teses) da Geografia sobre pesca artesanal}

A busca por trabalhados que abordam a pesca artesanal foi realizada em bancos de dados online de teses e dissertações e nos sites dos Programas de Pós-Graduação em Geografia. Também foram considerados os trabalhos de geógrafos, que desenvolveram pesquisa de Mestrado ou Doutorado em Áreas Afins.

Foram identificados 104 trabalhos sobre pesca artesanal na Geografia brasileira, sendo estes: trabalhos de conclusão de curso de graduação e especialização, dissertações de mestrado e teses de doutorado. Destes foi possível ter acesso a 71 trabalhos - Dissertações e Teses. Foram considerados os trabalhos defendidos e disponíveis para consulta até 31 de dezembro de 2015.

A análise das respostas seguiu as orientações da análise de conteúdo. Esta consiste em um conjunto de técnicas de análise de comunicação, visando obter indicadores que permitem a inferência de conhecimentos relativos às condições de produção/recepção dessas mensagens. A principal distinção entre as diversas técnicas de análise de conteúdo seria entre aquelas mais qualitativas, que buscam identificar a presença ou a ausência de certas características no material analisado, e as quantitativas, que investigam a frequência com que aparecem certos termos (CORTES, 1998). 
Para Laurence Bardin (2007) a análise de conteúdo consiste em três procedimentos: a pré-analise, a exploração material e o tratamento dos resultados. Esses devem resultar no levantamento de questões emergentes. A pré-analise e exploração material permitiu estabelecer os principais conceitos, métodos e técnicas de pesquisa. O tratamento dos resultados buscou identificar as abordagens teóricas e metodológicas priorizadas frente às principais problemáticas discutidas.

Em uma planilha do Excel® se estabeleceu um banco de dados com as informações referentes aos trabalhos (figura 3).

Para discutir esses trabalhos no contexto da pós-graduação brasileira foi necessária uma análise complementar. Essa se deu sobre as linhas de pesquisa dos 62 programas de pósgraduação em Geografia, que integraram o Sistema Nacional de Pós-Graduação até 2015. Para a análise material utilizou-se o software Nvivo®, onde verificou-se a frequência de determinados termos e construiu-se nuvens de palavras.

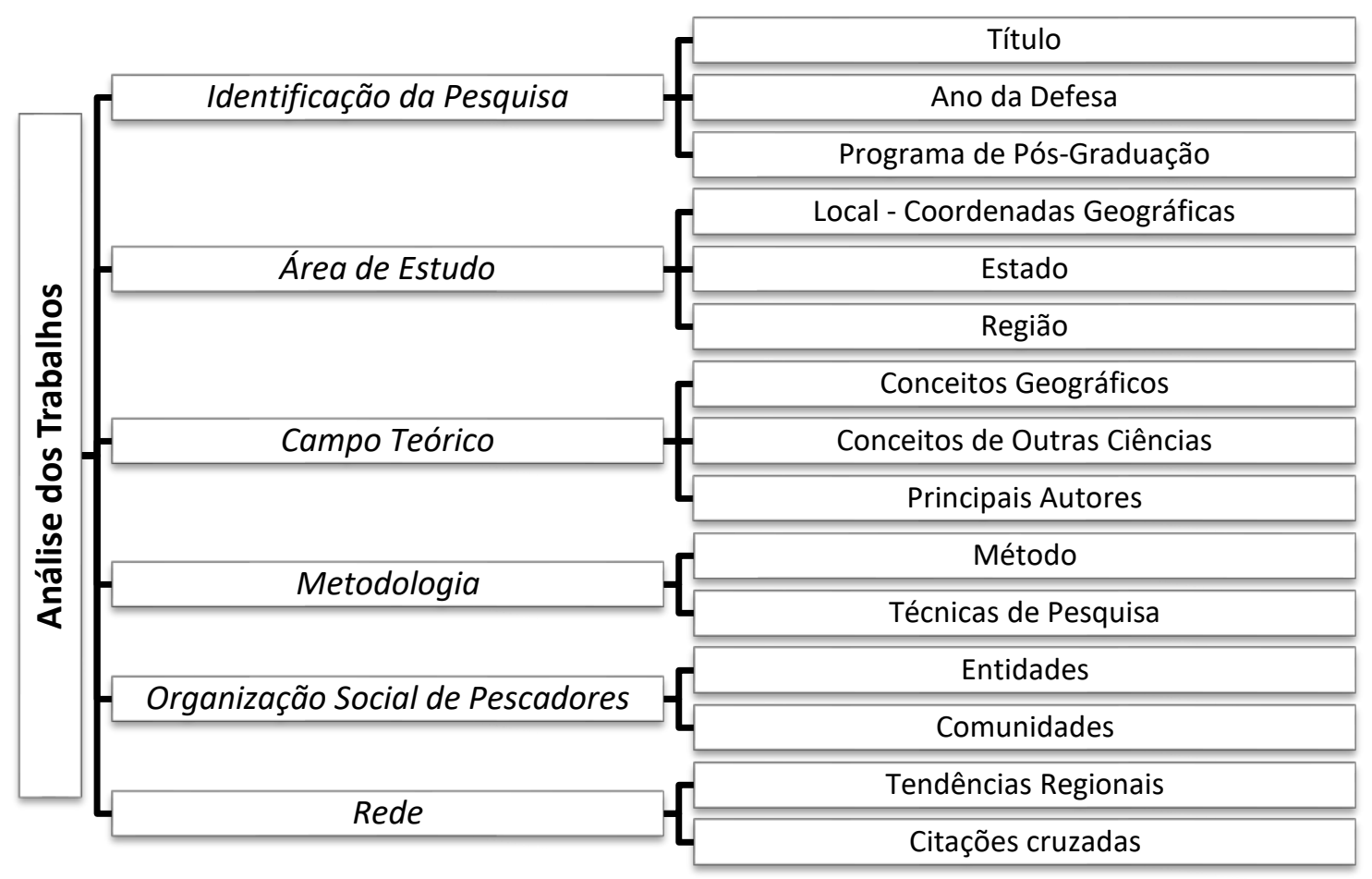

Figura 3: Diagrama da organização do Banco de Dados da análise de Dissertações e Teses Fonte: Elaborado por De Paula (2018).

\section{Representações cartográficas}

Sistematização e georreferenciamento dos resultados:

Para a análise espacial foram criadas três camadas (layers) específicas. A primeira camada se refere às instituições de ensino superior, onde foram realizadas as pesquisas de 
conclusão de curso, dissertações e teses (identificadas nos questionários e na pesquisa bibliográfica). A segunda, contempla as áreas de estudo onde foram realizadas as pesquisas analisadas (na pesquisa bibliográfica e nos questionários). E a terceira camada se refere às instituições, em que estão vinculados os pesquisadores que responderam os questionários (com base nos questionários).

Para os georreferenciamentos destas três camadas distintas, cada ocorrência foi codificada e registrada como "marcador" no Google Earth Pro®. Após essas marcações salvas na aba "meus lugares", as camadas foram arquivadas no formato "kml.", o qual é possível de leitura no ArcGis 10.2.2®. Neste software, o arquivo "kml." foi transformado em camada, sendo que se adotou o datum Sirgas 2000, Zona 22S, para que sejam possíveis correlações com outros bancos de dados, como os do Instituto Brasileiro de Geografia e Estatística - IBGE.

Havendo as camadas (layers) das instituições (PPGs e de vinculo dos geógrafos) e áreas de pesquisa, foram constituídos os shapefiles, ligando tais camadas às tabelas dos bancos de dados da análise de trabalhos e dos questionários, os quais deram suporte às representações cartográficas. Além dos citados layers e shapefiles também foram utilizados shapefiles do IBGE (limites municipais, estaduais, das grandes regiões, do território nacional e da Zona Econômica Exclusiva- ZEE) e dos países vizinhos do Brasil, disponibilizado pela ESRI.

\section{Construção de mapas temáticos:}

Tendo constituído um banco de dados georreferenciado, que integra a análise dos trabalhos (dissertações e teses) e os resultados dos questionários, foram elaboradas representações cartográficas. Estas expõem onde estão os pesquisadores, suas atividades e onde as pesquisas foram realizadas (instituição de pesquisa, área de estudo, município, estado), e quais os principais aportes teóricos e metodológicos em que se baseiam tais abordagens.

Para compreender as instituições que realizaram as pesquisas analisadas, foram construídos mapas por instituição e estado, cuja simbologia foi composta com áreas de intensidade e gráficos de setor. Nestes, constam a participação das instituições de ensino superior que realizaram pesquisas sobre a pesca na Geografia brasileira.

Também foram construídos mapas, cuja simbologia foi composta por áreas de intensidade e gráficos de setor, com base em áreas de pesquisa e estados, que expõem as principais características, conceitos, métodos e técnicas de pesquisa.

Com o objetivo de entender quem são estes sujeitos que abordam a pesca artesanal na Geografia brasileira, foram mapeadas as instituições onde estes se encontram. Assim, foi 
possível apresentar mapas por instituição e por estado, cuja simbologia, áreas de intensidade e gráficos de setor permitiram caracterizar as suas atividades.

Também se construiu mapas de fluxo para evidenciar a relação entre regiões. Esses relacionam áreas de pesquisa e programas de Pós-Graduação, bem como citações (com base na área de estudo) e local em que se encontra o pesquisador.

Para expor determinadas análises no Brasil foi utilizada a ferramenta "spatial analyst" do ArcGis 10.2.2® denominada “densidade de kernel”. Como há uma expressiva concentração das respostas em alguns estados, para a elaboração destes mapas utilizou-se o como base o desvio padrão, isso quer dizer que se considerou dispersão dos valores individuais em torno da média. Estes expuseram a densidade das instituições de pesquisa em que foram realizados os trabalhos, das áreas de estudo, e das instituições onde estão os geógrafos.

\subsection{Instituições onde Foram Realizadas as Pesquisas}

Das pesquisas identificadas sobre a pesca artesanal na Geografia brasileira se observa avanços significativos nos primeiros anos do século XXI. Foram identificadas 104 pesquisas realizadas até 2015 (trabalhos de conclusão de curso, monografias, dissertações e teses). Para a presente análise considerou-se 71 trabalhos, sendo eles dissertação de mestrado (61) e teses de doutorado (10). A escolha das dissertações e teses se deve ao fato de estarem disponíveis em bancos de teses, o que permitiu o acesso aos trabalhos na íntegra.

Cabe destacar a densidade (figura 4) muito alta desses trabalhos nas Instituições de Ensino Superior do Sul, Sudeste e Nordeste brasileiro. No Norte do país e no Centro-oeste a densidade é considerada moderada. A área de densidade baixa se refere à onde não ocorrem instituições que realizaram estudos sobre a pesca artesanal. 


\section{GEOGRAFIAS DA PESCA ARTESANAL BRASILEIRA:}

Densidade de Programas de Pós-Graduação em Geografia Onde Foram Realizadas as Pesquisas

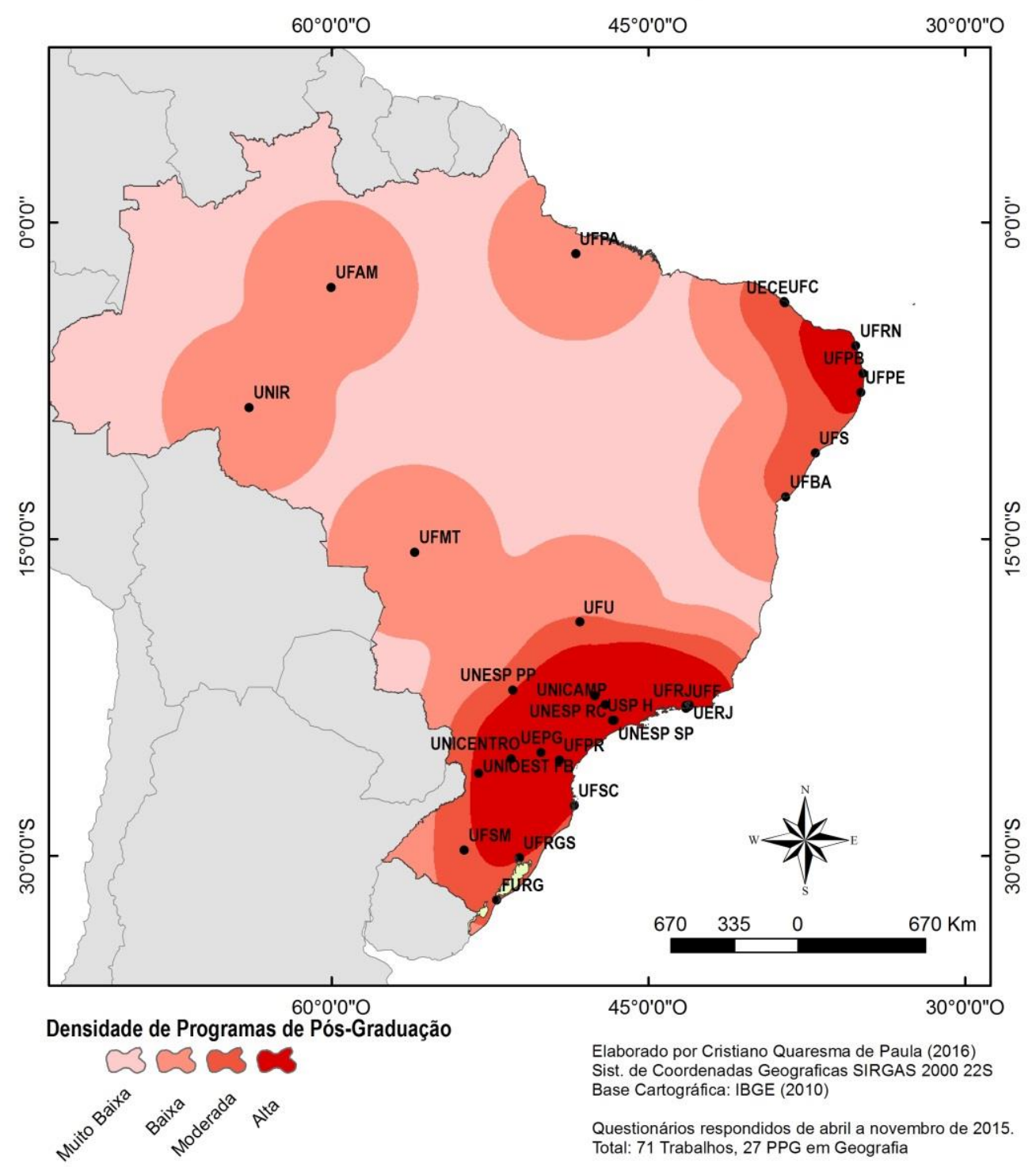

Figura 4: Mapa de Densidade de Programas de Pós-Graduação onde Foram Realizadas as Pesquisas.

Fonte: Elaborado por De Paula (2018).

É importante observar a predominância das pesquisas de mestrado no universo analisado $(85,92 \%)$ no Brasil. As pesquisas de doutorado também são frequentes $(14,08 \%)$ do total identificado. Considerando também as respostas dos questionários é necessário frisar que existem mais pesquisas sendo realizadas, contudo, para esta análise, considerou-se somente as defendidas até dezembro de 2015. Outros tipos de pesquisa ocorrem, como de pós-doutorado e monografias de conclusão de curso, entretanto, pela dificuldade de acesso aos materiais na íntegra, se optou por restringir a análise às teses e dissertações. 
Agora, tratando especificamente dos trabalhos que foram considerados na análise, será percorrida uma periodização por instituição e estado (figuras 5 e 6). No período de 1982 até 2000, no universo analisado foram defendidas Dissertações na UFPE, UFF e na USP Geografia Humana (3), totalizando cinco dissertações. Até o ano 2000 ainda não se encontrou nenhuma defesa de tese que abordasse a pesca artesanal.

De 2001 a 2005 foram defendidas duas dissertações e três teses. As dissertações foram apresentadas na UFC, UNESP de Presidente Prudente e USP - Geografia Humana. Das teses, cabe destacar que duas foram defendidas em programas de pós-graduação de outras áreas e uma na Geografia Humana da USP. Ressalta-se que, em 2001, foi defendida na Geografia Humana da USP a Tese do Doutor Eduardo Schiavone Cardoso, primeiro a abordar a pesca no Brasil como um todo.

De 2006 a 2010 há um salto de trabalhos realizados sobre pesca na Geografia Brasileira. Neste período foram defendidas 21 dissertações, na UFAM (2), UFBA (2), UECE, UFC, UFRN (2), UFPA (3), UFPE, PUC Rio, UNIOESTE Francisco Beltrão, FURG, UFRGS, UFSM, UFSC (2), e duas em programas de pós-graduação de fora da Geografia. Ainda foram defendidas duas na Geografia Humana da USP.

Esse período foi muito significativo no que se refere à expansão das pesquisas em Geografias da pesca. Enaltece-se a expansão nesse período entre os estados do Nordeste brasileiro, sobretudo nos cursos de mestrado. Contudo, ainda as teses de doutorado e pósdoutorado que ocorrem estão limitadas ao estado de São Paulo, principalmente à Geografia Humana da USP.

De 2011 a 2015 foram defendidas 33 dissertações e 5 teses. Os Trabalhos foram apresentados na FURG (3), PUC Rio, UEPG, UERJ, UFAM (2), UFBA (2), UFC (2), UFF, UFMT (3), UFPA, UFPB, UFPE, UFPR, UFRGS, UFRJ (2), UFS, UFSM, UFU, Unicamp (2), Unicentro, UNIOESTE de Francisco Beltrão e em outro programa externo à Geografia. As teses foram defendidas na UECE, UFF, UNESP Rio Claro, USP Geografia Humana e em outro programa de pós-graduação.

Neste período, continua a expansão das pesquisas sobre pesca artesanal na Geografia em todos os níveis da formação. É um período em que ocorreu defesa de dissertações em todas as regiões brasileiras. Também houve a expansão nas pesquisas de doutorado para outras regiões além da Sudeste.

Já estão mapeados (através dos questionários) 12 trabalhos que deverão ser defendidos entre 2016 e 2020. Quanto a esse período cabe frisar a expansão das pesquisas em nível de 
doutorado (9). Estes devem ser defendidos na UFRGS, UEL, UNESP Presidente Prudente (2), UERJ Maracanã, UFF, UFG, UFBA e UFPE. Ainda estão serão defendidas duas dissertações de mestrado na UFS e UFAM. Assim, se observa a expansão das pesquisas de doutorado em outras regiões brasileiras.

\section{GEOGRAFIAS DA PESCA ARTESANAL BRASILEIRA:}

Período em que as Pesquisas Foram Realizadas, por IES

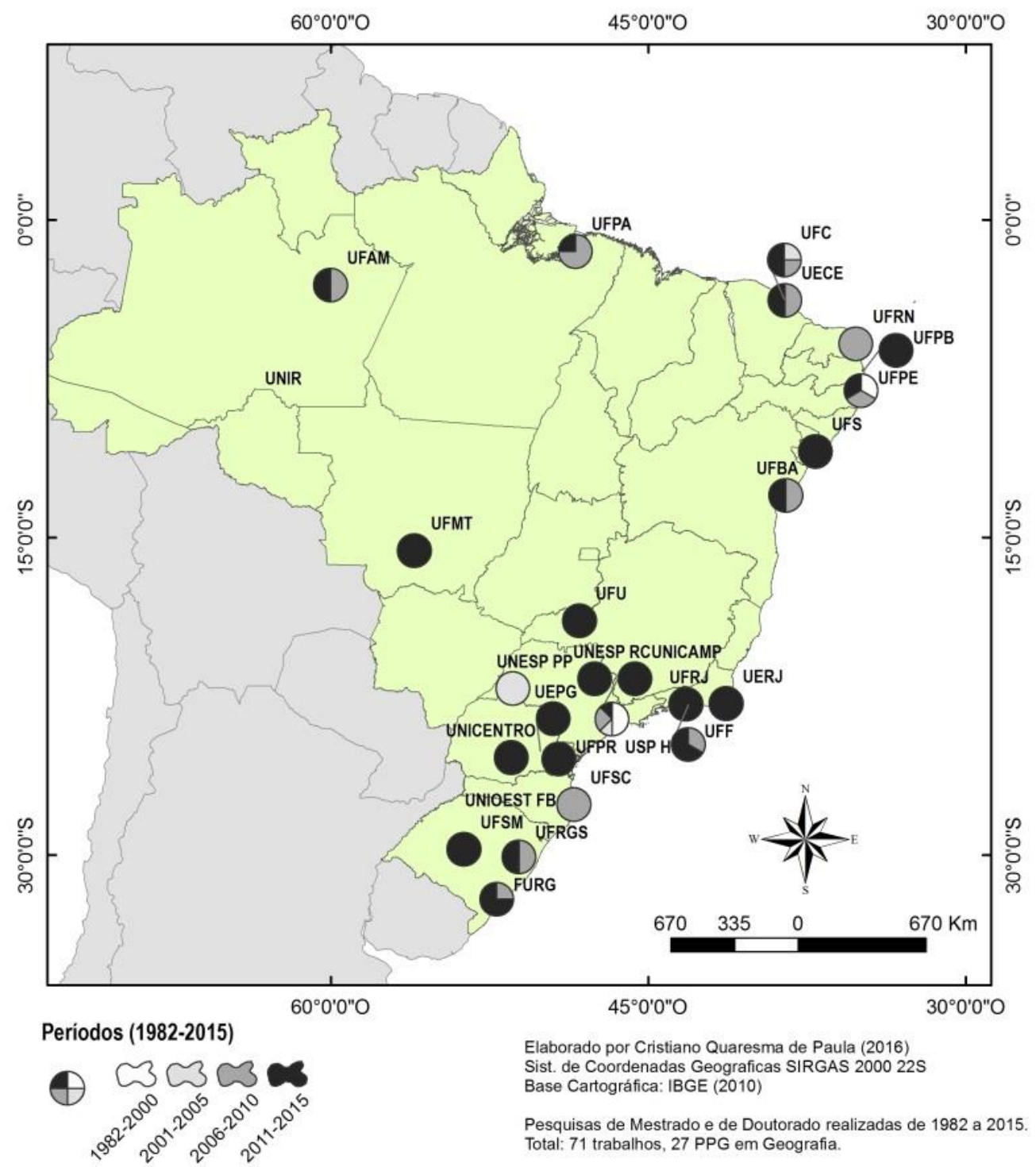

Figura 5: Mapa da Periodização das Pesquisas por Instituição de Ensino Superior.

Fonte: Elaborado por De Paula (2018). 


\section{GEOGRAFIAS DA PESCA ARTESANAL BRASILEIRA:}

Periodos em que as Pesquisas Foram Apresentadas, por UF

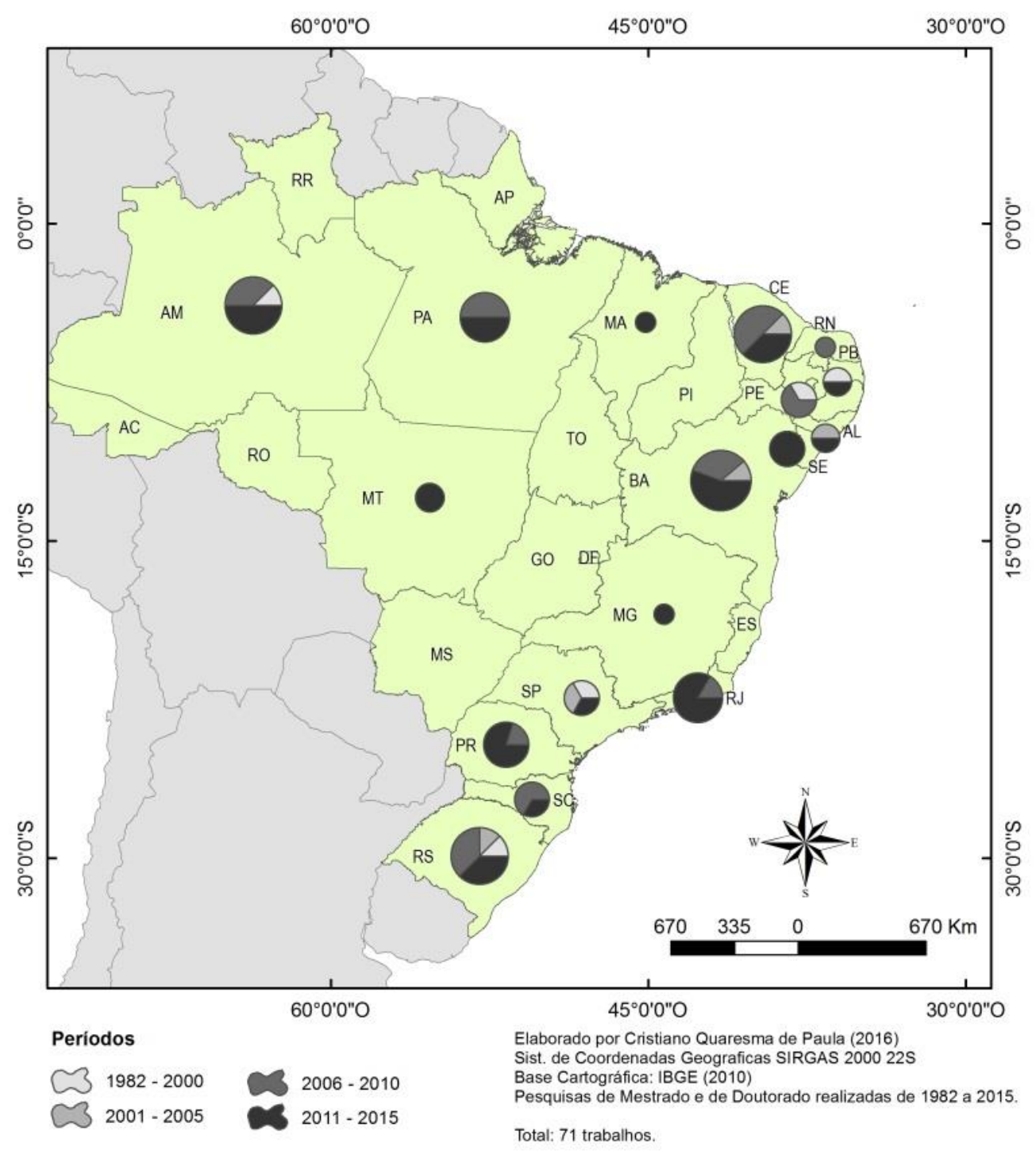

Figura 6: Mapa da Periodização das Pesquisas por Unidade da Federação.

Fonte: Elaborado por De Paula (2018).

Para pensar essa periodização da realização das pesquisas sobre pesca artesanal na Geografia brasileira é fundamental resgatar Suertegaray (2003, 2007), Mendonça (2005) Silva e Dantas, (2005) e Spósito (2015) que discutem a expansão da Pós-graduação em Geografia no Brasil. Nesse sentido cabe enfatizar os Planos Nacionais de Pós-Graduação (2005-2010) e (2010-2020) que fomentaram a expansão da pós-graduação em nível regional e mesoregional, respectivamente. Nesse sentido a expansão das pesquisas está diretamente relacionada com políticas de Estado, que nesse caso tinha um horizonte de expansão até 2020, mas é 
interrompida em 2016 com o Golpe de Estado que destituiu a Presidente Dilma Rousseff (GUILHERME, 2017). Como esse processo analítico se encerrou em 2015, não foi possível avaliar a repercussão dos cortes em "gastos" públicos no setor de ciência, tecnologia e inovação, do novo Governo, sobre as pesquisas em Geografias da Pesca.

Outro favor que se entende que tem propiciado o aumento maior no número de pesquisas em alguns programas de pós-graduação em detrimento de outros se refere à pluralidade de abordagens, característica do momento atual da Geografia brasileira (MORAES, 2005). Isso se evidencia nas linhas de pesquisa dos programas de pós-graduação, que estão relacionadas aos grupos de pesquisa, orientações, disciplinas ofertadas, etc. As nuvens de palavras evidenciam distinções em nível regional (figuras 7, 8, 9, 10 e 11).

A região Norte (figura 7), tem a imergência na discussão sobre a gestão do Território, no âmbito da pós-graduação. Nessa região também há grande interesse nos estudos a respeito da Natureza, a qual se expressa na Paisagem da Amazônia. Destaca-se relevância do conhecimento constituído sobre a Amazônia e pelos amazônidas, intensamente fomentados por editais próprios decorrentes do PNPG (2005-2010). Apesar de ser uma região menos representativa, em número de programas de pós-graduação, observa-se um diálogo profícuo com a proposta da tese - por isso a sua evidencia nos trabalhos analisados-.

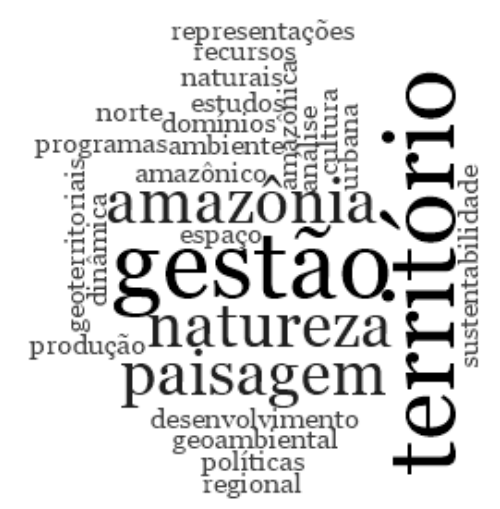

Figura 7: Nuvem de Palavras, Linhas de Pesquisa dos PPGs (Geografia) da região Norte Fonte: Elaborado por De Paula (2018).

A região Nordeste (figura 8), a qual expõe um número significativo de pesquisas, também é favorecida no que diz respeito às linhas de pesquisa dos programas de pós-graduação. A questão Territorial é enaltecida nos estudos que pretendem analisar a dinâmica de produção do espaço. Nesse sentido cabe destacar as particularidades regionais evidenciadas nas linhas de pesquisa, como a situação de diversas cidades litorâneas, as políticas públicas, o 
desenvolvimento e o planejamento. A natureza se exprime na análise da paisagem, das características ambientais, por meio de diversas metodologias.

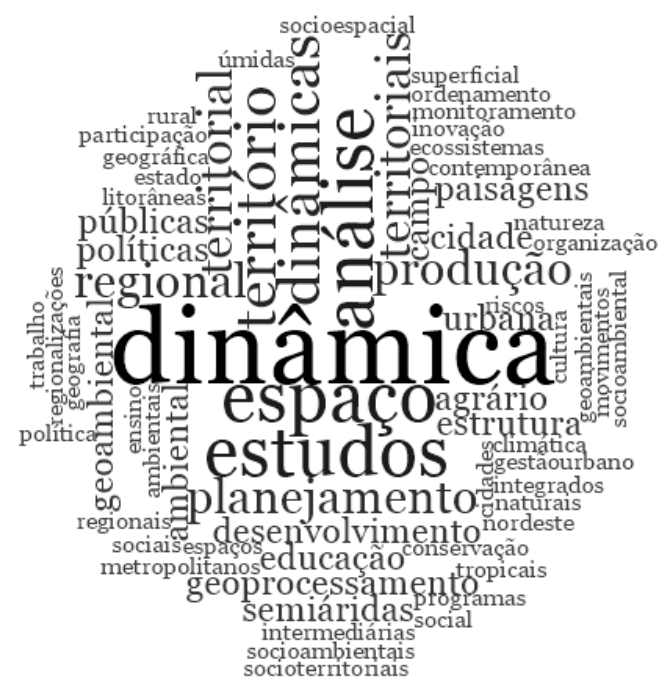

Figura 8: Nuvem de Palavras, Linhas de Pesquisa PPGs (Geografia) da região Nordeste Fonte: Elaborado por De Paula (2018).

A região Centro-Oeste (figura 9) teve menor presença entre os trabalhos analisados e entende-se que há relação com as linhas de pesquisa dos programas. As propostas de pesquisa estão muito centradas na análise do espaço e do ambiente, de forma que enfatiza dinâmicas de gestão, planejamento, produção, ordenamento e representação. A análise ambiental se evidencia no sentido do uso de geotecnologias, e da repercussão de políticas.

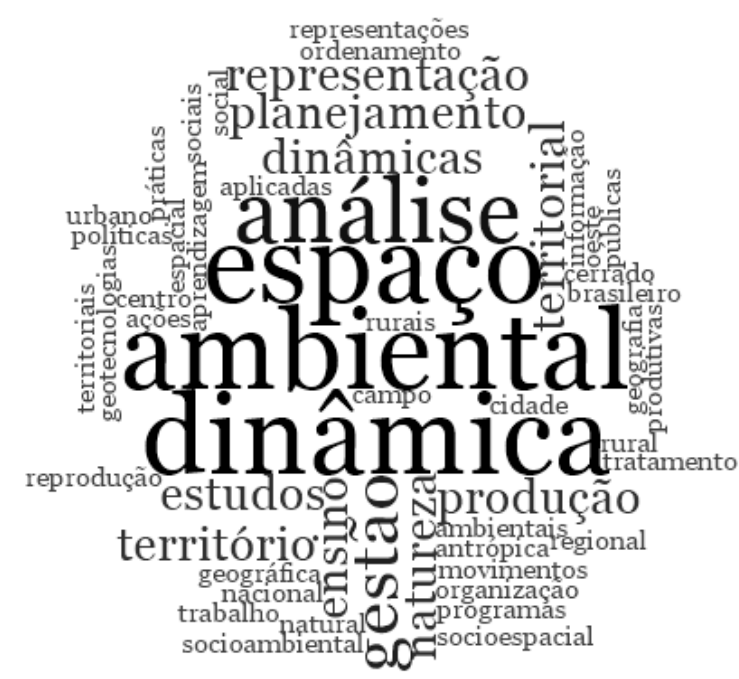

Figura 9: Nuvem de Palavras, Linhas de Pesquisa dos PPGs (Geografia) região Centro-Oeste Fonte: Elaborado por De Paula (2018).

A região Sudeste (figura 10) concentra um maior número de programas de pósgraduação, portanto a diversidade de linhas de pesquisa complexifica a análise. Entende-se que 
a falta de evidencia de pesquisas sobre a pesca artesanal se deve principalmente a grande diversidade de problemáticas pesquisadas. Percebe-se que a própria Geografia estão em questão nas pesquisas. Também aborda a produção do espaço, principalmente urbano. Contudo a dinâmicas ambientais e territoriais também têm importância no âmbito da pesquisa, assim como da natureza, da paisagem e da região. Está bastante presente a relação entre urbano e rural, e estabelece pesquisas com grande diversidade de métodos e técnicas.

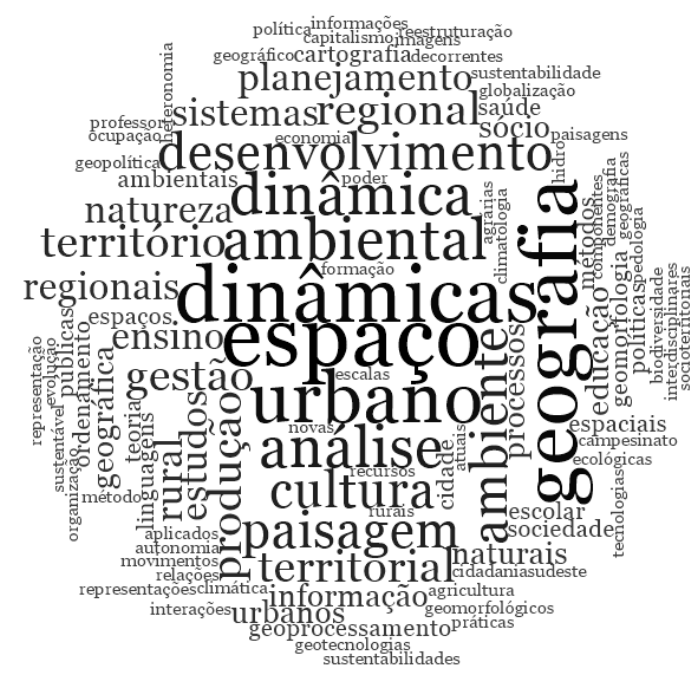

Figura 10: Nuvem de Palavras, Linhas de Pesquisa dos PPGs (Geografia) região Sudeste Fonte: Elaborado por De Paula (2018)

Na região Sul (figura 11) têm destaque as pesquisas que analisam dinâmicas do ambiente, e produção do Espaço, principalmente urbano. Há também foco em estudos regionais, como situações de fronteira e de estudos da natureza (geomorfologia, geologia, oceanografia). Também se destacam pesquisas que abordam questões territoriais e representações sociais.

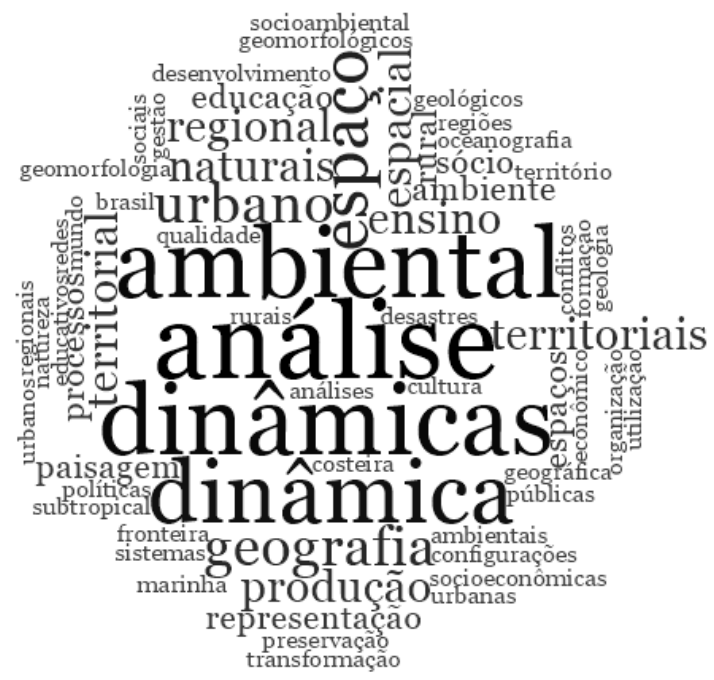

Figura 11: Nuvem de Palavras, Linhas de Pesquisa PPGs (Geografia) região Sul Fonte: Elaborado por De Paula (2018). 
Esse panorama das linhas de pesquisa é fundamental para compreender as abordagens teóricas que se expressam nos trabalhos, bem como entender em que medida a linha de interpretação proposta para as "Geografias da Pesca" têm aderência nos programas de pósgraduação.

\subsubsection{Motivação para pesquisar a pesca artesanal}

Considerou-se relevante, nesse momento, expor as motivações que levaram os pesquisadores a estudarem a pesca artesanal. No questionário respondido por geógrafos apresentou-se o seguinte questionamento: Qual a sua principal motivação para pesquisar a pesca artesanal na Geografia? No total, 61 pesquisadores responderam essa questão. A nuvem de palavras (figura 12) expõe o conteúdo dessas respostas.

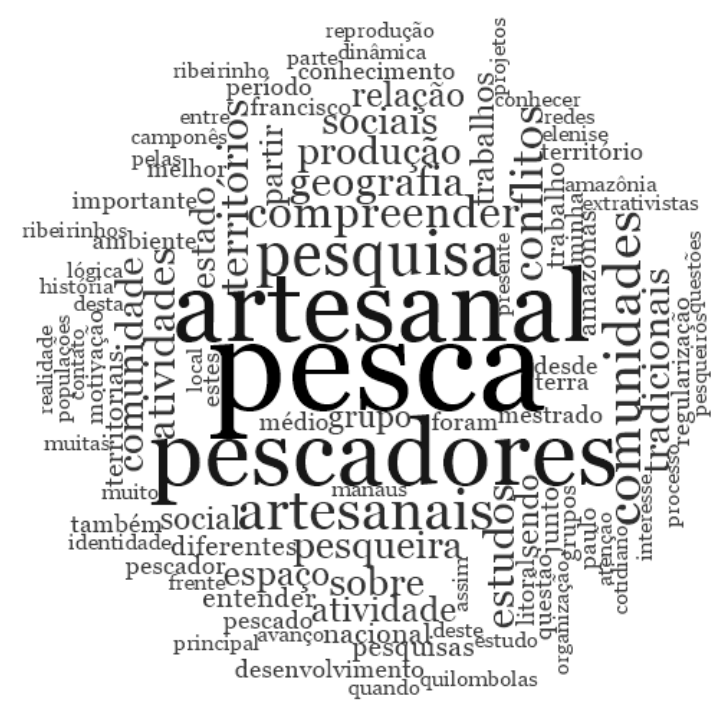

Figura 12: Nuvem de Palavras "Motivação para pesquisar a pesca artesanal na Geografia" Fonte: Elaborado por De Paula (2018).

Para essa questão, as principais respostas foram: i. Interesse pelo modo de viver das comunidades tradicionais; ii. Devido a uma oportunidade de pesquisa ou trabalho; iii. A partir de uma situação de conflito; iv. Pelas características da pesca artesanal; v. Por ter vínvulo familiar/comunitário com a atividade; vi. e Envolvimento com o movimento social.

\section{i. $\quad$ Modo de viver e cultura das comunidades tradicionais}

Entre os pesquisadores, 24,59\% começaram a pesquisar a pesca artesanal devido ao interesse pelo modo de viver e cultura das comunidades tradicionais. Ressalta-se que, até mais 
do que a pesca, tem surgido diversos trabalhos sobre comunidades tradicionais e povos originários. Isso tem instigado muitos pesquisadores a compreenderem melhor as relações sociais, relação com a natureza e expressões culturais. Além disso, há uma série de leis nacionais e acordos internacionais que garantem direitos específicos a essas comunidades, o que provoca muitos pesquisadores a estudarem o processo de (re)invenção dos grupos sociais a partir da cultura, passando a acessar direitos de comunidades tradicionais.

A partir do vínculo institucional atual, observa-se que esses pesquisadores têm elaborado um importante acervo de compreensões sobre os pescadores, como comunidades tradicionais. É importante ressaltar que essa abordagem tem um importante viés político, pois tal definição já garantiu aos indígenas e quilombolas o direito de usar o território tradicional. Sendo assim, a Geografia dos povos tradicionais se encontra na perspectiva crítica, que reconhece sujeitos sociais invisibilizados. Tal visibilidade se dá por meio de projetos de pesquisa e extensão.

Os pesquisadores motivados pelos estudos desses aspectos são predominantes na região Nordeste, mas também são expressivos no Sudeste e Sul. Jamile Araújo Rodrigues (Bahia) destaca que:

A atividade pesqueira artesanal está diretamente liga a cultura nordestina, sendo base da economia de muitas comunidades e está sendo cada vez mais agredida e de diversas formas e por diferentes setores. Portanto, há necessidade de pesquisas para conter essas interferências.

Ressalta-se que diversos pesquisadores estão interessados em pesquisar a pesca artesanal com base no cotidiano das comunidades de pescadores, como Eline Almeida Santos (UFS) e Anelino Silva (UFRN). Suana Medeiros Silva (UFPE) expõe "O interesse pela comunidade em questão seu modo de vida e sentimento de pertencimento ao lugar e à pesca artesanal".

\section{ii. Oportunidade de pesquisa ou trabalho}

Os pesquisadores que se integraram na pesquisa sobre pesca artesanal a partir de uma oportunidade de pesquisa ou trabalho, correspondem a $24,59 \%$ do total das respostas e estão evidentes em todas as regiões, sendo que predominam na região Sudeste, mas também são expressivos no Nordeste.

Nesse sentido é fundamental destacar o papel dos grupos e projetos de pesquisa como possibilidade de visibilidade das problemáticas da pesca artesanal e, assim, de envolvimento de novos pesquisadores. Como foi mapeado, ainda não são muitos os grupos de pesquisa 
envolvidos, contudo, se observa já resultados importantes como projetos de pesquisa e extensão, bem como dissertações e teses sobre a pesca artesanal brasileira. Além dos grupos, cabe enfatizar a atuação profissional do geógrafo que, por vezes, lhes coloca em contato com os pescadores - como foi apontada a diversidade de instituições -.

Diversos pesquisadores destacam seu envolvimento a partir do Grupo de Pesquisa, como Marina Morenna Alves de Figueiredo (COSTEIROS - UFBA) e Ana Gloria Cornelio Madruga (UFPB). Rodrigo Corrêa Euzébio (NUTEMC - UERJ) destaca sua inserção a partir do grupo de pesquisa:

Conheci a pesca artesanal participando das atividades de pesquisa junto ao NUTEMC. Nesse momento me interessei pela forma criativa com que as pessoas que vivem da pesca artesanal estabelecem sua existência. Por essa razão, passei a estudar com mais profundidade as técnicas de pesca, num esforço de compreender como essas pessoas se inserem na dinâmica metropolitana, absorvendo as inovações tecnológicas e criando alternativas para reinventarem suas existências.

\section{Outros, como Ricardo Augusto Souza Machado (UEFS) e Catherine Prost (COSEIROS}

-UFBA) se envolveram com a pesquisa em pesca artesanal a partir de atividade profissional. Carla Ramoa (UFRJ) destaca seu envolvimento com a pesca a partir de uma atividade profissional: "Trabalhei durante anos produzindo mapas para a Petrobras, que, assim como outras instituições enxergam, muitas vezes, o espaço como socialmente vazio. Sendo assim, quis fazer uma cartografia "do avesso" revelando o discurso de quem realmente vivia nos espaços".

Ressalta-se que em algumas situações, a pesquisa que apresentou a pesca artesanal aos pesquisadores tem abordagem completamente distinta do que se direcionaria sua trajetória, como é o caso de Ingrid Regina da Silva Santos (UFG):

No período em que estive participando do Projeto "Nutrientes e pesticidas nas águas superficiais das principais bacias do Pantanal setentrional: uma abordagem integrada" me envolvi na busca pela compreensão da percepção de diferentes atores sociais utilitários do Rio Cuiabá, para as mudanças nesse importante afluente. A partir desta oportunidade fui me enveredando aos estudos com os ribeirinhos do pantanal por compreender que, no contexto do estado de Mato Grosso, os ribeirinhos são os mais prejudicados com as mudanças no ambiente.

\section{iii. Situações de conflito}

Entre os pesquisadores $22,95 \%$ relatam que iniciaram seu envolvimento com as discussões sobre a pesca artesanal a partir de situações de conflitos. Essa motivação é 
predominante entre os pesquisadores da região Norte, mas também é expressiva nas regiões Nordeste, Sudeste e Sul.

Como vem sendo destacado, as Geografias da Pesca, no âmbito do pensamento geográfico crítico tende a expor condições de conflitos em que estão situados os pescadores artesanais. A existência de grupos e projetos de pesquisa que abordam tais conflitos tem atraído pesquisadores interessados por essa dinâmica da sociedade. Sendo assim, a pesquisa parte de uma problemática do real, que encontra espaço de discussão no meio acadêmico.

Cabe enfatizar que na região Norte, a motivação para pesquisar diz respeito aos conflitos entre pescadores no uso dos espaços aquáticos comuns como apresenta Gleison Rodrigues (UEA) e Georgete Cabral de Abreu (CREA AM). Dilson Gomes Nascimento (UFAM) enfatiza que

Sobretudo as transformações ocorridas na pesca na Amazônia entre os camponeses, pois esta, a partir da década de 1960 principalmente, sofreu várias modificações com a introdução das linhas sintéticas utilizadas nas confecções das redes artesanais de pesca, com o surgimento do gelo e dos frigoríficos que compram e exportam o pescado, etc.

Júlio César Suzuki (USP) se interessa por "discutir a situação subalterna em que se encontram os pescadores artesanais do estado de São Paulo, bem como em contribuir com projetos que possam ajudá-los no que considerem como importante". Nesse sentido, Nathalia dos Santos Lindolfo (NUTEMC - UERJ FFP) destaca a importância de "Compreender os impactos da reestruturação urbana na vida dos pescadores artesanais”. Antonio Lopes Ferreira Vinhas (SEEDUC RJ) destaca a "industrialização e construções de portos, criando uma área de exclusão de pesca”.

César Augusto Ávila Martins (NAU - FURG) destaca seu envolvimento a partir do horizonte de pesquisa que evidenciava conflitos:

A pesquisa realizada na década de 1990 estava ligada ao debate daquele período sobre as estratégias de reprodução simples e ampliada das classes subalternas na lógica do desenvolvimento desigual e combinado do modo de produção capitalista na formação social brasileira. Havia um discurso hegemônico sobre a extinção de determinadas formas de produção na lógica do processo de modernização com base na elevação das forças produtivas que ignorava a distinção entre a produção e reprodução do capital em suas múltiplas escalas. A pesquisa baseada no materialismo histórico e dialético radicalizou a explicação no entendimento da lógica da realidade e, ao mesmo tempo em que abriu um leque para estudos posteriores, passou a ser ignorada por evitar projeções e a adoção de perspectivas salvacionistas. 


\section{iv. Características da pesca}

Ainda $11,49 \%$ dos pesquisadores informaram que a motivação em estudar a pesca artesanal se deve às suas características, tanto como atividade econômica quanto pela relação com os ecossistemas. Essa motivação é mais expressiva na região Nordeste.

A diversidade de projetos de pesquisa e extensão presentes nos grupos de pesquisa, bem como as possibilidades decorrentes da orientação em nível de pós-graduação, têm permitido aos pesquisadores abordarem questões características da pesca (gerais), como relação dos pescadores com o ambiente enquanto extrativistas, seja nuances observados regionalmente e localmente. Isso tem permitido pensar a pesca artesanal brasileira.

Janaina Barbosa da Silva (UFCG) ressalta seu interesse em compreender a relação da comunidade com o ecossistema do manguezal. Cleidinilson de Jesus Cunha (UECE) ficou instigado pela complexa relação entre pesca e vazão do rio São Francisco:

\footnotetext{
A pesca artesanal envolve diversidade e complexidade, especialmente pelo fato de estudá-la na perspectiva de agroecossistemas tradicionais, bem como associá-la com a regularização da vazão do rio São Francisco. Outro aspecto é a perda de identidade que a pesca artesanal vem passando em várias regiões do país em virtude da introdução de atividades 'modernas'.
}

Eneias Barbosa Guedes, ficou motivado por estudar a pesca, devido a importância dessa atividade extrativista para o estado do Pará e pela falta de reconhecimento dos pescadores: "o estado do Pará é um dos grandes produtores extrativos do pescado. Contudo, os pescadores não têm tido espaço para falar sobre suas demandas e isso tem me chamado atenção para fazer investigação.

\section{v. Vínculo com a atividade}

Em menor número, mas de grande importância, 11,48\% dos pesquisadores informaram que pesquisam a pesca artesanal devido a terem vínculo, por ser de origem de família de pescadores e/ou de comunidade de pescadores. Esse vínculo está mais presente em pesquisadores das regiões Sudeste, Sul e Centro-Oeste.

Destaca-se a presença de pescadores-pesquisadores como algo sui generis na Geografia brasileira, somam-se a esses, pesquisadores que fazem parte de família de comunidades de pescadores. Ressalta-se as possibilidades que se abrem de aprendizados dentro dos próprios grupos de pesquisa, onde a Geografia acadêmica se encontra com a experiência vivida. Nesse sentido a presença da pesca artesanal, em grupos, projetos, discussões da pós-graduação também abre portas para esses sujeitos. 
Três dos pesquisadores destacam que são pescadores, entre eles Carlos Roberto Scheibel (SEED Paraná). Cleyton Luiz Pies (UNIGUAÇU) destaca que:

Sempre fui pescador artesanal. Dependi da pesca para cursar minha faculdade, a cada dia vinha percebendo a diminuição de indivíduos por espécies nativas. Notando as dificuldades com a reprodução de peixes em tanques-redes busquei na pesquisa com os pescadores possíveis soluções para ser viável a engorda de pescado em tanques, que viria suprir a falta de pescados no reservatório aumentando a renda de sua família.

Zenildo Crisostomo Prado (UFMT) pesquisa a pesca artesanal "Por ter em minha construção enquanto sujeito forjada na relação com o camponês ribeirinho que vive da pesca, e por entender que o rio é um espaço coletivo que tem garantido alimento e possibilitado a continuação do modo do camponês ribeirinho, tem sofrido serias interferências que pode estar comprometendo a vida do camponês ribeirinho".

Ainda três pesquisadores se mostraram motivados por serem de origem de família de pescadores artesanais. Larissa Tavares Moreno (UNESP PP) destaca que: “A pesca artesanal sempre esteve presente no meu universo pessoal, venho de uma família de pescadores. Além desta motivação, sempre me preocupei em minimamente denunciar as injustiças e expor pelo viés dos pescadores suas lutas e resistências frente a todo um degradante aparato mercadológico e institucional".

\section{vi. Envolvimento com movimento social}

Ainda são poucos os pesquisadores que informaram a motivação de realizar a pesquisa em pesca artesanal estar associada ao envolvimento com movimento social - 4,92\%. Destacase as pesquisadoras do GeograFar - UFBA e sua relação com o Movimento dos Pescadores e Pescadoras Artesanais - MPP.

Nesse sentido é fundamental destacar o posicionamento dos grupos de pesquisa frente aos movimentos sociais e disponibilidade de diálogos. Pesquisadores e grupos quando debatem com movimentos sociais, iniciam processos dialógicos que são enriquecedores, tanto para a pesca quando para a Geografia, pois gera ressignificações.

Kássia Aguiar Norberto Rios (UFRB e GeograFar-UFBA) destaca seu envolvimento com o MPP: "As contradições sociais, ambientais, econômicas e culturais que envolvem a pesca artesanal. Desde 2004, tais questões me chamaram atenção no desenvolvimento de alguns estudos e pesquisas. Com a aproximação do MPP, desde 2009 tais questões foram fomentadas e novos estudos foram construídos". 
Guiomar Germani (GeograFar - UFBA) enfatiza a mobilização de pesquisadores em atividade do movimento social:

Também cabe registrar que este processo foi muito enriquecido pelas trocas estabelecidas com outros pesquisadores e grupos de pesquisa e junto temos conseguido estabelecer atividades que envolvem diferentes áreas do conhecimento e onde a Geografia é constantemente desafiada para melhor entender os conflitos que tem como base e origem as disputas territoriais. A exemplo do envolvimento na Campanha Nacional de regularização de seus territórios onde os mapeamentos são produtos e processos importantes tanto para o grupo social se reconhecer como para a sociedade reconhecê-los.

Diante do exposto, se percebe que o envolvimento dos geógrafos com as problemáticas da pesca artesanal é profícuo na medida em que existem possibilidades de inserção. A sociedade em si apresenta problemáticas à Geografia (aspectos culturais, situações de conflito, questões econômicas, etc.). Contudo, cada vez mais a Geografia tem que constituir um contexto de abertura para tais problemáticas (grupos, projetos, orientações em pós-graduação, etc.) de forma que a pesca se expresse na construção do conhecimento geográfico.

\subsection{Pesquisadores e instituições que abordam a pesca artesanal}

Os pesquisadores que responderam os questionários (74 respostas) estão vinculados a 54 instituições. As figuras 13 e 14 apresenta a distribuição dessas instituições no Brasil. Em cada instituição mapeada responderam de um a cinco pesquisadores. A instituição de onde surtiram mais respostas é a UERJ-FFP, seguida da UFBA e FURG.

A maioria dessas instituições, onde estão os pesquisadores, são Universidades Federais $(41,89 \%)$. Também são numerosos os pesquisadores que estão vinculados às Universidades Estaduais (28,38\%). Os demais estão vinculados à Instituições de Educação Básica (12,16\%), Institutos Federais (6,76\%), Universidades Particulares (4,05\%) e Institutos de Pesquisa $(4,05 \%)$ e Consultorias $(2,70 \%)$. 


\section{GEOGRAFIAS DA PESCA ARTESANAL BRASILEIRA:}

\section{Questionários Respondidos, por instituição}

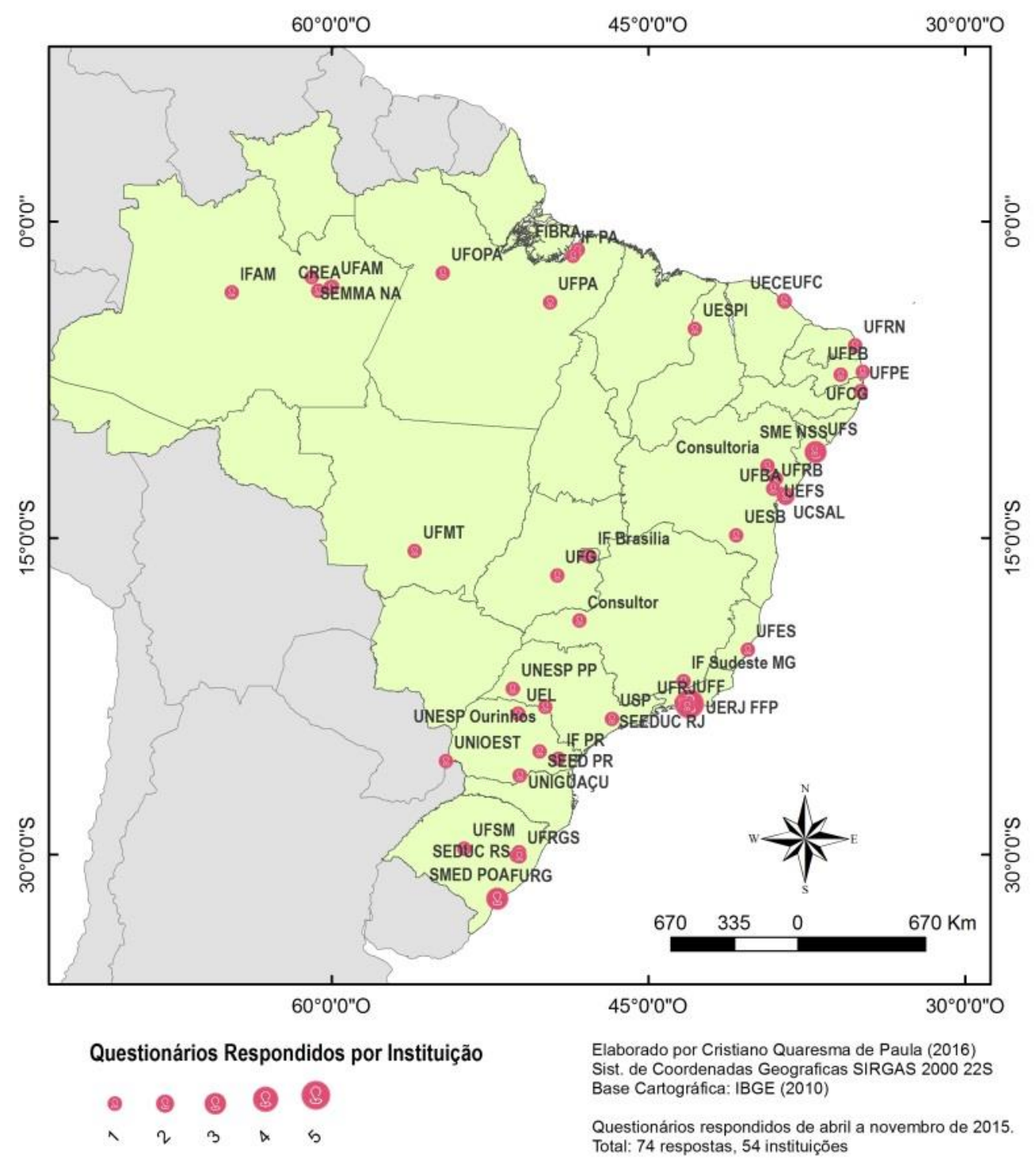

Figura 13: Mapa de Questionários Respondidos, por Instituição

Fonte: Elaborado por De Paula (2018) 


\section{GEOGRAFIAS DA PESCA ARTESANAL BRASILEIRA:}

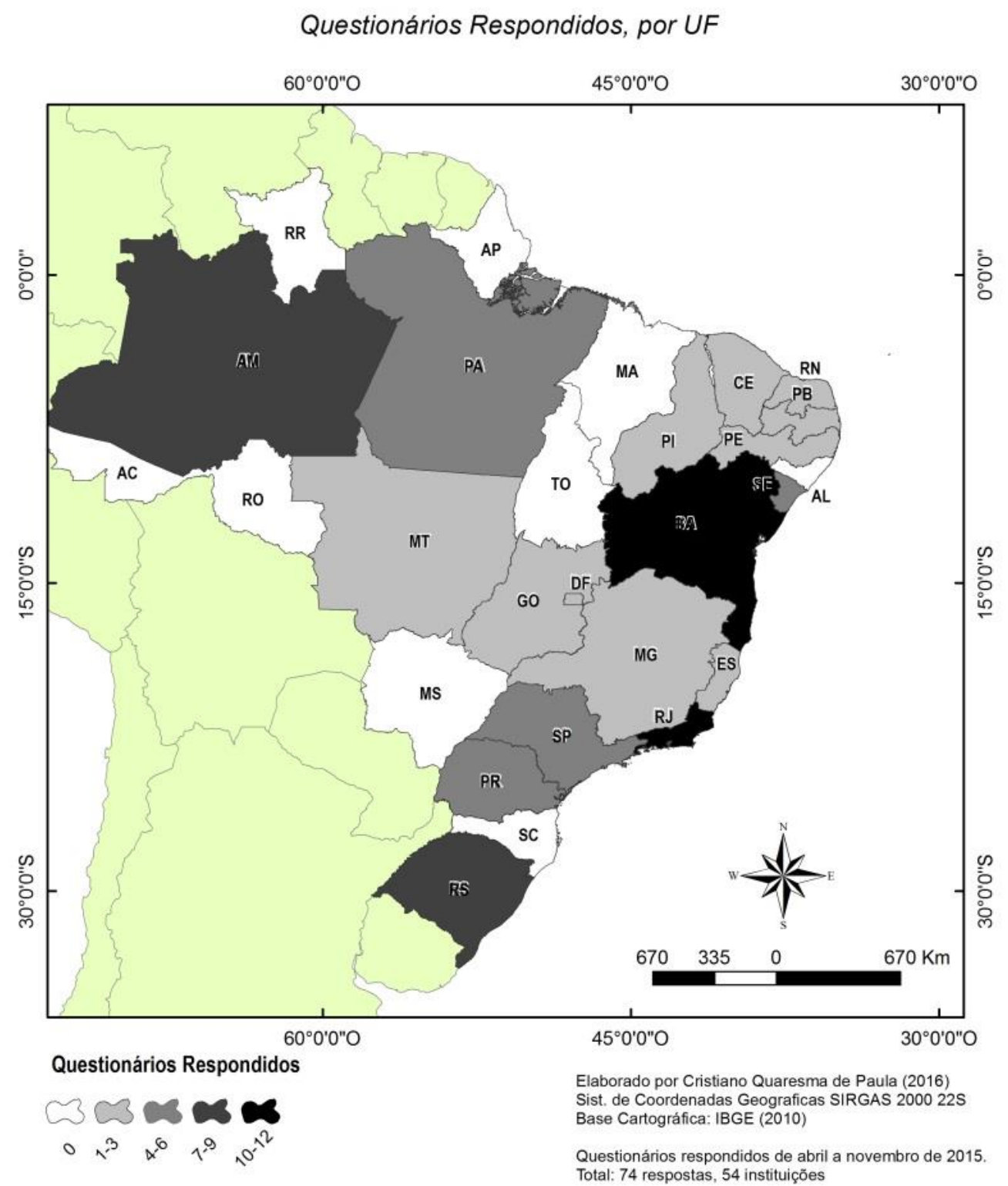

Figura 14: Mapa de Questionários Respondidos por Unidade da Federação Fonte: Elaborado por De Paula (2018)

Observando a distribuição dos pesquisadores que responderam os questionários, por unidades da federação, é possível concluir que do estado do Rio de Janeiro, houve o maior número de respostas (16,22\%). Este foi seguido da Bahia (14,86\%) e do Rio Grande do Sul (12,16\%). Na sequência, o estado do Amazonas conteve (10,81\%).

Cabe destacar que das 27 unidades da federação, 19 tiveram pesquisadores que responderam os questionários. Fazendo a análise regional dos questionários, observa-se que o maior número de respostas é da região Nordeste $(33,78 \%)$ e Sudeste $(25,68 \%)$. Na sequência, 
o maior número de respostas é da região Sul $(18,92 \%)$ seguida da região Norte $(17,97 \%)$ e a região com menos respostas é a Centro-oeste (4,05\%). O gráfico 1 expõe essa distribuição:

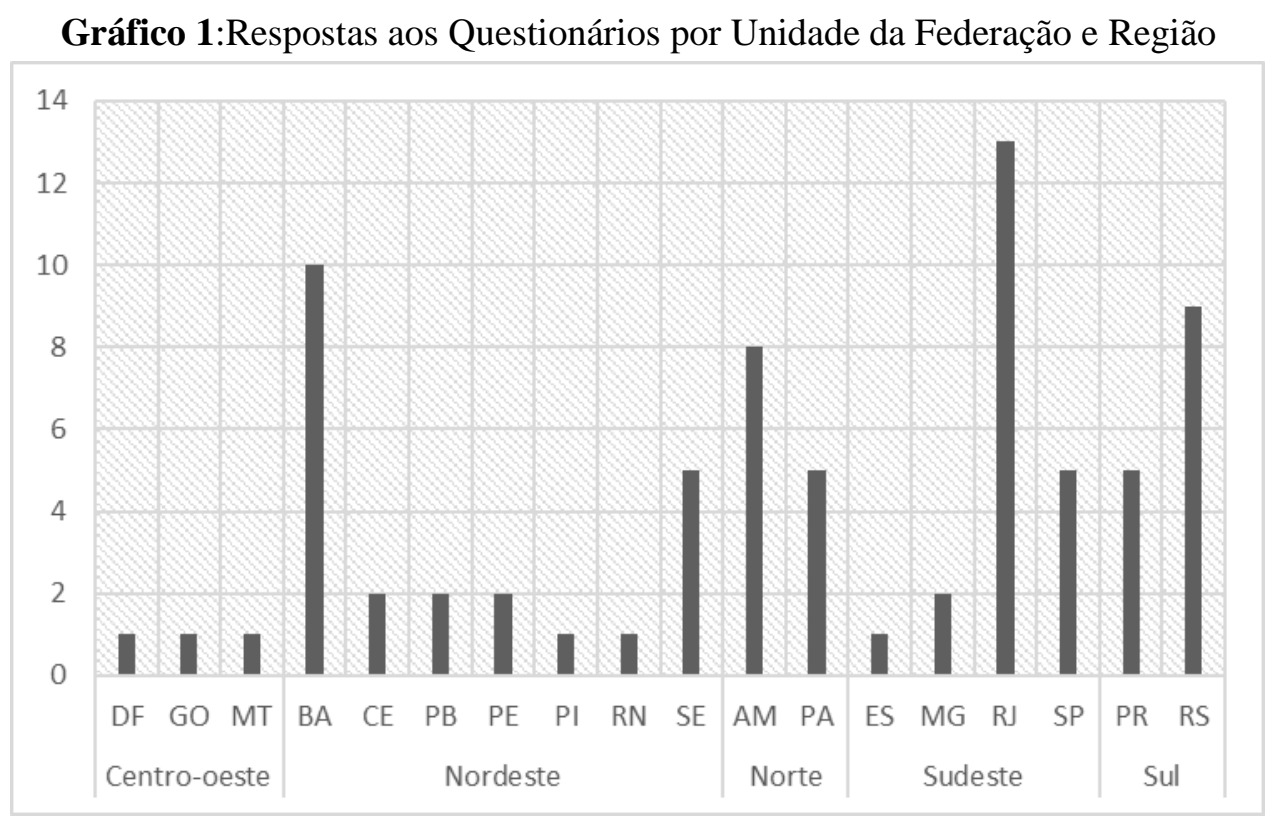

Fonte: Elaborado por De Paula (2018).

A partir do mapeamento das instituições, onde estão os pesquisadores que responderam os questionários, elaborou-se o mapa de densidade (figura 15). Este mapa apresenta a alta densidade de pesquisadores que responderam os questionários em instituições no eixo sulsudeste-nordeste. Também foi considerável a densidade na região amazônica. A partir dos questionários, se observa a lacuna de respostas vindas do centro do Brasil. Considerando este mapa, pode-se inferir uma significativa distribuição dos pesquisadores ao longo do Brasil.

Do ponto de vista da constituição de uma rede de pesquisadores caberia observar a potencialidade dos pontos de alta densidade e estabelecer estratégias para o de baixa densidade. Os pontos de densidade intermediária contribuem para estabelecer articulação entre os pesquisadores dos pontos de alta densidade. 


\section{GEOGRAFIAS DA PESCA ARTESANAL BRASILEIRA:}

Densidade de Pesquisadores que Responderam Questionários, por Instituição

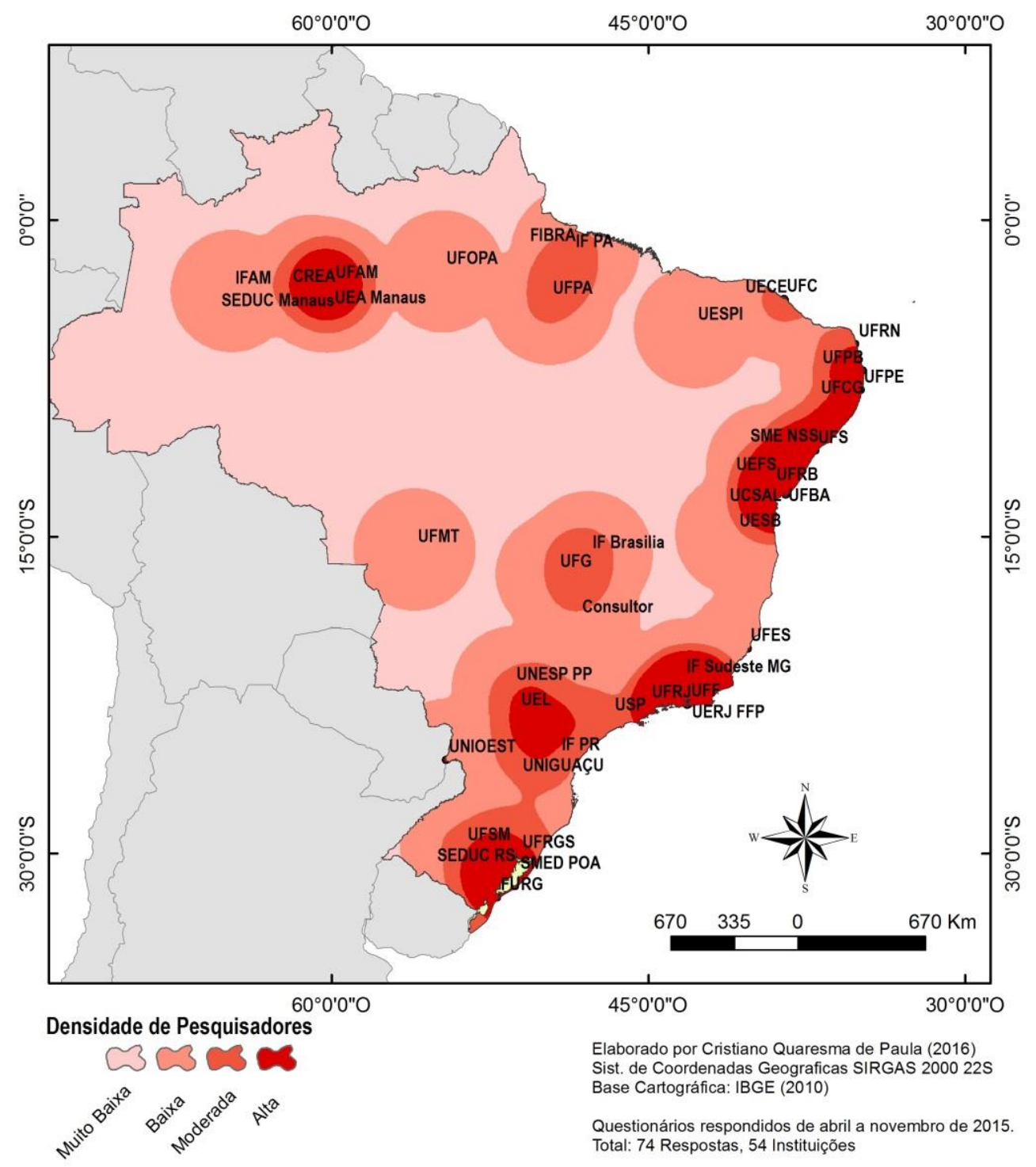

Figura 15: Mapa de Densidade de Questionários Respondidos por Instituição Fonte: Elaborado por De Paula (2018)

Partindo dos mapas presentes nas figuras 16 e 17, os quais expõem os vínculos com as instituições, identifica-se que 47,67\% estão associados à instituição atual como professores. O segundo vínculo mais frequente foi de estudante (24,41\%). Já $19,76 \%$ estão vinculados às instituições mapeadas como pesquisadores. Estão vinculados como "outros" 8,13\%. Cabe destacar que existem casos que no mesmo questionário houve resposta de mais de um vínculo, como estudante e pesquisador, por exemplo. 
As áreas que acusam alta densidade de pesquisadores vinculados às instituições (figura 15) coincidem com os estados cujos há maior número de professores, identificados na pesquisa. Também se entende que o elevado número de pesquisadores vinculados às instituições como estudantes revela o envolvimento com as problemáticas da pesca na pesquisa de pós-graduação.

Com base nas figuras 16 e 17 é importante salientar que muitas vezes nas instituições, onde apenas um pesquisador respondeu o questionário, este é professor. Isto é muito evidente nas instituições da região Norte, como é o caso dos campi da UEA.

\section{GEOGRAFIAS DA PESCA ARTESANAL BRASILEIRA:}

Vínculo Atual, por Instituição

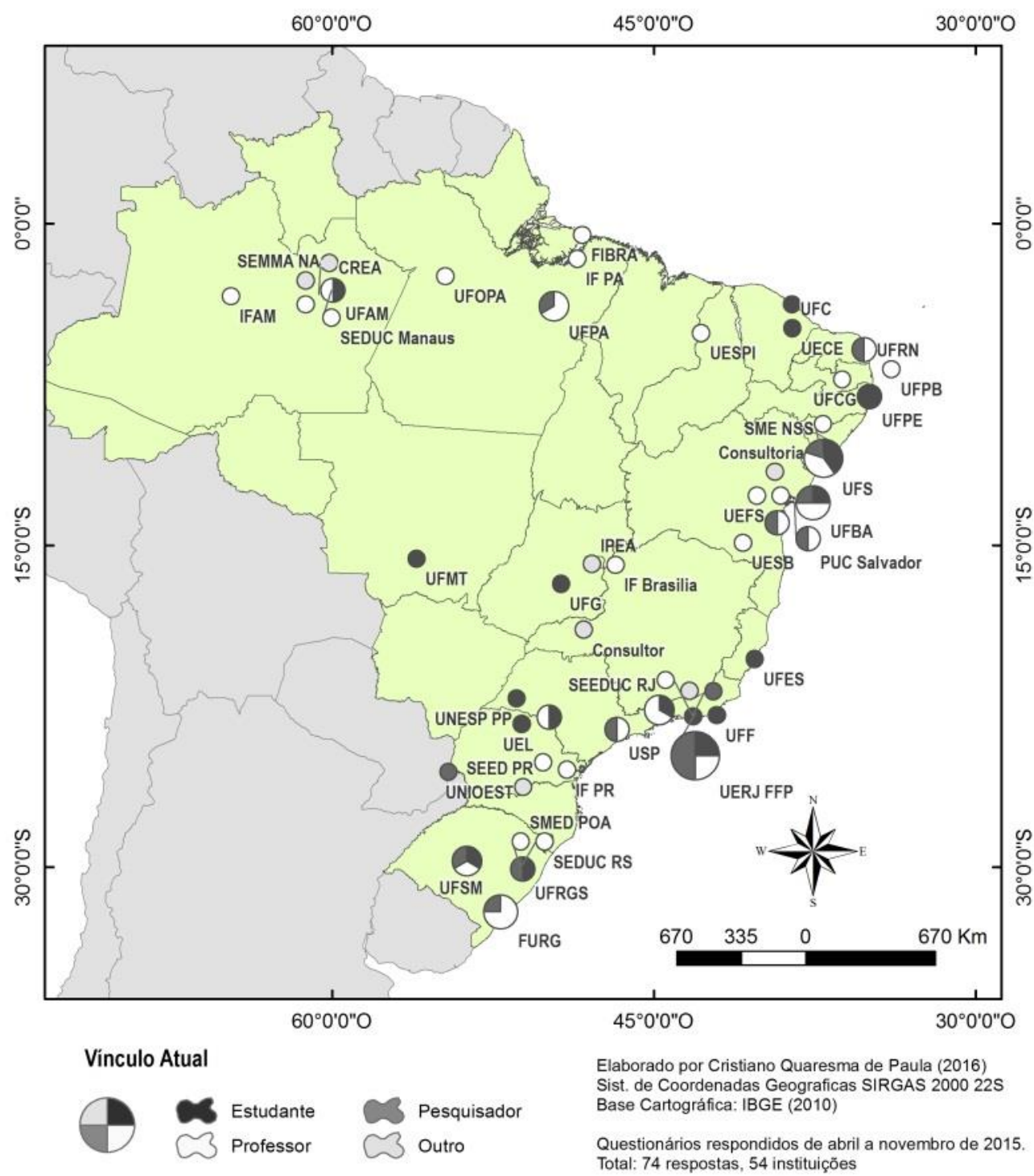

Figura 16: Mapa de Vinculo Atual, por Instituição

Fonte: Elaborado por De Paula (2018) 


\section{GEOGRAFIAS DA PESCA ARTESANAL BRASILEIRA:}

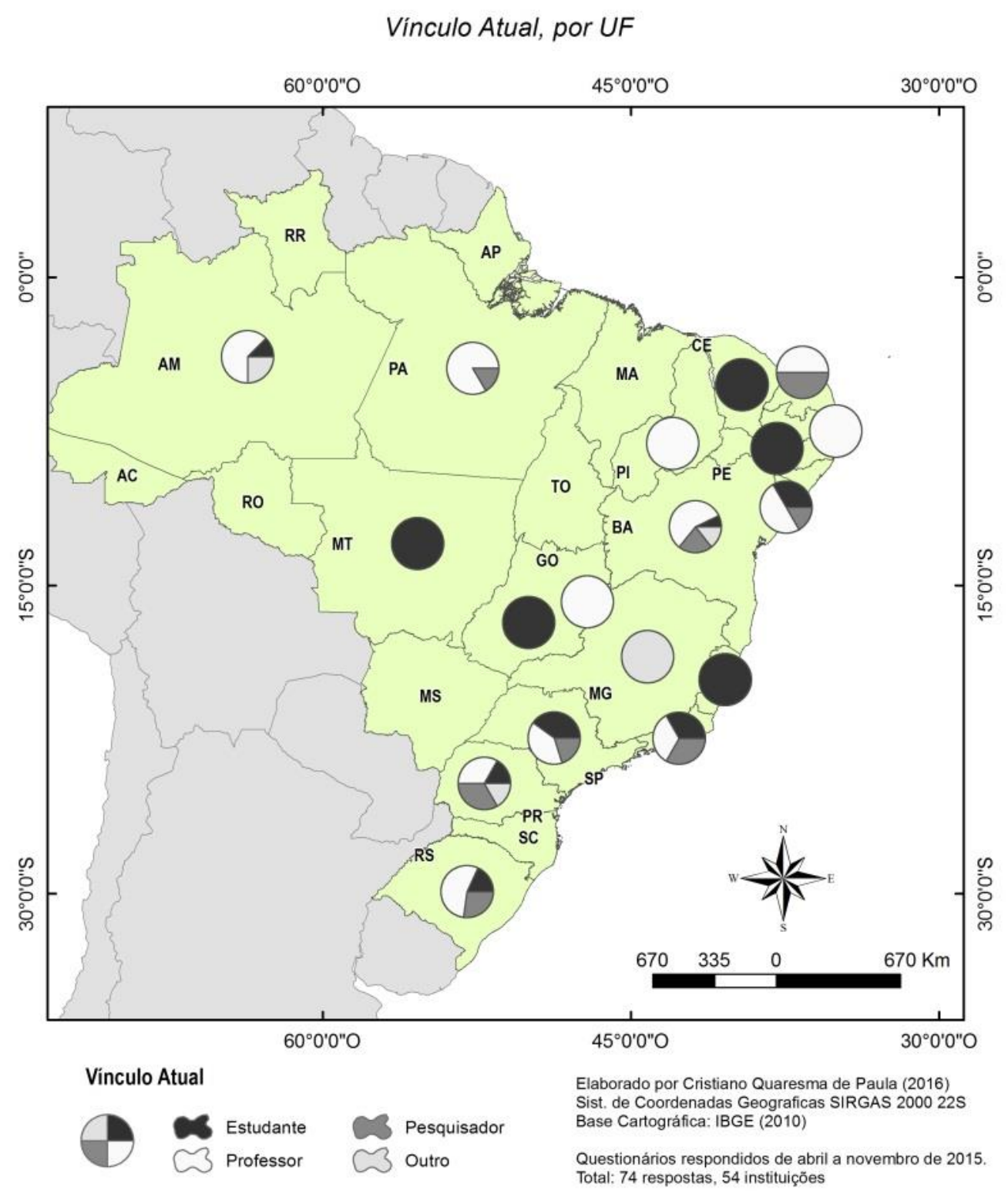

Figura 17: Mapa de Vinculo Atual, por Unidade da Federação

Fonte: Elaborado por De Paula (2018)

Quanto aos pesquisadores vinculados como estudantes, contata-se que os mesmos predominam no Nordeste, onde em diversas instituições os questionários foram respondidos somente por estudantes. Nesse sentido, destacam-se a UFC, UECE, UFPE e UFS. Compreendese que, repetidas vezes, foram os estudantes que responderam, pois são os indivíduos que estão comprometidos com as problemáticas da pesca, geralmente na pós-graduação, onde o orientador não tem a pesca artesanal como principal problemática de pesquisa, mas a partir de seus estudos estabelece diálogos com ela. 
No Sudeste e Sul do Brasil há maior variação de vínculos (pesquisador, estudante, professor) entre os pesquisadores que responderam os questionários. Também é onde o vínculo como pesquisador é mais evidente. Mais adiante será exposto que isto está relacionado com a presença de grupos de pesquisa.

A partir dessa amostragem já é possível concluir que, frequentemente, as universidades onde estão os pesquisadores que responderam os questionários, não são as instituições mais "tradicionais" da Geografia Brasileira, principalmente analisando o Sudeste e Sul do Brasil. Logo, corresponde a um conjunto de pesquisadores em instituições, onde a pós-graduação é mais recente.

Quanto à formação, salienta-se que os questionários foram encaminhados para geógrafos, ou seja, por aqueles que fazem Geografia. A análise das respostas está expressa no gráfico 2 e nas figuras 18 e 19. Assim, entendemos que eles têm (ou estão em) formação em Geografia na graduação ou pós-graduação. Também se considerou na análise indivíduos que embora não tenham formação em Geografia são professores nos cursos de Geografia.

Gráfico 2: Formação dos Pesquisadores, por Região

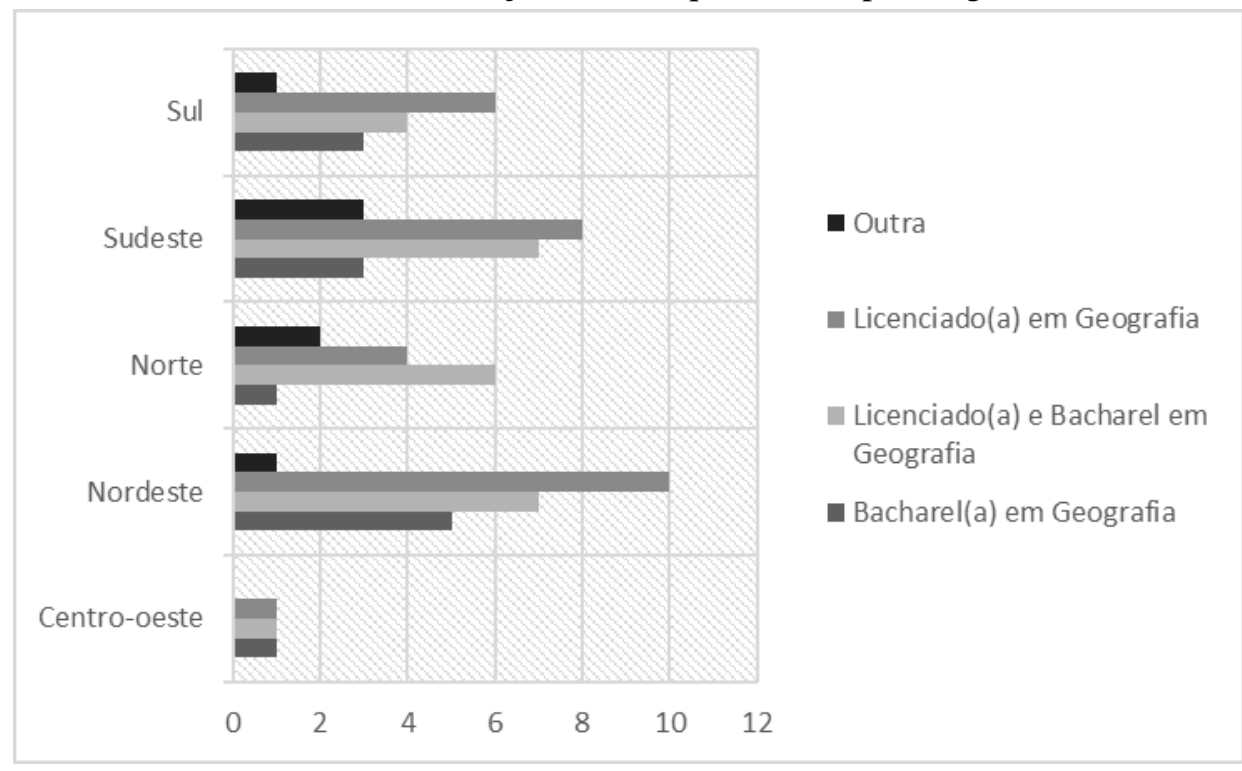

Fonte: Elaborado por De Paula (2018) 


\section{GEOGRAFIAS DA PESCA ARTESANAL BRASILEIRA:}

Formação, por Instituição

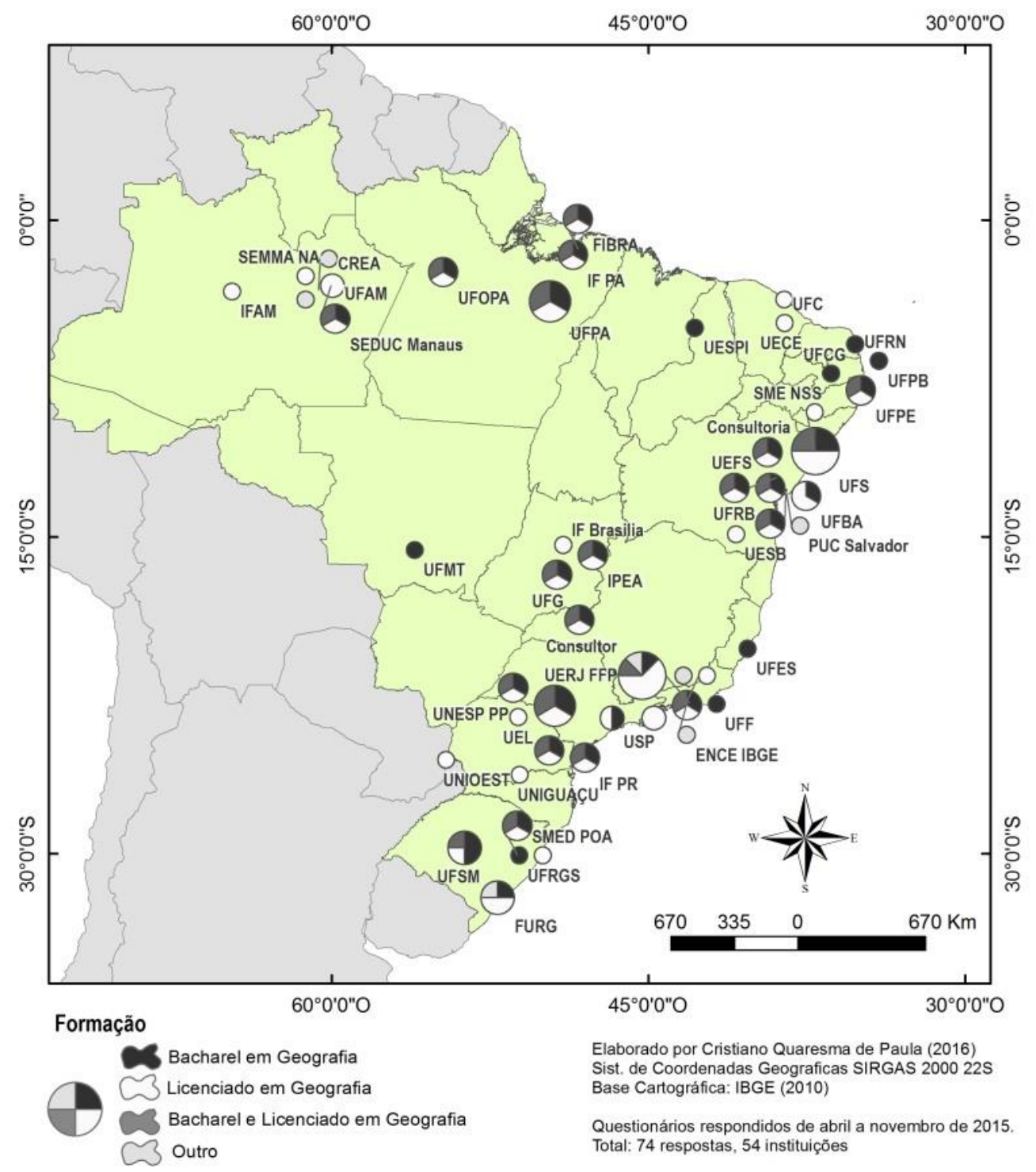

Figura 18: Formação por Instituição

Fonte: Elaborado por De Paula (2018) 


\section{GEOGRAFIAS DA PESCA ARTESANAL BRASILEIRA:}

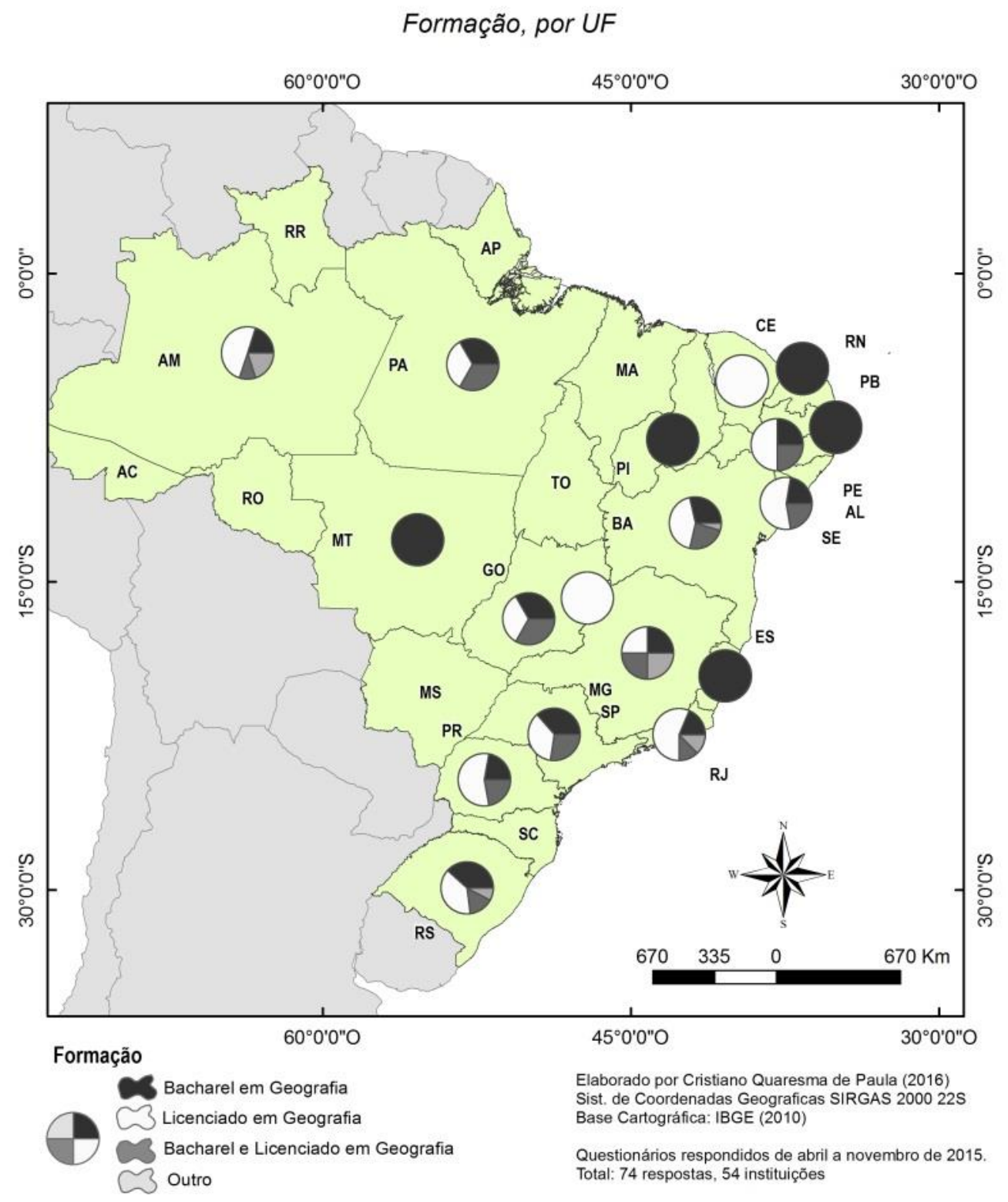

Figura 19: Formação, por Unidade da Federação

Fonte: Elaborado por De Paula (2018)

Primeiramente, frisa-se que a categoria "Outros" representa 9,46\% do total das 74 respostas. Logo, são doze pesquisadores com formação em Ciências Humanas, Serviço Social, Ciências Econômicas, Oceanografia, Geologia e Zootecnia. Os estados da região Sudeste são os que apresentam mais pesquisadores com essas formações em outras áreas (15,79\% do total da região).

Os licenciados em Geografia correspondem a 39,19\% do total das respostas. Verificase em todas as regiões (gráfico 2) que o maior número dos pesquisadores possui licenciatura, 
sendo que alguns são bacharéis também. No mapa por instituição se constata que são raras às vezes que os pesquisadores não têm formação em licenciatura. Em alguns casos há presença de muitos licenciados que responderam os questionários, como é o caso da UERJ/FFP.

Os bacharéis em Geografia significam $17,57 \%$ do total. O maior número de pesquisadores formados, exclusivamente em bacharelado em Geografia, ocorre nos estados da região Nordeste $(24,00 \%$ do total da região). Na análise por instituição se ressalta que a formação em bacharelado também tem ocorrência em todo o Brasil, contudo, a maioria desses profissionais também tem formação em licenciatura. Das instituições que responderam somente bacharéis destacam-se UFRN, UFPB e UFCG, no Nordeste.

Os licenciados e bacharéis em Geografia são 33,78\% do total. Cabe destacar que dos estados da região Norte, $46,15 \%$ dos que responderam tem essa formação. Isso se confirma na análise por instituição, onde se destaca que a maioria das instituições da região Norte tem número equitativo de licenciados e bacharéis. É importante lembrar que 54 dos que responderam os questionários têm formação em licenciatura em Geografia e 48 são bacharéis nesta ciência.

Tendo compreendido quem são estes pesquisadores e a quais instituições eles estão vinculados, a análise irá expor suas participações em grupos e projetos de pesquisa e extensão. Frisa-se que, das respostas dos questionários, 98,08\% informam que participam de grupos de pesquisa como está exposto nas figuras 20 e 21. 


\section{GEOGRAFIAS DA PESCA ARTESANAL BRASILEIRA:}

Participação em Grupos de Pesquisa, por Instituição

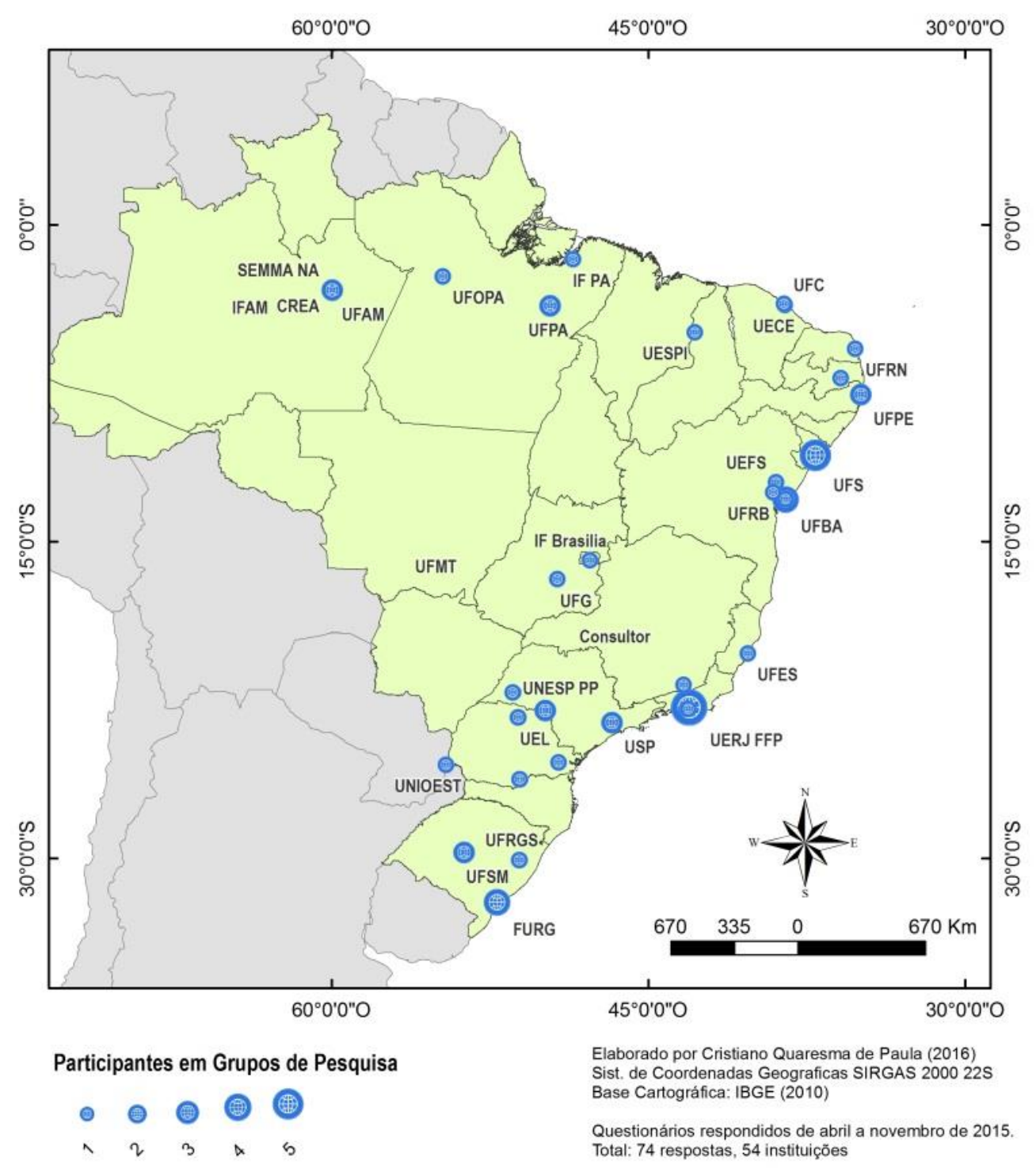

Figura 20: Participação em Grupo de Pesquisa por Instituição

Fonte: Elaborado por De Paula (2018) 


\section{GEOGRAFIAS DA PESCA ARTESANAL BRASILEIRA:}

\section{Participação em Grupo de Pesquisa, por UF}

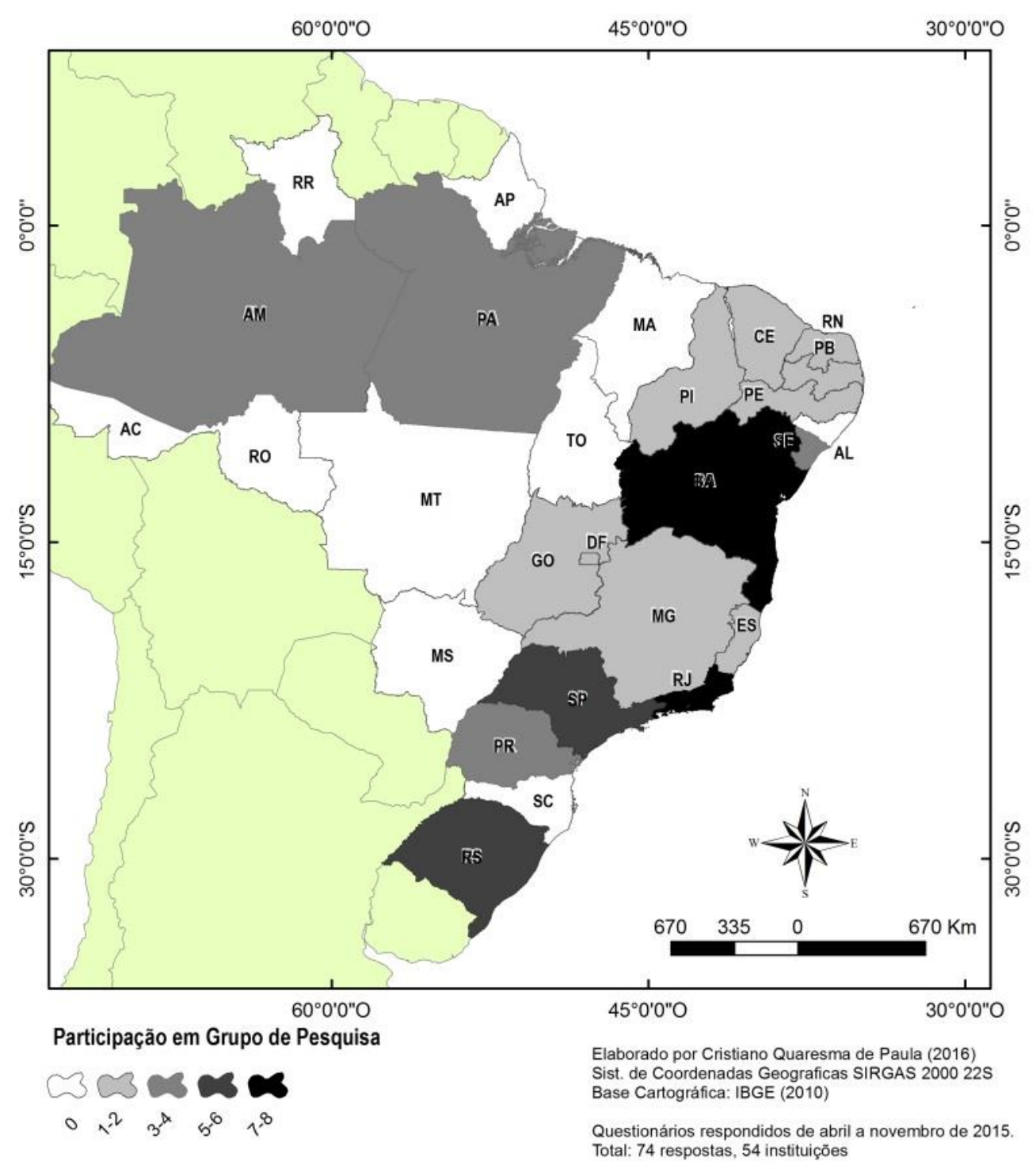

Figura 21: Participação em Grupo de Pesquisa por Unidade da Federação Fonte: Elaborado por De Paula (2018)

Salienta-se que, $36,54 \%$ do total dos que responderam os questionários, que participam de grupos de pesquisa, encontram-se em estados da região Nordeste e 26,92\% da região Sudeste (gráfico 3). 
Gráfico 3: Participação em Grupo de Pesquisa, por Região

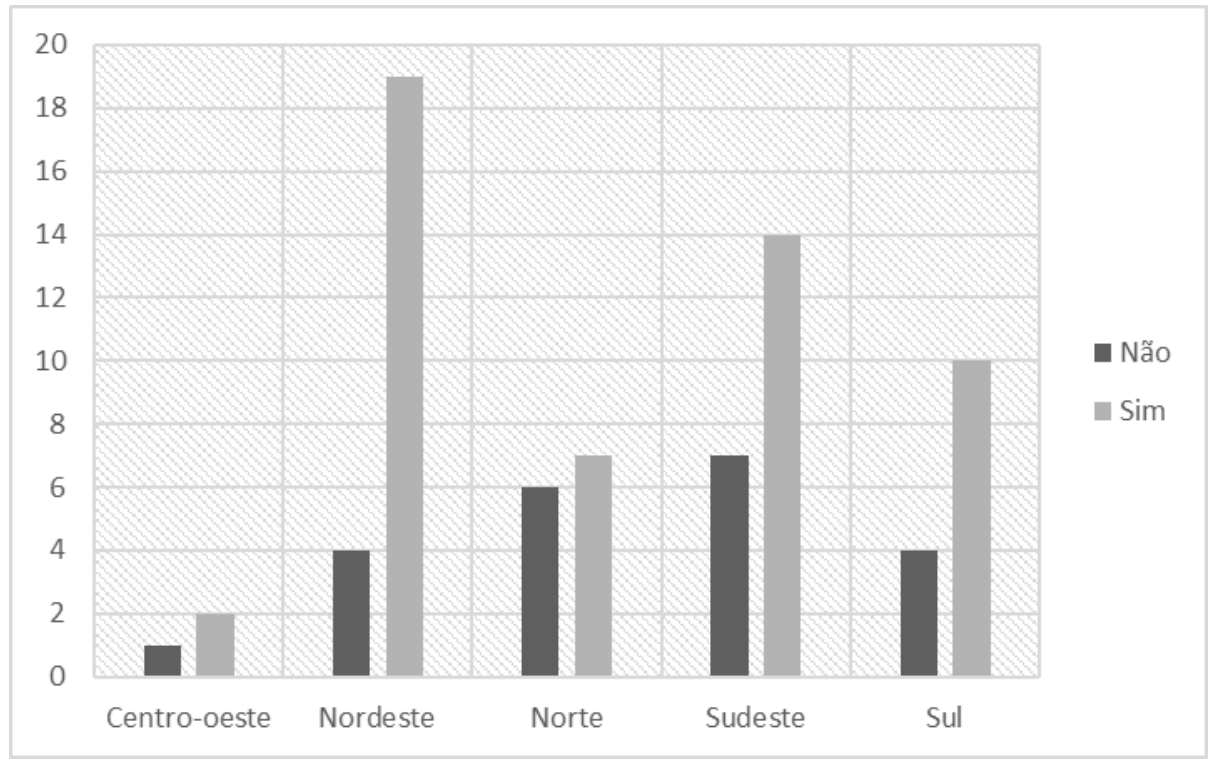

Fonte: Elaborado por De Paula (2018)

Os estados da Bahia e do Rio de Janeiro são os que tiveram mais pesquisadores que responderam os questionários e participam de grupos de pesquisa. Nesse sentido, cabe destacar a atuação do NUTEMC - Núcleo de Pesquisa e Extensão: Urbano, Território e Mudanças Contemporâneas da UERJ/FFP e o GeograFar - Geografia dos Assentamentos na Área Rural da UFBA.

Entretanto, é importante frisar que considerando o total por região, no Nordeste 20,83\% dos que responderam não participam de grupos de pesquisa. Além do GeograFar já citado, destacam-se Gestão Ambiental em Região Costeira - COSTEIROS, também da UFBA, e Grupo de Pesquisa em Geoecologia e Planejamento Territorial - GEOPLAN da UFS.

Já da região Sudeste $35,00 \%$ não participam. A região Norte tem uma proporção de $46,15 \%$ de pesquisadores que não atuam em grupos de pesquisa. Nesta região, pode-se citar o Grupo Acadêmico Produção do Território e Meio Ambiente na Amazônia - GAPTA e Grupo de Estudo Paisagem e Planejamento Ambiental - GEPPAM, da UFPA.

$\mathrm{Na}$ região Sul não se concentra o maior número dos que participam de grupos de pesquisa, mas considerando o percentual na região se observa que 64,29\% dos pesquisadores participam. Segundo os que responderam os questionários há variedade de grupos de pesquisa, como podemos exemplificar na FURG, a participação dos pesquisadores no ASA - Núcleo de Análise Socioambiental, NAU - Núcleo de Análises Urbanas e LACRIO - Laboratório de Análise da Criosfera. 
Em relação a participação dos pesquisadores que responderam os questionários em projetos de pesquisa, que envolvem problemáticas dos pescadores artesanais, existem ocorrências em dez unidades da federação, como está presente nas figuras 22 e 23.

\section{GEOGRAFIAS DA PESCA ARTESANAL BRASILEIRA:}

Participação em Projetos de Pesquisa, por Instituição

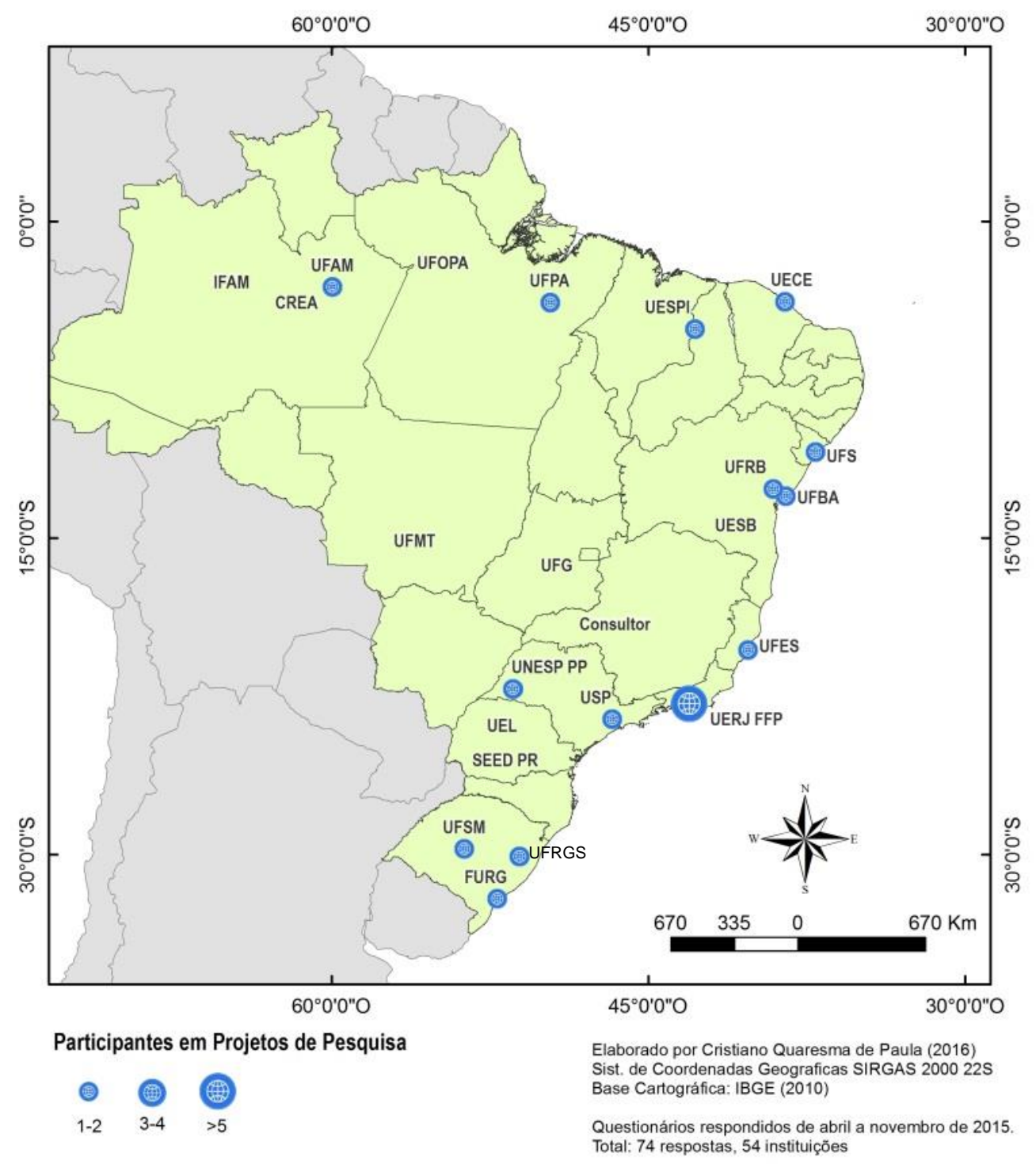

Figura 22: Mapa de Participação em Projeto de Pesquisa, por Instituição

Fonte: Elaborado por De Paula (2018) 


\section{GEOGRAFIAS DA PESCA ARTESANAL BRASILEIRA:}

Participação em Projetos de Pesquisa, por UF

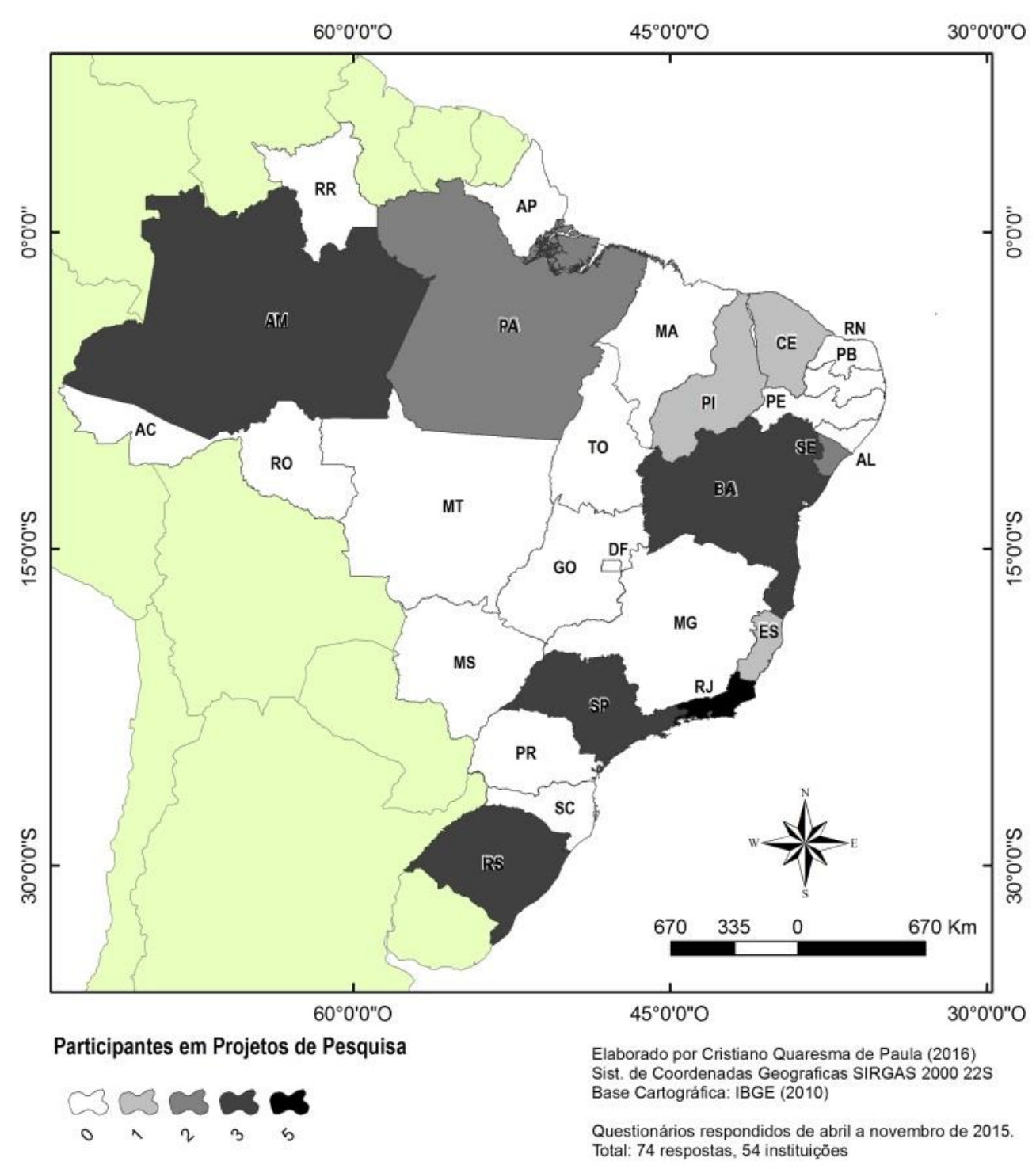

Figura 23: Mapa de Participação em Projeto de Pesquisa, por Unidade da Federação Fonte: Elaborado por De Paula (2018)

O estado do Rio de Janeiro apresenta cinco pesquisadores envolvidos com projetos de pesquisa. Do NUTEMC - UERJ/FFP, por exemplo, foram apontados os projetos: "Território e Cartografia da Ação Social: análise da cadeia produtiva, das condições de trabalho e das formas de luta dos trabalhadores da pesca artesanal no Rio de Janeiro"; "Economia Política do Território: Análise da cadeia produtiva da pesca artesanal na metrópole do Rio de Janeiro" e "Modernização: mapeamento de riscos para a pesca artesanal no estado do Rio de Janeiro", entre outros. 
No estado da Bahia, três pesquisadores que responderam os questionários participam de projetos de pesquisa. Do GeograFar - UFBA, por exemplo, enaltece-se os projetos "Mapeamento dos Conflitos da Pesca Artesanal na Bahia" e "Identidade das Comunidades Tradicionais Pesqueiras", entre outros. Neste estado também cabe frisar os projetos - "Manejo Comunitário de Recursos Naturais na Resex Marinha Baía do Iguape (MARENA)" e "Gestão Ambiental e Conflitos Territoriais nas Resex Marinhas da Bahia" do grupo Gestão Ambiental em Região Costeira - UFBA.

No Rio Grande do Sul, três pesquisadores responderam que participam de projetos de pesquisa. Foi apontado o projeto "Mapeamento Participativo nas Comunidades Ribeirinhas da FLONA de Tefé - AM" do NEGA - Núcleo de Pesquisa Geografia e Ambiente - UFRGS.

No Estado do Pará, também, dois pesquisadores responderam que participam de projetos de pesquisa. Destes, destacamos os projetos "Biodiversidade, Populações Tradicionais e Uso dos Recursos em Áreas Protegidas" - GEPPAM - UFPA e "Mapeamento Participativo e Estratégias de Sobrevivência de Populações Tradicionais na Amazônia Paraense" - GAPTA UFPA. Os pesquisadores da Região Centro-Oeste não declararam estarem envolvidos em projetos de pesquisa atualmente.

Segundo os pesquisadores que responderam os questionários e participam de projetos de pesquisa, 48,28\% apontaram que os projetos são financiados. Outros 31,03\% informam que alguns projetos são financiados e outros não. E 20,69\% afirmam que os projetos de que participam não são financiados (gráfico 4).

Gráfico 4: Financiamento dos Projetos de Pesquisa por Região

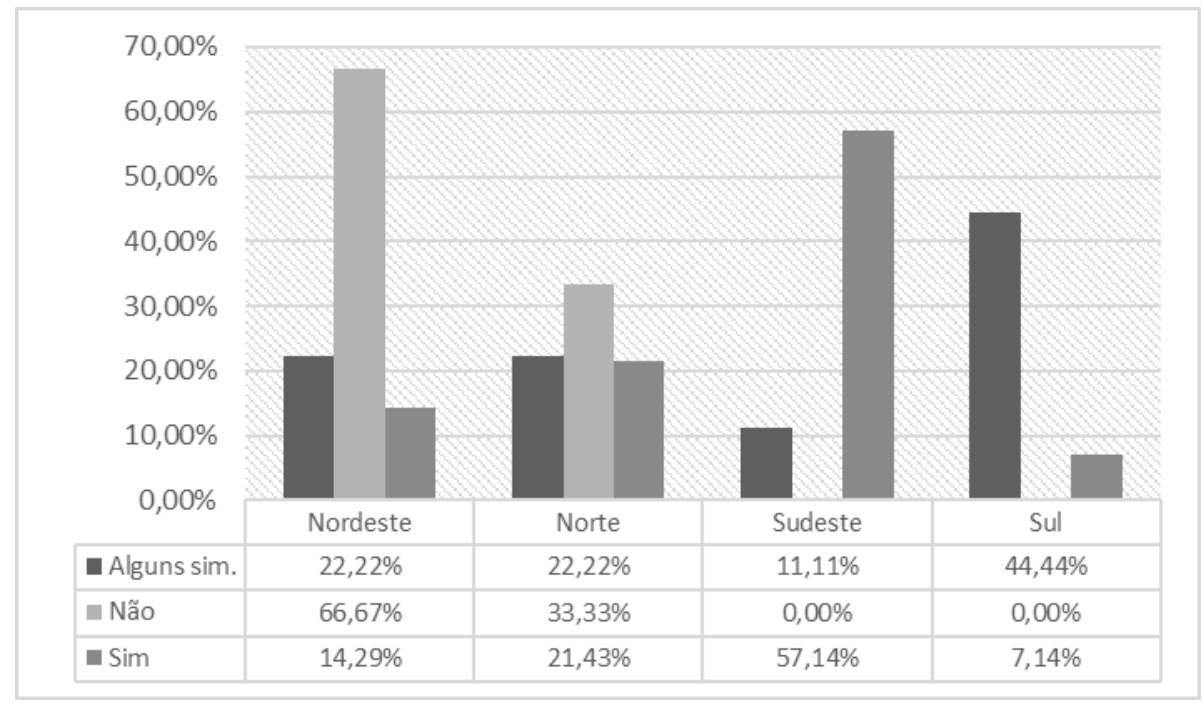

Fonte: Elaborado por De Paula (2018) 
O CNPq - Conselho Nacional de Desenvolvimento Científico e Tecnológico - é o principal órgão financiador dos projetos de pesquisa, segundo dez pesquisadores que responderam os questionários. Para doze pesquisadores, as agências estaduais costumam financiar esses projetos. Os demais financiadores apontados são CAPES - Coordenação de Aperfeiçoamento de Pessoal de Nível Superior, MEC - Ministério da Educação e Cultura, MCT - Ministério de Ciência e Tecnologia, Petrobrás e ONGs.

A participação dos pesquisadores em projetos de extensão tem menor ocorrência no Brasil. Tal participação está muito concentrada nos estados do Rio de Janeiro e Bahia. Entre os projetos de extensão (figuras 24 e 25) que os pesquisadores apontaram que participam, cabe destacar no Rio de Janeiro o projeto "Pescando por Meio de Redes Sociais" - NUTEMC UERJ/FFP. E da Bahia, um exemplo é o "Campanha Nacional pela Regularização dos Territórios das Comunidades Tradicionais Pesqueiras no estado da Bahia: Desafios e Perspectivas" do GeograFar - UFBA. Também na região Nordeste no estado do Rio Grande do Norte, um pesquisador apontou o projeto "Pescador Artesanal de Cajueiro (Touros - RN) na Perspectiva da Inclusão Social e da Cidadania" promovido pelo Grupo de Estudos Urbanos e Regionais - UFRN.

No Estado do Pará há participação de um pesquisador no projeto "Conservação e Uso dos Recursos Naturais em Áreas Protegidas no Nordeste Paraense" da GAPTA - UFPA. No Rio Grande do Sul o Projeto "Mapeamento Participativo nas Comunidades Ribeirinhas da FLONA de Tefé - AM” também promove extensão junto ao NEGA - UFRGS. 


\section{GEOGRAFIAS DA PESCA ARTESANAL BRASILEIRA:}

Participação em Projetos de Extensão, por Instituição

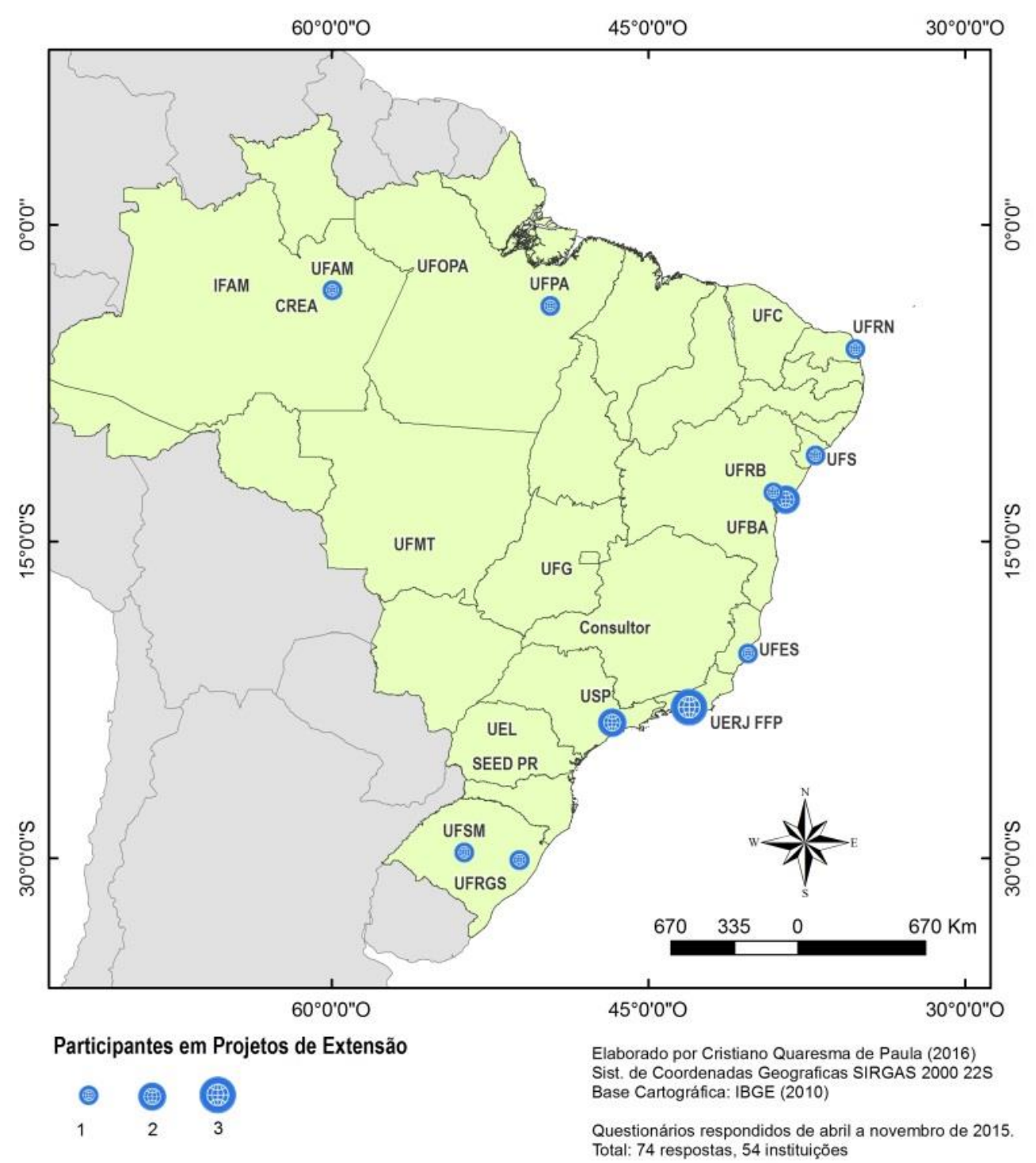

Figura 24: Mapa de Projetos de Extensão por Instituição

Fonte: Elaborado por De Paula (2018) 


\section{GEOGRAFIAS DA PESCA ARTESANAL BRASILEIRA:}

Participação em Projetos de Extensão, por UF

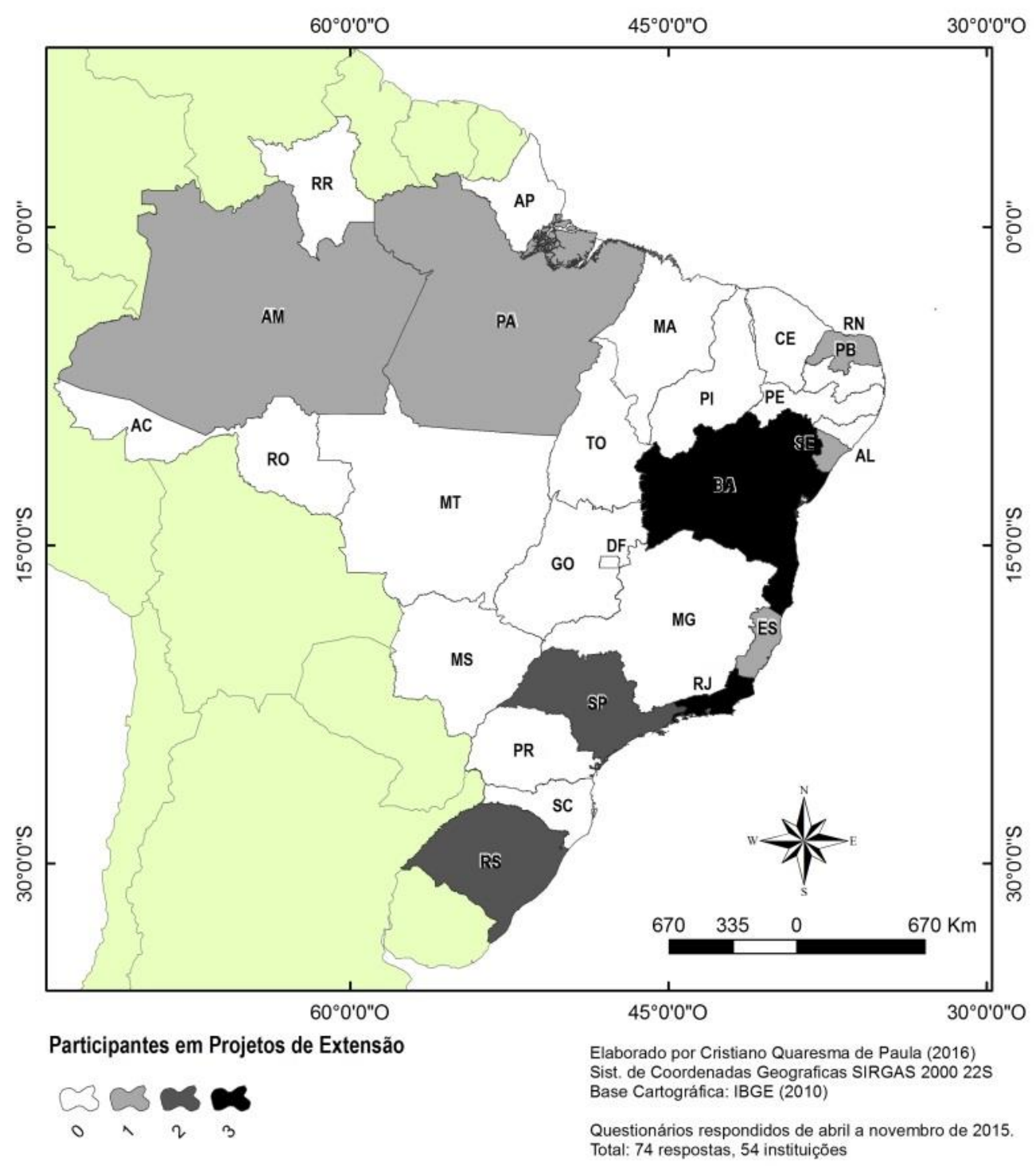

Figura 25: Mapa de Projetos de Extensão por Unidade da Federação Fonte: Elaborado por De Paula (2018)

Dos pesquisadores que responderam os questionários e participam de projetos de extensão, 43,35\% apontaram que os projetos são financiados. Outros 37,50\% informam que alguns projetos são financiados e outros não. Já 18,75\% afirmam que os projetos de que participam não são financiados (gráfico 5).

Cinco pesquisadores que responderam os questionários apontaram o $\mathrm{CNPq}$ como financiador de projetos de extensão. Sete pesquisadores apontaram as agências estaduais como órgãos de fomento à extensão. Para o financiamento dos projetos de extensão, cinco 
pesquisadores apontaram o Edital PROEXT do MEC. Os demais financiadores apresentados são a CAPES e as Universidades.

Gráfico 5: Financiamento dos Projetos de Extensão por Região

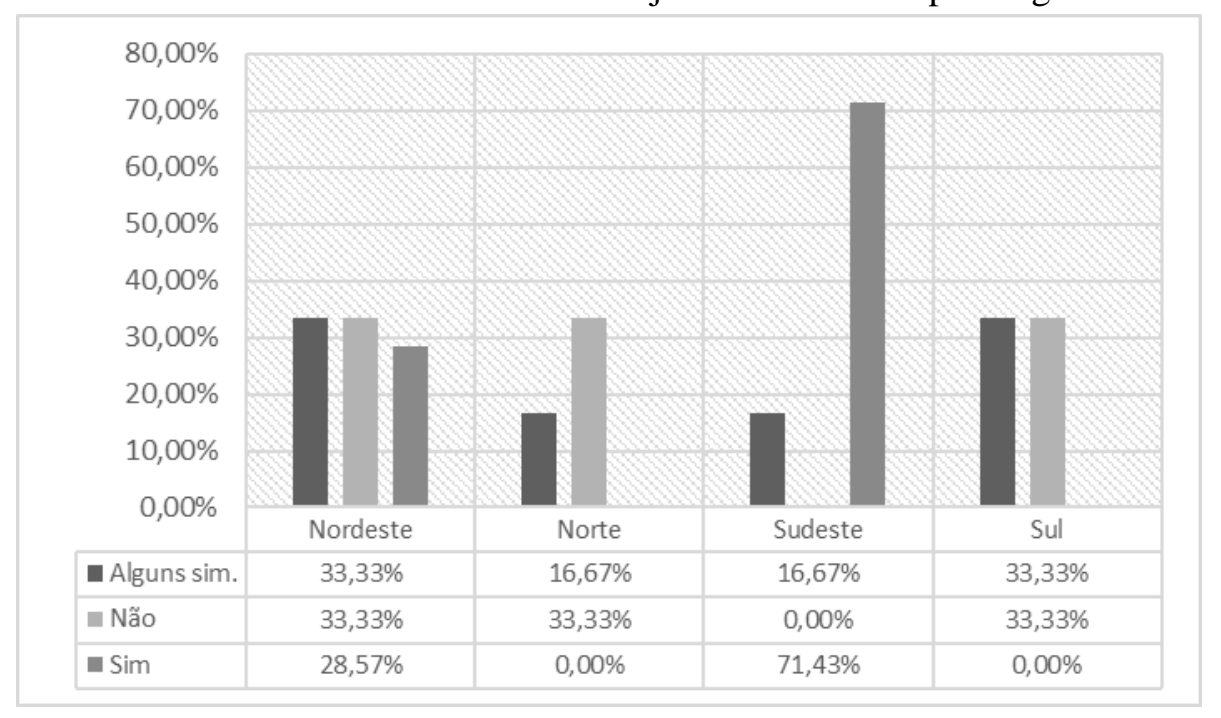

Fonte: Elaborado por De Paula (2018)

É significativa a informação de que 33 dos pesquisadores que responderam os questionários, atuam como professores universitários (44,59\% do total), os quais estão presentes em 11 unidades da federação e em 26 Instituições de Ensino Superior - IES (figuras 26 e 27). 


\section{GEOGRAFIAS DA PESCA ARTESANAL BRASILEIRA:}

\section{Professores Universitários, por Instituição}

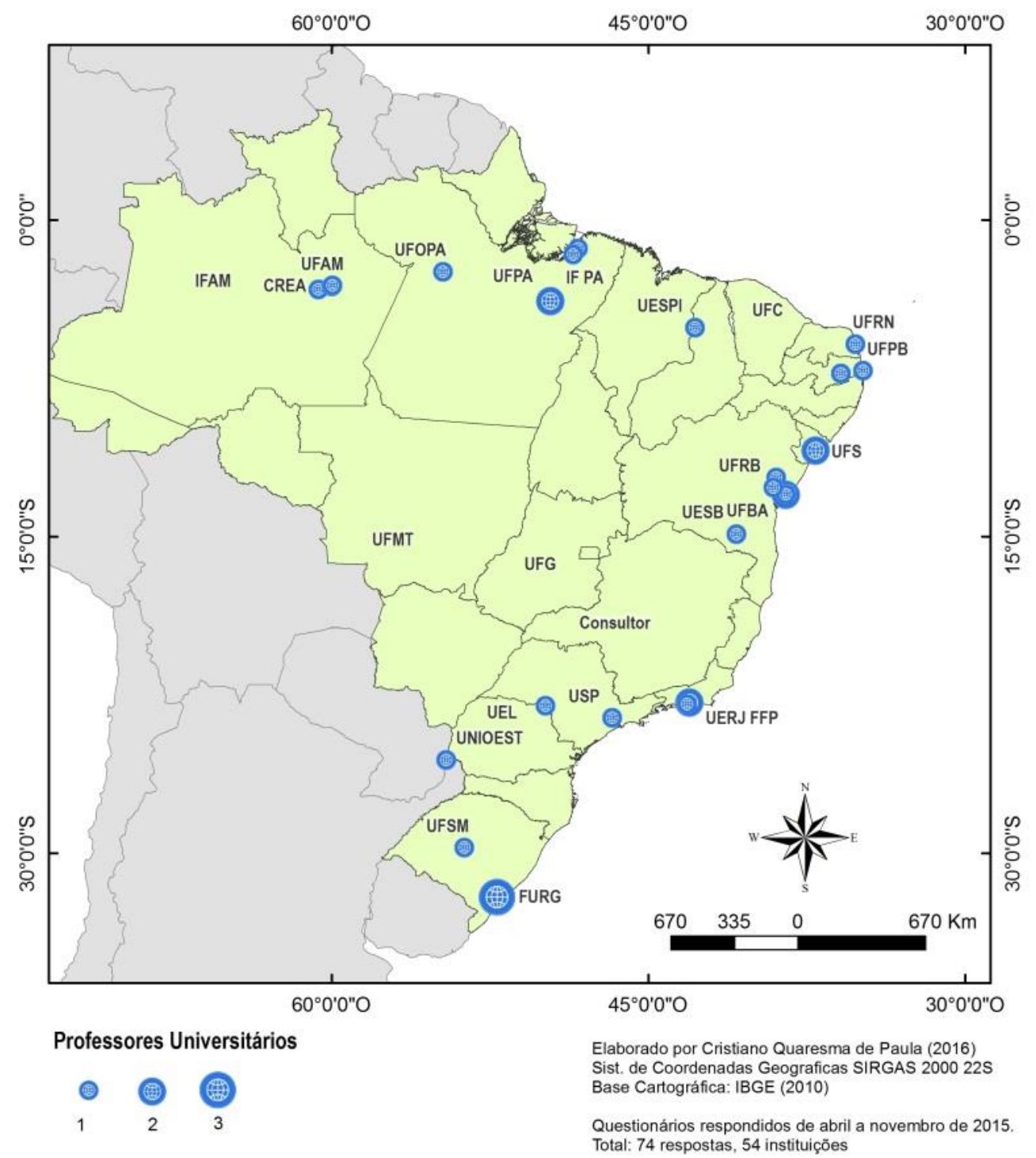

Figura 26: Mapa de Professores Universitários por Instituição

Fonte: Elaborado por De Paula (2018) 


\section{GEOGRAFIAS DA PESCA ARTESANAL BRASILEIRA:}

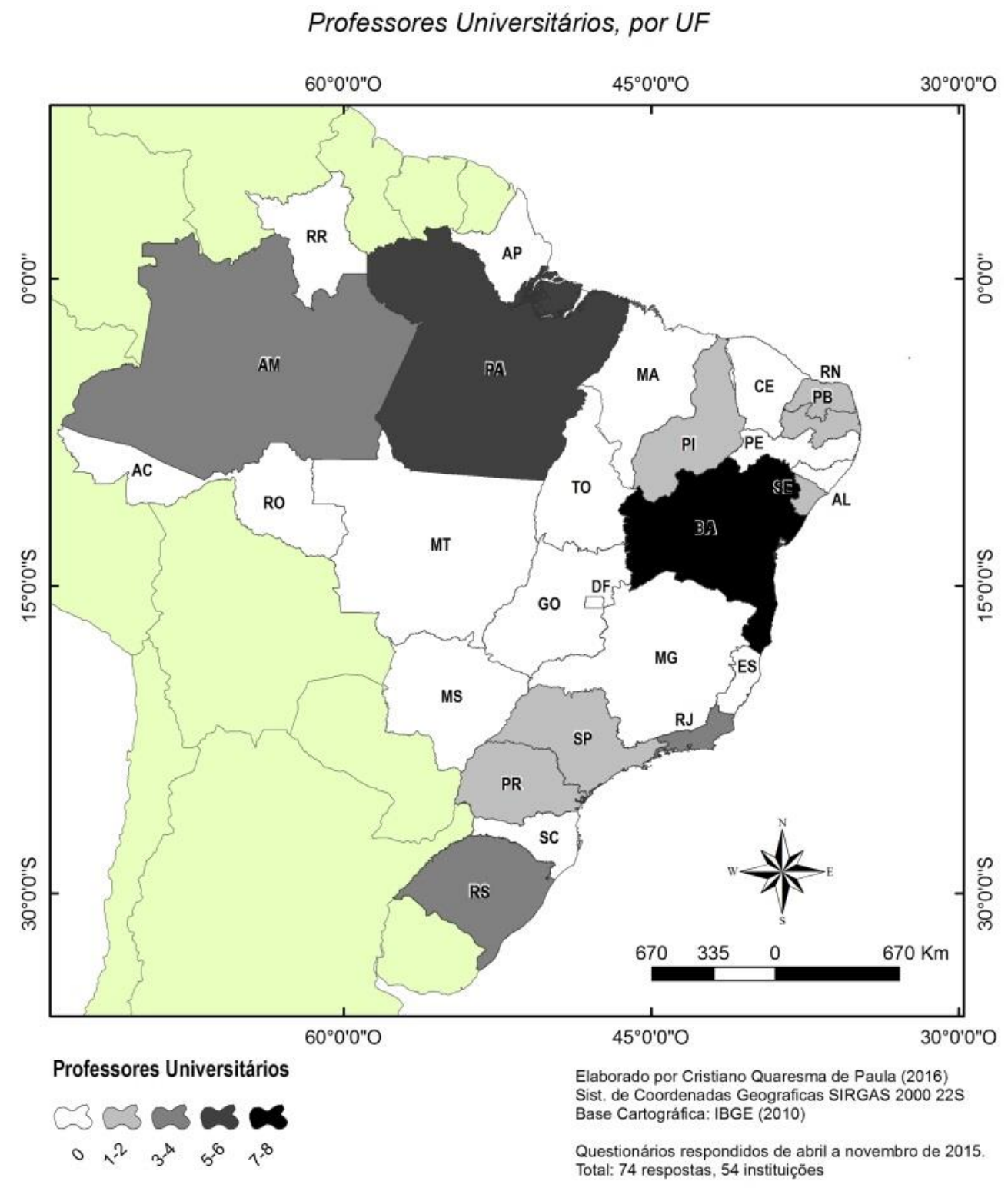

Figura 27: Mapa de Professores Universitários por Unidade da Federação Fonte: Elaborado por De Paula (2018)

Segundo o gráfico 6 a região Nordeste foi a região que apresentou o maior número de professores universitários vinculados às IES (12 IES, 14 professores universitários), que responderam os questionários. O estado da Bahia foi o que mais registrou respostas de professores universitários (8), sendo dois da UFBA.

Na região Norte nove responderam que são professores universitários, de oito IES. O estado do Pará também apresenta um considerável número de professores universitários que desenvolvem pesquisas sobre pesca artesanal (5) destes, dois estão na UFPA. 
Gráfico 6: Professores Universitários por Instituição

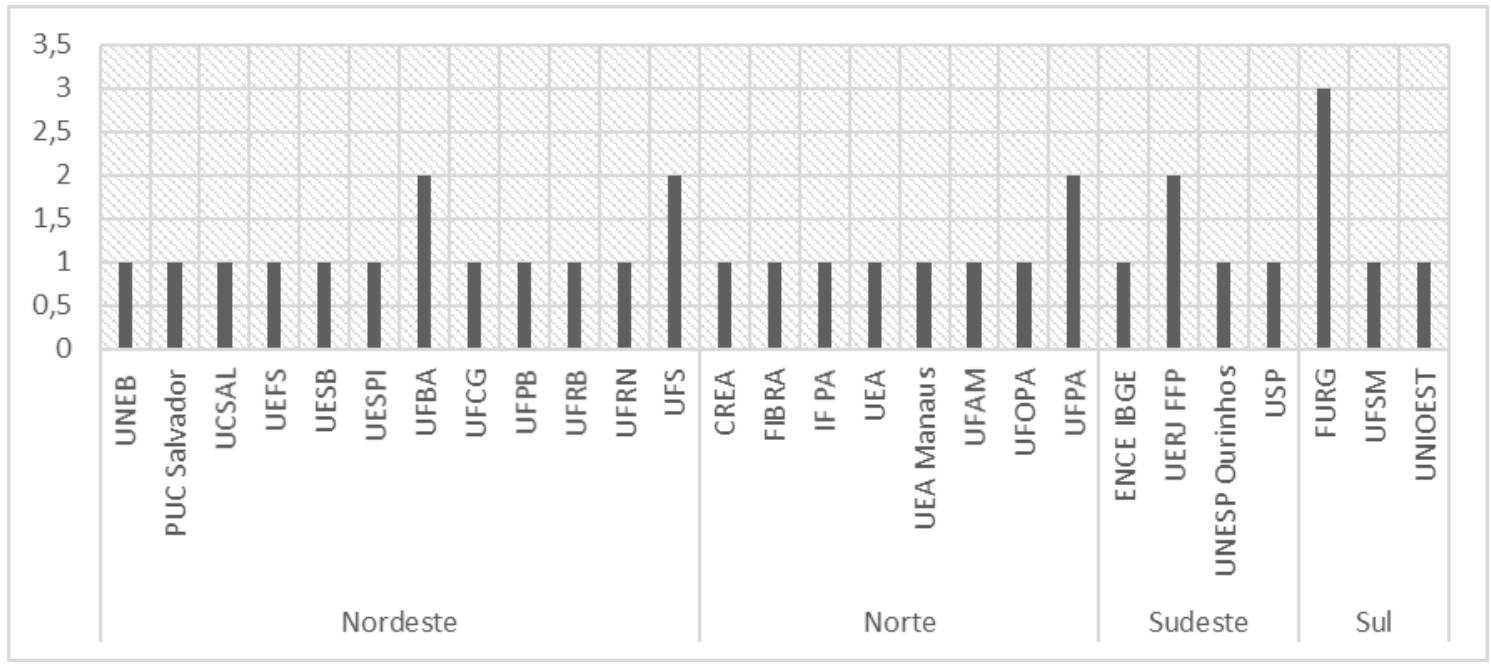

Fonte: Elaborado por De Paula (2018)

No Sul do Brasil responderam professores universitários de três IES. O Rio Grande do Sul apresenta o maior número de professores universitários da região, que responderam os questionários (4). Cabe destacar que destes, três são da FURG.

O Sudeste, que em todos outros mapas apresentou o maior número de pesquisadores que responderam os questionários, apresenta um número intermediário de professores universitários, considerando o universo da pesquisa (5 IES, 5 professores). Entre os estados desta região o Rio de Janeiro contém o maior número (3), sendo dois da FFP-UERJ. Já na região Centro-Oeste nenhum professor universitário respondeu o questionário.

Considerando o potencial do professor universitário no que tange a possibilidade de desenvolver ensino, pesquisa e extensão universitária no âmbito da pesca artensal, é considerável o número de respostas desses sujeitos para promover o diálogo sobre Geografias da pesca.

Para abordar o ensino enfatiza-se a atuação dos professores universitários no magistério superior (figuras 28 e 29). Os professores universitários que responderam os questionários, atuam principalmente nos cursos da graduação (28) em Geografia bacharelado e/ou licenciatura. Ainda dez lecionam em cursos de especialização na área da Geografia. Quinze são professores em cursos de mestrado em Geografia e seis em nível de doutorado. Ainda dez professores lecionam em outros cursos de graduação, especialização, mestrado e doutorado. É possível constatar a disposição desses professores em diversas universidades das regiões Nordeste (14), Norte (9), Sudeste (5) e Sul (5). 


\section{GEOGRAFIAS DA PESCA ARTESANAL BRASILEIRA:}

Atuação como Professor Universitário, por Instituição

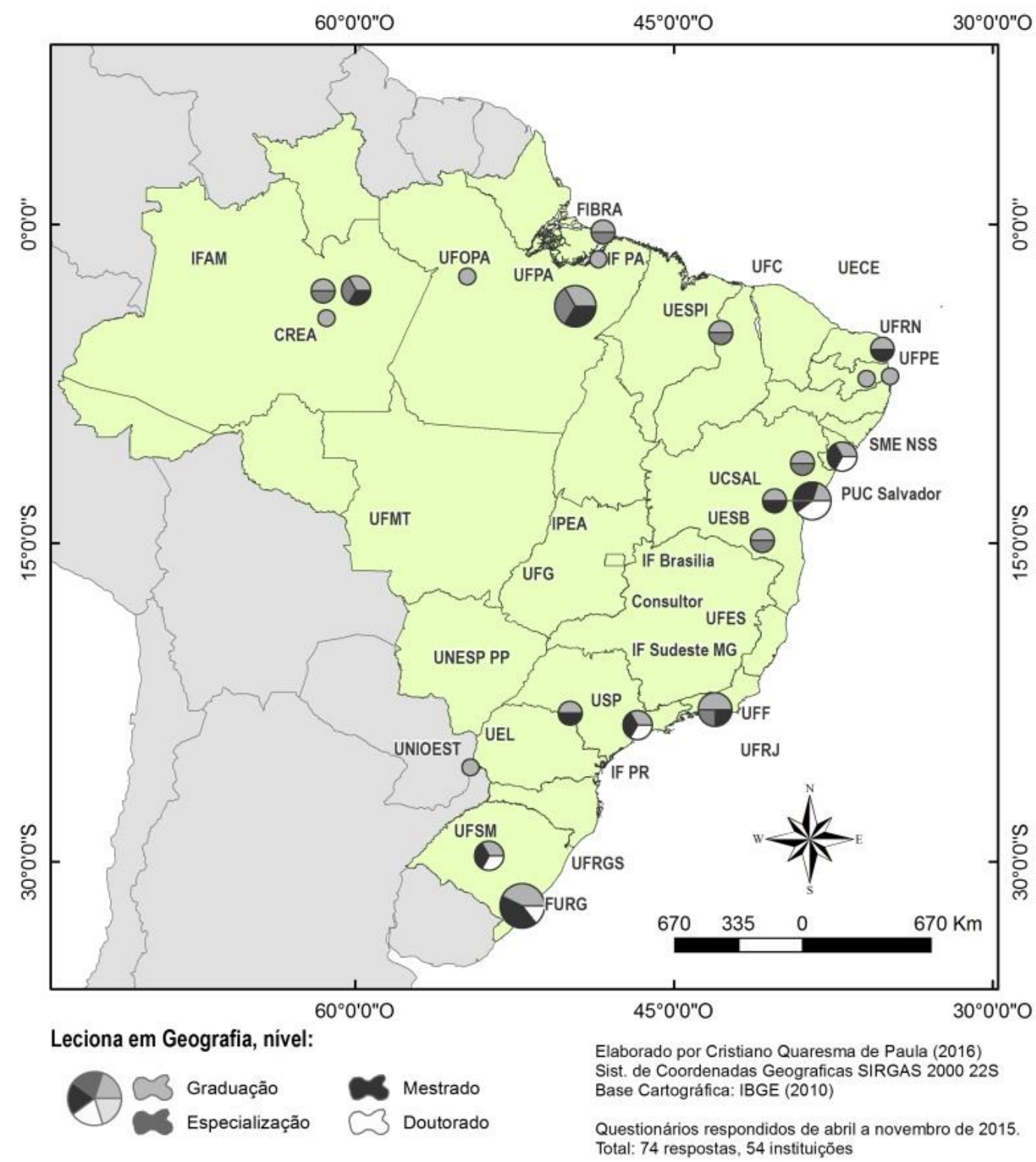

Figura 28: Mapa de Atuação como Professor Universitário por Instituição

Fonte: Elaborado por De Paula (2018) 


\section{GEOGRAFIAS DA PESCA ARTESANAL BRASILEIRA:}

Atuação como Professor Universitário, por UF

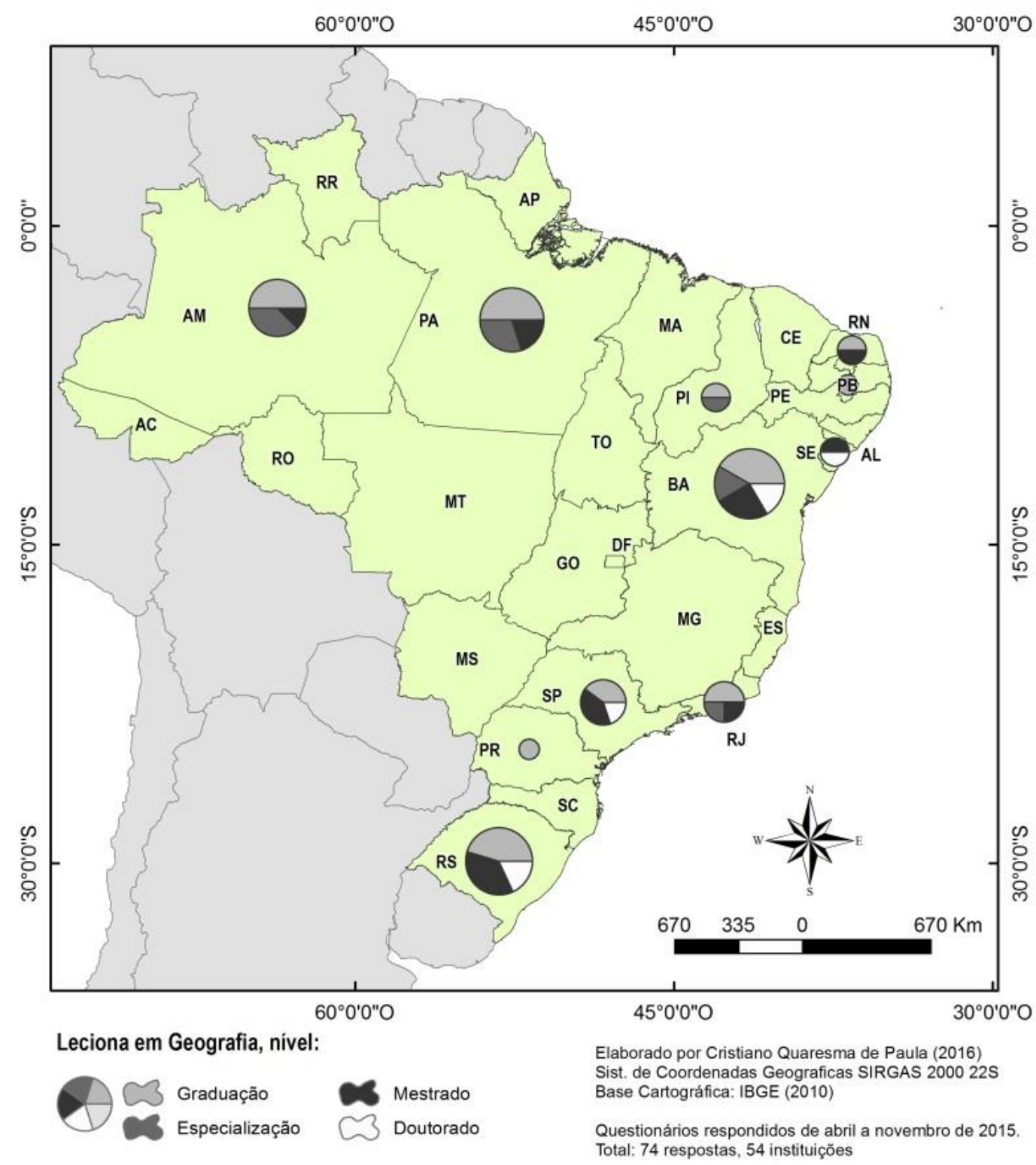

Figura 29: Mapa de Atuação como Professor Universitário por Unidade da Federação Fonte: Elaborado por De Paula (2018)

Em todos os Estados onde responderam professores universitários, os mesmos atuam em cursos de graduação em Geografia. A análise por instituição apresenta o vínculo com curso de graduação, na maioria das instituições onde estão lotados os professores universitários.

É importante a presença de professores em cursos de mestrado em oito dos 12 estados, onde docentes responderam os questionários. Observando a distribuição por instituição fica 
mais evidente a distribuição dos professores de mestrado ao longo do eixo sul-sudeste-nordeste. Exemplos dessas presenças são a FURG no Sul, e a UFBA no Nordeste.

A docência em cursos de especialização é menos numerosa (5 de 12 estados). Esse tipo de atividade aparece com maior força na região Norte, no caso do Amazonas equivale à graduação. Observando o mapa por instituição isso é ainda mais manifesto, e expõe um comportamento diferente do restante do Brasil - equivalência visível na UFPA e IF PA.

A atuação dos professores em cursos de doutorado ainda é a menos evidente (4 de 12 estados). Os professores em nível de doutorado estão concentrados no Rio Grande do Sul na FURG e UFSM, Bahia na UFBA e São Paulo na USP.

Para vislumbrar as principais atividades desenvolvidas pelos professores universitários (figuras 30 e 31), que responderam os questionários (além da pesquisa e extensão já apresentados anteriormente) no âmbito do magistério de disciplinas do ensino superior, de orientação de trabalhos de conclusão de curso de graduação, mestrado e doutorado e participação de bancas de trabalhos de conclusão de curso, dissertações e teses. 


\section{GEOGRAFIAS DA PESCA ARTESANAL BRASILEIRA:}

Atuação como Professor Universitário (Atividades), por Instituição

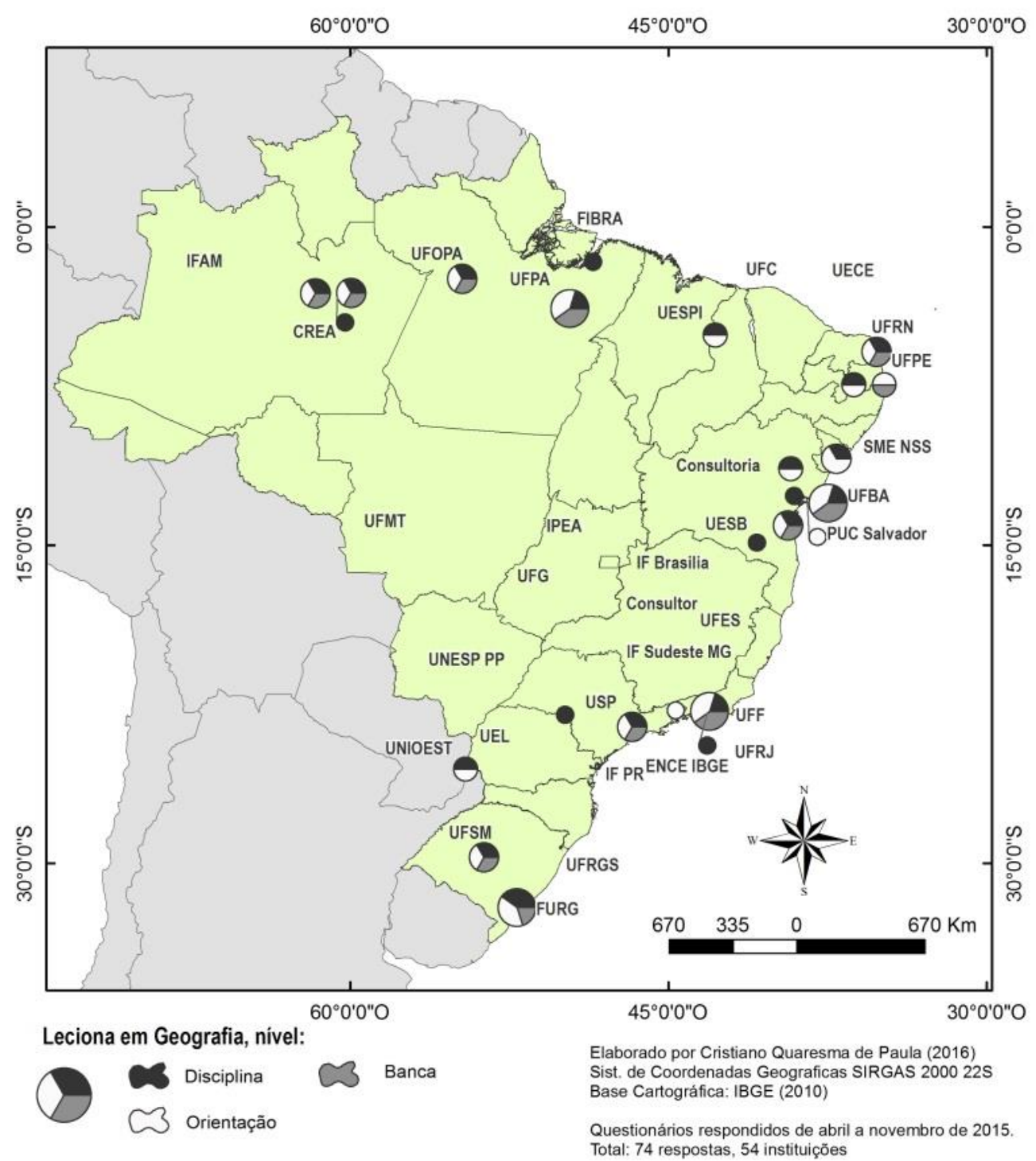

Figura 30: Mapa de Atividades Desenvolvidas no Magistério Superior por Instituição Fonte: Elaborado por De Paula (2018) 


\section{GEOGRAFIAS DA PESCA ARTESANAL BRASILEIRA:}

Atuação como Professor Universitário (Atividades), por UF

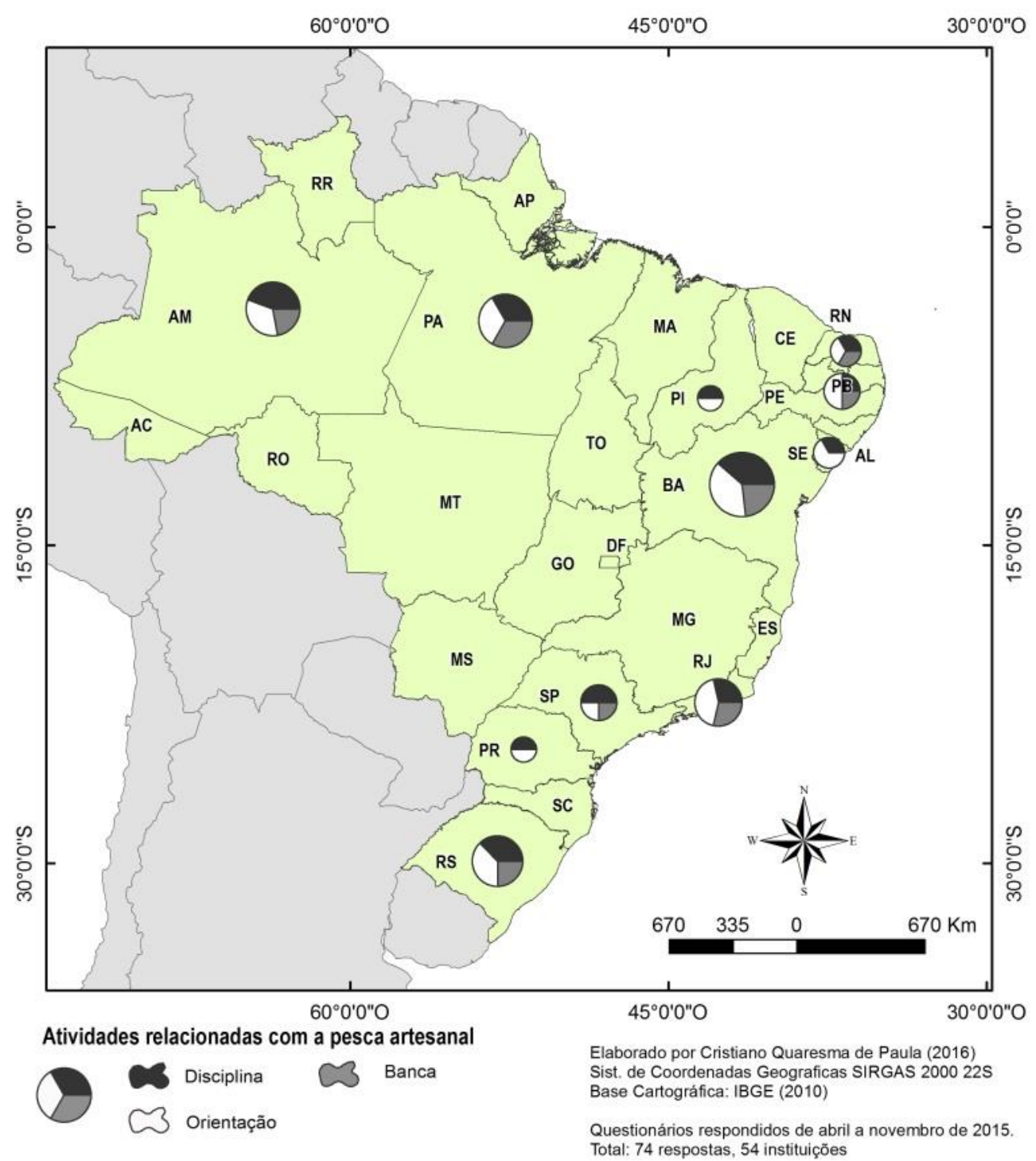

Figura 31: Mapa de Atividades Desenvolvidas no Magistério Superior por Unidade da Federação Fonte: Elaborado por De Paula (2018)

A atuação como professor de disciplina (graduação, mestrado e doutorado) é apontada pela maioria dos professores universitários (19 dos 33 que responderam). Analisando quais são essas disciplinas, constata-se que a maioria não se refere diretamente à pesca, mas integra problemáticas dos pescadores, como Geografia Agrária, Cartografia, Geografia Humana, Geografia Urbana, Teoria e Método, Biogeografia, entre outras. Existem casos de disciplinas específicas como Organização Espacial da Pesca (FURG); Populações Tradicionais (Geografia Humana USP) e Comunidades Tradicionais: Terra, Território e Territorialidades (UFBA). 
Assim se evidência a pesca não como um tema, mas uma problemática possível de ser abordada transversalmente em diversas disciplinas dos cursos de Geografia.

Os professores que orientam na graduação e pós-graduação também são frequentes (25 de 31). Destes 21 são orientadores em trabalhos de conclusão de curso de graduação. Três orientam monografias de especialização. Ainda nove são orientadores de dissertações de mestrado e quatro orientam teses de doutorado. Em alguns estados há equivalência entre atividades em disciplinas e orientações, abordando a pesca (Amazonas, Pará e Rio Grande do Sul). No caso do Rio de Janeiro, por exemplo, ainda a atividade de orientação é mais frequente que a atuação como professor de disciplinas.

Por fim, 15 dos professores universitários dizem que costumam participar de bancas de trabalhos que abordam a pesca artesanal; 09 participam de bancas de trabalhos de conclusão de curso e 05 de especialização. Ainda 12 costumam ser convidados para bancas de avaliação de dissertações de mestrado e 02 de teses de doutorado.

Cabe ressaltar a importância da atuação dos professores universitários que atuam como orientadores e em bancas de avaliação dos trabalhos de graduação, especialização, mestrado e doutorado. Compreende-se estas presenças como possibilidade de ampliação das discussões das problemáticas dos pescadores no âmbito da Geografia brasileira.

\subsubsection{A pesquisa sobre pesca artesanal na Geografia brasileira}

Tendo compreendido os contextos institucionais em que os estudos foram realizados e nos quais os geógrafos estão vinculados, buscou-se então compreender o entendimento dos pesquisadores sobre o estágio atual da pesquisa sobre a pesca artesanal na Geografia brasileira. No questionário, 49 geógrafos responderam a seguinte questão: Qual a sua opinião sobre as pesquisas referentes a pesca artesanal na Geografia brasileira? A nuvem de palavras (figura 32) apresenta o conteúdo dessas respostas. 


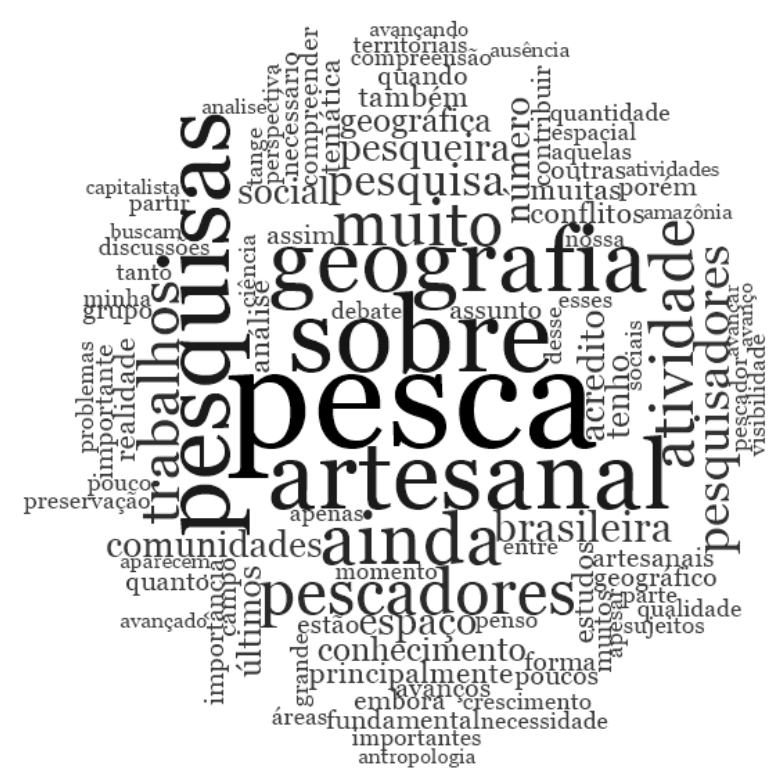

Figura 32: Nuvem de Palavras "Pesquisas sobre a pesca artesanal na Geografia brasileira" Fonte: Elaborado por De Paula (2018).

As principais respostas foram: i. A pesca artesanal constitui uma problemática emergente na Geografia; ii. Há grande relevância no debate sobre a pesca artesanal no âmbito da Geografia; iii. Ainda são poucas as referências na Geografia sobre a pesca artesanal; e iv. Os avanços das discussões na Geografia ocorrem lentamente em proporção às problemáticas da pesca artesanal.

\section{i. $\quad$ As pesquisas sobre a pesca artesanal na Geografia estão emergentes}

Dos pesquisadores que responderam os questionários, 30,61\% entendem que a Geografia brasileira vem se abrindo para as problemáticas dos pescadores artesanais e já verificam tais problemáticas como emergentes e em tendência de consolidação. Essa é uma compreensão presente entre pesquisadores de todas as regiões, predominante na região Sudeste, mas também em destaque na região Nordeste.

Em diálogo com as informações referentes à expansão da pós-graduação (BRASIL, 2016) e aumento das pesquisas (dissertações e teses), principalmente após 2005 e com maior intensidade após 2010, comprova-se a emergência em número. Isso se dá em um contexto do pensamento geográfico crítico, que põe em evidencia os sujeitos sociais e seus conflitos na produção do espaço.

Catia Antonia da Silva (NUTEMC - UERJ FFP) compreende que "está em emergência, um campo inovador e importante para repensar o fazer geográfico". Fernando Braconaro ressalta que "Há uma diversidade de trabalhos, porém, carece de discussão metodológica". 
Na compreensão de Taíse dos Santos Alves (GeograFar - UFBA) a Geografia permite múltiplas possibilidades de estudo da pesca artesanal, contribuindo com diversos olhares:

E limitam o debate como temática. Sobretudo, os pesquisadores que se debruçam nas pesquisas conseguem dá visibilidade e importância da atividade pesqueira permeando por diferentes discussões dentro da Geografia, social, política, econômica, escolar, representações sociais, cartografias, dentre outras. Pois a compreensão atividade pesqueira é complexa e merece percorrer diferentes olhares e dimensões.

Jeruza Rosário (UNEB/ GeograFar-UFBA) ressalta a demanda crescente e a qualidade dos trabalhos

Vejo que as pesquisas sob o olhar da Geografia em pesca artesanal têm obtido grandes ganhos, ainda que ainda sejam em número muito aquém do desejado, tendo em vista o extenso litoral que temos. De toda forma, ressalto o alto nível de qualidade de nossa pesquisa brasileira nesta área.

Já Cristina Buratto Gross Machado (UEL) atenta que além do crescimento no âmbito acadêmico, há necessidade de envolvimento com os pescadores artesanais, suas comunidades e movimentos sociais:

Acredito que estejamos avançando, vejo crescer o número de pesquisadores envolvidos com a questão e também o número de trabalhos em eventos e revistas. Mas creio que falta uma ligação maior com os movimentos dos pescadores, senti isso na minha pesquisa, a necessidade de contribuir mais com esses sujeitos, essa foi a minha lacuna. No doutorado, estou pensando sobre formas de contribuir para este coletivo também, e não só a academia.

Manuel de Jesus Masulo da Cruz (UFAM), ressalta para a necessidade de divulgação dessas pesquisas e o desenvolvimento de um trabalho em rede:

A pesquisa sobre a pesca artesanal na Geografia brasileira tem avançado significativamente nas duas últimas décadas, entretanto, precisa ser mais divulgada os resultados dessas pesquisas. Para tanto, a criação do grupo Interinstitucional Rede de Geografia da Pesca pode contribuir muito com essa divulgação. Aproximação de pesquisadores é fundamental.

\section{ii. Relevância do debate sobre a pesca artesanal no âmbito da Geografia}

Tratando das pesquisas sobre a pesca na Geografia, 26,53\% dos pesquisadores destacaram como relevante estabelecer essa discussão. Essa compreensão foi predominante entre os pesquisadores da região Sul, mas também tem destaque nas regiões Sudeste e Norte.

Em relação a relevância do estudo da pesca artesanal na Geografia brasileira, é importante enaltecer que desde o período de renovação da Geografia, em especial com a 
constituição da Geografia Crítica (MORAES, 2005), o pensamento geográfico abre espaço para sujeitos que até então eram marginalizados na sociedade e na ciência. Outro fator a considerar são as linhas de pesquisa dos programas de pós-graduação, que abrem espaço para abordar os territórios dos pescadores artesanais e problemáticas ambientais relacionadas com a pesca.

Cleyton Luiz Pies (Uniguaçu) enfatiza a importância das pesquisas sobre a pesca artesanal na Geografia e a contribuição social:

São de suma importância para conhecer os espaços onde a pesca se desenvolve, preservando a vida aquática no seu habitat natural, quando a pesquisa apontar possíveis impactos ocorridos buscar junto aos orgãos competentes soluções aos problemas, assim podendo manter a quantidade de pescado e a qualidade do espaço onde a pesca artesanal ocorre, a segurando a renda do pescador artesanal.

Dilson Gomes Nascimento (UFAM) destaca que "os trabalhos sobre a pesca são esclarecedores de várias questões nas quais os pescadores têm sido envolvidos, como a exploração por atravessadores e a situação de pobreza e conflitos que os mesmos têm enfrentado". O autor atenta para a utilização de denominações comuns, que não expressam a complexidade da pesca em diversas regiões. Nesse sentido, Christian Nunes da Silva (GAPTA - UFPA) atenta "que é necessário o aprofundamento teórico e cartográfico nas pesquisas sobre a atividade pesqueira. A discussão conceitual, a partir de categorias geográficas, ainda é muito tímida em nossa área de pesquisa".

Grazielle Ferreira (UNIOEST) aponta para o universo a ser pesquisado na pesca artesanal brasileira e sobre a diversidade de abordagens possíveis:

Pensar em pesca artesanal é importante no Brasil visto sua extensão de águas e a quantidade de trabalhadores, e refletir sobre as suas principais problemáticas pressupõe o entendimento da pesca artesanal como uma atividade complexa e que forma territórios que perpassam por uma série de desafios e de conflitos, que tem como base comum a valorização capitalista do espaço geográfico e as diferenciações de interesses sociais, políticos e econômicos. Nos últimos anos, a pesca artesanal tem sido foco de muitas pesquisas que refletem sua realidade e diversidade trazendo para o debate as medidas necessárias a serem tomadas para melhorar atividade pesqueira artesanal.

\section{iii. Poucas referências na Geografia}

Por outro lado, 24,49\% dos pesquisadores que responderam a questão sobre as pesquisas sobre a pesca artesanal na Geografia brasileira, entendem que ainda são poucas as referências 
nessa área do conhecimento. Essa compreensão tem maior destaque entre os pesquisadores da região Norte.

Considera-se relevante rebater o entendimento da existência de poucas referências na área da Geografia sobre a pesca com a evidencia de 104 trabalhos identificados na pesquisa, embora com o processo de expansão recente. Em De Paula (2016) também está expresso a presença das problemáticas da pesca artesanal em Encontros de Geógrafos - ENG e CBG. Sendo assim, a falta de referências, é na verdade, a falta de conhecimento sobre a pesquisa em pesca artesanal na Geografia Brasileira.

Ana Paulina Aguiar (UEA Manaus) entende que a pesca artesanal é "um campo de estudos que merece melhor dedicação tanto no que trata das discussões sobre territorialidades, quanto no contexto da Geografia Econômica e Geografia do Trabalho".

Tiago Rossi de Moraes (UFSM) entende que:

A Geografia pouco tem se dedicado a análise da pesca artesanal, esta é uma temática que não costuma despertar interesse dos novos pesquisadores, principalmente no Rio Grande do Sul. Isso é lamentável, pois a ciência geográfica tem muito a contribuir em estudos relativos a pesca artesanal e organização dos pescadores.

\section{iv. Avança lentamente em proporção ao movimento da sociedade}

Ainda na perspectiva dos pesquisadores anteriores, em 18,37\% das respostas quanto pertinência dos estudos sobre pesca artesanal na Geografia, entendem que os mesmos estão avançando lentamente em proporção ao movimento da sociedade. Essa visão é predominante entre os pesquisadores da região Nordeste.

Como já se destacou o avanço, em número, tem sido intenso a partir de 2005 e, principalmente a partir de 2010. Contudo, os pesquisadores também se referem a avanços qualitativos no que diz respeito a teorias e métodos empregados. Isso será melhor compreendido na próxima sessão desse Capítulo.

Anelino Silva (UFRN) aponta para a necessidade de compreender a essência da pesca artesanal:

As pesquisas sobre a pesca artesanal têm avançado, embora lentamente. A compreensão da essência do pescador e, por consequência da pesca é labiríntica. Não basta pontuar os problemas de uso de tecnologias, econômico e social. Necessário se faz apreender o que não conseguimos captar.

Guiomar Germani (GeograFar - UFBA) destaca que "Embora nos últimos tempos aparecem importantes trabalhos sobre a pesca artesanal na Geografia brasileira, o grupo social dos pescadores e pescadoras artesanais ainda continua marginal e invisível aos geógrafos". A 
pesquisadora destaca a invisibilidade desses trabalhos no âmbito da Geografia: "Independente de realizarem pesquisas específicas, em cada pedaço do espaço geográfico eles estão presentes, mas não aparecem na mesma proporção nos trabalhos realizados em nossa área do conhecimento".

Rosemeri Melo e Souza (GEOPLAN-UFS) destaca que a pesquisa sobre pesca na Geografia apresenta lacunas:

As relações entre pesca e gênero, por exemplo, consistem aspecto ainda incipientemente desenvolvido na pesquisa geográfica sobre a pesca artesanal, bem como as repercussões das políticas territoriais sobre as comunidades haliêuticas. Outra lacuna significativa consiste na reprodução social e espacial de grupos plurivalentes de pescadores(as) artesanais.

Com o olhar voltado para as pesquisas sobre pesca promovidas nos Programas de PósGraduação em Geografia, evidencia-se a concentração da pesquisa realizada em programas do Sudeste, Nordeste e Sul. Desde 2005 se observa a maior presença de cursos fora do eixo Sudeste-Sul, como resultado de uma política de Estado (PNPG 2005-2010/2011-2020). Isso deu maior visibilidade para as problemáticas dos pescadores evidenciadas por pesquisadores das regiões Nordeste e Norte. Diante disso, a maioria dos pesquisadores compreendem essas pesquisas como emergentes e relevantes. Contudo, a divulgação de tais estudos ainda é reduzida.

\subsection{Análise das Pesquisas considerando as Áreas de Estudo}

Tendo compreendido onde e quando e em que perspectiva são realizadas essas pesquisas, do ponto de vista institucional, nesse momento a análise será realizada a partir das áreas de estudo. No universo total (figura 33) da pesquisa, cabe destacar que o estado da Bahia foi o que teve mais áreas de estudo analisadas (9 trabalhos). Na sequência estão Amazonas, Ceará e Rio Grande do Sul (8 trabalhos). Rio de Janeiro e Pará concentraram seis pesquisas. Alagoas, Maranhão, Minas Gerais, Mato Grosso, Paraíba, Pernambuco, Rio Grande do Norte, Santa Catarina, Sergipe e São Paulo, tiveram de um a quatro trabalhos analisados. 


\section{GEOGRAFIAS DA PESCA ARTESANAL BRASILEIRA:}

Trabalhos Analisados por UF

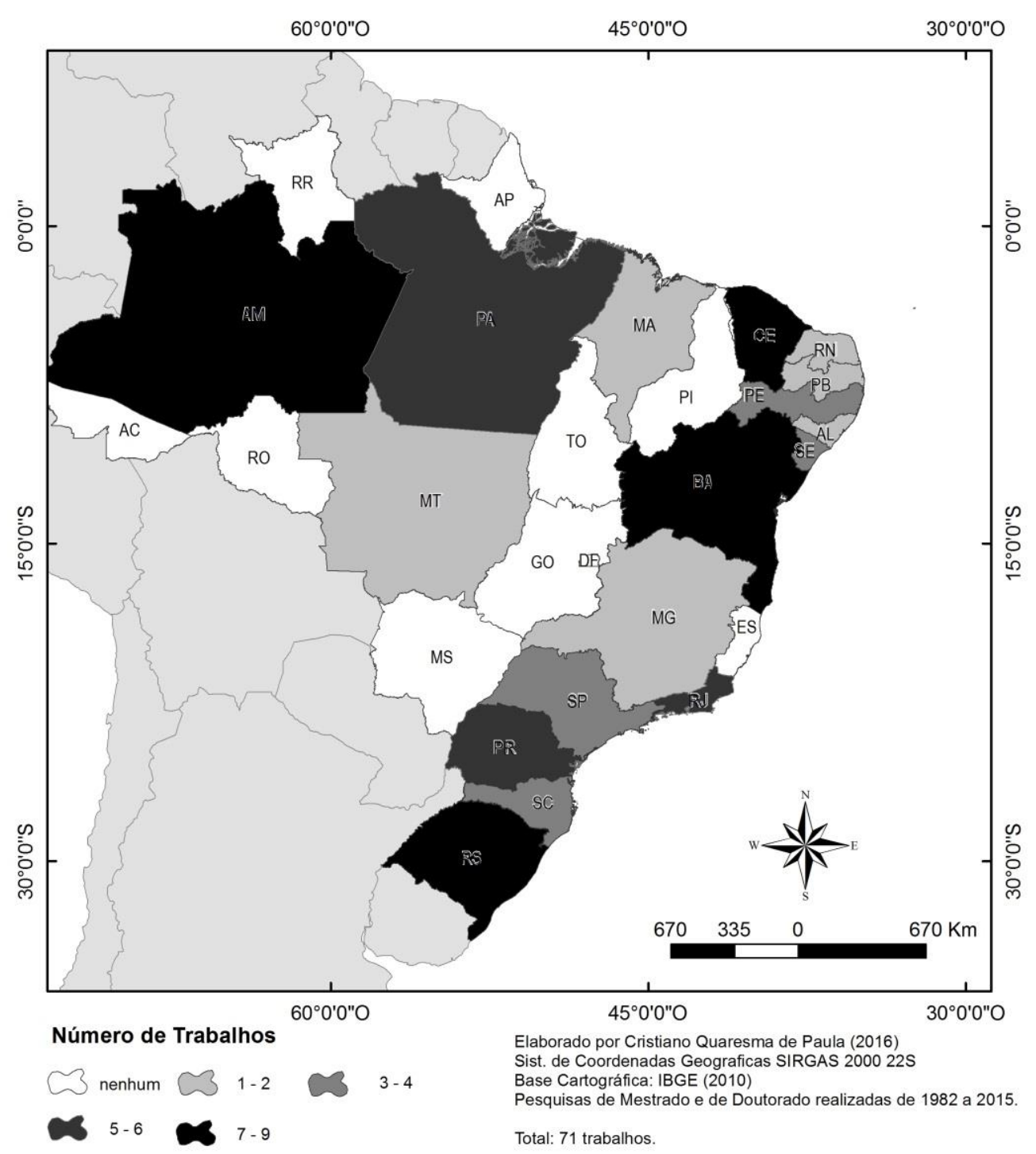

Figura 33: Mapa de Trabalhos Analisados, por Unidade da Federação Fonte: Elaborado por De Paula (2018)

A figura 14 expõe o mapa de densidade das áreas, que ocorreram as pesquisas no Brasil. Se comparar esse mapa com o de densidade de instituições (figura 34) conclui-se que há uma maior concentração das instituições de pesquisa, do que das áreas de estudo. Ainda se observa que algumas áreas que concentram muitas instituições, como a região Sudeste, não apresentam densidade tão elevada de áreas de estudo, o que tem relação com a diversidade de propostas de pesquisa dos programas. Cabe destacar que neste momento estão sendo consideradas somente as pesquisas de mestrado e doutorado. 


\section{GEOGRAFIAS DA PESCA ARTESANAL BRASILEIRA:}

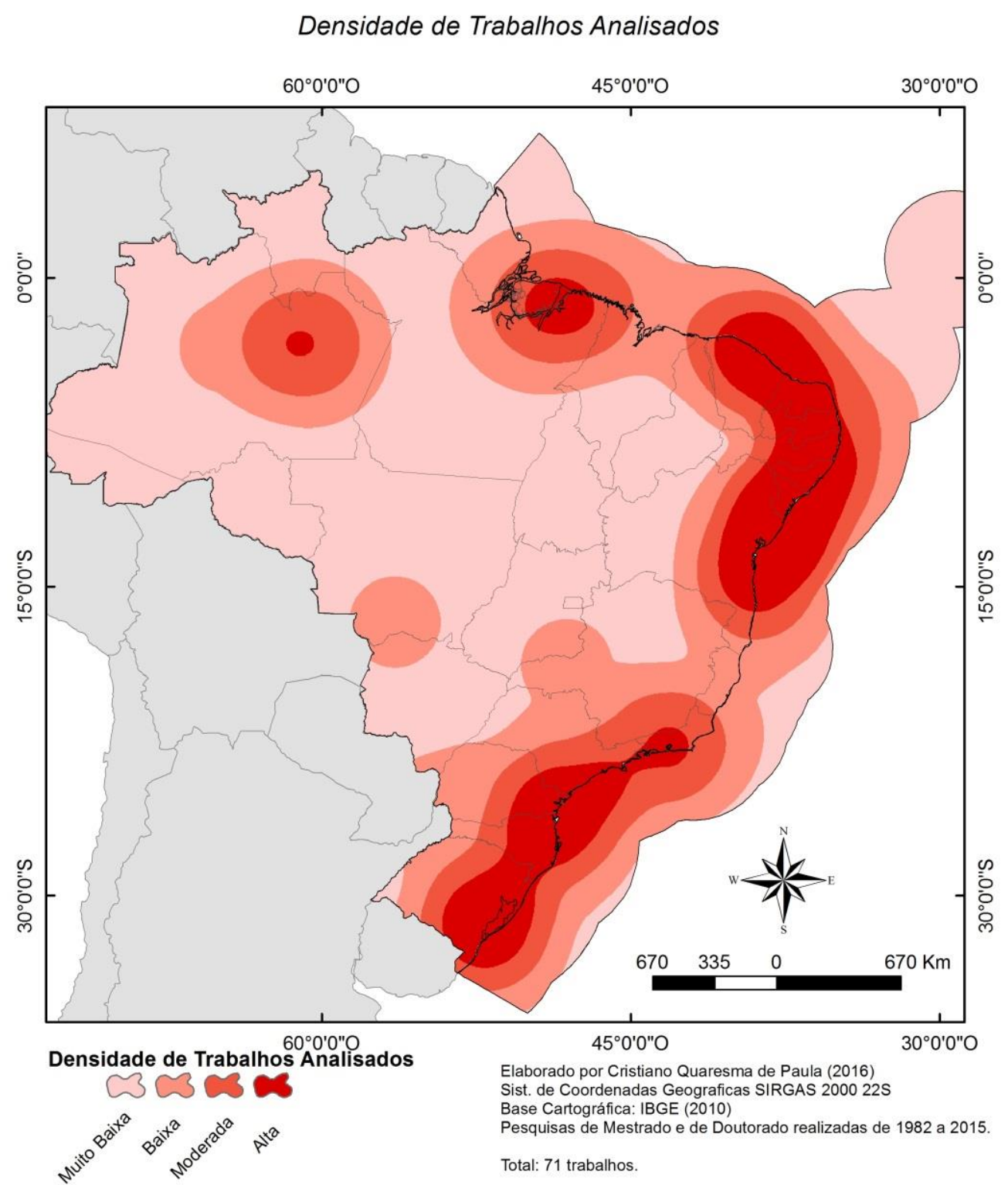

Figura 34: Mapa de Densidade de Pesquisas Analisadas.

Fonte: Elaborado por De Paula (2018)

Destaca-se a área de alta densidade sobre os estados do Nordeste e Sul e em pontos mais concentrados do Sudeste e do Norte. Há a prevalência de pesquisas na região litorânea, em detrimento das águas interiores.

Ressalta-se que ocorrem pesquisas com densidade moderada-alta na região amazônica. Nas áreas de densidade baixa ou moderada que não estão na costa, existem importantes corpos de água, como é o caso da complexa rede hidrográfica amazônica, Pantanal Mato-grossense, estuário do Rio São Francisco, Rio Araguaia, e Lago Itaipu. 
O mapa de densidade dos trabalhos em Geografias da pesca exprime a evidência das problemáticas dos pescadores em abordagens dos geógrafos de forma considerável do Brasil. As áreas de densidade alta assumem protagonismo nessas abordagens e se demonstram potenciais para o diálogo entre os geógrafos. As áreas de densidade moderada e baixa se põem como possibilidade para se tramar uma rede de cooperação e ações conjuntas.

Ainda para caracterizar essas pesquisas foi relevante compreender os estágios da formação acadêmica em que foram realizadas. Esta análise não está baseada nas instituições de pesquisa, mas nas áreas da pesquisa (figura 35).

\section{GEOGRAFIAS DA PESCA ARTESANAL BRASILEIRA:}

Trabalhos Analisados (Dissertações e Teses), por UF

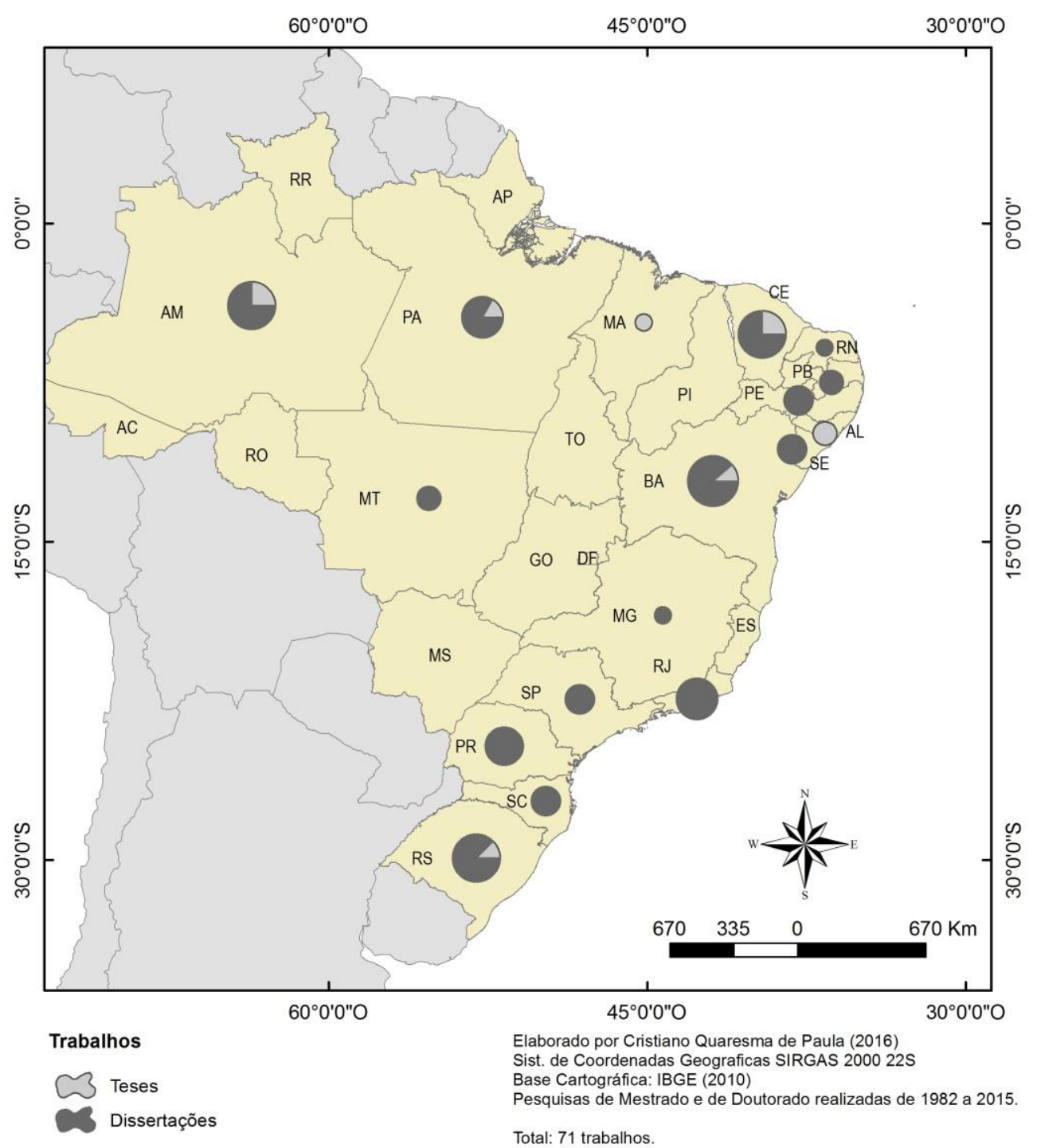

Figura 35: Mapa de Trabalhos Analisados (Dissertações e Teses), por Unidade da Federação. Fonte: Elaborado por De Paula (2018) 
As dissertações de mestrado (figura 36) foram os trabalhos mais numerosos, considerados na análise. Foi a principal modalidade de trabalhos analisados (61) de todas as regiões brasileiras. Só na região Nordeste estão 37,70\% dissertações de mestrado analisadas. Na sequência tem-se a região Sul $(22,95 \%)$ e Norte $(19,67 \%)$ no número de dissertações. A região Sudeste concentrou $16,39 \%$ das dissertações de mestrado e a Centro-oeste somente 3,28\%. Há uma distribuição dessas dissertações em todo o Brasil, com destaque na região Nordeste e menor número no Centro-oeste.

\section{GEOGRAFIAS DA PESCA ARTESANAL BRASILEIRA:}

\section{Densidade de Trabalhos (Dissertações de Mestrado)}

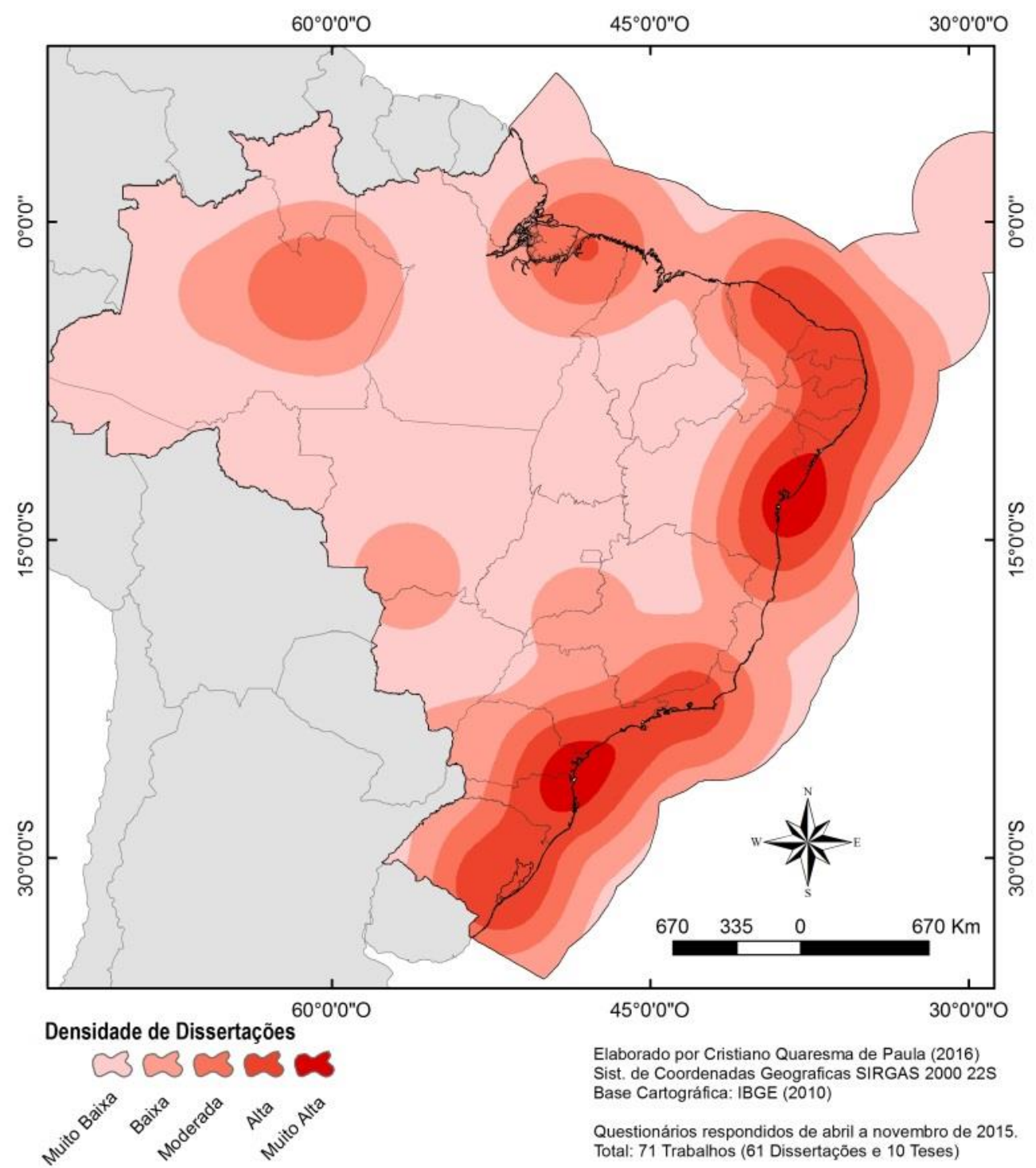

Figura 36: Mapa de Densidade de Trabalhos (Dissertações de Mestrado).

Fonte: Elaborado por De Paula (2018). 
Foram analisadas 10 teses de doutorado (figura 37), das quais 50\% correspondem à região Nordeste. A região Norte contém $40 \%$ das áreas de pesquisa analisadas através das teses de doutorado. A região Sul concentra $10 \%$ das teses e as demais regiões não tiveram áreas de estudo analisas por meio de teses. As Geografias da Pesca, que se expressa através das teses de doutorado, referem-se prioritariamente à região Nordeste.

\section{GEOGRAFIAS DA PESCA ARTESANAL BRASILEIRA:}

\section{Densidade de Trabalhos (Teses de Doutorado)}

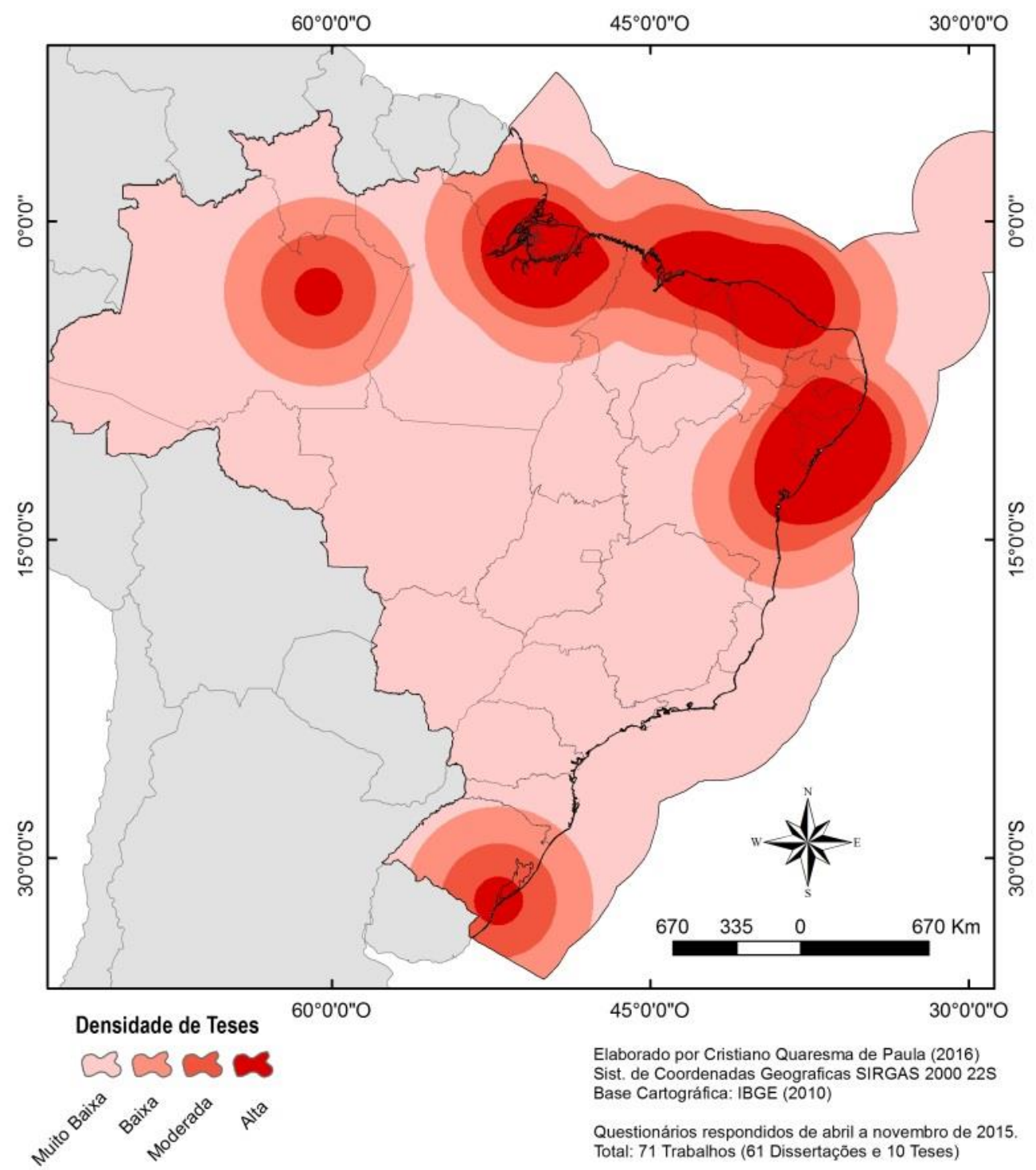

Figura 37: Mapa de Densidade de Trabalhos (Teses de Doutorado)

Fonte: Elaborado por De Paula (2018). 
Ao comparar o mapa de densidade das pesquisas analisadas com a densidade de dissertações de mestrado, contata-se que são bem semelhantes. Assim, do ponto de vista da densidade, as dissertações de mestrado correspondem à abrangência das áreas de estudo das Geografias da pesca artesanal brasileira.

Apesar do número mais restrito de teses de doutorado analisadas (10) nota-se um comportamento diverso das dissertações. As áreas de pesquisa de teses estão muito concentradas no Nordeste brasileiro.

\subsubsection{Principais abordagens conceituais}

É importante distinguir que as abordagens de território, espaço e ambiente são as mais frequentes nos trabalhos. Do total de conceitos empregados, 70,43\% das abordagens se referem aos conceitos de território, $43,66 \%$ se referem aos conceitos de espaço e 33,80\% de ambiente (figura 38). 


\section{GEOGRAFIAS DA PESCA ARTESANAL BRASILEIRA:}

\section{Conceitos Abordados por UF}

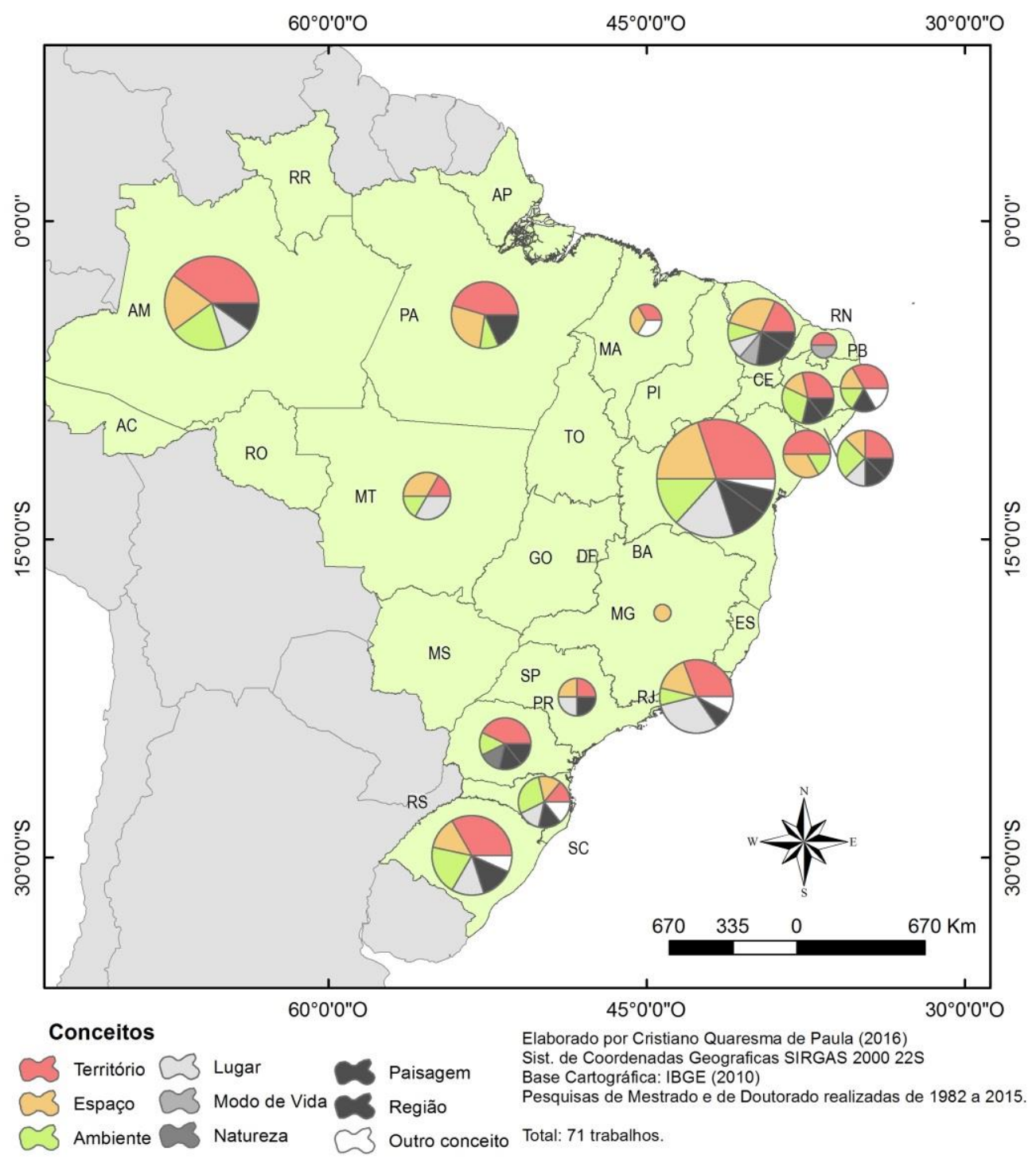

Figura 38: Mapa de Principais Abordagens Conceituais, por Unidade da Federação. Fonte: Elaborado por De Paula (2018).

As abordagens de território são as que mais aparecem nos trabalhos sobre pesca artesanal (50 vezes), estas predominam em todas as regiões exceto na Centro-oeste. Nas regiões Nordeste e Norte estão a maior parte das pesquisas que abordam o conceito de território, $42 \%$ e $28 \%$ respectivamente. Destaca-se os estados do Bahia (9) e Amazonas (8). Estas também são muito frequentes no Sul (18\%) e Sudeste (10\%), destacam-se, por exemplo, os estados do Rio Grande do Sul (5) e Rio de Janeiro (4). 
Perspectivas de espaço também são frequentes nas pesquisas analisadas (31 vezes). Este é o conceito mais frequente nos trabalhos da região Centro-Oeste ( 2 vezes). Do total das abordagens do conceito de espaço, a região Nordeste apresenta 48,39\% do total, onde se destaca o estado Bahia (6). A região Norte empregou 25,81\% do total das abordagens do conceito de espaço, onde se destacam Amazonas (4) e Pará (3). A região Sudeste empregou 12,90\% do total, deste do Rio de Janeiro (2) e a Região Sul somente 6,45\%, sendo do estado do Rio Grande do Sul (2).

As abordagens do conceito de ambiente também são recorrentes nas pesquisas analisadas (24 vezes). Na região Nordeste, essas abordagens são bastante utilizadas (45,83\%), onde destaca-se o estado da Bahia (4). A região Sul apresenta $25 \%$ das abordagens de ambiente e a região Norte 20,83\%, destas destacam-se os estados do Rio Grande do Sul (3) e Amazonas (4). Na região Sudeste estão somente $4,17 \%$ dos trabalhos que abordam o conceito de espaço, sendo um trabalho no Rio de Janeiro. Igualmente no Centro-Oeste $(4,17 \%)$ sendo um trabalho no Mato Grosso.

Os conceitos de lugar e paisagem se evidenciam em 26,76\% dos trabalhos analisados. São 19 pesquisas que apresentam essas abordagens conceituais, sendo que o conceito de lugar é uma abordagem considerável na região Nordeste (36,84\%), onde destaca-se o estado da Bahia (5) e Sudeste (26,32\%) onde se evidencia o Rio de Janeiro (4). Nas regiões Sul (15,79\%), Norte $(10,53 \%)$, e Centro-Oeste (10,53\%) as abordagens de lugar são menos numerosas. Nestes, destaca-se Rio Grande do Sul (2). Amazonas (2) e Mato Grosso (2).

O conceito de paisagem foi abordado em 17 das pesquisas analisadas. Assim, 35,29\% das abordagens corresponde a região Nordeste, 29,41\% a região Norte e 23,53\% região Sul. Nestas, se destacam os estados da Bahia (3), Pará (2) e Rio Grande do Sul (2). A região Sudeste integrou $11,76 \%$ dos trabalhos que abordam esse conceito, nos estados do Rio de Janeiro e São Paulo (ambos 1)

Os conceitos de região $(9,86 \%)$, modo de vida $(2,82 \%)$ e natureza $(1,41 \%)$ são os menos frequentes. São sete trabalhos que abordam o conceito de região, sendo seis deles da região Nordeste, dos quais dois do estado da Bahia. O conceito de modo de vida só apareceu em duas pesquisas da região Nordeste. E o conceito de natureza aparece somente uma vez, na região Sul, estado do Paraná. 


\section{Abordagens de território}

Os conceitos de território são os mais adotados nas pesquisas analisadas (50 de 71). Se comparar a densidade dos trabalhos que utilizam conceitos de território dos que estabelecem abordagens ambientais, verificamos que são bem semelhantes. O que se evidencia é uma densidade muito alta de abordagens de território no Sudeste e densidade alta na região Sul. A concentração semelhante das abordagens ambientais e territoriais já indica a relação entre estes conceitos (figura 39).

\section{GEOGRAFIAS DA PESCA ARTESANAL BRASILEIRA:}

Densidade de Trabalhos que Abordam o Conceito "Território"

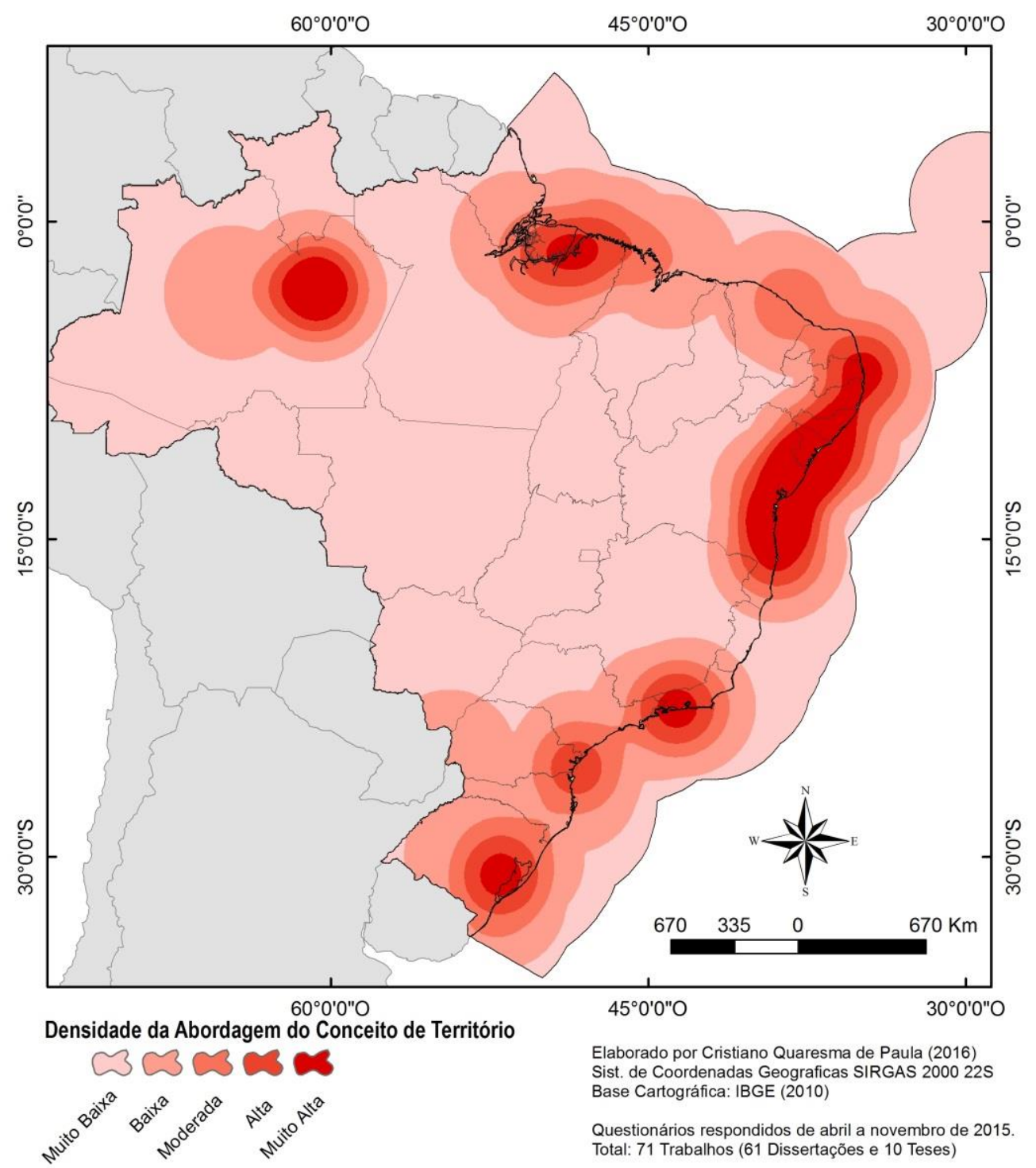

Figura 39: Mapa de Densidade de Trabalhos que Abordam o Conceito de Território Fonte: Elaborado por De Paula (2018). 
O autor mais evocado quanto às abordagens de território é Claude Raffestin. Christian Silva (2006A) frisa que o autor insere a discussão sobre o poder na apropriação do território e na produção do espaço. Raffestin (1993) entende o poder como componente de qualquer relação e alicerce do jogo de forças que convergem para a configuração sócio-territorial de determinado tempo e espaço, organizados por energia e informação. Assim, a construção do território se forma nas tessituras, nós e redes que constituem um sistema territorial (SILVA, 2006A).

Para Raffestin (1933) falar de território é fazer uma referência implícita à noção de limite, o que expressa a relação que um grupo mantém com uma porção do espaço. Compreende-se como delimitar, isolar ou subtrair momentaneamente ou manifestar o poder em uma área precisa (SILVA, 2006A). Assim, como enfatiza Janaina Silva (2006B) território é espaço apropriado pelos sujeitos no seu dia-a-dia.

Outro autor que influencia as abordagens de território nos trabalhos analisados é Robert Sack (1986). Queiroz (2012) ressalta que sendo o território o resultado da ação de um sujeito, a territorialidade é a própria ação. Nessa perspectiva Sack (1986) expõe que a territorialidade é estratégia individual ou coletiva de usar, ocupar, controlar e identificar uma parcela específica do espaço. Logo, na perspectiva do autor, o conceito de territorialidade consiste em uma estratégia para a gestão do território em questão, onde se estabelece diferentes graus de acesso às pessoas, o que pode incidir em conflitos envolvendo atores externos e internos (QUEIROZ, 2012).

Influenciado por estes autores e presente em diversos trabalhos, encontra-se Haesbaert (2006). Este, frisa na Geografia brasileira, que o território deve ser abordado em um sentido amplo, multidimensional e multiescalar, assim tal conceito deve ser abordado segundo os contextos histórico e geográfico que foi concebido (FERREIRA, 2014).

Dumith (2012) baseada em Haesbaert (2007) destaca que "territorializar-se significa criar mediações espaciais que proporcionem efetivo poder sobre a reprodução enquanto grupos sociais". No entanto, deve ser considerada a variedade geográfica, pois tais mediações são influenciadas por aspectos culturais e de identidade.

Ainda sobre Haesbaert (2007), Cunha (2011) destaca que o autor estabelece três vertentes básicas para apreender a noção de território. Primeiro, a noção jurídica-política e o entendimento da constituição de poderes legais, o poder político do Estado. Segundo, a noção cultural e simbólica a partir da apropriação e valorização simbólica de um grupo sobre seu espaço vivido na constituição de identidades. Terceiro, a noção econômica do território, a qual ressalta a questão da apropriação do território como fonte de recursos. 
Saquet (2010) também é interlocutor do conceito de território na Geografia brasileira. Torres (2014) se baseia no autor para tratar da produção espaço-temporal do território, por meio de relações de poder estabelecidas por um grupo social. Acrescenta que, este território, pode ser temporário ou permanente, ocorre em diversas escalas - além do território nacional. $\mathrm{O}$ autor enfatiza que tanto as relações de poder como as identidades e os processos de territorialização, desterritorialização e reterritorialização são relacionais e historicamente instituídos. Assim, o tempo histórico pode ser uma categoria fundamental para a análise e interpretação do território (TORRES, 2014).

Também é importante a contribuição de Saquet (2010) quanto à discussão sobre a relação do sujeito com o território, o que remete à construção humana, cultural, histórica e integrando tempo e espaço (TORRES, 2014). "O território e a territorialidade são produtos do entrelaçado dos sujeitos de cada lugar, destes com o ambiente e com indivíduos de outros lugares, efetivando tramas transescalares em diferentes níveis territoriais" (SAQUET, 2010, p.116).

Nas discussões sobre território, com base em outros autores, Giannela (2009) destaca Souza (2006) que relaciona território e autonomia. Ressalta que o processo de modernização no capitalismo global é avassalador nas comunidades tradicionais, mas estas coletividades territorialmente referenciadas defendem sua qualidade de vida e identidade cultural.

Segunda Ferreira (2013) "para o geógrafo Milton Santos o território somente pode ser compreendido por meio da análise de seus usos e interesses". Assim, o autor apresenta o conceito de território usado para apresentar os fortes domínios do Estado e das empresas no final do século XX. Cabe ressaltar o diálogo estabelecido entre e com Milton Santos e autores de outras áreas do conhecimento, como a Socióloga Ribeiro (2011) que destaca os diversos usos do território em cooperação e concorrência numa luta para a manutenção da identidade, o que remete ao estabelecimento de movimentos sociais (FERREIRA, 2013).

Outras referências internacionais, abordadas em menor número são Bonnemaison (2002) e Di Méo (2006). Sobre o primeiro, Torres (2014) elenca a reflexão de que a cultura produzida em termos de espaço não pode ser separada da ideia de território. Ainda é pela experiência de uma cultura que se estabelece território, o qual fortalece a relação simbólica entre cultura e espaço. Di Méo (2006) destaca que o território contém os recursos necessários para o desenvolvimento do indivíduo e expressa territorialidades individuais e coletivas. Logo, no território, seus atores e agentes são capazes de imaginar, criar e gerenciar políticas e medidas 
que atendam aos seus objetivos e intencionalidades de apropriação da natureza (DE PAULA, 2013).

\section{Abordagens de espaço}

Observando a densidade do emprego do conceito de espaço nas pesquisas sobre a pesca na Geografia brasileira, identifica-se a distribuição de áreas de alta densidade em todas as regiões brasileiras. Verifica-se que há predileção por este conceito na Geografia brasileira, o qual é utilizado conforme a problemática em questão. As mais extensas áreas de concentração encontram-se no Sudeste e Nordeste brasileiro (figura 40).

\section{GEOGRAFIAS DA PESCA ARTESANAL BRASILEIRA:}

Densidade de Trabalhos que Abordam o Conceito "Espaço"

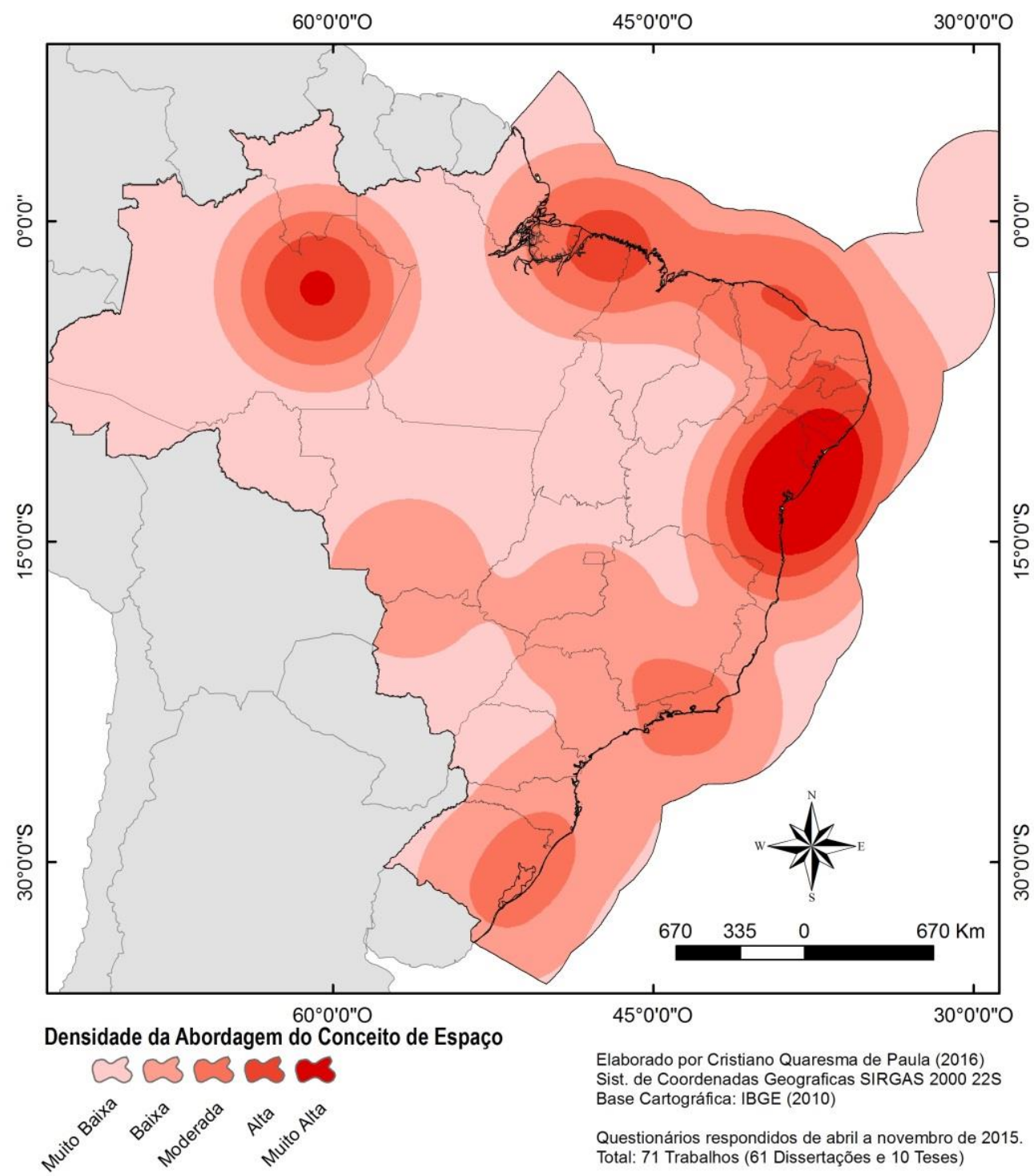

Figura 40: Mapa de Densidade de Trabalhos que Abordam o Conceito de "Espaço" Fonte: Elaborado por De Paula (2018) 
Nesse momento será dado ênfase ao conceito de espaço nas abordagens de "Geografia da Pesca". Observa-se a densidade alta da adoção desse conceito, que é bastante frequente nos trabalhos (31 de 71). Isso expõe a importância dos conceitos de espaço geográfico na Geografia brasileira. Contudo, cabe frisar a pluralidade de conceitos empregados para designar espaço e as adjetivações (urbano, agrário, social e pesqueiro).

As concepções de Milton Santos são as mais evocadas no que se refere ao emprego do conceito de espaço. Kuhn (2009) enaltece o argumento de Santos (2004) que entende o espaço, enquanto objeto da Geografia. Para o autor, no entanto, tal definição não é uma tarefa simples "Há o espaço de uma nação - sinônimo de território, de Estado; há o espaço terrestre, da velha definição da Geografia; e há, igualmente o espaço extraterrestre, recentemente conquistado pelo homem e, até mesmo o espaço sideral, parcialmente um mistério" (SANTOS, 2008, p. 150).

Logo, é pressuposto da análise geográfica considerar o espaço em suas diversas perspectivas, sobretudo como resultado das relações estabelecidas entre sociedade e natureza, mediada pelo trabalho e pelas técnicas (KUHN, 2009). Nesta perspectiva "o espaço é morada do homem, é o lugar de vida e de trabalho" (SANTOS, 2008 apud KUHN, 2009).

Também baseada em Santos (2004), Rios (2012) compreende o espaço como social, logo a sua produção se dá por meio das relações sociais e das relações entre sociedade e natureza, as quais são mediadas pelo trabalho humano. Logo, a produção do espaço deve considerar os diversos agentes, os quais produzem o espaço geográfico local. A autora ressalta o espaço como materialização dos processos sociais, logo humano ou social (SANTOS, 2004 apud RIOS, 2012).

Em síntese a concepção de espaço, na perspectiva de Santos (2006), aborda a formação socioespacial, fixos e fluxos, meio técnico-científico-informacional. Nessa perspectiva se discute o espaço na sua relação com o tempo, o qual é empiricisado pela técnica.

Além da perspectiva de Santos há presença de discussões sobre o espaço por outros autores, vinculados a vertente Teórica Marxista. Entre eles são evocados Lefebvre, Soja e Harvey. Lefbvre (2008) é mencionado pelos autores que se referem ao espaço social, vivido e concebido. Assim, não trata das coisas no espaço, mas a própria produção do espaço, o qual está atrelado a reprodução das relações sociais de produção (COSTA, 2010).

Costa (2010) ressalta, com base neste autor, que toda sociedade produz seu espaço, ou caso prefira, toda sociedade produz um espaço. Outros autores que derivam das abordagens de Lefebvre são mencionados como Carlos (2007) que vai ressaltar que a noção de produção supera, sem ignorar, a dimensão econômica, elevando a análise a outro patamar. Como destaca 
Nunes (2011), para Carlos (2007) na prática socioespacial, não há sociedade sem a condição de produzir espaço. Esta autora também é muito evocada no que se refere as abordagens do espaço urbano.

Outro autor bastante referenciado é Soja (1993), o qual vai tratar de forma diferenciada a espacialidade no modo de produção capitalista em distinção dos outros modos de produção já passados. Soja (1993, p 65) apud Costa (2010) vai compreender a "produção e reprodução peculiares de um desenvolvimento geograficamente desigual, através de tendências simultâneas para a homogeneização, a fragmentação e a hierarquização".

Ainda nas discussões sobre o espaço, na perspectiva Teórico Marxista, outro autor citado é Harvey (2004). Com base neste autor, Cavalcante (2012) ressalta a produção diferenciada do espaço em uma lógica de dialética da relação entre global e local. Logo, entende que a globalização merece ser vista de forma multilateral e interdependente de relações entre potências emergentes e economias desenvolvidas. Assim, um dos conceitos apontados por Harvey (2004) é de desenvolvimento geográfico desigual, destacando o papel e as dificuldades das potências periféricas (CAVALCANTE, 2012).

Entre os autores brasileiros, que estabelecem discussões na perspectiva Teórico Marxista também é referenciado Oliveira (1982). Segundo Prado (2014), este autor oferece elementos teóricos importantes para leitura do processo de materialização no espaço-tempo das relações concretas que produziram o espaço. Oliveira (1982, p. 97) ressalta como "O traço geral do espaço e do tempo consiste no fato de que neles estão unidos os momentos da mutação e da estabilidade". Tais circunstâncias e contradições intrínsecas a elas tendem a se refletirem nas representações do espaço, enquanto forma de ser da matéria, que refletem na sua essência e nas propriedades e relações dos fenômenos. Oliveira (1982) além de discutir o espaço no capitalismo, aparece nas reflexões sobre o espaço agrário.

Também foi citada quanto a utilização do conceito de espaço Doren Massey (2008). Santos (2012) destaca que essa autora estabelece três proposições para a análise do espaço: produto de inter-relações e interações, desde a imensidão global ao pequeno; esfera da possibilidade de existência de multiplicidade, pluralidades e coexistências de trajetórias; sempre em construção, sendo produto de relações vinculadas a práticas materiais em um processo de sempre fazer-se. Logo Santos (2012) ressalta o espaço em Massey, como dimensão do social e coexistência contemporânea da multiplicidade. As abordagens de Massey também contribuem com a discussão de gênero na pesca. 
O conceito de espaço foi tratado à parte para enfatizar a importância deste para a Geografia. Segue-se a perspectiva de Suertegaray (2001) que entende o espaço geográfico como uno e múltiplo, podendo ser compreendido através de conceitos operacionais. Neste Capítulo será enfatizada a discussão dos conceitos de ambiente e território. Contudo, serão expostos brevemente outros conceitos elencados pela autora como lugar, paisagem, região e modo de vida.

\section{Abordagens de ambiente}

O conceito de Ambiente também está muito presente nas pesquisas analisadas sobre a pesca artesanal (24 de 71). Constatou-se esta presença mais significativa nas regiões Sul e Nordeste, onde se registra uma densidade muito alta. As áreas de densidade alta também se estendem ao longo do Sudeste. Na região Norte também se observa áreas de densidade moderada. No Centro-Oeste este conceito também está presente, mas com uma densidade mais baixa (figura 41). 


\section{GEOGRAFIAS DA PESCA ARTESANAL BRASILEIRA:}

Densidade de Trabalhos que Abordam o Conceito "Ambiente"

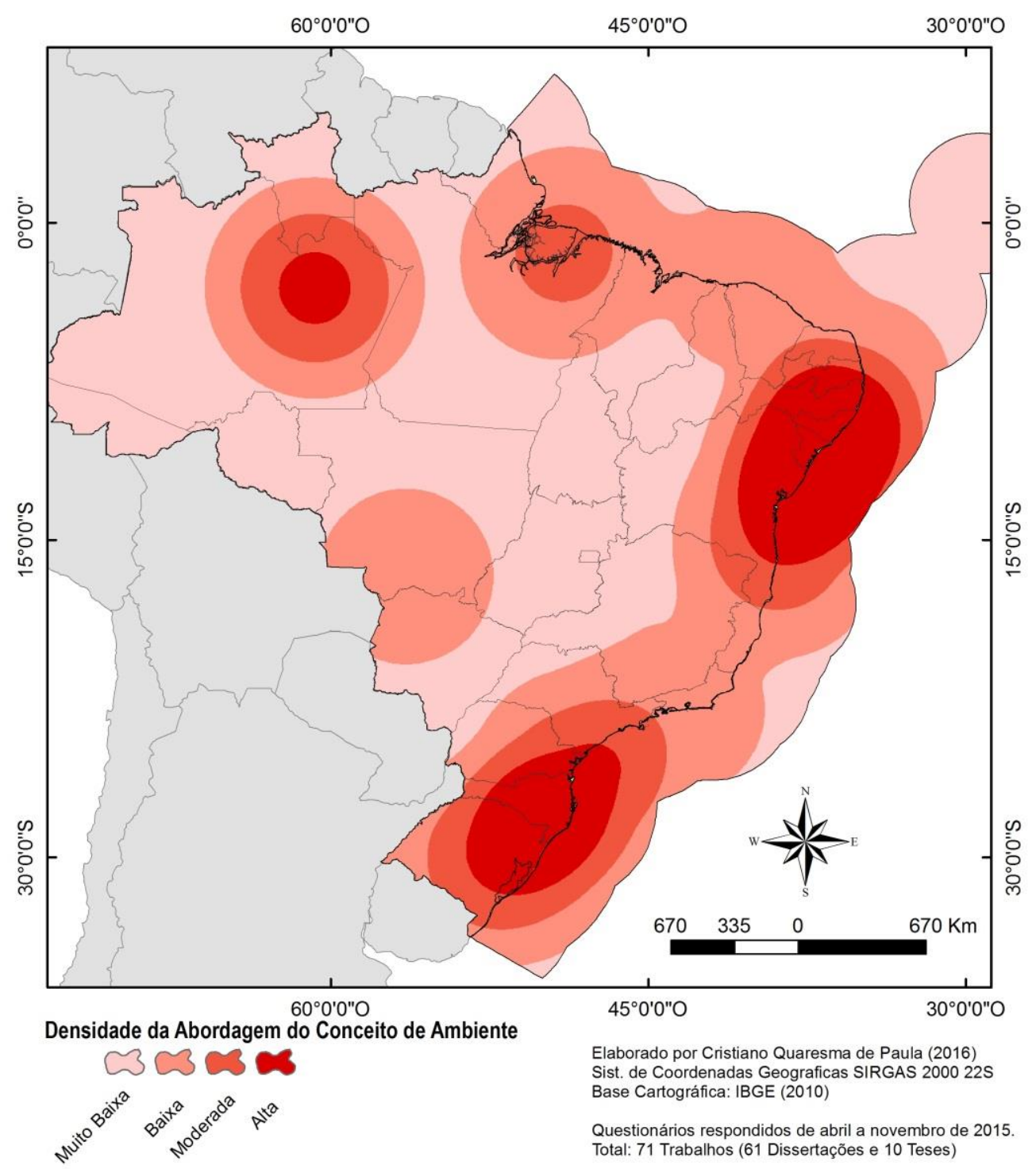

Figura 41: Mapa de Densidade de Trabalhos que Abordam o Conceito de Ambiente Fonte: Elaborado por De Paula (2018).

É pertinente afirmar que costumeiramente o conceito de ambiente não é apresentado com aprofundamento teórico-epistemológico. Em diversos trabalhos este conceito é considerado dado a priori. Contudo, conferiu-se em outros o empenho em estabelecer nuances do conceito, que o configuram de modo especial para a análise dos geógrafos.

Rodrigues (2014), por exemplo, para abordar a questão ambiental em unidades de conservação recorre Bertrand (2007) ressaltando que há necessidade de especializar este conceito, uma vez que por muito tempo o natural invadiu o social, muito mais do que o social o natural. Assim, o ambiente em um primeiro momento é margem distante e facultativa, mas 
passa a ser uma periferia obrigatória e cada vez mais exigente, até o momento presente em que é nó górdio da gestão territorial e da qualidade de vida.

A questão ambiental se expressa prioritariamente na discussão das relações estabelecidas entre sociedade e natureza. Para isso, é destacado o papel das técnicas e do trabalho, como enfatiza Santos (2004) mencionado por Rios (2012). Nunes (2011), por exemplo, não faz referência direta a uma questão ambiental, mas a discussão está presente quando a autora enfatiza as relações entre homem e natureza. Estas relações se diferem devido ao estabelecimento de valor de uso ou valor de troca.

Diversas vezes a discussão ambiental está presente nas abordagens de outros conceitos, como território. Machado (2007) enfatiza com base em Ratzel (1990) que os povos naturais se distinguem do "povo civilizado" pelo grau de dependência da natureza. Nesta perspectiva o ambiente se põe como relação e fonte de recursos presentes no território. Como destaca Vinhas (2011) baseado em Santos (2004) "para os atores hegemônicos o território usado é um recurso, garantia de realização dos seus interesses particulares". Para outros autores como Saquet (2010) o território é espaço de vida e fonte de recursos. Pode-se entender assim, os recursos ambientais.

Porto-Gonçalves é o autor mais referido, no que tange especificamente à questão ambiental nos trabalhos analisados. Em De Paula (2013) o autor (2010) é referido sobre a apropriação social da natureza pela sociedade, o que para determinados grupos se dá de forma diferenciada e se expressa em seus saberes. Ainda imergem no contexto atual, em que existem políticas públicas voltadas para determinados modos de viver, e se reinventam como povos tradicionais. Santos (2012) com base em Porto-Gonçalves (2006) discute a questão ambiental no âmbito político, mais especificamente na repercussão dos movimentos ecológicos a partir dos anos 70. Geralmente, os trabalhos que fazem referência a este autor também trazem contribuições de Leff (2006), logo se integram na construção de uma racionalidade ambiental, que se põe como possibilidade à atual racionalidade econômica.

Sem aprofundamento conceitual, considerou-se relevante frisar a presença do termo impacto ambiental na maior parte dos trabalhos. Repetidamente tal discussão se baseia na legislação ambiental vigente. A maioria dos trabalhos que tratam dos impactos ambientais fazem referências às normas da política ambiental brasileira e internacional. Contudo, muitos autores se restringem a estas, utilizando os conceitos empregados em tais políticas sem estabelecer críticas aos mesmos.

Ainda cabe ressaltar que o conceito de ambiente se apresenta híbrido nas abordagens. Tal hibridização que está sendo ressaltada se refere à relação deste com outros conceitos 
geográficos como natureza, espaço e território. Em algumas ocasiões se utiliza abordagens que problematizam outros conceitos para estabelecer a discussão ambiental. Isto é rico, uma vez que a questão ambiental é transversal, no contexto atual em que se vive uma crise ambiental que se expressa na sociedade geral e nos saberes gerados por ela.

Por fim, faz-se referência à Suertegaray (2017), que destaca o tratamento de impactos ambientais por geógrafos de forma distinta de outros profissionais, como os ecólogos. Nesse caso não se estuda somente impactos da sociedade sobre a natureza, mas os impactos de uma natureza transfigurada sob a sociedade, principalmente dos grupos que tem maior dependência do ambiente, como as comunidades tradicionais.

\section{Abordagens de lugar e paisagem}

Quanto ao conceito de lugar destacam-se as abordagens de Tuan e Relph. Rosário (2009) ressalta que para Tuan (1980) o espaço é mais abstrato que o lugar. Um espaço se transforma em lugar na medida que é conhecido e dotado de valor. É assim que se constitui sentimentos de lugar, dando concretude ao espaço terrestre ou aquático. Para Tuan a topofilia se evidência nos laços afetivos ao lugar. "Quando irresistível, podemos estar certos de que o lugar ou meio ambiente é o veículo de acontecimentos emocionalmente fortes ou é percebido como um símbolo" (ROSÁRIO, 2009).

Silva (2007) também aborda o conceito de lugar, mas baseado em canadense Edward C. Relph (1979). Tratando da percepção, postula que está "relaciona o modo de existência e o destino dos homens e, que assim, forma toda a experiência ambiental humana". O autor destaca que na medida que os ambientes são atrativos, confortáveis e favorecem experiências prazerosas, são considerados topofílicos. Contudo, quando os ambientes nos proporcionam sensações de aversão, desagrado ou depressão são considerados lugares topofóbios (SILVA, 2007).

Chaves (2011) ressalta a importância do lugar e território, com referência em Claval (1999), que entende o território como espaço de realização das práticas espaciais do grupo. Já o conceito de lugar é a garantia de sobrevivência e manutenção deste grupo. Logo são conceitos necessários para a sua apropriação e defesa, mantendo a soberania do grupo sobre este espaço.

Bertrand apud Moraes (2010) é o autor mais presente nas discussões sobre paisagem entre os trabalhos analisados. Moraes (2010) se fundamenta no postulado desse autor que ressalta que a paisagem não é a simples adição de elementos geográficos na análise, mas o resultado da combinação dinâmica, portanto instável, de elementos físicos, biológicos e 
antrópicos, os quais agem dialeticamente formando a paisagem como conjunto único, indissociável e em perpétua evolução.

Bonnemaison também está presente nos trabalhos que tratam do conceito de paisagem, este se detém à presença de marcas e artefatos existentes na paisagem, as quais podem ser compreendidas como geossímbolos. Bonnemaison (2002) ressalta que esse o espaço de existência de geossímbolos é uma forma de linguagem, um instrumento de comunicação compartilhado por todos e, sobretudo, o lugar onde se inscreve o conjunto da visão cultural, como ressalta Scheibel (2013).

\section{Abordagens de modo de vida, natureza e região}

Os conceitos menos frequentes nos trabalhos analisados são modo de vida, natureza e região, respectivamente. Braconaro (2011) destaca a importância da adoção do conceito de modo de vida para compreender as práticas sociais. Baseado em Sorre o autor destaca que este conceito extrapola os aspectos materiais e envolve elementos imateriais, incorporando os valores, conhecimentos ecológicos, tempos sociais e lógicas próprias (BRACONARO, 2011 apud SORRE,1984). Claval entende que o conceito de modo de vida serve primeiramente para mostrar a adaptação dos grupos ao ambiente, logo integra uma dimensão social e cultural (BRACONARO, 2011 apud CLAVAL, 1997).

O conceito de natureza stricto sensu raramente ocorre nas pesquisas analisadas. Como já se destacou, as abordagens ambientais exploram as relações da natureza com a sociedade. A natureza tem ênfase em trabalhos como de Farias (2009), que critica a dicotomia entre sociedade/natureza, por exemplo no estabelecimento de políticas ambientais, que propõem uma natureza intocada como problematiza Diegues (2001).

Não aparece a discussão sobre o conceito de região, que é considerado um termo dado e expressa a organização político-administrativa do Estado brasileiro ou para designar uma área com características comuns, como é o caso da região de Manacapuru apresentado por Silva (2009). Não houve trabalho que propôs uma regionalização.

\section{Abordagens conceituais adotadas de outras áreas do conhecimento}

Os conceitos que tratam da pesca artesanal, nas pesquisas, geralmente se baseiam em Diegues (1983). Este é o autor não geógrafo mais presente nos trabalhos analisados. Outra autora frequente nos conceitos relacionados com pesca artesanal é Maldonado (1986). 
Como destaca Alves (2015) a pesca, segundo Diegues (1983), é a "última atividade extrativista realizada em grande escala que nos remete aos primórdios da humanidade". Ao longo dos anos, foi agregada ao valor de troca a esta atividade inserindo-se também nos moldes do capital. Ressalta ainda que o autor evidencia a atividade pesqueira artesanal como um conjunto de práticas cognitivas e culturais, habilidades práticas e saber fazer transmitido oralmente nas comunidades de pescadores artesanais, com a função de assegurar a reprodução do seu modo de vida (ALVES, 2015).

Rios (2012) fundamentada em Maldonado (1986) aponta a diferenciação das categorias de pescador a partir da propriedade dos meios e instrumentos de trabalho, das áreas em que estas categorias realizam a captura, a remuneração do produto capturado, dentre outras características abordadas.

Ainda se evidenciam outros autores nas discussões sobre pesca artesanal, como Begossi (2004) que discute o conhecimento dos pescadores sobre áreas/territórios de pesca, como assinala Santos (2012). Sobre o sujeito ribeirinho, com destaque no manejo dos recursos ambientais, Cruz (2007) faz referência à McGrath (1993).

Do ponto de vista ambiental são citados nos trabalhos, diversas abordagens de autores de outras áreas do conhecimento. O conhecimento sobre saber, complexidade e racionalidade ambiental está baseado em autores como Leff (2007) e Morin (2000) como frisa Farias (2009). Outra abordagem discutida se refere à Educação Ambiental, que recebe contribuições de Freire (1996) e Reigota (1984), como acrescenta Santos (2008). Somam-se a essas discussões outras como a de percepção ambiental apresentada por Merleau Ponty citado por Silva (2007) e justiça ambiental problematizada por Acselrad (2002), mencionado por Perez (2012). Ainda foi citado Vieira (2006) na discussão sobre ecodesenvolvimento, como destaca De Paula (2010).

É recorrente com base em autores de outras áreas do conhecimento o emprego dos conceitos de cultura, tradição e identidade. Entre os autores que abordam a cultura se evidenciam Eagleton (2001) na relação entre sociedade e natureza e Eliot (1988) que ressalta que cultura se refere ao grupo e não ao indivíduo, como apresenta Silva (2012B). Já Santana (2013) destaca as discussões de Laraia (1989) quanto a epistemologia do conceito de cultura. A mesma ressalta Castells (2000) que define identidade como uma fonte de significados e experiências de um povo. Discutindo identidade também são mencionados Santos (2001) que discute a diferenciação desigual e Hall (2012) que afirma que identidade e diferença são processos relacionais que se constituem e distinguem por meio da relação com o outro, como retoma Barbosa (2014). 
Discutindo tradição, Giannella (2009) faz referência à Giddens (1991) o qual ressalta que a mesma está no conhecimento e na passagem deste conhecimento através de gerações. Já Hobsbawn (2007) entende as tradições como inventadas e compostas por um conjunto de práticas, reguladas por regras ou aceitas pelas coletividades, de natureza ritual ou simbólica, que pretendem inserir valores e normas de comportamento através da repetição (GIANNELLA, 2009). Quanto à modernidade, Machado (2013) com base em Latour (2009) problematiza os limites da modernidade.

As discussões sobre trabalho também estão presentes nos materiais analisados. Alguns autores se baseiam no geógrafo Thomaz Júnior (2009) a respeito da fragmentação do trabalho no capitalismo, como destaca Cardoso (2013). Contato (2012) cita os autores Ellis (2000) que entende que o meio de vida compreende os ativos, as atividades e o acesso a eles, que juntos determinam a vida individual ou doméstica e Marschke (2005) o qual entende que os meios de vida requerem opções e flexibilidade. Custódio (2006) é um dos autores que reconhecem o conceito de pluriatividade, discutida por Schneider (1999) para tratar da relação de outras atividades com agricultura.

As discussões sobre recursos comuns também estão presentes nos trabalhos analisados, como em Maier (2009). Entre os autores citados destaca-se Berkes, que argumenta sobre os regimes de propriedade que podem ser classificados em três categorias: o regime de propriedade privada, o regime de propriedade estatal e o regime de uso comum. Ostrom (1990) estabelece princípios para avaliação do quanto robustas são as instituições de recursos comuns, como analisa Dumith (2013).

No diálogo com o turismo, Costa (2010) destaca Andrade (2004) que expõe o quanto qualquer análise a respeito do turismo deve ter como pressuposto que "o homem, o espaço e o tempo constituem os três pré-requisitos para qualquer reflexão equilibrada a respeito do fenômeno". Já Moraes (2010) referência a autora Cruz (2003), que entende o turismo como prática social, que envolve o deslocamento no território e consome o espaço geográfico, e Coriolano (2002) que compreende como uma modalidade de lazer que implica em deslocamento e infraestruturas.

O conceito de trabalho também é abordado a partir de Marx (1980) quando se discute a mais valia na produção de mercadorias, como aborda Silva (2009). Na perspectiva teórica Marxista também cabe salientar a discussão de Lukács (1981) de ser social, que permite pensar a natureza do ser a partir da ontologia do trabalho e sua centralidade nas relações sociais como destaca Nunes (2011). Outra discussão presente é do conceito de camponês, a partir Shanin 
(1980), que entende a formação de uma pequena unidade de produção-consumo que encontra seu principal sustento na agricultura e apoiada principalmente no trabalho familiar, como estuda Cruz (2007).

\subsubsection{Principais abordagens metodológicas}

É importante ressaltar que a maior parte das pesquisas não realizam uma discussão sobre o método com base filosófica, mas tratam de procedimentos de pesquisa. Dentro do que foi possível identificar, apresenta-se cinco perspectivas: Composição; Materialismo Histórico e Dialético, Fenomenologia, Sistêmico e Pensamento Complexo. Também buscou-se destacar as principais técnicas de pesquisa.

A figura 42 apresenta o mapa dos métodos utilizados nos trabalhos, por Unidade da Federação. Em 39,44\% das abordagens se observa a composição, isso quer dizer que os autores não designam o método que abordam e fazem uso de procedimentos de diversos métodos. Nestas abordagens, se destacam as regiões Nordeste e Sul ( 8 trabalhos em cada), principalmente os estados Bahia e Paraná.

Por outro lado, 36,62\% dos autores fazem referência direta ao Materialismo Histórico e Dialético. O emprego deste método se destaca a regiões Nordeste (10) e Norte (9), onde se destacam os estados Amazonas, Bahia e Ceará.

Outros $15,49 \%$ fazem referência direta ao método Sistêmico. Destaca-se a região Nordeste, onde ressalta o estado da Bahia e Pernambuco com dois trabalhos cada. Ainda 7,04\% se situam no horizonte de pensamento complexo. Estas abordagens se evidenciam na região Nordeste, onde pode-se exemplificar o estado do Ceará (2). Em menor número, 7,04\% dos autores fazem referência ao método Fenomenológico. As ocorrências são na região Sul, estado do Rio Grande do Sul (2) e Nordeste, estado do Sergipe (2). 


\section{GEOGRAFIAS DA PESCA ARTESANAL BRASILEIRA:}

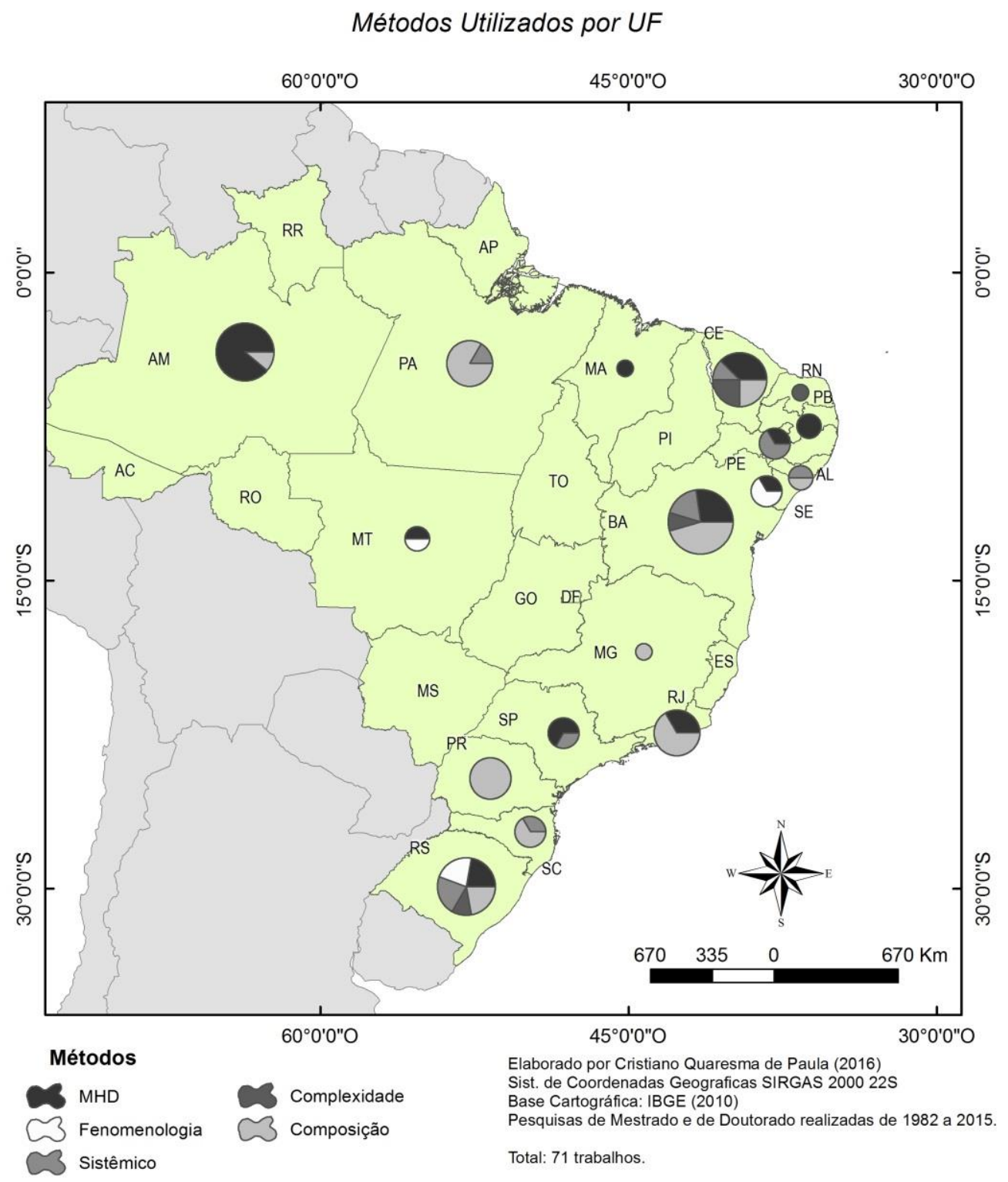

Figura 42: Mapa de Métodos Utilizados por Unidade da Federação Fonte: Elaborado por De Paula (2018)

Quanto às técnicas de pesquisa, considera-se importante destacar a presença de trabalhos de campo em todos os trabalhos analisados em arquivo digital. Suertegaray (2009) apresenta que em cada método há uma composição distinta de procedimentos de campo, pois se pretende destacar aspectos distintos da realidade.

Outro procedimento metodológico que ocorreu com frequência nos trabalhos foram as entrevistas (48 trabalhos). Cabe enaltecer uma diversidade de técnicas de entrevistas (aberta, 
estruturada, semiestruturada, periódica). Ainda é evidente a presença de outras técnicas de entrevista como a história oral.

Em 22 trabalhos há referência à observação como técnica de pesquisa. Neste sentido ocorreram trabalhos que desenvolveram observação in loco, observação direta. Também cabe frisar a presença de observação participante. Os grupos focais também se destacam como espaço que permite a relação entre pesquisadores e problemáticas de pesquisa.

Um procedimento de pesquisa muito recorrente é o questionário (15). Estes questionários surgem diante da necessidade de produzir informações primárias para tratar de questões específicas.

Para a análise das informações desses instrumentos de pesquisa citados, pode-se destacar a análise estatística e análise de conteúdo. Contudo, diversos trabalhos não fazem referência ao processo de análise dos resultados.

Quanto à pesquisa com dados secundários, cabe marcar o papel da pesquisa bibliográfica apontada como procedimento de pesquisa em diversos trabalhos. Ainda foi citado o uso de dados secundários decorrentes da análise de documentos e tabelas oferecidos por órgãos oficiais, como o Instituto Brasileiro de Geografia e Estatística - IBGE.

A cartografia compõe outra área cujos instrumentos de pesquisa favoreceram as pesquisas. Autores citam o uso de técnicas de geoprocessamento, como sensoriamento remoto para a elaboração das representações cartográficas. Contudo, o maior uso da cartografia se inscreve dentro do que vem sendo chamado da "cartografia social", que pressupõe a construção de mapas em conjunto com as comunidades (mapeamento comunitário, mapeamento/cartografia participativa, etc.).

Em menor número, mas são evidentes trabalhos que utilizam outras técnicas de pesquisa como etnografia, fotografia, diagnósticos, oficinas e estudos de caso.

Entende-se que, o método se apresenta como horizonte de diálogo entre pesquisadores como linguagem. Sendo assim, o entendimento dos métodos é fundamental para discutir as "Geografias da Pesca" e estabelecer processos dialógicos em rede. Esses métodos expostos também dialogam com o momento do pensamento geográfico brasileiro (MORAES, 2005), que nas pesquisas analisadas estão mais influenciados pelo pensamento geográfico crítico, do que por abordagens teorético-quantitativas. Alguns estudos apresentam tabelas e análises estatísticas, contudo, na maioria das vezes, são utilizadas para darem suporte ao debate crítico. 


\subsubsection{Instituições/entidades de pescadores artesanais}

Por fim, serão distinguidos os principais interlocutores nas pesquisas (figura 43), ou seja, as entidades de pescadores artesanais:

\section{GEOGRAFIAS DA PESCA ARTESANAL BRASILEIRA:}

Entidades de Pescadores que Participaram das Pesquisas, por UF

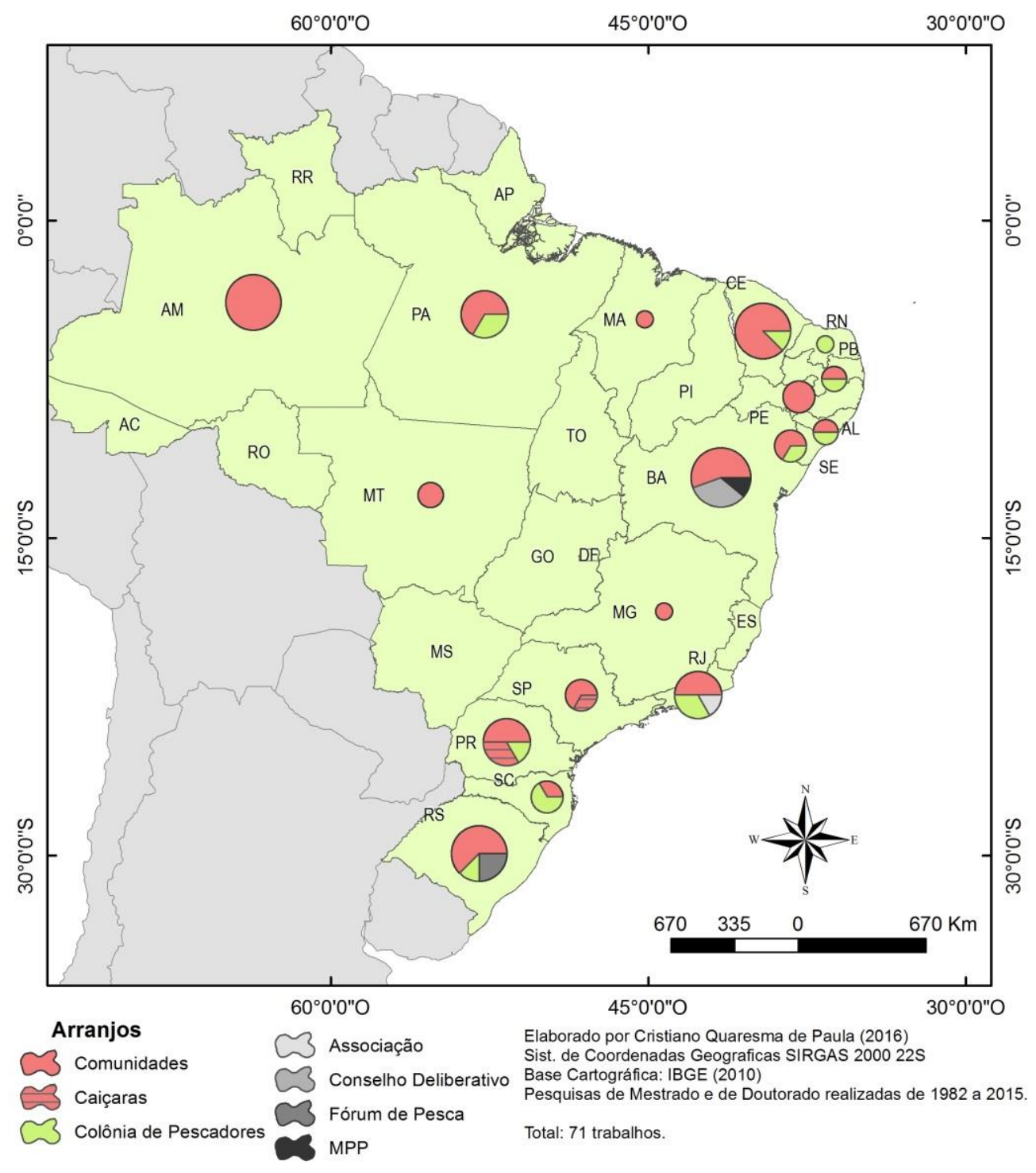

Figura 43: Entidades de Pescadores que Participaram das Pesquisas, por Unidade da Federação Fonte: Elaborado por De Paula (2018)

As comunidades de pescadores são apontadas como os principais grupos abordados $67,61 \%$. Esta predominância se observa em todos os estados brasileiros, contudo, no caso dos trabalhos analisados da região Norte, como a Comunidade de São Francisco e São Raimundo de Manacapuru (CRUZ, 2007) e Centro-oeste, como a comunidade Barra do Aricá (PRADO, 
2013), esta categoria de organização social de pescadores aparece em todos os trabalhos. Nos trabalhos realizados em Minas Gerais e Pernambuco também só ocorreu esse arranjo institucional.

Na sequência, são significativos os trabalhos que estudam as Colônias de Pescadores. Estas instituições foram estudadas na maioria dos estados brasileiros, 31\%. Resende (2014, p.49) destaca que a instituição de Colônias de Pescadores serviu de estratégia do Estado para dominar seu território conhecendo-o, favoreceu o controle das áreas costeiras pela Marinha e possibilitou ao governo republicano o controle dos meios de produção do setor. Cabe reconhecer que, desde a Constituição de 1988, essas entidades ganharam status de sindicato. Destaca-se que o maior número de trabalhos com colônias de pescadores, ocorrem na região Sul, como é o caso da Colônia Z11 - São Miguel do Iguaçu (FERREIRA, 2014) e Nordeste como a Colônia de Z5 de Lucena (SILVA, 2012B).

$\mathrm{Na}$ análise das associações de pescadores, estão incluídas as cooperativas. Este grupo também é citado com frequência, sendo observado que o aumento dessas instituições está estritamente relacionado com a insatisfação quanto à estrutura institucional das Colônias dos Pescadores. Também, a primeira gestão do Ministério da Pesca e Aquicultura - Governo Lula - promoveu a criação desse tipo de entidade, o que foi revertido no Governo Dilma, onde as Colônias de Pescadores recuperaram sua centralidade enquanto representação dos pescadores para o acesso às políticas públicas. A região sudeste é onde ocorrem mais trabalhos com associações de pescadores, como é o caso Associação de Pescadores e Aquicultores de Pedra de Guaratiba - APAPG (RAINHA, 2014).

No caso do Estado de São Paulo ocorre outro arranjo comunitário que, por deter particularidades no que tange à relação entre pesca e pequena atividade agrícola, são identificados como Caiçaras (DIEGUES, 2004B). Fora da Geografia eles foram amplamente estudados, sobretudo pelo Núcleo de Apoio à Pesquisa sobre Populações Humanas em Áreas Úmidas Brasileiras (NUPAUB). Contudo, trabalhos sobre os caiçaras vêm sendo realizados por geógrafos.

No caso do Rio Grande do Sul tem sido citado o arranjo institucional Fórum de Pesca Artesanal, como é o caso do Fórum Delta do Jacuí (DE PAULA, 2013). Essas são entidades que envolvem tanto gestores quanto representações de pescadores. Não são deliberativos, mas colaboram com a gestão da pesca na sua região de abrangência e tem aberto vias de comunicação junto ao Estado. 
$\mathrm{Na}$ análise, somente do Estado da Bahia foram apresentados trabalhos sobre o Movimento dos Pescadores e Pescadoras Artesanais (MPP). Isso se deve principalmente pelo envolvimento do Grupo de Pesquisa “GeograFar" da UFBA com o referido movimento, no que tange à Campanha Nacional pela Regularização dos Territórios das Comunidades Tradicionais de Pescadores e ao Projeto Escola das Águas.

Também ocorrem trabalhos junto aos conselhos consultivos e deliberativos de unidades de conservação. Estes trabalhos ocorreram na região Nordeste como o Conselho Deliberativo da Baía do Iguape (ROSÁRIO, 2009).

Assim, compreende-se que se estabelece um diálogo de saberes entre geógrafos e entidades de pescadores artesanais, e disso, resultam inúmeras experiências de Geografias da pesca. Agora o desafio está em estabelecer articulações entre essas experiências.

\subsubsection{Principais problemáticas de pesquisa}

Com base nas dissertações e teses analisadas, observou-se que as principais problemáticas de pesquisa são: Resistência à modernização (29), Abordagens de Gestão da Pesca e do Ambiente (12), Trabalho (12), Cultura e Modo de Viver (7), Organização Produtiva (7) e Educação Ambiental (3), como apresenta o gráfico 7 e figura 44.

Gráfico 7: Principais Problemáticas Estudadas, por Região

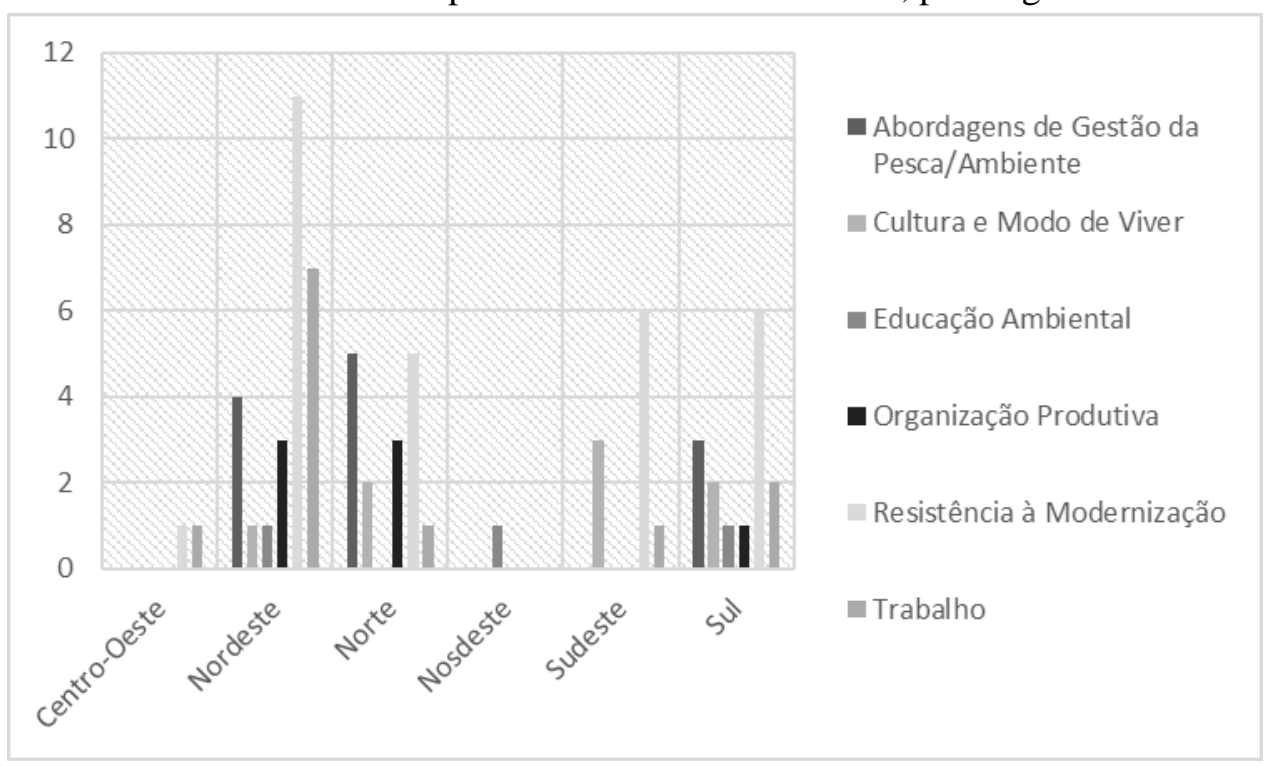

Fonte: Elaborado por De Paula (2018) 


\section{GEOGRAFIAS DA PESCA ARTESANAL BRASILEIRA:}

\section{Principais Problemáticas Estudadas, por UF}

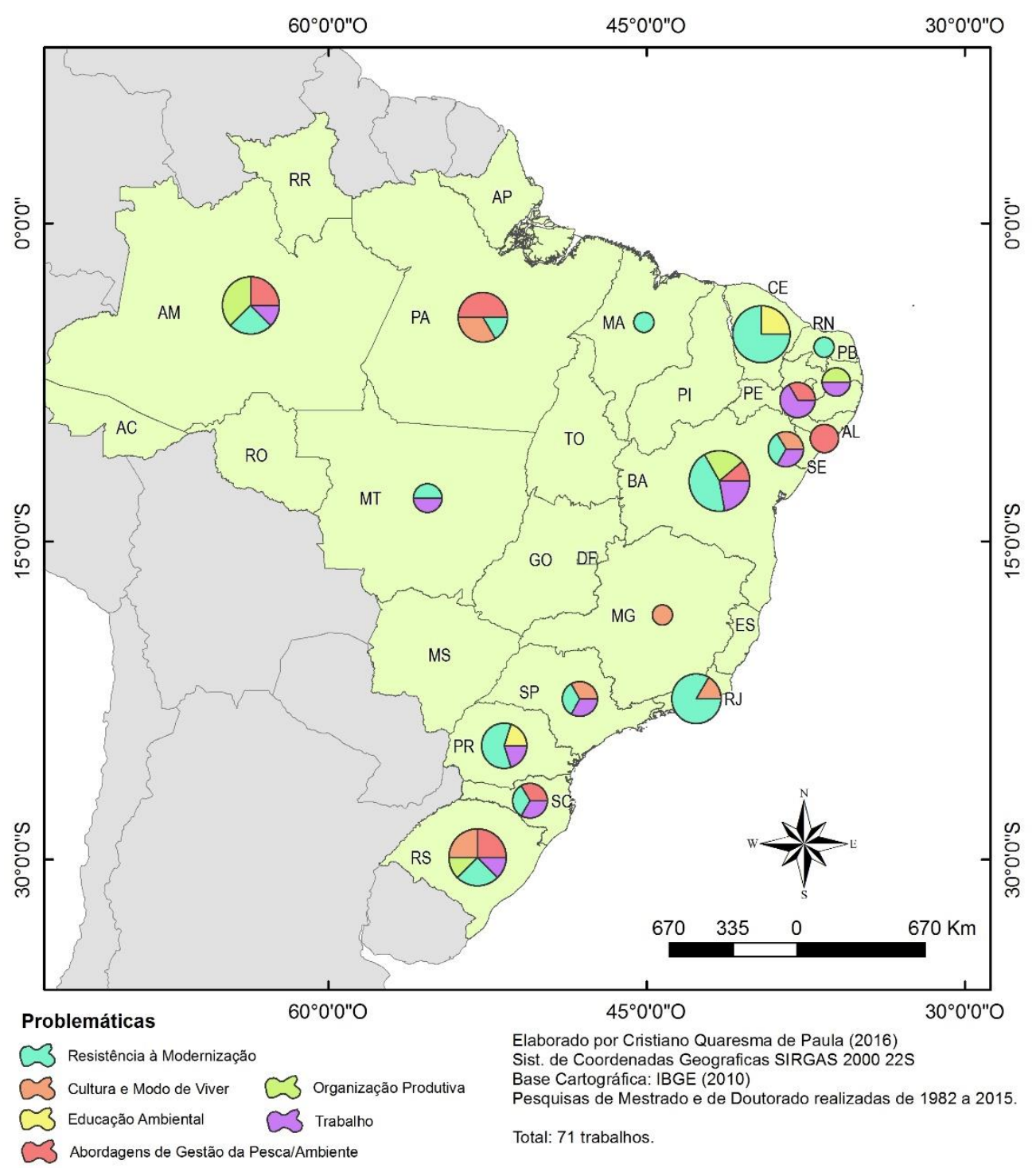

Figura 44: Principais Problemáticas Estudadas, por Unidade da Federação Fonte: Elaborado por De Paula (2018).

\section{Resistência à modernização}

Os trabalhos que tratam da resistência das comunidades frente ao avanço das atividades econômica estão evidentes em todas as regiões Brasileira. Na região Nordeste encontram-se $37,93 \%$ dos trabalhos que abordam a resistência das comunidades. Estes ocorrem prioritariamente no Ceará (17,24\%) e Bahia (13,79\%). Lima (2002) apresenta a resistência das comunidades marítimas do Ceará, frente a inúmeros conflitos e enfatiza a tradição e os costumes como integrantes da dinâmica do território. Já Cavalcante (2012) enaltece mudanças 
e permanências decorrentes da modernização no litoral da Ceará, enfatizando o avanço do turismo sobre comunidades tradicionais que resistem no território. Na Bahia, Rios (2012) expõe as resistências dos pescadores artesanais frente à pressão da carcinicultura, destacando a luta pela permanência no território. Já Rosário (2009) ressalta a resistência das marisqueiras, frente a modernização que avança sobre o território tradicional.

A região Sudeste é responsável por 20,69\% dos trabalhos que abordam a resistência dos pescadores artesanais à modernização. Na região, destaca-se o estado do Rio de Janeiro (17,24\% do total), onde Vinhas (2011) ressalta o papel da identidade, enquanto comunidade tradicional e a resistência dos pescadores frente à modernização na Pedra de Guaratiba - Rio de Janeiro. Rainha (2015), na mesma área de estudo, enfatiza o vínculo entre pesca artesanal e o "lugar" de vida dos pescadores, como argumento de resistência frente ao avanço das atividades da modernização.

A região Sul também apresenta 20,69\% dos trabalhos que abordam a resistência dos pescadores, onde destaca-se o estado do Paraná. (10,34\%). Pérez (2012) enaltece a resistência dos pescadores da Vila do Superagui, frente a uma série de políticas públicas que visam o “desenvolvimento" econômico. Barbosa (2014), destaca o papel do Movimento dos Pescadores e Pescadoras Artesanais do Litoral do Paraná (MOPEAR) na resistência dos pescadores frente a conflitos por terra no Paraná.

Na região Norte, $17,24 \%$ dos trabalhos que abordam a resistência à modernização, destaca-se o estado do Amazonas (6,90\%). Neste, Cruz (2007) ressalta o choque entre modos de apropriação estabelecidos entre "camponeses-ribeirinhos" e outros atores que tem gerado conflitos. Nestes, os "camponeses-ribeirinhos" resistem a modernização do território. Já a região Centro-Oeste concentra somente 3,45\% desses trabalhos, onde Prado (2015) apresenta a resistência dos pescadores artesanais frente às restrições de proprietários de terras, que impedem o acesso ao rio, em Santo Antônio de Leverger-Mato Grosso.

\section{Abordagens de gestão da pesca e do ambiente}

Diversos trabalhos se dedicam a discutir a gestão da pesca e do ambiente, destacando limites da gestão estatal e expondo experiências exitosas a partir da gestão comunitária e compartilhada. A região Nordeste, apresentou a maior concentração desses trabalhos, com $41,67 \%$ do total. Cunha (2015), por exemplo, apresenta a proposta de gestão a partir dos agroecossistemas, no estuário do Rio São Francisco, Alagoas, isso implica em considerar os impactos que os sistemas produtivos desencadeiam sobre importantes ecossistemas da pesca. 
A região Norte apresenta 33,33\% dos trabalhos. No estado do Pará (25\% do total) Silva (2006A, 2012A) enaltece a experiência de manejo comunitário a partir de Acordos de Pesca. Desta forma, as regras da gestão da pesca são estabelecidas pelos próprios comunitários e reconhecidas pelo Estado, por meio de Instrução Normativa própria.

Já na região Sul, 25\% dos trabalhos que abordam a gestão, sendo 16,67\% relativos aos Rio Grande do Sul. As experiências decorrem de Fóruns de Pesca, que discutem propostas de gestão frente às problemáticas dos pescadores. Maier (2009) expõe propostas, a partir das comunidades, para a pesca do Siri, que ganha importância frente a crise na pesca do Camarãorosa.

\section{Trabalho}

O trabalho do pescador artesanal também integra problemáticas de pesquisa, por vezes a partir da adjetivação "tradicional". A região Nordeste concentra 58,33\% das dissertações e teses que discutem o trabalho na pesca artesanal, destas $16,67 \%$ estão nos estados da Bahia e do Pernambuco. Na Bahia, o estudo de Figueiredo (2013) expõe os processos que integram o trabalho dos pescadores artesanais na Reserva Extrativista de Canavieiras. No estuário de Itapessoca, Pernambuco, Silva (2006B) enaltece a repercussão de impactos sobre o trabalho do pescador.

Na região Sul encontram-se 16,67\% dos estudos concentrados nas problemáticas relacionadas ao trabalho, onde destacam-se Rio Grande do Sul e Paraná, ambos com 8,33\%. Contato (2012) ressalta políticas do trabalho, como ênfase ao direito do seguro-defeso e sua importância para as comunidades e ecossistemas. Ferreira (2014) destaca o processo de reconhecimento da mulher, enquanto pescadora, no Lago Itaipu. As regiões Centro-Oeste e Sudeste apresentaram menos pesquisas abordando essa problemática (8,33\% cada).

\section{Modo de viver das comunidades}

Quanto as problemáticas que abordam os modos de viver, e cultura dos pescadores e suas comunidades, a região Sudeste apresentou a maior parte dos trabalhos, 37,50\%. Gomes (2012) destaca as compreensões dos pescadores sobre o ambiente, que decorrem das características do grupo social, em Atafona, Rio de Janeiro. Braconaro (2011) apresenta o modo de vida na pesca, no Rio Araguari, Minas Gerais. Nas Regiões Norte e Sul encontram-se 25\% dos trabalhos. No Pará, Araújo (2012) enaltece as ameaças ao modo de viver dos pescadores locais, frente ao avanço de pescadores migrantes e da urbanização sobre o território tradicional. 
No Rio Grande do Sul, Lima (2003) apresenta os elementos materiais e imateriais inerentes à cultura da comunidade de pescadores da Ilha da Marambaia, Rio Grande. A região Nordeste expõe 12,50\%, onde Torres (2014) apresenta marcas e signos na interpretação do "sentido de ser pescador", em São Cristóvão, Sergipe.

\section{Organização produtiva}

As discussões sobre a cadeia produtiva da pesca artesanal ocorreram, principalmente, nas regiões Norte e Nordeste (42,8\% cada). Abreu (2011) analisa a produção pesqueira em Manacapuru, Amazonas, em função do capital extraído da água, e sua relação com a indústria pesqueira. Na Bahia, Queiroz (2011) retoma os circuitos da economia urbana para situar a comercialização da pesca no circuito “inferior”. Na região Sul (14,29\%), Martins (2002) também analisa pesca a partir da industrialização do setor no Município de Rio Grande, Rio Grande do Sul.

\section{Educação ambiental}

Embora em número reduzido, também houve pesquisas que abordaram contextos de educação ambiental em comunidades de pescadores artesanais, as quais ocorreram nas regiões Nordeste e Sul. Santos $(2008,2013)$ apresentou o processo de implantação da educação ambiental, reconhecendo a importância da pesca artesanal, em escolas do município de Acaraú, Ceará. Farias (2009) expôs um projeto de educação ambiental, em contexto de Unidade de Conservação, na Vila de Superagui - Paraná.

\subsubsection{Futuro da pesca artesanal}

Após analisar as pesquisas considerando a dinâmica da área de estudo, foi necessário abrir o diálogo junto aos pesquisadores para enfatizar os desafios e possibilidades que se apresentam para o futuro da pesca artesanal. No questionário respondido por geógrafos fez-se o seguinte questionamento: Qual a sua compreensão sobre o futuro da pesca artesanal brasileira? Destaca-se que 51 pesquisadores responderam a essa pergunta, cujo universo de respostas está exposto na nuvem de palavras (figura 45): 


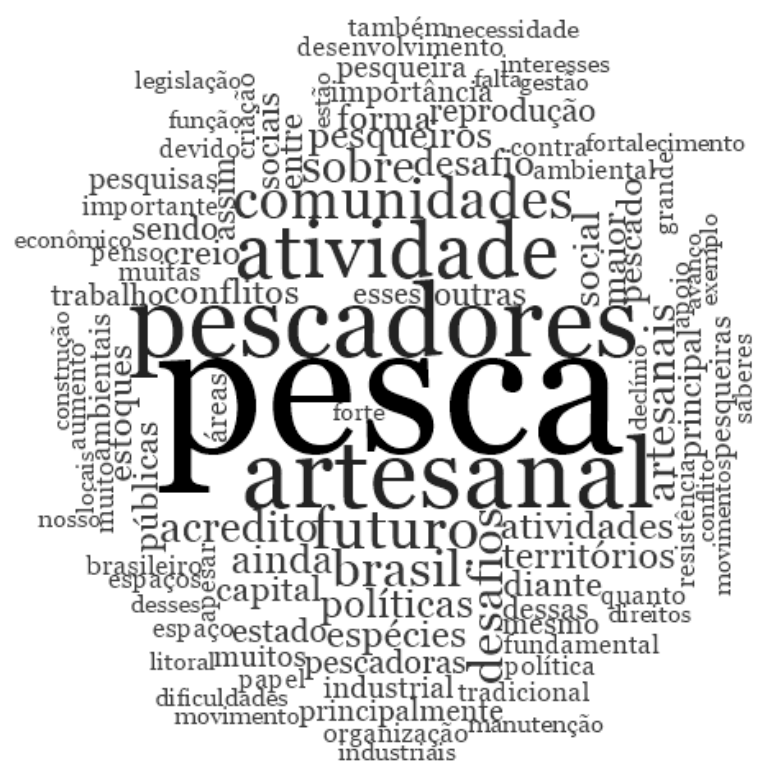

Figura 45: Nuvem de Palavras "Futuro da Pesca Artesanal" Fonte: Elaborado por De Paula (2018).

As principais respostas para essa pergunta foram: i. Depende do reconhecimento das comunidades tradicionais; ii. O problema se deve a falhas na gestão e na falta de políticas públicas; iii. A pesca artesanal é ameaçada pelo avanço de outras atividades econômicas; iv. A pesca enquanto atividade econômica está em declínio.

\section{i. $\quad$ Depende do reconhecimento das comunidades tradicionais}

Para 38,89\% dos pesquisadores o futuro da pesca artesanal seria mais "promissor" se o Estado brasileiro reconhecesse as comunidades tradicionais de pescadores. Isso significa em envolver os pescadores na criação de normas para a pesca e reconhecer os territórios das comunidades tradicionais de pescadores. Assim, os pescadores artesanais seriam reconhecidos como sujeitos de direito, e com especificidades por serem comunidades tradicionais. Nas palavras de Eduardo Schiavone Cardoso (UFSM) a pesca "vai resistir no tempo, com a gestão cada vez mais sendo elaborada pelos pescadores".

Retoma-se que essa problemática foi destacada nos trabalhos que revelam o modo de viver, por meio da tradição. Estes são realizados prioritariamente com comunidades de pescadores, envolvendo uma grande diversidade de métodos, onde o trabalho de campo ganha importância fundamental na relação entre pescador e pesquisador. Segundo os trabalhos, essa discussão deve estar baseada teoricamente na relação que os pescadores têm com o ambiente e na constituição de territórios. 
Ressalta-se que essa resposta foi comum entre pesquisadores em todas as regiões brasileira, e predominante no Nordeste e Sudeste. Rodrigo Corrêa Euzébio (NUTEMC UERJ/FFP) destaca os ataques às comunidades tradicionais:

\begin{abstract}
A pesca artesanal tem sofrido ataques em três frentes: perda dos territórios; restrição no acesso dos direitos, com uma forte burocratização das formas de acesso as políticas públicas e na obtenção e/ou manutenção dos registros de pesca; e, redução das suas formas de pesca, com a criminalização pelos órgãos ambientais, do uso de determinadas técnicas e da pesca de determinadas espécies. Nesse contexto, observa-se o crescimento da Aquicultura, que recebe vultosos investimentos do Estado brasileiro e começa a aumentar sua participação na produção do pescado brasileiro. Nesse sentido, creio que seja importante uma reorganização dos pescadores no sentido de aumentarem suas participações nas tomadas de decisões e na organização da economia pesqueira.
\end{abstract}

Guiomar Germani (GeograFar - UFBA) entende que o caminho é visibilizar a pesca artesanal, inclusive no meio acadêmico:

Considero que o principal desafio da pesca artesanal no Brasil é tirar sua invisibilidade. Evidenciar quem são estes pescadores e pescadoras, onde e como se encontram, quais suas especificidades, fazer avançar as políticas públicas de apoio e de reconhecimento de seus territórios, de seus saberes e artes e, sobretudo, reconhecer a importância da atividade em seu âmbito social, econômico e político. Atualmente, este desafio aumenta em todas as dimensões, pois tudo parece ir na contramão das necessidades do grupo social dos pescadores e pescadoras artesanais. Isto coloca muito mais responsabilidade aos pesquisadores envolvidos com esta temática e dá sentido a suas atividades de ensino, pesquisa e extensão.

Para Kássia Aguiar Norberto Rios (UFRB e GeograFar - UFBA) “O maior desafio é a regularização dos territórios pesqueiros, assim como a luta contra a invisibilidade histórica dessas comunidades. Daí a importância na construção de debates, discussões e pesquisas sobre a temática".

\title{
ii. Problema na gestão e política pública
}

Já 31, 48\% dos pesquisadores associam as problemáticas da pesca à gestão estatal e carência de políticas públicas específicas para a pesca artesanal. Assim, é fundamental destacar que no Brasil o Estado tem a prerrogativa da gestão da pesca. Contudo, como destaca Eneias Guedes (UFOPA), existem "pressões e políticas que vão na contramão dos interesses dos pescadores". Em situações específicas essa gestão é compartilhada com as comunidades. Contudo, decisões técnicas e políticas acarretam em prejuízos de ordem ambiental e econômica, 
que deixam os pescadores artesanais em situação de vulnerabilidade social. Frente a esse quadro, também a necessidade de políticas públicas para o pescador artesanal.

Retomando as problemáticas analisadas nas dissertações e teses, se verifica um diálogo direto com as abordagens de gestão da pesca e do ambiente. Neste caso é importante destacar que a discussão se baseou, prioritariamente, em trabalhos de campos com as comunidades, reconhecendo seus saberes e formas de gestão, e as consequências da inadequada gestão. Acrescenta-se a emergência dos conceitos de ambiente e território uma vez que, na perspectiva das comunidades, a gestão do território se dá também por meio de saberes adquiridos na relação com o ambiente.

Essa linha de compreensão predomina entre os pesquisadores das regiões Norte e Sul. Cristina Buratto Gross Machado, enfatiza que a pesca industrial é privilegiada por políticas de Estado.

Vejo avanços nos últimos 12 anos, mas a pesca industrial ainda é privilegiada diante das políticas governamentais. Com relação a legislação, áreas e espécies permitidas à pesca artesanal, também tem muitas coisas que deveriam ser revistas, bem como uma fiscalização eficiente por parte dos órgãos públicos que os protegesse dos conflitos com os barcos industriais (isso na realidade que conheço em SC), por exemplo.

Já Marcia Aparecida da Silva Pimentel (GEPPAM - UFPA) destaca que o futuro da pesca depende de políticas públicas para o setor:

Há vertente que defende sua extinção em função do "rolo compressor" do sistema capitalista urbano-industrial. No entanto, acredito na articulação política, nas políticas públicas sociais e de apoio técnico aos pescadores e tiradores de caranguejo, presentes em minha área de estudo. Os desafios são muitos porque o conflito é inerente e envolve interesses divergentes.

Em relação aplicação de políticas públicas, Ana Paulina Aguiar Soares (UEA Manaus) destaca que apesar de algumas existirem, a aplicação das mesmas encontra dificuldades. Como os "desafios quanto aos desvios na execução de políticas como o seguro defeso (uma conquista dos movimentos)".

Como destaca Larissa Tavares Moreno (UNESP Presidente Prudente) as dificuldades impostas pelo Estado aos pescadores artesanais parecem objetivar a desmobilização dos mesmos, contudo encontra resistência no corpo social:

Pensando pelo viés mercadológico e institucional-burocrático do Estado, a pesca artesanal na realidade nunca foi prioridade e realmente incentivada com o devido valor que merece. Mas diante de alguns casos e exemplos de pescadores artesanais espalhados pelo país, há um elemento intrínseco a eles 
que os movem para o confronto diário para com os desafios, problemáticas e conflitos que persistem em desmotivá-los, mas a cada dia esses pescadores e pescadoras ainda lutam e resistem como podem. Ou seja, os desafios que o futuro reserva são vários. $\mathrm{O}$ embate e a luta são iminentes assim como será fundamental a forte organização social e política dos pescadores e pescadoras.

\section{iii. Ameaçada por outras atividades econômicas}

Ainda $18,52 \%$ dos pesquisadores que responderam os questionários entendem que o futuro da pesca artesanal brasileira é ameaçado pelo avanço de outras atividades econômicas. Essa perspectiva de resposta teve maior destaque nas regiões Nordestes e Sul.

Essa compreensão dos pesquisadores dialoga com a análise dos trabalhos que expõe a resistência à modernização. Retoma-se que essas dissertações e teses destacam o avanço de outras atividades econômicas e da pesca predatória sobre as comunidades de pescadores e pesqueiros tradicionais. Promovem consequências no território pesqueiro como perda de produtividade, insalubridade ambiental, remoção das famílias. Sendo assim, integram tanto abordagens de conceitos de território, quanto de ambiente e se evidenciam no trabalho de campo.

Como destaca Shauane Itainhara Freire Nunes (GEPECT - UFS) o avanço de outras atividades econômicas expõe o conflito entre atividade tradicional e capital. "Os territórios onde se dá a prática da atividade são territórios do capital, então, alguns processos tendem a dificultar ou mesmo impedir a prática da atividade, o que não quer dizer, que a atividade continue resistindo". Tiago Rossi de Moraes (UFSM) destaca que devido a pesca industrial e mais recentemente a aquicultura, por incentivo do Estado, os "Pescadores artesanais do Brasil constantemente têm seus territórios e o direito legal sobre eles ameaçados por interesses do capital".

Júlio César Suzuki (USP) entende que o avanço de atividades econômicas tem reduzido a quantidade de pescado e o enfrentamento da pesca artesanal tem se dado por meio da luta dos movimentos sociais:

Há enorme dificuldades, como a redução do volume do pescado, a realização da pesca predatório, aumento dos dejetos no oceano, avanço da urbanização sobre áreas de moradia de pescadores, ausência de política de apoio à permanência dos pescadores, criação de áreas de proteção ambiental sobre terras de uso consuetudinário de pescadores artesanais; mas há perspectivas de luta com a criação de movimentos sociais que demandam direitos necessários à sobrevivência destes sujeitos. 
Catherine Prost (Costeiros - UFBA) destaca que "Entre os principais desafios, estão os conflitos territoriais e/ou ambientais com atores econômicos na região costeira sob a forma de grandes projetos industriais ou de infraestrutura, ou ainda, de urbanização ou avanço de instalações turísticas". A pesquisadora vê possibilidades a partir do território pesqueiro, das Reservas Extrativistas e da valorização dos saberes:

\footnotetext{
É importante, portanto, ressaltar o peso econômico e social da pesca artesanal, garantir os territórios de pesca.

No tocante às Resex, o desafio é demonstrar que o modelo pode representar uma alternativa ao modo dominante de produção uma vez que existem ameaças a sua perpetuação.

A valorização dos saberes ambientais deve ser ampliada para favorecer a ecologia dos saberes e alternativas ao desenvolvimento.
}

\section{iv. Declínio da pesca como atividade econômica}

Por fim, $11,11 \%$ dos pesquisadores compreendem que a pesca artesanal está em declínio, enquanto atividade econômica.

Nesse contex to se observa o diálogo direto com as problemáticas das dissertações e teses que abordam o trabalho tradicional. Retoma-se que o trabalho como mediação do pescador e o ambiente só é possível com a gestão adequada dos recursos. No mundo da pesca, isso se dá por meio de saberes aprendidos, mas quando essa lógica se rompe em detrimento da exploração econômica sem limites, a atividade entra em declínio. Sendo assim, nem o ambiente se recupera, nem o pescador consegue a sua reprodução social. Diante disso, cada vez mais os pescadores defendem seus territórios e recursos do ambiente presentes nele.

Fernando Custódio Soares (USP) destaca que devido a sujeição da atividade pesqueira artesanal ao capital, o futuro não se apresenta muito promissor:

Identifiquei este ponto em uma das pesquisas que efetuei, na comunidade do Perequê, onde pescadores artesanais de camarão, ainda utilizando de objetos e maquinário tradicional, eram forçados (compelidos) a lutar contra frentes difíceis de se vencer na atividade diária de pesca, como a alta de preço do combustível de embarcações, as absorções de lucro cada vez maiores de atravessadores/processadores de pescados, a competitividade de valor do pescado de pescadores artesanais contra quantidades imensas de pescados de embarcações industriais-pesqueiras. Ao meu ver, o quadro que se desenha no futuro da pesca tradicional não é promissor, infelizmente, e isso acarretará em perdas não apenas na tradicionalidade da pesca, mas também na perda da tradicionalidade das comunidades que as praticam. 
Christian Nunes da Silva (GAPTA - UFPA) entende que sobre-exploração dos recursos extrativistas tendem a levar ao declínio da produção. Em decorrência disso, abre espaço para o crescimento da produção aquícola.

Nesse momento, é de suma importância que as questões emergentes identificadas na análise das questões abertas dos questionários, não foram tomadas a priori da análise das dissertações e teses. Contudo, se observa que os pesquisadores se posicionam dentro do horizonte em que estabeleceram as pesquisas. Também evidencia que as abordagens teóricas e metodológicas tomadas pelos geógrafos, promovem discussões que põe em questão o futuro da pesca, logo, há um processo de entendimento que pode auxiliar as comunidades e a gestão. 


\section{Capítulo II}

\section{Impactos Ambientais, Disputas no Território e Conflitos POR Território na Pesca Artesanal Brasileira}

No açude e na barragem: pescando a liberdade!

No Capítulo anterior, a análise das dissertações e teses apontou que os principais conceitos abordados para tratar as problemáticas da pesca artesanal brasileira são espaço, território e ambiente. Neste momento, será dado ênfase a território e ambiente, que segundo Suertegaray (2001) correspondem a conceitos de análise do espaço geográfico.

Inspirada em Bruno Latour (1994), que estabelece o híbrido conceitual "naturezacultura", Suertegaray (2002) propõe a análise do híbrido que se expressa no contínuo estabelecido entre o "território da natureza a natureza do território". Para considerar natureza transfigurada pela sociedade, a proposta analítica está centrada na relação entre território e ambiente.

Nos trabalhos analisados, foi possível distinguir dentro da perspectiva da complexidade, três relações entre território e ambiente na pesca artesanal brasileira. A primeira está centrada em impactos ambientais provocados por outras atividades econômicas que levam à extinção de territórios tradicionais de pesca - nessa proposta está acentuado o conceito de ambiente como condição para a perenidade do território. A segunda apresenta um quadro de disputas no território, onde se evidenciam relações de apropriação do território com objetivo de acessar os recursos ambientais, evidenciando os conceitos de território e ambiente. Por fim, a terceira abordagem evidencia a situação de conflitos por território, onde indivíduos de outras atividades econômicas buscam o domínio do território apropriado pelas comunidades de pescadores artesanais - nesse caso destaca-se o conceito de território como espaço de exercício do poder.

É fundamental destacar que na primeira abordagem não há uma situação de disputa e/ou conflito entre pescadores artesanais e outras atividades econômica. Geralmente os impactos decorrem de uso indireto ou de um uso que já está consolidado e por isso não é questionado pelos pescadores artesanais. Logo, para a existência do território é fundamental a presença de "reserva", apontada por Raffestin (1986, 1986C).

O entendimento de disputas no território põe em relação impactos ambientais e conflitos por territórios. Nessa abordagem os impactos ambientais são gerados ou geradores de conflitos 
por território. Essa relação dialética se expressa na ideia de "disputa" que tanto pode ser pelo recurso presente, que gera impactos ambientais que desestabilizam a dinâmica territorial, quanto pode ser originada a partir de relações onde o jogo de forças pela apropriação e/ou domínio prejudica a capacidade de suporte do ambiente. No caso das disputas ainda é fundamental destacar que há o reconhecimento dos territórios e territorialidades dos pescadores artesanais. Isso distingue da abordagem anterior, em que o território dos pescadores era visto unicamente como ambiente (fonte de recursos ou depositório). Também, distingue-se da terceira abordagem, onde os conflitos decorrem da relação assimétrica de poder exclusivamente. Em algumas situações a mediação dos conflitos decorrentes da disputa pode permitir a presença de múltiplos territórios.

Já os conflitos por território são apontados para destacar contextos em que a apropriação do território pelos pescadores artesanais encontra limite no domínio estabelecido por outras atividades econômicas. Isso pressupõe a negação ao território anteriormente ocupado pelas comunidades, como se não existissem. A falta de entendimento inerente ao conflito e a resistência das comunidades para permanecem no território incide em confrontos, que evidenciam a dissimetria do poder. Os conflitos por território não se esgotam até que um dos lados saia vitorioso. Além do uso da violência, as atividades econômicas que se impõem sobre o território tradicional encontram apoio nos agentes do Estado, que viabilizam sua permanência e domínio. Frente aos conflitos, é fundamental a existência de leis que garantam a presença no território tradicional.

Diante do exposto, os referenciais teóricos apresentados pretendem dar sustentação à discussão sobre territórios e territorialidades, destacando que há relação com concepções de natureza e de ambiente. Para isso, o Capítulo apresenta como principal teórico o geógrafo Claude Raffestin. O autor ao tratar da territorialidade humana, da ecogênese territorial, e dos processos de territorialização, desterritorialização e reterritorialização, integra compreensões de natureza e distingue sociedades tradicionais e modernas.

No campo metodológico, dentro da perspectiva do pensamento complexo (MORIN, 1990) a composição de procedimentos metodológicos integrou a análise de conteúdo de dissertações e teses e a construção de representações cartográficas.

Diante do exposto, objetivou-se nesse Capítulo: evidenciar a partir das dissertações e teses dos geógrafos as principais problemáticas relativas aos territórios da pesca artesanal brasileira; e estabelecer uma proposta analítica sobre os territórios pesqueiros no Brasil considerando os diálogos entre pescadores e geógrafos no âmbito da pesquisa geográfica. 


\subsection{Pressupostos Teóricos: Território e Territorialidade}

O conceito de território constitui o centro da análise desse Capítulo. Há o intuito de compreender o território enfatizando as relações sociais, e da sociedade com a natureza (ambiente). Contudo, nessa perspectiva relacional, deseja-se sempre enfatizar o poder. Buscando a perspectiva relacional e multiescalar Claude Raffestin será tomado como principal referência.

Embora lançado em língua portuguesa, em 1993, a primeira edição de "Pour une géographie du pouvoir" data de 1980. Esse livro é tomado com grande relevância nos trabalhos sobre território na Geografia brasileira. Contudo, compreendendo o pensamento em movimento, buscou-se outros textos do autor, que, sobretudo tratassem da gênese territorial, da relação entre território e natureza, e distinguisse territórios e territorialidades modernos e tradicionais.

A pesquisa bibliográfica evidenciou, então, alguns artigos e Capítulos de livro (RAFFESTIN e BRESSO, 1982; RAFFESTIN, 1986, 1986B，1986C, 1989, 1996, 2012; RAFFESTIN e BARAMPAMA, 1998). Entre estes destaca-se "Ecogenèse territoriale et territorialité" (RAFFESTIN, 1986A), "Tradition, modernité, territorialité" (RAFFESTIN e BRESSO, 1982) e "Space, territory, and territoriality" (RAFFESTIN, 2012), os quais expressam os principais argumentos teóricos aqui apresentados.

Parte-se de alguns pressupostos que relacionam território e poder, conhecimentos e práticas - tradicionais e modernas-. Na sequência, busca-se entender a ecogênese territorial e a proposta de análise da semiosfera. Por fim, destaca-se os processos de Territorialização, Desterritorialização e Reterritorialização, destacando questões temporais e informacionais.

\section{Território e Poder, Conhecimentos e Práticas}

Raffestin (1986) recorre à metáfora do corpo para explicar a sua compreensão de território. O corpo humano é composto por um conjunto de órgãos que podem ser compreendidos como endossomáticos. Contudo, a historicidade acrescentou ao ser humano um número infinito de instrumentos exossomáticos, que ele produziu e continua (re)produzindo. Quando pensa a "Terra" como corpo, entende que a mesma também é constituída de instrumentos endossomáticos (solo, mar, montanhas, florestas, desertos, etc.), que não devem nada originalmente à ação humana. Pelo contrário, o território é um microinstrumento 
exossomático que resulta da capacidade dos homens de transformar tanto a natureza envolvente como suas relações sociais através do trabalho. Assim, o território é o produto da transformação do endossomático terrestre pelo exossomático humano. (RAFFESTIN, 1986, p. 176-177).

Desta forma Raffestin e Barampama (1998, p. 67) situam a Geografia Humana do poder como forma de análise espaço-temporal das realizações das sociedades. Para isso, é necessária uma teorização relacional que abre espaço para a semiótica, que fornece um quadro de referências para análises do poder por meio de símbolos. Enfatizam que a relação de poder não se desenvolve em um tempo único e uniforme, mas é significada por temporalidades específicas para os atores em questão. Assim, o quadro analítico é multidimensional e deve integrar atores, energia e informação, códigos, objetivos, estratégias, contexto espaço-temporal e o canal de relacionamento ou comunicação.

No entendimento dos autores o poder pode ser concebido de três formas: um valor a ser adquirido - o "poder atributo"; como uma esfera confinada à "política" e ao comportamento do homo politicus, de acordo com a tradição enraizada nas obras de Weber" e como um processo "relacional". O poder atributo é adquirido, mantido e perdido através de atores, onde a compreensão depende de noção de influência, autoridade e poder. O poder como uma esfera da política, está bem ilustrado pela clássica Geografia política alemã, inglesa, americana, italiana e francesa; tem a tendência de valorizar a relação estado/poder e/ou estado/política. Uma nova perspectiva de interpretação é a concepção relacional de poder, o qual passa a ser concebido como fluxo, isto é, como um processo de comunicação inerente para qualquer relacionamento (RAFFESTIN, BARAMPAMA, 1998, p. 64).

Di Méo (2006) destaca que o território contém os recursos necessários para o desenvolvimento do indivíduo e expressa territorialidades individuais e coletivas. Logo, no território, seus atores e agentes são capazes de imaginar, criar e gerenciar políticas e medidas que atendam aos seus objetivos e intencionalidades de apropriação da natureza. Para ele, o território político, frequentemente, se torna um instrumento de exclusão, dominação e segregação. Entretanto, a lei, quando é projetada e decidida por uma democracia, também gera realizações altruístas e generosas, favorecendo a integração ou a diversidade social, cidadania, justiça, partilha e cooperação, etc. O território torna-se espaço de legitimidade e validade, mas também gera um contexto de contrato social.

Suertegaray (2001) concorda quando entende que na Geografia o território se expressa no âmbito do espaço geográfico e privilegia a dimensão política ou a dominação-apropriação deste. Frisa que, conceitualmente, o território está associado às relações de poder sobre o espaço 
e seus recursos. Destaca que as abordagens clássicas incidiam na escala nacional, onde o conceito de território era associado à ideia de Estado-Nação. Atualmente, embora com a perspectiva analítica da apropriação-dominação do espaço, admite-se tratar as territorialidades como expressão da coexistência de grupos em um mesmo espaço físico, inclusive em tempos diferentes.

Tratando-se da coexistência de grupos, é importante enaltecer que, não necessariamente a presença de múltiplas territorialidades incide em conflitos, como apresenta Heidrich (2010):

Muitas territorialidades coexistem sem conflito, mas também não são poucas as relações em que o conflito se estabelece por causa da ação de territorializar. Como já foi possível observar anteriormente (HIDRICH, 2009), quando uma determinada territorialidade consistir em ação no mesmo plano de outra, a sua ocorrência, então, lhe afeta diretamente. Porém, o que se percebe em profusão na condição multiterritorial, é que se multiplicam as territorialidades em planos diferenciados (p.30).

Ainda sobre o papel da comunicação, Raffestin e Barampama (1998) retomaram Luhmann, que parte da teoria da complexidade. O exercício do poder, trata-se de exercício e não de aquisição, é uma comunicação bem-sucedida quando o critério adotado por uma das partes é, ao mesmo tempo, a estrutura de motivação da outra, nisto os símbolos assumem a função de mediação (RAFFESTIN, BARAMPAMA, 1998, p. 65).

Destaca-se então, que o problema vai para além do poder do Estado e suas articulações para conduzir relações humanas, mas abrange todos os tipos de relações condicionadas pela circulação do poder. Logo, a fonte do poder não é única, pelo contrário, é fragmentada e onipresente.

Les phénomènes de répartition qui traitent de population, de langue, de religion, d'activité économique ou d'expression culturelle ne s'épuisent pas en eux-mêmes mais renvoient toujours à des dissymétries que les acteurs déterminés cherchent à préserver, à augmenter, à restreindre, à annuler. La production territoriale elle-même peut être ainsi interprétée comme une projection du champ de pouvoir sur un espace donné. Il suffit d'un changement des codes politiques, par exemple la référence à des codes centralisateurs ou décentralisateurs, pour modifier les maillages, pour réorganiser les réseaux et les hiérarchies (RAFFESTIN, BARAMPAMA, 1998, p. 67).

Heidrich (2010) ressalta que as relações de conflitos no âmbito da abordagem territorial dizem respeito tanto aos indivíduos, quanto as instituições. $\mathrm{O}$ autor afirma que:

Muitos problemas que afetam a territorialidade humana são exatamente problemas entre indivíduos e instituições, especialmente aqueles que se 
referem aos conflitos territoriais, como as ocupações de áreas em que a sociedade estipula a redefinição de uso, por exemplo as áreas de preservação da natureza (HEIDRICH, 2009; SANCHES, 2004). Sendo assim, a abordagem territorial pode ser vista como um caminho de reflexões que se refere (a) à territorialidade das instituições e das sociedades, que envolvem o poder político; (b) a territorialidade dos indivíduos, grupos e comunidades, que envolvem o poder social; (c) às questões territoriais em que se intersectam, se entrelaçam e se conflitam instituições e indivíduos, que envolvem o entrechoque de poderes políticos e sociais (2010, p.27-28).

Em Raffestin (1993) utiliza-se a metáfora da prisão, onde o território constitui a prisão que os homens constroem para si. A ideologia da prisão pode ser definida pelo estabelecimento de relações assimétricas para permitir que o prisioneiro se integre a sociedade. No caso da prisão, o paradoxo está em seu auge, pois as relações são dissimétricas. De fato, a territorialidade fora da prisão é constituída por relações assimétricas e simétricas, mas na prisão, as características dissimétricas são sobredeterminadas e as relações de poder estabelecidas negam a possibilidade de simetria. Assim, a territorialidade simétrica pertence ao mais puro imaginário. O axiomático da simetria leva à dissimetria relacional! (RAFFESTIN, 1986B, p.95).

O tratamento desta questão pelo paradigma da territorialidade tem sido muito frutífero, tanto mais quanto lida com um "território" isolado e delimitado de maneira absoluta. Assim, a interferência com o exterior não está ausente, mas estritamente controlada e controlável. Para explicar o paradigma da territorialidade quanto o problema da tortura, Raffestin (1985) propõe que uma das maneiras de lidar geograficamente com uma questão social era levar em conta os sistemas de relacionamento: "Les conditions de possibilité de la torture existent donc dès que la société est infestée de relations dissymétriques qui contraignent le pouvoir à restreindre la circulation, à surveiller l'habitat et à multiplier les lieux de contrôle (RAFFESTIN 1985)" (., 1986B, p.95).

Quanto à abordagem relacional de análise, em entrevista concedida à Castilho (2013), Raffestin afirma que essa perspectiva é ainda mais fundamental no momento atual e que " $L a$ géographie estl'explicitation de la connaissance de la connaissance et de la pratique que les hommes ont de la réalité matérielle qu'est la Terre. L'objet de la géographie est relationnel et non pas matériel!" (CASTILHO, 2013, p.176). O autor complementa que problemática relacional permanecerá por muito tempo, uma vez que o objeto das ciências humanas é relacional. Ou seja, explicar o conhecimento do conhecimento e da prática que os homens têm da realidade material. "La géographie n'est pas l'étude de la terre mais l'explicitation de la 
connaissance de la connaissance et de la pratique que les hommes ont de la Terre" (CASTILHO, 2013, p.179).

Dentro desses conhecimentos e práticas pretende-se enaltecer a ideia de natureza com base em Raffestin (1996). O autor entende que o ser humano "produz" a ideia da natureza - seja a physis dos gregos ou a natura dos latinos - para afirmar sua presença e seu papel (RAFFESTIN, 1996, p. 37). Em diálogo com Moscovici (1968), Raffestin enfatiza que não existe uma única "história" humana, da mesma maneira que não existe uma, mas muitas classificações de objetos naturais que são expressões culturais das relações humanas com a exterioridade (RAFFESTIN, 1996, p. 38).

Cela dit les écosystèmes ne sont, en fait, que des images d'une réalité imparfaitement connue mais que chaque culture formalise pour son propre compte et considère comme la NATURE. De ces écosystèmes nous ne possédons qu'une connaissance imparfaite et très partielle quand bien même nous connaissons, ou croyons en connaître, les mécanismes généraux. Les images que nous en avons ne sont que la résultante de l'usage que nous en faisons. Cela revient à dire que nos images sont très lacunaires et que la précision de nos constructions ne progresse qu'à l'occasion de crises, c'est-àdire de ruptures. On pourrait imaginer une théorie des lacunes qui aurait pour fil conducteur, non pas ce que les sociétés utilisent mais justement ce qu'elles n'utilisent pas dans un écosystème donné. Ce serait, en somme, l'image en creux de la nature. (RAFFESTIN, 1996, p. 38).

Raffestin (1996) destaca que relação com a natureza é sempre de uso e não de conhecer por si. Segue a perspectiva do "embarque" da natureza de Heidegger que propõe derivar as forças, as energias, os materiais, mas absolutamente não entender independentemente de qualquer uso. Assim se revela a técnica, mas a intenção é sempre em um sistema cultural, logo, não há conhecimento puro que esteja completamente separado de qualquer preocupação utilitária. (p.39). Desta forma, a natureza enquanto ideia é uma criação humana:

C'est assez dire que l'idée de nature est profondément paradoxale puisqu'elle sert à fonder, à justifier et à légitimer les relations que les hommes entretiennent avec ce qu'ils dénomment "la nature », dont les images leur sont fournies par leurs modèles culturels au coeur desquels réside la nécessité des besoins. Instance éternellement cachée, dissimulée et emprisonnée, la nature ne ressortit donc qu'à l'idée et en cela même, n'en déplaise à beaucoup, elle ne saurait être qu'une création anthropocentrique essentielle mais néanmoins relative (RAFFESTIN, 1996, p.40).

Na modernidade, a natureza foi compreendida, seja pela cultura, política ou economia, como externa ao humano. Desta forma, a "leitura de nossa base filosófica- cientifica se inscreve na necessidade atual de decifrar um mundo extremamente complexo, onde sob muitos aspectos a natureza não é natural" (SUERTEGARAY, 2009A, p. 20). Milton Santos (2006) compreende 
que a natureza é socialmente construída. Aponta que a natureza artificializada é uma característica da atualidade, no meio técnico-científico-informacional.

As consequências desse movimento são, entre outros, os privilégios concedidos à informação funcional, cujos fluxos sustentam a técnica e, inversamente, o esquecimento das informações regulatórias susceptíveis de impedir a destruição do mundo não humano. A ação humana parece ter abolido a fronteira entre polis e physis. Logo, "La différence de l'artificiel et du naturel a disparu, le naturel a été englouti par la sphère de l'artificiel ; et en même temps l'artefact total, les oeuvres de l'homme devenues monde, en agissant sur lui-même et par luimême, engendre une nouvelle espèce de "nature", c'est-à-dire une nécessité dynamique propre, à laquelle la liberté humaine se trouve confrontée en un sens entièrement nouveau" (RAFFESTIN, 1996, p.41).

Ao contrário, para o estabelecimento de políticas para a sustentabilidade ambiental, Di Méo (2006) supõe que é necessária a definição das entidades territoriais que viabilizem ferramentas de gestão adequadas e eficazes aos grupos sociais, gerando novas formas de relação com o ambiente. A boa governança requer um envolvimento prático e emocional dos diferentes grupos e de sua ação.

Suertegaray (2009) compreende que na leitura ambiental as formas de socialização do uso dos recursos da natureza estão presentes nas marcas deixadas no território pelas técnicas. Assim, "Decifrar e mesmo redimensionar essas marcas exigem o reconhecimento de que, muito dos problemas ambientais, como ensina Alier, são conflitos ecológicos distributivos ou, na expressão geográfica, territoriais" (p. 24).

Para elaborar a compreensão da territorialidade Raffestin se inspira em Moscovici (1968) - na ideia de estados da natureza -. Esses forneceram um quadro para uma compreensão geral e "evolutiva" da territorialidade, onde o "trabalho de reprodução e invenção desempenha um papel fundamental, seja no estado orgânico, mecânico, sintético ou cibernético da natureza" (RAFFESTIN, 2012p. 128).

To these states of nature there correspond territorialities or systems of relations that constrain the admission that the classical opposition of nature and culture does not exist precisely because the nature that is transmitted from one state of nature to another is strongly marked by anterior cultures. The idea of nature changes over the course of time, as do the actors who mold future ecosystems. The molding of ecosys- tems is a dual process, insofar as it is material through ko «rperliche Arbeit (manual labor) and immaterial through Geistesarbeit (intellectual labor). (RAFFESTIN, 2012p. 128). 
Nessa compreensão geográfica, a natureza sendo transfigurada passa a ser outra socializada, instrumentalizada, tecnificada ou cibernética -. Assim, a ótica ambiental da Geografia se distingue da ecológica, pois inclui o homem não como ser naturalizado, mas como um ser social que ao mesmo tempo é produtor e produto de tensões ambientais (SUERTEGARAY, 2001).

Nessa perspectiva Raffestin (1986B) apresenta a territorialidade não como um conceito, mas como um paradigma que expõe a relação complexa entre o grupo humano e seu ambiente. O ambiente é então compreendido como entorno espaço-temporal (constitui-se tanto de propriedade espaciais quanto temporais), onde se interconectam comportamentos que estão ocorrendo em determinado espaço e tempo. (p.94).

Raffestin (1986C) destaca que a territorialidade humana não é apenas constituída por relações com territórios concretos, mas também por relações com territórios abstratos como línguas, religiões, tecnologias, etc. "Esiste una relazione complessa tra l'uomo, nella sua manifestazione societaria, e l'ambiente fisico in cui agisce: questa relazione è descrivibile come organizzata secondo una: serie di regole, comunicabili e implicite nelle relazioni societarie stesse" (p.77). Deste modo, como tem sido frisado, mediadores e processos de comunicação são fundamentais no estudo da territorialidade humana. (p.78).

Compreendendo a territorialidade a partir da superação da dicotomia natureza-cultura, observa-se que a transformação dos ecossistemas resulta de um processo duplo de trabalho (manual e intelectual). O primeiro desempenha um papel essencial na produção material, enquanto o segundo é importante na produção de representações, "mas devem ser considerados em conjunto, como dois lados da mesma moeda". Para o autor, uma limitação da Geografia contemporânea é não ter tomado em consideração o trabalho e, portanto, não ter analisado como tal. Assim, trabalho é apresentado como categoria constitutiva da territorialidade:

Labor is a constitutive category of territoriality, because it lies at the origin of power. Without labor there is neither transformation nor conservation or maintenance of ecosystems nor, finally, representation. As the original source of power, labor plays a fundamental role in the ecogenesis that is difficult to reconstitute, but possible to sketch with some validity as is done by rural and urban historians (RAFFESTIN, 2012p. 128).

Pensando a territorialidade a partir de sistemas sucessivos, o autor adverte que todos os sistemas de relações são complexos, as mais antigas não são mais fáceis de compreender que as mais recentes. Logo, uma sociedade tradicional não é mais simples de compreender do que a contemporânea. Ainda cabe compreender os acréscimos culturais decorrentes de momentos 
de transgressão que destacam as normas ligadas à interdição. Em outras palavras, em toda a territorialidade, funciona uma dialética de "proibição e transgressão, interdição e violação, normas e a falta de respeito" (RAFFESTIN, 2012, p. 128). Justamente a transgressão leva a noção de limite:

This problem of transgression leads us to the notion of the 'limit', not only in a concrete sense, in space, but also in the abstract space of rules and symbols. It is impossible to understand territorial production without the notions of border or trans- gression, the latter of which has the value of a cultural mechanism of regulation: culture is a catalogue of limits, and history a catalogue of their transgression. A culture is also a catalogue of possible transgressions: every limit is an opportunity for trans- gression and thus, in a certain sense, an occasion for creativity (RAFFESTIN, 2012, p. 128).

Acrescenta-se que a compreensão de Raffestin (2012) de que a construção de território mobiliza três "mundos": coisas e estado material "things and material states", estados de consciência, emoção e conhecimento subjetivo "states of conscience, emotion, and subjective knowledge" e conhecimento tomado objetivamente "knowledge taken objectively". O território é então o ponto de convergência entre esses três mundos, em um determinado momento, mas múltiplo em representações. Essas representações múltiplas permitem desconstruir a história de um território. $\mathrm{O}$ autor destaca o efeito da intervenção no estado material do território: "The distinction of these levels is all the more indispensable in that intervention in the materiality of territory risks provoking modifications in the two other worlds. As a material prominence, constructed territory unleashes resonances that risk affect- ing the two other worlds" (RAFFESTIN, 2012, p.130). O autor enfatiza que na construção de territórios a questão da escala não costuma ser abordada, exceto na sua dimensão material, e que poucos tem se interessado em abordar esse problema nos aspectos dos dois outros mundos. Contudo, entende que as "proeminências e as ressonâncias" não podem ser explicadas, no entanto, sem uma visão sintética de escala (RACINE et al, 1980 apud RAFFESTIN, 2012, p. 130).

Os territórios são, então, construídos e desconstruídos nas mais diferentes escalas espaciais e temporais, em um campo de forças onde se manifestam relações de poder espacialmente delimitadas (SOUZA, 1995). Logo, o território deve ser abordado de acordo com os contextos históricos e geográficos em que foi produzido. Assim, interessa tanto como articulador de conexões ou redes em escala global, quanto como uma área-abrigo e fonte de recursos, em escala local (HAESBAERT, 2007, p. 97).

Buscou-se em Claude Raffestin e Mercedes Bresso (1982) elementos que permitem compreender a distinção da dinâmica territorial em sociedades tradicionais e modernas, 
tomando por base conhecimentos e práticas. Vale salientar que o texto apresenta alguns limites para leituras da América Latina, pois trata sobre o tradicional em sociedades europeias (feudais). Contudo, expõe considerações importantes para compreender os territórios e territorialidades, e a hibridização entre conhecimentos tradicionais e modernos.

Nas sociedades tradicionais, conhecimentos e práticas se confundem na vida cotidiana, que é lugar de viver e sobreviver. Desta forma, na vida cotidiana a apropriação é feita por meio de tentativas repetidas e marcadas por falhas e sucessos em relação ao objetivo. A partir desses testes repetidos e sua adequação ou inadequação aos objetivos é desenhada uma experiência, memorizada, acumulada e transmitida: a tradição (RAFFESTIN, BRESSO, 1982, p. 187).

$\mathrm{Na}$ tradição, a "prática" é atualizada enquanto o "conhecimento" que garante a potencialidade da coerência, tanto na "physio-logique", quanto na "éco-logique" e na "sociologique". Vive-se, no passado, nas tradições do corpo, da natureza e da sociedade, as quais alimentaram a ação, enquanto trabalho (RAFFESTIN, BRESSO, 1982, p. 188). Desta forma, a mobilização da tradição através do trabalho estava intimamente ligada a condições determinadas pela eco-lógica e socio-lógica de determinado lugar e tempo:

Le miroir de ces traditions a presque toujours été le travail dans lequel se concentraient les capacités et les habiletés consacrées par «l'expérience». Le travail était non seulement miroir de la tradition mais encore metteur en scène de cette expérience. Dans ces conditions, le travail était essentiellement de reproduction, encadré par un apprentissage long, il était ensuite restitué dans des limites fixées, finalement assez étroites. Médiateur originel, le travail reflétait également la territorialité, c'est-à-dire le réseau de relations qui pouvait être tissé avec les êtres et les choses ; le travail à travers son organisation assurait la cohérence de la totalité sociale (Raffestin et Bresso, 1979, p. 153 (RAFFESTIN, BRESSO, 1982, p. 188)

No entendimento dos autores no contexto tradicional, há estabilidade nas territorialidades. Quando essa territorialidade é destruída, se traduz em toda uma desestabilização do cotidiano até que se estabeleça um novo equilíbrio. Como conhecimentos e práticas se confundem, o processo de constituição de novas práticas é mais lento, tendo em vista que são mais o resultado de adaptações de longo prazo do que respostas de curto prazo a mudanças na rede de relações subjacentes à cotidianidade (RAFFESTIN, BRESSO, 1982, p. 188).

Por outro lado, explicar o conhecimento ou preferir a dicotomia entre conhecimento e prática é precisamente o que caracteriza a modernidade, que pode ser definida como um processo de divisão característico do pensamento ocidental. Raffestin, Bresso (1982) complementam 
Cette fission caractéristique, qui va dégager le principe de modernité, se réalisera entre le XVI et le XVII siècles. Il y a, entre le XVI et le XVII, une rupture, une discontinuité, une crise sur les origines de laquelle on pourrait s'interroger mais ce n'est guère le lieu de le faire. Bornons-nous à constater que cette crise marque le début de la science moderne qui va effectivement distinguer nettement la connaissance d'une part et la pratique d'autre part. (p. 189).

Desta divisão, (dicotomização) surge o princípio da modernidade e: O homem da Idade Média e do Renascimento vive em uma natureza de "formas" e "substâncias" que recebem "qualidades", cujas combinações formam e explicam a diversidade de coisas. Assim, a natureza está submetida a uma ordem coerente com as necessidades da sociedade. O homem do século XVII pelo procedimento da medida inaugura uma nova fase de explicitação dos fenômenos. Explicação que requer a criação de conceitos é o início desta divisão anunciada: o conhecimento de um lado e as práticas do outro. Esta é a aparência do princípio da modernidade. Este princípio da modernidade encontra na matemática sua linguagem preferida (RAFFESTIN, BRESSO, 1982, p. 189).

Raffestin e Bresso (1982) acrescentam o fenômeno a convergência entre o princípio da modernidade e a atitude técnica, pela conjunção da ciência e da tecnologia que modificará a vida cotidiana e a territorialidade. Em um primeiro momento a tradição não deixou de inspirar a vida cotidiana como um todo e o princípio da modernidade ainda se expressava apenas em espaços limitados. No entanto, pelo avanço da técnica a divisão mencionada é irreversível e não vai parar de investir gradualmente todo o corpo social (RAFFESTIN, BRESSO, 1982, p. 190).

Para explicar os limites entre tradição e modernidade Raffestin e Bresso (1982) apresentam dois contextos: "tradição pura", "modernidade pura". A tradição pura corresponde ao estágio em que práticas e conhecimentos se confundem. O trabalho, então, consiste em um conjunto de operações globais aprendidas e processadas em determinadas situações. Há pouca ou nenhuma mudança, pois a prática é conduzida pelo que foi aprendido para alcançar o objetivo estabelecido. A análise dessa experiência acumulada pode revelar um conhecimento e ou prática muito notável e útil. Portanto, é possível, através da aplicação do princípio da modernidade, recuperar na tradição o conhecimento e/ou prática que o sustenta (RAFFESTIN, BRESSO, 1982, p. 190).

Em contraste na modernidade pura há combinação de conhecimentos e práticas totalmente novos. A modernidade pura ocupa um lugar cada vez maior, infiltra todos os lugares, substitui tudo. Por isso deve-se retornar a essas duas noções de informação funcional e informações regulatórias. A informação funcional é tudo o que é usado para produzir algo 
(objetivo a ser alcançado). As informações funcionais estão concentradas na produtividade e no custo da saída. Mas o processo de produção implica em relações com o Outro (ambiente físico e humano, orgânico e inorgânico), relações que podem ser mais ou menos destrutivas do Outro (RAFFESTIN, BRESSO, 1982, p. 190).

A crise atual, que afeta em vários graus o fisio-eco e o sociológico, demonstra que a pura modernidade privilegia o resultado em detrimento do processo. A falta da informação regulatória ameaça as três lógicas, logo pela falta de controle dos processos envolvidos. A permanência de certas sociedades tradicionais só pode ser explicada pela presença simultânea de informação funcional e informação regulatória nos processos que iniciam para satisfazer suas necessidades. Por outro lado, a fragilidade da sociedade moderna se explicada pelo privilégio concedido às informações funcionais sobre informações regulatórias (RAFFESTIN, BRESSO, 1982, p. 190).

Raffestin e Bresso (1982) estabelecem a hipótese de que nas sociedades que reivindicam a tradição, os objetivos têm base em um referencial real, expresso nessa relação complexa de "cotidiano-territorialidade" imperfeitamente conhecida, mas vivida. Em sociedades modernas, os objetivos são definidos por um quadro imaginário de referência que não é o "cotidiano da territorialidade" vivido, mas o utópico, sonhado, projetado no futuro e que deve cumprir os desejos de todos.

Les sociétés traditionnelles n'ignoraient pas l'utopie mais celle-ci était le plus souvent morale et non pas technique (sauf celle de Bacon qui coöncide justement avec l'apparition du principe de modernité). Les sociétés modernes en appliquant les méthodes de l'extrapolation technique, scientifique et sociologique sont entrées dans la futurologie active: le futur est devenu le référentiel. Le principe de modernité, dans ces conditions, déterritorialise, dans le sens où ses objectifs tiennent de moins en moins compte du réseau de relations des physio-éco et sociologiques qui malgré l'adaptation bien connue de l'être humain ne peut pas être modifié constamment (RAFFESTIN, BRESSO, 1982, p. 191).

A modernidade pura está repleta de perigos, pois para se libertar das restrições estabelecidas pela sociedade tradicional, criou proibições absolutas. As ideias de crescimento e poder que eram noções relativas nas sociedades tradicionais, tornaram-se praticamente absolutas nas sociedades modernas. A modernidade se mobilizada pelas noções de crescimento e poder, logo dá uma importância excessiva à informação funcional, mas pouca atenção às informações regulatórias que podem questionar a escolha feita por esse ou aquele repositório imaginário (RAFFESTIN, BRESSO, 1982, p. 191). 
Entre a tradição pura e modernidade pura, Raffestin e Bresso (1982) estabelecem limites de possibilidades:

Entre la tradition pure et la modernité pure, on découvre deux autres situations possibles: la combinaison de connaissances traditionnelles explicitées et de pratiques nouvelles ou encore la combinaison de connaissances modernes et de pratiques traditionnelles. Dans ces deux cas, le principe de modernité agit tout en récupérant ce que la tradition peut fournir. C'est tout le problème des technologies appropriées ou intermédiaires qui permettent d'amorcer des transformations à des coûts humains et économiques supportables, c'est-à-dire sans bouleversement radical des réseaux de relation et en préservant l'information régulatrice essentielle (RAFFESTIN, BRESSO, 1982, p. 191).

\section{Ecogênese territorial}

Após essa compreensão da relação entre conhecimento e prática, e sua repercussão nos territórios e territorialidades em sociedades tradicionais e modernas, pretende-se dar ênfase à produção de territórios. Para tanto, será tomado como referência Raffestin (1986) que discute a ecogênese territorial.

"L'écogenèse territoriale est la chronique d'un "corps à corps », l'histoire d'une relation dans laquelle nature et culture fusionnent". O território é entendido como um estado de natureza, na perspectiva de Moscovici (1968), que se refere ao trabalho humano exercido sobre uma parcela do espaço, que está sujeita a uma combinação complexa de forças e ações mecânicas, físicas, químicas, orgânicas e outras. O território se apresenta como a reordenação de espaço, cuja ordem está baseada nos sistemas de informação disponíveis, os quais pertencem a determinada cultura. Logo, o território pode ser considerado como espaço informado pela semiosfera (RAFFESTIN, 1986, p. 177).

La sémiosphère est caractérisée par une frontière, une limite abstraite et/ou concrète qui joue le rôle de "membrane » (analogie biologique utilisée par Lotman) dont les fonctions sont de limiter l'accès, de filtrer et de transformer de 1'« externe » en « interne » (RAFFESTIN, 1986, p.178)

O autor faz referência à áreas que não sofreram mudanças a partir da atividade humana voluntária (trabalho). Estes lugares escaparam assim da ecogênese territorial e, de certo modo, podem ser concebidos como zonas de fronteira entre espaço e território. Na realidade, esses espaços estão integrados em territórios, mas aparecem como "esquecidos": estão fora da “fronteira territorial”. Estas áreas relíquias ou persistentes permanecem fora do ecogênese 
territorial, ou seja, não tem sido objeto de tradução para o sistema de significados que transforma espaço em territórios (RAFFESTIN, 1986, p.178).

A ecogênese territorial não leva em consideração todas as formas espaciais disponíveis, ou seja, os limites da ecogênese territorial são os limites da semiosfera considerados. Portanto, é possível definir ecogênese territorial como um processo de tradução e transformação de formas espaciais de uma semiosfera. Dito isto, considera-se a questão da ecogênese territorial como um processo de "semiotização" do espaço (RAFFESTIN, 1986, p.179-180).

Pour parvenir à une théorie écogénétique du territoire, il faut rechercher dans les codes le point d'appui du levier théorique. (...) La «clé du déchiffrement» n'est pas dans la réalité matérielle qu'est l'espace mais dans la sémiosphère que le groupe humain mobilise pour transformer cette réalité matérielle. Pour agir, l'homme se réfère à un espace sémiotique, au sens large, délimité par une frontière qui a une double fonction abstraite et concrète qui détermine ce qui est retenu et transformé, ce qui est traduit ou non traduit dans l'extériorité. (Raffestin, 1986B, p.94).

Na semiosfera os arranjos territoriais não são aleatórios, mas resultado de uma prática e um conhecimento de apropriação de uma "superfície" -não refere à superfície da Terra, mas qualquer superfície, onde se possa distribuir elementos- (RAFFESTIN, 1986, p. 181).

Qualquer representação do espaço, na sua forma mais simples, requer os três elementos da geometria euclidiana: superfície, ponto e linha - mas esses elementos são apenas "projetos de territórios" -. A produção territorial em si é constituída por malhas, nós e redes que representam invariavelmente instrumentos que qualquer grupo humano usa para constituir uma "reserva" e, portanto, para se proteger contra as modificações do ambiente. "Les mailles, les noeuds et les réseaux sont des invariants en ce sens que toutes les sociétés, depuis la préhistoire jusqu'à nos jours, les ont mobilisés dans leurs pratiques et leurs connaissances, mais à des degrés divers et avec des morphologies variables" (RAFFESTIN, 1986, p. 181). Raffestin (1986B, p.95) destaca que os territórios de pequenas dimensões são como "laboratórios naturais da ecogênese", onde essa diversidade evidente na semiosfera é sempre sustentada pelas referidas invariantes territoriais.

Para Raffestin (1986C) a produção territorial sempre combina malhas, nós e redes, mas a combinação dessas invariantes varia entre as civilizações de forma diferente para criar reservas. Em outras palavras, se essas civilizações usam esses três instrumentos essenciais, privilegiam um ou outro para construir sua autonomia, que é o coração da territorialidade, cujo propósito é o controle e a regulamentação dessas "reservas". (RAFFESTIN, 1986C, p.78). Raffestin (1986) distingue sociedades caçadoras-coletoras - que serão tratadas como 
extrativistas -, sociedades sedentarizadas por meio da agricultura, sociedade urbana e sociedade contemporânea (p. 182). Ressalta-se que em Raffestin (1986C) os dois primeiros grupos são considerados sociedades tradicionais, e os dois últimos como sociedades modernas.

A compreensão da autonomia aqui permite pensar o domínio da territorialidade humana: "le système de relations qu'entretient une collectivité - et, partant, un individu qui y appartient — avec l'extériorité et/ou l'altérité à l'aide de médiateurs » [387]. Les médiateurs renvoient immédiatement à la sémiosphère, car les limites de ma territorialité sont les limites de mes médiateurs" (RAFFESTIN, 1986, p. 183).

Nas civilizações tradicionais extrativistas, nômades ou seminômades, as três invariantes territoriais são encontradas, mas são apresentados de forma fluida. Na verdade, há uma "malha", o território coberto, que é delimitado e é essa área que constitui a reserva de recursos úteis. Os "nós" são justamente pontos de fixação de alimentos e abrigo: estas são as reservas que eles são renovados periodicamente de forma sazonal. As "redes" consistem em rotas percorridas com frequência. (RAFFESTIN, 1986C, p.78)

Raffestin (1986) entende que entre os extrativistas existe uma estreita relação entre autonomia e território. Assim a ecogênese territorial integra imediatamente as noções de limite, de centralidade no local de coleta e circulação. Logo, a delimitação, a centralização e a comunicação são o cerne do processo de territorialização, desterritorialização e reterritorialização (RAFFESTIN, 1986, p. 182).

Quanto aos limites Saquet (2010, p. 84) acrescenta que esses podem mudar, conforme as estratégias de controle e delimitação de espaços. Logo, a territorialidade não tem caráter estático; essa pode ser ativada ou desativada e é mantida mediante um esforço constante, por vezes, através de uma ação não territorial. A territorialidade não exige uma área definida, envolve estratégia de influência e a delimitação só cria território se as fronteiras afetam o comportamento ou controlam o acesso. Contudo, como destaca Heidrich (2008, p. 242), também a territorialidade não se esgota na demarcação do espaço, mas existe por aquilo que o poder deseja definir. Portanto, mesmo sendo um aspecto fundamental, a demarcação só ganha sentido por meio da objetividade daquilo que se deseja e pelo que existe em seu interior.

Ressalta-se que os extrativistas têm os meios de produção suficientes para satisfazer as suas necessidades materiais, por isso o território delimitado por sinais que constituem a reserva natural. Quando os limites não são respeitados por pessoas de fora do território, ou parte do território não está acessível ao grupo, a crise se estabelece. A perda de autonomia resulta em 
um desequilíbrio que pode chegar ao desaparecimento do grupo em questão (RAFFESTIN, 1986C, p.78). Desta forma, a autonomia depende da manutenção da reserva no território.

Nel territorio del gruppo primitivo, l'organizzazione privilegia soprattutto la dimensione orizzontale e sono gli uomini che « si muovono » passando da una «riserva rinnovabile » trovata, a un'altra. Essi vivono dunque costantemente nell'incertezza, per assenza totale di previsione, il loro grado di autonomia è una funzione della probabilità di rinnovamento delle risorse da una stagione all'altra. In altri termini, la riserva esiste ma non costituisce stock nel senso che essa non è che una riserva a tempo determinato, perfettamente conosciuta in quanto misurata (RAFFESTIN, 1986C, p.80).

Já entre os agricultores, o aumento da probabilidade de armazenamento implica na constituição de "structures protectrices, palissades ou remparts". O "nó" agrícola, a quadratura do solo é o fundamento material da propriedade, que viabiliza o imposto sobre a propriedade (RAFFESTIN, 1986, p. 182).

A sedentarização revela um alto grau de autonomia baseado na mobilidade dos homens que vão de um ponto a outro, e na criação de um sistema de reserva. Sistema de reserva que mobiliza recursos para mantê-los à disposição dos homens em determinados pontos fixos. $\mathrm{O}$ sistema existe, pois há uma "cadeia de recursos" da produção de um novo estado da natureza a ser preservada com mão-de-obra até que os bens sejam armazenados, a primeira forma de capitalização. Neste tipo de civilização, a "malha" que é atualizada por toda a produção territorial, em que se destaca o sistema de reserva (RAFFESTIN, 1986C, p.80).

A cidade representa o centro, o " $h u b$ ", conforme expressão de Leroi-Gourhan, uma nova organização. A cidade é um "nó" que controla malhas, o fundamento de sua autonomia. O mercado da cidade, através do jogo de preços, organiza as superfícies que o cercam. Com base em Von Thünen, Raffestin (1986) entende que não são apenas sinais como os preços que organizam as "malhas", mas todas as informações, de que a cidade é o local de chegada ou o local de partida (p. 182).

A partir desse momento, o sistema de reserva se torna uma verdadeira cadeia de elementos territoriais articulados um com o outro. A cidade das civilizações tradicionalistas ${ }^{5}$ é um nó. A partir deste momento, mesmo que de forma lenta e progressiva, o sistema de reserva está conectado a nós urbanos. O nó, como ferramenta territorial, é privilegiado. As cidades préindustriais conheciam uma autonomia que dependia do seu grau de controle dessa articulação, tomada como um todo, e seus elementos são levados a si próprios. É dos séculos XIV e XV,

5 Raffestin (1986C, p.79) distingue historicamente três sociedades, tradicionais (extrativistas e agricultores), tradicionalistas e modernistas (urbanas, mas muito vinculada a produção do campo) e modernas (onde a informação ganha maior importância). 
quando as cidades começaram a se desenvolver, que a relação cidade-campo assumiu um tom conflitante. Em suma, a relação entre cidade e campo é identificada com o histórico de aquisição ou perda de autonomia (RAFFESTIN, 1986C, p.81-82).

A produção territorial passa a ser condicionada pelos atores urbanos e seus objetivos. As rotas de circulação são abertas, construídas, bem conservadas e controladas para aumentar o nível de autonomia da cidade; elas têm forma "raios" ligados ao sustentáculo constituído pela cidade. O mercado urbano é, por si só, um mecanismo regulatório, na verdade, determina os preços dos recursos. Mas a cidade usa, através de seus regulamentos, o mercado para aumentar indevidamente suas reservas. $\mathrm{O}$ sistema de reservas incluiu, diferentes ferramentas territoriais: campos cultivados, estradas, mercados e celeiros (RAFFESTIN, 1986C, p. 82).

$\mathrm{Na}$ contemporaneidade é o terceiro invariante privilegiado: a rede. Hoje, a ecogênese territorial reside no controle das redes de circulação, comunicação e telecomunicações. A informação é, com energia, o recurso essencial que passa por redes cada vez mais complexas. É a teoria da comunicação que atualmente administra ecogênese territorial e o processo de territorialização, desterritorialização e reterritorialização (RAFFESTIN, 1986, p. 182).

\section{Invariante territorial/ \\ Sociedade \\ Tradicional \\ Transição \\ (tradicionalista e \\ modernista)}

\section{Moderna}

Quadro 1: Invariantes territoriais

$$
\text { malha }
$$

nó

rede
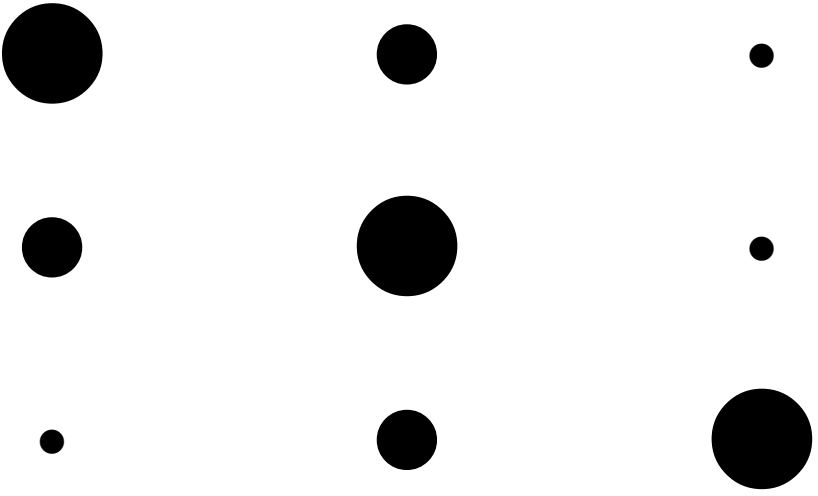

Fonte: Adaptado de Raffestin (1986C, p. 79).

Raffestin (1986C) destaca que as redes de circulação de homens e mercadorias foram ativadas há muito tempo, mas a novidade reside no advento e na multiplicação de redes de comunicação distintas das redes de circulação. Hoje em dia, uma das condições da autonomia reside no controle das redes de comunicação de informação. A informação é, com energia, o recurso essencial que circula por redes cada vez mais complexas. Se as redes condicionam cada vez mais a autonomia das sociedades, isso se deve ao fato de que a informação multifacetada 
(publicações de patentes, dados técnicos, publicidade, ficção) se tornou um recurso básico para a gestão. Assim, o acesso à informação é fundamental, inclusive quando se trata de questões da natureza:

Tuttavia, da questa banalità bisogna tirar fuori una grave conseguenza: l'autonomia dipende sempre più dall'accesso a questa informazione. Se la ripartizione delle risorse rinnovabili e non-rinnovabili deriva da fattori non umani, climatici, pedologici e geologici, la distribuzione dell'informazione deriva da decisioni umane: "esistono ormai paesi ricchi e paesi poveri di dati (data rich and data poor) »(RAFFESTIN, 1986C, p.83)

As informações são fundamentais para todas as políticas e determinam o processo de territorialização, desterritorialização e reterritorialização das sociedades. A nova lógica informacional é responsável pela distribuição dos trabalhadores e do capital. Logo, a informação é limitada, o que importa é a rede para se comunicar e divulgá-la. A teoria da comunicação na atualidade organiza o sistema territorial e o processo de territorializaçãodesterritorialização-reterritorialização, através do qual é possível adquirir, perder ou recuperar autonomia (RAFFESTIN, 1986C, p.84).

Raffestin (1986) enfatiza que se for considerada a ecogênese territorial dos chamados países desenvolvidos, observa-se que até o século XX, os territórios materiais concretos - a externalidade - eram em grande parte "regionalizado"; em outras palavras, a regulação intrassocietal ainda tinha um significado. (RAFFESTIN, 1986, p. 183)

Nesse sentido se observa que havia coerência entre o território e a territorialidade porque havia uma coerência entre a ação de uma sociedade e a semiosfera a que se referia. Esta unidade relativa e o processo de territorialização - desterritorialização e reterritorialização (T-D-R) foram modificados, pois a regulamentação passou a ser externa. "La territorialité est moins « spatialisée » que «temporalisée » parce qu'elle est commandée par la modernité dont «la mode est l'emblème »". No entanto, a modernidade é desenvolvida em apenas alguns lugares que têm meios de difusão ultrarrápida. $\mathrm{O}$ território concreto tornou-se menos significativo do que o território da informação, em termos de territorialidade (RAFFESTIN, 1986, p. 183).

Le fait même que la région ne soit plus qu'un discours démontre assez que l'on est passé à une territorialité "temporalisée », c'est-à-dire à un système de relations qui dépend de la variation de la quantité d'information dans un territoire donné (RAFFESTIN, 1986, p. 184)

O autor complementa que no período atual se retorna ao regionalismo, e a ressurgência de certos valores. "Dans cette dernière perspective, la territorialité est souvent entendue comme identitê". O autor enfatiza que na perspectiva da "identidade cultural" não devem ser 
confundidos os conceitos, pois não se trata de um "retorno" impossível para uma cultura local, mas para uma reinterpretação ou projeção de uma tradição (RAFFESTIN, 1986, p. 184).

\section{Territorialização-Desterritorialização-Reterritorialização (TDR)}

Raffestin (2012) destaca a produção de territórios sobre territórios preexistentes. Neste caso as mudanças no ambiente físico e na natureza supõem um suprimento de território que não é utilizado, ou é menos utilizado do que no passado, e uma demanda de território para integrar novas atividades. Assim, dois processos se associam -desterritorialização e reterritorialização (p.131). Desta forma, como destaca Haesbaert (2007) a dinâmica territorial é um processo contínuo de territorialização, desterritorialização e reterritorialização.

Diante disso, o autor expõe duas possibilidades: a destruição total do território anterior ou a reciclagem:

For this there will be two possibilities: either there is a space immediately available or territory is recycled, creating landscape to meet demand. According to the circumstances, the costs are not the same, and everything depends on the resources available. Recomposition can be total or partial. It is total when everything is razed and reconstructed; it is partial when the external is preserved and the internal is altered. There is a wide range of possible outcomes, according to the extent to which all the parameters affected by the operation are taken into account. (RAFFESTIN, 2012, p. 131).

Nesse processo Raffestin (2012) aponta dois eixos: o paradigmático e o sintagmático. Entende que toda recomposição é realizada através do empréstimo de elementos paradigmáticos, a fim de fazer com que eles sejam sintagmas adaptados a novas atividades. Assim, vemos novas modificações dos perfis de paisagens emergentes que revelam, por um tempo, a nova estrutura de territorialidade. A produção de territórios por meio de territórios é uma operação de criação ou recreação de valores em ambos os sentidos do termo: valores econômicos, culturais, sociais e políticos (RAFFESTIN, 2012, p. 131).

Ressalta-se que essa criação de valores ocorre por meio da memória e do esquecimento, dissoluvelmente ligados. "Behind the memory of a culture there is the oblivion of another culture from whose elements it was nourished before being itself forgotten in order to permit the constitution of another memory and so on, so long as there are communities and societies". Nesse processo territórios podem ser construídos, desconstruídos e reconstruídos, funcionalizados, desfuncionalizados e refuncionalizados (RAFFESTIN, 2012, p. 131).

Na perspectiva da produção de territórios, observa-se a constituição de Geografias fabricadas, implementadas por determinada cultura, inclusive pela propaganda. Essa Geografia 
produzida já não é mais esforço de gerações, passando a projetar lugares e territórios a partir de um plano publicitário. "Territory is no longer a cause, but is 'caused' in the same way as most other objects. In all of this fabrication there is the criss crossing of syntagm and paradigm. All fictive but produced spaces and territories now serve as positive or negative reference: fiction informs the real”. (RAFFESTIN, 2012, p. 131).

Raffestin (1986) já apontava que o processo T-D-R está submetido, em certa medida, ao ciclo do produto caracterizado pela inovação, desenvolvimento e maturidade, de acordo com a função da informação técnico-econômica. Portanto a territorialidade é uma função da informação e do tempo. Esse tipo de territorialidade não contempla o espaço vivido, identidade regional ou cultura local. Na melhor das hipóteses, pode-se tratar de informações consumadas, cuja identidade está condicionada a modelos culturais dominantes. Desta forma, mesmo que a sociedade permaneça a viver e atuar em um território concreto, que resulta de uma produção, suas relações são muito menos condicionadas por esse território do que pela informação disseminada ali. (p.184).

Raffestin (1986C, p. 86) enfatiza que a territorialidade humana pode ser expressada, neste caso, pela evolução das fases de um ciclo duplo, dinâmico e constituído de continuidade e descontinuidade. Tratam-se de ciclos de territorialidade em pequena e grande escala. Ciclos estão condicionados por sistemas de informação que desencadeiam ações: inovação, difusão, obsolescência (IDO). Assim, a territorialidade é definida pela reunião de dois processos, um territorial (TDR) e o outro informativo (IDO). Desta forma, a territorialidade expressa a interação entre dois sistemas, um espacial e outro informativo, na perspectiva de garantir a autonomia de um grupo ao longo do tempo. Para o autor esse constitui um eixo de reflexão que se baseia na hipótese de que as relações com a externalidade e com a alteridade são em grande parte condicionadas pelas mudanças que ocorrem nos sistemas informacionais.

\subsection{Caminho metodológico}

A composição de procedimentos metodológicos está orientada pela teoria do pensamento complexo (MORIN, 1990, 1996, 2008). A dialógica é estabelecida entre abordagens dos geógrafos sobre tais problemáticas, que pressupõem o diálogo deles com as comunidades, tendo em vista as comunidades e entidades apontadas no Capítulo anterior. $\mathrm{O}$ holograma vai sendo formado na medida em que cada pesquisa compõe uma análise da Geografia brasileira e, concomitante, a Geografia brasileira permite estabelecer leituras sobre 
cada pesquisa. Por fim, o processo recursivo se evidencia na medida que as abordagens no curso do processo não são tomadas a priori, desta forma é a problematização que evidencia as abordagens e não as abordagens que dirige a problematização. Entre os procedimentos destacados, apresenta-se análise de conteúdo (BARDIN, 2007) e representações cartográficas.

\section{Análise do Conteúdo}

De 1980 a 2015 foram identificados 104 trabalhos, dos quais foi possível ter acesso à 71, entre dissertações e teses, conforme explicitado no Capítulo I. A análise dos trabalhos, a partir do Banco de Dados (planilha do Excel®), permitiu reconhecer os conceitos mais adotados (BARDIN, 2007) para abordar as problemáticas da pesca artesanal (figura 46). Seguindo a perspectiva de Bardin (2007) a análise das abordagens conceituais permitiu distinguir três questões emergentes: Impactos Ambientais, Disputas no Território e Conflitos por Território.

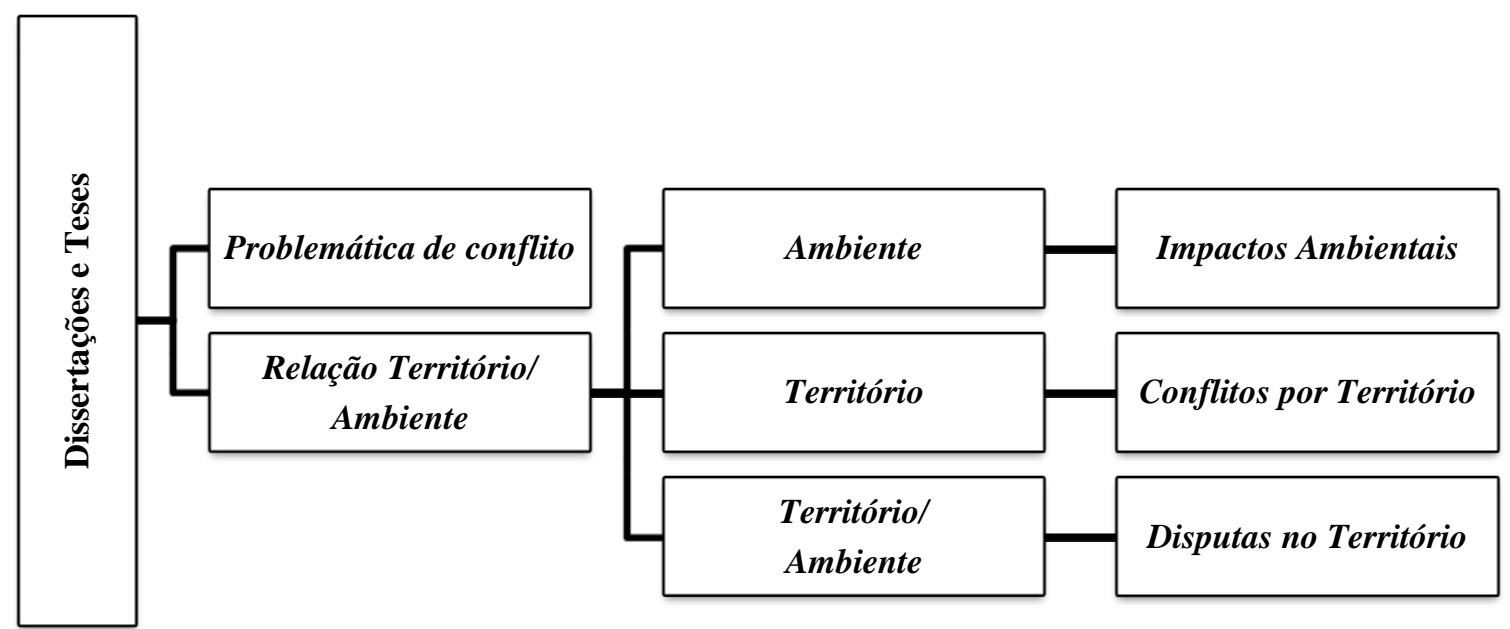

Figura 46: Diagrama de Análise das Dissertações e Teses

Fonte: Elaborado por De Paula (2018).

\section{Representações Cartográficas}

Com o Geodatabase constituído na etapa anterior foi construído um conjunto de mapas temáticos que expõem a expressão das três abordagens propostas: impactos ambientais, disputas no território e conflitos por território.

Foram construídos mapas que expõem a distribuição (pontual) das atividades que causam impactos ambientais no Brasil, com base nos trabalhos analisados. Também foram criados mapas, cuja simbologia será composta por gráficos de setor, com base em estados e regiões, que expõem as principais atividades causadoras de impactos ambientais ou disputam territórios com a pesca artesanal. 
Ainda para compreender a concentração dessas três abordagens propostas foram construídos mapas de densidade de kernel (ferramenta "spatial analyst" do ArcGis 10.2.2®). Utilizou-se como cálculo o desvio padrão para uma melhor visualização dos resultados.

\subsection{Impactos Ambientais, Disputas no Território e Conflitos por}

\section{Território}

A análise do uso dos conceitos de território e ambiente nas dissertações e teses analisadas, permitiram estabelecer um horizonte de compreensão do híbrido estabelecido entre o território da natureza e a natureza do território (SUERTEGARAY, 2012). Como foi destacado no referencial teórico, o conceito de território é fundamental nessa pesquisa, contudo, destacase as relações com a natureza (ambiental) que distinguem sociedades tradicionais e modernas, como aponta Raffestin.

A relação entre as abordagens dos conceitos de território e ambiente, permitiram distinguir três possibilidades de interpretação de conflitos na pesca artesanal brasileira. Impactos Ambientais, Disputas no Território e Conflitos por Território.

Dos trabalhos analisados, 14,71\% abordam impactos ambientais. Contudo, cabe destacar que a leitura geográfica deveria se distinguir da ecológica, e reconhecer que além de impactar os ecossistemas, há repercussão desses impactos sobre as comunidades que dependem do ambiente e seus recursos (SUERTEGARAY, 2017). Desta forma, impactos no ambiente repercutem no território tradicional de pesca e frequentemente leva ao fim da territorialidade. Raffestin (1986C) enfatiza a importância da "reserva" na constituição das territorialidades das sociedades extrativista, e na permanência de suas territorialidades tradicionais. $\mathrm{O}$ autor enaltece a relação entre estados de natureza e territórios/territorialidades, desta forma a transformação ou transfiguração das condições naturais implica em consequências nos processos de territorialização e desterritorialização (RAFFESTIN, 2012).

Já 33,87\% destacam as disputas no território. Esses trabalhos expõem a relação território e ambiente, na medida em que a presença de recursos ambientais gera disputas no território, que por consequência tendem a comprometer tais recursos. Desta forma as disputas no território expressam tanto impactos ambientais quanto conflitos por território. Ressalta-se que, além das disputas por recursos, entram em choque visões de natureza e lógicas de apropriação (RAFFESTIN1996, SUERTEGARAY, 2009), o que impede a perenidade dos recursos no território. Ressalta-se que tais disputas também pressupõem o reconhecimento de territórios e 
territorialidades, e nem sempre resulta em desterritorialização. Heidrich (2010) destaca contextos em que múltiplas territorialidades coexistem no espaço, contudo, tais disputas podem incidir em conflitos.

Por fim, 51,47\% expõem conflitos por território. Como destaca Raffestin, (1986C) quando o território/territorialidade não é reconhecido pelos que estão fora, resulta na perda de autonomia em uma situação de desequilíbrio que pode chegar ao desaparecimento de determinado grupo. Os conflitos resultam prioritariamente do exercício do poder (RAFFESTIN, BARAMPAMA, 1998), que nesse caso é assimétrico ou dissimétrico (RAFFESTIN, 1986B). O poder aqui, exercício pelas atividades detentoras do capital econômicas, encontra suporte no Estado e suas instituições (HEIDRICH,2010). Ressalta-se a proeminência da rede informacional, tendo em vista que essas atividades econômicas estão dentro de uma lógica de relações externa ao lugar. Na pesca esses conflitos além de incidirem sobre os pesqueiros tradicionais, expulsa as comunidades dos seus territórios tradicionais de moradia e vivência.

Do ponto de vista das invariantes territoriais destacadas por Raffestin (1986, 1986C) destaca-se que a malha territorial na pesca artesanal é composta por uma ampla área que integra pesqueiros tradicionais, área de moradia e de vivência. Os nós são expressos nos pesqueiros tradicionais, que expressa a reserva. As redes ligam a área de moradia e vivência aos pesqueiros tradicionais, bem como o deslocamento entre pesqueiros. Raffestin destaca que qualquer mudança nessas invariantes provoca consequências nos territórios e territorialidades e uma nova estabilidade decorre de um processo longo.

\subsection{Impactos Ambientais}

Quanto às invariantes territoriais, observa-se que para além da malha que constitui o território pesqueiro, se observa a influência da rede da cidade (urbano). Desta forma, o território tradicional constitui para a cidade uma fonte de recursos necessária para a sua manutenção. A cidade forma então um nó, que é ligado em rede ao território tradicional. Em um primeiro momento, se evidencia a subjunção da malha do território tradicional ao nó do urbano, pela rede expressa na dinâmica do mercado. Na contemporaneidade, destaca-se ainda a influência da rede, informacional, que situa a cidade em uma dinâmica global. A partir dessa rede novos fatores, como a instalação de indústrias e serviços, passam a se instalar na cidade, gerando demandas, consequências e avançando sobre o território tradicional. Dentro desse contexto, as 
consequências são percebidas em toda a malha do território tradicional, contudo, provocam a desterritorialização do nó - pesqueiro tradicional.

Os impactos ambientais, impedem a permanência dos nós, que expressam os pesqueiros tradicionais. Por afetarem os ecossistemas, assim a territorialidade deixa de existir, pois atinge a reserva, fundamental para a condição territorial das sociedades extrativistas. Por consequência, a reterritorialização dos pescadores acaba sendo realizada em áreas mais distantes, influenciando a rede, que liga pesqueiro e área de moradia e vivência. Acrescenta-se que a reterritorialização ocorre ao longo do tempo, na medida em que os pescadores adquirem conhecimentos sobre o ambiente inerente ao novo território - malha.

$\mathrm{Na}$ análise das dissertações e teses que abordaram a pesca artesanal na Geografia brasileira, identificou-se trinta contextos de impactos ambientais que têm atingido o ambiente e, consequentemente, a produtividade da pesca. Como são impactos no ambiente, comprometem as condições da água, solo e ar e, também, comprometem a qualidade de vida das comunidades de pescadores que estão presentes no território.

Com base no Mapa presente na figura 47 pode-se verificar os impactos ambientais discutidos nas pesquisas, o quais foram mais presentes nas regiões Nordeste $(56,67 \%)$ e Sul $(40 \%)$. A região Norte concentrou somente 3,33\% das pesquisas analisadas e as regiões Sudeste e Centro-Oeste não tiveram trabalhos representados. 


\section{GEOGRAFIAS DA PESCA ARTESANAL BRASILEIRA:}

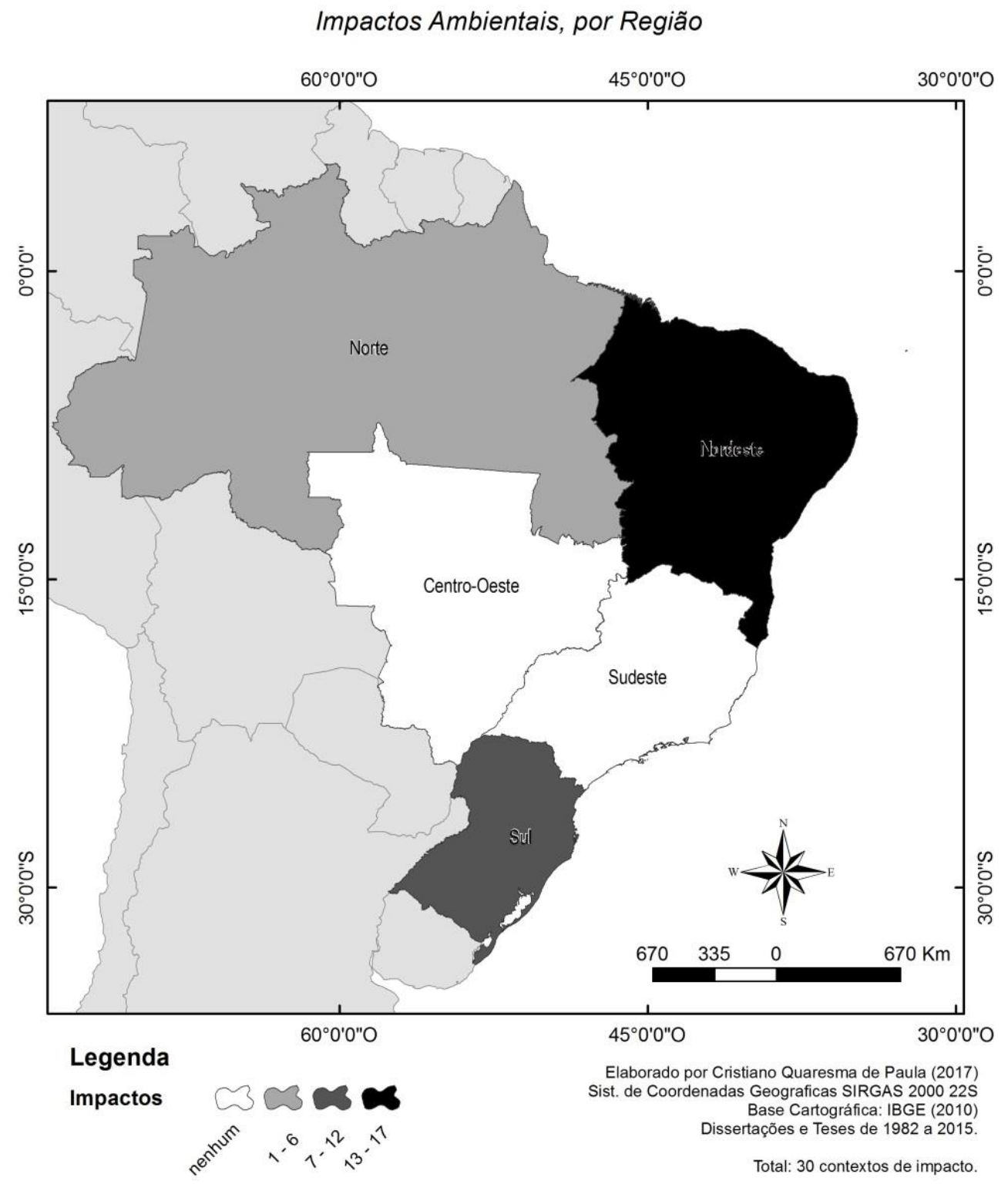

Figura 47: Mapa de Impactos Ambientais, por Região

Fonte: Elaborado por De Paula (2018)

A figura 48 evidencia que as principais causas de impacto ambiental presentes nos trabalhos analisados são industrialização, urbanização, agricultura e pesca industrial. Cabe destacar que nesse contexto a análise está centrada no ambiente, ou seja, às condições ambientais que permitem a presença da fauna aquática em condições de qualidade e quantidade necessárias para a atividade pesqueira artesanal. 


\section{GEOGRAFIAS DA PESCA ARTESANAL BRASILEIRA:}

Impactos Ambientais

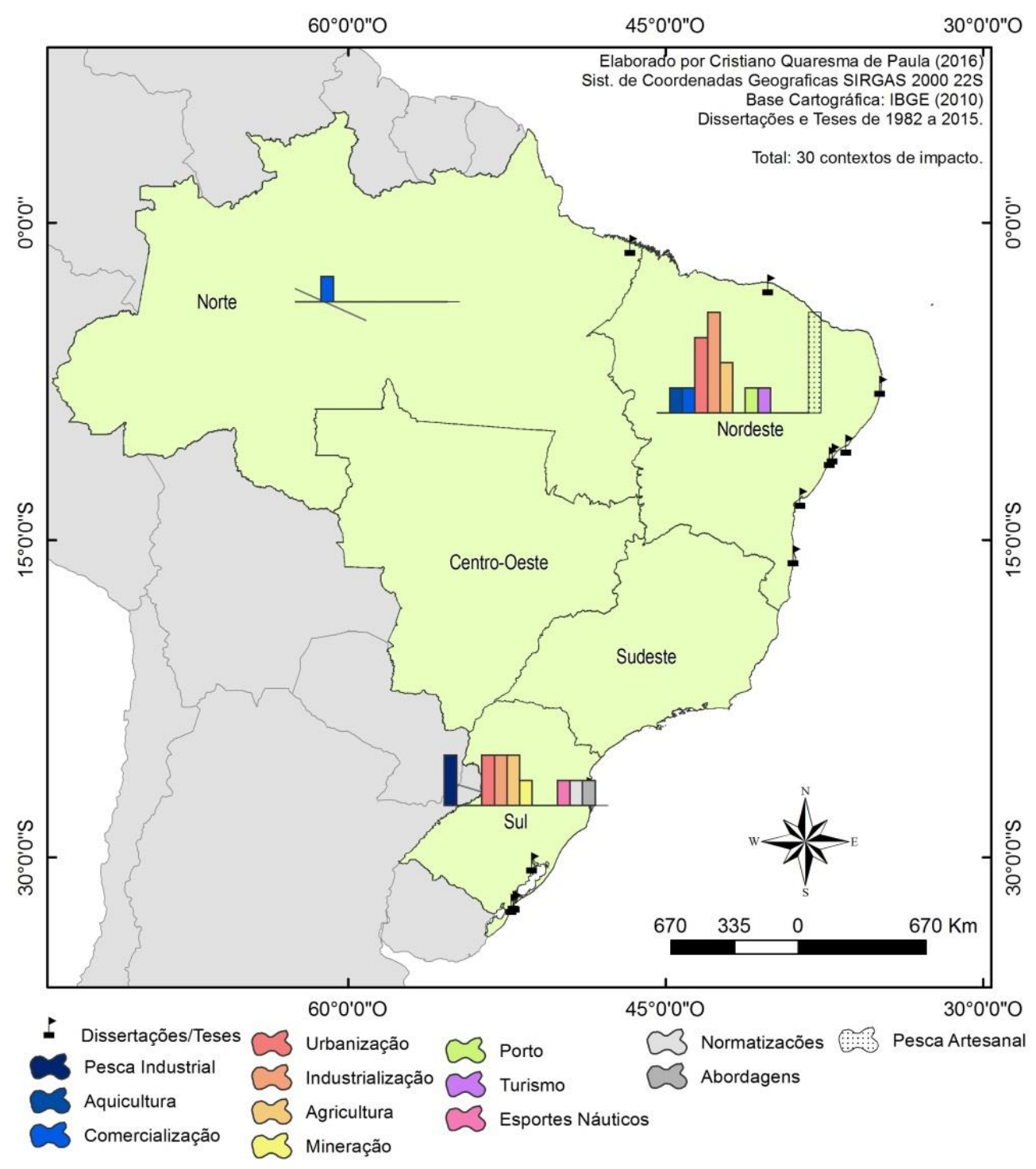

Figura 48: Mapa de Atividades Causadoras de Impactos Ambientais, por Região Fonte: Elaborado por De Paula (2018).

\section{Industrialização}

A principal causa de impacto ambiental abordada nos trabalhos analisados é a industrialização ( $20 \%$ dos trabalhos). Refere-se ao processo de instalação de indústrias ou complexos industriais sobre ou nas proximidades das comunidades pesqueiras, ou dos pesqueiros tradicionais.

No caso da região Nordeste é fundamental considerar a importância dos manguezais para a atividade pesqueira artesanal. Silva (2012B), em diálogo com as pescadoras do mangue 
em Lucena - Paraíba, destaca que costumeiramente a poluição dos corpos d'água causa a morte de peixes, mariscos, entre outras espécies que eram tradicionalmente coletadas. Além da queda na produtividade, a autora ressalta a contaminação de outras espécies como caranguejo e ostra, o que afeta a qualidade do pescado. Identificou que as usinas de cana-de-açúcar lançam vinhoto, que contamina os estuários e, consequentemente, o mangue que é abastecido por esses cursos de água, em desacordo com a legislação ambiental vigente (SILVA, 2012B, p.32).

Torres (2014, p. 86) no Povoado de Pedreiras - São Cristóvão, Sergipe - também apresenta a contaminação da água dos estuários como o principal impacto da atividade industrial. Essa autora também observa que as condições do ambiente, em situação de contaminação afeta a qualidade do peixe, de moluscos e de crustáceos. Outros autores como Figueiredo (2013) apresentam que, em Canavieiras - Bahia, os resíduos industriais (calda de usina, cloro, metais pesados e outros produtos) lançados diretamente nos estuários ou a montante desses podem causar intoxicações aos organismos marinhos e, consequentemente, redução de seu valor comercial em função dessa contaminação (p.40).

Na região Sul esse contexto de impacto ambiental também é apresentado por Silva (2007) quando informa que o Rio dos Sinos situado na Região Metropolitana de Porto Alegre - Rio Grande do Sul, em um polo industrial, recebe afluentes de curtumes, metalúrgicas, fábricas de calçados entre outros. Sendo assim, este corpo d'água está contaminado por metais pesados e apresenta Índice de Qualidade da Água - IQA entre Regular e Ruim (p.96).

Também na região Sul Martins (2002) expos o comprometimento dos estoques pesqueiros no Estuário da Laguna dos Patos devido ao distrito industrial da cidade de Rio Grande - Rio Grande do Sul. O autor destaca que desde o fim dos anos 1980 os noticiários já alarmavam para as consequências do avanço da industrialização para a pesca artesanal na região em mais de trinta pontos de emissão de poluentes (ALMEIDA et all.,1993 apud MARTINS, 2002, SN).

\section{Urbanização}

A urbanização, assim como a industrialização é considerada como um processo causador de impacto ambiental em 16,67\% das pesquisas analisadas. Neste caso as condições de sanidade ambiental são comprometidas pelo rápido crescimento das cidades, que provoca modificações nas características do ambiente (ex. aterro de áreas de mangue, desvio de rios, etc.), e pela falta de infraestruturas que possibilitem a redução do impacto no ambiente, como sistema de esgoto, coleta e reciclagem de lixo, sistemas de drenagem pluvial, etc. 
Na região Nordeste Figueiredo (2013), em estudo realizado em Canavieiras-Bahia destaca que o crescimento das cidades sem sistema de coleta de esgotos acarreta no lançamento desses dejetos in natura nos estuários e no mar, somando-se à poluição industrial, isso provoca a intoxicação da fauna aquática (p.40).

Em Aracaú - Ceará, Santos (2013) entende que a ocupação da cidade se deu com a instalação de edificações tendo o rio como "quintal" e depósito de lixo. Acrescenta-se a isso, o ocultamento de rios pelo traçado urbano e o aterro do ambiente de manguezal por habitantes com poucos recursos econômicos. Sendo assim, a instalação do sítio se deu em contraposição à dinâmica da natureza. Além dos impactos diretos sofridos pela população como alagamentos, cabe frisar a perda de ambientes de pesca e de coleta de mariscos.

Na região Sul, Silva (2007) especifica que a qualidade da água no Lago Guaíba "apresenta como principal contaminante as elevadas cargas orgânicas oriundas dos esgotos domésticos" (p.100). Isto prejudica a presença das espécies pesqueiras capturadas pelos pescadores artesanais da região, que tem que se descolocar para pesqueiros mais distantes (ao Sul do Lago) para que tenham acesso a pescado de melhor qualidade.

Lima (2003, p.465) ressalta as águas poluídas que escoam das estradas situadas próximas aos corpos d'água. $\mathrm{O}$ autor atenta que os poluentes chegam ao Estuário da Laguna dos Patos - Rio Grande do Sul por meio de dejetos líquido, gozosos e sólidos, que são provenientes das áreas mais urbanizadas. $\mathrm{O}$ autor afirma que este contexto tem elevado o índice de poluição e, consequentemente, a diminuição dos pescados.

\section{Agricultura}

As atividades agrícolas também são apontadas nos trabalhos analisados como causadoras de impacto ambiental. Neste caso cabe salientar as alterações no ambiente provocadas pela instalação de grandes projetos agropastoris, bem como a contaminação dos corpos d'água devido aos defensivos químicos amplamente utilizados nas lavouras. Logo, devido às intervenções e contaminações provocadas no ambiente há redução na quantidade e qualidade do pescado.

Na região Nordeste Figueiredo (2013) destaca os danos causados pela atividade agrícola na pesca devido à contaminação do ambiente, em Canavieiras - Bahia. Ressalta que os agrotóxicos e pesticidas utilizados nas plantações são carreados pelos rios contaminando os mesmos (VARJABEDIAN apud FIGUEIREDO, 2013, p. 40). Machado (2007) acrescenta que 
o uso de defensivos agrícolas significa uma ameaça aos rios e solo, pela deposição inadequada dos recipientes usados para manuseá-los (p.82).

Machado (2007) enaltece o impacto das atividades agrícolas sobre os manguezais em Canavieiras - Bahia. Entende que a "pressão sob os estoques naturais é diferenciada nas áreas de manguezal. Os impactos verificados, a depender do grau de magnitude, podem comprometer a biodiversidade local e o equilíbrio do ecossistema" (p.82). O impacto ocorre por que as atividades agrícolas e agropecuárias ocorrem na área intermediária entre mangue e restinga. Devido à expansão dessas atividades acontece a substituição da vegetação nativa por pasto, isto promove processos erosivos, o que compromete os rios e demais corpos d'água.

Já na Região Sul, Silva (2007) atenta para a contaminação da água, causada pelos agrotóxicos que são carreados para os rios. Na sua classificação, o autor apresenta o agrotóxico como agente "mais prejudicial à atividade da pesca nas águas" do Lago Guaíba e do Delta do Rio Jacuí - Rio Grande do Sul. Segundo os pescadores, a contaminação dos rios provoca consequências tanto nos peixes, quanto nos demais animais que dependem do ambiente como as aves (p.140).

\section{Pesca Artesanal}

Também esteve presente nos trabalhos a compreensão de que a pesca artesanal causa impactos. Contudo, diferente das atividades anteriormente citadas, os impactos da pesca artesanal não se dão sobre o ambiente aquático, mas sobre as espécies capturadas. Neste sentido, considera-se esse impacto ambiental, mas é importante distingui-lo entre os demais. O impacto da pesca à fauna aquática decorre da utilização de apetrechos de pesca predatórios ou do aumento do esforço de pesca, em níveis superiores à capacidade de resiliência dos estoques pesqueiros.

Os trabalhos que consideram a pesca artesanal como causadora de impacto ambiental são prioritariamente da Região Nordeste. Silva (2006B, p.77) destaca que as pescadoras e os pescadores, entrevistados em Goiana - Pernambuco, reconhecem que a pesca intensiva é uma das principais causas de impactos sob o mangue. Em entrevistas realizadas por Santos (2012, p.70) no município de Nossa Senhora do Socorro - Sergipe, os pescadores e as pescadoras também associam a redução da pesca "à exploração intensiva do ambiente (13\%)".

Santos (2012) destaca o desrespeito ao período de maturação das espécies como atividade predatória no ambiente de mangue. Cunha (2015) também enfatiza o impacto do não cumprimento do período de defeso e seu reflexo na redução dos estoques pesqueiros no Estuário 
do Rio São Francisco - Alagoas e Sergipe. O autor acrescenta que existem outras técnicas predatórias realizadas pelos pescadores artesanais, como a redinha na captura do caranguejo.

\section{Comercialização}

A comercialização do pescado é apontada, indiretamente, como causadora de impacto ambiental devido à pressão que causa na cadeia produtiva da pesca. Provoca a utilização de práticas predatórias de captura e aumento de esforço de pesca para atender à demanda do mercado. Assim, como a pesca artesanal, não se refere a um impacto ao ambiente, mas à fauna aquática.

Na região Norte, essa problemática é apresentada por Araújo (2012) em Augusto Correa - Pará. O autor aborda a migração de pescadores artesanais do Nordeste, que utilizam artes de pesca mais predatórias, que já levaram à redução dos estoques nessa região e, então, buscam em outras regiões o pescado para atender a demanda do mercado.

Já na região Nordeste, Santos (2012) ressalta a pressão que os comerciantes de pescado provocam na atividade pesqueira. Entende que o aumento da população nas cidades resulta na maior necessidade de extração das espécies de modo que atenda às necessidades da população. Neste sentido, a própria valoração do pescado enquanto mercadoria, acaba levando os pescadores a abandonarem práticas tradicionais e usarem apetrechos mais predatórios.

\section{Pesca Industrial}

A pesca industrial é considera uma atividade causadora de impacto ambiental e responsável pela redução dos estoques pesqueiros no Brasil (PASCUOTO, 2004). Primeiramente, há o impacto na fauna aquática, tanto no pescado capturado, quanto nos que são descartados por não atenderem os padrões de qualidade da indústria. Segundo, pelas alterações que provoca no ambiente, quando ocorre a pesca de arrasto ou a utilização de bombas. De fato, a pesca industrial como causadora de impacto ambiental reflete os preceitos da implementação da lógica industrial em uma atividade extrativista. Ou seja, busca-se equiparar o tempo da pesca aos ritmos das indústrias de beneficiamento, o que exige o aumento da capacidade de captura por meio do incremento do esforço de pesca.

Os impactos ambientais provocados pela pesca industrial estão presentes em trabalhos realizados na região Sul, no Estuário da Laguna dos Patos - Rio Grande do Sul. Lima (2003, p.465) destaca que a pesca tradicional da "miragaia" se extinguiu em meados dos anos 1980 devido à pesca industrial. Já Maier (2009) ao analisar um contexto de crise na pesca artesanal 
do camarão-rosa, ressalta que a redução dos estoques pesqueiros decorre da política de fomento à pesca industrial na região, desde os anos 1970.

\section{Porto}

Os portos também estão relacionados a impactos ambientais, devido às significativas alterações provocadas no ambiente em que são instalados. A alteração mais significativa é a dragagem do canal de navegação para o deslocamento das embarcações de grande porte. Isto acarreta em alterações hidrodinâmicas importantes, que exige adaptações das espécies presentes nesse ambiente transformado ou a migração para outros ambientes.

Na região Nordeste Silva (2012B) destaca as mudanças provocadas pelas dragagens do porto de Cabedelo em Lucena - Paraíba. Segundo a autora "O objetivo é aumentar a profundidade da bacia de manobras do porto para onze metros para receber embarcações de até 40 pés de calado, com cargas de 70 mil toneladas. A capacidade original do porto é de 30 pés de calado e 35 mil toneladas". Contudo, por falta de capacidade técnica não se pode comprovar esse impacto nas espécies pesqueiras, segundo a administração do cais (CAIS DO PORTO, 2010, apud SILVA, 2012B p.90).

\section{Aquicultura}

A aquicultura em escala agroindustrial também é apontada como causadora de impacto ambiental. Neste caso os impactos ocorrem quando os tanques de criação transbordam e os produtos químicos utilizados para esses cultivos são carreados para os corpos d'água. Isso implica em alterações nos ambientes, bem como na escassez das espécies como destaca Torres (2014) em diálogos com os pescadores no Povoado de Pedreiras, São Cristóvão - Sergipe.

\section{Turismo}

A atividade turística também tem causado impactos ambientais na pesca artesanal, devido a intensificação do uso dos recursos ambientais. $\mathrm{O}$ turismo implica em maior demanda de água e pescado em determinados períodos. Com isso, os recursos são utilizados em quantidade acima da capacidade. O avanço do turismo geralmente não é acompanhado da instalação de infraestruturas de esgoto, coleta de lixo, etc., o que implica em um quadro de degradação ambiental. Por consequência, os ambientes em que habitam as espécies são comprometidos e há redução na quantidade e qualidade do pescado. Machado (2007) em Canavieiras - Bahia destacou os impactos negativos "no ecossistema pela instalação de 
infraestrutura, e/ou por procedimentos inadequados, derivados da falta de planejamento e definições políticas coerentes com o uso sustentável dos atributos naturais do manguezal”. O autor destaca a intenção dos agentes públicos e empresas de instalarem grandes complexos hoteleiros na região (p.84).

\section{Mineração}

A mineração também aparece como uma atividade econômica que provoca impactos ambientais diretos. Neste caso, ocorrem alterações no ambiente decorrentes das atividades de extração de recursos minerais e contaminação da água pelo uso de produtos químicos nesse processo. Consequentemente, a fauna aquática não encontra no ambiente a condição favorável para a sua permanência, sendo então, contaminada. Na região Sul, Silva (2007) destaca os impactos provocados pela extração de areia no Delta do Rio Jacuí, região metropolitana de Porto Alegre - Rio Grande do Sul. Segundo o autor, os barcos de dragagem (conhecidos como areeiras), que utilizam bombas de sucção, no período da piracema e em áreas de desova dos peixes, têm comprometido a reprodução dos mesmos. Além disso, extraem areia do entorno das ilhas, onde, segundo os pescadores, são locais prioritários para a desova e maturação das diversas espécies de peixes (p.140).

\section{Esportes Náuticos}

Assim como o Turismo, alguns esportes náuticos têm provocado impactos nas espécies pesqueiras. Isto decorre da instalação de uma dinâmica de uso dos corpos d'água de forma muito intensa, principalmente nas áreas de desova e maturação das espécies, o que provoca a migração das mesmas para áreas mais protegidas. Na região Sul, é apresentado um exemplo por Silva (2007) no Lago Guaíba - Rio Grande do Sul. O autor expõe que em parte do lago há a instalação de um píer onde se concentra elevado número de embarcações, bem como jet sky. Na percepção dos pescadores "os barcos e jet sky são altamente prejudiciais à pesca pois, além de afugentarem os peixes, fazem "eclodir" as ovas de futuros alevinos, matando-os através do barulho de seus motores" (p.142).

\section{Normatizações da Pesca e do Ambiente}

O estabelecimento de normatizações incompatíveis com as características do ambiente e das espécies também é considerado como causador de impacto na fauna aquática, objeto de interesse da pesca artesanal. Isto se deve à falta de efetividade de leis que estão desatualizadas 
ou em escala muito ampla, e não correspondem às condições ambientais de determinadas regiões. Assim, em vez de conservar as espécies, conduz para o exercício de pescarias mais predatórias, o que compromete os estoques. Na região Sul, Maier (2009) salienta a situação de vulnerabilidade das espécies devido a ineficiência da legislação em regular a atividade pesqueira, no caso do siri-azul (Portaria SUDEPE n²4 de 26 de julho de 1983), no Estuário da Laguna dos Patos, Rio Grande do Sul. Segundo o autor, a norma não acompanhou a evolução das artes de pesca, nem atualizou o calendário diante de importantes mudanças ambientais e eventos climáticos. Com base no conhecimento dos pescadores, o autor aponta para possibilidades de artes de pesca menos predatórias e um calendário mais adequado para a pesca do siri (p.14).

\section{Abordagens de Fiscalização}

A ausência ou ineficiência da fiscalização ambiental sobre a atividade pesqueira predatória (industrial, comercial e artesanal) também é apontada como causadora de impacto ambiental sob as espécies pesqueiras. Neste sentido há um quadro de falta de profissionais capacitados e de sucateamento das infraestruturas dos órgãos, sobretudo estaduais, de fiscalização, o que inviabiliza o cumprimento da legislação que permitiria a permanência dos estoques pesqueiros em condições de sustentabilidade. Na região Sul, Machado (2013) destaca que a presença desses órgãos na fiscalização das atividades pesqueiras é de suma importância para a manutenção do equilíbrio entre pesca e a reprodução das espécies. Contudo, quando os órgãos ambientais foram questionados sobre a ineficiência de suas atividades, se justificaram utilizando o argumento da falta de equipamentos, barcos e de pessoal capacitado, como causa das falhas na fiscalização (p.24).

Tendo compreendido as atividades econômicas que provocam impactos ambientais que causam a desterritorialização dos pescadores, a partir das dissertações e teses analisadas e especializadas (figura 49) destaca-se que prevalência desses impactos nas regiões Sul e Nordeste. 


\section{GEOGRAFIAS DA PESCA ARTESANAL BRASILEIRA:}

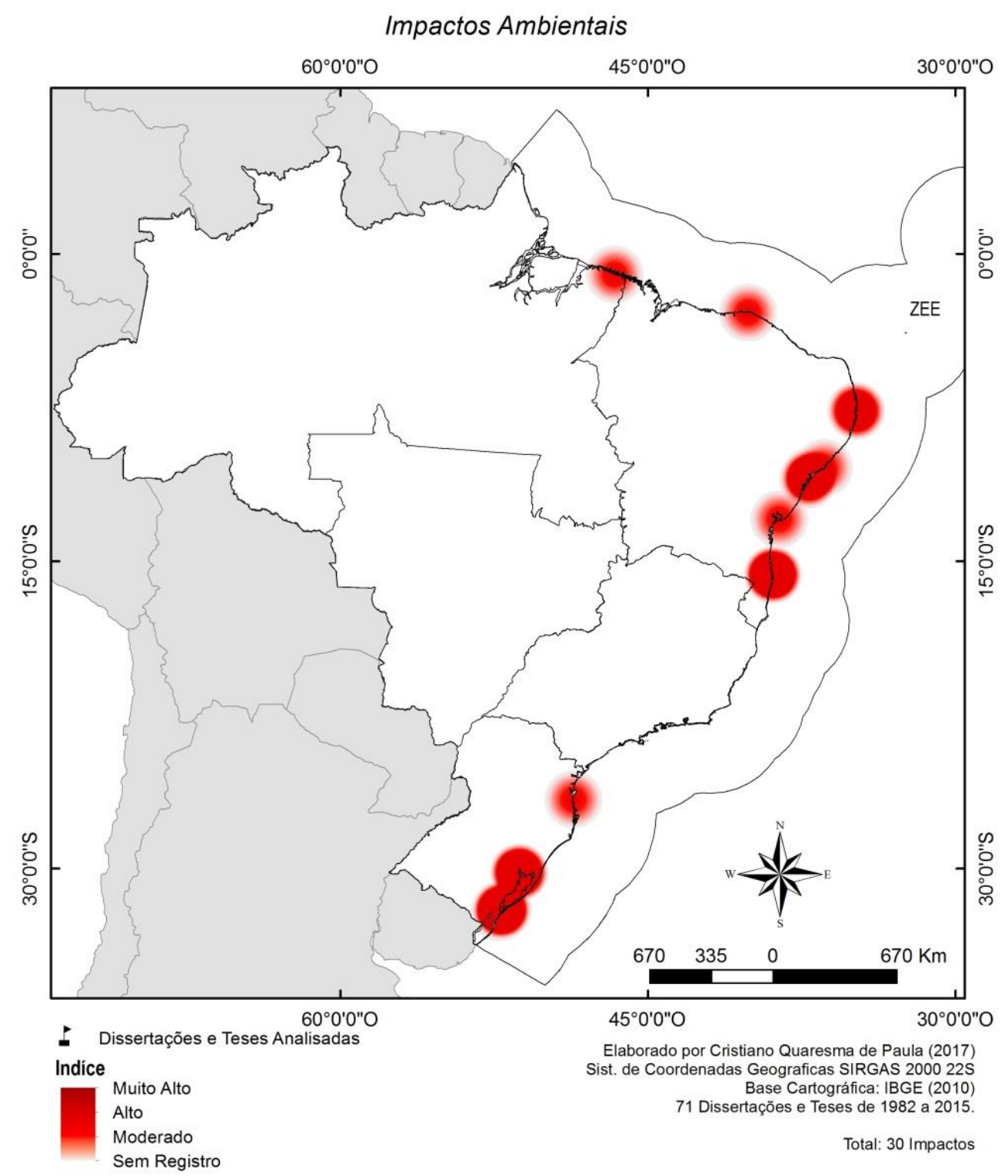

Figura 49: Mapa de Densidade de Impactos

Fonte: Elaborado por De Paula (2018).

$\mathrm{Na}$ região Sul, o agronegócio se destaca como causador de impacto ambiental. Ressaltam-se as outorgas de direitos de uso de águas públicas por grandes projetos de irrigação e a poluição dos recursos hídricos por efluentes agrícolas contaminados por agrotóxicos.

A industrialização também se evidencia nos trabalhos como causadora de impacto ambiental. A instalação de grandes projetos industriais tem esgotado os recursos ambientais presentes, sobretudo água e solo. A contaminação resulta na perda de qualidade dos peixes e, por vezes, em eventos de elevada mortandade destes. Quanto à urbanização, é apontado o 
crescimento das cidades sem o desenvolvimento de estruturas de saneamento correspondentes à demanda, que tem extinguido a pesca em determinados corpos d'água.

Nesta região a pesca industrial está muito presente, cujas características das embarcações e dos apetrechos implicam em pescarias extremamente predatórias em comparação à praticada pelos pescadores artesanais. Outra atividade presente na região, e que provoca impactos ambientais, é a mineração exercida sobre os ambientes onde ocorre a desova dos peixes e que tem impedido a renovação dos estoques pesqueiros. De forma semelhante alguns esportes náuticos utilizam equipamento em áreas de reprodução de peixes, que tem comprometido a desova e maturação das espécies.

Ainda cabe destacar os impactos no pescado decorrentes de legislações ambientais desatualizadas ou que não respeitam as características ambientais da região. Por outro lado, a falta de fiscalização ambiental permite o exercício da pesca industrial nas águas interiores, inclusive durante a piracema.

Na região Nordeste a Aquicultura é frequentemente apontada como causa de impactos ambientais. Nesta região a instalação de empreendimentos, sobretudo de carcinicultura, cujas técnicas fazem uso de uma série de produtos químicos, tem levado a contaminação de corpos d'água e na extinção de espécies pesqueiras.

Os grandes projetos industriais têm acarretado na contaminação do ambiente e, consequentemente, na qualidade (por vezes extinção) do pescado. Soma-se a isso a expansão dos portos, cujas atividades frequentemente promovem eventos de contaminação e degradação ambiental e as dragagens que comprometem a morfologia do fundo e a hidrodinâmica dos corpos d'água.

A urbanização tem gerado outras formas de uso do ambiente, cujos impactos são observados na redução da quantidade e da qualidade do pescado. A contaminação dos corpos de água por efluentes domésticos e industriais é uma importante problemática resultante do crescimento das cidades sem a instalação das infraestruturas necessárias. O turismo também se destaca nesse processo, cujo aumento significativo da população das cidades agrava ainda mais os impactos ambientais. Além disso, há a pressão sobre o mercado para atender as demandas da população residente e turista. A expansão da agricultura avança sobre o mangue, há o uso indiscriminado de defensivos agrícolas que contaminam os corpos de água, e assim, é reduzida a quantidade e a qualidade do peixe.

Já na pesca, deve ser considerado o impacto da comercialização do pescado, cuja submissão às normas do mercado exige uma maior pressão sobre os recursos e o emprego de 
tecnologias predatórias. Cabe destacar que nessa região, por consequência disso, a pesca artesanal é apontada algumas vezes como causadora de impacto ambiental.

Na região Norte a organização social da pesca artesanal apresenta distinções. É nessa região onde se apresenta a modalidade "pesca comercial". Distingue-se da pesca artesanal comunitária, pois apresenta determinada subordinação do pescador ao comerciante (dono do barco frigorifico, ou que fornece o gelo) assim como se distingue da pesca industrial, por não utilizar tecnologias tão predatórias. Contudo, devido a pesca comercial, a comercialização de pescado é apontada como a maior causa de impactos ambientais. Isso se deve pelo aumento na pressão sobre os recursos, principalmente espécies de alto valor econômico e em vias de extinção como o Pirarucu. Embora não seja uma região muito urbanizada, já se verifica consequências da urbanização devido ao aumento da demanda de pescado.

\subsection{Disputas no Território}

A segunda abordagem propõe a distinção de disputas seja pelo domínio (poder), seja pelos recursos do ambiente. Por consequência, essas disputas causam tanto impactos quanto conflitos, que influenciam a dinâmica territorial da pesca artesanal. Tais atividades econômicas fazem uso do território por meio de uma lógica de apropriação/domínio que está descomprometida com a perenidade dos recursos, pois visam somente desenvolver seus processos, por isso incide em impactos e conflitos. As disputas no território se dão tanto pelos recursos pesqueiros, quanto pelo sitio adequado para a realização de outras atividades econômicas. Nessa perspectiva, destaca-se a influência de invariantes territoriais na dinâmica territorial da pesca artesanal.

Observa-se que a dinâmica territorial é que evidencia uma disputa entre pescadores artesanais e outras atividades econômicas. Essas atividades estão relacionadas em redes técnicas e informacionais de outras escalas, regional, nacional e global. Dentro desse contexto, veem a atividade pesqueira como a subutilização dos recursos do ambiente. A pressão das redes e a conjunção de uma perspectiva de fomento da economia leva os gestores públicos a privilegiam e flexibilizam a entrada desses novos atores no território.

As disputas no território provocam pressão nos nós (pesqueiros tradicionais) e redes (que ligam território de moradia e vivência aos pesqueiros e liga pesqueiros). Isto por que determinadas atividades impõem seu domínio sobre o território e geram impactos no ambiente e/ou impedem o deslocamento do pescador para o pesqueiro. Se a pesca artesanal e essas 
atividades não estão dispostas, incide em conflitos e ocorre a desterritorialização, frequentemente dos pescadores artesanais.

As disputas no território se evidenciaram 69 vezes nas dissertações e teses analisadas. A região Nordeste concentrou a maior parte dessas disputas mapeadas (46,38\%). A região Norte apresenta $(18,84 \%)$ e a região Sul $(14,29 \%)$. A região Sudeste totaliza $(13,30 \%)$ e a região Centro-Oeste $(1,45 \%)$ dos trabalhos analisados, como apresenta o mapa (figura 50).

\section{GEOGRAFIAS DA PESCA ARTESANAL BRASILEIRA:}

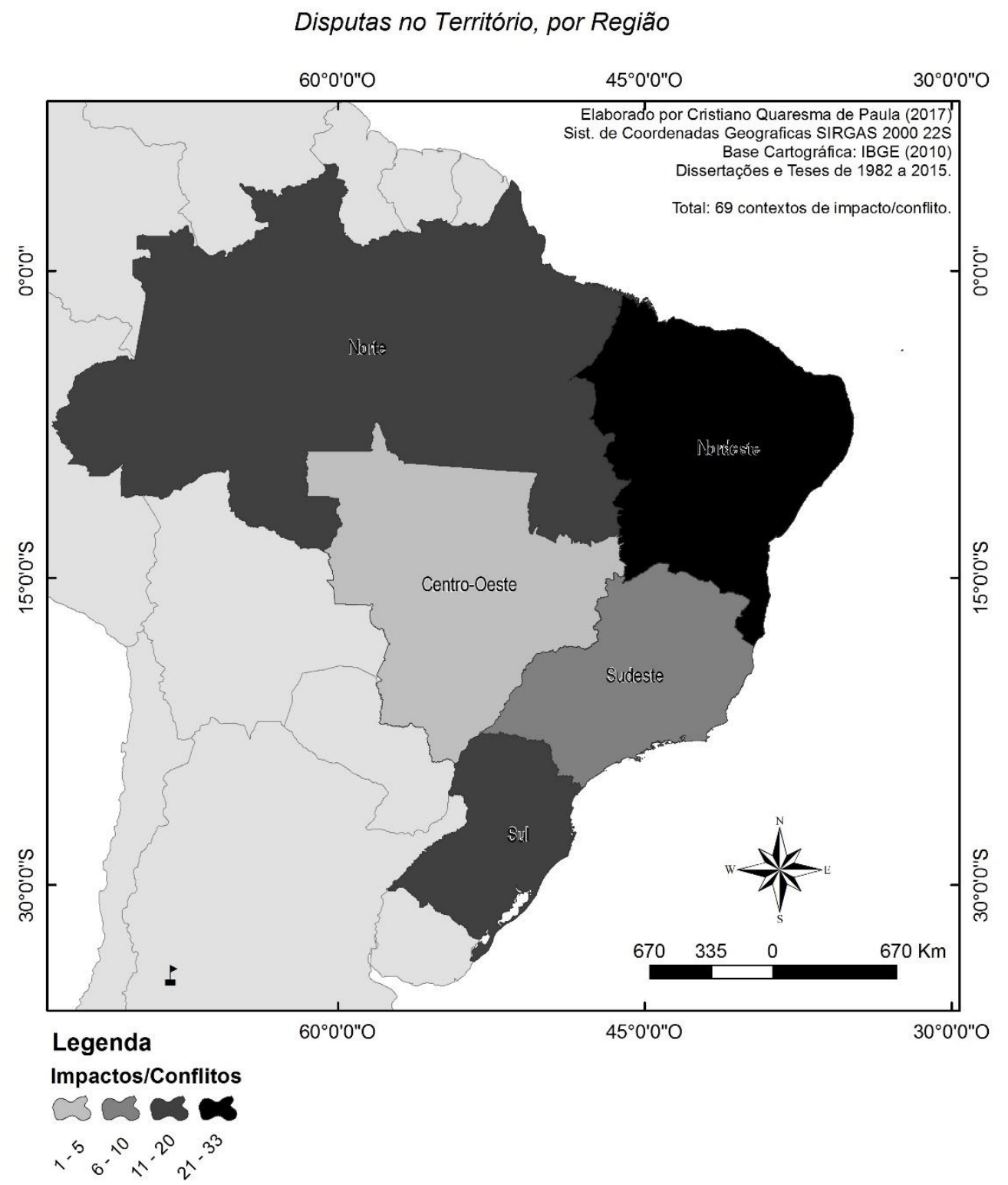

Figura 50: Mapa de Disputas no Território, por Região

Fonte: Elaborado por De Paula (2018) 
A figura 51 apresenta as disputas no território identificadas nas dissertações e teses analisadas. As principais disputas observadas são as relacionadas à aquicultura, pesca industrial, pesca comercial e geração de energia.

\section{GEOGRAFIAS DA PESCA ARTESANAL BRASILEIRA:}

Disputas no Território

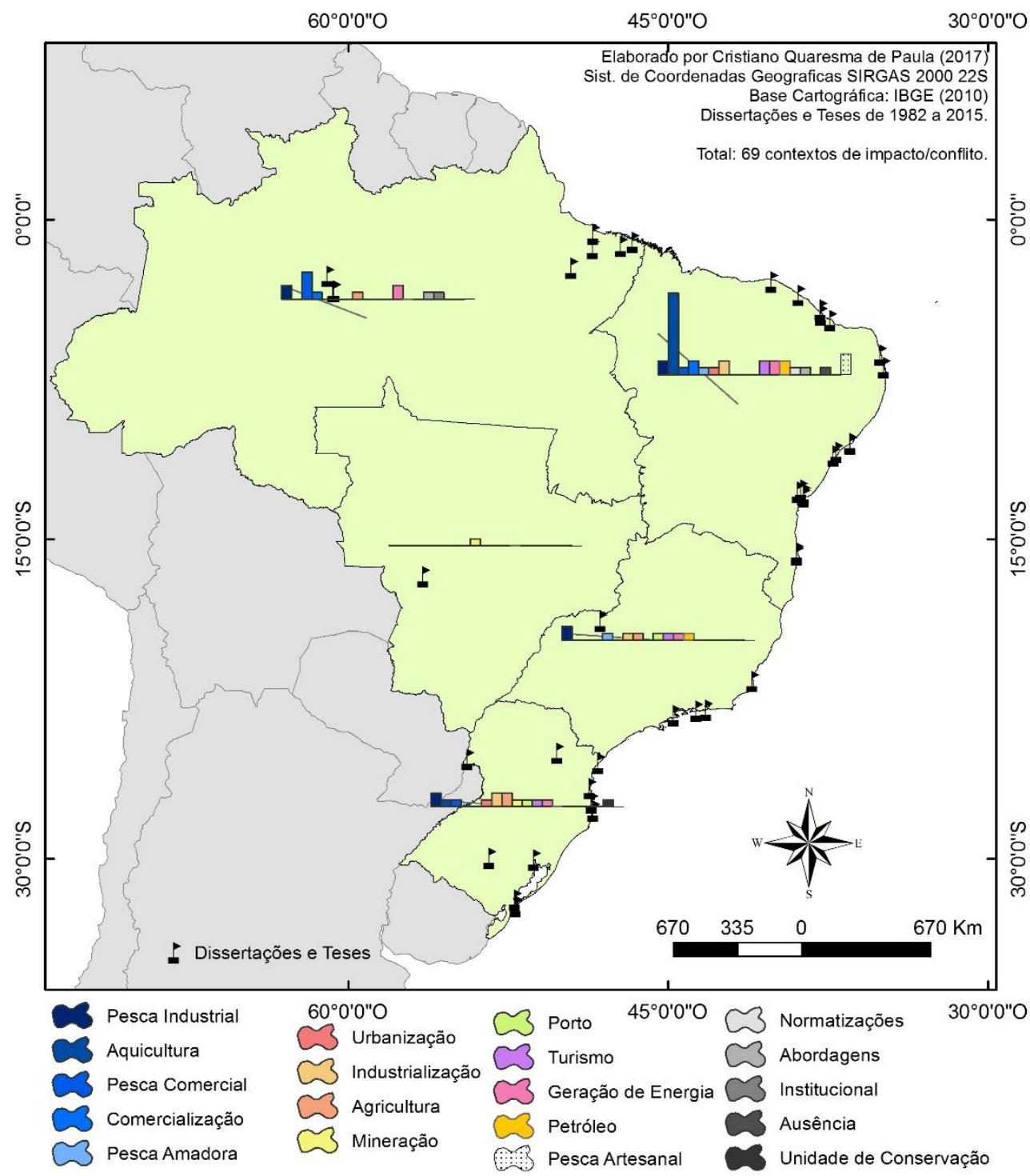

Figura 51: Mapa de Atividades que Disputam Territórios, por Região

Fonte: Elaborado por De Paula (2018)

\section{Aquicultura}

A aquicultura aparece nas dissertações e teses analisadas como uma atividade econômica que provoca disputas no território. Isso pressupõe que modificações causadas no ambiente influi na quantidade e qualidade do pescado, e devido à perda de produtividade na pesca, os pescadores artesanais são levados a abandonarem seus territórios tradicionais. Por 
outro lado, quando essa atividade é instalada sobre o território pesqueiro, acaba proibindo o acesso dos pescadores que tradicionalmente realizavam o manejo do pescado, sem comprometer a perenidade do mesmo. Cabe destacar o papel do Estado no fomento dessa atividade econômica sem reconhecer os territórios tradicionais das comunidades de pescadores artesanais.

Na região Nordeste, Santos (2008) destaca problemas ambientais relacionados à carcinicultura em Acaraú, Ceará. A autora destaca que a "descaracterização de áreas, inundações, diminuição na quantidade e variedade de peixes e camarões de pesca, destruição dos mangues, salinização do lençol freático e poluição das margens dos rios” (p.73). Em decorrência disso, o território pesqueiro deixa de existir e os filhos de pescadores não dão seguimento a essa atividade tradicional.

Também no Ceará, Rodrigues (2005), apresenta o “desmatamento das áreas de mangue visando à construção de tanques, canais para captação de água do rio e a descarga de dejetos dos viveiros" em Aracati. As alterações comprometem o equilíbrio do ecossistema dos manguezais, assim, pescadores artesanais e marisqueiras perdem importantes territórios da pesca artesanal $(\mathrm{p}, 14)$.

Galvão Neto (2009) em Canguaretama, Rio Grande do Norte, apresenta que a indiscriminada instalação de empresas de aquicultura, sobretudo, a carcinicultura no mangue, é a principal causa de supressão de manguezais do Nordeste do Brasil (p.52). O autor apresenta a poluição dos corpos d'água e a destruição do mangue como responsáveis pelo fim da pesca no Rio Grande do Norte. Também destaca que é "restringido o acesso de pescadores a seus sítios tradicionais de pesca e de abrigo e manutenção de suas embarcações, através da construção de cercas e da ação de vigias armados" (p46).

Cunha (2015) expõe a situação do Estuário do Rio São Francisco, Alagoas e Sergipe, onde identificou nos trabalhos de campo que a implantação de viveiros para a carcinicultura "tem representado um fator decisivo para os problemas de ordem ambiental, econômica e social, pois a vegetação de mangue é retirada". O autor ressalta que incentivos governamentais para o cultivo de camarão no Baixo São Francisco têm desprezado a importância do "fortalecimento da pesca artesanal e da coleta de crustáceos e moluscos na mesma área, bem como os valores socioculturais da população local”. Os proprietários dos viveiros estabelecem restrições para o acesso por parte dos pescadores e catadores de caranguejo aos "portos, pois são construídas cercas, caracterizando a apropriação de um espaço que anteriormente era de uso coletivo". Isto tem "ampliado os conflitos pelo uso dos recursos pesqueiros na área dos 
manguezais” (pp.200-202). Cunha (2006) enaltece que essas mudanças ocorridas no ambiente "contribuem fortemente para a perda da identidade cultural e dos saberes da tradição, sendo necessário traçar metas de planejamento econômico-ambiental que consistam em propor direções para a dinâmica sociocultural dos moradores (MARQUES, 1999)” (p.104).

Santos (2012) também aponta que para o desenvolvimento da carcinicultura foi necessário o desmatamento do manguezal, comprometendo o pescado em Nossa Senhora do Socorro, Sergipe. Devido à redução das áreas de mariscagem os pescadores têm que se deslocar para lugares mais distantes ou até mesmo abandonar essa atividade tradicional (p.67).

Rios (2012), no distrito de Acupe, Santo Amaro, Bahia destaca que a primeira transformação ocorrida com a inserção da carcinicultura foi a retirada do mangue para dar lugar aos viveiros de cultivo do camarão, já que a maioria dos empreendimentos do distrito encontrase inserida em manguezais. Desta forma, a autora entende que "a inserção de empreendimentos relacionados à carcinicultura no território da pesca artesanal constitui-se em formas de apropriação/produção diferenciadas em um espaço de uso comum, pois a carcinicultura assim como a pesca artesanal, também constrói seu território" (p.65). As contradições existentes entre pesca artesanal e carcinicultura, devido as transformações que esta última provocou no território, tem colocado a comunidade em constante alerta quanto a transformação das condições sociais, ambientais, culturais e econômicas de seu território (p.219).

Kuhn (2009) acrescenta que o território pesqueiro sofre impactos tanto dos danos causados pela carcinicultura, como a destruição das áreas de mangue, quanto da concorrência do mercado. Em São Francisco do Paraguaçu, Bahia, a autora observou a redução das possibilidades de negociação do pescado da pesca artesanal, o qual não consegue concorrer com os investimentos da carcinicultura e nem com a escala da produção.

Em Canavieiras, Bahia, Figueiredo (2013) ressalta que as instalações de tanques criatórios ocorrem principalmente no mangue, onde há poluição por dejetos, modificações no sistema natural hídrico e a supressão da vegetação. Segundo o autor "A carcinicultura é, portanto, uma atividade com potencial negativo no modelo de manejo praticado na região" (p.38). Figueiredo (2013) e Dumith (2012) enfatizam o papel do Estado no desenvolvimento desses projetos e flexibilização de licenciamentos ambientais. Dumith (2012) exemplifica que em 2002 houve um episódio de grande mortandade de caranguejo e peixe expondo as famílias de pescadores a uma situação de insegurança alimentar. Além disso, o avanço da atividade intensificou conflitos, por meio de ameaças a pescadores, funcionário do IBAMA e de ONGs (p.105). 
Também em Canavieiras, Bahia Machado (2007) enfatiza as significativas transformações nas áreas de manguezais próximas das fazendas de camarão. Ressalta as consequências da "construção de tanques sobre a produtividade estuarina com a substituição dos manguezais, e a queda da produtividade dos bancos de corais devido à morte dos organismos, deve apontar para um efeito sinérgico sobre a produtividade costeira, com consequências diretas à economia e à sociedade". O autor destaca que essa atividade afeta a população de Canavieiras, que vive tradicionalmente dos recursos do manguezal, lagoas, matas e estuários (pp.83-84).

Na região Sul, Custódio (2006) enfatiza os impactos da atividade de maricultura em Governador Celso Ramos, Santa Catarina. O autor destaca que "superpopulações em algumas áreas de produção podem trazer problemas de poluição das águas, devido ao acumulo de dejetos, distúrbios das comunidades naturais dos fitoplâncton e contaminação dos estoques.”. $\mathrm{O}$ autor acrescenta que essas mudanças nos pesqueiros afetam diretamente as espécies pesqueiras, o que compromete a permanência da pesca artesanal (p.77).

\section{Pesca Industrial}

Além de avançar sobre os territórios tradicionais da pesca artesanal, a pesca industrial impossibilita a continuidade dos estoques pesqueiros em situação de equilíbrio. Sendo assim, a pesca artesanal perece, seja pela perda de territórios, seja pela falta de recursos nos pesqueiros tradicionais. Essa lógica de apropriação dos recursos que não reconhece o tempo da natureza e seus ciclos, foi responsável pelo colapso dos principais recursos pesqueiros no Brasil. Cabe enfatizar que, muitas vezes, a pesca industrial objetiva capturar recursos muito específicos, mas os apetrechos de pesca predatórios acabam atingindo espécies, que quando em condições adequadas de maturação, seriam capturadas pela pesca artesanal.

Na região Nordeste, Lima (2002) expõe que a pesca industrial captura a Lagosta "miúda", o que impede o ciclo reprodutivo. Consequentemente, os estoques pesqueiros são degradados e diminui a rentabilidade dos pescadores artesanais, os quais dependem desse recurso presente no território. A lógica da captura indiscriminada se opõe a lógica da pesca artesanal, que busca respeitar os ciclos e ambientes de reprodução e maturação das espécies. Segundo a autora, o embate entre essas duas lógicas tem provocado "guerras no mar" "crônicas, de uma tragédia anunciada pelo descaso do poder público, pela falta de fiscalização e pela ganância dos empresários do setor pesqueiro" (p.206). 
Na região Norte, Guedes (2009) também sustenta sua argumentação na distinção entre os objetivos e interesses da pesca artesanal e industrial em torno do uso dos territórios. $\mathrm{O}$ autor enaltece que o aumento da pressão sobre os recursos tem resultado na redução da quantidade do peixe. Acrescenta que há uma disputa latente entre pescadores artesanais e pescadores industriais nas localidades Céu e Cajuúna, assim como em toda a Amazônia paraense. "A superposição da pesca industrial sobre os territórios tradicionalmente explorados pelos pescadores artesanais vem estabelecendo uma grave disputa pelo mesmo, restringindo o espaço de produção e convertendo as "águas férteis" estuarinas em territórios econômicos e políticos, onde se enfrentam pescadores industriais e artesanais em condições desiguais" (p.128).

Como destaca Lima (2008) o avanço da pesca industrial de forma predatória sobre o estuário amazônico tem levado os pescadores artesanais a buscarem pesqueiros em locais mais distantes, abandonando seus pesqueiros tradicionais. A autora enfatiza que devido a isso há um incremento no esforço de pesca e se evidenciam conflitos entre pescadores que migram e os pescadores locais. "Dessa forma, as questões econômicas, técnicas e ambientais se intercruzam e a mobilidade é cada vez mais forçada para garantir a sobrevivência do pescador (pp.58-59).

Na região Sudeste, Giannella (2009) distingue as técnicas utilizadas por pescadores artesanais e industriais. "Esses barcos de pesca industriais localizam os cardumes através de aparelhos sofisticados, como o GPS e sonar, e capturam tudo o que o pescador artesanal levaria meses para pescar em apenas um dia, antes do peixe chegar até a beira da praia, que é até onde o pescador artesanal, com suas técnicas de pesca, pode ir" (p.120). Os barcos da pesca industrial não permitem que os cardumes se aproximem da costa e utilizam redes de arrastos altamente predatórias. Ao contrário, os pescadores artesanais, por terem embarcações e apetrechos mais simples, o que não permite o deslocamento até maiores profundidades, perdem o acesso aos recursos pesqueiros.

Cardoso (1996) apresenta que a pesca industrial compete diretamente com a pesca artesanal no Litoral norte paulista. O autor evidencia a presença de grandes barcos atuaneios e caçoeiros $^{6}$, bem como os barcos de arrasto de camarão, que "são apontados pelos pequenos pescadores como responsáveis pela diminuição do pescado na região" (p.70). Segundo o autor, os pescadores artesanais observam a redução dos principais estoques pesqueiros, e entram em disputa com os pescadores industriais, como os do arrasto e do cerco.

6 Atuaneiros e Caçoeiros são barcos da pesca industrial especializados no Atum e no Cação, respectivamente. Contudo não se restringem à captura dessas espécies. 
Na região Sul, Pérez (2012) apresenta o enfrentamento entre pescadores artesanais e pescadores industriais na Vila de Superagui, Guarapeçaba, Paraná. A autora enfatiza que apesar dos dados estatísticos não apontarem uma significativa presença da pesca industrial no Paraná, os relatos dos pescadores expõem que "há efetivamente presença industrial, que vem especialmente de Santa Catarina, estado que tem um dos maiores índices de presença da pesca industrial" (p.45).

Machado (2013) apresenta a interferência do Estado estabelecendo limites para o exercício da pesca industrial e artesanal em Barra Velha, Santa Catarina. A autora ressalta que o estabelecimento de uma área exclusiva para a pesca artesanal acabou reduzindo os conflitos por território. Contudo, com a pressão da pesca industrial no entorno, houve redução do pescado e o pescador artesanal, que detém poucas infraestruturas para a navegação, acaba tendo que realizar pescarias em áreas protegidas. Por isso, a autora destaca a necessidade desses limites serem revistos.

\section{Pesca Comercial}

As dissertações e teses também apresentam disputas no território com a pesca comercial. Neste caso, a pressão sobre os recursos pesqueiros tem reduzido os estoques, o que resulta na maior competição entre pescadores artesanais e comerciais pelos pesqueiros mais piscosos.

Na região Norte Silva (2009) evidencia a complexidade dos diversos interesses dos "pescadores profissionais embarcados, camponeses-ribeirinhos que se lançaram na pesca comercial de um lado, camponeses-ribeirinhos que não concordavam com a invasão dos seus territórios pesqueiros de outro, ocasionaram o aparecimento de conflitos pela apropriação e uso dos recursos aquáticos na Amazônia". O autor apresenta como caso emblemático o ocorrido no Lago Januacá, localizado entre os municípios de Manaquiri e Careiro-Castanho, no estado do Amazonas, em 1973, com mortes de ribeirinhos e pescadores comerciais, conhecido na região como "guerra do Peixe". O autor aponta que essas disputas por recursos pesqueiros na Amazônia ficaram mais evidentes desde o início da década de 1980 por ser notória a redução dos recursos pesqueiros na região. $\mathrm{O}$ autor enfatiza que as primeiras reivindicações dos “camponeses-ribeirinhos" foram manifestadas no interior das dioceses e prelazias (p.178).

Para Lima (2004) a chamada "guerra do peixe" não é só uma competição por recursos; é também a manifestação de resistência de um modelo social de reprodução. Janauacá é uma localidade que está interligada a diversas outras, nesse fato ocorrido, outras comunidades também se envolveram no conflito armado para "expulsar" os considerados "invasores". Foi um problema a ser resolvido não somente por membros do local, mas por toda uma coletividade 
local e de outras localidades das proximidades. No dia do ocorrido, um barco saiu a buscar, nas margens, os "soldados" para essa guerra, ainda na madrugada. O clima de tensão se espalhou pelas proximidades, crianças e mulheres ficavam em casa, os homens saíam armados com faca, terçado, machado, espingardas com munição e outros meios para a sua defesa, ou seja, para a defesa de seu território de pesca, ameaçado por membros externos. (ABREU, 2010, p.74).

Abreu (2010) também destaca que em Manacapuru, um polo regional de venda de pescado, o aumento da procura de pescado no rio Solimões, que tem resultado na redução dos estoques. A autora apresenta disputas envolvendo pescadores "de fora" e os da comunidade. "A existência de conflitos se deu no início da delimitação da área para a pesca (o lanço) e sua apropriação pelos comunitários. Havia questionamento por parte de pescadores de outras comunidades, requerendo o direito de uso do espaço aquático, essa situação se agravou bastante, sendo necessária a intervenção de instituições do judiciário" (pp. 69-70).

Cruz (2007) expõe que no Baixo Rio Solimões a redução dos recursos pesqueiros alertou para as comunidades quanto ao uso do ambiente em condições acima da sua capacidade de resiliência, levando a organização das comunidades com propostas em defesa dos seus territórios tradicionais. O autor destaca encontros promovidos em Itacoatiara (1985), Coari (1986) que ficaram conhecidos como "do movimento em defesa da escassez do peixe no estado do Amazonas". "Em síntese, os objetivos desses três primeiros encontros foram a troca de experiências e o esclarecimento dos motivos dos conflitos entre os pescadores profissionais embarcados e os camponeses-ribeirinhos" (p.168). "Durante a realização do $3^{\circ}$ Encontro, em 1986, o irmão Falco Michelis, apresentou a proposta, trazida pela prelazia de Tefé, de preservação dos lagos. Tal proposta foi gestada entre os próprios camponeses-ribeirinhos daquela prelazia, apresentando o manejo de três tipos de lagos: lago de procriação, santuário ou sagrado; lago de manutenção, subsistência ou consumo e lagos livres” (p.181).

Araújo (2012) analisando as disputas entre pescadores de Augusto Corrêa, Pará e pescadores comerciais imigrantes do Ceará observa a insatisfação dos pescadores locais quanto as técnicas utilizadas por esses "invasores". "O movimento de apropriação e expansão territorial da atividade pesqueira comandada por empresários e donos de embarcação nordestinos" no município de Augusto Corrêa - PA, estabeleceu disputas no território entre pescadores migrantes e os pescadores tradicionais locais (p.129).

Na região Nordeste, Machado (2007) em diálogo com as lideranças comunitárias de Canavieiras, Bahia, entende que os problemas mais sérios são os de ordem estrutural, ou seja, a pesca comercial predatória, inclusive a praticada por pescadores de outros estados, os quais 
avançam sobre os territórios tradicionais das comunidades locais, e exaurem os recursos pesqueiros. $\mathrm{O}$ autor propõe a promoção de políticas públicas para o setor pesqueiro, como meio de minimizar essa problemática (p.146).

\section{Geração de Energia}

A geração de energia hidrelétrica também promove disputas no território. Nesse caso, esses empreendimentos sobrepõem pesqueiros tradicionais e territórios ocupados pelas comunidades de pescadores artesanais. Quanto aos pesqueiros cabe destacar que são significativas as mudanças nas características hidrológicas dos rios, o que compromete todo o habitat das espécies tradicionalmente capturadas pela pesca artesanal. Quanto às comunidades, essas são desterritorializadas, deixam para trás além das suas residências, sua organização social, memórias individuais e coletivas, etc.

Na região Norte, Cruz (2006) evidencia que no município de Cometá houve uma drástica redução na pesca devido às alterações no regime hidrológico do rio após a construção das barragens da Usina Hidroelétrica. O autor enfatiza que o "ritmo de enchente e vazante passou a ser regulado pelas atividades de operação da UHE. Isso pode ter desorientado e modificado o comportamento migratório dos cardumes de algumas das principais espécies de peixes comerciais da região, contribuindo para a diminuição nas capturas" (p.120). Segundo o autor, além do impacto ecológico há impactos sociais e culturais no baixo Tocantins, uma vez que o rio tem papel fundamental na construção do modo de viver dos ribeirinhos (Cruz, 2006, 2011). Cruz (2011) destaca que a construção da hidrelétrica provocou um radical processo de desterritorialização das comunidades ribeirinhas, indígenas e urbanas, pois sofreram mobilização compulsória, sendo obrigadas a deixar suas casas, terras, pesqueiros, etc. $\mathrm{O}$ autor enfatiza que à montante esse processo convergiu para a criação do Movimento de Atingidos por Barragens -MAB, "que encampou as inúmeras demandas das mais diversas comunidades afetadas pela construção da barragem" (p.223).

Na região Nordeste, no Estuário do Rio São Francisco, Alagoas e Sergipe, Cunha (2006) destaca que barragens foram construídas ao longo do rio, promovendo alterações na dinâmica do sistema fluvial, que interferem na organização "socioeconômica" da população residente. No caso da Usina Hidrelétrica de Xingó Cunha (2015) destaca que “a baixa vazão maximiza problemas como a extrema redução da carga de sedimentos, com consequências na cadeia alimentar, interferindo na transferência de energia e nutrientes entre produtores e consumidores" (p.206). Emergem danos socioambientais devido aos barramentos onde 
historicamente ocorriam atividades que contemplam os elementos da paisagem representada especialmente pelo rio São Francisco, como a pesca artesanal.

Na região Sudeste, Braconaro (2011) enfatiza a preocupação com a biodiversidade ictiológica existente nos rios da Bacia do Rio Araguari, no triângulo mineiro, promovido pela construção das usinas hidrelétricas que implica na redução ou até mesmo extinção das atividades de pesca para grande parte da população rural (pp.115-119). Os pescadores tiveram sua atividade extinta, após o represamento, pois a maioria dos peixes que eram capturados no rio não se reproduzem nessas novas condições. "A perda não se reduz ao aspecto material, implica também, em perdas de referências socioespaciais que foram herdadas, construídas individualmente e coletivamente ao longo da vida destas pessoas e que, historicamente, obtinham seus meios de vida e produção dos bens alimentares com a exploração das terras, das águas e das matas" (p.108).

Na região Sul, Ferreira (2014) enfatiza a influência do funcionamento da Usina Hidrelétrica Itaipu Binacional Paraná, sobre as territorialidades dos pescadores artesanais. Segundo a autora "o fechamento das comportas da Usina de Itaipu, para o aumento da produção de energia elétrica, ou a escassez de chuvas, ocasiona o rebaixamento do lago, o que na época da desova (ou piracema, entre os meses novembro a fevereiro)" resulta na queda dos estoques pesqueiros (p.113). Assim, além da perda de territórios tradicionais devido a instalação da usina, frequentemente os pesqueiros tradicionais são extintos por não haver produtividade em função do funcionamento da mesma.

\section{Industrialização}

O processo de instalação e funcionamento de atividades industriais também promove disputas no território com os pescadores artesanais. Esses defendem ambientes sensíveis como os manguezais diante das transformações intensas decorrentes da atividade industrial. $\mathrm{Na}$ disputa nos territórios, a atividade industrial encontra apoio no Estado, cujo projeto não reconhece os territórios tradicionais das comunidades de pescadores, e, por isso, não mensuram as consequências na subsistência e modo de viver das comunidades. Diante disso, as disputas se refletem na resistência para se manter no território e nas denúncias quanto aos impactos ambientais.

Na região Nordeste, Costa (2010) e Santos (2012) apontam que a poluição dos manguezais devido às atividades industriais tem impossibilitado a pesca e a mariscagem, nesse importante território pesqueiro tradicional. Costa (2010) enaltece a importância dos manguezais 
para a vida marinha, e que compõem importantes territorialidades, bem como o processo de devastação dos mesmos pelos empreendimentos salineiros no estado do Ceará. Santos (2012) destaca que os pescadores veem nas fábricas uma ameaça para a continuidade da atividade pesqueira devido à impactos negativos como a poluição da água e do solo que resultam na redução do pescado e dos mariscos. Na concepção dos pescadores inseridos em sua pesquisa "as causas das transformações do complexo estuário-manguezal estão relacionadas em grande parte à poluição provocada pelos efluentes industriais" (p.70).

Na região Sul, Santana (2013) retoma que nos anos de 1970, a instalação de um parque industrial na área litorânea, dedicado principalmente à produção de fertilizantes e de óleos vegetais em Rio Grande, Rio Grande do Sul, resultou no aumento da poluição e da degradação ambiental. A autora acrescenta o impacto da construção do Distrito Industrial de Rio Grande (DIRG) no modo de vida dos pescadores artesanais, pois facilitou o acesso até a localidade e proporcionou uma nova alternativa de emprego, fato que contribuiu para que a atividade pesqueira artesanal perdesse importância (p.95). Já De Paula (2013) no Delta do rio Jacuí, Porto Alegre - RS, apresenta repercussões ambientais da atividade industrial como bombas de sucção de água, e lançamento de efluentes industriais sem tratamento nos corpos d'água que tem resultado na desterritorialização dos pescadores artesanais, e no agravamento de conflitos por território.

Na região Sudeste, Vinhas (2011) expõe que a "Baía de Sepetiba se formou um cenário de disputas devido às constantes contaminações por metais pesados da Cia. Ingá Mercantil, que permaneciam já acomodados no fundo, sendo remobilizados pela dragagem da construção do porto da TKCSA" (p.104). O autor argumenta que há uma intencionalidade em jogo, de transformar a área em um polo siderúrgico e portuário, que se realiza com a territorialização de diversas empresas e desterritorialização dos pescadores artesanais. Nas palavras do autor "A imposição de um modelo de "modernização" pelo viés da industrialização para Baía de Sepetiba gerou uma dicotomia através da apropriação/ dominação, caracterizando o mar como território, dando origem a conflitos e consequentemente a resistências, que ocorrem de maneiras variadas, fruto de suas variadas apropriações (p.68).

\section{Turismo}

A pressão da indústria do turismo sobre o ambiente tem levado à perda de produtividade na pesca e, assim, à extinção de territórios pesqueiros tradicionais. A privatização de praias também compromete o acesso dos pescadores aos pesqueiros tradicionais. Cabe destacar que, 
nessa disputa no território, pescadores embatem com elites locais, regionais e capital internacional.

Na região Nordeste, Moraes (2010) destaca o avanço do turismo sobre importantes ecossistemas utilizados pelas comunidades e o turismo local como uma forma de resistência à indústria do turismo. O projeto de turismo local aparece como um contraponto ao avanço das segundas residências, complexos hoteleiros e resorts, que são empreendimentos de atores exógenos, inclusive de capital internacional. Galvão Neto (2009) em Canguaretama, Rio Grande do Norte destaca que além dos prejuízos que provoca a contaminação dos mananciais de água, ocorrem conflitos decorrente da apropriação de lagoas destinadas à pesca de subsistência de pequenas comunidades locais por empresas do lazer (p.70). O autor enfatiza que essa atividade não reconhece as comunidades, e as práticas estabelecidas para manejar os recursos presentes no território (p.126).

Na região Sudeste, Camargo (2013) também enfatiza que o desenvolvimento do turismo em Paraty, Rio de Janeiro segue um plano de ordenamento territorial que visa atender às exigências das elites urbanas. Essas elites dispõem de influências políticas e econômicas para o desenvolvimento do turismo que lhe interessa, com estações balneárias, residências secundárias e condomínios de luxo. Além de avançar sobre territórios tradicionais das comunidades, provocou o "aterramento de mangues, canalização do mar para construção de marinas e despejo de esgotos em corpos de água doce" (p.106).

Na região Sul, Chamas (2008) expõe que na ilha do Campeche, Santa Catarina, a visitação turística atingiu um nível preocupante em termos conservacionistas e potencializou disputas com as comunidades locais. Neste cabe, enfatizar a relação entre poder territorial, considerando a gestão do parque e as comunidades ali territorializadas é interesse econômico, pois o turismo se coloca como uma importante atividade econômica (p.92).

\section{Agricultura}

As atividades agropastoris têm provocado a perda de importantes pesqueiros tradicionais das comunidades de pescadores artesanais. Isto se deve, principalmente, à captação de água para irrigação, despejo de agrotóxico e as bombas de sucção de água nas áreas de criadouros. Quanto à pecuária cabe enfatizar a erosão dos solos e, consequente assoreamento dos corpos d'água que eram importantes pesqueiros. Os pescadores denunciam esses impactos aos órgãos "competentes" como estratégia de defesa do território pesqueiro e muitas vezes entram em confronto com os funcionários das fazendas. 
As consequências da agricultura sobre os territórios tradicionais dos pescadores artesanais se evidenciam na região Sul, prioritariamente. Scheibel (2013) aponta que no Rio Pitangui, afluente da margem direita do rio Tibagi, por atravessar uma grande área dos municípios de Castro, Ponta Grossa e Carambeí, estado do Paraná, acaba sofrendo uma série de impactos ao longo de seu curso, tais como: ações decorrentes e/ou recorrentes das atividades agropecuárias em suas margens, processos de alteração do curso natural para práticas agrícolas em áreas de planície, carreamento de sedimentos e de carga de agrotóxicos para seu curso e assoreamento do seu leito, depredação ou inexistência da mata ciliar (p.34). Segundo o autor, esse contexto tem resultado na perda de importantes pesqueiros tradicionais para as comunidades de pescadores. Diante disso, os pescadores têm que se reterritorializar em áreas mais distantes, onde surgem conflitos entre territorialidades.

Moraes (2015), na região Central do Rio Grande do Sul, entende que entre todas as atividades, a utilização de agroquímicos que chegam às águas é apontada pelos pescadores como o mais grave problema para a pesca e para o rio devido a contaminação da água, resultando na extinção das espécies de peixes (p.96). O autor ressalta que consequências do cultivo de arroz - orizicultura - sobre a pesca artesanal que tem gerado preocupação devido ao uso de defensivos químicos, consumo excessivo de água para irrigação e mal-uso das telas de proteção dos dutos de sucção de água. Segundo o autor, no Rio Grande do Sul, é recorrente nos meses de verão não haver vazão nos rios suficiente para toda demanda por água, isso configura o "cultivo do arroz como "um dos principais problemas enfrentados pela atividade pesqueira em águas interiores no Rio Grande do Sul” (p.32). Mapeando os dutos de sucção de água e os pesqueiros tradicionais dos pescadores, o autor observa a sobreposição de territórios, o que vem incidindo em disputas importantes, como ocorre no rio Vacacaí.

Como afirma De Paula (2013) os pescadores do Fórum Delta do Jacuí, região Metropolitana de Porto Alegre, Rio Grande do Sul apontam que os principais impactos que a agricultura tem provocado nos territórios pesqueiros se devem as bombas de sucção, utilizadas para a irrigação, que quando posicionadas nas áreas de desova e/ou maturação dos peixes, sem a tela de proteção, sugam os alevinos. Além disso, os agrotóxicos utilizados nas lavouras são carregados para os corpos d'água onde habitam as espécies pesqueiras (p.15). No fórum, os pescadores denunciam essas atividades e cobram dos órgãos públicos o cumprimento da legislação ambiental como forma de defesa do território pesqueiro.

Em relação à pecuária, na região Norte, Guedes (2009) frisa as disputas envolvendo fazendeiros criadores de búfalos e ribeirinhos são frequentes, pois nos campos naturais de 
Soure, Pará existem grandes lagos que concentram espécies de peixes de água doce, que sempre foram capturados pelos pescadores artesanais. "Não obstante, a intensificação da criação de gados bufalinos vem destruindo esses territórios de pescadores, pois a natureza do próprio búfalo provoca erosão, diminuindo as possibilidades da pesca de subsistência das populações locais" (p.130).

\section{Comercialização de Pescado}

A pressão que a comercialização do pescado provoca sobre a pesca artesanal acaba promovendo a pesca predatória e a redução da produtividade dos territórios, bem como o acirramento de conflitos entre pescadores nos pesqueiros tradicionais. Sendo assim, os pescadores artesanais acabam sendo subordinados à dinâmica do mercado, e, devido a essa pressão que sofrem, acabam tendo que utilizar apetrechos predatórios que rompem com a lógica do conhecimento tradicional e, por isso, geram conflitos entre pescadores.

Na região Nordeste, Lima (2002) ressalta que a pressão do mercado tem promovido sobre a pesca predatória da lagosta com "compressor" (aparelho de mergulho) no Litoral do Ceará. Contudo, a autora ressalta que a otimização não resulta em bom preço, pois o aumento da produção somente maximiza os lucros dos envolvidos nesse processo (proprietário do barco de apoio/compressor e do atravessador no processo de revenda). "Os "cafanguistas", pescadores, ganham pouco, vivem com a insegurança devido a inadequação dos equipamentos de mergulho". Sendo assim, além de reduzir a quantidade e qualidade de peixe no território a autora aponta que emergem disputas com outros pescadores que não concordam com esse uso do território (p.206).

Figueiredo (2013) expõe que em Canavieiras, Bahia, a pressão do mercado tem resultado na pesca predatória com utilização de apetrechos inadequados. Segundo Vennuci (2002) apud Figueiredo (2013) “o conhecimento tradicional dos pescadores com relação às áreas de desova de espécies se confirma pela prática generalizada de captura de alevinos em áreas de mangue com redes de malha fina em grandes quantidades, sendo essa prática ativa em qualquer manguezal do mundo, resultante da pressão do mercado por pescados, contribuindo, assim, para a degradação desse ecossistema". Além de comprometer a reprodução das principais espécies da pesca artesanal, significa uma ruptura na lógica da sustentabilidade e dos acordos comunitários levando a desestabilização dos territórios tradicionais (p.39).

Na região Norte, Rodrigues (2014) ressalta a complexidade da cadeia produtiva do pescado e sua influência sobre a pesca artesanal em Novo Airão, Amazonas. A autora entende 
que "Os peixes denominados de lisos (os bagres), por meio da grande intensificação da pesca comercial, há muito tempo vem diminuindo no tamanho do peixe e dos cardumes, o que contribui para a escassez dos bagres grandes, acima de $50 \mathrm{~cm}$ no Rio Solimões”. Neste sentido, a autora enfatiza o papel dos frigoríficos que passam a ter atuação regional, a fim de terem estoques suficientes para os meses em que a pesca é menos produtiva devido à cheia dos rios (p.88).

\section{Pesca Artesanal}

Os impactos e conflitos na pesca artesanal ocorrem quando regras comunitárias são descumpridas por pescadores locais ou, não são reconhecidas por pescadores de outras localidades que vem utilizar o território e provocam impactos que resultam na redução do pescado. No caso dos pescadores de outras localidades que disputam território com os pescadores locais, isso se deve por que seus territórios tradicionais foram extintos pela pesca artesanal e, sobretudo, por outras atividades econômicas que se instalaram sobre os territórios tradicionais.

Na região Nordeste, Costa (2010) ressalta que novos conflitos com a atividade pesqueira no município de Icapuí, Ceará têm surgido devido à introdução de "atratores artificiais para as lagostas, as chamadas marambaias, utilizadas na pesca de mergulho". Segundo o autor, são centenas de milhares de tambores metálicos, despejados no mar. Logo, é crescente o número de conflitos entre "pescadores artesanais (que respeitam o período de defeso e se utilizam dos instrumentos de pesca legais em suas pequenas embarcações) e praticantes da pesca de mergulho (ou de compressor, como comumente é chamada por usar tal equipamento)". Além das consequências ambientais do desrespeito à piracema dos peixes, crescem as situações de conflitos entre pescadores. Muitas vezes, os praticantes da pesca de mergulho têm "despescado" as cangalhas ${ }^{7}$ utilizadas pelos pescadores artesanais (p.37).

Torres (2014) apresenta impactos e conflitos relacionados com a pesca de camboa ${ }^{8}$ no Povoado de Pedreiras, São Cristóvão, Sergipe. “A camboa além de afetar a reprodução dos peixes, também é prejudicial para a mata ciliar. As varas usadas na confecção das camboas muitas vezes são retiradas do próprio mangue". No entendimento dos pescadores esse é um dos fatores responsáveis pela escassez de pescado (p.87). A autora relata conflitos entre pescadores

${ }^{7}$ Cangalhas: armadilhas de pesca utilizadas na região Nordeste.

${ }^{8}$ Pesca de Camboa: é uma pescaria de tradição afro-indígena em que se faz uma cerca ao redor do cardume. 
que utilizam essa técnica e os demais. Sendo assim, o território pesqueiro com falta de recursos para todos é palco de conflitos entre pescadores que utilizam técnicas diversas.

$\mathrm{Na}$ região Sul, Contato (2012) evidencia conflitos entre pescadores artesanais no município de Rio Grande, Rio Grande do Sul. "O aumento desordenado do número de pescadores geralmente vindos de outras localidades, e consequentemente, o aumento excessivo no esforço de pesca gerou conflitos nessa organização local existente uma vez que os "novos integrantes" da atividade não respeitavam as regras de uso estabelecidas tradicionalmente ao longo dos anos". Assim, se concentram os impactos ambientais e se acirram conflitos relacionados às normas de uso do território pesqueiro (p.20).

Na região Norte, Cunha (2011) aponta que em Capanema, Pará o período da piracema dos peixes que era respeitado pelos pescadores do Lago, vem sendo desrespeitado. "O lago tem sido explorado de forma intensiva por um grande número de pescadores da comunidade, o que se intensificou também nos últimos anos, assim como por pescadores de outros municípios da região e que não respeitam esse período". Assim, tais ações provocam ameaças dos recursos pesqueiros, e geram conflitos na própria comunidade quanto às normas de uso do território (p.112)

\section{Petróleo}

Além dos impactos ambientais causados nos territórios tradicionais das comunidades de pesca pela indústria do Petróleo, e dos danos irreversíveis provocados que provoca nos pesqueiros tradicionais, esse conflito confronta distintas lógicas de apropriação da natureza. Assim, as comunidades de pescadores vêm e resistem ao avanço dessa indústria e de outras atividades relacionadas a ela sobre seus territórios tradicionais.

Na região Nordeste, Costa (2010) destaca que Icapuí concentra uma parte considerável da produção de petróleo em terra do estado do Ceará. "Vale lembrar que a atividade de exploração em seu território tem gerado também impactos ambientais durante testes de prospecção e abertura de trilhas na mata de tabuleiro para a manutenção de poços, merecendo maior atenção dos órgãos e entidades ligadas à defesa do meio ambiente". Assim, a indústria do Petróleo faz significativas alterações no território das comunidades tradicionais, e promove impactos ambientais (p.40).

Além dos impactos e conflitos da indústria do Petróleo também ocorrem por que essa atividade econômica acaba desencadeando outros processos sobre os territórios tradicionais das comunidades de pescadores. Alves (2015) enfatiza que na Comunidade de Baiacu, Vera Cruz, 
Bahia, o processo de expansão urbana entre 1950 e 1980 está relacionada com a "criação da Petrobras, implementação da Refinaria Landulfo Alves, do Centro Industrial de Aratu (CIA), do Polo Petroquímico de Camaçari, do sistema Ferry Boat e lanchas, a construção da Ponte do Funil (que liga a Ilha ao continente, especificamente ao Recôncavo Baiano) e da BA 001”. Estas intervenções no ambiente, após a ampliação do acesso à Ilha, e o crescimento urbano e turístico acarretou "na ocupação desordenada do espaço litorâneo, causada pela expansão urbana leva a inúmeros aterros de mangues, desmatamentos litorâneos, construção de estradas e marinas que interrompem ou destroem os ciclos de energia e nutrientes dos ecossistemas estuarinos, erosão costeira, favelas, lixo e esgoto ao ar livre" (MINEIRO, 2010, p. 78 apud ALVES, 2010, p.118).

$\mathrm{Na}$ região Sudeste, Chaves (2011) entende que o conflito entre a Petrobras e os pescadores artesanais da Baía de Guanabara, Rio de Janeiro é marcado pelo vazamento de óleo em Janeiro de 2000. Cerca de "500 (quinhentos) pescadores foram cadastrados pela Petrobras e as indenizações foram pagas de acordo com a renda de cada categoria de trabalhador. Os pescadores manifestaram-se questionando os critérios da Petrobras e alegando que "não só pescadores estavam se apresentando para o recebimento da compensação" (ACSELRAD, 2002, p.306 apud CHAVES, 2011, p. 92). Desse impacto ambiental, entre outros marcados pela resistência dos pescadores frente à Petrobrás houve a mobilização das comunidades para defenderem os seus territórios. "Há uma imposição territorial de atividades que representam o status hegemônico da sociedade, sobre a configuração já existente” (p.92).

\section{Abordagens}

As abordagens dos órgãos responsáveis pela gestão ambiental também interferem tanto nas condições ambientais da pesca, quanto no território pesqueiro. A falta de eficiência nas abordagens possibilita a pesca predatória e a degradação causada por outras atividades econômicas pode causar a redução dos estoques e, assim, a extinção de territórios tradicionais. Contudo, abordagens agressivas também geram desestabilizações nos territórios tradicionais, o estabelecimento de uma situação de tensão e conflito com os fiscais e polícia. Assim, os pescadores se vêm sem prerrogativa de agirem sobre o território, e acabam buscando brechas na atividade de fiscalização para manterem as pescarias, inclusive contra a legislação ambiental.

Na região Nordeste, Cunha (2006) destaca que nos Manguezais do Brejo Grande, Estuário do Rio São Francisco, Sergipe os pescadores "argumentam sobre a necessidade da presença mais efetiva e enérgica do órgão quanto ao combate ao desmatamento realizado por carcinicultores em várias áreas de mangues, bem como na proibição de técnicas predatórias”. 
Também apresentam conflitos com os funcionários do Instituto Brasileiro de Recursos Naturais Renováveis (IBAMA) devido à ausência de conversações prévias sobre o Período do Defeso e a forma de abordagem dos fiscais aos pescadores.

Já na região Norte, em Belém do Pará, Lima (2008) destaca a falta de fiscalização devido grande extensão dos pesqueiros, bem como o modelo de gerenciamento que "leva a um sistema de manejo desordenado e sem regras. Somando, os conflitos entre as diversas instituições para delimitação de competências sobre a gestão dos recursos" (p.99). Desta forma está comprometida a permanência dos recursos e, por isso, a existência dos territórios tradicionais de pesca.

\section{Mineração}

A mineração causa impactos ambientais quando altera as características hidrológicas dos corpos d'água e destrói importantes habitats das espécies pesqueiras, e assim, extingue territórios tradicionais. Além disso, as embarcações utilizadas para mineração não distinguem os territórios pesqueiros e, frequentemente, avançam sobre os mesmos causando perda de apetrechos de pesca e colocando em risco de morte os pescadores que estão realizando a pesca.

Na região Sul, De Paula (2013) apresenta a mobilização dos pescadores artesanais do Fórum Delta do Jacuí, Rio Grande do Sul, contra a atividade mineradora. Segundo o Fórum, essa atividade causa impactos ambientais por que os equipamentos de retirada de areia destroem áreas de reprodução dos peixes e sugam os alevinos, o que tem prejudicado as safras. Contudo, além do impacto sobre a reprodução dos peixes, apontam que as Areeiras não respeitam as áreas tradicionais de pesca e, costumeiramente, causam danos às redes dos pescadores artesanais. Os pescadores do rio Jacuí costumavam acampar em ilhas, as quais não existem mais devido à extração de areia, esse fenômeno é conhecido como as "ilhas sumidas".

$\mathrm{Na}$ região Centro-Oeste, Santos e Jezus (2014) destacam que "um dos setores econômicos existentes de maior impacto na bacia do rio Cuiabá é o de exploração mineral, tanto de metais, quanto os de não-metais". Sendo assim, ocorre a transformação dos "ecossistemas" do rio, e os impactos ambientais impedem a permanência dos territórios tradicionais de pesca. Em decorrência disso, ocorrem conflitos entre pescadores artesanais e funcionários da mineração. 


\section{Pesca Amadora e Esportiva}

A pesca amadora e a pesca esportiva avançam sobre os territórios pesqueiros causando impactos ambientais, que não são devidamente mensurados. Essas modalidades de pesca não seguem as normas da legislação ambiental a que estão sujeitos os pescadores artesanais, o que acaba resultando na redução dos estoques pesqueiros no território. Ainda geram conflitos por território na medida em que pescadores artesanais e amadores embatem, pois, esses últimos, não seguem as regras de uso do território pesqueiro.

Na região Sudeste, Cardoso (1996) aponta que os mergulhadores frequentam as Ilhas Vitória e Monte de Trigo, Litoral Paulista, para o exercício da caça submarina, devido às características físicas das ilhas que favorece a presença de várias espécies de pescado. "Por esporte, estes sujeitos acabam por retirar o pescado que poderia ser capturado pelos ilhéus, o que é motivo de revolta dos moradores das ilhas, em especial nos fins de semana e épocas de veraneio quando inúmeras lanchas com mergulhadores se dirigem para as ilhas”. Esse contexto incide em conflitos por território, entre esses pescadores eventuais e pescadores artesanais que dependem do território para a manutenção do seu modo de viver.

Na região Nordeste, Cunha (2011) destaca que em Capanena, Paraíba "A pesca esportiva utiliza artes da pesca como anzóis, malhadeiras, linhas ou outros meios que às vezes não são adequados para a captura das espécies existentes no lago, enquanto a pesca de subsistência é uma modalidade que tem como propósito a obtenção de alimentos, embora uma parte possa ser comercializada com o objetivo de obter gêneros para atender às necessidades básicas da comunidade" (p.65). Assim, os impactos da pesca esportiva têm efeito no território pesqueiro que perde produtividade e no âmbito do território das comunidades tradicionais de pescadores que não conseguem a sua reprodução social, uma vez que perdem os meios necessários para a sua subsistência.

\section{Porto}

A instalação e funcionamento de terminais portuários causam significativas modificações no ambiente, o que acaba interferindo na presença das espécies pesqueiras. Além disso, o estabelecimento de área de exclusão acaba impedindo o acesso dos pescadores aos territórios pesqueiros tradicionais. Soma-se ainda a remoção de comunidades de seus territórios tradicionais para a instalação de infraestruturas portuárias.

Na região Sudeste, Gomes (2012) associa o declínio da pesca de camarão à atividade do Porto do Açu em São João da Barra, Rio de Janeiro. “A pesca do camarão, por exemplo, se dá 
próxima à costa, local onde se acumularia o alimento do crustáceo. Com a movimentação do leito oceânico operada no Açu e com o aumento da turbidez da água que isso acarreta, há o temor de que esse tipo de pescado declina (p.104). Contudo, o conflito por território mais intenso diz respeito "à provável limitação da circulação das embarcações menores na ocasião do início das atividades do porto". Com o tráfego de embarcações de grande porte, não será mais possível que os barcos de pesca se aproximem de certas áreas do litoral. "Alguns pescadores relataram já terem sido ameaçados em alto-mar, inclusive com armas de fogo, ao se recusarem a ser afastar de embarcações ligadas à implantação do porto” (p.105).

Na região Sul, Santana (2013) entende que os conflitos entre pescadores do Superporto de Rio Grande, Rio Grande do Sul, devem-se à vulnerabilidade dos ecossistemas e a ampliação da área de atividade portuária que restringe o trafego de embarcações artesanais, e provoca remoção de comunidades de seus territórios tradicionais. Segundo a autora o "complexo portuário ocupa atualmente grande parte do estuário, e vai se ampliar para São José do Norte (BARROS et al., 2010 apud SANTANA 2013, p.103).

\section{Urbanização}

A poluição dos corpos d'água por efluentes domésticos e resíduos sólidos causa impactos no ambiente que tem comprometido a quantidade e a qualidade do pescado. Isso acaba provocando a extinção de territórios pesqueiros tradicionais e a migração dos pescadores artesanais para locais mais distantes. Na região Sul, De Paula (2013) apresenta esse processo no Lago Guaíba, Rio Grande do Sul que tem provocado conflitos entre pescadores artesanais e pescadores imigrantes. Quanto aos resíduos sólidos, os próprios pescadores tomaram a inciativa, por meio de um projeto denominado "Pescando Lixo", onde os pescadores aproveitam o período da piracema para recolher material reciclável no Lago Guaíba.

\section{Ausência de Fiscalização}

A ausência de monitoramento/fiscalização da legislação ambiental também é apresentada como responsável por impactos ambientais e geradora de conflitos por territórios nas comunidades tradicionais de pescadores. Na região Norte, Cunha (2011) em Capanema, Pará destaca que os pescadores do "Lago Segredo, de acordo com os relatos, sentem muito pela ausência de fiscalização dos órgãos competentes municipais, estaduais e federais no que se refere à normatização da atividade pesqueira na Comunidade do Segredinho, tendo em vista 
que os gestores municipais não identificam o Lago Segredo como território de pesca e, consequentemente, comunidade de atividade pesqueira" (p.63).

\section{Normatizações}

As normatizações incongruentes com as características do ambiente e das espécies pesqueiras também não são suficientes para a conservação do pescado nos territórios tradicionais pesqueiros. Essas normas geralmente são construídas sem participação dos pescadores, que identificando as falhas da fiscalização não tem condições de propor novas alternativas. Na região Nordeste, Silva (2012B) apresenta esse contexto em Lucena, Paraíba “A pesca da fiação por conta da ausência do defeso e consequentemente do seguro do defeso, é o motivo mais citado pelos pescadores para a queda na produção. Não havendo o defeso, pescam o ano inteiro para gerar renda, mesmo acreditando que assim as espécies não se reproduzem nem se desenvolvem naturalmente (por conta da pesca da fiação)". Neste caso, a autora destaca a falta de período de defeso da Lagosta, no litoral da Paraíba, bem como dos estados do Pernambuco e Rio Grande do Norte. Sendo assim, a produtividade dos territórios pesqueiros está ameaçada. Contudo, os limites das normatizações se impõem como empecilho para a efetiva gestão do território pesqueiro como evidencia o argumento do agente ambiental do IBAMA entrevistado pela autora "Esclarece ainda que como os pescadores cadastrados no RGP tem direito a pescar em todo território nacional, ficaria difícil controlar o número de pecadores que buscariam o direito do defeso em Lucena, caso fosse concedido (p.92)

\section{Institucional}

Os conflitos institucionais se dão quando se estabelece a oposição entre comunidades tradicionais de pescadores artesanais e gestores do Estado, em um contexto em que ambos disputam a prerrogativa de agirem sobre o território. Na região Norte, Guedes (2009) enaltece que em Soure, Pará, os agentes do Estado são vistos pelos pescadores como pouco eficientes em estabelecer "normas e controle que limite o acesso, cerceando as práticas de capturas lesivas a reprodução as espécies e criando políticas de ordenamento da pesca" (p.130). Desta forma, são as próprias instituições estatais apontadas como responsáveis pela redução dos recursos e extinção de territórios tradicionais. O autor enfatiza que por outro lado há a compreensão de que o "Estado também considerou o pequeno pescador como um indivíduo reacionário, inculto, incapaz de assimilar os padrões tecnológicos aspirados pelo poder estatal e pelas regras de mercado" (LOUREIRO, 1985 apud GUEDES p.130). 


\section{Unidades de Conservação}

A instalação de Unidades de Conservação, costumeiramente, provoca conflitos por territórios entre comunidades tradicionais e gestores. Impactos ambientais negativos sobre as espécies são menos frequentes. Contudo, ocorrem quando as práticas de gestão em vez de promoverem a recuperação dos recursos acaba intensificando a degradação. Na região Sul, Pérez (2012) apresenta um exemplo no Parque Nacional Superagüi, Guaraqueçaba, Paraná, onde "os conflitos com a possível instalação de recifes artificiais - que em lugar de servirem para a reprodução da biodiversidade marinha, serviriam para cortar as redes dos pescadores artesanais e significariam lixo no fundo do mar". Assim, incide negativamente tanto no ambiente, quanto nas práticas tradicionais de uso do território pesqueiro (p.45).

Evidenciou-se, então, atividades econômicas que provocam de forma associada impactos ambientais e conflitos por território, nas dissertações e teses analisadas e espacializadas (figura 52). 


\section{GEOGRAFIAS DA PESCA ARTESANAL BRASILEIRA:}

\section{Disputas no Território}

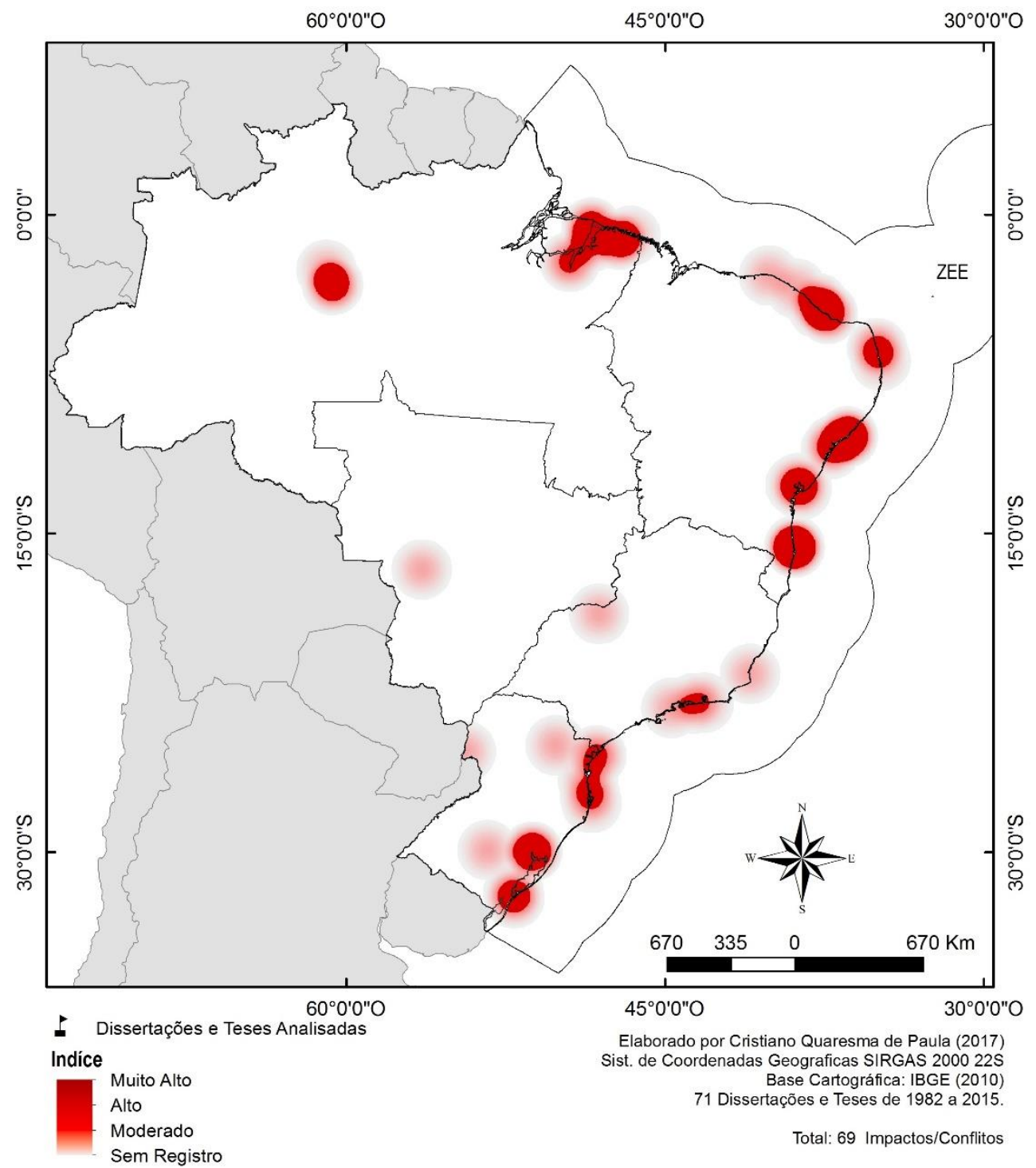

Figura 52: Mapa de Densidade de Disputas no Território Fonte: Elaborado por De Paula (2018)

Na região Nordeste, a aquicultura é apontada como a principal causa das disputas no território. Neste sentido, além dos impactos provenientes do uso de produtos químicos é fundamental destacar os conflitos relacionados às restrições dos acessos dos pescadores artesanais aos pesqueiros tradicionais. Ainda cabe enfatizar o desmatamento dos manguezais, onde são instalados os empreendimentos de aquicultura como um fator que compromete a perenidade dos recursos no território pesqueiro. 
Nesta região, a Pesca Artesanal também é apontada como causadora de impactos ambientais e incidente de conflitos por territórios. Neste caso, inúmeros outros impactos e conflitos que tem provocado a redução dos recursos, bem como a pressão do mercado, tem resultado em alterações nas relações internas às comunidades pesqueiras. Muitos pescadores para alcançar a subsistência de suas famílias acabam fazendo uso de apetrechos de pesca mais predatórios do que os que eram tradicionalmente utilizados. Isso implica em transgressões às regras acordadas coletivamente, logo promove tanto impactos que reduzem a oferta de recursos pesqueiros, quanto conflitos entre pescadores.

Ainda há uma pluralidade de outras atividades que causam impactos e conflitos por território. Como a comercialização de pescado, usinas hidrelétricas, pesca industrial, indústria do petróleo e atividade turismo.

Na região Sul, a principal atividade causadora de disputas no território é a pesca industrial. Nesta região há conflitos entre pescadores artesanais e pescadores industriais, muitas vezes vindos de outros estados. Ocorre que importantes recursos pesqueiros capturados pelos pescadores artesanais, também são disputados por pescadores industriais. Contudo, os pescadores industriais possuem capacidade de captura muito superior aos pescadores artesanais e não estão preocupados como a perenidade dos recursos no território, porque as embarcações lhe permitem a busca de outros territórios mais produtivos. A resistência à pesca industrial tem ocorrido por meio do estabelecimento de espaços de discussão e gestão da pesca e construção de normativas que favorecem pescadores locais e limitam o esforço de pesca no território.

A agricultura e a industrialização também são apontadas como causadoras de impactos e conflitos. Ambas as atividades citadas utilizam recursos hídricos para os seus processos, bem como utilizam produtos químicos que são carreados para os corpos d'água. Em decorrência disso territórios tradicionais de pesca estão sendo extintos.

Na região Norte, as abordagens de disputas no território se expressam principalmente na pesca comercial, pela submissão aos desígnios do capital, que são contrários à lógica tradicional, o que provoca a sobre-exploração dos pesqueiros que tradicionalmente são utilizados pelos pescadores artesanais. Assim, entram em conflitos pescadores comerciais e pescadores artesanais pelos recursos presentes no território.

Dentro desta mesma lógica, mas com maior pressão sobre os recursos se estabelece o conflito entre pesca industrial e pesca artesanal. Neste caso, além da pressão da cadeia de comercialização, as relações de produção distinguem pescadores artesanais, que são proprietários dos meios de produção, de pescadores industriais que são empregados dos 
proprietários dos barcos. Além disso, entram em choque a lógica de produção artesanal (no tempo da natureza) e a lógica industrial (no tempo da máquina), a qual resulta em significativos impactos ambientais.

Cabe destacar a geração de energia hidrelétrica como outra causa de disputas no território. Neste caso é a descaracterização dos corpos d'água que extingue territórios pesqueiros tradicionais. Além disso, a construção de barragens remove as comunidades de seus territórios tradicionais.

Na região Sudeste, a pesca industrial é apontada como principal impacto ambiental que tem levado ao colapso nos recursos pesqueiros, bem como ao estabelecimento de conflitos entre pescadores artesanais e industriais.

Também são apontadas disputas causadas pela industrialização, instalação e ampliação de portos e geração de energia hidrelétrica. Todos esses dizem respeito ao uso dos corpos d'água para instalação de outras atividades econômicas, que prometem o desenvolvimento. Contudo, além de causarem prejuízos irreparáveis ao ambiente, e ao recurso pesqueiro, impedem a presença dos pescadores artesanais em seus territórios tradicionais e restringem o acesso aos pesqueiros.

Na região a mineração é apontada como causadora de disputas no território. As alterações nos rios, devido à atividade mineradora, têm influenciado os habitats das espécies pesqueiras, que tem migrado para outros locais. Isso tem extinguido os pesqueiros tradicionais dos pescadores artesanais.

\subsection{Conflitos por Território}

Tratando os conflitos por território de forma independe da ocorrência de impactos ambientais, a malha do território pesqueiro é ameaçada devido ao avanço de atividades econômicas sobre os nós expressos no lugar de moradia e vivência principalmente. A influência de redes técnicas e de informação buscarão a subordinação da malha - território tradicional aos seus preceitos. Segue a perspectiva de que o espaço não está ocupado, ou que é subutilizado. Desta forma, além da influência da rede que subordina cada vez mais o território tradicional à cidade e suas demandas, há a presença de redes globais que buscam a exploração do espaço por meio de atividades econômicas que vão utilizar o potencial paisagismo e atrativos "naturais" presentes no território tradicional. Há o conflito explicito entre lógicas de apropriação e domínio do espaço. 
Tendo em vista que na malha do território tradicional há uma complexidade de nós ligados em rede, a expulsão dos pescadores do território tradicional de moradia e vivência influi sobre essa rede. Quando são estabelecidos em locais distantes dos pesqueiros tradicionais, geralmente a atividade pesqueira é extinta e se dá a desterritorialização. Assim, a malha que representa o território pesqueiro como um todo é desfeita. Contudo, esse processo não se dá sem tensões e conflitos. A resistência dos pescadores artesanais se dá por meio da ação direta, e da denúncia aos órgãos públicos reivindicando direitos de comunidades tradicionais. Por outro lado, essas atividades econômicas encontram apoio no Estado, quando se inserem em projetos que visam a modernização do espaço.

As dissertações e teses analisadas, que abordaram a pesca artesanal na Geografia brasileira, apresentaram 105 contextos de conflitos por território. Esses decorrem do domínio do espaço por determinada atividade econômica impedindo a permanência dos pescadores no território de moradia e vivência ou nos pesqueiros tradicionais.

O mapa presente na figura 53 expõe que nas pesquisas que discutiram conflitos no território foram mais presentes na região Nordeste (46,67\%). A região Sul apresenta $(20,95 \%)$ e a região

Norte $(17,14 \%)$. A região Sudeste totaliza $(12,38 \%)$ e a região Centro-Oeste $(2,86 \%)$ dos trabalhos analisados. 


\section{GEOGRAFIAS DA PESCA ARTESANAL BRASILEIRA:}

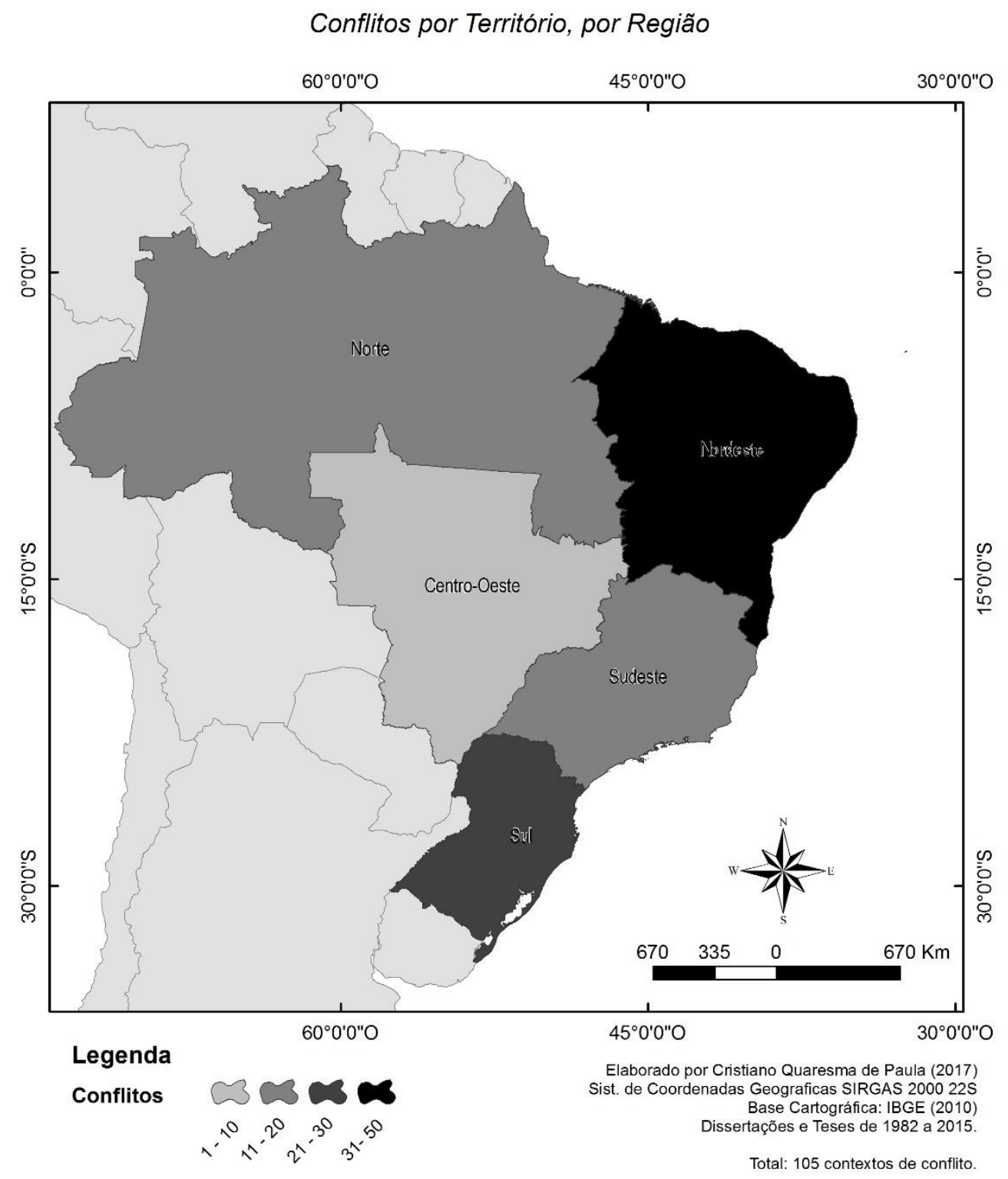

Figura 53: Mapa de Conflitos por Território, por Região

Fonte: Elaborado por De Paula (2018).

A figura 54 apresenta o mapa de conflitos por território identificados nas dissertações e teses analisadas. Os principais conflitos identificados são os relacionados a questões fundiárias, do turismo, com Unidades de Conservação, da especulação imobiliária e relativos à comercialização de pescado. 


\section{GEOGRAFIAS DA PESCA ARTESANAL BRASILEIRA:}

\section{Conflitos por Territórios}

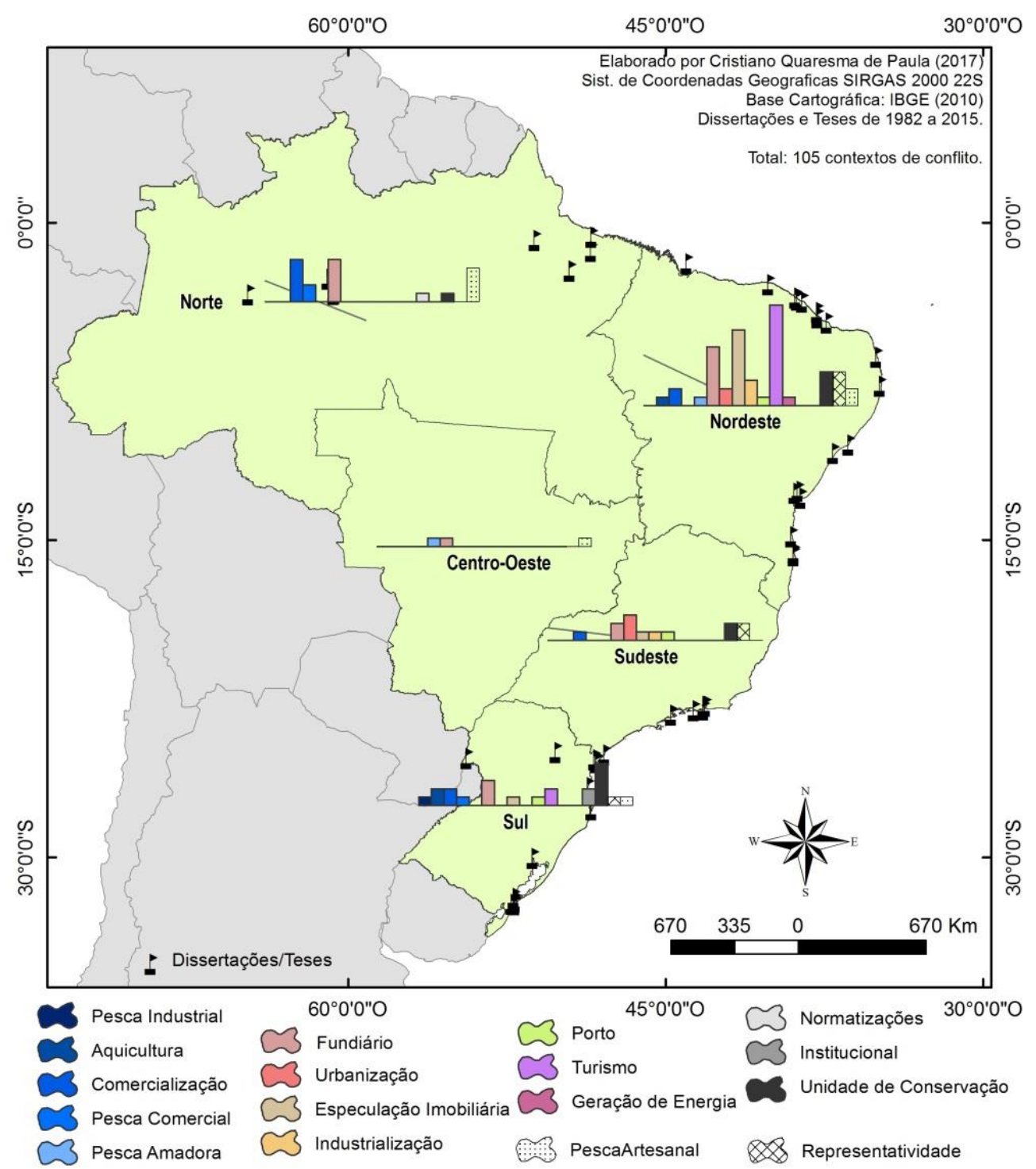

Figura 54: Mapa de Atividades entram em Conflitos por Território, por Região Fonte: Elaborado por De Paula (2018)

\section{Fundiário}

Os conflitos mais presentes, por território, são os fundiários. Estes são estabelecidos entre as comunidades de pescadores e outros atores que disputam o território, através da posse da terra. Estes refletem a estrutura fundiária brasileira, onde as comunidades de pescadores, enquanto posseiros, fazem uso da terra/água de forma comunal é desapropriada por grandes latifundiários que invocam seus direitos de posse de propriedade privada. 
Nesse sentido, os conflitos fundiários que se revelam em comunidades de pescadores e ribeirinhas se incluem entre as problemáticas dos pequenos trabalhadores rurais e refletem a problemática da desigual distribuição de terras no Brasil, como aponta Oliveira (2007). O autor complementa que:

Os conflitos mais presentes, por território, são os fundiários. Estes são estabelecidos entre as comunidades de pescadores e outros atores que disputam o território, através da posse da terra. Estes refletem a estrutura fundiária brasileira, onde as comunidades de pescadores, enquanto posseiros, fazem uso da terra/água de forma comunal é desapropriada por grandes latifundiários que invocam seus direitos de posse de propriedade privada (OLIVEIRA, 2007, p. 155).

Cabe salientar que além das terras onde estão situadas as comunidades esses conflitos se dão também pelos pesqueiros, uma vez que os cercamentos dos latifúndios restringem o acesso aos corpos d'água próximos a eles, os quais são tradicionalmente utilizados pelos pescadores artesanais.

Como resultado desses conflitos, se observa uma série de violências no campo como apresentam os relatórios da Comissão Pastoral da Terra (CPT), inclusive muitas vezes culminando na morte dos posseiros, os quais nesse caso são pescadores. Outro ponto a destacar é que nos conflitos por terra as instâncias judiciais costumam favorecer o latifundiário em defesa da propriedade privada.

A região Norte é que apresenta a maior concentração de conflitos fundiários, dentro do universo pesquisado nas dissertações e teses. Como destaca Queiroz (2012) em pesquisa realizada em Tefé - Amazonas, a população ribeirinha costuma ocupar as áreas de várzea e de terra firme, formando agrupamentos rurais, que o autor chama de "vilas". Contudo, quando essa ocupação ocorre próximo aos castanhais ocorrem conflitos com os donos dos castanhais, que algumas vezes tem que ser resolvido com mediação da justiça (p.55).

Já Rodrigues (2014) em Novo Airão - Amazonas, destaca os conflitos fundiários decorrentes de comunidades que são retiradas de áreas onde são instaladas unidades de conservação de proteção integral. Segundo o autor, esses passam a ocupar bairros periféricos, onde se veem impedidos de desenvolver suas atividades tradicionais, pois não tem acesso aos recursos que extraiam da natureza e perdendo "esse meio de produção acabam por não administrar o novo cotidiano" (p. 76).

Cruz $(2006 ; 2011)$ em pesquisas realizadas com os ribeirinhos de Cometá - Pará enfatiza que "as progressivas transformações da estrutura fundiária representam uma ruptura 
na dinâmica local de apropriação da terra". O autor discorre sobre os conflitos fundiários decorrentes da instalação de grandes empreendimentos, como a elevação do valor da terra.

Quanto ao acesso aos territórios tradicionais Cruz (2011) destaca a importância da organização social dos pescadores frente a essa problemática, enfatizando os "Acordos de Pesca" como instrumento de construção e afirmação da territorialidade dos pescadores. "Nesse sentido, os Acordos de Pesca significaram uma ameaça às fontes do poder que sustentavam essas formas de dominação, cujos "donos de beiradas", que se julgavam os "donos do rio", mantinham um total domínio sobre os recursos pesqueiros disponíveis nessas áreas, excluindo as comunidades mais pobres que ali viviam" (2011, p.224).

Guedes (2009) acrescenta que nos lagos ou corpos d'água localizados em terrenos particulares nas comunidades de Céu e Cajuúna, Soure - Pará os proprietários que são fazendeiros impedem o acesso de pescadores aos pesqueiros e, frequentemente, cobram pelas pescarias desenvolvidas em sua propriedade (131).

$\mathrm{Na}$ região Nordeste os conflitos fundiários, registrados nas dissertações e teses analisadas comprometem a permanecia das comunidades de pescadores em seus territórios tradicionais. Em Barreiras, Maranhão, Costa (2015) atenta que a valoração da terra tem intensificado os "conflitos referentes à posse da terra, com casos de ocupações e processos judiciais de desocupação e/ou negociações por parte do poder público municipal" (p.204). Assim, o autor também entende que os conflitos decorrem de alterações substanciais nos padrões de propriedade e posse da terra, cujas motivações se relacionam com necessidades locacionais da atividade turística, fundos especulativos como reservas de valor, participação de investidores estrangeiros, etc. (p.211).

Já Lima (2002) ressalta a situação de insegurança que vivem as comunidades de pescadores devido a inexistência de titularidade da terra. Essa realidade brasileira se agrava diante "do poder dos grileiros, dos especuladores e empreendedores turísticos (interessados em enseadas, falésias, campos de dunas e praias para abrigar e laurear resorts e hotéis) que agem para garantir a posse de terras, mediante o registro de falsas escrituras, de indevida cessão de usucapião, de avanços de marcos e cercamentos de áreas de uso em comum e de compra de posses por valores irrisórios" (p. 205). Costa (2010) traz o exemplo de Acapuí, Ceará, onde houve a elevação dos preços praticados na venda de imóveis de em média de $1000 \%$ em uma década. Segundo o autor, esse incremento incorre em conflitos e em grilagem de terras à beira mar. Destaca casos em que a comunidade resiste e consegue provar a ilegalidade dos documentos de propriedade apresentados por empreendedores (p.78). 
Rios (2012) enaltece esses processos de mobilização das comunidades em defesa dos seus territórios tradicionais. A autora ressalta que em São Francisco do Conde, Bahia o caminho adotado para a resistência tem sido a demarcação e titulação dos territórios quilombolas. Essa conquista foi importante para conscientizar "dos direitos por parte dos pescadores(as) artesanais na luta e defesa de seus territórios" (p.228).

Na região Sul, Machado (2013) também relata a expulsão de pescadores artesanais de suas residências, por não terem o documento que comprova a titularidade da terra. Esse processo em Barra Velha, Santa Catarina se dava com a ação dos "grileiros", os quais "regulamentavam as posses para eles ou a quem lhes desejasse, e obrigavam as pessoas a sair ou a vender pelo valor que eles oferecessem. Sem o conhecimento das leis, as pessoas acabaram cedendo" (p.66).

Barbosa (2014) relata que nos anos 1980 na Ilha do Superagui, Guarapeçaba, Paraná os moradores de "Barra de Ararapira enfrentaram a invasão da Companhia Agropastoril Litorânea do Paraná que, alegando possuir documentos de propriedade na região, pretendia ali abrigar criações de búfalos". Contudo, a intenção era "utilizar os animais para afastar a população e construir um grande empreendimento imobiliário”. A população, no entanto, resistiu e cercou "seu território e desafiaram, com suas foices e facões de lavradores, capatazes armados" (p.136)

Farias (2009) destaca conflitos fundiários decorrentes da instalação Unidades de Conservação. Ressalta "que grande parte das populações - caiçaras, ribeirinhos, seringueiros, quilombolas etc. - ocupam as terras, que passam a fazer parte do território das UCs há muito tempo e não possuem registro legal de propriedade privada, pois, anteriormente, seguiam formas de relação e de ocupação do espaço definidas apenas pelo local de moradia como parcela individual e o uso comum do solo na parcela restante da área habitada, regulamentado pelos costumes locais e por normas compartilhadas internamente" (p.63).

Na região Sudeste Camargo (2013) problematiza sobre os impactos dos conflitos fundiários estabelecidos entre especuladores, construtoras e antigos posseiros, muitos deles caiçaras. O autor destaca as tentativas da elite, por meio de suas influências políticas, de desapropriar os posseiros da Praia do Sono, em Paraty, Rio de Janeiro.

Já Ferreira (2013) destaca que na Ilha do Governador, Rio de Janeiro, a Colônia de Pescadores Z-10 convive não só com “conflitos em relação à valorização da área, mas à ocupação histórica irregular e ainda ao fato de historicamente estar situada em área da Marinha que foi recentemente passada para o controle da Prefeitura”. As incertezas têm reforçado a 
necessidade dos moradores se agarrarem à história de institucionalização do espaço pela Marinha (p.154).

Na região Centro-Oeste, Prado (2015) destaca que no município de Antônio de Leverger, Mato Grosso, “após a divisão da terra em chácaras não se pode mais pescar nos lugares onde se pescava, pois, os donos das chácaras não permitem mais pescar nesses locais". Isto se agrava por que esses proprietários de terra fizeram de suas chácaras pesqueiro, então "também estão colocando tablados do outro lado do rio, à margem das fazendas para alugar, entrando em conflito com os camponeses ribeirinhos que colocam seus tablados nesse local". $\mathrm{O}$ autor entende que nesse contexto tem se dado os conflitos e disputas por espaço e consolidação dos territórios (p.27).

\section{Turismo}

O segundo conflito por território mais citado é a atividade turística. Logo, refere-se à instalação de grandes empreendimentos turísticos sobre ou próximo das comunidades de pescadores artesanais. Em casos mais graves, as comunidades são expulsas para a instalação de resorts e outros empreendimentos. Em outras situações o aumento do valor da terra e dos serviços básicos do entorno, progressivamente, pressiona os pescadores a venderem os seus imóveis e se alocarem em regiões mais periféricas. Também há conflitos por territórios dos pesqueiros tradicionais, por que a "privatização" das praias, com a instalação de empreendimentos à beira mar que impedem a passagem dos pescadores, inviabiliza o acesso ao território pesqueiro. Ressalta-se que, quando a comunidade se mantém, o turismo como atividade de mercado transforma a paisagem comunitária em uma mercadoria a ser consumida. Isso interfere nas dinâmicas sociais e nos modos de viver das comunidades.

A grande maioria dos conflitos por territórios com empreendimentos turísticos presentes nas dissertações e teses analisadas ocorreram na região Nordeste. Paula (2012) em Fortaleza, Ceará enfatiza que os espaços litorâneos despontam como "objeto de desejo para grupos de elevado poder aquisitivo no estabelecimento de residência fixa e/ou no usufruto de suas amenidades durante o desenvolvimento de atividades de lazer, recreação e descanso, tais como a vilegiatura marítima e o turismo litorâneo" (p.19) contrastando com os usos do território estabelecidos pelas comunidades de pescadores artesanais". Logo, a atividade turística tem gerado fortes conflitos em diversas comunidades pesqueiras, pois a "ligação dessa atividade com dinâmicas produtivas globais incide sobre as comunidades onde se instala com valores e 
formas de organização distintas das que seu modo de vida requer estabelecer" (COSTA, 2010, p.69).

Tais conflitos, como aponta Figueiredo (2013) analisando Canavieiras, Bahia se dão em terra e mar. Nos territórios das comunidades, os investimentos em turismo também promovem a especulação imobiliária e intensifica a grilagem de terras da União para a instalação de empreendimentos hoteleiros. Atinge os pesqueiros quando são fechados os acessos aos mesmos (praia e manguezal), devido às cercas que são instaladas nos empreendimentos (MACHADO apud FIGUEIREDO, 2013, p. 83). Entretanto, como salienta Costa (2015) em pesquisa realizada no Maranhão "esse processo não se dá sem conflitos, uma vez que as pressões se intensificam sobre um espaço cada vez mais raro (...) evidenciando as contradições desses novos usos instalados no litoral" (p.47).

Lima (2002) ressalta que no Litoral do Ceará a "atividade turística se beneficia cada dia pelas belezas naturais, deixando à margem os modos de vida dos camponeses haliêuticos, que foram transportados para outro lugar" (p.20). Em outros casos, como ressalta Nunes (2011) a comunidade permanece, pois há a venda e consumo da paisagem das comunidades. No povoado do Mosqueiro, Aracaju, Sergipe "foi construída uma orla que ocupa o lugar de embarque e desembarque das canoas dos pescadores" (p.52). Já em outros contextos, como o que é apresentado por Cavalcante (2012) em Cumbuco e Caucaia, Ceará, considera-se que a presença da comunidade desvaloriza a atividade turística. Segundo a autora "a venda da imagem de uma pequena vila de pescadores e seu modo de vida específico está se tornando impraticável”, pois a vila que por muito tempo foi a catalizadora do veraneio e turismo passa então a ser encarada como um problema, pois a atividade turística se desvinculou da "venda" da antiga imagem do local e agora visa a construção de uma imagem "Cumbuco consolidado por um turismo de alto nível e um veraneio composto por grandes condomínios, além de toda uma infraestrutura que vem em auxílio desses grandes investimentos hoteleiros e imobiliários” (p. 119).

Os casos de resistência das comunidades também são apresentados nas dissertações e teses analisadas. Rios (2012) destaca que por meio da mobilização das comunidades os pescadores conseguiram frear a instalação de um complexo turístico de grande porte na Ilha de Cajaíba, São Francisco do Conde, Bahia (p.220). Dumith (2012) enaltece que, frequentemente, a administração municipal, bem como associações relacionadas ao turismo são contra a instalação de Reservas Extrativistas, pois essas unidades de conservação inibem o avanço dessa atividade econômica sobre as comunidades (p.154). 
Cabe frisar a relação da atividade turística com outras atividades econômicas. Rodrigues (2005) ressalta que "o turismo dotou Aracati de infraestrutura para transporte, energia e comunicações que, associada às outras condições socioeconômicas, locais e externas, favoreceram a implementação da carcinicultura. Atualmente, o cultivo de camarões imprime em Aracati uma especialização territorial produtiva que se consolidou a partir dessa série de condições socioeconômicas" (p.19).

Antes de encerrar essa análise na região Nordeste é necessário fazer uma distinção no que se refere ao turismo comunitário. Em Icapuí, Ceará projetos foram desenvolvidos em comunidades pesqueiras como propostas de enfrentamento ao avanço dos grandes empreendimentos turísticos no litoral. Segundo Costa (2010) "a proposta de hospedagem domiciliar apresentada pelo projeto "Em Cada Casa uma Estrela" se mostra com relevante papel na difusão do turismo comunitário como possibilidade" (p.69).

Na região Sul, Machado (2010) apresenta o processo do avanço do turismo sobre as comunidades pesqueiras em Barra Velha, Santa Catarina. Segundo a autora, na medida em que a cidade cresceu e se articulou com a indústria do turismo, houve a sobreposição do espaço turístico do espaço tradicionalmente ocupado pelos pescadores. "E mesmo com esse crescimento da cidade e a pressão do turismo massificado, os pescadores resistem. Resistem porque dependem daquele território como base de subsistência e também por possuírem vínculos com o lugar" (p.102). No Parque Superagui, Paraná, Farias (2009) distingue os moradores que são beneficiados pelo turismo, que são proprietários de pequenas pousadas e restaurantes, dos empreendedores que não tem nenhuma relação com a cultura caiçara, gerando conflito de interesses de ordem econômica, social e cultural (p.98).

\section{Unidade de Conservação}

As dissertações e teses analisadas evidenciam conflitos entre Unidades de Conservação e comunidades de pescadores artesanais. Esses conflitos ocorrem porque essas unidades são implantadas sobre territórios tradicionais de comunidades de pescadores. Nas unidades de conservação de proteção integral (exemplo: Parques, Reservas Biológicas, etc.) os conflitos são mais intensos, pois proíbem a presença das comunidades em seus limites. Soma-se a isso a proibição de uso dos recursos, proibindo o acesso aos pesqueiros tradicionais. As unidades de conservação de uso sustentável possibilitam a presença das comunidades no seu interior, contudo, os usos são sujeitos às normas presentes nos planos de manejo. Entre as categorias de uso sustentável, os conflitos são menos intensos, possuem Conselho Deliberativo (Exemplo: 
Reservas Extrativistas, Reservas de Desenvolvimento Sustentável, Florestas Nacionais, etc.) que envolvem mais as comunidades na construção das regras, e essa participação reduz a incidência de conflitos.

Na região Sul, De Paula (2013, p.76), no Delta do Jacuí, Porto Alegre, Rio Grande do Sul, ressalta que os pescadores artesanais estão em constante conflito com Unidades de Conservação estaduais e federais. Segundo o autor "Estas áreas integravam territorialidades importantes para os pescadores que estavam presentes desde muito antes da instituição dessas unidades de conservação". Os principais conflitos relatados pelos pescadores dizem respeito a proibição de ancorarem dentro das unidades quando ocorrem tempestades, proibição de pescar, e questões fundiárias quando as residências estão dentro da área da unidade. Como destaca Chamas (2008) as comunidades tradicionais veem frequentemente seu território ser ocupado. No caso da Ilha do Campeche no passado foi ocupado por um grupo organizado que tomou o “espaço que tradicional e informalmente era usufruído por pescadores artesanais dos arredores, há muitas gerações”, na atualidade se veem inseridos em uma unidade de conservação (p.92).

Farias (2009) e Barbosa (2014) relatam os conflitos estabelecidos entre o Parque Nacional Superagui, Paraná e as comunidades de pescadores. Segundo Barbosa (2014) as restrições se estenderam sobre as práticas e tecnologias tradicionais que "se constituem como elementos identitários essenciais à construção da identidade local, como as formas de construção de casas, embarcações, roças, caça, dentre outros aspectos”. A autora ressalta que frente às proibições "as comunidades tiveram que intensificar as atividades que gerassem algum tipo de renda para a compra de alimentos que agora precisam ser trazidos dos centros urbanos" (p.142). Como frisa Farias (2009) "Grande parte dos conflitos emergentes em UCs reflete a falta deste plano e motivam a reflexão sobre o modelo de conservação da natureza adotado e, que é enfático em nosso país, por evidenciar o modelo norte americano de proteção, desconsiderando a população nativa" (p.70). Esse contexto é apresentado por Scheibel (2013) que destaca que a implantação do Parque Nacional dos Campos Gerais poderá ser determinante e impedir e/ou proibir parcial ou totalmente a pesca em toda a área do parque (p.95).

Na região Nordeste, Costa (2015) também ressalta os impactos resultantes da instalação de Parques Nacionais. Com base em pesquisa realizada no Parque Nacional dos Lençóis Maranhenses relaciona as limitações impostas ao uso das Unidades de Conservação que provocam conflitos, tanto sobre populações que vivem na área, quanto pelos que estão presentes nas zonas de amortecimento e áreas de entorno. 
Ainda na região Nordeste, cabe ressaltar a presença de Unidades de Conservação de uso sustentável como Reservas Extrativistas, e, inclusive Reservas Extrativistas Marinhas. Com base em pesquisa realizada em Canavieiras - Bahia Dumith (2012) enfatiza que nos últimos anos as comunidades pesqueiras artesanais vêm requisitando cada vez mais RESEXs Marinhas. Essas possuem como "princípios teóricos norteadores básicos a sustentabilidade socioecológica, o princípio da precaução, a cogestão adaptativa, a junção dos conhecimentos ecológico e científico, usos tradicionais de múltiplos recursos e processos participativos transescalares" (DIEGUES, 2008 apud DUMITH, 2012, p.66).

Rosário (2009), pesquisando comunidades que integram a da Reserva Extrativista Baía do Iguape em Maragogipe, Bahia, atenta que no âmbito dos espaços de participação da unidade é necessário que as comunidades assumam uma postura ativa, frente aos diversos atores que compõem o Conselho Deliberativo.

Na região Sudeste Cardoso (1996) e Scheibel (2013) expõem os conflitos decorrentes da instalação de Parques Nacionais sobre comunidades de pescadores. Como destaca Cardoso (1996) “muitas das áreas abrangidas pelos Parques fazem parte dos espaços utilizados pelas comunidades caiçaras para a feitura de suas roças, para a caça, para a extração de madeiras e fibras vegetais e mesmo para suas áreas de moradia”. O autor ressalta os conflitos estabelecidos entre comunidades de pescadores e gestores do parque, que impõem restrições de uso que impactam os modos de viver tradicionais das comunidades (p.34).

Na região Norte, Rodrigues (2014) ressalta que em Novo Airão, Amazonas, “a implantação de diversas unidades de conservação produziu uma nova espacialidade dos espaços de uso e proteção com a criação ante ao marco legal do ideário ambiental, em prejuízo ao modo de vida dos moradores que são tratados genericamente como antrópicos (p.37).

\section{Especulação Imobiliária}

A especulação imobiliária constitui um conflito que atinge principalmente o território onde estão instaladas as comunidades de pescadores artesanais. Os desígnios do capital avançam sobre o território ocupado pelas comunidades tradicionais, no contexto de (re)produção do espaço urbano. Contudo, a presença das comunidades representa um entrave para tal avanço, de modo que o aumento do valor da terra vai pressionando os pescadores, que são na maioria das vezes posseiros, a venderem seus imóveis. As mudanças que vão ocorrendo devido a instalação de empreendimentos imobiliários vão progressivamente descaracterizando o território, os serviços que são instalados para a nova população residente não são acessíveis 
para as comunidades, e assim os comunitários vão procurando outras áreas onde encontrem condições mais adequadas para a sua reprodução social.

Carlos (2015) esclarece que no processo de mundialização (relação global/local) decorre o movimento de produção do espaço urbano da passagem da hegemonia do capital produtivo industrial para o capital financeiro. Este último se realiza através dessa reprodução, produzindo "um novo espaço" sob a forma de "produto imobiliário". "Nesse momento, a mercadoriaespaço mudou de sentido com a mudança de orientação (prioridade) das aplicações financeiras: da realização do ciclo industrial da mercadoria à produção do imobiliário" (p.26). A autora destaca que o Estado - através do poder local -, intervém no processo de produção da metrópole. Para isso, reforça a hierarquia dos lugares, "criando novas centralidades, expulsando para a periferia os antigos habitantes, recriando um espaço de dominação e impondo sua presença em todos os lugares, agora sob controle e vigilância (seja direta ou indireta)" (p.27). Contudo, esse processo não se dá sem lutas:

As lutas surgem a partir de relações sociais contraditórias, criadas e aprofundadas pelo desenvolvimento do processo de reprodução lato sensu, o que faz com que as batalhas se resolvam pelo jogo político das forças sociais. Isso tem colocado, no centro do debate, o direito à cidade como possibilidade de questionamento sobre as formas de atuação do poder público - em que o espaço se revela instrumento político intencionalmente organizado e manipulado por meio de um poder que se realiza enquanto estratégia de classe -, bem como diante das condições de vida precarizada. Questiona-se, assim, o processo de valorização aliado às estratégias dos empreendedores imobiliários que reproduzem um espaço voltado aos interesses particulares do grande capital, e que, ao intervirem no urbano, interferem na prática socioespacial e, com isso, nos modos de apropriação do espaço da vida (CARLOS, 2015, 34).

Na região Nordeste, Figueiredo (2013) atenta que em Canavieiras, Bahia, os próprios investimentos em turismo levaram a intensificação da especulação imobiliária. No entendimento de Lima (2002) desde a década de 1980 a modelo de desenvolvimento socioeconômico nordestino passou a pressupor a valorização e a ressignificação da zona costeira e seus atrativos para o turismo. Assim, a autora entende que o litoral passa a ser um mercado, o que fez emergir conflitos entre comunidades e empreendedores imobiliários.

A elevação dos preços dos terrenos aparece como um dos principais fatores que provocaram a retira das famílias de pescadores por pressão da especulação imobiliária. Segundo Costa (2015), consequentemente, há o deslocamento das comunidades, uma vez que há a "alteração do valor das moradias à beira-mar, alimentado por um processo especulativo de valorização que transforma lentamente os loteamentos em investimentos para a classe média e 
intensifica a urbanização litorânea". Assim, o autor destaca que "ruas fantasmas próximas à praia constituem a paisagem de muitos lugares antes ocupados por comunidades de pescadores e que passaram a se configurar como lugar de veranistas, onde as segundas residências predominam" (p.48).

Para Costa (2010) "conflitos por terras em comunidades pesqueiras e a compra de áreas próximas ou mesmo nas praias para loteamento tem elevado o preço dos terrenos, favorecido à especulação imobiliária e, cada vez mais, forçando parte dos habitantes das comunidades pesqueiras a se retirar de seu espaço" em Acapuí, Ceará (p.42). Moraes (2010) também entende que a "especulação imobiliária com a busca de espaços para instalação de hotéis, pousadas e restaurantes à beira-mar houve uma supervalorização dos imóveis, prejudicando a vila dos pescadores" em Cumbuco, Ceará. Desta forma, a autora associa o turismo e especulação imobiliária como impactantes no litoral devido a "supervalorização de áreas, desapropriação dos moradores nativos e descaracterização do ambiente natural de moradia e trabalho da comunidade local ou tradicional” (p.100).

Nunes (2011) aponta que frente à especulação imobiliária as comunidades resistem. A autora ressalta que "o processo de urbanização e especulação imobiliária hoje privatiza os espaços que correspondem ao Povoado Mosqueiro, o que diminui e mesmo impede a coleta de frutas, o cultivo de roçados e de pequenos animais e o próprio acesso dos pescadores a algumas partes da margem do rio" (p.51).

Na região Sudeste, Ferreira (2013) destaca os conflitos na Ilha do Governador, Rio de Janeiro entre "ocupação histórica - que se deu por concessão e mediante o controle da Marinha, e apesar de não estar mais na área dessa instituição ainda mantém um estreito relacionamento com a mesma, como herança de outros tempos" e especulação imobiliária, com a valorização da terra e atração de novos moradores, que "também estão sendo influenciados por processos de urbanização do presente e por aquelas que buscam abrigar-se longe da violência, tão comum na cidade" (p.80).

Na região Sul, Machado (2010) destaca que em barra Velha, Santa Catarina incorporadores imobiliários aliados aos cartórios de registros de imóveis pressionaram os moradores posseiros, apresentando-se como donos dos imóveis. Segundo a autora, eram feitas propostas de baixo valor e abusando da falta de conhecimento jurídico das pessoas, as convenciam a vender os lotes. Assim, “A praia da Península, que por décadas, abrigou a antiga vila de pescadores (também pertencente à Colônia Z4), com a valorização imobiliária e o loteamento da prefeitura, tornou-se, por um tempo, área nobre da cidade” (p.66). 


\section{Comercialização}

A comercialização de pescado também é considerada uma atividade que provoca conflitos por território na pesca artesanal. A pressão dos comerciantes sobre os pescadores para o aumento da oferta de pescado provoca a submissão dos pescadores ao mercado. Isto interfere nas relações entre pescadores artesanais e destes com seus territórios tradicionais. Na cadeia produtiva se evidenciam outras razões desses conflitos. Frequentemente se evidencia a figura do atravessador, este detendo o capital oferece os meios necessários para o exercício da pesca. Em troca disso, exige exclusividade para a compra e ofertas constantes de pescado, o que leva os pescadores a descumprirem regras elaboradas nas comunidades, implicando em conflitos nos territórios pesqueiros.

Na região Norte, a comercialização de pescado é apontada como uma das maiores geradoras de conflitos no território pesqueiro. Cruz (2007) aponta que há "um processo de monopolização do território pelo capital monopolista na várzea de Manacapuru, pois sua lógica é a permanência dos camponeses-ribeirinhos, os quais agora têm como objetivo produzir pescado para esses capitalistas" (p.188). Abreu (2010), também no Baixo Rio Solimões, Amazonas, destaca que há uma complexa rede de empresários que tem a prerrogativa de sugar a renda proveniente do pescado. Segundo o autor, a indústria monopoliza o território e "drena a renda proveniente da água efetivada pelo trabalho dos pescadores" (p.77).

Nesse contexto, Cruz (2007) destaca que o não desaparecimento do "camponêsribeirinho" se deve a estes serem imprescindíveis às empresas de pesca. Queiroz (2012) complementa que na comercialização do pescado, os pescadores não são expropriados, pois são os maiores conhecedores da atividade pesqueira.

Já Guedes (2009) entende que pressões externas que cobravam maior quantidade de pescado e a pesca industrial inseriram na atividade pesqueira artesanal "um conjunto complexo de padrões e comportamentos, marcado por valores de mercado, impondo uma relativa reestruturação dos antigos valores éticos tradicionais, historicamente, estabelecidos pelas populações tradicionais de pescadores" (p.124).

Na região Nordeste, Queiroz (2011) destaca que em Ilhéus - Bahia, os principais agentes de circulação do pescado são os comerciantes. Segundo a autora, o fato do "pescador esperar pelos comerciantes favorece a ação dos atravessadores que adquire o pescado a preços baixos revendendo o produto a estabelecimentos comerciais". Assim, no caso de Ilhéus, a falta de 
meios para o transporte do pescado representa uma deficiência estrutural nesta etapa do circuito produtivo (distribuição) que submete o pescador ao atravessador (p.60).

Kuhn (2009) em São Francisco do Paraguaçu, Cachoeira, Bahia apresenta uma situação semelhante, onde se a presença de uma rede complexa de negociação expõe atravessadores em diversas escalas da comercialização. Segundo a autora, "é nesse jogo de intermediação que boa parte da renda obtida pelos pescadores artesanais com a produção de pescado é apropriada por outros. É nesse embate com o mercado que o pescador é expropriado da riqueza que produziu com a sua força de trabalho e com o seu conhecimento" (p.104).

Na região Sul, Santana (2013) destaca que no Estuário da Laguna dos Patos, Rio Grande do Sul os pescadores artesanais são explorados pelos atravessadores que "compram o pescado por um preço muito abaixo do valor de mercado, apropriando-se do trabalho excedente". A autora acrescenta que "Essa subordinação está ligada, em alguns casos, apenas no nível da comercialização e em outros, também no próprio processo de trabalho, com o endividamento do pescador junto ao intermediário, antes mesmo de possuir algum produto". Neste contexto também se evidencia que a associação da pesca ao capital não representa o fim da pesca artesanal, pois a continuidade da mesma, de forma precária, servindo como mão de obra explorada pelo capitalista (p.94).

Ferreira (2014) também entende que esse é um dos graves problemas enfrentados pelos pescadores do Lago Itaipu, Paraná, quando os intermediários se apropriam da renda dos pescadores. A autora entende que é "preciso fazer com que a cadeia de produção se estruture no sentido de capacitar e fortalecer os pescadores artesanais. Com mais autonomia no processo produtivo, os pescadores teriam condições de vida mais dignas" (p.164).

Na região Sudeste, Cardoso (1996) entende que a circulação do pescado aparece como entrave para a reprodução da pesca artesanal. $\mathrm{O}$ autor identificou, em pesquisa realizada com caiçaras no Litoral Paulista, que o sistema de intermediação reduz drasticamente a renda dos ilhéus. Essa subordinação é menos intensa quando os pescadores buscam realizar a venda direta do pescado, mas em períodos de maior oferta de peixe há necessidade de vender para as peixarias (p.70). Cardoso (1996) ressalta que a problemática da comercialização tem impedido que os pescadores obtenham sua subsistência unicamente pela pesca, sendo assim, buscam outras atividades. 


\section{Pesca Artesanal}

Os conflitos por território na pesca artesanal também estão presentes nas dissertações e teses analisadas. É importante enfatizar que, embora sejam conflitos entre pescadores, na maioria das vezes são decorrentes de outros contextos que provocaram mudanças no território. Neste momento, as mudanças não são de ordem ambiental, mas se referem às relações sociais. Todo um contexto de acordo que existe nas/entre comunidades é rompido e emergem conflitos.

$\mathrm{Na}$ região Norte, os conflitos entre pescadores artesanais são frequentemente apresentados. Cruz (2011) analisando os acordos de pesca em Cometá, Pará, ressalta que os conflitos por território na pesca não se restringem aos "de fora", mas muitos são "internos nas próprias comunidades implementadoras dos acordos, não raramente havendo um alto grau de tensão no que se refere à fiscalização e punição daqueles pescadores que transgridam as regras comunitárias construídas coletivamente" (p. 307). Guedes (2009) ressalta que muitas vezes os conflitos ocorrem por que os pescadores artesanais utilizam os pesqueiros próximos às suas residências. Logo, entram em conflito com os pescadores "de fora" e pescadores comerciais que disputam esses territórios (p130).

Silva (2006A) ressalta a gravidade desses conflitos que resultam até em assassinato de pescadores. No caso de Augusto Correia, Pará Silva (2012A) enfatiza que os conflitos por territórios pesqueiros foram reduzidos por meio do estabelecimento de Acordos de Pesca. O autor destaca que sendo elaboradas pelos próprios membros das comunidades passam a vigorar em um contexto de contrato social (p.164).

Uma das razões dos conflitos por territórios na pesca é a imigração de pescadores de outras regiões que entram em choque com os pescadores locais (CRUZ, 2006. p. 131). Lima (2008) ressalta que em Belém do Pará "pescadores artesanais estão se deslocando mais intensamente para outros locais de pesca dentro do próprio estuário, que além de ser "sacrificante", também gera conflitos com os pescadores destas áreas que os percebem como intrusos ou "pescadores de fora" por utilizarem seus recursos" (p.33).

Na região Nordeste, os conflitos entre pescadores nos territórios pesqueiros, costumam ocorrer prioritariamente pelo descumprimento das normas estabelecidas pelas comunidades como destaca Galvão Neto (2009) em Canguaretama, Rio Grande do Norte. O autor entende que essas normas "viabilizam uma melhor convivência entre os membros do grupo". No caso das regras de uso das estruturas de apoio à pesca, quando são desobedecidas ou não são reconhecidas por pescadores de outras comunidades, incidem em conflitos (p. 83). 
Silva (2012B) traz um exemplo importante que gera instabilidade e conflitos nos territórios pesqueiros. Em Lucena, Paraíba, a autora ressalta que as normas da legislação ambiental não são compreendidas de forma uniforme pelos comunitários. Em decorrência disso, emergem desentendimentos que resultam em conflitos pelas formas de uso do território pesqueiro (p.91).

Na região Sul, os conflitos por território na pesca artesanal também são estabelecidos entre pescadores locais e pescadores de outras regiões. De Paula (2013) destaca que os pescadores do Delta do Jacuí veem os pescadores do Estuário da Laguna dos Patos como "invasores". Isso "tem mobilizado essa comunidade na busca do impedimento da presença desses”. Soma-se a isso a presença de legislações ambientais distintas para os dois grupos, logo, os pescadores locais "se vêm ameaçados, sobretudo, durante a piracema da região quando são impedidos de pescar, mas observam a prática da pesca por pescadores de outras regiões" (p. 76).

Ferreira (2014) destaca conflitos entre pescadores "profissionais e pescadores clandestinos" no lago Itaipu, Paraná. Esse conflito se dá por que a Colônia de Pescadores entende como pescadores artesanais somente os registrados na mesma. Segundo a autora, o "pescador clandestino" "é totalmente invisível para o governo, para a sociedade e sobretudo para os próprios pescadores cadastrados, que os querem longe do Lago por não pagarem os deveres" (p.114).

Na região Centro-Oeste, Prado (2015) ressalta que os conflitos entre pescadores foram reduzidos por meio de acordos comunitários. $\mathrm{O}$ autor ressalta que esses acordos se basearam em regras de manejo e não em proibição da pesca. Contudo, o autor crítica que o Estado, como mediador do Acordo de Pesca, buscou garantir que o acordo não abordasse o modelo de propriedade privada ou discutisse questões que poderiam perturbar a ordem dos interesses econômicos (p.48).

\section{Representatividade}

As organizações sociais que representam os pescadores artesanais também promovem conflitos nos territórios pesqueiros. Esse conflito impede o diálogo entre pescadores quando cria oposições e cisões no grupo. Consequentemente, reduz a representatividade dos pescadores em discussões com outros grupos e com o Estado.

Na região Nordeste, Alves (2015) expõe a complexidade dessas oposições que são estabelecidas entre instituições que representam os pescadores artesanais em Veracruz, Bahia 
"Em vista às relações políticas que se encontram entre os Pescadores x Colônias; Pescadores X Associações; Pescadores x Sindicato; Sindicato x Colônias; Colônias x Associações; e Cooperativa $\mathrm{x}$ Pescadores percebeu-se disputas de poder e autonomia sobre a atividade no município" (p.125).

Kuhn (2009) no caso do conflito entre Colônias e Associações de Pescadores em São Francisco do Paraguaçu, Cachoeira, Bahia, entende que foi estabelecida uma dicotomia que "reflete o processo histórico em que foram instituídas as entidades representativas dos pescadores" (p.88). Em relação às Colônias de Pescadores, (SILVA, 2012B) concluiu que, em Lucena Paraíba, essas instituições são falhas na representação dos pescadores. Observou que os presidentes dessas instituições "Quando não são despolitizados, alheios aos seus direitos, deveres e poder de reivindicação, não querem se envolver com questões políticas porque se sentem incapazes de mudar o que está posto". Contudo, a autora não nega que "Uma pequena minoria milita em prol da causa coletiva ou individual, mas são enfraquecidos pela maioria inerte e pelas corrupções" (p.106).

Na região Sudeste, Rainha (2015) expõe a relação conflituosa entre Colônias e associações de pescadores na Pedra de Guaratiba, Rio de Janeiro. Segundo o autor, esse conflito "vem causando sérios problemas no processo de construção da legitimidade necessária ao fomento de uma pauta reivindicativa e política concisa que os fortaleçam na luta pelo direito ao trabalho e pelo seu pleno reconhecimento perante a sociedade". O autor entende que os conselhos diretivos dessas entidades "vem recebendo forte apoio financeiro dos grupos industriais locais para operar uma série de medidas as quais têm provocado graves consequências aos pescadores artesanais pertencentes ao seu quadro associativo” (p.117).

Também na Pedra de Guaratiba, Rio de Janeiro, Vinhas (2011) entende que os conflitos entre pescadores e colônias são frutos "da discordância de ideias mediante as políticas administrativas do poder público e a proposta da empresa" nas discussões sobre medidas compensatórias. O autor denuncia que a "forma como as medidas compensatórias são entendidas na Pedra de Guaratiba contribuem para a configuração territorial em multiterritórios". Sendo assim, articulações entre entidades e tentativas de fusão são algumas das estratégias dessas instituições de deter a representação social dos pescadores e, assim, determinarem o uso dos recursos financeiros (p.89)

Na região Sul, Maier (2009) destaca a importância da coesão social dos pescadores para a gestão do território. Com base em pesquisa no Estuário da Laguna dos Patos, Rio Grande do Sul, o autor quando há pouca coesão social ocorrem "conflitos tais como: locais de pesca, 
discordâncias pelo uso de redes de arrasto (principalmente pelos pescadores que migram), roubos, entre outros" (p.45).

\section{Urbanização}

A urbanização provoca conflitos por território na pesca artesanal na medida em que as cidades avançam e se sobrepõem áreas historicamente ocupadas pelas comunidades de pescadores artesanais e sobre pesqueiros tradicionais. Esse é um fenômeno que, frequentemente, é responsável pela remoção dos pescadores das suas áreas de origem, bem como pela inserção deles na lógica urbana e deterioração dos vínculos comunitários que é um dos pilares de sustentação dos territórios das comunidades.

Como destaca Carlos (2007) o momento atual revela:

Continuidades e descontinuidades que se combinam como consequência das transformações na relação espaço/tempo urbanos traduzidas nos "lugares da metrópole" sob a forma de rupturas de ritmo, da realização desigual do poder, das relações entre classes diferenciadas, que se traduzem em movimentos de construção e transformação, lidas na morfologia urbana e passíveis de serem apreendidas na vida cotidiana (onde aparecem sob a forma de conflito) (p.10).

Desta forma, a análise urbana também expõe uma situação de crise da cidade, que se expressa no "aprofundamento de velhas contradições, bem como da produção de outras novas, em um movimento triádico que surge enquanto persistências/ transformações/deteriorações dos lugares da vida" (p.11).

Rainha (2015) abordando a modernização no bairro Pedra de Guaratiba, Cidade do Rio de Janeiro, lembra que o urbano é produto da interação entre diversos grupos sociais e dos conflitos estabelecidos entre si. Assim, na produção e reprodução do espaço urbano os diversos agentes agem segundo suas estratégias. Desta forma, "a intensidade da ação desses agentes se dará de acordo com as oportunidades que lhes são permitidas (ou proibidas), levando assim, a vivência de uma experiência urbana plural, porém, segmentada e produtora da exclusão" (p.58).

Já Ferreira (2013) destaca a resistência da comunidade pesqueira para se manter no seu território na Ilha do Governador, Rio de Janeiro. Os núcleos residenciais onde estão os pescadores vêm sofrendo influências dos processos urbanos. Assim, o adensamento populacional acaba por invisibilizar o pescador dentro de classificações genéricas como “aglomerados urbanos" propostos pelo IBGE (p.71).

Na região Nordeste, Costa (2015) enfatiza que a urbanização litorânea tem como fator expressivo as segundas residenciais. "Essas habitações para uso esporádico, quase sempre 
destinadas ao veraneio ou outras formas de lazer, ganham volume a partir da expansão das classes médias urbanas que se configuram também a partir do crescimento do setor de serviços”. O autor destaca que os impactos são os "mais variados, destacando-se os conflitos nas comunidades litorâneas, quase sempre associados ao impedimento do acesso à praia por parte dos pescadores ou a imposição de barreiras que implicam na dificuldade desse acesso e da atracação de suas embarcações" (p.54).

Nunes (2011) destaca que em Aracaju, Sergipe, o processo de adensamento populacional na área de expansão da cidade encontra-se acima da média devido a fatores como o aumento de domicílios individuais, melhorias de vias de transporte, etc. Assim, altera-se o uso do solo e a comunidade, cuja característica era a atividade pesqueira, vê o urbano se impor sobre o seu modo de viver. Em decorrência disso, vivem pressionadas pelos agentes da especulação imobiliária e promotores do turismo (p.50).

\section{Industrialização}

A lógica de produção industrial é diferente do extrativista artesanal. Essa oposição se dá devido à subsunção do extrativista ao tempo da natureza, enquanto o industrial produz segundo as possibilidades da técnica/informação (SANTOS, 2009). Logo, a industrialização compete pelo território pesqueiro primeiramente quando se sobrepõe às áreas tradicionais de pesca, segundo, pela influência que causa nas comunidades atraindo trabalhadores que não compreendem o modo de viver das comunidades tradicionais, negam suas normas e seus saberes.

Na região Nordeste, Rios (2012) destaca que os "conflitos existentes na maioria das comunidades pesqueiras do estado da Bahia se dão pela inserção de atividades industriais nas áreas de uso das comunidades". A autora argumenta que devido às industrias terem lógica de apropriação da natureza, diferente das comunidades, acabam por comprometer a existência delas, por isso, ocorrem diversos conflitos (p.119).

Lima (2002) no litoral do Ceará, apresenta as graves consequências do avanço da industrialização sobre as áreas historicamente ocupadas pelas comunidades, com apoio da gestão pública, que está alinhada aos interesses do grande capital. A autora apresenta o exemplo na desapropriação de uma grande área, com base em um decreto estadual que declarou utilidade pública, para a construção do "Complexo Industrial-Portuário do Pecém, em São Gonçalo do Amarante, município litorâneo da região metropolitana de Fortaleza” (p.205). 
Na região Sudeste, Rainha (2015) enfatiza os conflitos em decorrência da reação dos pescadores aos danos causados ao meio pela siderúrgica. Apresenta a resistência dos pescadores artesanais à instalação e funcionamento do terminal da $\operatorname{TKCSA}^{9}$ (p.211).

\section{Aquicultura}

As atividades de aquicultura também são apontadas como geradoras de conflitos por territórios. Neste caso, o conflito se dá pelos pesqueiros tradicionais, seja pela proibição do uso ou pela restrição ao acesso dos mesmos.

Na região Sul, Pérez (2012) alerta para a instalação de empreendimentos de aquicultura em Guaraqueçaba, Paraná, inclusive com apoio da FAO. A autora entende que se trata de "privatização de áreas onde atualmente os pescadores artesanais pescam e utilizam para se alimentar e reproduzir suas vidas" (p.44). Ferreira (2014) entende que a formulação de políticas e investimentos na atividade aquícola expõe que "A lógica empresarial da aquicultura entra em conflito com a lógica artesanal da pesca e chama para a cena, novamente, a discussão do valor de uso e do valor de troca do espaço”. Em São Miguel do Iguaçu, Paraná, a autora observa que a aquicultura se desenvolveu nas áreas tradicionalmente usadas por pescadores artesanais, sendo que "na lógica da pesca artesanal, não podem existir cercas, embora existam territórios construídos a partir do conhecimento do espaço do lago" (p.154).

Na região Nordeste, Santos (2013) destaca os impactos da carcinicultura no estado do Ceará. A autora enaltece que "o que se observa a partir da realidade socioespacial são resultados negativos especialmente nos manguezais que sofrem impactos, muitas vezes, decorrentes dessas novas tecnologias aplicadas pelo grande capital e que visam, sobretudo, um lucro imediato". (p.39).

\section{Portos}

O avanço dos portos é apontado como causador de conflitos por território. Primeiro, porque provoca a remoção das comunidades que estavam tradicionalmente presentes no território. Segundo, por que gera áreas de exclusão da pesca que impede o acesso aos pesqueiros tradicionais.

Na região Sudeste esses conflitos são intensos. Vinhas (2011) destaca os conflitos resultantes da instalação do terminal da TKCSA na Baía de Sepetiba, Rio de Janeiro. Segundo o autor, o "primeiro porto privado da Baía de Sepetiba, o da TKCSA, trouxe conflitos com os

\footnotetext{
${ }^{9}$ TKCSA: Companhia Siderúrgica do Atlântico.
} 
pecadores artesanais, na medida em que criou uma área de exclusão da pesca, onde os pescadores não podem armar suas cercadas nem pescar do barco, diante do aumento pelo fluxo de navios que aumentou" (p.68).

Na região Sul, Martins (2002) apresenta a reestruturação produtiva que decorreu da instalação do complexo portuário-industrial em Rio Grande, Rio Grande do Sul. O autor ressalta que o porto somado à política que privilegiam o ritmo industrial em detrimento do ritmo da natureza favoreceu a presença de indústrias de beneficiamento de pescado, as quais propiciaram a intensificação da pesca industrial.

\section{Pesca Amadora e Esportiva}

As dissertações que apresentam a pesca amadora ou esportiva como causadora de conflitos por territórios expõem o argumento de que essas modalidades de pesca são priorizadas, seja pela administração pública ou por empresários. Assim, instalam-se empreendimentos sobre os pesqueiros tradicionais e restringe-se o acesso aos pescadores artesanais

Na região Nordeste, Figueiredo (2013) apresenta essa problemática em Canavieiras, Bahia. Segundo o autor, esse conflito tem destaque pelas condições ambientais de Canavieiras que favorece a presença de uma fauna aquática que causa interesse dos pescadores esportivos. Contudo, são áreas de pesca artesanal e o conflito se dá na concorrência entre essas duas atividades pelos pesqueiros.

Na região Centro-Oeste, Prado (2015) expõe a instalação de fazendas para a pesca esportiva em Santo Antônio de Leverger, Mato Grosso. Segundo o autor, as "cevas junto ao tablado são a realização da apropriação e uso privado do rio, pois onde se tem uma ceva fixa ninguém que não seja o dono ou alguém que ele autorizou ou alugou pode pescar". O argumento dos empresários é que a ceva exige investimento financeiros, o que, para eles, acaba por legitimar a apropriação e uso privados daquele local (p.54).

\section{Institucional}

Conflitos institucionais atingem os territórios quando apresentam entraves para os pescadores realizarem as suas atividades tradicionais. Esses costumam resultar da incapacidade das instituições governamentais de desempenharem as suas atribuições ou da falta de diálogo dessas com as comunidades. 
Na região Sul, Farias (2009) destaca problemas para as comunidades gerados em decorrência da instalação do Parque Superagui. Houve a desestabilização dos territórios tradicionais de uso, e a própria gestão apresenta entraves para a resolução de problemas como "regularização fundiária, de uso do solo, além dos problemas ambientais que comprometem a qualidade de vida da população caiçara e a conservação dos ecossistemas do Parque" (p.91).

Já Contato (2012) aponta que no Estuário da Laguna dos Patos, Rio Grande do Sul as comunidades de ilhéus, por estarem mais distantes dos centros urbanos não tem acesso às instituições governamentais. Essa é uma das causas apresentadas para a falta de efetividade de políticas públicas como o seguro defeso (p.55).

\section{Pesca Industrial}

O processo de modernização do setor pesqueiro favoreceu o avanço da pesca industrial sobre os territórios da pesca artesanal, implicando em conflitos. "A atividade pesqueira em todo o mundo experimentou um acelerado processo de crescimento durante todo o século $\mathrm{XX}$, especialmente a partir da década de 1960, com o desenvolvimento da pesca industrial" (AZEVEDO, 2012, p. 29 apud SANTANA, 2013, p.95).

\section{Geração de Energia}

Os empreendimentos de geração de energia entram em conflitos com os territórios das comunidades de pescadores artesanais quando avançam sobre seus territórios tradicionais. Santos (2013) relata os conflitos gerados pela instalação de empreendimentos de energia eólica em Acaraú, Ceará. A autora destaca que "entre os problemas enfrentados por esses moradores, destaca-se o avanço das dunas sobre residências e comércios de forma descontrolada e instalação de forma indiscriminada de aparelhagens para obtenção de energia eólica com ocupação de suas praias e dunas" (p.87).

\section{Normatizações}

As normas que impõem regras de uso também resultam em conflitos nos territórios tradicionais das comunidades de pescadores. Essas regras criadas de cima para baixo não consideram a organização social das comunidades e a relação diferenciada que estabelecem com a natureza. Santos (2013), em pesquisa realizada em Acaraú, Ceará destaca que "enquanto o Estado preocupa-se em manter "intocada a natureza”, o sujeito social pensa em suas horas de trabalho, e como vai exercê-lo para que não tenha o dissabor de se encontrar com um fiscal do 
Estado, e acabe sendo autuado, multado e tendo seus objetos e apetrechos de pesca apreendidos" (p. 69).

Nas dissertações e teses analisadas e especializadas (figura 55) ficou evidente a promoção de conflitos por territórios entre pescadores artesanais e agentes de outras atividades econômicas. O Mapa permite observar que essa abordagem dos conflitos por território é predominante nos trabalhos analisados, e tem maior distribuição no Brasil.

\section{GEOGRAFIAS DA PESCA ARTESANAL BRASILEIRA:}

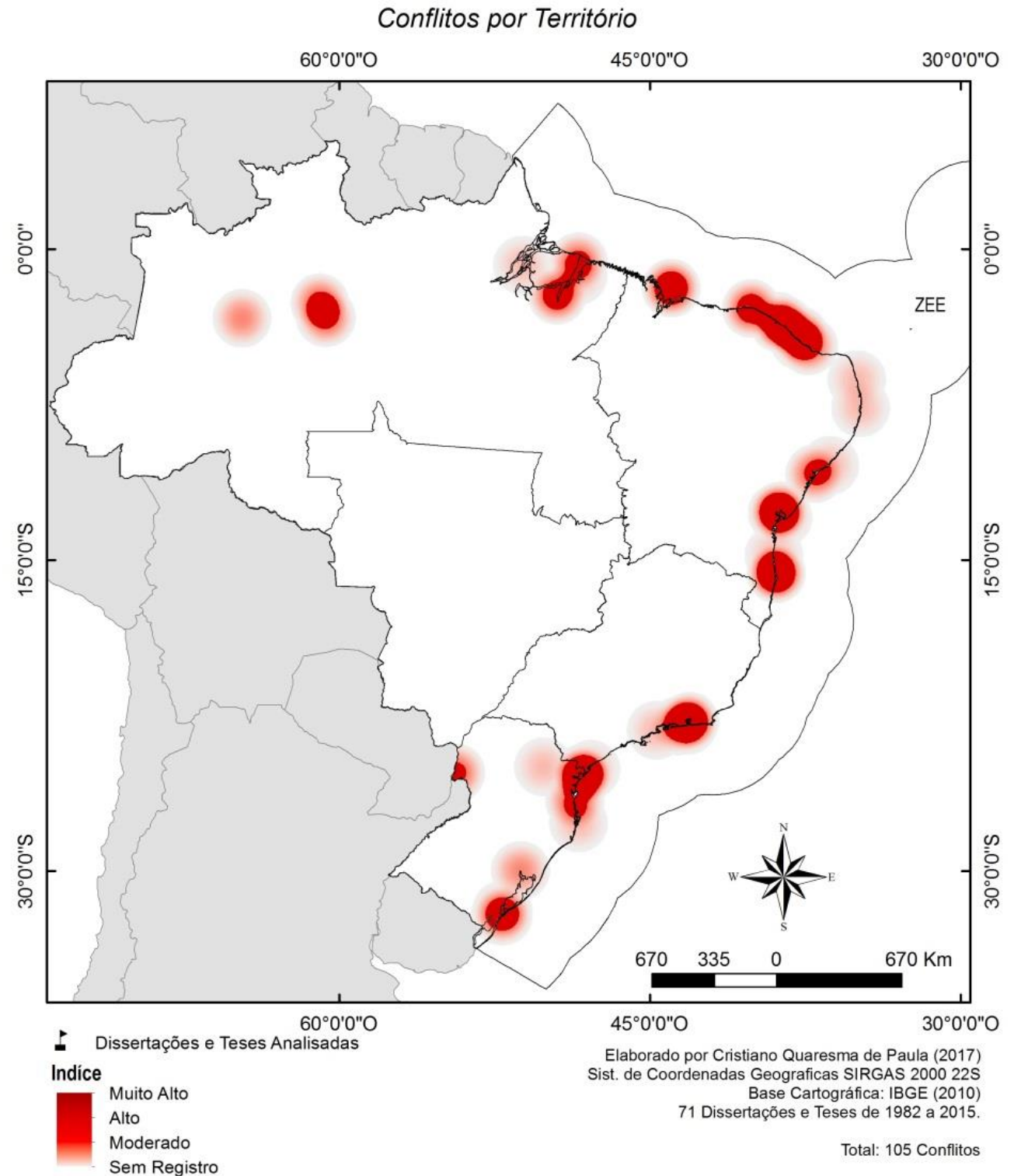

Figura 55: Mapa de Densidade de Conflitos por Território

Fonte: Elaborado por De Paula (2018) 
$\mathrm{Na}$ região Nordeste o Turismo é apontado como principal atividade que disputa territórios com as comunidades de pescadores. É evidente que a valorização da paisagem associada aos corpos d'água tem atraído grandes empreendimentos turísticos para a região, como resorts. Contudo, tal instalação tem impactado o modo de viver tradicional das comunidades e frequentemente a "privatização" das praias públicas tem inviabilizado a atividade pesqueira.

Estão associadas a essa atividade os conflitos fundiários e a especulação imobiliária. Sendo os pescadores posseiros, por iniciativa dos próprios Estado que visa a modernização, são desapropriados de suas terras e alocados em áreas periféricas da cidade, por vezes longe dos pesqueiros. Aqueles que resistem sofrem ofensivas diárias e a negação de serviços básicos, como abastecimento de água e luz. A especulação imobiliária também age nesses contextos, aumentando o valor da terra e promovendo o oferecimento de serviços que não são acessíveis aos comunitários até que os mesmos não tenham mais condições de sobreviver no local e aceitem vender a terra.

Também é apontado o agravamento de disputas internas na pesca artesanal. Como foi dito, a influência de atividades que propõe a modernização implica na erosão de "saberes tradicionais" e vínculos comunitários. Por consequência, existem casos em que os pescadores entram em conflito por territórios ou pela forma como o território é usado (esforço de pesca).

Cabe destacar também aos conflitos decorrentes da instalação de Unidades de Conservação sobre os territórios pesqueiros e os relacionados à representatividade social dos pescadores.

Na região Sul, esse conflito com Unidades de Conservação é o mais evidente nos trabalhos analisados. O estabelecimento dessas unidades impede a reprodução social do pescador em dois sentidos. Primeiro, tem seu modo de vida impactado com normas que são alheias ao lugar e, com raras exceções, não são consultados na elaboração das regras a que são submetidos. Segundo, porque o zoneamento das unidades costuma gerar áreas de exclusão da pesca, o que impede que os pescadores acessem pesqueiros que eram tradicionais.

Conflitos fundiários também ocorrem na região Sul, considerando que geralmente as áreas ocupadas pelas comunidades são "posses", o que lhes deixam sujeitos a desocupações em situações em que são propostos projetos públicos e/ou privados que prometem o desenvolvimento do potencial econômico do local.

Na região já começam a se evidenciar conflitos relacionados com a aquicultura. Projetos estão sendo propostos com apoio do poder público sobre os territórios pesqueiros ou muito 
próximos. A comercialização de pesca também gera conflitos, principalmente pela presença do atravessador na cadeia produtiva. Somam-se ainda conflitos institucionais, com entidades gestoras da pesca e do ambiente, e embates com projetos turísticos.

Na região Norte o principal conflito por território é fundiário. As comunidades resistem à grilagem de terras e desapropriação promovida por agentes privados e públicos que visam à instalação de grandes projetos na região Amazônica. Compreendendo que o território pesqueiro é agua "onde está o recurso pesqueiro" e terra "onde está a comunidade" essa problemática dialoga com aqueles que abordam a questão agrária, sobretudo a relação entre pequenos agricultores e latifundiários.

A comercialização de pescado e a pesca comercial também geram conflitos por territórios pesqueiros, na medida em que são alteradas as relações sociais entre os pescadores. Os comerciantes de pescado provocam cisões nas comunidades e subordinação dos pescadores como seus empregados. No que tange a comercialização a lógica do mercado vai progressivamente erodindo os saberes e práticas tradicionais. Logo, provoca alterações nos modos de viver dos pescadores, que vão sendo descaracterizados dentro da sua atividade e da sua comunidade.

Na região Sudeste, efetivamente, a urbanização chegou ao território pesqueiro, tanto que tem provocado em muitas pesquisas a discussão sobre o pescador urbano. As pesquisas apontam os conflitos estabelecidos entre território pesqueiro e a modernização do espaço. Neste sentido, além do avanço do tecido urbano e seus impactos cabe destacar os conflitos entre indústria e comunidades de pescadores, o qual estabelece o embate entre desenvolvimento econômico e comunidades tradicionais (apresentadas pelos agentes do desenvolvimento como arcaicas e entraves para o progresso).

Conflitos fundiários também são apontados na região Sudeste, sobretudo em casos de comunidades que resistem em seus territórios tradicionais. Contudo, frequentemente são despejadas e alocadas em periferias urbanas erodindo com a tradição comunitária e com os saberes da pesca.

Também se evidenciam conflitos estabelecidos devido a representatividade dos pescadores, onde se destaca a oposição Colônia/Associação de Pescadores. Os trabalhos indicam que a busca do domínio dessa representativa pelas Colônias está relacionada com a busca de captação de recursos. 
Destaca-se também os conflitos relacionados com a instalação de Unidades de Conservação, sobretudo as de proteção integral que proíbem a presença das comunidades e o exercício da pesca artesanal em seu território.

Na região Centro-Oeste o principal conflito decorre da configuração fundiária. Neste sentido o avanço do agronegócio sobre as comunidades tradicionais ocorre de forma ainda mais violenta. Também são incorporadas às fazendas as áreas de beira de rio, o que impede o acesso dos pescadores ao rio e seus pesqueiros.

Essas mesmas fazendas promovem outra atividade que entra em conflito com os territórios tradicionais de pesca - a pesca esportiva. Essa atividade econômica promovida na região não é devidamente mensurada, mas as pesquisas apontam que competem com a pesca artesanal por pescado. 


\title{
Capitulo III
}

\section{As Três faces da Modernização na Pesca Artesanal Brasileira- um DIÁLOGO COM O MOVIMENTO SOCIAL}

Hidronegócio: Resistir!

Como observou-se no Capítulo anterior, os territórios tradicionais das comunidades de pescadores estão ameaçados devido ao avanço de outras atividades que entram em conflito/disputas com os pescadores e impactam o ambiente. Como destaca o Relatório “Conflitos Socioambientais e Violações de Direitos Humanos em Comunidades Tradicionais Pesqueiras no Brasil”:

\begin{abstract}
O surgimento de inúmeros conflitos socioambientais presentes nas comunidades tradicionais pesqueiras, possuem parâmetros históricos que se baseiam no controle sobre a natureza enquanto "recurso" econômico, empreendido pela ação do capital. Este controle desencadeia dois profundos problemas instituídos no conflito: o domínio tecnológico ligado ao produtivismo econômico e o domínio sobre a territorialidade onde a terra, a água e os ecossistemas tornam-se recursos de interesse do capital (TOMÁZ; SANTOS, 2016, p. 12).
\end{abstract}

Assim, enfrentam-se duas formas de apropriação da natureza. De um lado, os pescadores artesanais que estão integrados no ambiente de que dependem e constituem territórios, pois o manejo incita regras de uso comunitário. De outro, o capital que se impõe invocando o desenvolvimento econômico, o avanço tecnológico, o progresso da sociedade. As consequências do capital na pesca, nos corpos d'agua e nas comunidades pesqueiras foi devastador. Assim, "desenvolvimento", "avanço" e "progresso" são falácias que sustentam o discurso da prerrogativa de domínio do espaço por outras atividades econômicas, o qual se sustenta na invisibilidade da pesca artesanal que é adjetivada de "arcaica", "atrasada" e “entrave" para o desenvolvimento.

Em síntese, o Capítulo II demonstrou que no Brasil, no âmbito da Geografia, se evidenciam três relações dos conceitos de território e ambiente na pesca artesanal. A menos frequente nos trabalhos analisados (dissertações e teses de geógrafos) diz respeito aos impactos que provocam danos ao ambiente a ponto de não ser mais possível a presença das espécies pesqueiras. Como a produtividade é um aspecto fundamental no território pesqueiro, os pescadores têm que buscar novos territórios em locais longes das suas comunidades. Assim, 
esses impactos também prejudicam a continuidade entre território terra (das moradias e vivência comunitária) e território água. As principais atividades que provocam esses impactos são: industrialização, urbanização e agricultura - como já foi detalhado no Capítulo anterior.

A segunda relação que foi observada trata de disputas nos pesqueiros estabelecidos entre pescadores artesanais e outras atividades econômicas que pretendem o domínio do espaço. Nesse caso, o conflito se estabelece, principalmente, pelo uso do ambiente para o exercício de outra atividade ou pelo próprio pescado. Tais disputas envolvem decisões político-econômicas e ideológicas tomadas a partir de interesses particulares. "Esses empreendimentos estão associados às velhas e novas políticas de domínio e poder" (TOMÁZ; SANTOS, 2016, p. 12). Desta forma, se evidencia a episteme território a partir do par dialético apropriação do espaço por pescadores artesanais e domínio do território por agentes de outras atividades econômicas. Contudo, esse cenário também resulta em danos ambientais, na mudança nas condições geológicas, hidrográficas, ecossistemas, etc. Por consequência, além da restrição de uso do território pesqueiro pelas comunidades de pescadores artesanais, tem-se a drástica redução dos recursos pesqueiros ou da qualidade do ambiente de moradia e vivência comunitária. Nas pesquisas analisadas as principais atividades que entram em disputas no território com os pescadores artesanais é a pesca industrial/comercial e o hidronegócio (aquicultura e barragens para a produção de energia hidrelétrica).

A terceira e mais frequente relação entre território e ambiente nos trabalhos analisados aborda conflitos por território, onde se destacam as relações de poder em detrimento das condições ambientais. Esse território é de suma importância para a sociabilidade dos pescadores artesanais, constituição dos seus saberes tradicionais, estabelecimento de vínculos que são fundamentais para o manejo das pescarias. Esse território, no caso da pesca artesanal, tem continuidade no ambiente aquático - como já se frisou os pescadores artesanais, geralmente, estabelecem moradias nas proximidades dos ambientes pesqueiros. Contudo, essas áreas que chamam atenção pela qualidade ambiental e beleza paisagística tem chamado atenção de promotores de outras atividades econômicas que veem o território como um recurso para o capital. Como geralmente os pescadores estão na condição de posseiros, os conflitos fundiários emergem em todo o Brasil. Tais conflitos se dão com grandes fazendeiros, com o próprio poder público que deseja a industrialização, mas, principalmente, devido aos novos usos do território pelos especuladores imobiliários e promotores do turismo.

Diante do que foi exposto e detalhado no Capítulo anterior, observa-se a partir dos trabalhos dos geógrafos que, a relação ambiente e território se evidencia na pesca artesanal 
brasileira ao ponto que é possível fazer recortes analíticos. Se a relação território e ambiente apresenta distinções, a modernização como fenômeno transformação do espaço geográfico também merece ser compreendida, até por que essa episteme tem orientado a luta dos pescadores artesanais brasileiros organizados em movimento social. Sendo assim, a partir do mote da relação território e ambiente, na sequência, serão analisadas as três possibilidades de leitura da modernização.

No campo teórico parte-se da discussão de moderno, modernidade e modernização. Para tanto, utiliza-se como principal referência Boaventura Santos, que destaca a colonialidade do saber, discute epistemologia das ausências e emergências e propõe epistemologias do Sul. Tratando da modernização no âmbito da Geografia, busca-se referência em Catia Antonia da Silva, que apresenta a modernização como um híbrido da ação do Estado e da grande empresa, onde há disputa do presente e do futuro.

Quanto ao método, na perspectiva do pensamento complexo (MORIN, 1990, 1996, 2008), a composição de técnicas de pesquisa integrou: análise de conteúdo de dissertações e teses; análise de conteúdo de documentos dos movimentos sociais de pescadores artesanais; construção de representações cartográficas. Ainda se realizou trabalhos de campo em atividades do movimento social e junto a Grupos de Pesquisa que abordam a pesca artesanal.

Diante do exposto, esse Capítulo busca: reconhecer as principais problemáticas debatidas pelos pescadores artesanais organizados em movimento social, no tempo presente e analisar a modernização que avança sobre os territórios tradicionais de pescadores artesanais no Brasil a partir do movimento social em diálogo com concepções da Geografia.

\subsection{Pressupostos Teóricos: Moderno, Modernização e Modernidade}

Latour (1994) na introdução de "Jamais Fomos Modernos" entende que as palavras "moderno", "modernização" e "modernidade" aparecem como contraste a um passado arcaico e estável. Estão no centro de um embate onde se estabelecem ganhadores e perdedores. O moderno indica uma ruptura na passagem regular do tempo, em um combate no qual há vencedores e vencidos. Isso impõem uma flecha irreversível do tempo e atribui um prêmio aos vencedores. "Nas inúmeras discussões entre os Antigos e os Modernos, ambos têm hoje igual número de vitórias, e nada mais nos permite dizer se as revoluções dão cabo dos antigos regimes ou os aperfeiçoam" (p.15). 
Boaventura Santos (2007) entende que o pensamento moderno ocidental é um pensamento abissal, pois estabelece uma linha que separa um sistema de distinções visíveis e indivisíveis. As distinções visíveis se estabelecem por meio de linha que divide a realidade social em dois universos o "deste lado da linha" e o "do outro lado da linha". Contudo, nessa divisão, o "do outro lado da linha" desaparece como realidade, pois é produzido como inexistente. Essa inexistência "significa não existir sob qualquer modo de ser relevante ou compreensível". Assim, o lado existente só existe a partir da inexistência, invisibilidade e ausência não dialética do "outro" lado (p.72).

A criação do "outro", assim, é fundamental para a construção do Ocidente como forma de conhecimento hegemônico. O "outro" se constitui como desqualificado, repositório de características inferiores em relação ao saber e poder ocidentais e, desta forma, acessíveis para ser usado e apropriado. "A produção da alteridade colonial, como espaço de inferioridade, assumiu várias formas que reconfiguraram os processos de inferiorização já existentes (sexo, raça, tradição)" (p.18). Isso evidencia que, para além de dimensões políticas e econômicas, o colonialismo teve uma dimensão epistemológica, que não se encerrou após o fim dos impérios coloniais. Desta forma interessa entender em que medida o Sul continua a ser afetado por esse processo de colonização que é obstáculo para pensar a diversidade epistemológica do mundo (SANTOS, MENESES E NUNES, 2006).

Quijano (2005) enfatiza que, nessa perspectiva, modernidade e racionalidades foram concebidas como experiências e produtos exclusivos dos europeus. Assim, as relações intersubjetivas e culturais entre Europa Ocidental e restante do mundo foram codificadas em jogo de novas categorias "Oriente-Ocidente, primitivo-civilizado, mágico/mítico-científico, irracional-racional, tradicional-moderno. Em suma, Europa e não-Europa”. Sob essa codificação das relações "europeu/não-europeu", raça é uma categoria básica. "Essa perspectiva binária, dualista, de conhecimento, peculiar ao eurocentrismo, impôs-se como mundialmente hegemônica no mesmo fluxo da expansão do domínio colonial da Europa sobre o mundo" (p.111).

Não seria possível explicar de outro modo, satisfatoriamente em todo caso, a elaboração do eurocentrismo como perspectiva hegemônica de conhecimento, da versão eurocêntrica da modernidade e seus dois principais mitos fundacionais: um, a ideia-imagem da história da civilização humana como uma trajetória que parte de um estado de natureza e culmina na Europa. E dois, outorgar sentido às diferenças entre Europa e não-Europa como diferenças de natureza (racial) e não de história do poder. Ambos os mitos podem ser reconhecidos, inequivocamente, no fundamento do evolucionismo e do 
dualismo, dois dos elementos nucleares do eurocentrismo (QUIJANO, 2005, p. 111).

Ressalta-se as estratégias de conhecimento como formas de poder e dominação, na medida em que o selvagem e a natureza são duas faces do mesmo desígnio "domesticar a natureza selvagem, convertendo-a em recurso natural”. Esse desejo sintetiza a vontade de domesticar que "torna a distinção entre recursos naturais e recursos humanos tão ambígua e frágil no século XVI como hoje” (SANTOS, MENESES E NUNES, 2006, p.20).

Esse fato dos europeus ocidentais se colocarem como a culminação de um estado civilizatório, desde um estado da natureza, resultou na compreensão de que eles seriam os modernos da humanidade e de sua história (como o novo e ao mesmo tempo mais avançado da sua espécie). Por consequência, atribuíam ao restante da espécie a categoria de natureza, por isso inferiores. Isso levou os europeus a imaginarem "serem não apenas os portadores exclusivos de tal modernidade, mas igualmente seus exclusivos criadores e protagonistas". Ressalta-se que imaginar a si e ao restante da espécie ao seu modo não foi um privilégio dos europeus, mas sim "o fato de que foram capazes de difundir e de estabelecer essa perspectiva histórica como hegemônica dentro do novo universo intersubjetivo do padrão mundial do poder" (QUIJANO, 2005, p.112).

Portanto, seja o que for a mentira contida no termo "modernidade", hoje envolve o conjunto da população mundial e toda sua história dos últimos 500 anos, e todos os mundos ou ex-mundos articulados no padrão global de poder, e cada um de seus segmentos diferenciados ou diferenciáveis, pois se constituiu junto com, como parte da redefinição ou reconstituição histórica de cada um deles por sua incorporação ao novo e comum padrão de poder mundial. Portanto, também como articulação de muitas racionalidades. Em outras palavras, já que se trata de uma história nova e diferente, com experiências específicas, as questões que esta história permite e obriga a abrir não podem ser indagadas, muito menos contestadas, com o conceito eurocêntrico de modernidade. Pela mesma razão, dizer que é um fenômeno puramente europeu ou que ocorre em todas as culturas, teria hoje um impossível sentido. Trata-se de algo novo e diferente, específico deste padrão de poder mundial. Se há que preservar o nome, deve tratar-se, de qualquer modo, de outra modernidade (QUIJANO, 2005, P. 113).

Quijano (2005) apresenta duas implicações que são decisivas como resultado da história do poder colonial. Primeiro, que os povos foram destituídos de suas singularidades e identidades históricas. Segundo, a constituição de uma identidade racial, colonial e negativa que não tem lugar na história da produção cultural da humanidade. Assim, se constitui a ideia de raças inferiores, capazes de produzir culturas inferiores. O não-europeu é então associado ao passado, em outras "palavras, o padrão de poder baseado na colonialidade implicava também 
um padrão cognitivo, uma nova perspectiva de conhecimento dentro da qual o não-europeu era o passado e desse modo inferior, sempre primitivo" (p. 116).

A modernidade ocidental estabelece também o monopólio sobre as formas de verdade científica e não-científicas. Não será dado ênfase as disputas estabelecidas entre ciências e filosofia/teologia, pois se entende que todas elas estão do "mesmo lado da linha". "Do outro lado" estão os conhecimentos "populares, leigos, plebeus, camponeses ou indígenas", os quais desaparecem como conhecimentos "relevantes ou comensuráveis". Esses são invisibilizados como formas de conhecimento, por não serem aplicáveis na distinção científica do verdadeiro ou falso ou das verdades inverificáveis da filosofia e teologia (SANTOS, 2007, pp.72-73).

A linha abissal também apresenta o legal e o ilegal como distinções universais a partir do direito moderno - do Estado ou internacional -. Essa distinção deixa de fora todo um “território social” onde essa dicotomia seria impensável como princípio organizador, isto é, "o território sem lei, fora da lei, o território do a-legal, ou mesmo do legal e ilegal de acordo com direitos não reconhecidos oficialmente" (SANTOS, 2007, p.73).

Existe, portanto, uma cartografia moderna dual nos âmbitos epistemológico e jurídico. A profunda dualidade do pensamento abissal e a incomensurabilidade entre os termos da dualidade foram implementadas por meio das poderosas bases institucionais - universidades, centros de pesquisa, escolas de direito e profissões jurídicas - e das sofisticadas linguagens técnicas da ciência e da jurisprudência. $\mathrm{O}$ outro lado da linha abissal é um universo que se estende para além da legalidade e da ilegalidade e para além da verdade e da falsidade. Juntas, essas formas de negação radical produzem uma ausência radical: a ausência de humanidade, a subumanidade moderna. Assim, a exclusão se torna simultaneamente radical e inexistente, uma vez que seres subumanos não são considerados sequer candidatos à inclusão social (a suposta exterioridade do outro lado da linha é na verdade a consequência de seu pertencimento ao pensamento abissal como fundação e como negação da fundação). A humanidade moderna não se concebe sem uma subumanidade moderna. A negação de uma parte da humanidade é sacrificial, na medida em que constitui a condição para que a outra parte da humanidade se afirme como universal (e essa negação fundamental permite, por um lado, que tudo o que é possível se transforme na possibilidade de tudo e, por outro, que a criatividade do pensamento abissal banalize facilmente o preço da sua destrutividade) (SANTOS, 2007, p.75).

Após a independência das colônias, a tendência seria para o encolhimento e, finalmente, a eliminação das linhas que separam os dois lados, contudo, a "teoria da dependência, a teoria do sistema mundo moderno e os estudos pós-coloniais", advertem que não foi isso o que aconteceu (SANTOS, MENESES E NUNES, 2006, p.20). Como destaca Castro-Gómez (2005) o dispositivo que gera o sistema mundo moderno-colonial é reproduzido, então, no interior de cada um dos Estados nacionais, dentro daquilo que Quijano (2005) chama de "colonialidade do 
poder". Ditada pelo poder colonial, uma "política justa será aquela que, mediante a implementação de mecanismos jurídicos e disciplinares, tente civilizar o colonizado através de sua completa ocidentalização" (CASTRO-GÓMEZ, 2005, p. 83). Castro-Gómez complementa que:

O conceito da "colonialidade do poder" amplia e corrige o conceito foucaultiano de poder disciplinar ao mostrar que os dispositivos pan-óticos erigidos pelo Estado moderno inscrevem-se numa estrutura mais ampla, de caráter mundial, configurada pela relação colonial entre centros e periferias devido à expansão europeia. Deste ponto de vista podemos dizer o seguinte: a modernidade é um "projeto na medida em que seus dispositivos disciplinares se vinculam a uma dupla governamentabilidade jurídica". De um lado, é exercida para dentro pelos estados nacionais, em sua tentativa de criar identidades homogêneas por meio de políticas de subjetivação; por outro lado, a governamentabilidade exercida para fora pelas potências hegemônicas do sistema-mundo moderno/colonial, em sua tentativa de assegurar o fluxo de matérias-primas da periferia em direção ao centro. Ambos os processos formam parte de uma única dinâmica estrutural (CASTRO-GÓMEZ, 2005, p.83).

Isso implica no que Boaventura Santos (2007) chama de "regresso colonizador", ou seja, no ressurgimento de formas de governo colonial tanto nas cidades metropolitanas, quanto naquelas anteriormente sujeitas ao colonialismo europeu. $\mathrm{O}$ autor complementa que:

A expressão mais saliente desse movimento pode ser concebida como uma nova forma de governo indireto, que emerge em diversas situações em que o Estado se retira da regulação social e os serviços públicos são privatizados, de modo que poderosos atores não-estatais adquirem controle sobre a vida e o bem-estar de vastas populações. A obrigação política que ligava o sujeito de direito ao Rechtstaat, o Estado constitucional moderno, antes prevalecente neste lado da linha, passou a ser substituída por obrigações contratuais privadas e despolitizadas, nas quais a parte mais fraca se encontra mais ou menos à mercê da parte mais forte. Essa forma de governo apresenta algumas semelhanças perturbadoras com o governo da apropriação/violência que historicamente prevaleceu do outro lado da linha (SANTOS, 2007, pp. 79-80).

Resulta disso, contextos que Santos (2007) chama de fascismo social, ou seja, "um regime social de relações de poder extremamente desiguais, que concedem à parte mais forte poder de veto sobre a vida e o modo de vida da parte mais fraca". Entre as cinco formas de fascismo social elencadas pelo autor, será destacado o fascismo territorial.

O "Fascismo Territorial" ocorre quando atores sociais com denso capital patrimonial "tomam do Estado o controle do território onde atuam ou neutralizam esse controle, cooptando ou violentando as instituições estatais e exercendo a regulação social sobre os habitantes do território sem a participação destes e contra os seus interesses". Esses novos territórios coloniais privados estão em Estados que geralmente estiveram sujeitos ao colonialismo europeu "Sob 
diferentes formas, a usurpação original de terras como prerrogativa do conquistador e a subsequente "privatização" das colônias encontram-se presentes na reprodução do fascismo territorial e, mais geralmente, nas relações entre terratenentes e camponeses sem terra". (SANTOS, 2007, p. 81).

Boaventura Santos (2002, p.239) vai propor então uma racionalidade cosmopolita, a qual terá que seguir uma trajetória inversa, nessa fase de transição, ou seja, expandir o presente e contrair o futuro. Assim, o autor entende que será possível criar um espaço-tempo suficiente para o conhecimento e valorização da inesgotável experiência social que está em curso no mundo de hoje. Para expandir o presente, o autor propõe uma sociologia das ausências e, para contrair o futuro, uma sociologia das emergências. Esse cosmopolitismo subalterno se apresenta como uma promessa real e se manifesta em movimentos e organizações que configuram uma "globalização contra-hegemônica, lutando contra a exclusão social, econômica, política e cultural gerada pela mais recente encarnação do capitalismo global, conhecida como “globalização neoliberal” (SANTOS, 2007, p. 83).

Sendo a exclusão social um produto das relações de poder desiguais, tais iniciativas são animadas por um "ethos redistributivo" no sentido mais amplo da expressão — compreendendo a redistribuição de recursos materiais, sociais, políticos, culturais e simbólicos - , e como tal baseado simultaneamente nos princípios da igualdade e do reconhecimento da diferença (SANTOS, 2007, p. 84).

Parte-se, então, do entendimento da sociologia das ausências. Isso supõe compreender que aquilo que não existe é na verdade produzido como não-existente, ou seja, como uma alternativa não-creditável ao que existe (SANTOS, 2011, p. 30). "O objetivo da sociologia das ausências é transformar objetos impossíveis em possíveis e com base neles transformar as ausências em presenças" (SANTOS, 2002, p. 246).

La no-existencia es producida siempre que una cierta entidad es descalificada y considerada invisible, no-inteligible o desechable. No hay por eso una sola manera de producir ausencia, sino varias. Lo que las une es una misma racionalidad monocultural. Distingo cinco modos de producción de ausencia o no-existencia: el ignorante, el retrasado, el inferior, el local o particular y el improductivo o estéril (SANTOS, 2011, p.30).

A primeira lógica de produção da não-existência é a monocultura do saber e do rigor do saber. Implica na transformação da ciência moderna e da "alta cultura" em critérios únicos de verdade e qualidade estética. Nesses dois campos, tudo o que o "cânone" não legitima ou reconhece passa a ser considerado inexistente. A inexistência aqui, assume a forma de ignorância e incultura (SANTOS, 2002, 2011). 
A monocultura do saber se apresenta como uma "destruição criadora" que se traduziu como "epistemicídio". A morte de conhecimentos não modernos acarretou na liquidação e subalternização de grupos sociais, cujas práticas se baseavam em tais conhecimentos. Ressaltase que foi um processo histórico violento na Europa, mas muito mais nas outras regiões do mundo sujeitas ao colonialismo europeu (SANTOS, 2006, p. 13).

Essa lógica de produção de não-existência deve ser superada pela ecologia de saberes. Propõe-se identificar outros saberes e estabelecer outros critérios de rigor que se operam nos contextos e práticas sociais consideradas inexistentes. A legitimidade desses saberes para participarem do debate epistemológico vem da credibilidade deles no contexto (SANTOS, 2002, p.250).

\begin{abstract}
A ideia central da sociologia das ausências neste domínio é que não há ignorância em geral nem saber em geral. Toda a ignorância é ignorante de um certo saber e todo o saber é a superação de uma ignorância particular (Santos, 1995: 25). Deste princípio de incompletude de todos os saberes decorre a possibilidade de diálogo e de disputa epistemológica entre os diferentes saberes. O que cada saber contribui para esse diálogo é o modo como orienta uma dada prática na superação de uma certa ignorância. $\mathrm{O}$ confronto e o diálogo entre os saberes é um confronto e diálogo entre diferentes processos através dos quais práticas diferentemente ignorantes se transformam em práticas diferentemente sábias (SANTOS, 2002, p.250).
\end{abstract}

Assim, a ecologia dos saberes tem por premissa a ideia da "inesgotável diversidade epistemológica do mundo, o reconhecimento da existência de uma pluralidade de formas de conhecimento, além do conhecimento científico". Por consequência tem-se que renunciar a uma epistemologia geral e reconhecer que "Existem em todo o mundo não só diversas formas de conhecimento da matéria, da sociedade, da vida e do espírito, mas também muitos e diversos conceitos e critérios sobre o que conta como conhecimento (SANTOS, 2007, p. 85-86).

Boaventura Santos (2007) destaca que no processo de aprendizagem conduzido pela ecologia de saberes é crucial a comparação entre o "conhecimento que está sendo aprendido e o conhecimento que nesse processo é esquecido e desaprendido". Ressalta que a ignorância só significa uma forma desqualificada de ser e de fazer no momento em que "aquilo que se aprende vale mais do que aquilo que se esquece". Se constitui a utopia do interconhecimento, quando se aprende outros conhecimentos sem se esquecer os próprios (p.87).

Ressalta-se que não se trata de supor que os saberes não científicos são alternativos ao saber científico. "A ideia de alternativa pressupõe a ideia de normalidade e esta, a ideia de norma, pelo que, sem mais especificações, a designação de algo como alternativo tem uma conotação latente de subalternidade" (SANTOS, 2002, p.250). Desta forma a busca de 
credibilidade para os conhecimentos não-científicos não implica em descrédito do científico, mas na sua utilização contra-hegemônica. Por um lado, explora-se a pluralidade interna das ciências e de outro promove a interação e interdependência entre saberes científicos e não científicos (SANTOS, 2007, pp. 87-88).

Boaventura Santos (2007) destaca que em muitas áreas da vida social a ciência moderna tem demonstrado maior eficácia do que outras formas de conhecimento, mas que há outros modos de intervenção no real, que hoje são valiosos, para os quais a ciência moderna pouco contribuiu, como é o caso da preservação da biodiversidade. Esta foi possível graças aos conhecimentos camponeses e indígenas, que se encontram ameaçados justamente pela crescente intervenção da ciência moderna.

E não deveria nos impressionar a riqueza dos conhecimentos que lograram preservar modos de vida, universos simbólicos e informações vitais para a sobrevivência em ambientes hostis com base exclusivamente na tradição oral? Dirá algo sobre a ciência o fato de que por intermédio dela isso nunca teria sido possível? (SANTOS, 2007, p.88).

As investigações científicas têm sido postas em causa pela dificuldade de serem lidas com situações e processos caracterizados "pela complexidade e pela impossibilidade de identificar e de controlar todas as variáveis com influência sobre essas situações ou processos". Isso repercute no próprio campo científico de duas formas: “cresce a influência e a importância da complexidade enquanto conceito transversal a diferentes disciplinas e áreas científicas" e "proliferam as consequências não previstas ou não desejadas dos próprios usos e aplicações das ciências e de diferentes tipos de tecnologia, muitas vezes com consequências provavelmente irreversíveis". Dessas duas dinâmicas emergem, nas últimas décadas, debates consistentes que atravessam transversalmente o campo da ciência (SANTOS et al., 2006, p. 14).

Diante do exposto, o pensamento pós-abissal pode ser sintetizado como "aprender do Sul", com base em uma epistemologia do Sul. Assim, se confronta a monocultura da ciência moderna ao passo que se funda no reconhecimento da "pluralidade de conhecimentos heterogêneos" e "em interações sustentáveis e dinâmicas entre eles sem comprometer a sua autonomia", desta forma prevalece a ideia de que "o conhecimento é interconhecimento" (SANTOS, 2007, p. 85).

Assim, a ecologia dos saberes se apresenta como uma "contraepistemologia". SANTOS (2007) destaca dois fatores de que resultam o impulso básico para o seu avanço:

O primeiro consiste nas novas emergências políticas de povos do outro lado da linha como parceiros da resistência ao capitalismo global: globalização 
contra-hegemônica. Em termos geopolíticos, trata-se de sociedades periféricas do sistema-mundo moderno onde a crença na ciência moderna é mais tênue, onde é mais visível a vinculação da ciência moderna aos desígnios da dominação colonial e imperial, onde conhecimentos não-científicos e nãoocidentais prevalecem nas práticas cotidianas das populações. $O$ segundo fator é uma proliferação sem precedentes de alternativas, as quais, porém não podem ser agrupadas sob a alçada de uma única alternativa global, visto que globalização contra-hegemônica se destaca pela ausência de uma alternativa no singular. A ecologia de saberes procura dar consistência epistemológica ao pensamento pluralista e propositivo. (pp. 86-87)

A segunda lógica se baseia na monocultura do tempo linear (SANTOS, 2011), e de história com sentido e direção únicos e conhecidos. Esse sentido da história tem sido formulado de diversas formas ao longo dos últimos duzentos anos: "progresso, revolução, modernização, desenvolvimento, crescimento, globalização”. Essa lógica situa na frente os países centrais do sistema mundial (conhecimentos, instituições e formas sociabilidade). Por conseguinte, produz a não existência declarando como atrasados tudo o que, segundo essa lógica, é assimétrico em relação ao que é avançado. "Neste caso, a não-existência assume a forma da residualização que, por sua vez, tem, ao longo dos últimos duzentos anos, adaptado várias designações, a primeira das quais foi o primitivo, seguindo-se outras como o tradicional, o pré-moderno, o simples, o obsoleto, o subdesenvolvido." (SOUZA SANTOS, 2002, p. 247).

Para superar a monocultura do tempo linear, Boaventura Santos (2007) propõe a ecologia das temporalidades. Significa entender que o tempo linear é uma entre outras concepções de tempo e que considerando o mundo como unidade de análise, nem é a mais praticada. A primazia do tempo linear decorre da primazia da modernidade ocidental que o adotou como seu:

"Foi a concepção adotada pela modernidade ocidental a partir da secularização da escatologia judaico-cristã, mas nunca eliminou, nem mesmo no Ocidente, outras concepções como o tempo circular, a doutrina do eterno retorno e outras concepções que não se deixam captar adequadamente nem pela imagem de linha nem pela imagem de círculo" (p.251).

Ressalta-se que as sociedades entendem o poder a partir das concepções de temporalidade que nela circulam, daí a necessidade de conhecer essas diferentes concepções de tempo. Relações de dominação resistentes se assentam em hierarquias entre temporalidades e continuam hoje sendo constitutivas do sistema mundial. Essas hierarquias reduzem a experiência social à condição de resíduo, pois são contemporâneas de maneiras que a temporalidade dominante, o tempo linear, não é capaz de reconhecer. Assim, a sociologia das 
ausências liberta as práticas sociais dessa designação de resíduo, reconhecendo sua própria temporalidade e suas possibilidades de desenvolvimento autônomo (SANTOS, 2002, p.251).

Uma vez libertada do tempo linear e entregue à sua temporalidade própria, a atividade do camponês africano ou asiático deixa de ser residual para ser contemporânea da atividade do agricultor hi-tech dos EUA ou do executivo do Banco Mundial. Do mesmo modo, a presença ou relevância dos antepassados em diferentes culturas deixa de ser uma manifestação anacrónica de primitivismo religioso ou de magia para se tornar uma outra forma de viver a contemporaneidade (SANTOS, 2002, p. 251).

Na perspectiva da ecologia das temporalidades, quando recuperadas e conhecidas essas temporalidades "as práticas e as sociabilidades que se pautam por elas tornam-se inteligíveis e objetos credíveis de argumentação e de disputa política". Assim há a dilatação do presente, pela "relativização do tempo linear" e pela "valorização das outras temporalidades que com ele se articulam ou com ele conflituam" (SANTOS, 2002, p.252). A coexistência de diversas "temporalidades ou durações em diferentes práticas" de conhecimento incita na expansão da "moldura temporal". "Na medida em que as modernas tecnologias tendem a favorecer a moldura temporal e a duração da ação estatal, tanto na administração pública como na política (o ciclo eleitoral, por exemplo), as experiências subalternas do Sul global têm sido forçadas a responder tanto à curta duração das necessidades imediatas de sobrevivência como à longa duração do capitalismo e do colonialismo" (SANTOS, 2007, p. 89)

A terceira lógica é classificação social, embasada na monocultura da naturalização das diferenças. Neste caso hierarquias são naturalizadas com a distribuição da população em categorias. "Ao contrário do que sucede com a relação capital/trabalho, a classificação social assenta em atributos que negam a intencionalidade da hierarquia social”. Logo, a relação de dominação é uma consequência e não a causa dessa hierarquia, passando a ser considerada como uma obrigação de quem é classificado como superior. "Embora as duas formas de classificação (raça e sexo) sejam decisivas para que a relação capital/trabalho se estabilize e se difunda globalmente, a classificação racial foi a mais profundamente reconstruída pelo capitalismo". Isso produz a não-existência fundada na inferioridade insuperável, por que é tida como natural (SANTOS, 2002, p. 247-248).

Para enfrentar a monocultura de naturalização das diferenças, Boaventura Santos (2002) propõe a ecologia dos reconhecimentos. Trata-se de combater a desqualificação dos agentes, e as práticas e saberes de que são protagonistas. "A colonialidade do poder capitalista moderno e ocidental, a que se referem Quijano (2000), Mignolo (2000) e Dussel (2001), consiste em 
identificar diferença com desigualdade, ao mesmo tempo que se arroga o privilégio de determinar quem é igual e quem é diferente" (p. 248).

Quanto à colonialidade do poder Castro-Gómez (p.83) baseado em Aníbal Quijano entende que a espoliação colonial é legitimada por um imaginário que estabelece "diferenças incomensuráveis entre o colonizador e o colonizado". Complementa que:

\begin{abstract}
As noções de raça e de cultura operam aqui como um dispositivo taxonômico que gera identidades opostas. O colonizado aparece assim como o "outro da razão", o que justifica o exercício de um poder disciplinar por parte do colonizador. A maldade, a barbárie e a incontinência são marcas identitárias do colonizado, enquanto que a bondade, a civilização e a racionalidade são próprias do colonizador. Ambas as identidades se encontram em relação de exterioridade e se excluem mutuamente
\end{abstract}

Assim, a sociologia das ausências confronta-se com a colonialidade, propondo a articulação entre o princípio da igualdade e o princípio da diferença. Isso abre caminho para a possibilidade "de diferenças iguais", ou seja, "uma ecologia de diferenças feita de reconhecimentos recíprocos". Desta forma se evidencia que "As diferenças que subsistem quando desaparece a hierarquia tornam-se uma denúncia poderosa das diferenças que a hierarquia exige para não desaparecer" (SANTOS, 2002, p. 252).

A lógica da escala dominante é a quarta na produção da inexistência (SANTOS, 2011). Pressupõe que a escala adotada como primordial determina o quão relevante são as outras possíveis escalas. Ressalta-se que, na modernidade, a escala dominante aparece como forma de universal e global. "O universalismo é a escala das entidades ou realidades que vigoram independentemente de contextos específicos". Já a globalização "é a escala que nos últimos vinte anos adquiriu uma importância sem precedentes nos mais diversos campos sociais". Nesta lógica, a não-existência é produzida na forma do particular e do local. As entidades aprisionadas nessas escalas não são consideradas alternativas, credíveis ao que existe de modo universal ou global (SANTOS, 2002, p. 248).

Em reação a essa lógica de produção de ausência, Boaventura Santos (2002, p.252) propõe a ecologia das trans-escalas, onde "a lógica da escala global, é confrontada pela sociologia das ausências através da recuperação do que no local não é efeito da globalização hegemônica". Isso exige que o local seja conceitualmente "desglobalizado" para que seja possível identificar nele o que não foi integrado na globalização hegemônica. Escobar (2005, p.69) destaca que o lugar, como a cultura local, pode ser considerado o outro da globalização. Desta forma, a discussão do lugar deveria oferecer uma perspectiva importante para repensar a globalização e a questão das alternativas ao capitalismo e à modernidade. 
O que foi integrado é o que designo por globalismo localizado, ou seja, o impacto específico da globalização hegemônica no local (Santos, 1998b; 2000). Ao desglobalizar o local relativamente à globalização hegemónica, a sociologia das ausências explora também a possibilidade de uma globalização contra-hegemónica. Em suma, a desglobalização do local e a sua eventual reglobalização contra-hegemónica ampliam a diversidade das práticas sociais ao oferecer alternativas ao globalismo localizado (SANTOS, 2002, p. 252).

Desta forma a sociologia das ausências "exige neste domínio o exercício da imaginação cartográfica", ver em cada escala de representação o que ela explicita e o que ela oculta, e trabalhar com mapas cognitivos que operam "simultaneamente com diferentes escalas, nomeadamente para detectar as articulações locais/globais" (SANTOS, 2002, p. 252).

Por fim, a quinta lógica que produz não existência é a produtivista que se baseia na monocultura dos critérios de produtividade capitalista (SANTOS, 2011). Nessa lógica o crescimento econômico se apresenta como objetivo inquestionável assim como os critérios de produtividade que o atende, tanto no campo da natureza quanto no do trabalho humano. "A natureza produtiva é a natureza maximamente fértil, num dado ciclo de produção, enquanto o trabalho produtivo é o trabalho que maximiza a geração de lucros igualmente num dado ciclo de produção". Assim, a não-existência se produz na forma do improdutivo (SANTOS, 2002, p.248).

A ecologia da produtividade aparece como possibilidade à lógica produtivista que promove ausência. Propõe a recuperação e valorização de sistemas de produção, "das organizações econômicas populares, das cooperativas populares, das empresas autogeridas, da economia solidária, etc.", que o capitalismo ortodoxo descredibilizou. Este domínio da sociologia das ausências é controverso, pois põe em questão o paradigma do "desenvolvimento e do crescimento econômico infinito" e a primazia dos "objetivos de acumulação sobre os objetivos de distribuição que sustentam o capitalismo global” (SANTOS, 2002, p.253).

Cabe destacar que esse "paradigma e essa lógica nunca dispensaram outras formas de produção e apenas as desqualificaram para as manter na relação de subalternidade”. Cabe então à sociologia das ausências evidenciar essas formas para além da relação de subalternidade (SANTOS, 2002, p.253).

Em cada um dos cinco domínios, o objectivo da sociologia das ausências é revelar a diversidade e multiplicidade das práticas sociais e credibilizar esse conjunto por contraposição à credibilidade exclusivista das práticas hegemónicas. A ideia de multiplicidade e de relações não destrutivas entre os agentes que a compõem é dada pelo conceito de ecologia: ecologia de saberes, 
ecologia de temporalidades, ecologia de reconhecimentos e ecologia de produções e distribuições sociais (p.253).

As ecologias propostas por Boaventura Santos (2002, p.253) tem em comum a ideia de que "realidade não pode ser reduzida ao que existe". Assim, inclui as realidades ausentes por meio do silenciamento, supressão e marginalização, ou seja, da produção de inexistência.

Em conclusão, o exercício da sociologia das ausências é contra-factual e tem lugar através de uma confrontação com o senso comum científico tradicional. Para ser levado a cabo, exige imaginação sociológica. Distingo dois tipos de imaginação: a imaginação epistemológica e a imaginação democrática. A imaginação epistemológica permite diversificar os saberes, as perspectivas e as escalas de identificação, análise e avaliação das práticas. A imaginação democrática permite o reconhecimento de diferentes práticas e atores sociais. Tanto a imaginação epistemológica como a imaginação democrática têm uma dimensão desconstrutiva e uma dimensão reconstrutiva (SANTOS, 2002, p. 253).

Boaventura Santos (2007) propõe que para a realização do cosmopolitismo subalterno é necessário realizar aquilo que chama de sociologia das emergências, a qual consiste na "amplificação simbólica de sinais, pistas e tendências latentes que, embora dispersas, embrionárias e fragmentadas, apontam para novas constelações de sentido referentes tanto à compreensão como à transformação do mundo (p.83).

Na perspectiva de Santos (2002) da mesma forma que o presente pode ser dilatado por meio da sociologia das ausências, o futuro pode ser contraído através da sociologia das emergências. Esta consiste em substituir o vazio do futuro - do tempo linear - por um futuro de possibilidades plurais e concretas, "simultaneamente utópicas e realistas" que vão sendo construídas no presente.

\begin{abstract}
A sociologia das emergências é a investigação das alternativas que cabem no horizonte das possibilidades concretas. Enquanto a sociologia das ausências amplia o presente, juntando ao real existente o que dele foi subtraído pela razão metonímica, a sociologia das emergências amplia o presente, juntando ao real amplo as possibilidades e expectativas futuras que ele comporta. Neste último caso, a ampliação do presente implica a contração do futuro, na medida em que o Ainda-Não, longe de ser um futuro vazio e infinito, é um futuro concreto, sempre incerto e sempre em perigo. Como diz Bloch, junto de cada esperança está um caixão à espera (1995: 311).
\end{abstract}

Diante das incertezas do futuro a sociologia das emergências consiste na ampliação simbólica dos "saberes, práticas e agentes" para identificar neles tendências de futuro, sobre as quais deve-se trabalhar para "maximizar a probabilidade de esperança em relação a probabilidade de frustração". Essa "ampliação simbólica" é, no fundo, uma forma de 
"imaginação sociológica" que objetiva "por um lado, conhecer melhor as condições de possibilidade da esperança"; e de outro, "definir princípios de ação que promovam a realização dessas condições" (SANTOS, 2002, p. 256).

Pode-se dizer que enquanto a sociologia das ausências se move no campo das "experiências sociais", a sociologia das emergências está no "campo das expectativas sociais". "A discrepância entre experiências e expectativas é constitutiva da modernidade ocidental" (SANTOS, 2002, p. 257). O autor ainda complementa:

Através do conceito de progresso, a razão proléptica polarizou esta discrepância de tal modo que fez desaparecer toda a relação efetiva entre as experiências e as expectativas: por mais miseráveis que possam ser as experiências presentes, isso não impede a ilusão de expectativas radiosas (p.257).

Já a sociologia das emergências mantém esta discrepância, entretanto, lhe concebe de forma independente da ideia do progresso, entendendo-a como concreta e moderada. É importante destacar que a razão proléptica reduziu o campo das experiências e, portanto, contraiu o presente, quando ampliou enormemente as expectativas. Assim, a sociologia das emergências propõe uma relação mais equilibrada entre experiência e expectativa, o que implica em dilatar o presente e encurtar o futuro. Isso não significa minimizar as expectativas, mas "radicalizar as expectativas assentes em possibilidades e capacidades reais, aqui e agora" (p. 257).

No entendimento de Boaventura Santos (2002) ao dilatarem o presente e contraírem o futuro, a sociologia das ausências e a sociologia das emergências contribuem para desacelerar o presente, atribuindo-lhe "um conteúdo mais denso e substantivo do que o instante fugaz entre o passado e o futuro a que a razão proléptica o condenou”. A ampliação simbólica operada pela sociologia das emergências visa:

Analisar numa dada prática, experiência ou forma de saber o que nela existe apenas como tendência ou possibilidade futura. Ela age tanto sobre as possibilidades como sobre as capacidades. Identifica sinais, pistas ou traços de possibilidades futuros em tudo o que existe. Também aqui se trata de investigar uma ausência, mas enquanto na sociologia das ausências o que é ativamente produzido como não existente está disponível aqui e agora, ainda que silenciado, marginalizado ou desqualificado, na sociologia das emergências a ausência é de uma possibilidade futura ainda por identificar e uma capacidade ainda não plenamente formada para a levar a cabo.

A ampliação simbólica resulta do excesso de atenção dado pela sociologia das emergências a aquilo que era negligenciado. "Essa investigação prospectiva opera através de 
dois procedimentos: "tornar menos parcial o nosso conhecimento das condições do possível; tornar menos parciais as condições do possível”. Boaventura Santos (2002) explica que:

O primeiro procedimento visa conhecer melhor o que nas realidades investigadas faz delas pistas ou sinais; o segundo visa fortalecer essas pistas ou sinais. Tal como o conhecimento que subjaz à sociologia das ausências, trata-se de um conhecimento argumentativo que, em vez de demonstrar, convence, que, em vez de se querer racional, se quer razoável. É um conhecimento que avança na medida em que identifica credivelmente saberes emergentes, ou práticas emergentes (p. 258).

No âmbito da Geografia, Silva (2017) entende que a modernização territorial se molda no âmbito do capitalismo, dos países centrais e periféricos, como ideário concebido a partir de teorias de ordenamento territorial e planejamento urbano-regional da Geografia Econômica (p.249).

A modernização deve ser concebida, cientificamente, como um híbrido da ação do Estado e da grande empresa, onde há disputa do presente e do futuro. Nobert Elias (1993, 1994) apud Silva (2017, p. 250) aponta que para o “processo modernizador” se impor, nega a história dos lugares e dos sujeitos sociais, da tradição, da cultura e da economia local. A autora complementa que nesse "processo modernizador em diferentes contextos no Brasil subjugam sujeitos sociais na sua dimensão socioespacial multicultural como é o caso dos pescadores artesanais" (p.251).

Assim a autora situa a Geografia nos estudos da modernização:

A Geografia faz parte das ciências humanas e, como tal, as análises sobre o
desenvolvimento baseiam no projeto de colonização do futuro (secularização),
como ensina Marramao (1997). A contribuição geográfica, historicamente,
apontava para um lado: a construção do sistema mundo - conexão de ideias,
projetos, ações e objetos, e de outro lado, o mapeamento dos recursos naturais
e humanos, das concentrações populacionais e das estruturas produtivas. Um
conceito que aparece tanto na Geografia como na Economia regional do pós-
guerra na análise do planejamento nacional, é o de "vazio demográfico", ou
conhecido de vazios espaciais, ou seja, pouco povoados ou, ainda refere-se ao
espaço natural, espaço de fronteira do desenvolvimento, predominantemente.
(p.251).

Segundo a autora, os ideários do Estado que constituem leituras de mundo, na colonização do futuro, se apresentam em teorias geográficas (de ocupação, domínio, soberania) onde a dimensão do visível passa a negar a totalidade (sujeitos, economias, objetos, ações etc.), gerando invisibilidade (SILVA, 2017, p. 251). Nessa perspectiva a modernização constitui um processo de ruptura e um novo modelo de produção do espaço que associa modernismos e lógicas ampliadas de produção do capitalismo: 
Modernismos (projeção-movimento cultural-filosófico e intelectual) e modernização (ação técnico, instrumental e racional) são precursores da modernidade (espaço produzido - materialidade e imaterialidade) Os modernismos como ideologias (valores) em disputa, disputam o sentido de futuro e condicionam, escolhem, redefinem ações e projetos, negam sujeitos e espaços, julgam contextos e sujeitos (WEBER 2000, 2006; HARVEY, 1992). Os modernismos na sua dimensão acadêmica redefinem o sentido e a representação dos sujeitos sociais em nome da objetividade científica (weber, 2006). Teorias, nesse sentido, são instrumentos discursivos de reconstrução de leituras do mundo e formas de representações socioespaciais, constituindose em ideários e pressupostos para a ação política e o exercício de poder porque o discurso científico afirma-se como discurso competente (FOUCAULT, 2011) (p.252).

Silva (2017) destaca que o poder se instaura por meio da razão instrumental, mas no silencio e ocultamento, que são construídas por práticas políticas. Destaca que frequentemente a "cena pública e os fóruns de participação social já foram forjados e os sentidos já definidos, negando grupos sociais subalternos". Entende que o cotidiano praticado por homens e mulheres simples é atravessado por projetos "próteses" que são estranhos à "vida coletiva" e às normas do "espaço vivido e praticado". Nesses processos ocultos de produção da dominação emergem movimentos sociais que resistem e lutam, questionando aquilo que está ocultado e se impõe com única forma de ver o futuro. Visibilidade e invisibilidade então se apresentam como par dialético que evidenciam no espaço brasileiro experiências concretas que possibilitam avanços analíticos referentes a "historicidades e espacialidades", e evidenciam novas formas de insurgências e de leituras de mundo (p.255). Nesse sentido:

As resistências adquirem corporeidade e co-presença e anunciam o período denominado por Milton Santos (1996) de período popular da história, um período demográfico, que vai requerer do fazer científico mais compreensão da complexidade, das Geografias das existências, dos interstícios do cotidiano praticado, o que pressupõem uma outra leitura do tempo (lento da vida coletiva) na dialética com outra leitura do espaço (movimento entre o global e lugar, identificação na produção social do espaço as experiências sociais múltiplas e nas experiências particulares que tecem a vida urbana coletiva e a vida rural no país (SILVA, 2017, p.254)

Observa-se, então, que a Geografia reconhece as dimensões de racionalidade e subjetividade dos sujeitos, a interação destes com a modernidade (conflitiva ou não) e suas cosmologias (visão de mundo, do ser, do estar, do espaço e do tempo experimentado). A autora defende a análise geográfica a partir de diversas escalas, mas defende que tratando dos "conflitos territoriais, das lutas das comunidades tradicionais fundamental trabalhar e 
aprofundar a escala do lugar e do cotidiano para que o narrador (geógrafo) possa trazer as vozes dos sujeitos, suas leituras e seus saberes" (p.268)

Isso implica em construir processos metodológicos que coloquem em evidencia as horizontalidades (lugar e cotidiano) e as verticalidades (ordens distantes), sempre situadas em escalas nacionais e globais (SILVA, 2017, p. 268). "Então aparece o desafio para a Geografia de trabalhar entre as escalas, mas partindo de uma delas para produzir o contexto da coerência da compreensão da problemática (SUERTEGARAY, 2001, 2002 apud SILVA, 2017, p. 268).

\subsection{Caminho Metodológico}

Segue a perspectiva do pensamento complexo com base em Morin $(1990,1996,2008)$. A dialógica se expressa a partir de um diálogo entre os trabalhos analisados (expresso no Capítulo anterior e retomados nesse) e do diálogo entre compreensões da Geografia e do movimento social. A recursividade organizacional ocorre na medida em que as três possibilidades de análises propostas se substantificam ao passo que o diálogo ocorre, ou seja, elas se expressam no processo. O princípio hologramático se evidencia na medida em a análise do conjunto, que se denomina Pesca Artesanal Brasileira, ocorre retomando experiências no local, seja área de estudo de geógrafos, seja lugar de vida e território dos pescadores. Ao mesmo tempo do território pesqueiro (experiências plurais), se estabelece possibilidades interpretativas para a pesca artesanal do Brasil.

\section{Análise de Conteúdo}

Foram estabelecidas análises de conteúdo a partir de fontes dos movimentos sociais da pesca artesanal e das dissertações e teses analisadas. Para a caracterização das fontes dos movimentos sociais, já na metodologia, se apresenta resultados da exploração material, na qual utilizou-se o software Nvivo®, e verificou-se a frequência de determinados termos e construiuse nuvens de palavras.

\section{Denúncias do Movimento Social}

Foram analisadas as denúncias registradas no Blog Pelo Território Pesqueiro ${ }^{10}$ do Movimento dos Pescadores e Pescadoras Artesanais - MPP. A nuvem de palavras (figura 56) evidencia o teor das denúncias:

\footnotetext{
${ }^{10}$ www.peloterritóriopesqueiro.blogspot.com.br
} 


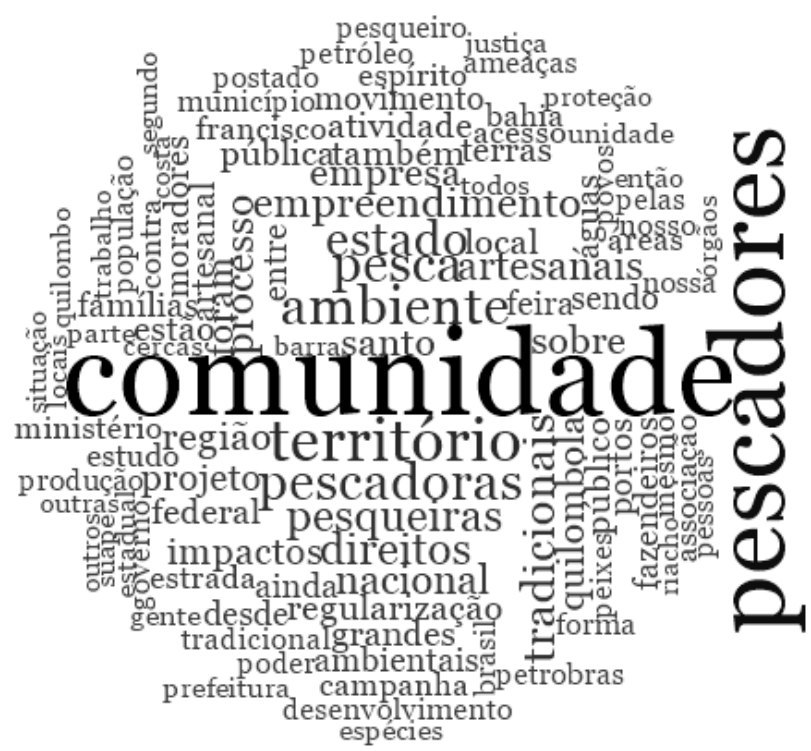

Figura 56: Nuvem de Palavras - Denúncias do Blog Pelo Território Pesqueiro Fonte: Elaborado por De Paula (2018).

No âmbito da "Campanha Nacional pela Regularização do Território das Comunidades Tradicionais Pesqueiras", o Blog Pelo Território Pesqueiro expõe notícias relacionadas com ações do MPP e denúncias de conflitos no território tradicional. A nuvem de palavras evidencia que o foco das denúncias são as comunidades e os pescadores artesanais. Contudo, é fundamental atentar e destacar as palavras Território e Ambiente, as quais compõem a argumentação do movimento social.

A organização das 44 denúncias se deu a partir do arquivamento individual de cada uma e composição de um banco de dados na Plataforma Excel®. Cada denúncia foi identificada com Id. (nome do arquivo), Data da Denúncia, Local de Ocorrência (estado, cidade, localidade), fonte (quem elaborou a denúncia) e link (acesso digital da denúncia). Identificou-se em cada denúncia a Atividade denunciada (dentro das já identificadas no Capítulo II), os atores/agente Denunciados e as Consequências (impactos/conflitos/disputas sofridos e resistências).

A constituição do banco de dados (figura 57) permitiu seguir as etapas de exploração material dos dados e pré-analise propostas por BARDIN (2007). Isso permite estabelecer, a partir do reconhecimento das atividades causadoras, em cada uma das denúncias, três faces da modernização. Essas estão associadas a suas consequências nos ecossistemas, nos pesqueiros tradicionais, e nas áreas de moradia e vivência das comunidades. 


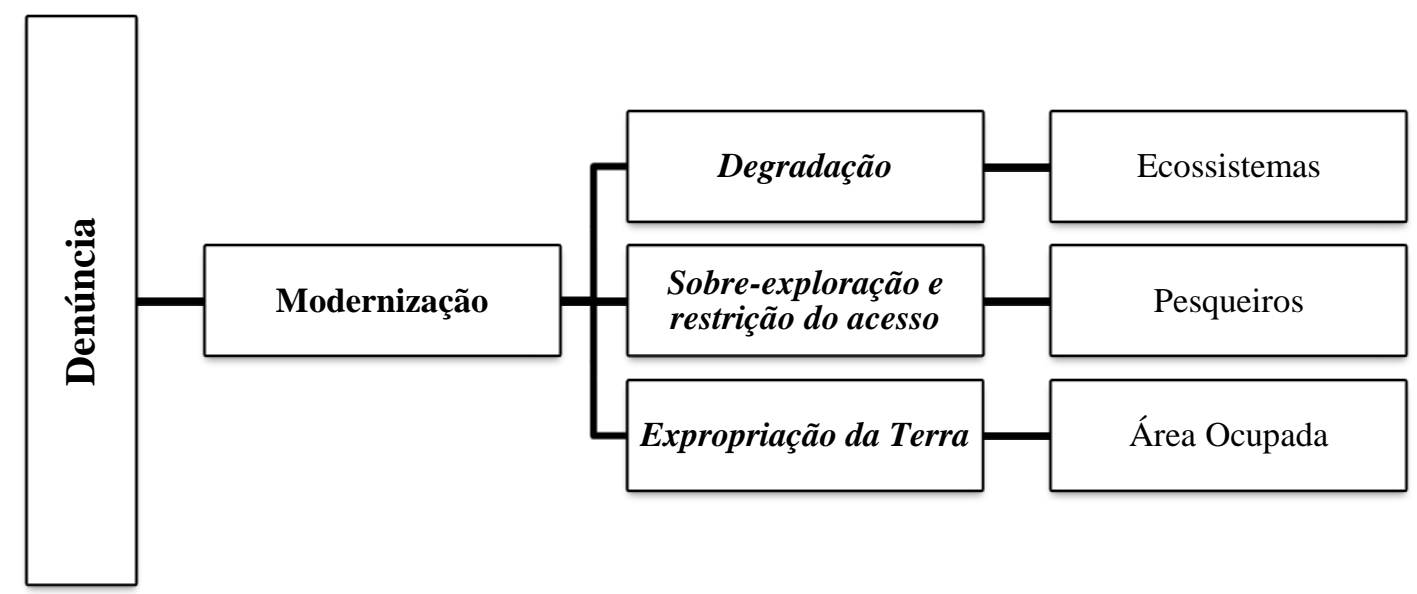

Figura 57: Diagrama de Análise das Denúncias

Fonte: Elaborado por De Paula (2018)

Destaca-se que essa análise também compôs dados expressos no Relatório "Conflitos Socioambientais e Violações de Direitos Humanos em Comunidades Tradicionais Pesqueiras no Brasil" promovido pelo Conselho Pastoral dos Pescadores - $\mathrm{CPP}^{11}$. A nuvem de palavras (figura 58) evidencia que o conteúdo do relatório dialoga com as denúncias apresentadas no Blog Pelo Território Pesqueiro, pois o CPP é apoiador do MPP (inclusive muitas denúncias foram elaboradas pela assessoria de imprensa da CPP). Isso se evidencia na linha comum de argumentação e enfrentamento político. No entanto, destaca-se dois aspectos, o foco nos pescadores, uma vez que o relatório defende os "direitos humanos", e no território, sem enfatizar o conceito de ambiente.

11 O CPP segue o princípio de promover o serviço pastoral aos pescadores e pescadoras, tendo como finalidade o protagonismo social e político, fortalecer e promover as relações de igualdade de gênero, incentivar o trabalho coletivo e a zelar para que aconteçam gestões baseadas nos princípios democráticos das organizações da categoria. https://cppnorte.wordpress.com/historico/ 


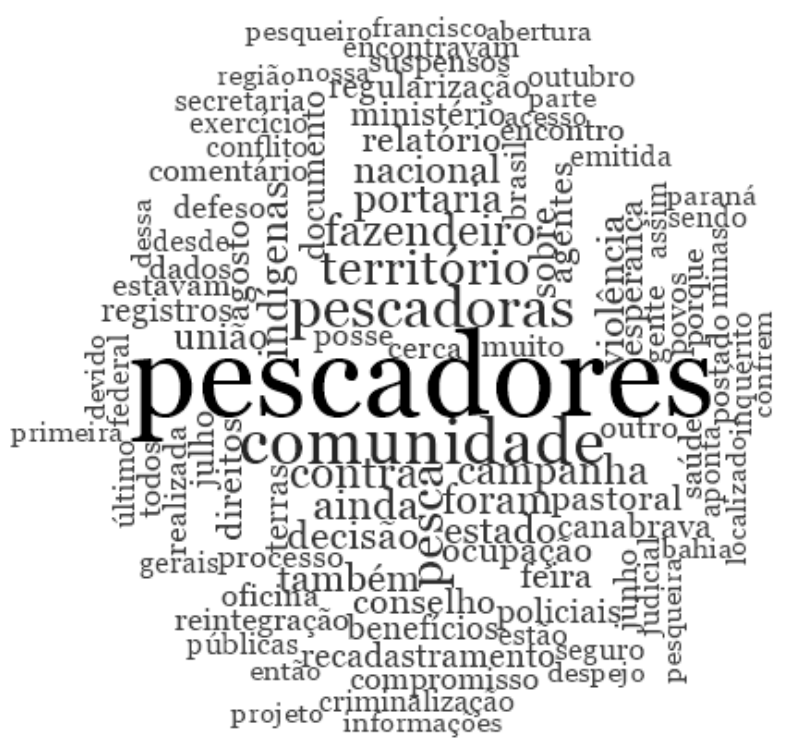

Figura 58: Nuvem de Palavras - Relatório "Conflitos Socioambientais e Violações de Direitos Humanos em Comunidades Tradicionais Pesqueiras no Brasil"

Fonte: Elaborado por De Paula (2018)

\section{Dissertações e Teses}

De 1980 a 2015 foram identificados 104 trabalhos, dos quais foi possível ter acesso à 71 trabalhos entre dissertações e teses, conforme explicitado no Capítulo I. No Capítulo anterior, a análise dos trabalhos a partir do Banco de Dados (planilha do Excel@), estabeleceuse categorias utilizando-se a técnica de análise de conteúdo (BARDIN, 2007). Essa análise permitiu identificar Impactos Ambientais, Disputas no Território, e Conflitos por Território (figura 59).

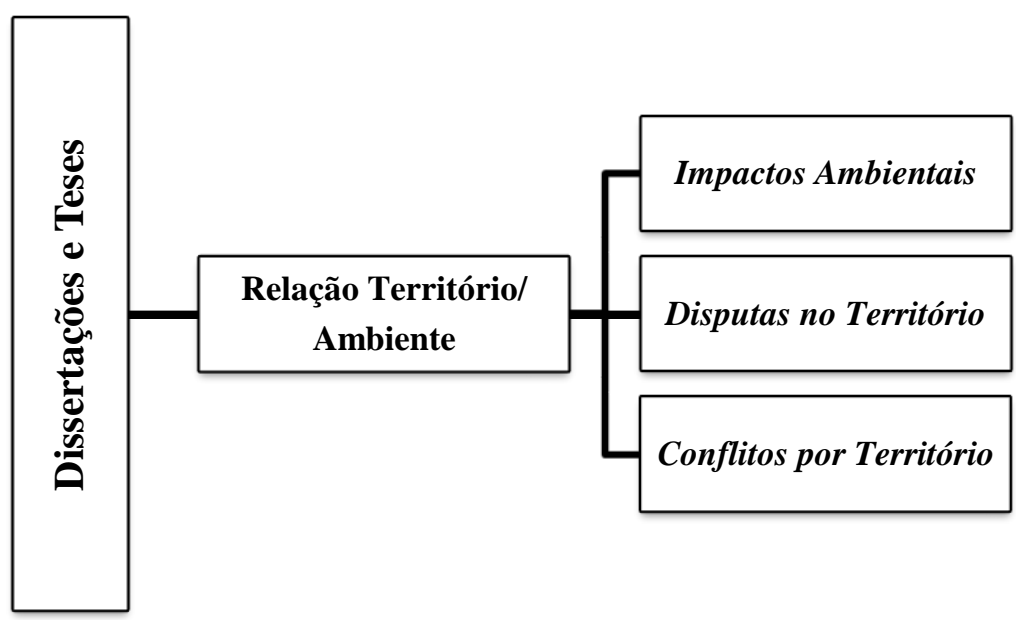

Figura 59: Diagrama de Análise das Dissertações e Teses

Fonte: Elaborado por De Paula (2018) 
Tendo compreendido na etapa anterior as atividades denunciadas pelo movimento social, neste Capítulo, buscou-se estabelecer o diálogo entre elas e os argumentos apresentados nas dissertações e teses (figura 60):

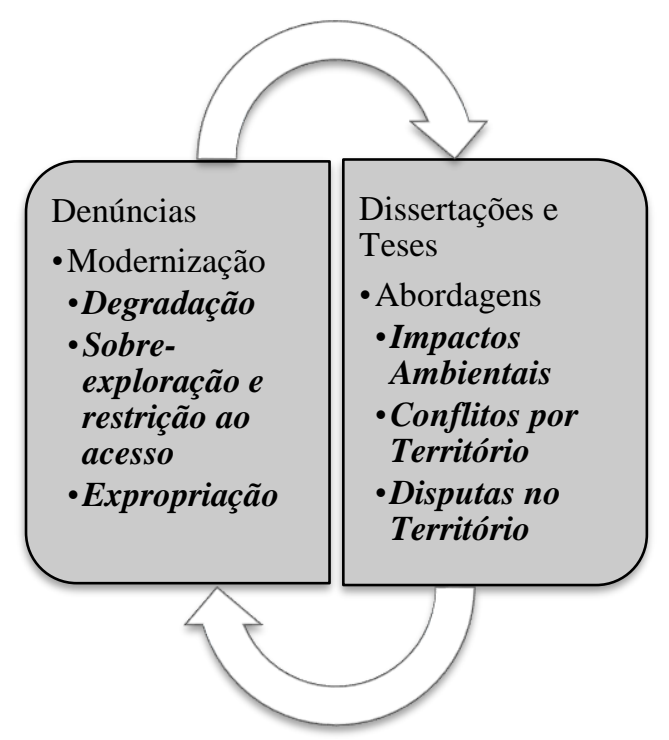

Figura 60: Diagrama de Análise de Correlação entre as Dissertações e Teses e as Denúncias do Blog Pelo Território Pesqueiro

Fonte: Elaborado por De Paula (2018)

\section{Representações cartográficas:}

Retornou-se ao banco de dados georreferenciado, que integra a análise dos trabalhos (dissertações e teses) para elaborar representações cartográficas que evidenciem a espacialização das três faces da modernização.

Para elaborar os mapas sobre às faces da modernização utilizou-se a ferramenta "spatial analyst" do ArcGis 10.2.2® denominada "densidade de kernel”. Como há uma expressiva concentração de determinadas atividades em determinadas regiões, para a elaboração destes mapas utilizou-se o como base o desvio padrão, isso quer dizer que se considerou dispersão dos valores individuais em torno da média.

\section{Trabalhos de Campo}

Os trabalhos de campos foram realizados junto a grupos de pesquisa que abordam a pesca artesanal e em atividades do movimento social. O procedimento de pesquisa adotado foi a "pesquisa participante", pois pressupõe o estabelecimento de um relacionamento multilateral com o grupo, onde o pesquisador efetivamente participa das discussões e se compromete com os resultados (WHYTE, 2005). 
Cabe destacar alguns pontos relevantes sobre a observação participante (WHYTE, 2005; VALLADARES, 2007): resulta de um processo longo, onde se constitui um contexto em que é concedido ao pesquisador o direito de participar; o pesquisador se insere na estrutura social do grupo; a interação entre pesquisador e pesquisado orienta a pesquisa, o que exige a auto avaliação do pesquisador e de seus pressupostos; é fundamental que o pesquisador reconheça e seja reconhecido como de fora do grupo; a presença do pesquisador recebe mediação de um intermediário do próprio grupo; o pesquisador, ao mesmo tempo que observa, é observado; os dados se apresentam por meio do exercício de ouvir e ver mais do que por meio de entrevistas; a presença constante do pesquisador resulta em confiança do grupo; o processo de aprendizagem deve ser reflexivo; o pesquisador também é cobrado e se compromete com a devolução da pesquisa.

\section{Grupos de Pesquisa}

Tendo identificado as instituições que realizam pesquisas sobre pesca artesanal na Geografia brasileira, coube visitar grupos onde ocorrem essas pesquisas e reconhecer as problemáticas e os diálogos que ocorrem entre geógrafos e pescadores.

Buscou-se estabelecer diálogo com os Grupos de Pesquisa das seguintes instituições:

- Universidade do Estado do Rio de Janeiro- UERJ: Núcleo de Pesquisa e Extensão: Urbano, Território e Mudanças Contemporâneas - NUTEMC.

Em novembro de 2015 participou-se das atividades do Grupo, reconheceu-se as principais áreas de estudo e realizou-se trabalho de campo em reunião que constituiu o Fórum de Pescadores em Defesa da Baía de Sepetiba.

- Universidade Federal da Bahia: A Geografia dos Assentamentos na Área Rural - GeograFar, e Grupo Costeiros.

Participou-se do III Seminário Nacional Espaços Costeiros de 4 a 7 de outubro de 2016. Onde foi possível dialogar com participantes dos citados grupos que realizam pesquisas sobre a pesca artesanal. Ressalta-se que, no seminário, foi possível compreender e dialogar com acadêmicos, funcionários públicos e pescadores que participaram das atividades.

- Universidade Federal do Pará: Grupo Acadêmico a Produção do Território e Meio Ambiente na Amazônia - GAPTA.

O contato com o grupo se deu no I Seminário Nacional: Territórios, Ordenamentos e Representações (I SETOR), de 16 a 20 de janeiro de 2017, organizado pelo GAPTA e Universidade Federal do Amapá. O evento foi composto por mesas e grupos de trabalho que 
permitiram o diálogo sobre problemáticas relacionadas à região amazônica, onde destacou-se as repercussões de grandes empreendimentos nas comunidades ribeirinhas de pescadores artesanais.

- Universidade Federal do Rio Grande do Sul - UFRGS: Núcleo de Estudos Geografia e Ambiente - NEGA.

A participação no NEGA se dá desde 2011, primeiramente em pesquisa realizada no Delta do Jacuí e Lago Guaíba e, a partir de 2012, na Floresta Nacional de Tefé - Amazonas.

- Além dos referidos grupos de pesquisa, cabe destacar a aproximação com pesquisadores (geógrafos) que abordam a pesca artesanal em eventos científicos nacionais.

Encontro Nacional de Geógrafos - ENG e Congresso Brasileiro de Geógrafos - CBG.

Desde o ENG de 2012 um grupo de geógrafos tem proposto Espaços de Diálogo e Espaços de Socialização de Coletivos para agregar os pesquisadores da pesca artesanal. Isso ocorreu no XVII ENG (2012), VII CBG (2014); XVIII ENG (2016). Esse grupo tem se articulado por meio de uma rede acadêmica e social chamada Rede de Geografia(s) da Pesca.

Participou-se também do XI e XII Encontro da Associação Nacional de Pós-graduação e Pesquisa em Geografia - ENANPEGE, no Grupo de Trabalho: Espaço, Cultura e Diferença: as dimensões étnicas, sociais e ambientais dos sujeitos e dos conflitos socioespaciais.

\section{Movimentos sociais}

Realizou-se trabalhos de campo junto a movimentos sociais de pescadores artesanais, principalmente o Movimento dos Pescadores e Pescadoras Artesanais - MPP. Contudo, destaca-se também o diálogo e militância no âmbito do Fórum de Pescadores Delta do Jacuí.

Para Rodrigues (2012, p. 25) movimentos sociais são manifestações da sociedade civil, as quais se expressam fora da esfera político-partidária, do sistema político e do parlamento. De acordo com os seus objetivos e formas de organização podem ser considerados "libertários, contestatórios, conservadores, reacionários, revolucionários, portadores de novas ideias e defensores de ideias dominantes". A autora complementa:

Os movimentos sociais mostram que a sociedade se move em várias direções e com vários significados. Explicitam problemas reais, organizam-se fora de uma comunidade política, realizam um processo de dessacralização do sistema político (partido, parlamentos) e provocam enfraquecimento do papel da intelligentsia. Dessacralização não quer dizer despolitização. Pelo contrário, trata-se da politização do espaço, da política fora do parlamento, 
dos partidos do sistema político. Cria uma nova dimensão da política com suas contradições e seus conflitos (pp.25-26).

Considera-se importante apresentar esses movimentos sociais destacados e que apresentam argumentos que compõem esse Capítulo:

- Movimento dos Pescadores e Pescadoras Artesanais - MPP

O MPP foi criado em 2009 a partir da necessidade dos pescadores artesanais brasileiros de terem uma representação nacional principalmente frente ao poder público. A nuvem de palavras (figura 61) da rede social (facebook) do MPP evidencia o conteúdo das postagens e comentários. Esses estão consoantes com a "Campanha Nacional pela Regularização dos Territórios das Comunidades Tradicionais Pesqueiras" e evidenciam o foco nos pescadores e suas comunidades. Território, direitos e tradicional também evidenciam as publicações do movimento.

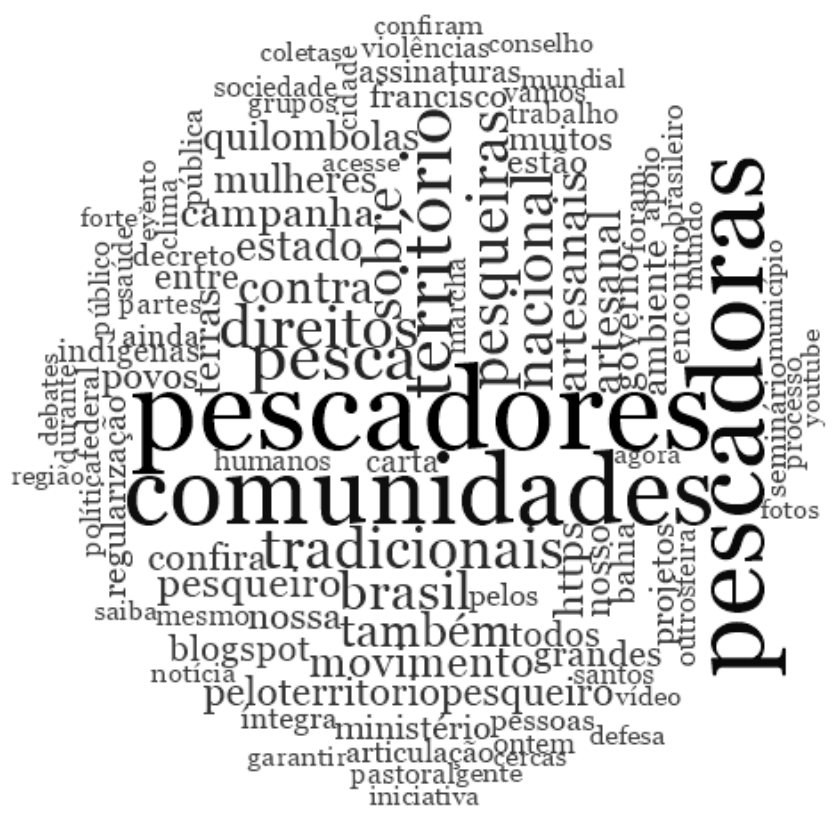

Figura 61: Nuvem de Palavras - Rede Social do Movimento dos Pescadores e Pescadoras Artesanais

Fonte: Elaborado por De Paula (2018).

Junto ao MPP, destaca-se a observação participante nos seguintes eventos:

II Assembleia Nacional do Movimento dos Pescadores e Pescadoras Artesanais do Brasil - MPP, realizada de 23 a 25 de agosto de 2016 em Aquiraz - CE.

I Encontro da Articulação Sudeste-Sul do Movimento dos Pescadores e Pescadoras Artesanais realizado de 8 a 11 de dezembro de 2016 em Paranaguá - PR. 
II Encontro da Articulação Sudeste-Sul do Movimento dos Pescadores e Pescadoras Artesanais, realizado de 26 a 29 de outubro de 2017, em Jaguaruna - SC.

Compõem, também, argumentos presentes nesse Capítulo a participação do pesquisador no Fórum de Pescadores Delta do Jacuí, desde 2011. Para além da pesquisa de mestrado houve continuidade nessa participação como apoiador desse movimento social de escala "local e regional”. Os pescadores do Delta do Jacuí, Lago Guaíba e Norte da Laguna dos Patos estão organizados no sistema de gestão compartilhada da pesca - Fórum Delta do Jacuí. Esse espaço tem discutido as principais problemáticas relacionadas com a pesca da região (DE PAULA, 2013).

\subsection{As Três Faces da Modernização}

Na perspectiva da modernização, como apresenta Silva (2017), há uma disputa do presente e do futuro, assim, o capital se impõe sobre os territórios das comunidades tradicionais por considera-los potenciais para seus processos produtivos. Para a análise presente, buscou-se estabelecer o diálogo entre as dissertações e teses, denúncias da página do Movimento dos Pescadores e Pescadoras Artesanais - MPP e Relatório "Conflitos Socioambientais e Violações de Direitos Humanos em Comunidades Tradicionais Pesqueiras no Brasil" da Conselho Pastoral dos Pescadores - CPP. Na pesca artesanal observa-se o avanço da modernização sobre os territórios tradicionais a partir de três faces.

A primeira face versa sobre a degradação causada pela modernização, a qual avança sobre os corpos d'água, e ecossistemas associados (mangues, marismas, matas de várzea, etc.). Essa face da modernização está menos presente nas pesquisas analisadas (38) e nas denúncias do Blog Pelo Território Pesqueiro (5) do MPP, contudo, suas marcas se evidenciam na intensa transformação da natureza, alteração dos seus processos e, por isso, redução na quantidade e na qualidade do pescado. Desta forma cabe compreender os contextos de industrialização, urbanização, agroindústria e mineração enquanto projeto de Estado. Compreender essa face da modernização enfatiza a degradação ambiental que extingue territórios dos pescadores artesanais.

A segunda face da modernização se evidencia na sobre-exploração e restrição do acesso aos pesqueiros. Essa é aquela que atinge o pesqueiro tradicional, seja pela sobre-exploração do pescado, seja pela proibição do acesso ao mesmo. Nessa perspectiva da modernização foram 
identificados nos trabalhos analisados (49) e denúncias do Blog Pelo Território Pesqueiro (52) como principais atividades o Hidronegócio (Aquicultura, Barragens de Usinas Hidrelétricas, Porto e Industria Naval, Plataforma e Industria do Petróleo) e Pesca (Industrial, Comercial e Amadora). Essa face da modernização tem de um lado o hidronegócio que restringe o acesso aos pesqueiros, e de outro a pesca predatória (não artesanal) que tem levado ao colapso de pescarias tradicionais, devido a assimetria de poder estabelecida pelo "fascismo social", como aponta Boaventura Santos (2007).

Nessa perspectiva, cabe destacar o "fascismo territorial" (SANTOS, 2007) promovido pela terceira face da modernização que promove a desapropriação da terra, a mais frequente nos trabalhos analisados. Diz respeito ao avanço das atividades econômicas sobre o espaço das comunidades tradicionais de pescadores. Essa face da modernização é a mais frequente nos trabalhos analisados (72) e nas denúncias do Blog Pelo Território Pesqueiro (75). As comunidades de pescadores artesanais têm essa distinção do território ser ao mesmo tempo aquático e terrestre. Contudo, prevalece a "monocultura da diferença", "monocultura do saber", "monocultura do tempo linear" e a "lógica da escala dominante" produzindo a inexistência dos pescadores (SANTOS, 2002) e produzindo argumentos de vazios demográficos (SILVA, 2017). Assim, as áreas de moradias das comunidades despertam o interesse dos agentes da modernização que as consideram um espaço que não é devidamente explorado pelo capital. Assim, se instalam sobre as comunidades e provocam a expulsão dos pescadores, ou nas proximidades submetendo as comunidades a outras lógicas de relação social. Os conflitos fundiários são decorrentes dessa face da modernização, bem como o turismo predatório e a especulação fundiária. Assim, trata-se da modernização que disputa com as comunidades a posse da terra, que até então é de uso comunitário, mas passa a ser vista como mercadoria com valor de uso e de troca.

A "produção de inexistência" pelas faces da modernização apontadas, se assenta na "monocultura" do saber, que nega o conhecimento dos pescadores artesanais que baseiam as práticas de gestão do território. Na "monocultura do tempo linear", que nega a ancestralidade que integra esses saberes e o tempo da natureza que rege a vida das comunidades. A "monocultura da diferença", provoca desqualificação e inexistência desses sujeitos sociais, em vez de serem reconhecidos pelo trabalho e cultura. A "lógica da escala dominante" impõe ao modo de viver e à pesca os preceitos da globalização, negando a vida no local. Finalmente, a "monocultura dos critérios de produtividade" desqualifica a atividade tradicional, sua relação 
com a natureza e seus ciclos, e impõe outras lógicas de produção que não são constituídas coletivamente (SANTOS, 2002, 2011).

$\mathrm{Na}$ resistência dos pescadores e nas estratégias de enfrentamento à modernização, se evidenciam "emergências" Essas devem ser destacadas, e ampliadas, fortalecendo a constituição de um cosmopolitismo subalterno (SANTOS, 2002, 2007, 2011). O diálogo entre as problemáticas da Geografia (trabalhos analisados - dissertações e teses) e as pautas do movimento social (denúncias do Blog Pelo Território Pesqueiro - MPP) evidencia "emergências" frente as faces da modernização. Na sequência, serão apresentadas as atividades relacionadas a cada uma das faces da modernização previamente apresentadas, estabelecendo diálogo entre a análise que distingue relações entre ambiente e território e contextos referidos nas denúncias apresentadas.

\subsection{Primeira Face da Modernização: a degradação}

A partir da análise das denúncias do MPP, observou-se que a modernização provoca a degradação dos ambientes que são fundamentais para as espécies pesqueiras é aquela que apresenta maior equidade no que se refere às três abordagens propostas de relação conceitual entre ambiente e território. Dos 39 contextos analisados, 16 abordam impactos ambientais, 13 disputas no território e 9 conflitos por território. Dessa forma, se observa um peso maior à questão ambiental, direcionando o foco da análise para o ambiente aquático e ecossistemas associados ao mesmo. Assim, é fundamental considerar os corpos d'água (interiores e costeiros), manguezais, matas ciliares, matas de várzea/igapó, marismas, etc.

Os principais impactos/disputas/conflitos são provocados pelo avanço da Urbanização, a instalação e funcionamento de industrias, agronegócio e mineração. Com base nas pesquisas analisadas a maior concentração está na região Nordeste (17) e Sul (13). Na sequência, estão as regiões Sudeste (6), Norte (1) e Centro-Oeste (1), sempre lembrando que esta última teve um número reduzido de pesquisas analisadas (figura 62). 


\section{GEOGRAFIAS DA PESCA ARTESANAL BRASILEIRA:}

Primeira Face da Modernização: degradação dos ecossistemas.

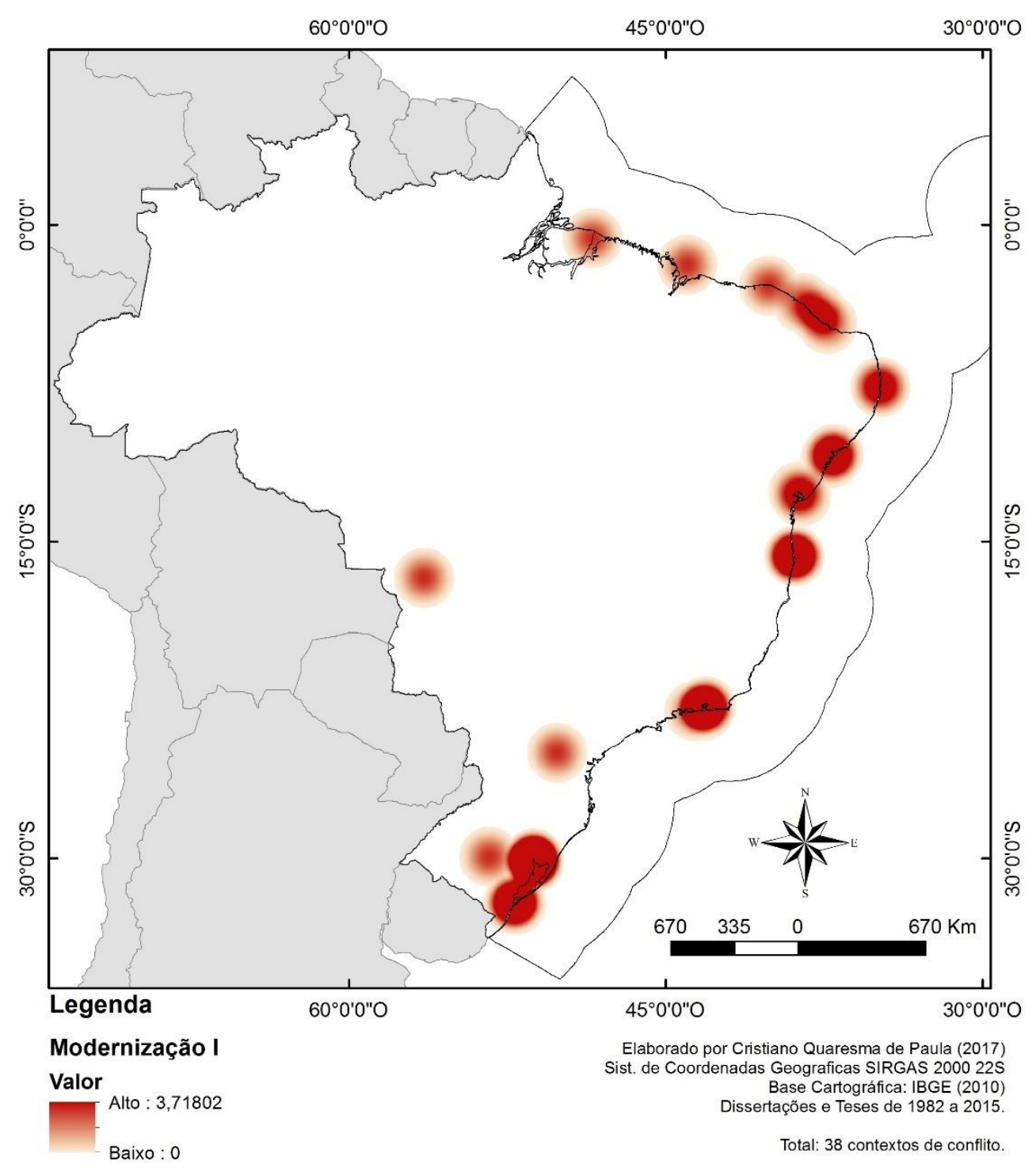

Figura 62: Mapa da Primeira Face da Modernização: degradação dos ecossistemas Fonte: Elaborado por De Paula (2018).

Em diálogo com o movimento social se observa que a modernização que causa a degradação ambiental está presente nas falas que se referem à escassez. Contudo, na página de denúncias do Blog Pelo Território Pesqueiro essa modernização está menos presente (6). Entende-se que isso se deve pelo reconhecimento do fato da transfiguração da natureza a um ponto em que o empenho está prioritariamente em defender os territórios que ainda não estão tão degradados. Já nos trabalhos da Geografia é possível acompanhar esse processo de degradação, as consequências nas comunidades, nos seus modos de viver, na subsistência. 
Fica evidente no Rio Grande do Sul, uma mancha de maior intensidade no complexo Laguna dos Patos - Lago Guaíba. Principalmente no Lago Guaíba e Delta do Jacuí se evidencia o contexto de degradação ambiental decorrente da modernização. Destaca-se o despejo de esgoto urbano da Região Metropolitana de Porto Alegre, os efluentes industriais que chegam no lago, principalmente da indústria calçadista do Vale do rio dos Sinos e o despejo de agrotóxicos provenientes dos monocultivos da região. Em trabalho de campo realizado junto ao Núcleo de Estudos Geografia e Ambiente - NEGA/UFRGS foi possível observar que esse estado de degradação influencia a quantidade e a qualidade de pescado, o que tem levado os pescadores a se desterritorializarem (DE PAULA, 2013).

Na Bahia também se observa a presença dos impactos ambientais da modernização que provoca degradação ambiental. No III Seminário Espaços Costeiros promovido pelo Grupo de Pesquisa Costeiros da UFBA a fala da pescadora que Marizelha Lopes integrante do MPP apontou para a contaminação e degradação da água, solo e ar devido ao complexo industrial instalado na Ilha de Maré. Segundo a pescadora a visita à ilha deveria ser chamada de "toxitur" tamanho o nível de degradação ambiental causado pela indústria petroquímica. Também salientou que os dejetos urbanos e resíduos sólidos da região metropolitana de Salvador são carreados pelo mar para o entorno da ilha intensificando o quadro de degradação. As famílias perecem pela redução da pesca e devido a doenças causadas pela poluição.

Observa-se no Rio de Janeiro uma concentração mais intensa de trabalhos, onde é importante fazer referência ao NUTEMC, no qual os pesquisadores estão muito empenhados em compreender os impactos da modernização, nas baías de Sepetiba e de Guanabara no tempo presente. Em trabalho de campo com os pesquisadores do núcleo, na constituição do Fórum de Pesca da Baía de Sepetiba ficou evidente a preocupação dos pescadores da região com a degradação ambiental provocada pelos principalmente pela intensa urbanização e industrialização do entorno.

Com base nas denúncias do Blog Pelo Território Pesqueiro - MPP, no Relatório “Conflitos Socioambientais e Violações de Direitos Humanos em Comunidades Tradicionais Pesqueiras no Brasil" e em trabalhos de campo realizado junto ao MPP, serão discutidas as principais atividades promotoras da modernização que causam degradação ambiental. Cabe salientar que essa discussão está baseada na proposta analítica que visa destacar impactos ambientais, disputas no território e recursos do ambiente, e conflitos por território.

O Relatório "Conflitos Socioambientais e Violações de Direitos Humanos em Comunidades Tradicionais Pesqueiras no Brasil” tratando da degradação ambiental enfatiza 
que: “A contaminação da terra e da água com agrotóxicos dos monocultivos, empreendidos por setores industriais e mineradoras estão entre os piores índices apresentados" (TOMÁZ; SANTOS, 2016, p. 15).

\section{Industrialização}

A industrialização é apontada como a principal atividade da modernização que provoca a degradação ambiental nos trabalhos analisados (15). Contudo, a degradação ambiental causada pelas indústrias é menos frequente nas denúncias analisadas (2). Cabe destacar que não se considerou nessa analisa as plataformas de petróleo e a indústria naval. Porém, consideramse as consequências da indústria petroquímica.

Segundo as denúncias presentes no Blog Pelo Território Pesqueiro esses impactos já se evidenciam com a redução do pescado em quantidade e qualidade na baía de Guanabara - RJ ${ }^{12}$, e no Litoral do Espirito Santo ${ }^{13}$. Na baía de Guanabara se observa a "influência direta e indireta dos empreendimentos de grandes empresas causadoras de impactos ambientais, como Petrobras". No Espírito Santo "em nome do progresso e do desenvolvimento, sofreram o primeiro impacto com a chegada da PETROBRAS. Esta matou peixes, tartarugas, contaminou a terra...”. No Relatório “Conflitos Socioambientais e Violações de Direitos Humanos em Comunidades Tradicionais Pesqueiras no Brasil" a indústria petroquímica é destacada como uma atividade causadora de impacto ambiental no Litoral da Bahia, mais precisamente nas comunidades de Tororó e de Ilha de Maré. Nesta última, o relatório apresenta que "os empreendimentos poluem o meio ambiente e causam mortandade de peixes e dos mariscos e atingem a saúde da população, causando doenças como o câncer. As árvores da ilha estão morrendo com a poluição da atmosfera e da água, assim como o manguezal" (TOMÁZ, SANTOS, 2016, p.72).

Em relação aos impactos ambientais que prejudicam a pesca artesanal e obrigam os pescadores artesanais a abandonarem seus territórios tradicionais, cabe destacar o desmatamento dos manguezais (SILVA, 2012B), contaminação das águas (TORRES, 2014;

12 PELO TERRITÓRIO PESQUEIRO. Na Baía de Guanabara/RJ, pescadores e pescadoras artesanais sofrem com a intervenção da Indústria Petrolífera. Disponível em: <http://denunciapeloterritorio.blogspot.com.br/2014/04/na-baia-de-guanabararj-pescadores-e.html>. Acesso em: 01 out 2016.

13 PELO TERRITÓRIO PESQUEIRO. Carta denúncia dos crimes cometidos contra as famílias pescadoras do distrito de Regência, Linhares-ES. Disponível em: $<$ http://denunciapeloterritorio.blogspot.com.br/search?updated-max=2013-08-22T06:57:00-07:00\&maxresults $=2 \&$ reverse-paginate $=$ true $>$. Acesso em: 01 out 2016. 
SILVA, 2007) e, consequentemente, a contaminação do pescado (FIGUEIREDO, 2013). Esses, segundo os trabalhos analisados e informações apresentadas pelo movimento social, reduzem a quantidade e a qualidade do pescado. Assim, os pescadores artesanais se veem progressivamente obrigados a abandonarem seus territórios tradicionais.

As disputas no território se evidenciam na resistência para se manterem no território pesqueiro frente à degradação do mesmo. Ressalta-se a relação entre degradação dos ecossistemas e atividades tradicional, onde os pescadores veem o território pesqueiro, as atividades que causam degradação veem o ambiente como recurso. A devastação e poluição dos manguezais impossibilitam a mariscarem e a pesca (COSTA, 2010, SANTOS, 2012). Como demostra o documentário "No Rio e no Mar"14 a contaminação química do mangue, além da contaminação do pescado põe em condição de insalubridade a marisqueira.

Eu tinha doze anos quando meu pai apresentou esse monstro pra gente", fala Marizélia Lopes, pescadora de Ilha de Maré e uma das líderes do Movimento dos Pescadores e Pescadoras (MPP), apontando para a refinaria da Petrobras em Madre de Deus, na Baía de Todos os Santos (Trecho do documentário "No Rio e no Mar").

Acrescenta-se as bombas de sucção de água e os efluentes industriais lançados sem tratamento nos corpos d'água (DE PAULA, 2013) muitas vezes acumulando metais pesados no fundo, que nas dragagens são movimentados (VINHAS, 2011) levam a extinção de territórios pesqueiros tradicionais. Além disso, a instalação de complexos industriais atrai novos moradores para as proximidades dos pesqueiros, que contribuem no incremento do processo de degradação ambiental (SANTANA, 2013). A resistência das comunidades para se manterem nos territórios pesqueiros tradicionais, frente à degradação causada pelas industrias se dá por meio de estratégias de manutenção da atividade, mesmo em situação de insalubridade

Em relação aos conflitos por território, se observa que entram em choque duas racionalidades de apropriação do território - os pescadores artesanais enquanto extrativistas veem seus territórios serem degradados por atividades industriais, que seguem outra lógica de apropriação dos recursos -. Essas últimas utilizam a água em seus processos drenando os corpos d'água da pesca artesanal, despejam efluentes contaminados, etc. Seguem a compreensão que os recursos estão disponíveis para os seus processos produtivos e o território pesqueiro não existe, pois, a prerrogativa é do desenvolvimento econômico.

14 " No Rio e no Mar. Direção: Jan Willem Den Bok e Floor Koomen: COPYRIGHTS, 2016. 1 DVD (56.44 $\mathrm{min})$. 
Nesse sentido, além da degradação dos pesqueiros tradicionais, cabe enfatizar as consequências dos processos industriais nos territórios de moradia e vivência dos pescadores artesanais, devido a imposição de outra lógica de uso da natureza (RIOS, 2012). Cabe destacar que os avanços dessa atividade sobre as áreas das comunidades encontram apoio dos governos locais e suporte do grande capital (LIMA, 2002) e que o enfrentamento se dá pela resistência das comunidades (RAINHA, 2015).

Na II Conferência Nacional do Movimento dos Pescadores e Pescadoras Artesanais foi denunciado que os poluentes lançados pela indústria, sobretudo petroquímica, e suas consequências nos modos de viver dos pescadores e risco de vida pela condição de insalubridade. Na fala da pescadora Marizélia Lopes no documentário "Na terra e no mar" se observa esse tipo de transformação das áreas das comunidades: "Esses empreendimentos fizeram com que Ilha de Maré deixasse de ser o paraíso que era".

Esses conflitos têm levado os pescadores artesanais a se mobilizarem em movimento social para também defenderem os territórios onde se situam as comunidades, frente ao quadro de degradação que tem consequências inclusive na saúde. Denunciam nas instituições formais, como os órgãos ambientais, Ministério Público, e fazem manifestações com o intuito de chamarem atenção das autoridades competentes. A reportagem que segue demonstra uma dessas formas de mobilização para defender os territórios tradicionais:

Mais de 200 pescadores e pescadoras da Ilha de Maré (BA) acabam de ocupar, na manhã de hoje (14/02/17), a sede da CODEBA (Companhia das Docas do Estado da Bahia), localizada no bairro do Comércio em Salvador (BA). O protesto é para denunciar a grave poluição química que tem contaminado a ilha e tem adoecido muitos dos pescadores e pescadoras da localidade ${ }^{15}$.

Diante do que foi exposto a modernização proposta pela industrialização causa degradação ambiental. Essa degradação se manifesta na poluição/contaminação dos ambientes aquáticos e terrestres. Os impactos provocados nos ambientes de pesca têm levado à extinção da atividade tradicional. Em outros casos os pescadores resistem na atividade, disputando o direito de uso do território. Os conflitos se estabelecem, devido as consequências dessa degradação na pesca e na vida humana, chegando aos territórios de moradia e vivência das comunidades.

15 PELO TERRITÓRIO PESQUEIRO. Pescadores de Ilha de Maré ocupam sede da CODEBA. Disponível em: <http://peloterritoriopesqueiro.blogspot.com.br/2017/02/pescadores-de-ilha-de-mare-ocupamsede.html>. Acesso em: 12 out 2017. 


\section{Urbanização}

A modernização promovida pela urbanização também causa degradação ambiental, seja pela captação excessiva de água, pelo aterramento de ecossistemas importantes, mudanças nas características dos rios e pelo despejo de efluentes líquidos e sólidos nos corpos d'água. Segundo o Relatório "Conflitos Socioambientais e Violações de Direitos Humanos em Comunidades Tradicionais Pesqueiras no Brasil" "os níveis de degradação e contaminação dos rios e mares do Brasil passam principalmente pelos esgotamentos sanitários sem tratamentos de cidades e povoamentos" (TOMÁZ, SANTOS. 2016, p.13). Nesse sentido é fundamental também considerar a falta de planejamento urbano para a conservação do ambiente onde estão os territórios tradicionais das comunidades de pescadores.

No Relatório de Tomáz e Santos (2016) se observa as consequências nocivas da urbanização na região do Baixo Amazonas e de Marajó, Comunidade de Juá onde foi instalado condomínio junto à comunidade tradicional e o esgoto é despejado diretamente no lago que é o pesqueiro. Também na Bacia do Rio São Francisco, município de Serra Talhada, que recebe efluentes de esgoto sanitário das cidades, que são despejados diariamente no rio. Já no Litoral da Bahia, em São Roque do Paraguaçu é denunciado que devido a ocupação urbana desordenada as áreas de manguezais foram suprimidas, provocando consequências à mariscagem e pesca.

Quanto aos impactos ambientais que provocam a desterritorialização dos pescadores artesanais é fundamental considerar a poluição/contaminação provocada pelo crescimento das cidades sem sistema de coleta de esgoto (FIGUEIREDO, 2013, SILVA, 2007, LIMA, 2003) e a própria ocupação da cidade que avança sobre ecossistemas importantes como manguezais, sobretudo para a construção de moradias de populações mais empobrecidas (SANTOS, 2013).

Sobre os impactos ambientais associados a degradação causada pela urbanização é importante destacar o grau de transformação dos corpos d'água onde estão os territórios dos pescadores artesanais. Ressalta-se nesse sentido o Rio São Francisco onde se constata que as cidades e povoamentos despejam resíduos sólidos e efluentes domésticos o que, segundo os pescadores provocou a proliferação de "parasitas e corpos estranhos"16 comprometendo a pesca. Em Serra Talhada análises da água realizadas pelo poder público identificou a presença

${ }^{16}$ PELO TERRITÓRIO PESQUEIRO. Carta do Povo do Rio "Eu Viro Carranca Hoje, pra Defender o Velho Chico". Disponível em: < http://denunciapeloterritorio.blogspot.com.br/2015/05/carta-do-povo-do-rioeu-viro-carranca.html>. Acesso em: 01 out 2016. 
de bactérias e toxinas (TOMÁZ, SANTOS, 2016). Nesse caso o território pesqueiro deixa de existir devido à perda de produtividade na pesca, seja qualidade ou quantidade de pescado.

Os conflitos por território também são presentes quando corre degradação do ambiente pela urbanização. Esses conflitos se dão tanto nos pesqueiros, quanto nas comunidades. O avanço do urbano sobre áreas que antes constituíam comunidades de pescadores põe em cena novos atores, agentes e estratégias de reprodução do espaço, frequentemente resultando na exclusão dos pescadores (RAINHA, 2015), apesar da resistência de muitas comunidades (FERREIRA, 2013). Consequentemente a lógica de produção artesanal, com mais relação com os ciclos e ritmos da natureza vai sendo substituído, o que implica em degradação (NUNES, 2011). Além disso a urbanização e a constituição de segundas residências trazem para o âmbito do território comunitário serviços, que contribuem com o processo de degradação (COSTA, 2015).

Destaca-se que o próprio processo de adensamento populacional promovido pela urbanização tende a exigir do pescador artesanal uma maior demanda de pescado, o que atrai outras pessoas para a atividade pesqueira, contribuiu com a intensificação da captura provocando degradação e causa consequência nas relações entre pescadores, nas regras e acordo comunitários, de forma que desestabiliza a coesão comunitária. Além disso, a poluição/contaminação dos corpos d'água, terra e ar promovidos pelo avanço do urbano interfere no modo de viver dos pescadores. Comunidades passam a conviver com a falta de água potável, como se observa na bacia do Rio São Francisco:

Constatamos as Cidades e povoamentos, continuarem jogando lixo e esgotos no Rio São Francisco, e vimos nesta região muitos parasitas e corpos estranhos presentes em nosso ecossistema, e o poder público com projetos enganadores de esgotamento sanitário e poucas ou nenhumas medidas satisfatórias serem realizadas. ${ }^{17}$

A disputa nos territórios pesqueiros com a urbanização se dá pelo avanço do tecido urbano sobre ecossistemas onde é realizada a pesca, por meio de aterros e desmatamentos, ou o despejo de resíduos sólidos e efluentes domésticos sobre esses territórios causando degradação. É fundamental destacar que nesse processo a problemática ambiental orienta ações territoriais dos pescadores. Existem diversas experiências no Brasil em que os próprios pescadores realizam a coleta de resíduos sólidos urbanos dos corpos d'água como estratégia de

${ }^{17}$ PELO TERRITÓRIO PESQUEIRO. Carta do Povo do Rio "Eu Viro Carranca Hoje, pra Defender o Velho Chico". Disponível em: < http://denunciapeloterritorio.blogspot.com.br/2015/05/carta-do-povo-do-rio-euviro-carranca.html>. Acesso em: 01 out 2016. 
reduzir o dano ambiental no território tradicional. Um exemplo é o projeto Pescando Lixo realizado no âmbito da Colônia de Pescadores Z5, no Lago Guaíba em Porto Alegre - RS (DE PAULA 2013). Ressalta-se que geralmente essa disputa com a urbanização leva os pescadores artesanais a procurarem outros territórios de pesca, migrando para áreas mais longínquas da comunidade. Frequentemente entram em disputa com pescadores locais que já haviam estabelecido territórios de pesca, além de resultar a intensificação do uso desses pesqueiros. Contudo, dependendo da condição do ambiente esse território pode voltar a ser acessado.

\section{Agronegócio}

As atividades agropecuárias, sobretudo as relacionadas ao agronegócio, também apresentam consequências da modernização associadas à degradação ambiental. Ressalta-se o despejo de agrotóxicos e adubos químicos nos corpos d'água, os desmatamentos de matas ciliares, o avanço sobre os manguezais.

Cabe ressaltar que nesse momento não estão sendo considerados conflitos relacionados às questões fundiárias. Por isso, não serão apresentados conflitos por territórios das comunidades. Ganha centralidade, então, a questão ambiental expressa por meio de impactos e disputas no território que geram degradação.

A degradação causada pelo uso indiscriminado de defensivos químicos está expressa em denúncia apresenta no Blog Pelo Território Pesqueiro "Constatamos exasperados a terra e a água sendo contaminadas por altos índices de agrotóxicos e adubos químicos, empreendidos pelo agronegócio devastador" ${ }^{18}$. A poluição/contaminação por agrotóxicos e fertilizantes químicos também tem registros no o Relatório "Conflitos Socioambientais e Violações de Direitos Humanos em Comunidades Tradicionais Pesqueiras no Brasil” no Região Centro Maranhense, Litoral da Bahia (municípios Sento Sé, Rodelas), litoral de Santa Catarina. Em relação à captação excessiva de água para irrigação há registro em no Submédio São Francisco e de processos erosivos devido ao desmatamento de matas ciliares e pecuária intensiva em no Litoral da Bahia e na Região Centro Maranhense.

Entende-se que o principal impacto de degradação ambiental provocado pelas atividades agropastoris é a contaminação dos corpos d'água por defensivos e fertilizantes químico (FIGUEIREDO, 2013; SILVA, 2007) o que também ameaça a qualidade do solo (MACHADO, 2007). Contudo é de grande importância que o avanço da atividade agrícola que causa pressão

18 PELO TERRITÓRIO PESQUEIRO. Nota à sociedade: Denúncia da Comunidade Pesqueira Caraíbas/MG. Disponível em: < http://denunciapeloterritorio.blogspot.com.br/2013/10/nota-sociedade-denunciada-comunidade.html >. Acesso em: 01 out 2016. 
sobre os ecossistemas (matas ciliares e mangue) reduzindo a biodiversidade (MACHADO, 2007) e desencadeia processos de desiquilíbrio, como a erosão dos solos.

Impactos ambientais decorrentes da irrigação intensa e desmatamentos de matas ciliares - que desencadeia processos erosivos e assoreamentos dos corpos d'água - faz com que os pescadores artesanais da bacia do Rio São Francisco questionem a seca no semiárido como fenômeno natural responsável pela escassez de água:

Diante desta situação crítica, não podemos acreditar que a seca, enquanto fenômeno natural do Semiárido, seja responsabilizada mais uma vez por este colapso, sendo que os grandes irrigantes continuam usando a mesma quantidade de água para o agronegócio de exportação e a Chesf mantem uma baixa vazão para geração de energia ${ }^{19}$.

Assim, o assoreamento e poluição/contaminação são os principais impactos ambientais da agropecuária que causam degradação. Outro exemplo é a Região Centro Maranhense, onde os agrotóxicos dos monocultivos de cana-de-açúcar e eucalipto são carreados para os rios contaminando os mesmos e inviabilizando a pesca. As áreas de criação de gado atingem as margens dos rios, provoca desmatamentos, o que resulta em assoreamento e redução do pescado no maranhão (TOMÁZ, SANTOS, 2016).

As comunidades de pescadores estabelecem disputas no território decorrentes da degradação dos corpos d'água pela atividade agropecuária. Por poluir/contaminar e assorear corpos d'água (SCHEIBEL, 2013) onde se encontram importantes pesqueiros degradam importantes áreas de criação e maturação das espécies, ao ponto que muitas espécies são extintas ou drasticamente reduzidas. Isso ocorre mesmo que a legislação ambiental estabeleça regras para preserva-las (MORAES, 2015), como a utilização de telas nos dutos de sucção de água para irrigação. (MORAES, 2015; DE PAULA, 2013). A pecuária também disputa territórios com a pesca artesanal, quando provoca o assoreamento de lagos (GUEDES, 2009) e rios, que constituem importantes territórios pesqueiros.

Frente ao avanço de outras atividades econômicas que avançam sobre o território pesqueiro, os pescadores artesanais recorrem aos órgãos ambientais denunciando os crimes cometidos pelo agronegócio. Contudo, é o próprio Estado que motiva o avanço dessa atividade econômica, e viabiliza o uso dos recursos hídricos por meio de outorgas de uso, que não

${ }^{19}$ PELO TERRITÓRIO PESQUEIRO. Carta do Povo do Rio "Eu Viro Carranca Hoje, pra Defender o Velho Chico". Disponível em: < http://denunciapeloterritorio.blogspot.com.br/2015/05/carta-do-povo-do-rioeu-viro-carranca.html>. Acesso em: 01 out 2016. 
consideram o impacto na pesca artesanal. Como consequência os pescadores têm que migrar para outros territórios de pesca, onde entram em conflito com pescadores locais, como ocorre nas margens do rio Arari, Região do Marajó (TOMÁZ, SANTOS, 2016).

\section{Mineração}

Para o Relatório "Conflitos Socioambientais e Violações de Direitos Humanos em Comunidades Tradicionais Pesqueiras no Brasil" a mineração é uma das atividades econômicas que mais provocam degradação ambiental em todo o mundo. "Ela altera intensamente a área minerada e as áreas vizinhas, onde são feitos os depósitos de estéril e de rejeitos. Além de introduzir no ambiente substâncias químicas nocivas durante a fase de beneficiamento do minério" (p.13). Entre os impactos citados destacam-se poluição da água, poluição do ar, poluição sonora, subsidência do terreno, incêndios causados pelo carvão e rejeitos radioativos. Assim, impacta os pesqueiros tradicionais e disputa território com as comunidades de pescadores.

Segundo Tomáz e Santos (2016) há registros de degradação, como contaminação dos corpos d'água e desmatamento causado pela atividade mineradora no Litoral Norte do Maranhão, Litoral de Santa Catarina e Litoral da Bahia. No Blog Pelo Território Pesqueiro destaca-se a resistência dos pescadores frente ao crime ambiental ocorrido na bacia do Rio Doce, que atingiu até o Oceano Atlântico provocado pela Mineradora SAMARCO, VALE BHP.

Entre os impactos da atividade mineradora que causa degradação é importante considerar as mudanças causadas nos corpos d'água, e ação sobre as áreas de criação e maturação das espécies pesqueiras (SILVA, 2007). A contaminação por rejeitos de mineração ganha destaque no Relatório "Conflitos Socioambientais e Violações de Direitos Humanos em Comunidades Tradicionais Pesqueiras no Brasil”. Registra que no Litoral Norte Maranhense houve destruição de áreas de manguezais e estuários por parte de Mineradora devido aos vazamentos constantes de materiais químicos adicionados à matéria orgânica transportada para o mangue, contaminando o manguezal, provocando redução de pescados. Isso compromete a continuidade da pesca nos territórios pesqueiros tradicionais. Essa problemática é grave e compõe um projeto de desenvolvimento em expansão que avança sobre a Amazônia:

O coração da Amazônia está ameaçado. A região de maior biodiversidade do planeta sofre com a pressão da construção de barragens hidrelétricas. São 150 barragens pensadas nos seis maiores rios. Isto representa um aumento de mais de $300 \%$ em relação as já existentes em uma área que se espalha por cinco 
países: Brasil, Bolívia, Colômbia, Equador e Peru. As consequências são a perda de florestas e a perda de conexão entre os Andes e as Planícies Amazônicas - a cordilheira é responsável pela maior parte dos sedimentos, nutrientes e matéria orgânica que chegam ao rio. Muitas espécies de peixes desovam em rios que dependem da influência andina, incluindo as que migram para as cabeceiras (TOMÁZ, SANTOS, 2016, p.11).

O avanço da mineração sobre os pesqueiros tradicionais e a degradação causada leva os pescadores artesanais à mobilização e a se integrarem em movimento social (DE PAULA, 2013), para buscar fazer frente ao progresso dessa atividade que não reconhece os territórios tradicionais (SANTOS, 2014). Segundo denúncia do Blog Pelo Território Pesqueiro, os pescadores artesanais do município de Caetité-BA estão se mobilizando frente a instalação do Projeto Pedra de Ferro da empresa Bahia Mineração - Bamin, que inicia sua fase experimental de operação na exploração de minério de ferro". As comunidades "temem perder os rios, riachos, poços e barragens que abastecem as famílias da região"20.

Como a denúncia destaca:

A necessidade de preservação apontada pelos moradores da área contrasta com o projeto da Bahia Mineração, que no imenso vale onde está o leito do riacho Pedra de Ferro pretende implantar a sua barragem de rejeito, transformando o rico manancial num imenso mar de lama. Numa região que ao longo do tempo vem sofrendo com a escassez de água, destruir um rio não cabe no imaginário da população local. Não é legal, ético, moral.

Cabe destacar o caso emblemático de Mariana/MG, onde o rompimento da barragem de rejeitos da Mineradora Samarco BHP contaminou o Rio Doce, afluentes e um longo trecho do Oceano Atlântico que se estende do Espírito Santo até Bahia. Por onde passou a lama desalojou comunidades, extinguiu fauna e flora e causou mortes, como apresenta o Relatório:

Milhares de pessoas perderam seu meio de sustento. À medida que os rejeitos de minérios atingiam as águas do Rio Doce e chegavam no mar, os peixes e os pescadores ficaram destruídos. "Nossas vidas foram soterradas num mar de lama", afirmam os pescadores artesanais. Cerca de 2 mil famílias de comunidades pesqueiras foram afetadas em 41 municípios desde Mariana até a Foz do Rio Doce, em Linhares/ES. Não se pode mensurar a mortandade de peixes ocorrida. Para o IBAMA, a ictiofauna que habita os rios Gualaxo do Norte, Carmo e Doce foi afetada drasticamente e o desastre foi maior ainda porque os peixes se encontravam em período de reprodução. Não faltam exemplos de conflitos semelhantes envolvendo empresas como a Vale S.A. no Brasil e no exterior. Essa empresa de mineração foi responsável pelo desastre de Mariana (TOMÁZ, SANTOS, 2016, pp.11-12).

${ }^{20}$ PELO TERRITÓRIO PESQUEIRO. Bamin quer transformar leito de rio vivo em barragem de rejeito. Disponível em: < http://denunciapeloterritorio.blogspot.com.br/2013/10/bamin-quer-transformar-leitode-rio.html>. Acesso em: 01 out 2016. 
Desde então os pescadores se veem impedidos de realizar a pesca no território tradicional, no rio Doce, e em uma extensa área no Oceano que passou a ser definida como de exclusão da pesca, devido ao nível de contaminação das águas e das espécies pesqueiras. Articulados em movimento social, os pescadores cobram das autoridades a punição das empresas envolvidas no crime, como expõe a denúncia presente no Blog Pelo Território Pesqueiro:

Na última sexta-feira pela manhã, 04, aconteceu o "Abraço ao Rio Doce", manifestação que reuniu cerca de 2 mil pessoas, entre pescadores e pescadoras vindos de diversos estados do Brasil em Linhares/ES, na ponte da BR101, para denunciar a pouca visibilidade dada ao caso das comunidades pesqueiras e exigir posicionamento do governo e da SAMARCO sobre medidas de mitigação socioambientais a curto e longo prazo para a pesca artesanal e para todos os impactados. Foram quase 2 horas de caminhada pelas ruas de Linhares até os manifestantes chegarem a Ponte da BR 101. Encenações, cartazes, faixas e gritos pediam que a SAMARCO se responsabilizasse e dialogasse com as famílias impactadas. "Queremos discutir as medidas que a empresa vai tomar, queremos garantir nossas vidas, nosso sustento. Esse desastre não pode passar impune", desabafou uma das pescadoras. ${ }^{21}$

Diante do que foi apresentado, a degradação ambiental é uma face da modernização, resultado prioritariamente do avanço das atividades industriais, da expansão da cidade, de seus impactos, da implementação de projetos do agronegócio e da instalação e funcionamento de mineradoras. Essas atividades provocam impactos ambientais quando afetam o ambiente ao ponto de extinguirem o território pesqueiro, estabelecem disputas no território e conflitos por território quando se impõem sobre o território apropriado pelas comunidades e desejam o domínio do espaço.

Entendendo a degradação como resultado desses processos, os pescadores artesanais, organizados em movimento social, se apropriaram do conceito de "racismo ambiental". Esse conceito tratado desde os anos 1990 abordam política públicas que prejudicam prioritariamente os grupos étnicos vulneráveis. Isso quer dizer que, quando vão ser definidos projetos de desenvolvimento que provocam degradação ambiental, escolhe-se áreas onde estão as comunidades das quais são consideradas como impotentes frente ao grande capital.

${ }^{21}$ PELO TERRITÓRIO PESQUEIRO. Pescadores fecham Ponte de Linhares/ES em manifestação pelo Rio Doce. Disponível em: < http://peloterritoriopesqueiro.blogspot.com.br/2015/12/pescadores-fechamponte-de-linhareses.html>. Acesso em: 01 out 2016. 


\subsection{Segunda Face da Modernização: Sobre-exploração e restrição do}

\section{acesso}

Com base na análise das denúncias apresentadas no Blog Pelo Território Pesqueiro observou-se que a segunda face da modernização é aquela que se expõe nos pesqueiros tradicionais, prioritariamente. Assim, afetam os territórios pesqueiros por meio da sobreexploração dos recursos pesqueiros e/ou interrompem o acesso entre território onde está situada a comunidade e pesqueiro tradicional. Ambas as formas causam impactos ambientais, disputas no território e conflitos por territórios pesqueiros. Dos trabalhos analisados (dissertações e teses) identificou-se 72 contextos em que a problemática versa sobre essa face da modernização. Destes 43 dizem respeito às disputas estabelecidas no território por recursos do ambiente, 23 são contextos se referem à conflitos por território e seis impactos ambientais. Observa-se que a maioria dos trabalhos tratam de disputas no território por recursos do ambiente, ou seja, fica evidente a correlação entre conceitos de ambiente e território quando se trata dos pesqueiros tradicionais.

Disputas no território, conflitos por território e impactos ambientais são provocados pelos Hidronegócio (Aquicultura e Barragens), Pesca Predatória (Pesca Industrial, Pesca Comercial, Comercialização do Pescado e Pesca Amadora); Portos e Plataformas de Petróleo. A figura 63 apresenta a expressão desses contextos no Brasil, com base na análise de dissertações e teses. Como é possível observar, essa face da modernização tem maior expressão na região Nordeste (30). Na sequência, apresentam-se regiões Norte (18), Sul (15), Sudeste (8) e Centro-oeste (1). 


\section{GEOGRAFIAS DA PESCA ARTESANAL BRASILEIRA:}

Segunda Face da Modernização: sobre-exploração e restrição ao acesso

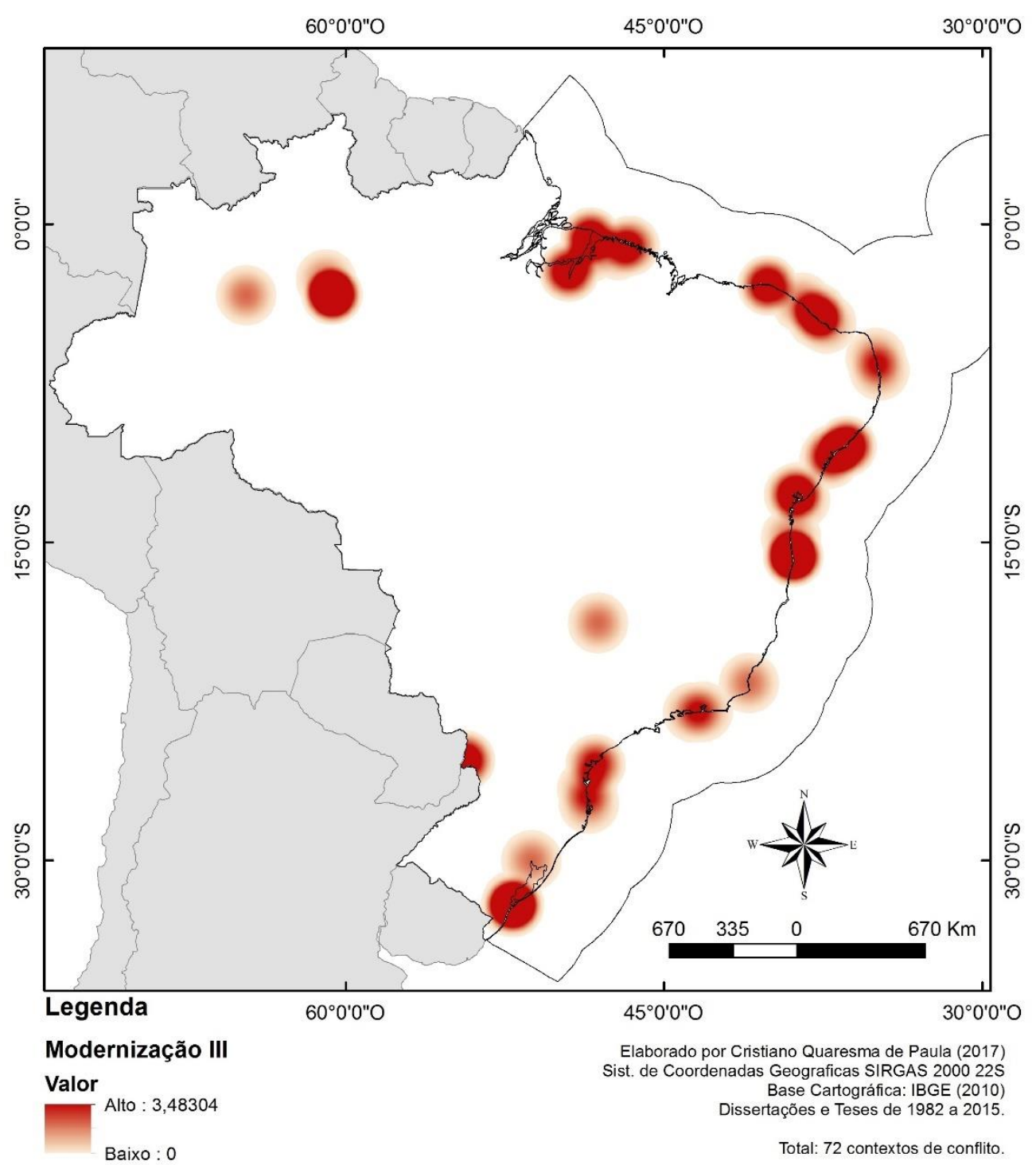

Figura 63: Mapa da Segunda Face da Modernização: sobre-exploração e restrição ao acesso Fonte: Elaborado por De Paula (2018).

Em diálogo com o movimento social se observa que a modernização que promove a sobre-exploração dos recursos pesqueiros ou impossibilita o acesso, está presente nas denúncias que evidenciam a situação de vulnerabilidade dos pesqueiros tradicionais. Cabe enfatizar que na página de denúncias do Blog Pelo Território Pesqueiro essa face da modernização é a mais frequente (75). Isso ocorre porque o MPP compreende os pesqueiros tradicionais como ambiente e território e de forma associada ao território de moradia e vivência das comunidades. Outro fator é que essa face da modernização é resultado de atividades econômicas que desejam 
explorar os pesqueiros, seja os recursos ou o sítio em que estão localizados. Logo, ao contrário da face anteriormente apresentada, aqui o processo em curso é de disputa no território (o pesqueiro tradicional) entre pesca artesanal e outras atividades econômicas. Nem sempre essas outras atividades econômicas reconhecem o território pesqueiro.

Em diversos estados do Nordeste se evidencia disputas, conflitos e impactos, sobretudo com a Carcinicultura Industrial, que avança sobre os territórios pesqueiros tradicionais e causa impactos no ambiente que tem prejudicado a pesca. Em trabalho de campo na II Assembleia Nacional do MPP, os pescadores cearenses destacaram o avanço dessa atividade econômica com apoio dos agentes públicos e viabilizada por meio de legislações federais. Uma das bandeiras do movimento social diz respeito a derrubar as cercas nas águas, ou seja, combater os empreendimentos de aquicultura que impedem o acesso dos pescadores artesanais aos pesqueiros tradicionais.

No caso do Amazonas, a pesca comercial tem disputado territórios tradicionais com pescadores artesanais causando conflitos e impactos. Em trabalho de campo junto ao Núcleo de Estudos Geografia e Ambiente - NEGA/UFRGS - na Floresta Nacional de Tefé - FLONA de Tefé - observou-se que as disputas e conflitos entre pescadores desta unidade e pescadores comerciais urbanos, foram minimizados por meio de acordos de pesca. Outra problemática presente na região é o hidronegócio expresso em barragens para a produção de energia. No I Seminário Nacional: Territórios, Ordenamentos e Representações (I SETOR) promovido pelo Grupo Acadêmico Produção do Território e Meio Ambiente na Amazônia - GAPTA/UFPA os pesquisadores destacaram que na atualidade são os gestores das barragens de hidroelétrica que definem períodos de cheia e seca.

A mancha sobre o Estuário da Laguna dos Patos, no Rio Grande do Sul, corresponde às disputas, conflitos e impactos relacionados à pesca industrial e aos portos. Diante das disputas com a pesca industrial, os pescadores locais se mobilizaram por meio do Fórum da Laguna dos Patos e conseguiram estabelecer normativa (BRASIL, 2004) que proíbe embarcações industriais (traineiras) no estuário. Cabe destacar que nessa região a pesca industrial levou ao colapso dos recursos pesqueiros, deixando os pescadores artesanais em situação de vulnerabilidade social. Já os portos, além de desalojarem as comunidades, geram extensas áreas de exclusão da pesca. No caso do Estuário da Laguna dos Patos, essas áreas constituíam territórios tradicionais.

A problemática dos portos/indústria naval também se evidencia no Rio de Janeiro. Em trabalho de campo junto aos pesquisadores do Núcleo de Pesquisa e Extensão: Urbano, 
Território e Mudanças Contemporâneas observou-se o avanço do Porto do Açu sobre as comunidades tradicionais, desalojando, impedindo o acesso aos territórios tradicionais e tornando impraticável a pesca em determinados locais devido aos impactos ambientais. No mesmo trabalho de campo, os pescadores da Ilha da Madeira - Itaguaí também demonstraram preocupação das comunidades com a instalação do complexo naval, o estaleiro para produção de submarinos na Base Naval da Marinha do Brasil. Essas comunidades veem sua mobilidade normatizada pela Marinha, agora convive com outros agentes fazendo uso do território tradicional, estabelecendo disputas, conflitos e impactos.

As denúncias Blog Pelo Território Pesqueiro - MPP, Relatório "Conflitos Socioambientais e Violações de Direitos Humanos em Comunidades Tradicionais Pesqueiras no Brasil" e trabalhos de campo realizado junto ao MPP, servirão de base para a análise das atividades promotoras da modernização que impedem o acesso dos pescadores ao território tradicionais, ou promovem a sobre-exploração dos pesqueiros. Assim, serão enfatizados impactos ambientais, disputas no território por recursos do ambiente e conflitos por território que tem comprometido os pesqueiros tradicionais.

\section{Hidronegócio}

Para estabelecer diálogo com os movimentos sociais da pesca, a aquicultura e a geração de energia hidrelétrica serão compreendidas como hidronegócio ${ }^{22}$. Segundo o Relatório “Conflitos Socioambientais e Violações de Direitos Humanos em Comunidades Tradicionais Pesqueiras no Brasill”, o hidronegócio se destaca enquanto disputa, conflito ou impacto sobre a pesca artesanal e avança sobre os pesqueiros tradicionais, disputando território com os pescadores artesanais. A expropriação forçada se dá, muitas vezes, por meio de ameaças ou de homicídios.

Na mesma lógica do agronegócio, o hidronegócio arrasa territórios pesqueiros por meio da privatização e mercantilização da água. Porém, a face esdrúxula do hidronegócio se apresenta principalmente como energia hídrica (as barragens), irrigação para o agronegócio, carcinicultura e piscicultura e a violação contra a vida de quem resiste e se opõe (TOMÁZ; SANTOS, 2016, p. 12).

${ }^{22} \mathrm{O}$ termo hidronegócio vem sendo adotado nas reivindicações de movimentos sociais, como MPP (Movimento dos Pescadores e Pescadoras Artesanais), MAB (Movimento dos Atingidos por Barragens), CPP (Conselho Pastoral da Pesca), CPT (Comissão Pastoral da Terra) entre outros. Segue a compreensão do agronegócio, mas enfatizando os corpos d'água, logo trata-se do "negócio" da água. Malvezzi (2012) destaca que esse termo tem sido tratado na academia como agrohidronegócios. 
Cabe destacar que a modernização que se evidencia nos projetos de hidronegócio "possuem um padrão político de intervenção estatal de mercantilização dos ecossistemas e das intervenções sobre os territórios de ocupação tradicional, ostentados como promessa de desenvolvimento e progresso". Assim, avança sobre a pesca artesanal com argumentos de que essa atividade do ponto de vista da "produção" é menos promissora do que a aquicultura e a geração de energia. Os governos, interessado nas divisas prometidas com a modernização do território estabelecem políticas de fomento e flexibilizam a legislação ambiental. "Os megaprojetos mobilizados pelo bloco hegemônico do capitalismo contemporâneo avançam com uma matriz energética nefasta apoiada nas hidrelétricas, eólicas, nucleares e nas transposições de rios; no avassalador hidronegócio, com a carcinicultura e piscicultura". Diante disso, entende-se que esse projeto contempla "empreendimentos que fazem parte do arcabouço de injustiça ambiental e social que devastam o planeta” (TOMÁZ; SANTOS, 2016, p. 102).

\section{Aquicultura}

A aquicultura enquanto atividade do hidronegócio promove disputas no território, conflitos por território e impactos ambientais. Nesse momento além da utilização do ambiente em condições de sobre-exploração destaca-se os "cercamentos" das águas, impedindo o acesso das comunidades ao território pesqueiro. Cabe enfatizar que esse continuo entre território de moradia e vivência comunitária e território pesqueiro é de fundamental importância para compreender a pesca artesanal como atividade tradicional e não somente atividade econômica.

Disputas, conflitos e impactos com a aquicultura se apresentam no Relatório "Conflitos Socioambientais e Violações de Direitos Humanos em Comunidades Tradicionais Pesqueiras no Brasil" principalmente relacionados à restrição do acesso e mudanças nas características do ambiente, com a supressão dos manguezais e despejo de efluentes contaminados. A perda do acesso ao território pesqueiro é uma problemática que se evidencia no Litoral do Ceará - Vila de Volta, Barra Velha, Praia de Barro Preto e Praia de Capim-Açu, Comunidade Quilombola do Cumbe, Curral Velho-; no Litoral de Pernambuco - Porto Casado, Pendências -; Região do Delta do Parnaíba/Piauí - Comunidade das Marisqueiras; Comunidade Tabuleiro-; Região litorânea de Santa Catarina; Litoral da Bahia - Glória/BA/Comunidades Agrovila 3 na Piçarreira, Acupe, Encarnação de Salinas, Resex Canavieiras, Abadia, Brejo Grande e Paracatuba/SE/Quilombo Brejão dos Negros-.

A problemática da aquicultura se apresenta nas análises de trabalhos (dissertações e teses) realizados em diversas regiões brasileiras. A ênfase dada para essa atividade é sobre as 
disputas, conflitos e impactos sobre os pesqueiros tradicionais, que são tradados como ambiente e território.

As disputas no território se destacam nos trabalhos analisados que evidenciam os impactos da modernização promovida pela aquicultura. Os recursos do ambiente são disputados na medida em que essa atividade econômica se apropria do ambiente e impõe à natureza seus processos, destruindo ecossistemas que são de fundamental importância para a produtividade dos pesqueiros tradicionais. O avanço da aquicultura sobre as áreas de manguezais (SANTOS, 2008; RODRIGUES, 2005; GALVÃO NETO, 2009; CUNHA, 2015; SANTOS, 2012; RIOS, 2012; KHUN, 2009; MACHADO, 2007) é uma problemática frequente, e nessa disputa, a pesca artesanal acaba perdendo território tradicional. Além da devastação dos manguezais, também destacam a contaminação por produtos químicos utilizados nesse processo produtivo (RODRIGUES, 2005; FIGUEIREDO, 2013; CUSTÓDIO, 2006). A denúncia presente no Blog Pelo Território Pesqueiro exemplifica essa disputa na comunidade de Encarnação de Salinas BA:

\begin{abstract}
A comunidade tradicional pesqueira de Encarnação de Salinas, situada no município de Salinas da Margarida, Bahia, está organizada em luta contra a degradação ambiental que vem sendo provocada por mais um empreendimento da carcinicultura que está se instalando na Praia da Igreja e de Santa Luzia.

O MPP/BA recebeu denúncias de moradores afirmando que, mesmo com a advertência do Instituto do Meio Ambiente e Recursos Hídricos (INEMA), os empreendedores estão colocando tratores para derrubar o manguezal nas áreas em que se pretende instalar o empreendimento. A comunidade está fazendo o enfrentamento com diversas articulações e denuncia, inclusive, ameaças de morte sofridas por algumas lideranças locais ${ }^{23}$.
\end{abstract}

Por outro lado, é importante enfatizar que existem disputas nos territórios na medida em que pesqueiros tradicionais são ocupados pela aquicultura, ou o acesso aos mesmos é negado devido a instalação de projetos aquícolas. É importante compreender que frequentemente esses empreendimentos são realizados em fazendas que beiram os corpos d'água, nesse sentido o acesso ao pesqueiro também é um elemento fundamental na manutenção do território pesqueiro tradicional. Essas restrições estabelecidas pela aquicultura geralmente fazem uso de cercas que impedem o acesso dos pescadores ao pesqueiro tradicional (GALVÃO NETO, 2009; CUNHA, 2015). Por consequência, as comunidades têm que se deslocar para distâncias maiores para

\footnotetext{
${ }^{23}$ PELO TERRITÓRIO PESQUEIRO. Em luta pelo seu território, lideranças da comunidade pesqueira de Encarnação de Salinas/Ba sofrem ameaças de morte. Disponível em: <http://denunciapeloterritorio.blogspot.com.br/2014/03/em-luta-pelo-seu-territorio-liderancas.html>. Acesso em: 01 out 2016.
} 
realizarem a pesca, (SANTOS, 2012) o que resulta em transformações de condições sociais, ambientais, culturais e econômicas do território (RIOS, 2012). Ressalta-se que, essas consequências também se expressam no rompimento da continuidade entre território, terra e água.

Os movimentos sociais da pesca artesanal demonstram preocupação do avanço da aquicultura no Brasil, tendo em vista as consequências negativas dessa atividade em outros países como o Chile (RIOS, BRAVOS, 2012). Essa problemática foi discutida em reunião do Conselho Pastoral dos Pescadores:

Nestes dias escutamos atentamente as experiências e os clamores dos pescadores brasileiros e chilenos que estão sendo expulsos violentamente dos seus territórios com a implantação da aquicultura industrial e intensiva, a exemplo da carcinicultura no Brasil e salmonicultura no Chile. Estas atividades têm promovido nos últimos anos uma destruição verdadeira dos estoques pesqueiros (reservas marinhas) e uma extensiva privatização dos manguezais e das águas (bem como dos espaços de moradia dos pescadores e pescadoras), inviabilizando a soberania alimentar e o processo de reprodução física e cultural das comunidades pesqueiras artesanais ${ }^{24}$.

É fundamental frisar o papel do Estado enquanto promotor da aquicultura empresarial estabelecendo políticas de fomento e garantido territórios para essa atividade (BRASIL, 2007B), em detrimento da pesca artesanal:

No Brasil, estamos acompanhando com bastante preocupação uma série de iniciativas (investimento público) do Governo através do Ministério da Pesca para alavancar o desenvolvimento da aquicultura. Percebemos que o governo brasileiro, a exemplo da experiência chilena, tem sido bastante subserviente na criação de leis que visam facilitar da implantação de parques aquícolas, tanto no litoral quanto nas águas continentais, sem a participação da sociedade. Inclusive passando por cima de acordos internacionais do qual é signatário como a convenção $\mathrm{n}^{\circ} 169$ da Organização Internacional do Trabalho - OIT, garantindo que discussões sobre mudanças em legislações que impactem nas comunidades tradicionais devem preceder de uma consulta a estes povos e comunidades.

Em reunião da Articulação Sudeste-Sul do Movimento dos Pescadores e Pescadoras Artesanais em Paranaguá-PR, discutiu-se com a Secretaria de Patrimônio da União - SPU a respeito da concessão de parques aquícolas previstos na IN Interministerial $\mathrm{N}^{\circ} 1$ de 10 de outubro de 2007. Os pescadores temem o avanço dessas atividades sobre o território pesqueiro.

${ }^{24}$ PELO TERRITÓRIO PESQUEIRO. Ameaça à Vida e aos Direitos das Comunidades Tradicionais Pesqueiras. Disponível em: http://denunciapeloterritorio.blogspot.com.br/2012/04/ameaca-vida-e-aos-direitosdas.html>. Acesso em: 01 out 2016. 
Sendo que a regulamentação da/do área/parque aquícola dá o direito ao proprietário do empreendimento a restringir ou proibir a presença dos pescadores artesanais.

A proibição da presença dos pescadores artesanais ou a restrição do acesso dos mesmos ao pesqueiro, implica em conflitos por território. Os trabalhos analisados expõem que a cessão de uso funciona como a "privatização" dos corpos d'água para os empresários do setor aquícola (PÉREZ, 2012). Assim, se opõem lógicas de apropriação do espaço, onde pescadores defendem a área comunal, onde há valor de uso; os empresários defendem a propriedade privada, com valor de troca (FERREIRA, 2014). Na pesca artesanal, o cercamento não faz sentido, já para as empresas são a garantia de domínio e da geração do lucro (SANTOS, 2013).

Além da cerca, o Movimento dos Pescadores e Pescadoras Artesanais denunciam no Blog Pelo Território Pesqueiro diversos casos em que seguranças de fazendas de aquicultura agem com violência contra os pescadores artesanais, impedindo que pesquem ou naveguem nas proximidades como enfatiza o Documentário "Vento Forte"25, onde os pescadores José Nilton e Gilda apresentam as restrições ao acesso (delimitação da área com cordas, boias indicando que a área não pode ser acessada, presença de seguranças) em Petrolândia (PE).

Em relação aos trabalhos que abordam impactos ambientais decorrentes da modernização provocada pela aquicultura, os principais decorrem da contaminação dos corpos de água (TORRES, 2014) e destruição dos manguezais. As comunidades de pescadores resistem a esses impactos e, assim, defendem o território pesqueiro. Contudo, são repelidos por funcionários dos empreendimentos, frequentemente com apoio de agentes do Estado:

Hoje pela manhã, cerca de 27 famílias que ocupavam a área de um viveiro de camarão abandonado, no Cumbe, Aracati/CE, foram despejadas por policiais militares, enquanto empresário da carcinicultura assistia o desespero das/os comunitários. Para protestar pela degradação do manguezal e reivindicar a garantia do território, desde o dia 10 de março, as moradoras e os moradores acampavam na área que dá acesso ao campo de dunas e cemitério local ${ }^{26}$.

\section{Geração de Energia}

A geração de energia hidrelétrica também provoca disputas no território e conflitos territoriais expressando a face da modernização que causa restrições de acesso ao território e sobre-exploração. Ressalta-se as mudanças provocadas, sobretudo na geração de energia

25 "Vento Forte". Direção: Patrícia Antunes: Arte Movimento, 2014. 1 DVD (1:02:00min).

${ }^{26}$ PELO TERRITÓRIO PESQUEIRO. Comunidade do Cumbe em Aracati é despejada por querer recuperação de área de manguezal. Disponível <http://denunciapeloterritorio.blogspot.com.br/2013/08/comunidade-do-cumbe-em-aracati-e.html>. Acesso em: 01 out 2016. 
hidrelétrica no ambiente, onde os pescadores estabeleciam territórios. Entre essas mudanças destaca-se a instalação de barragens, que também provocam desapropriação das comunidades de seus territórios de moradia e vivência, mas essa problemática será destacada nos conflitos fundiários.

O Relatório "Conflitos Socioambientais e Violações de Direitos Humanos em Comunidades Tradicionais Pesqueiras no Brasil" destaca que no caso da Amazônia o modelo de construção de hidrelétricas "segue a lógica perversa de violação de direitos humanos, desrespeito às leis e acordos internacionais, impactos profundos na biodiversidade e nas comunidades tradicionais". Nesse caso das hidrelétricas, além da restrição do acesso aos pesqueiros destaca-se que mudanças no ambiente provocam a redução drástica dos recursos em um projeto de modernização que não considera o impacto sobre a sustentabilidade das comunidades pesqueiras.

O coração da Amazônia está ameaçado. A região de maior biodiversidade do planeta sofre com a pressão da construção de barragens hidrelétricas. São 150 barragens pensadas nos seis maiores rios. Isto representa um aumento de mais de $300 \%$ em relação as já existentes em uma área que se espalha por cinco países: Brasil, Bolívia, Colômbia, Equador e Peru. As consequências são a perda de florestas e a perda de conexão entre os Andes e as Planícies Amazônicas - a cordilheira é responsável pela maior parte dos sedimentos, nutrientes e matéria orgânica que chegam ao rio. Muitas espécies de peixes desovam em rios que dependem da influência andina, incluindo as que migram para as cabeceiras.

As disputas no território, bem como os conflitos por território causados por hidrelétricas que causam a sobre-exploração e perda de acesso aos pesqueiros tradicionais se evidenciam no Relatório "Conflitos Socioambientais e Violações de Direitos Humanos em Comunidades Tradicionais Pesqueiras no Brasil” na Região do Baixo Amazonas e de Marajó: Tocantins (Comunidade Ilha Saracá, Comunidade de Prainha Beradão, Comunidade da Ilha Paquetá Potinga, Comunidade Jussara Cupijó e Comunidade Teré) e Pará (Comunidades de Cametá, Daniel de Carvalho, Santa Cruz, Brasília Legal, Fordilândia e Cuparí). Litoral da Bahia (Enseada do Paraguaçu, Ponta de Souza, Angolá, Santiago do Iguape, Juazeiro, Lagoa do Curralinho). Bacia do Rio São Francisco (Serra Talhada/PE/Barragem de Serrinha, Paulo Afonso/BA/Comunidade do Centenário, Cânion São Francisco/AL, BA, SE, Juazeiro/BA/Lagoa do Curralinho).

A face da modernização que se expressa na perda de acesso ou sobre-exploração dos pesqueiros tradicionais causados por hidrelétricas são abordados nas dissertações e teses analisadas principalmente como disputas no território. Ressalta-se as alterações no regime 
hidrológico do rio (CUNHA, 2006; FERREIRA, 2014), que influencia no comportamento das principais espécies capturadas na pesca artesanal (CRUZ, 2006; BRACONARO, 2011) e, consequentemente, na relação dos pescadores com o território que é disputado (CRUZ, 2011, BRACONARO, 2011).

A relação entre mudanças no ambiente e desterritorialização dos pescadores artesanais foi tratada no I Seminário Nacional: Territórios, Ordenamentos e Representações (I SETOR). Os pesquisadores da região amazônica foram enfáticos que os principais rios da Amazônia têm regime hídrico regulado pelas empresas que exploram esses corpos hídricos para a produção de energia. No caso Amazônico, é fundamental ressaltar que é a dinâmica dos rios que orienta o ciclo anual de produção, como verificado em trabalho de campo junto ao Núcleo de Estudos Geografia e Ambiente - NEGA - (SUERTEGARAY et al., 2016).

Contudo, essas transformações também se apresentam em outras regiões, no Litoral da Bahia, por exemplo, como destaca o Relatório "Conflitos Socioambientais e Violações de Direitos Humanos em Comunidades Tradicionais Pesqueiras no Brasil" "A criação da Barragem da Pedra do Cavalo (1970), construída pelo governo militar, alterou significativamente o ecossistema da Baía do Iguape, ocasionando impactos sociais, ambientais e econômicos em diversas comunidades tradicionais pesqueiras e remanescentes de quilombo localizadas nos municípios de Maragogipe e Cachoeira" (TOMÁZ; SANTOS, 2016, p.72).

Os conflitos por território se relacionam com a face da modernização, pois sobretudo há o impedimento do acesso aos pesqueiros tradicionais. Assim, a implementação do empreendimento hidrelétrico impõe domínio sobre o território (SANTOS, 2013). Como enfatiza Tomáz e Santos (2016):

Os famigerados projetos capitalistas põem em risco a nossa existência e a do rio com as velhas barragens hidrelétricas que já expulsaram mais de 250 mil pessoas de seus territórios e são responsáveis pela destruição do percurso natural do rio. Tudo isso a serviço de um modelo energético que compromete as águas, as lagoas marginais, a vazão do rio, a reprodução dos peixes e impede o acesso à terra e à água, além da agricultura de vazante (p.99).

Assim, as formas tradicionais de gestão do território pesqueiro são desconsideradas e proibidas. A resistência dos pescadores artesanais para se manterem nos territórios implicam em conflitos, onde o pescador artesanal tem que enfrentar um conjunto de atores, que em nome do capital defendem a modernização do território em um modelo de desenvolvimento predador, como o Relatório “Conflitos Socioambientais e Violações de Direitos Humanos em 
Comunidades Tradicionais Pesqueiras no Brasil” exemplifica o caso da transposição do Rio São Francisco:

Como se não bastasse, esse modelo de desenvolvimento predador propõe a construção de mais hidrelétricas, usinas nucleares e parques eólicos que ameaçam os territórios e comprometem ainda mais a vida do Velho Chico. A transposição, tão combatida por nós, virou instituição política de sustentação de empreiteiras com obras infindáveis para fortalecer a velha e a nova indústrias da seca (TOMÁZ, SANTOS, 2016, p.99).

\section{Portos, Industria Naval e Plataforma de Petróleo}

Complexos portuários, estaleiros navais e plataformas de petróleo se instalam sobre os pesqueiros tradicionais impedindo a pesca. Assim, disputam territórios e ambiente com os pescadores artesanais, promovem conflitos por território e impactos ambientais que resultam na restrição do acesso aos pesqueiros tradicionais e na sobre-exploração dos pesqueiros.

Ressalta-se a ênfase às disputas no território, entendendo que ao mesmo tempo em que há uma disputa pela apropriação/domínio do espaço, a própria permanência da pesca artesanal depende das condições ambientais. Dessa forma cabe destacar que o avanço dessas atividades econômicas segue a lógica do domínio do espaço onde a razão econômica desconsidera a impactos no ambiente. Uma situação destacada no Relatório "Conflitos Socioambientais e Violações de Direitos Humanos em Comunidades Tradicionais Pesqueiras no Brasil” é o estado de vulnerabilidade da Mata Atlântica, que é atacada em toda a costa brasileira:

Um dos exemplos desmedidos é o desmatamento de mais de mil hectares de mata para implantação do complexo portuário de Suape, em Pernambuco, que mexeu severamente na biota da região e na vida das comunidades pesqueiras. Mas o mais descabido é que em Pernambuco a Lei Estadual no 14.046/2010 foi aprovada para autorizar o desmatamento da Mata Atlântica e de mangues para expansão do porto sem sequer exigir estudos prévios. Segundo o Ministério Público Federal, a gestão de Suape é feita com processos repletos de vícios e ilegalidades (TOMÁZ, SANTOS, 2016, p.12).

O Relatório "Conflitos Socioambientais e Violações de Direitos Humanos em Comunidades Tradicionais Pesqueiras no Brasil" registra disputas/conflitos/impactos promovidos por portos no Litoral do Ceará: Taiba (Porto de Pecém); Litoral do Pernambuco: Praia de Suape (Porto de Suape). Região do Baixo Amazonas e de Marajó, no Pará: Vila Vieira, Amador, Ourives, Ilha Grande e Vila Barbosa; e Litoral da Bahia: Ilha de Maré, Tororó e Ilhéus. Sobre a indústria naval há registros no Litoral do Rio de Janeiro: Comunidades Ilha do Madeira/ Sepetiba/Pedra de Guaratiba, Baía de Guanabara/Municípios de Magé, Rio de Janeiro, Duque de Caxias, Itaboraí, São Gonçalo, Niterói e Guapimirim; Litoral do Ceará: Paracuru; Litoral 
do Pernambuco: Ilha de Tatuoca (Estaleiro Atlântico Sul), Gaibu; Litoral da Bahia: Tororó, Ilhéus, Enseada do Paraguaçu, Ponta de Souza, Guaí, São Roque do Paraguaçu, Salamina Putumuju, Angolá, Santiago do Iguape, São Francisco do Paraguaçu, Conceição de Salinas, Encarnação de Salinas, Cairu, Bom Jesus dos Pobres; Quando a indústria petrolífera destaca-se no Litoral do Rio de Janeiro: Comunidades Ilha do Madeira/ Sepetiba/Pedra de Guaratiba, Baía de Guanabara/Municípios de Magé, Rio de Janeiro, Duque de Caxias, Itaboraí, São Gonçalo, Niterói e Guapimirim; Litoral da Ceará: Paracuru; Litoral da Bahia: Ilha de Maré; Tororó; Porto D. João; e Litoral da Espirito Santo.

Cabe enfatizar que enquanto o referido relatório apresenta distinções entre impactos de portos e da indústria de construção naval, isso não foi destacado na análise das dissertações e teses, por isso no Capítulo 2 essa análise foi conjunta. Contudo, nesse momento se observa a articulação entre porto, indústria naval e indústria petrolífera. Desta forma essas três vertentes serão tomadas conjuntamente.

Em relação às disputas no território, cabe enfatizar as transformações que os portos e indústria naval causam nos territórios. As mudanças no ambiente (SANTANA, 2013) e consequente redução (GOMES, 2012) no pescado expressam a face da modernização que expõe a sobre-exploração dos pesqueiros. Soma-se a isso o estabelecimento de áreas de exclusão da pesca (GOMES, 2012), devido a circulação de navios, de forma que a modernização implica na restrição de acesso aos pesqueiros tradicionais. A indústria petroquímica também disputa territórios, causando impactos no ambiente (COSTA, 2010, CHAVES, 2011) o que frequentemente inviabiliza a presença da pesca.

Em relação aos portos e indústria naval é importante destacar o choque entre duas formas de apropriação da natureza. Enquanto os pescadores têm o modo de viver mais vinculados ao ambiente, a instalação de portos e indústria naval provoca modificação que além de impossibilitarem o acesso ao pesqueiro, influenciam os modos de viver das comunidades como é denunciado em Tomáz e Santos (2016), no caso da instalação do porto de SUAPE:

No que se refere especificamente às comunidades tradicionais pesqueiras, cabe destacar que, pelas relações específicas que os pescadores e pescadoras artesanais têm com a natureza na região, a implantação do Porto de Suape causou enorme impacto nos modos de ser, viver e produzir destas comunidades. Ressaltam-se os impactos causados pela expulsão de moradores e moradoras da região, a supressão e aterramento dos manguezais, a criação de áreas de exclusão de pesca, os danos à pesca e à saúde causados pela poluição produzida pelo porto, a diminuição do pescado e a mortandade de espécies raras da fauna marinha (como o mero e o boto-cinza), a ausência de medidas mitigatórias e compensatórias para todos estes impactos e a ausência 
de manifestação e participação das comunidades pesqueiras tradicionais diretamente impactadas (p.32).

Contudo, o Estado enquanto promotor da modernização viabiliza a instalação desses empreendimentos, sobre ambientes que são manejados pelas comunidades tradicionais, onde estabeleceram seus territórios, como registrado no Relatório "Conflitos Socioambientais e Violações de Direitos Humanos em Comunidades Tradicionais Pesqueiras no Brasil":

No território do Cajueiro, onde secularmente vivem centenas de famílias de pescadores, agricultores, extrativistas que contribuem para o equilíbrio ecológico da região, situa-se o mais antigo lugar de culto afro na Ilha do Maranhão, o Terreiro do Egito, que deu origem a vários terreiros que se espalharam não apenas no estado, mas por outras partes do mundo.

O Governo do Estado não esclarece publicamente várias questões, na mais total falta de transparência em relação a esse assunto: o que foi feito do processo para implantação desse terminal portuário, que a Secretaria de Meio Ambiente se nega a dar vistas? Ainda está em vigor a suspensão da licença prévia para instalação da empresa? (p.42)

Cabe enaltecer que nesse caso entende-se como disputa, porque a relação com o ambiente (impactado) que promove tensões no território. No território, expressam-se relações sociais, que igualmente são influenciadas como aponta denuncia apresenta no Blog Pelo Território Pesqueiro:

Os principais problemas ocasionados por Suape, colocados pelos pescadores e pelas pescadoras artesanais do território, vão desde as questões ambientais ao complexo quadro social. Esses impactos estão relacionados, o que faz com que as questões ambientais interfiram nas sociais ocasionando nas injustiças que se justificam em nome do crescimento predatório do Porto ${ }^{27}$.

Essa problemática de disputa no território que gera a sobre-exploração e restringe o acesso aos pesqueiros também é documentada (TOMÁZ, SANTOS, 2016) no Rio de Janeiro:

O grupo deu origem, em janeiro de 2007, à Associação Homens e Mulheres do Mar da Baía de Guanabara - AHOMAR, que assumiu a luta dos pescadores contra o descaso das empresas petrolíferas e de off-shore, responsáveis pelas obras causadoras de impactos negativos ao meio ambiente e, consequentemente, à pesca artesanal na Baía de Guanabara, no Rio de Janeiro. Em função das obras realizadas, inviabilizava-se a pesca na região, e as famílias dos pescadores ficavam sem seu sustento (p.60).

${ }^{27}$ PELO TERRITÓRIO PESQUEIRO. Suape: ameaça ao modo de vida de comunidades pesqueiras no Litoral Sul de Pernambuco. Disponível em: < http://denunciapeloterritorio.blogspot.com.br/2014/02/suapeameaca-ao-modo-de-vida-de.html>. Acesso em: 01 out 2016. 
O estabelecimento de áreas de exclusão da pesca devido ao avanço dos portos e indústria naval e do petróleo gera conflitos por território (VINHAS, 2011). Embora exista resistência por parte dos pescadores, para que permaneçam desenvolvendo a pesca nos pesqueiros tradicionais, o Estado prioriza a instalação de portos e polos navais, entendendo que favorecem o desenvolvimento econômico, e que provoca reestruturações produtivas que movimentam a econômica (MARTINS, 2002). Destarte a pesca artesanal que é a principal origem do pescado consumido no Brasil é desconsiderada e os pescadores que insistem em utilizar o território tradicional estão sujeitos à violência como é denunciado pelo Blog Pelo Território Pesqueiro:

Embarcações nossas já foram recebidas a tiros. Em 2010, visitamos 28 comunidades que beiram a Baía de Guanabara de Niterói a Duque de Caxias. Em todas elas, a pesca estava acabando. E isso é devido à perda do território, principalmente para empreendimentos petrolíferos. É uma expulsão dos pescadores. Boa parte deles está abandonando a profissão ou, diante da crise da atividade, sendo sustentados por terceiros - diz Alexandre ${ }^{28}$.

Além da violência física é importante destacar a imposição de regras que são alheias à dinâmica do território. Assim, a autonomia dos pescadores é perdida com a sua submissão às empresas "proprietárias" da terra, do pesqueiro ou do acesso ao mesmo. Um exemplo se evidencia na ilha de Tatuoca - PE:

Um exemplo a ser citado, que tem a ver com o direito a ir e vir, diz respeito aos moradores da Ilha de Tatuoca, que agora, para entrar e sair de onde vivem há décadas (mesmo antes da existência da empresa) receberam uma carteirinha de identificação da empresa Suape. Sem falar da verdadeira "milícia" (como chamam os moradores), que foi criada e é comandada pela Diretoria de Gestão Fundiária e Patrimônio da empresa, que infernizam e tornam a vida dos que ali moram insuportável. ${ }^{29}$

Em relação aos impactos ambientais, nesse momento se destaca as alterações no ambiente que é utilizado de forma mais intensa do que a sua capacidade de resiliência, ou seja, é sobre-explorado com a instalação e funcionamento de terminais portuários, industrias navais e plataformas de petróleo. No caso dos portos, destaca-se os impactos que as dragagens que alteravam a dinâmica ambiental e ciclo de vida das espécies pesqueiras (SILVA, 2012B).

28 PELO TERRITÓRIO PESQUEIRO. Na Baía de Guanabara/RJ, pescadores e pescadoras artesanais sofrem com a intervenção da Indústria Petrolífera. Disponível em: <http://denunciapeloterritorio.blogspot.com.br/2014/04/na-baia-de-guanabararj-pescadores-e.html>. Acesso em: 01 out 2016.

29 PELO TERRITÓRIO PESQUEIRO. Suape fora da Lei. Disponível em: < http://denunciapeloterritorio.blogspot.com.br/2013/11/suape-fora-da-lei.html>. Acesso em: 01 out 2016. 
Contudo, os impactos são variados como é denunciado no Blog Pelo Território Pesqueiro, no caso de SUAPE:

Desde abril a CPRH vem analisando os impactos ocasionados por Suape na localidade, inclusive, a morte de espécies protegidas por lei, como o peixe Mero e o boto-cinza. De acordo com o relatório do órgão, as obras incidem diretamente sob áreas estuarinas, habitats de diversas espécies de peixes que são fonte de subsistência das comunidades tradicionais pesqueiras do território. As investigações tiverem como base denúncias vindas de pescadores e pescadoras artesanais e informações de documentos, incluindo científicos, referentes à dragagem e derrocamento e aos impactos socioambientais. ${ }^{30}$

Ressalta-se que esses impactos não resultam da falta de lei ou de penalidades pelo descumprimento das mesmas. Contudo, as leis que deveriam proteger o ambiente e evitar a sobre-exploração não vem o conjunto do território e seus impactos, sobretudo nas espécies pesqueiras e na subsistência das comunidades, como é denunciado no caso de SUAPE:

O mais gritante desapego à lei são os anos e anos (mais de 10 anos) de descumprimento da aplicação das compensações ambientais impostas para que os desmatamentos dos mangues, restingas e mata atlântica ocorressem naquele território. Os inúmeros Termos de Ajustes de Conduta assinados com o Ministério Público foram sistematicamente desrespeitados pela empresa Suape. Em janeiro de 2012, a empresa publicou como matéria paga nos três jornais de grande circulação do Estado informe publicitário anunciando que o passivo ambiental daquela área tinha sido zerado. Até hoje, os moradores se perguntam onde foram realizadas as intervenções anunciadas com grande pompa? E o Ministério Público, que não se posicionou sobre o pedido de informação para que Suape apontasse em que locais teriam sido efetuadas aquelas intervenções? $?^{31}$

Em alguns casos, a mobilização das comunidades em audiências públicas e manifestações, por meio de movimento social, consegue barrar o avanço desses empreendimentos, como é apresentado no Relatório “Conflitos Socioambientais e Violações de Direitos Humanos em Comunidades Tradicionais Pesqueiras No Brasil" o caso do Maranhão, onde "o "investimento" da WTorre no porto, além de ameaçar Cajueiro e comunidades vizinhas, destruiria cerca de 20 hectares de mangues, comprometeria importantes mananciais de água potável, provocaria fortes impactos ambientais, gerando consequências para toda a Ilha de São Luís" (p.42).

\footnotetext{
${ }^{30}$ PELO TERRITÓRIO PESQUEIRO. Após denúncias de pescadores e pescadoras, SUAPE recebe multa de R\$ 2,5 milhões por crime ambiental. Disponível em: < http://denunciapeloterritorio.blogspot.com.br/2013/09/apos-denuncias-de-pescadores-e.html>. Acesso em: 01 out 2016.
} 
Cabe enfatizar que no caso das industrias do petróleo os impactos sobre o ambiente pesqueiro e de vivência comunitária são muito intensos, destacando-se a poluição/contaminação do solo, ar e água. No Rio de Janeiro os pescadores denunciam no Blog Pelo Território Pesqueiro os impactos das refinarias no ambiente e qualidade de vida dos moradores:

\begin{abstract}
A Baia de Guanabara é um grande ecossistema e, no seu entorno, moram mais de 10 milhões de pessoas que precisam ter qualidade de vida. Ocorre que toda essa população está sofrendo e vai sofrer com a poluição dessas atividades. Refinarias em operação, passando pelo Comperj em construção, geram poluição no mar e no ar. Há muito armazenamento de combustível na baía, oleodutos, gasodutos, navios com cargas perigosas, embarcações que soltam tintas tóxicas... ${ }^{31}$
\end{abstract}

No caso do Porto de Aratu, na Bahia, os pescadores denunciam no Blog Pelo Território Pesqueiros que os "acidentes" decorrentes dos portos e industrias associadas expressam o racismo ambiental, que permite a instalação dessas atividades extremamente poluidoras sobre os territórios tradicionais das populações mais pobres e dependentes do ambiente:

Esclarecemos que acidentes ambientais ligados a desembarque de navios ocorrem constantemente ao longo dos anos e é por conta desta situação que estudos ambientais indicam esta área como uma das mais poluídas da Baía de todos os Santos. A gravidade desta explosão poderia ter se espalhado pelos outros reservatórios de produtos muito mais nocivos à saúde e ao ambiente, retrata a vulnerabilidade socioambiental em que se encontram as comunidades pesqueiras e quilombolas de Ilha de Maré e entorno. Revelam também o desrespeito aos seus direitos constituídos caracterizando um quadro de racismo institucional e ambiental praticado pelas instituições públicas e privadas em nosso país. ${ }^{32}$

\title{
Pesca Predatória: Pesca Industrial/Comercial, Pesca Amadora/Esportiva,
}

\section{Comercialização de Pescado}

$\mathrm{Na}$ expressão da face da modernização que causa a sobre-exploração dos pesqueiros tradicionais é fundamental destacar os impactos, disputas e conflitos relacionados à pesca predatória (Pesca Industrial, Pesca Comercial, Pesca Amadora/Esportiva, e Comercialização de Pescado). Sobretudo, a pesca industrial é apresentada como responsável pelo colapso nos recursos pesqueiros no Brasil, tendo sido intensamente fomentada pelo governo através da

\footnotetext{
${ }^{31}$ PELO TERRITÓRIO PESQUEIRO. Ameaçada por megaempreendimento, comunidade pesqueira de Maricá/RJ luta pela conservação de seu território. Disponível em: < http://denunciapeloterritorio.blogspot.com.br/2014/10/ameacada-por-mega-empreendimento.html>. Acesso em: 01 out 2016.

${ }^{32}$ PELO TERRITÓRIO PESQUEIRO. Manifesto do MPP sobre explosão de navio no Porto de Aratu - Salvador/BA. Disponível em: < http://denunciapeloterritorio.blogspot.com.br/2013/12/manifesto-do-mppsobre-explosao-de.html>. Acesso em: 01 out 2016.
} 
Superintendência de Desenvolvimento da Pesca - SUDEPE, mas predileta até os dias atuais nas políticas nacionais. A pesca comercial, principalmente na região Amazônica, tem provocado mudanças nas práticas tradicionais da pesca, intensificando as capturas para atender as demandas do mercado, por isso a comercialização do pescado também é apresentada na compreensão dessa face da modernização que causa sobre-exploração. A pesca amadora e/ou esportiva também provoca a sobre-exploração por estarem sujeitas a outros enquadramentos normativos que permitem essas práticas em períodos e com instrumentos diversos aos da pesca artesanal, acrescenta-se a falta de fiscalização dessas atividades, o que permite capturas bem acima das permitidas.

No Relatório "Conflitos Socioambientais e Violações de Direitos Humanos em Comunidades Tradicionais Pesqueiras no Brasil" as referências à pesca predatória são menos frequentes. Quando ocorrem, enfatizam as consequências da pesca industrial. Isso se evidencia na Região do Delta do Parnaíba, no Estado do Piauí: Comunidade Pedra do Sal e Região do Baixo Amazonas e de Marajó, no Pará: Comunidade Vila dos Pescadores, Comunidade Cidade de Bragança, Comunidade de Curuçazinho, Comunidade Aricuru e Comunidade Penha.

Sobre a pesca industrial é importante destacar que as dissertações e teses analisadas destacam as disputas nos territórios tradicionais dos pescadores artesanais. Evidenciam que os saberes dos pescadores artesanais sobre o ambiente lhes permitem a territorialização onde há maior produtividade da pesca. Esses saberes incorporam também práticas de manejo que não exaurem os recursos em intensidade maior do que a possibilidade de renovação (LIMA, 2002). A pesca industrial, pelo contrário, faz uso de tecnologias de localização de estoques pesqueiros e captura acima da sua taxa de renovação (GIANNELLA, 2009, CARDOSO, 1996), pois a maior capacidade de navegação lhes torna independente dos recursos estritamente presentes no local, enquanto os pescadores artesanais dependem dos recursos locais (LIMA, 2008). Assim, disputam territórios tradicionais duas lógicas de apropriação e/ou domínio (GUEDES; 2009; PÉREZ, 2012). Tal disputa com a pesca industrial frequentemente resulta na desterritorialização dos pescadores, pois a sobre-exploração, face expressa dessa modernização, reduz a produtividade na pesca, fundamental para a manutenção dos territórios tradicionais (MACHADO, 2013).

Para exemplificar as disputas no território entre pesca artesanal e pesca industrial, vamos trazer o exemplo do Estuário da Laguna dos Patos - Rio Grande do Sul. Em 1998 frente a grave crise da pesca, principalmente do camarão rosa, essa crise ambiental evidenciava a face da sobre-exploração do recurso pela pesca industrial, sobretudo devido à presença de pescadores 
do Estado de Santa Catarina que se faziam presentes nas safras e utilizavam elevado número de redes de espera e redes de arrasto. Para evitar a presença desses atores territoriais de transição, os pescadores de Estuário constituíram um fórum de pesca denominado Fórum da Laguna dos Patos e a partir dessa instituição propuseram uma Instrução Normativa específica para a região de abrangência do estuário e que sendo aprovada restringiu a atividade pesqueira aos pescadores locais. Sendo assim, para que o ambiente se recuperasse, proibiu-se a pesca industrial no interior do estuário, por meio do estabelecimento de um território de uso exclusivo para os pescadores residentes.

Entre os impactos ambientais provocados pela pesca industrial destaca-se a redução e extinção dos recursos pesqueiros (MAIER, 2009) em tradicionais territórios da pesca artesanal, o que expressa a face da modernização - sobre-exploração -. Nesse sentido o aumento do esforço de pesca por meio da utilização de apetrechos de pesca predatórios e tecnologias que permitem a localização e exterminação de cardumes são impactos ambientais que promovem a extinção de importantes territórios de pesca.

Os impactos da pesca industrial expressam suas consequências na pesca artesanal na redução dos estoques pesqueiros. Importantes estoques pesqueiros como o da tainha, capturada nas regiões Sudeste e Sul, encontram-se prejudicados devido a sobre-pesca. Contudo, além do impacto sobre o recurso, cabe enfatizar os impactos da falta desses recursos sobre as comunidades que dependem dos mesmos no ambiente. Além da redução das pescarias, cabe destacar que normativas são aplicadas provocando restrições à pesca industrial, mas a pesca artesanal também é prejudicada. Um exemplo é o Plano de Gestão para o Uso Sustentável da Tainha (BRASIL, 2015C) proposto pelo Governo Federal, que proíbe a pesca industrial, mas também impõe restrições a pesca artesanal. Os pescadores do Rio Grande do Sul, por exemplo, seriam proibidos de pescar no período mais piscoso, como foi discutido no II Encontro da Região Sudeste-Sul do Movimento dos Pescadores e Pescadoras Artesanais.

A intensificação da pesca industrial também gera conflitos por território. Esses se devem ao avanço dessa atividade econômica (SANTANA, 2013) sobre territórios tradicionais, de forma que suas embarcações maiores, e uso de tecnologias mais ostensivas se impõem sobre os pescadores artesanais que se retiram do território para evitar a perda de equipamentos de pesca e os riscos à vida resultantes desse conflito.

No estado de Santa Catarina, a pesca industrial conta com embarcações e apetrechos muito ostensivos. Isso se opõe a pesca artesanal tradicional, praticada em lagunas e lagoas com embarcações de pequeno porte e número limitado de redes. Quando desejam explorar os 
mesmos pesqueiros os conflitos se evidenciam, expulsando os pescadores artesanais, que ficam em situação de risco de vida e frequentemente perdem apetrechos de pesca. Em determinados territórios, como em Laguna e Jaguaruna, os pescadores artesanais conseguiram estabelecer normativas que priorizam a pesca artesanal nas águas interiores, como ficou evidenciado em reunião da Articulação Sudeste-Sul do Movimento dos Pescadores e Pescadoras Artesanais.

A pesca comercial, também é apresentada nas dissertações e teses como promotora de disputas no território. Nesse caso cabe destacar que, assim como a pesca comercial não é regida pelos ciclos da natureza, mas pela dinâmica do mercado, o que resulta em sobre-exploração (CRUZ, 2007; ABREU, 2010). Sendo assim, são empregadas novas tecnologias que afastam essa modalidade de pesca da artesanal, que está mais relacionada com o ambiente e com as técnicas tradicionais de uso. Os barcos que fornecem gelo, por exemplo, permitem que os pescadores comerciais permaneçam mais tempo explorando o território pesqueiro, o que permite a captura sem limites. Contudo, geralmente se difere da pesca industrial, pelas relações de trabalho entre pescadores. De modo geral, se percebe que o pescador comercial se difere do pescador artesanal por estar mais vinculado ao mercado, o que faz com que abandonem formas tradicionais de manejo do ambiente e tratados comunitários de uso do território, inclusive avançando sobre territórios de outras comunidades (MACHADO, 2007; ARAÚJO, 2012), o que resulta em conflitos (SILVA, 2009).

Em trabalhos de campo realizados em Tefé-Amazonas, se observa a disputa no território entre pescadores artesanais e comerciais. Cabe enfatizar que movidos pela dinâmica do mercado, os pescadores comerciais frequentemente avançam sobre pesqueiros tradicionais e realizam pescarias que não estão consoantes com acordos comunitários. Assim, comprometem a presença dos recursos pesqueiros nos territórios tradicionais dos pescadores artesanais. Além disso, ocorre que muitas vezes os pescadores comerciais que disputam território com os artesanais vêm de locais externos à comunidade. Na unidade de conservação Floresta Nacional de Tefé - FLONA de Tefé, os pescadores comerciais urbanos disputavam territórios pesqueiros tradicionais com os pescadores artesanais locais. Os pescadores artesanais da FLONA estabeleceram acordos de pesca como forma de limitar o avanço da pesca comercial praticada pelos pescadores urbanos dentro desta unidade.

Assim, é fundamental também compreender o papel da comercialização do pescado como promotora da face da modernização que causa sobre-exploração. A comercialização demanda dos pescadores industriais e comerciais a intensificação das capturas, o que resulta na utilização exaustiva do ambiente por meio de técnicas mais predatórias (ARAÚJO, 2012). Essa 
pressão (SANTOS, 2012) se dá por demanda e preço, uma vez que além de terem que atender a demanda do mercado, os pescadores industriais e comerciais podem ser motivados a impactarem o ambiente e conflitarem por território em busca da obtenção de maior lucro, frente a desvalorização do pescado.

Os conflitos por territórios decorrentes da comercialização que causa sobre-exploração dos pesqueiros se dão no embate entre pescadores que estão sujeitos à lógica do mercado (industriais e comerciais) (GUEDES, 2009; ABREU, 2010) e pescadores artesanais que defendem e resistem no território (CRUZ, 2007). Acrescenta-se ainda a inserção de outros atores territoriais, como o atravessador que faz a intermediação entre pescador e mercado (indústria e consumidor) (CARDOSO, 1996; KUHN,2009; QUEIROZ, 2012, SANTANA, 2013; FERREIRA, 2014). Mesmo entre pescadores artesanais a comercialização pode motivar conflitos, uma vez que na busca de maior produtividade, normas de uso do território pesqueiro podem ser desconsideradas, o que gera, inclusive, o desmantelamento das relações comunitárias (GUEDES, 2009).

No estuário da Laguna dos Patos, assim como em diversos territórios no Brasil, a pesca está sujeita à dinâmica do mercado. No caso da pesca do camarão, por exemplo, antes da abertura da safra o preço pago pelo pescado é mais elevado, o que leva a prática da pesca à margem do que foi estabelecido pela lei. No âmbito das comunidades, os pescadores que seguem a lei, entram em conflito com os pescadores que realizam a pesca em desacordo com a normatização. Isso gera toda uma desestabilização dos vínculos comunitários. Acrescenta-se a presença do atravessador, que estabelece vinculo financeiro com os pescadores, de forma que provocam a dependência desses atores, que se submetem às suas demandas. Assim, a comercialização se evidencia como um fator fundamental a ser considerado, principalmente quando se considera os conflitos entre pescadores.

A pesca amadora e/ou esportiva se apresenta como causadora de impactos ambientais e conflitos por território, que geram a sobre-exploração dos pesqueiros tradicionais. Ressalta-se que os impactos dessas atividades se distinguem, pois não são devidamente mensurados, e apesar de sujeitos a normas próprias, essas modalidades de pescaria não são devidamente fiscalizadas, o que incorre na prática da pesca predatória (CARDOSO, 1996; CUNHA, 2011). Já os conflitos por território são estabelecidos entre pescadores artesanais, que possuem técnicas e normas de uso que mantem os territórios pesqueiros produtivos e pescadores eventuais, atores territoriais de transição, que não reconhecem essas formas de manejo e fazem uso do território de forma predatória (FIGUEIREDO, 2013). Os conflitos de uso do território se agravam quando 
outros agentes buscam o monopólio dos pesqueiros para a promoção da pesca esportiva (PRADO, 2015).

No Rio Jacuí, os pescadores artesanais denunciam os impactos da pesca amadora sobre os recursos pesqueiros. Destacam essa prática próximo às barragens, onde o peixe encontra-se confinado e a utilização de cevas (depósito de sacos de grãos, como milho) que atraem os peixes. Sendo assim, a captura ocorre de forma intensa se equiparando ou até sendo superior à da pesca artesanal.

\subsection{Terceira Face da Modernização: a expropriação da terra}

Com base no Blog Pelo Território Pesqueiro observou-se a predominância de denúncias sobre a terceira face da modernização, a qual expõe principalmente as áreas de moradia e convívio das comunidades tradicionais de pescadores artesanais. Assim, afetam os territórios comunitários por meio da expropriação da terra. Ressalta-se que, como já foi dito, a continuidade entre território de moradia e pesqueiro tradicional é fundamental para compreender os territórios da pesca artesanal. Dos trabalhos analisados (dissertações e teses) identificou-se 49 contextos em que a problemática versa sobre essa face da modernização. Destes, 43 dizem respeito aos conflitos por território, quatro disputas estabelecidas no território por recursos do ambiente e dois impactos ambientais.

Logo, é intrínseco à modernização que leva à expropriação do território comunitário impactos ambientais e disputas no território, contudo a ênfase é dada sobre os conflitos por território. A principais atividades causadoras são Turismo, Conflitos Fundiários e Especulação Imobiliária. A figura 64 apresenta a expressão desses contextos no Brasil, com base na análise de dissertações e teses. Como é possível observar essa face da modernização tem maior expressão na região Nordeste (31). Em menor número estão as regiões Sul (8), Norte (5), Sudeste (4) e Centro-oeste (1) 


\section{GEOGRAFIAS DA PESCA ARTESANAL BRASILEIRA:}

Terceira Face da Modernização: a expropriação da terra

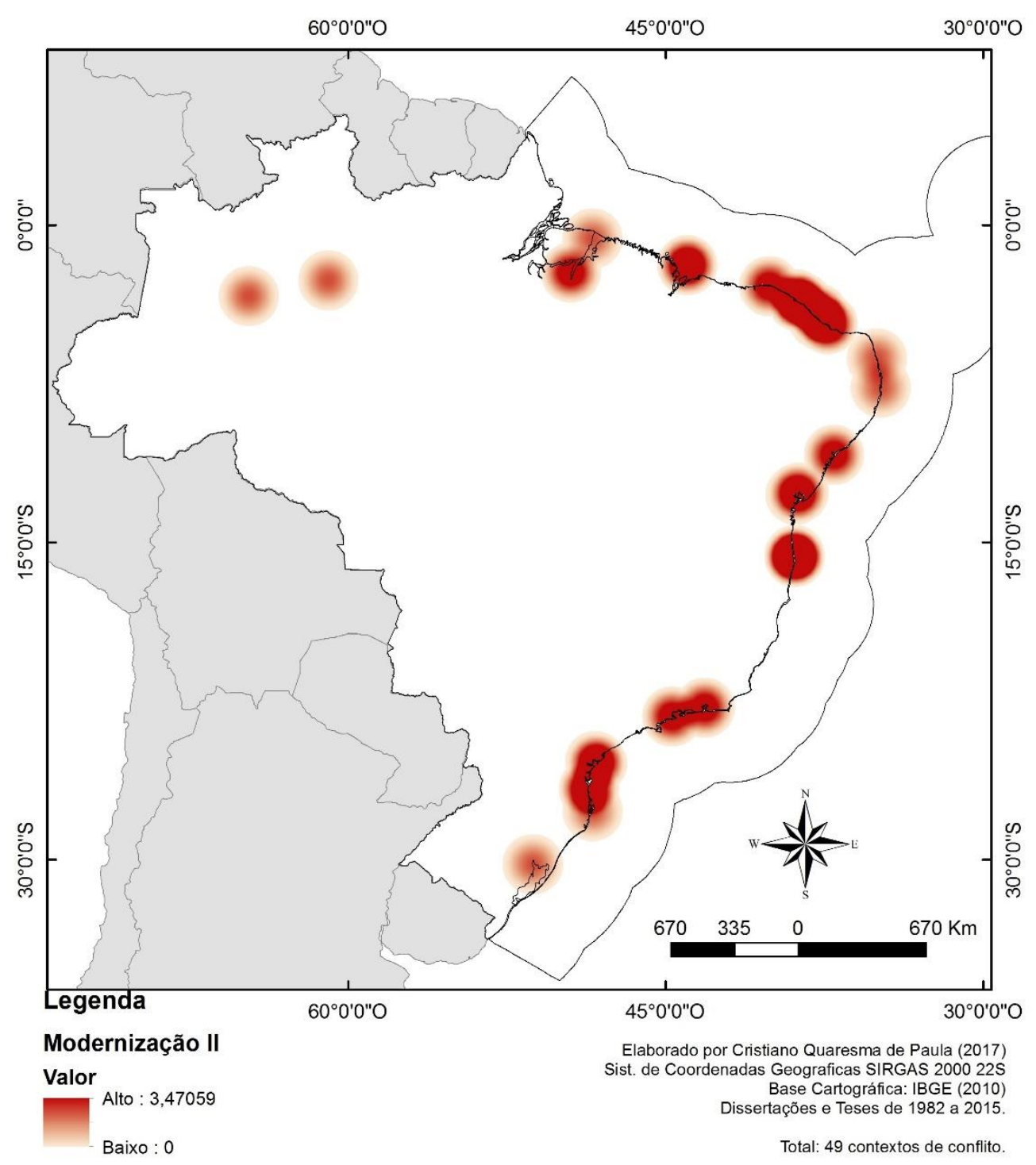

Figura 64: Mapa da Terceira Face da Modernização: a expropriação da terra Fonte: Elaborado por De Paula (2018)

Dialogando com o movimento social, constata-se que a modernização que promove a expropriação do território de moradia e convívio está ameaçada pelo avanço de atividades econômicas que desejam promover outro uso do espaço. Cabe enfatizar que na página de denúncias do blog Pelo Território Pesqueiro essa face da modernização é bastante frequente (52). Isso ocorre porque o MPP busca garantir a presença das comunidades tradicionais de pescadores artesanais em seus territórios, que são contíguos aos pesqueiros tradicionais. $\mathrm{O}$ conflito se estabelece, por que há o embate entre o território tradicional e a nova 
territorialização. Nesse caso, o território das comunidades se evidencia na terra ocupada, contudo, sendo na maioria das vezes posseiros, veem outras atividades econômicas estabelecerem o domínio do espaço pelo capital.

Cabe enfatizar que o turismo é a principal atividade econômica que promove a modernização que causa expropriação do território das comunidades. Essa atividade promove impactos ambientais, disputas no território, mas principalmente conflitos por território com a pesca artesanal. Já questões fundiárias e especulação imobiliária se restringem aos conflitos por território.

A região que mais evidencia os conflitos com o turismo de massa é a Nordeste. $\mathrm{Na}$ Assembleia Geral do MPP, na Reserva Extrativista do Batoque - CE, destacou-se o avanço da atividade turística sobre as comunidades tradicionais de pescadores artesanais. No próprio Ceará inúmero Resorts são instalados, com vastas infraestruturas que são alheias ao lugar de vida dos pescadores. Motivados pelo poder público municipal e estadual, esses empreendimentos promovem a remoção das famílias de pescadores artesanais. Um contraponto que vem ocorrendo nesse estado é a promoção do turismo de base comunitária. Na referida assembleia, alguns participantes ficaram hospedados em uma pousada da Rede Cearense de Turismo Comunitário - TUCUM -. Essa atividade turística não pretende receber hospedes acima da capacidade de suporte e oferece serviços mais consoantes com a dinâmica do território das comunidades.

As questões fundiárias também têm levado à expropriação dos territórios das comunidades tradicionais de pescadores. Essas estão relacionadas à luta pelo direito à terra estabelecida entre comunidades de pescadores artesanais e outros agentes econômico que pretendem a modernização do território. O agronegócio é a principal atividade econômica que entra em conflito por terra com as comunidades de pescadores, contudo, existem outras como a instalação de complexos turísticos, terminais portuários, industrias, etc. Na Assembleia Geral do MPP destacaram-se falas de pescadores artesanais/quilombolas que veem o direito de permanecer no território tradicional ameaçado pelo avanço do agronegócio. Outra problemática que incide em conflitos por território é a implementação de Unidades de Conservação. No I Encontro da Articulação Sudeste-Sul do MPP os pescadores do estado do Paraná destacaram essa questão no caso do Parque Nacional do Superagui, inclusive criticando a Secretaria de Patrimônio da União sobre a condução da regularização fundiária.

No espaço urbano, a problemática da especulação imobiliária também tem mobilizado comunidades de pescadores, expulsando-as de seus territórios tradicionais para a instalação de 
loteamentos e empreendimentos imobiliários. Nesse caso, o valor da terra urbana ganha centralidade, devido às amenidades como a paisagem associada e a proximidade dos grandes centros urbanos.

Na região Nordeste, essa problemática está muito relacionada ao turismo, uma vez que se propagam as segundas residências para veraneio como discutido na II Assembleia Nacional do MPP. A instalação de serviços urbanos que não são acessíveis aos comunitários e a capitalização da terra, tem promovido o deslocamento das comunidades para locais distantes dos pesqueiros tradicionais, inclusive levando a abandonarem a pesca. Ao longo do Litoral brasileiro o avanço da cidade sobre as áreas das comunidades também promove a especulação imobiliárias sobre os territórios das comunidades. Nesse caso, agentes do Estado e do capital se unem para a expropriação da terra e instalação de loteamentos e condomínios destinados à população que possui maior poder aquisitivo.

Cabe destacar que Turismo, Questões Fundiárias e Especulação Imobiliárias estão associados no entendimento da modernização do espaço que promove a expropriação da terra.

\section{Turismo}

O Movimento dos Pescadores e Pescadoras artesanais tem utilizado o termo "predatório" para situar as atividades turísticas que visam o consumo do espaço, sem respeitar a dinâmica da natureza e o modo de viver comunitário (MPP, 2012). Desta forma o turismo se destaca como atividade econômica que entra em conflito por território com as comunidades tradicionais de pescadores, causa impactos e disputas no território. Ressalta-se as ações dos promotores do turismo, alinhados com o poder público, com vistas à expropriação da terra onde estão territorializados os pescadores artesanais. Esses projetos, sem diálogo com as comunidades, instalam infraestruturas de atração turística e serviços que não são acessíveis aos pescadores artesanais, que não se encontram nessa lógica de consumo do espaço. Além disso, as comunidades se veem pressionadas a sair do território, devido à valorização da terra pelo mercado imobiliário.

Além das ações dos promotores do turismo com vistas à expropriação da terra, onde os pescadores artesanais estão territorializados, cabe ressaltar o incremento de indivíduos decorrente do turismo de massa (ZAOUAL, 2008), demandando novas infraestruturas, pressionando os recursos do ambiente e estabelecendo relações com os moradores que não estão de acordo com o modo de viver comunitário. 
No Relatório "Conflitos Socioambientais e Violações de Direitos Humanos em Comunidades Tradicionais Pesqueiras no Brasil”, o turismo é apontado como uma atividade econômica que desterritorializa comunidades de pescadores artesanais em todo o Brasil, contudo, assim como as dissertações e teses analisadas, destaca-se essa influência na região Nordeste. Apresentam-se o Litoral do Ceará (Comunidade Pé do Morro, Sítio Jardim, Praia Caponga, Praia de Barro Preto e Praia de Capim-Açu, Praia do Morro Branco); Litoral do Pernambuco (Praia do Rosado e Pirangi do Norte); Litoral da Bahia (Acupe; Cabaçu; Porto D. João; São Braz; Cambuta; Itapema; Conceição de Salinas; Encarnação de Salinas; Cabuçu; Bom Jesus dos Pobres; Cova de Onça; Ilhéus, Resex Corumbau).

Na Bacia do Rio São Francisco (Belém do São Francisco/PE/Lago de Itaparica/ Comunidade Manga de Baixo; Paulo Afonso/BA/Rio do Sal; Cânion São Francisco/AL, BA, SE; Paulo Afonso/BA, Delmiro Gouveia/AL, Olho D’Água do Casado/AL, Piranhas/ AL, Canindé do São Francisco/SE). Também são registrados casos na Região Litorânea de Alagoas e na Região do Delta do Parnaíba, no Estado do Piauí. Também há registros na Região do Baixo Amazonas e de Marajó, no Pará; no Tocantins (Comunidade Ilha Saracá, Comunidade de Prainha Beradão, Comunidade da Ilha Paquetá Potinga; Comunidade Jussara Cupijó e Comunidade Teré). Acrescenta-se a Região litorânea do Rio de Janeiro (Comunidades Ilha do Madeira/ Sepetiba/Pedra de Guaratiba) e Litoral de Santa Catarina.

Os espaços litorâneos onde se encontram os territórios das comunidades tradicionais de pescadores, tem despertado o interesse da indústria de turismo (PAULA, 2012). Essa lógica de consumo do espaço, organização e os valores dos atores envolvidos com o turismo se diferem da apropriação do território tradicional pelos pescadores artesanais (COSTA; 2010). Isso resulta em conflitos na terra e no mar (FIGUEIREDO, 2013), tendo em vista que essas paisagens “naturais" (LIMA, 2002) e a própria paisagem comunitária são cada vez mais raras (NUNES, 2011). Esses conflitos vão desde a influência cultural (e de consumo) da atividade turística sobre as comunidades, da disputa no território e desejo de remoção das comunidades tradicionais (CAVALCANTE, 2012), até a privatização de praias que impedem a continuidade entre território comunitário e pesqueiro tradicional. Frente a isso, as comunidades resistem e se mobilizam para frear esses empreendimentos (RIOS, 2012), apesar do esforço dos agentes públicos municipais (DUMITH, 2012) e de empreendedores de outros setores que tiram benefícios das infraestruturas instaladas para o turismo, como estradas (RODRIGUES, 2005).

No Blog Pelo Território Pesqueiro estão evidenciados esses conflitos por território estabelecidos entre pescadores artesanais e turismo predatório. Como é destacado na Ilha da 
Madeira -Itaguaí - RJ - o turismo faz parte de um conjunto de empreendimentos que apregoam a modernização do espaço. Nesta ilha, "Em conjunto com a intervenção da Odebrecht, empreendimentos de mineração e o turismo predatório já retiraram inúmeras famílias pesqueiras de seu território. Esses empreendimentos não consideram a pesca artesanal, o que faz com que as comunidades pesqueiras da região procurem outras atividades econômicas". A expropriação se evidencia na medida em que o avanço do turismo, aliado a outras atividades econômicas, tem resultado na expulsão das comunidades e inviabiliza a pesca ${ }^{33}$.

Cabe destacar a resistência das comunidades nesses processos. No caso das comunidades de pescadores, marisqueiras e quilombolas da Ilha de Boibepa - Cairú - Bahia a mobilização se deu exigindo o debate sobre o licenciamento do empreendimento. Mesmo com a aprovação do empreendimento Projeto Turístico-Imobiliário Fazenda Ponta dos Castelhanos, criado em 2001 pela empresa Mangaba Cultivo de Coco Ltda, a luta dos pescadores artesanais é para que prevaleça o diálogo e o respeito às comunidades tradicionais que veem seu território ameaçado $^{34}$.

As disputas pelos recursos do ambiente presentes no território das comunidades tradicionais de pescadores também devem ser consideradas. A pressão da indústria do turismo de massa sobre o ambiente, como os manguezais (MORAES, 2010), provoca modificações que reduzem a produtividade dos pesqueiros e a condição sanidade ambiental (GALVÃO NETO, 2009). Isso resulta também em reações e modificações nas relações que os pescadores artesanais estabelecem com o ambiente, e nas normas de gestão do território tradicional, frente a promoção do turismo de massa (CHAMAS, 2008). Ressalta-se que os indivíduos que tiram benefício do turismo costumam ser as elites urbanas, logo têm menor dependência do ambiente que exploram nessa atividade (CAMARGO, 2013).

Na Ilhota da Ilhota Coroa - Acupe/Santo Amaro - Bahia os pescadores artesanais denunciam o avanço de empreendimentos turísticos sobre o território tradicional, sem que as comunidades sejam consultadas e sem licenciamento ambiental. Destacam a importância dos recursos do ambiente na preservação do território tradicional "Esta ilhota faz parte do nosso

\footnotetext{
33 PELO TERRITÓRIO PESQUEIRO. Pescadores artesanais da Ilha da Madeira/RJ possuem território pesqueiro ameaçado. Disponível em: <http://denunciapeloterritorio.blogspot.com.br/2014/09/pescadores-artesanais-da-ilha-da.html>. Acesso em: 10 out 2016.

${ }^{34}$ PELO TERRITÓRIO PESQUEIRO. Comunidades da Ilha de Boipeba/BA lutam para defender território de megaprojeto imobiliário. Disponível em: <http://denunciapeloterritorio.blogspot.com.br/2014/07/por-assessoria-de-comunicacao-do-cpp.html>. Acesso em: 10 out 2016 .
} 
território pesqueiro e quilombola, onde o utilizamos historicamente para a pesca artesanal (coleta de mariscos), refúgio em tempos de tempestade e lazer comunitário. Do ponto de vista ambiental, a ilhota se configura como um importante ecossistema assegurando a reprodução de diversas espécies de peixes, crustáceos, manguezais, moluscos e pássaros ${ }^{35}$.

Acrescenta-se que as atividades turísticas de massa impõem um incremento no uso do ambiente e instalação de infraestruturas (MACHADO, 2007), que provoca impactos ambientais. Esses impactos geram modificações na dinâmica da natureza que, consequentemente, interferem na qualidade dos ambientes onde os pescadores artesanais estabelecem seus territórios. Desta forma, a desterritorialização dos pesqueiros tradicionais causada por impactos ambientais (SILVA, 2007) interfere na continuidade entre território pesqueiro e território de vida comunitária.

$\mathrm{Na}$ Ilha de Boibepa - Bahia, por exemplo, o empreendimento turístico não apresenta soluções para o acrescimento de quase $260 \%$ dos resíduos sólidos, nem para outros impactos ambientais que o próprio projeto aponta. Diante disso, os pescadores temem as consequências sobre a mariscagem, pesca e extrativismo. "Muitas das obras irão invadir áreas de pesca e mergulho, desmatarão boa parte do mangue preservado, atacarão áreas de guaiamum, dentre outras irregularidades já apontadas pelas entidades ambientais"36.

\section{Fundiários}

Os conflitos relacionados às questões fundiárias são centrais na análise da expropriação dos territórios das comunidades tradicionais de pescadores artesanais. Esses envolvem múltiplos atores relacionados às atividades econômicas que prometem a modernização do território. De outro lado, estão os pescadores artesanais que se apropriaram do espaço onde estabeleceram seu território tradicional. Os agentes públicos atuam de um lado viabilizando o avanço dessas atividades econômicas modernas, de outra se omitindo da sua função de defender os direitos adquiridos pelas comunidades tradicionais por meio de acordos nacionais e internacionais. Ressalta-se que, a resistência dos pescadores artesanais para se manterem no

\footnotetext{
35 PELO TERRITÓRIO PESQUEIRO. Manifesto em defesa da Ilhota Coroa Branca - Território Pesqueiro e Quilombola de Acupe - Santo Amaro/ Bahia. Disponível em: <http://denunciapeloterritorio.blogspot.com.br/2013/08/manifesto-em-defesa-da-ilhota-coroa.html>. Acesso em: 10 out 2016.

36 PELO TERRITÓRIO PESQUEIRO. Comunidades da Ilha de Boipeba/BA lutam para defender território de megaprojeto imobiliário. <http://denunciapeloterritorio.blogspot.com.br/2014/07/por-assessoria-de-comunicacao-do-cpp.html>. Acesso em: 10 out 2016.
} 
território, é enfrentada com violência física e psicológica, seja por particulares envolvidos com o empreendimento, seja com os próprios agentes públicos.

Em relação à questão fundiária, a análise apontou a existência exclusiva de conflitos por territórios, uma vez que disputas no território e impactos ambientais dessas atividades econômicas já estão contemplados nas análises anteriores. Ressalta-se que o conflito por terra expresso nas questões fundiárias não nega o território água. Ao contrário, destacou-se que a presença das comunidades de pescadores próxima aos corpos d'água onde estão os pesqueiros tradicionais compõem o conjunto que se denomina território tradicional das comunidades tradicionais de pescadores. Nesse sentido, a pesca artesanal deve ser considerada também no âmbito da questão agrária:

Observa-se no gráfico abaixo que a incidência de causadores dos conflitos socioambientais em territórios pesqueiros se dá, principalmente, entre os fazendeiros e particulares, a partir da omissão direta do poder público. Os outros causadores de conflitos estão relacionados a situações entre comunidades tradicionais e sem terras que lutam por Reforma Agrária também aqui nota-se a omissão do poder público, especialmente sobre a questão agrária (TOMÁZ; SANTOS, 2016, p.94).

Ressalta-se que os conflitos fundiários têm ganhado destaque nas pautas dos movimentos sociais de pescadores artesanais. Entende-se que o reconhecimento dos territórios tradicionais, por meio de instrumento de lei que regularize a posse específica:

No jogo do uso da terra e da água como mercadoria e da acumulação de bens, os megaprojetos expropriam as condições materiais e simbólicas dos pescadores artesanais. Nesta perspectiva em especial, a luta das comunidades pesqueiras é fortalecer a noção do reconhecimento do território tradicional com uma titulação e a formalização de sua posse específica. Para isto, o Movimento de Pescadores e Pescadoras Artesanais - MPP e o CPP se dedicam a uma luta constante para discutir e pautar a Campanha do Projeto de Lei de Iniciativa Popular sobre a Regularização do Território Pesqueiro. (TOMÁZ; SANTOS, 2016, p.104).

No Relatório "Conflitos Socioambientais e Violações de Direitos Humanos em Comunidades Tradicionais Pesqueiras no Brasil” são apresentados conflitos fundiários no Litoral da Bahia (Tororó, Rio dos Macacos; Porto D. João, Enseada do Paraguaçu, Guaí, Conceição de Salinas, Santiago de Iguape, São Francisco de Paraguaçu) e na Bacia do Rio São Francisco (Paulo Afonso/BA/Comunidade do Mulungu, Cânion São Francisco/AL, BA, SE; Brejo Grande e Paracatuba/SE/Quilombo Brejão dos Negros; Juazeiro/BA/Lagoa do Curralinho, Buritizeiro/MG/Comunidade Canabrava, Pedra Maria da Cruz/MG/Quilombo 
Caraíbas, Janúaria/MG/Comunidade de Croatá, Pirapora/MG/Comunidade Pesqueira da Fazenda Prata, Ibiaí/MG/Cidade de Ibiaí, São Francisco/MG/Ilha da Porteira, Buritizeiro/MG/Comunidade Limeira, Ponto Chique/MG/Ponto Chique, São Romão/MG/Comunidade Ribanceira, MG/Sangradouro Grande, São Francisco/MG/Travessão de Minas).

Mudanças na estrutura fundiária incidem em conflitos com comunidades tradicionais de pescadores artesanais e sua dinâmica de apropriação do território (CRUZ, 2006). Ressalta-se que esses atores geralmente se apropriaram do espaço e estabeleceram territórios de uso comum (QUEIROZ, 2012; PRADO, 2015), logo, encontram-se na situação de posseiros (CAMARGO, 2013). A ocupação histórica, no entanto, é contestada frente a outros atores que desejam o domínio do território para o estabelecimento de suas atividades econômicas, impedindo o uso do território pelas comunidades tradicionais (GUEDES, 2009). Assim, por meio de grilagem e/ou por iniciativa do próprio poder público (FERREIRA, 2013) essas comunidades passam a ser tradadas como invasoras (LIMA, 2002, MACHADO, 2013, BARBOSA, 2014) e enfrentam diversos processos de reintegração de posse em favor daqueles que detém o capital.

Outro fator importante a ser considerado é a valoração da terra, que frequentemente pressiona as comunidades a venderam seus terrenos e se afastarem do território tradicional (COSTA, 2010). Também se agravam os conflitos fundiários decorrentes da instalação de unidades de conservação sobre territórios comunitários tradicionais, as quais passam a resistir para se manterem em seus territórios (FARIAS, 2009) ou para que tenham a prerrogativa de fazerem a gestão do mesmo por meio do conhecimento tradicional (RODRIGUES, 2014). Sem direito "legal" de ser manterem no território as comunidades de pescadores, que também são quilombolas, têm buscado a titulação de território quilombola para garantir sua permanência no território tradicional (RIOS, 2012).

No Blog Pelo Território Pesqueiro são apontados diversos contextos de conflitos decorrentes de questões fundiárias, sobretudo, devido o entendimento das comunidades de pescadores como posseiros ou invasores, negando seus direitos enquanto comunidades tradicionais. Um caso emblemático é a Comunidade Pesqueira de Caraíbas - Minas Gerais:

A comunidade Caraíbas é quase que a única sobrevivente entre as 09 comunidades que historicamente viveram à margem direita do rio São Francisco, em Pedras de Maria da Cruz/MG, com sua vasta diversidade cultural. Estas comunidades viviam em paz com sua gente e com seu rio até que, a partir de 1980, fazendeiros passaram a praticar violência contra elas e a expulsá-las do local. A comunidade Caraíbas teve as suas moradias destruídas. 
Algumas famílias, em meio aos conflitos, resistiram, morando no seu território. Documentos confirmam sua existência desde antes de 1909. Contam os mais velhos que a comunidade se fez a partir de um casal de gorutubanos que se instalaram ali.

A comunidade, tradicionalmente, ocupa o território de modo diversificado: as ilhas, as áreas de vazantes, as margens do rio e a mata, conforme o período do ano, o clima, as enchentes etc. Vive da pesca, da agricultura de subsistência, coleta de frutos nativos etc ${ }^{37}$.

Contudo, esse território tradicional é reivindicado pelo fazendeiro local - Fazenda Pedras de São João. Na condição de posseiros, resistem às liminares de reintegração de posse, restrições do uso do território pela polícia e limitação no direito de ir e vir:

A comunidade, denuncia que policiais civis e militares penetram o seu território intimidando-a. E, como se não bastasse, outras ameaças se inserem na luta da mesma: as crianças não podem mais brincarem livremente, pois, recentemente, um funcionário do bananal que faz divisa com a área próxima às residências, usou arma de fogo para afastá-las do local; o gado do de locatário, sob responsabilidade da fazenda está pisoteando as lagoas marginais, a beira do rio, os quintais das famílias e impedindo-a de fazer o plantio das roças; as estrada de acesso à cidade está bloqueada pelos fazendeiros. A prefeitura, não enfrenta o problema, colocou lancha escolar que nem sempre responde às necessidades das crianças e cria conflitos desnecessários entre pais e funcionários municipais que atuam na área ${ }^{38}$.

Diante desse contexto, a comunidade tem se mobilizado junto aos órgãos públicos e poder judiciário. No entanto, não sendo atendidas vão para o confronto direto na luta por direitos. No Blog Pelo Território Pesqueiro está documentada a mobilização dos pescadores para reabrir a estrada que dá acesso ao território da comunidade ${ }^{39}$ e para reconstruir moradias que são derrubadas a mando dos fazendeiros locais. Por isso, a luta é pela "necessidade da demarcação física da área concedida, para a garantia da soberania alimentar e para condições de sobrevivência mínima da comunidade, embora reconheçam que o problema só se resolverá de fato, perante a ação de regularização do Território quilombola reivindicado" 40 .

37 PELO TERRITÓRIO PESQUEIRO. Nota à sociedade: Denúncia da Comunidade Pesqueira Caraíbas/MG. Disponível em: < http://denunciapeloterritorio.blogspot.com.br/2013/10/nota-sociedade-denunciada-comunidade.html>. Acesso em: 10 out 2016.

\footnotetext{
39 PELO TERRITÓRIO PESQUEIRO. Comunidade quilombola e pesqueira de Caraíbas retoma estrada tradicional em Pedras de Maria da Cruz (MG). Disponível em: $<$ http://peloterritoriopesqueiro.blogspot.com.br/2016/06/comunidade-quilombola-e-pesqueira-de.html>. Acesso em: 16 jun 2017

40 PELO TERRITÓRIO PESQUEIRO. Pescadores de Caraíbas reconstroem casa derrubada por gerente da fazenda Santa Clara. Disponível <http://peloterritoriopesqueiro.blogspot.com.br/2017/05/pescadores-de-caraibas-reconstroem-casa.html>. Acesso em: 16 jun 2017.
} 
Esse contexto de luta para se manter no território também ocorre em São Francisco do Conde - Bahia. Quando os pescadores se organizam para a demarcação do território (no caso de comunidades que também são quilombolas) há reação dos fazendeiros com violência, como o incêndio de casas de pesca: "Há suspeitas de que o incêndio tenha sido criminoso e de que se trata de uma retaliação de fazendeiros locais, em razão da recente visita técnica do INCRA e da Superintendência do Patrimônio da União (SPU) à área para viabilizar a identificação das terras da união para fins de regularização fundiária do território quilombola"41. Esses fazendeiros também fazem uso do poder público local como denuncia o Blog Pelo Território Pesqueiro:

\begin{abstract}
A comunidade pesqueira e quilombola Porto de D. João, localizada no município de São Francisco do Conde/BA, desde 2009 sofre violência e criminalização por parte da prefeitura local, que é aliada aos interesses dos grandes fazendeiros da região. Em novembro, o poder público municipal entrou com uma ação junto a justiça federal no intuito de anular a certificação quilombola da comunidade e paralisar o processo de regularização fundiária do INCRA, ação que viola o direito de auto-reconhecimento da comunidade garantido pela Convenção 169 da OIT $^{42}$.
\end{abstract}

Cabe enfatizar que na atualidade esses contextos de luta para o reconhecimento e demarcação ocorrem nas comunidades que também são remanescentes de quilombolas, as quais já tem lei específica. Isso tem garantido a permanência de diversas comunidades pesqueiras em seus territórios tradicionais (exclusivamente o território de moradia e vivência). Nas denúncias do Blog Pelo Território Pesqueiro esses contextos também são apresentados na comunidade pesqueira de Croatá, em Januária - Minas Gerais, que tem promovido ações de retomada do território, frente as restrições impostas pelos fazendeiros locais, como o direito de ir e $\operatorname{vir}^{43}$.

De fato, denúncias do Blog Pelo Território Pesqueiro demonstram a restrição do acesso ao território da comunidade como forma de pressão que inviabiliza a presença das mesmas no território. Contudo, também é frequente a derrubadas de moradias e expulsão de moradores,

\footnotetext{
${ }^{41}$ PELO TERRITÓRIO PESQUEIRO. MPP denuncia violência contra pescadores e quilombos da comunidade Monte Recôncavo, na Bahia. Disponível em: <http://peloterritoriopesqueiro.blogspot.com.br/2014/05/mpp-denuncia-violencia-contra.html>. Acesso em: 10 out 2016.

42 PELO TERRITÓRIO PESQUEIRO. Pressionada por fazendeiros, prefeitura de São Francisco do Conde/BA ataca de forma ilegal comunidade tradicional. Disponível em: <http://denunciapeloterritorio.blogspot.com.br/2014/12/pressionada-por-fazendeiros-prefeitura.html>. Acesso em: 10 out 2016

${ }^{43}$ PELO TERRITÓRIO PESQUEIRO. Comunidade pesqueira de Croatá (MG) retoma território tradicional. Disponível em: <http://peloterritoriopesqueiro.blogspot.com.br/2016/05/comunidade-pesqueira-decroata-mg.html >. Acesso em: 16 jun 2017.
} 
como é registrada a denúncia do ocorrido com família pesqueira em Ibiaí no Norte de Minas ${ }^{44}$. Contudo, esses contextos não correm sem resistência e luta, inclusive com a mobilização para a retomada do território da comunidade, como ocorrido com os pescadores da Ilha do Fogo, entre Juazeiro - Bahia e Petrolina - Pernambuco, no Rio São Francisco, onde o Exército Brasileiro havia desocupado o território ${ }^{45}$.

Os pescadores do Distrito de Regência, em Linhares - Espírito Santo, denunciam inúmeras ofensivas ao território comunitário e a resistência dos pescadores:

\begin{abstract}
A terceira e atual ofensiva, que dá sequência a este calvário de perseguições e danos, está sendo vergonhosamente emplacada pela empresa UNIÃO FERRAGENS E MONTAGENS. Esta, representada pelo Sr. EDIVAL SANTANA e proprietária de terras na vizinhança, está cercando, como se sua fosse, as terras dos caboclos, numa prática flagrante, inequívoca de esbulho. Nessa pretensão, fixou uma porteira de ferro com mourões de concreto, colocou corrente e cadeado, impedindo o direto de ir e vir das pessoas que dependem da servidão da estrada; soltou 150 cabeças de gado bovino na área, e estes, comeram as plantações que ali havia, causando perturbação e prejuízo aos ribeirinhos; não bastasse, contratou pessoas para destruir as casas das famílias, sem antes avisar ou propor alternativa.

Nesta ocasião, conseguiram destruir algumas; uma, inclusive, abrigava uma mulher e uma criança de seis anos que ficaram em pânico ao verem seu lar destruído. Para tanto, o Sr. Edval Santana sustenta ter adquirido o território ribeirinho da JUSTIÇA FEDERAL, representada por um Advogado e uma Juíza, até então desconhecidos, como também o são as provas documentais da suposta aquisição. Por fim, os posseiros procuraram o INCRA, que se comprometeu a vistoriar a área ${ }^{46}$.
\end{abstract}

Ressalta-se que além dos conflitos com fazendeiros locais, também há conflitos por território com o Estado, como ocorre no Quilombo Rio dos Macacos, Simões Filho - Bahia, o embate entre comunidades tradicionais e a Marinha do Brasil.

Nos últimos meses, como forma de enfrentar a organização política da comunidade Rio dos Macacos e a solidariedade de muitos grupos da Bahia e do Brasil, a Marinha protagonizou inúmeras ações violentas, a exemplo do assédio diário à comunidade com dezenas de fuzileiros armados; invasão de domicílios, atentando contra os direitos das mulheres; uso ostensivo de armamento exclusivo das Forças Armadas, criando verdadeiros traumas em

${ }^{44}$ PELO TERRITÓRIO PESQUEIRO. Fazendeiro destrói barraco de família pesqueira no Norte de Minas. Disponível em: <http://denunciapeloterritorio.blogspot.com.br/2015/04/fazendeiro-destroi-barraco-defamilia.html >. Acesso em: 10 out 2016.

${ }^{45}$ PELO TERRITÓRIO PESQUEIRO. Pescadores da Ilha do Fogo são exemplo de resistência na bacia do São Francisco. Disponível em: <http://peloterritoriopesqueiro.blogspot.com.br/2016/04/pescadores-da-ilhado-fogo-sao-exemplo.html >. Acesso em: 10 out 2016.

46 PELO TERRITÓRIO PESQUEIRO Carta denúncia dos crimes cometidos contra as famílias pescadoras do distrito de Regência, Linhares- ES. Disponível em: <http://denunciapeloterritorio.blogspot.com.br/2013/08/carta-denuncia-dos-crimes-cometidos.html>. Acesso em: 10 out 2016. 
crianças, adolescentes e idosos, que tiveram casas invadidas e armas apontadas para as suas cabeças; e impedimento das atividades econômicas tradicionalmente desenvolvidas pela comunidade, como a agricultura e a pesca de subsistência, como forma de inviabilizar a permanência no território (TOMÁZ; SANTOS, 2016, p.81).

Frente a diversas denúncias a órgãos públicos reivindicando direitos conquistados por meio de trados internacionais e leis nacionais, foi dado início ao processo de construção do "Relatório Técnico de Identificação e Delimitação (RTID), que é uma peça técnica fundamental para que a presença da comunidade no território seja entendida pelos poderes públicos" (TOMÁZ; SANTOS, 2016). Contudo:

Estranhamente e de forma arbitrária, a Marinha achou-se no direito de impedir um órgão da administração federal, o INCRA, de cumprir com o dever constitucional e o acordo institucional firmado no dia 3 de novembro de 2011. No dia 9 de dezembro, a Marinha anunciou que não ia permitir a entrada dos técnicos do INCRA no local, alegando que as ações daquele órgão no sentido de realizar os estudos necessários à regularização das terras dos quilombolas e, assim, cumprir com o que manda a Constituição seriam incompatíveis com o interesse público. Leia-se: incompatíveis com o interesse de ampliar a Vila dos Militares (p.81).

\section{Especulação Imobiliária}

No âmbito do espaço urbano a especulação imobiliária se destaca enquanto modernização que leva a expropriação da terra das comunidades de pescadores. Nesse caso, os equipamentos urbanos instalados, aliados às amenidades relacionadas à beleza da paisagem onde estão as comunidades, são fatores que elevam o valor de troca dos imóveis. Pressionadas pelo mercado imobiliário e sem ter acesso aos serviços relacionados à nova configuração urbana, as comunidades progressivamente vendem seus imóveis, que por serem "posse" são comercializados por um valor que ainda está abaixo do mercado. Consequentemente, os pescadores têm que procurar novas moradias em áreas longe dos pesqueiros tradicionais e, por isso, muitas vezes acabam abandonando a pesca. Como destaca o Relatório "Conflitos Socioambientais e Violações de Direitos Humanos em Comunidades Tradicionais Pesqueiras no Brasil" a especulação imobiliária "traz como consequência a expulsão das comunidades pesqueiras dos seus territórios ou o impedimento do acesso a partir da privatização das terras. Esta pressão é estabelecida em águas e terras públicas” (p.10).

Ressalta-se que o avanço do tecido urbano também insere os pescadores artesanais em problemáticas sociais que antes não estavam presentes nas comunidades, como o tráfico de drogas, assaltos, etc. Isso também contribui com a desvinculação dos comunitários ao território tradicional e, consequente, subsunção às propostas dos incorporadores imobiliários. 
Em Tomáz e Santos (2016) fica evidente a pressão do mercado imobiliário que se expressa em diversas regiões brasileiras. No Litoral do Ceará (Comunidade Emboaca, Comunidade Pé do Morro, Sítio Jardim, Vila de Volta, Praia do Caponga, Praia de Barro Preto e Praia de Capim-Açu, Praia Morro Branco, Lagoinha, Paracuru, Taiba). No litoral do Pernambuco (Aver-o-Mar) e do Rio Grande do Norte (Bairro dos Navegantes, Pirangi do Norte), Litoral e Região Centro Maranhense, Região do Delta do Parnaíba, no Estado do Piauí (Comunidade de Pedra do Sal). Ainda na Região do Baixo Amazonas e de Marajó, no Pará (Comunidade do Juá, Comunidades de Cametá, Daniel de Carvalho, Santa Cruz, Brasília Legal, Fordilândia e Cuparí, Vila Vieira, Amador, Ourives, Ilha Grande e Vila Barbosa). No Litoral de Santa Catarina, Litoral da Bahia (Porto D. João, Guaí, São Roque do Paraguaçu, São Braz, Cambuta, Acupe, Itapema, Cairu, Cabuçu, Bom Jesus dos Pobres, Batateira - Ilha de Tinharé) e Bacia do rio São Francisco (Petrolândia/PE/Ilha do Bode Roco, Belém do São Francisco/PE/Lago de Itaparica/ Comunidade Manga de Baixo, Cânion São Francisco/AL, BA, SE, Brejo Grande e Paracatuba/SE/Quilombo Brejão dos Negros, São Romão/MG/Comunidade Ribanceira).

A intensificação da especulação imobiliária está estritamente relacionada ao avanço do turismo (LIMA, 2002; FIGUEIREDO, 2013) ao longo do litoral, sobre os territórios das comunidades tradicionais de pescadores. Nesse sentido, o valor da terra é um fator fundamental no entendimento do deslocamento das comunidades de pescadores para locais mais afastados dos pesqueiros tradicionais (MACHADO, 2010; MORAES, 2010; COSTA, 2015). As comunidades, no entanto, resistem à privatização das áreas que eram de convívio comunitário (NUNES, 2011) e à imposição de outros modos de viver com a chegada de novos moradores atraídos por áreas menos influenciadas pelas problemáticas das grandes cidades (FERREIRA, 2013).

Os pescadores do Rio São Francisco denunciam em carta, as ações privatistas da terra no entorno desse importante território pesqueiro. No urbano, a especulação imobiliária se destaca como atividade que impede a permanência dos pescadores artesanais aos seus territórios tradicionais ${ }^{47}$.

Em reunião junto aos pescadores em Itaguaí-RJ foi relatado o contexto de insegurança em que vivem os pescadores devido ao tráfico de drogas. Existem relatos que na própria Baía

${ }^{47}$ PELO TERRITÓRIO PESQUEIRO. Carta do Povo do Rio "Eu Viro Carranca Hoje, pra Defender o Velho Chico. Disponível em: < http://denunciapeloterritorio.blogspot.com.br/2015/05/carta-do-povo-do-rio-euviro-carranca.html>. Acesso em: 10 out 2016. 
de Guanabara traficantes coagiram pescadores a atravessarem entorpecentes de barco, por meio de uma série de ameaçadas a vida.

\subsection{O Estado como promotor da Modernização}

Tendo compreendido as três faces que expressam a modernização que avança sobre os territórios da pesca artesanal, considerou-se relevante apresentar reflexões sobre o papel do Estado nesses contextos. Essa análise não está baseada em denúncias do Blog Pelo Território Pesqueiro, mas em discussões estabelecidas junto ao movimento social que permitem discutir algumas questões frequentes nas dissertações e teses analisadas. Nestes trabalhos se evidenciam 23 contextos relacionados ao Estado. Destes, 15 fazem referência à conflitos por território, 6 à disputas por recursos do ambiente no território e 3 a impactos ambientais. Ressalta-se que uma vez que o Estado brasileiro tem a prerrogativa da gestão do ambiente e da pesca artesanal, justifica-se a maioria dos contextos analisados terem referência à conflitos por território.

Os principais contextos analisados que expõem o Estado como agente da modernização são: instalação de unidades de conservação; normatizações da pesca e do ambiente; gestão da pesca (fiscalização), e conflitos institucionais.

\section{Unidade de Conservação}

Do ponto de vista das faces da modernização apresentadas e em diálogo com o movimento social, a instalação de Unidades de Conservação está estritamente relacionada com a face da modernização que provoca a expulsão dos pescadores artesanais dos seus territórios tradicionais. É fundamental destacar que a ocupação do espaço pelas comunidades, e o estabelecimento dos seus territórios tradicionais é anterior ao Sistema Nacional de Unidades de Conservação -SNUC (BRASIL, 2000). Consequentemente, as normas estabelecidas por esses documentos para o uso das unidades, com frequência, não estão de acordo com o processo de ocupação das mesmas. Destaca-se que no estabelecimento de Unidades de Conservação de Proteção Integral a presença de comunidades é proibida. Logo, há o processo de desapropriação e remoção das comunidades. Em alguns contextos, por falta de condições para a regularização fundiária a comunidade permanece, mediante uma série de normas impostas pelo conselho da unidade, que nesse caso não é deliberativo, ou seja, a comunidade participa, mas não delibera, o que é uma prerrogativa dos gestores com base na legislação ambiental. 
As unidades de conservação também estão relacionadas com a face da modernização que tira o acesso aos pesqueiros tradicionais. Ressalta-se que unidades de proteção integral e de uso sustentável estabelecem Planos de Manejo que criam normas de uso dos recursos do ambiente. Em alguns casos essas normas proíbem a pesca em importantes pesqueiros tradicionais, os quais eram manejados pelos pescadores artesanais por meio de saberes tradicionais. Além disso, a definição de determinados apetrechos de pesca também inviabiliza a pesca em determinados pesqueiros.

Os pescadores artesanais estão em constante conflito com unidades de conservação devido ao não reconhecimento da ocupação anterior e às formas tradicionais de uso dos recursos do ambiente (CARDOSO, 1996; CHAMAS, 2008; DE PAULA, 2013). Sobre os usos, há o embate entre a legislação ambiental (FARIAS, 2009, SCHEIBEL, 2013, RODRIGUES, 2014) e os usos tradicionais (COSTA, 2015), os quais expressam uma construção social (BARBOSA, 2014) a partir da relação estabelecida com o ambiente. Uma possibilidade de minimizar conflitos é envolver a comunidade local na construção do plano de manejo e reconhecer seus saberes, contudo, esse documento ainda não foi construído em muitas unidades (FARIAS, 2009). No ambiente das unidades de uso sustentável, para a pesca artesanal, se destaca o modelo das Reservas Extrativistas (DUMITH, 2012), onde o espaço de participação é ampliado no conselho deliberativo (ROSÁRIO, 2009).

Conflitos entre pescadores e Unidades de Conservação são numerosos, de 2011 a 2013 no âmbito do Fórum Delta do Jacuí acompanhou-se a construção do Plano de Manejo do Parque Estadual Delta do Jacuí. Antes disso, para resolver a questão fundiária sem necessidade de remoções essa unidade em parte foi transformada em Área de Proteção Ambiental Delta do Jacuí. Contudo, os rios que compõe esse Delta fluvial ficaram situados na área do parque, o que acarretou em proibir a pesca artesanal em importantes pesqueiros tradicionais.

Devido a mobilização dos pescadores artesanais no Fórum Delta do Jacuí - Região Metropolitana de Porto Alegre - Rio Grande do Sul, em audiências públicas e por meio de documentos protocolados na Secretaria Estadual do Meio Ambiente - SEMA, a aprovação do Plano de Manejo ficou associada à criação de um Acordo de Gestão. A primeira versão desse acordo foi construída em reunião dos gestores ambientais com o presidente da Colônia de Pescadores Z1. Quando os pescadores do Fórum tiveram conhecimento desses documentos observaram que as regras criadas não correspondiam à realidade dos pescadores de toda a região. Diante disso, novamente foram realizadas reuniões com a SEMA e no âmbito do Fórum 
as regras foram discutidas e o acordo firmado. Destaca-se que esse processo ocorreu ao longo de quase dois anos de luta dos pescadores artesanais para se manterem no território pesqueiro.

Situações envolvendo a regularização fundiária são também expressivas nos embates entre pescadores artesanais e Unidades de Conservação de Proteção integral. No caso dos pescadores artesanais que residem no Parque Nacional do Superagui - Paraná - o processo de regularização fundiária promovido pela Secretaria de Patrimônio da União - SPU se deu por meio de conflitos. Relatam que o processo de regularização não respeitou o território tradicional dos pescadores artesanais, e suas atividades tradicionais como pesca, roçado e extrativismo.

\section{Normatizações}

Outro ponto de total importância para compreender o papel do Estado diz respeito às normatizações da pesca e do ambiente. Destacam-se as normas construídas sem a participação das comunidades, aquelas estabelecidas de cima para baixo, geralmente a partir de um corpo de técnicos e consultores especialistas. Estas, costumeiramente, estão incompatíveis com as técnicas e normas tradicionais de uso dos recursos no território pesqueiro. As consequências expressam as faces da modernização que causa degradação ambiental, sobre-exploração e limitação no acesso aos pesqueiros e expropriação do território.

A face da degradação ambiental se expressa na medida em que as regras estabelecidas não são capazes de garantir a permanência dos recursos do ambiente em situação de equilíbrio. Isso não se restringe à normatização da pesca, mas toda a legislação ambiental incapaz de estabelecer normas que não limitam os danos ambientais sobre os ecossistemas fundamentais para a permanência das espécies pesqueiras.

Quanto a modernização que restringe o acesso aos pesqueiros ou promove sobreexploração de pesca destaca-se a contradição de normas que restringem as práticas tradicionais de pesca artesanal e, ao mesmo tempo, favorecem a pesca industrial por meio de flexibilizações normativas e política de fomento ao setor (industrial e aquicultura).

Do ponto de vista da norma também há expressão da face da modernização que promove a expropriação do território. O não reconhecimento do território tradicional das comunidades tradicionais, frequentemente, gera áreas de exclusão da pesca para o favorecimento de outras atividades econômicas. Também não reconhecem as particularidades do território pesqueiro, que é contiguo ao território de moradia e vivência das comunidades.

Diante do exposto, é fundamental considerar que as normas que não estão de acordo com as características do ambiente não são eficazes na conservação dos recursos (SILVA, 
2012A). No âmbito da normatização da pesca, os conflitos emergem na medida em que não envolvem a comunidade na construção, logo, não reconhece as práticas tradicionais de uso (SANTOS, 2013), estabelecidas a partir de conhecimentos tradicionais. As consequências de normas incapazes de manter os recursos em situação de equilíbrio se refle nas relações comunitárias, quando os pescadores passam a disputar recursos cada vez mais reduzidos (MAIER, 2009).

Em relação à normas de gestão da pesca que são construídas de cima para baixo serão destacados dois contextos. O primeiro trata-se da Portaria $n^{\circ} 445 / 14$ (BRASIL, 2014B); a qual inclui duas espécies do bagre Genidens barbus como Em Perigo de Extinção e Genidens planifrons como Criticamente em Perigo de Extinção. Ressalta-se que no caso do Rio Grande do Sul, as referidas espécies de Bagre foram indicadas no Decreto Estadual $\mathrm{N}^{\circ} 51.787$ (BRASIL, 2014A). A segunda trata-se do Plano de Gestão para o Uso Sustentável da Tainha no Sudeste e Sul do Brasil (BRASIL, 2015C).

Segundo notícia do Blog Pelo Território Pesqueiro "A portaria foi muito criticada por não levar em consideração as diferenças regionais, que faziam com que uma espécie estivesse ameaçada numa determinada área, mas sem perigo algum de extinção em outra região. Em alguns casos, a ausência de estudos mais recentes que confirmassem verdadeiramente a vulnerabilidade das espécies também foi motivo de crítica dos pescadores". A lista nacional foi suspensa e foi constituído pelo Ministério do Meio Ambiente - MMA um Grupo de Trabalho da Portaria 445 com participação de diversos seguimentos da sociedade ${ }^{48}$. Em decorrência disso a Portaria 445 não está em vigor no presente momento. Contudo, no caso do Rio Grande do Sul, o Decreto $N^{\circ} 51.797$ mantém a pesca do Bagre proibida no estado. Ressalta-se que é o único estado da federação onde essa pescaria essa proibida. Tal proibição se dá devido a repercussão da lista na Lei de Crimes Ambientais (BRASIL, 1998).

O que se acompanhou no âmbito do Fórum Delta do Jacuí foi uma disputa pelo domínio do saber competente. A fundação estadual que elaborou a referida lista apregoa ter utilizado técnicas de pesquisa referendadas internacionalmente e que o estudo contém as informações mais atualizadas sobre os estoques das espécies em questão. De outro lado, os pescadores artesanais argumentam que houve aumento na quantidade desses peixes nos corpos d'água da região nos últimos anos e que não foram consultados no processo de pesquisa que embasou a

${ }^{48}$ PELO TERRITÓRIO PESQUEIRO. Pescadores artesanais participam de retomada do GT da Portaria 445. Disponível em: <http://peloterritoriopesqueiro.blogspot.com.br/2017/07/pescadores-artesanaisparticipam-de.html > Acesso 10 nov 2017. 
referida lei. Os últimos dados comparativos de Estatística Pesqueira apresentados pela Fundação Zoobotânica datam de 1970, 1980, 1990 e 2000 apresentam a lacuna de 17 anos.

Diante da situação grave de insegurança alimentar que se encontram as comunidades de pescadores que viviam das pescarias de bagre, o Fórum Delta do Jacuí questionou via Ministério Público Federal: 1) o desrespeito à OIT 169 que prevê que normativas que afetam as práticas das comunidades tradicionais devem ser precedidas de pesquisa que promova a participação dos envolvidos; 2) que o estudo integre informações importantes na gestão da pesca artesanal na região como a criação dos cinco fóruns de pesca artesanal (que contemplam todo o estado), a implementação da política de seguro-defeso para a pescador artesanal e a construção de instruções normativas regionais; 3) que sejam mensurados os impactos provocados por outras atividades econômicas como a mineração; agronegócio, ampliação de complexo portuário de Rio Grande e a própria pesca industrial sobre a espécies, de forma que a pesca artesanal não seja a única atividade penalizada.

No âmbito da Articulação Sudeste-Sul do Movimento dos Pescadores e Pescadoras Artesanais, outra normativa que foi imposta de cima para baixo e põe em risco a permanência de uma pescaria tradicional é o Plano de Gestão para o Uso Sustentável da Tainha. Destaca-se como méritos desse plano o reconhecimento de fatores socioeconômicos, a distinção entre impacto provocado pela pesca artesanal e pesca industrial e esforço em propor cenários possíveis para a recuperação da espécie. Contudo, os limites apresentados para a pesca artesanal põem em risco a manutenção dessa atividade tradicional:

Destaca-se que esse plano não foi devidamente discutido com as comunidades, inviabiliza a pesca em determinados estados e, progressivamente, tende a acabar com a pesca artesanal dessa importante espécie. Os(as) pescadores(as) artesanais exigem que as normas do território pesqueiro sejam definidas a partir das comunidades ${ }^{49}$.

A Organização Não Governamental OCEANA apresentou no II Encontro da Articulação Sudeste-Sul do MPP, em Jaguaruna - SC, um estudo realizado por consultores que expõe a situação dos estoques de tainha e corrobora dados de uma metodologia de monitoramento proposto pela ONG denominado TAINHOMETRO e testado no litoral de Santa Catarina. A proposta é de que a gestão da tainha seja realizada por meio de cota de pesca. Nesse sentido a pescaria seria permitida até atingir determinada cota, e caso essa não fosse alcançada pela pesca artesanal haveria abertura para a pesca industrial.

\footnotetext{
${ }^{49}$ MPP (Articulação Sudeste-Sul), Carta de Jaguaruna. Resultado do II Encontro da Articulação Sudeste-Sul do Movimento dos Pescadores e Pescadoras Artesanais, 2017.
} 
Destaca-se que, no atual regramento da tainha, as regras estão baseadas com as características da espécie (tamanho, peso, estágio de maturação, etc.). A nova proposta do governo está mais centrada em limitações nos apetrechos de pesca e capacidade de navegação. Por outro lado, a proposta da ONG OCEANA está vinculada às cotas de pesca, ou seja, na população de tainha presente. Essas três propostas entram em conflito com a proposta do Movimento dos Pescadores e Pescadoras Artesanais, os quais propõem que a gestão seja estabelecida a partir do território pesqueiro. Isso quer dizer que nenhuma regra deve ser tomada a priori, mas devem estar relacionadas às características do ambiente, das práticas tradicionais de pesca, e dos acordos firmados.

\section{Fiscalização}

A fiscalização da pesca e do ambiente, ou ausência desta, também promovem as faces da modernização que gera degradação ambiental, que reduz os recursos e limita o acesso aos pesqueiros. A degradação ambiental ocorre quando não ocorre a fiscalização sobre as atividades econômicas que contaminam os corpos d'água. A sobre-exploração decorre da insuficiente e ineficiente fiscalização sobre a pesca industrial e comercial. Quando não advertem as atividades que impedem o caminho aos pesqueiros, também expõem a limitação ao acesso.

Ressalta-se que partindo do entendimento que a fiscalização promove a efetividade das leis estabelecidas, os limites e possibilidades estão condicionados à normatização vigente. Ainda, por meio da fiscalização o Estado impõe a sua intencionalidade. Logo, pode ser mais flexível para atividades econômicas que correspondem ao seu projeto de modernização, e mais intensa sobre aqueles que resistem a esse projeto. De fato, a fiscalização ambiental e da pesca, frequentemente, tem gerado a criminalização dos pescadores artesanais no Brasil.

Ressalta-se a necessidade de haver fiscalização sobre atividades econômicas que causam danos ambientais sobre os ecossistemas necessários para a presença das espécies pesqueiras (CUNHA, 2006). Isso diz respeito à capacidade dos órgãos ambientais brasileiros quanto a sua competência na defesa dos recursos ambientais. A ausência de fiscalização sobre atividades que exploram os recursos pesqueiros como a pesca industrial e comercial representa limites para permanência da pesca, sobretudo em corpos d'água de extensão mais restrita (CUNHA, 2011). A redução do pescado, por consequência, expõe conflitos entre pescadores, que passam a competir pelo pescado. Entende-se que as disputas no território pelos recursos do ambiente seriam reduzidas caso houvesse outro modelo de gerenciamento, cujas regras estivessem claras e menos impasses entre instituições quanto quem tem a prerrogativa da 
fiscalização (LIMA, 2008). No âmbito da pesca, entende-se a importância da fiscalização para a manutenção dos recursos do ambiente (MACHADO, 2013). Contudo, devido falta de infraestrutura os órgãos ambientais acabam por se deter a pesca artesanal, em detrimento da pesca industrial.

Quanto à fiscalização deseja-se dar ênfase à criminalização dos pescadores artesanais e da constituição da figura do pescador artesanal como um depredador do ambiente, enquanto desconsidera-se a ação de outras atividades econômica. No contexto que foi apresentado da pesca do Bagre no Rio Grande do Sul, houve um hiato de tempo em que as comunidades não compreendiam qual a lei que estava em vigor. Compreendendo que a Portaria 445 estava suspensa, alguns pescadores que dependiam da pesca do Bagre permaneceram pescando. Contudo a fiscalização ambiental promovida pela Polícia Militar do Rio Grande do Sul (Brigada Militar) autuou e prendeu pescadores que estavam realizando a atividade. Um casal de pescadores relatou no Fórum Delta do Jacuí o contexto de humilhação a que foram submetidos devido a ação violenta da fiscalização. Além de terem os apetrechos de pesca apreendidos, os pescadores foram registrados em boletim de ocorrência e no cumprimento da legislação ambiental sujeitos a multa. Frente a esse contexto, por iniciativa do Fórum Delta do Jacuí esses pescadores realizaram uma denúncia ao Ministério Público Federal, onde tramita o processo.

Outro contexto que deve ser enfatizado é o processo de criminalização dos pescadores artesanais da Baía de Sepetiba - Rio de Janeiro - como assassinos de botos. Além do contexto de violência sofrido nas abordagens dos órgãos ambientais, esses pescadores perecem diante da sociedade geral que está sujeita a manipulação midiática que associa os pescadores à morte de botos. A partir da mobilização dos pescadores artesanais no Fórum dos Pescadores em Defesa da Baía se Sepetiba e de denúncia junto ao Ministério Público Federal deu-se início a esse enfrentamento argumentando que os botos na verdade morriam por envenenamento provocado pela indústria petroquímica instalada no entorno da baía. Para fortalecer essa discussão, os pescadores em parceria com a Universidade do Estado do Rio de Janeiro promoveram o I Seminário de Avaliação Socioambiental Global da Baía de Sepetiba (RJ): diagnósticos e desafios para pensar a gestão regional ${ }^{50}$.

\section{Institucional}

A forma como os órgãos de Estado trata a pesca e o pescador artesanal também expressa as faces da modernização. Ressalta-se que se trata tanto da abordagem da pesca artesanal em

\footnotetext{
${ }^{50}$ Realizado de 29 e 30 de junho de 2016 na UERJ, campus Maracanã.
} 
políticas públicas como o tratamento dos agentes de governo aos pescadores artesanais e suas comunidades. Quanto a face da modernização que expressa a expropriação dos territórios tradicionais, evidencia a falta de política que garanta os territórios tradicionais de pescadores. A face da sobre-exploração e restrição do acesso, se expressa nas políticas que fomentam, principalmente, a pesca industrial e aquicultura em detrimento da pesca artesanal. Soma-se a isso legislações que vem "descaracterizando" o pescador artesanal, restringindo o seu acesso a políticas públicas do setor pesqueiro.

O movimento social vem denunciando diversos casos de discriminação institucional de órgãos e agentes públicos, reivindicando direitos presentes em tratados internacionais que defendem as comunidades tradicionais, de que o Brasil é signatário como a Resolução 169 da Organização Internacional do Trabalho.

No âmbito da pesca há uma disputa da gestão entre órgãos públicos e comunidades de pescadores (GUEDES, 2009). Progressivamente, os pescadores artesanais conquistaram o direito de participar em alguns processos de construção de normas, entretanto, em muitos casos permanece a visão de gestores de que os pescadores artesanais são incapazes de propor normativas (GUEDES, 2009) e que agem de forma predatória. Assim, conflitos institucionais permanecem como entraves para o pescador artesanal desenvolver a atividade tradicional e permanecer no território pesqueiro (FARIAS, 2009). Esse distanciamento entre instituições formais e pescadores artesanais (CONTATO, 2012) tem comprometido a efetividade de política públicas

A concessão do Registro Geral de Pesca - RGP é um exemplo da discriminação institucional recebida pela comunidade pesqueira artesanal. Esse registro é obrigatório para exercer a pesca artesanal e para ter acesso às políticas públicas relacionadas ao pescador como o seguro-defeso. Contudo, mudanças institucionais interferem na forma como esse documento é concedido e mantido. Desde 2012 o governo federal não emite novos RGPs, somente concede um protocolo de solicitação. Desde 2015 o sistema de renovação do RGP tem apresentado problemas e vários registros foram cancelados e suspensos prejudicando mais de 600 mil pescadores $^{51}$.

Diante disso, se estabelece a problemática que os pescadores cujo registro foi suspenso, não conseguem recuperar o registro, e os pescadores (novos) que não tinham esse documento também não têm acesso. Em 12 de junho 2017 cerca de 60 pescadores artesanais ocuparam a

51 PELO TERRITÓRIO PESQUEIRO. Pescadores e pescadoras ocupam mais uma vez a sede do MAPA. Disponível em <http://peloterritoriopesqueiro.blogspot.com.br/2017/08/pescadores-e-pescadorasocupam-mais-uma.html> Acesso em 10 nov 2017. 
sede do Ministério de Agricultura, Pecuária e Abastecimento, que naquele momento era responsável pela pesca artesanal, exigindo a regularização do RGP. A partir do acordo firmado para a desocupação, o Ministério da Indústria, Comércio Exterior e Serviços - MDIC, que assumiu a pasta da pesca artesanal, emitiu em 27 de julho de 2017 a Portaria 1275 que permitia que os pescadores sem RGP exercessem a atividade pesqueira, contudo, não garantia os direitos previdenciários que estavam previstos no acordo de desocupação ${ }^{52}$. Por conseguinte, cerca de um mês depois esse ato administrativo foi suspenso. No entanto, a regra se manteve para os trabalhadores da pesca industrial, evidenciando a discriminação institucional vivenciada pelos pescadores artesanais brasileiros.

Outro contexto que deve ser evidenciado e diz respeito ao tratamento institucional recebido pelos pescadores artesanais se refere aos Decretos 8424 (BRASIL, 2015A) e 8425 (BRASIL, 2015B) publicados em 2015 pelo extinto Ministério da Pesca e Aquicultura. O Decreto 8424 estabelece que o seguro defeso deve ser destinado exclusivamente para pescadores profissionais artesanais que exercem a atividade de forma ininterrupta. O Decreto 8425 estabelece normas para a concessão do Registro Geral de Pesca e para a concessão de autorização, permissão ou licença para o exercício da atividade a partir de categorias.

Ambos os decretos foram intensamente contestados pelos movimentos sociais de pescadores artesanais porque reconfiguram a noção de pesca e de pescador artesanal. Nas manifestações da II Assembleia Nacional do MPP frisou-se que tratar a pesca artesanal como atividade ininterrupta é negar a relação estabelecida entre os pescadores e o ambiente, onde o uso respeita os ciclos da natureza. Quanto às categorias de pescadores e a proposição da figura do "trabalhador de apoio à pesca artesanal" agride a condição do pescador artesanal como comunidade tradicional. Essa categorização vitima principalmente as mulheres pescadoras que não são embarcadas, pois restringe a ser pescador profissional artesanal ao indivíduo que está envolvido na captura, negando toda a cadeia produtiva e sujeitos envolvidos na pesca artesanal.

Em reação a esses decretos e visando a revogação dos mesmos os movimentos sociais de pescadores realizaram diversas reuniões com o MPA e mobilizações locais e nacionais. Contudo, o governo federal manteve os decretos:

"Como a gente previa o curso da reunião não foi bom. Os ministros chegaram com pouca disposição de ouvir e fazer encaminhamentos concretos, no sentido de reverter as questões que estávamos colocando como centrais, como:

${ }^{52}$ PELO TERRITÓRIO PESQUEIRO. MDIC publica portaria que libera o exercício da pesca para pescadores sem o RGP. Disponível em: <http://peloterritoriopesqueiro.blogspot.com.br/2017/08/mdic-publicaportaria-que-libera-o.html> Acesso em 10 nov 2017. 
reverter o decreto 8424 e 8425 ou construir coletivamente estratégias de incidência sobre esses instrumentos. Também pautamos que as carteiras suspensas e canceladas, por ausência de gestão, deveriam ser descanceladas e a suspensão deveria ser revista", explica a liderança do MPP de Salinas da Margarida, Elionice Sacramento ${ }^{53}$.

Tento em vista a violação da Convenção 169 da OIT, em relação aos direitos dos pescadores e pescadoras, no contexto do Grito de Luta da Pesca Artesanal, foi realizado um ato que integrou pescadores e indígenas que protocolaram a sede a Organização Internacional do Trabalho uma denúncia contra o governo brasileiro.

A convenção internacional 169, da qual o Brasil é signatário, estabelece a necessidade de consulta prévia às comunidades e povos tradicionais sobre todas as medidas suscetíveis de afetá-los. Com a publicação dos decretos 8424 e 8425 emitidos pelo governo federal, em 2015, foi criada a categoria do "trabalhador e trabalhadora de apoio à pesca artesanal", desconsiderando o regime de economia familiar e tradicional da pesca artesanal. Ao determinar qual atividade da cadeia produtiva terá acesso ao Registro "Prévio" da atividade pesqueira, o Estado violou o direito de autodefinição das comunidades tradicionais pesqueiras, o que motivou o documento de denúncia protocolado pelo Movimento dos Pescadores e Pescadoras artesanais e pelo Conselho Pastoral dos Pescadores na OIT.

O informe pede que a OIT recomende ao Estado Brasileiro a regularização da situação cadastral/administrativa dos pescadores e pescadoras artesanais do país, pede também que o Estado Brasileiro crie um procedimento específico com o objetivo de regulamentar a Consulta Prévia aos povos e comunidades tradicionais, com ampla discussão da metodologia com representantes das comunidades tradicionais. Por último, o informe pede que a OIT recomende a suspensão dos decretos 8424 e 8425.

Essa é a primeira vez que pescadores e pescadoras do Brasil protocolam um informe de violação da convenção 169 na Organização Internacional do Trabalho. O documento será encaminhado para Genebra, na Suíça, onde será analisado pelo Comitê de Peritos em Aplicação de Convenções e Recomendações da OIT. Após análise, o Comitê deve emitir parecer sobre a denúncia feita no documento ${ }^{53}$.

Ainda sobre o Decreto 8425 destaca-se que ele insere os pescadores que utilizam embarcação de pesca com arqueação bruta menor ou igual a vinte na categoria de "pescador profissional artesanal". Entende-se essa como uma estratégia de inserir pescadores industriais em políticas públicas exclusivas da pesca artesanal, evidenciando novamente que enquanto a pesca artesanal é penalizada a pesca industrial recebe privilégios.

Por fim, para evidenciar o tratamento dado à pesca artesanal ressalta-se a transferência de atribuições relacionadas ao setor pesqueiro entre ministérios e secretarias. Em 2003 foi

53 PELO TERRITÓRIO PESQUEIRO. Povos e comunidades tradicionais ocupam Palácio do Planalto. Disponível em < http://peloterritoriopesqueiro.blogspot.com.br/2016/11/povos-e-comunidadestradicionais-ocupam.html >. Acesso em 17 mai 2017. 
criada a Secretaria Especial de Aquicultura e Pesca - SEAP, vinculada à presidência da república. Esta foi extinta em 2009 com a criação do Ministério da Pesca e Aquicultura - MPA. Este por sua vez foi extinto em 2015 durante a reforma ministerial. Por decreto, instituiu-se a Secretaria de Aquicultura e Pesca no Ministério de Agricultura, Pecuária e Abastecimento MAPA. Em 2017 o setor pesqueiro e passa a ser responsabilidade do Ministério da Indústria, Comércio Exterior e Serviços - MDIC. Ainda neste ano a Medida Provisória $n^{\circ} 789$ na Lei $n^{\circ}$ 13.502, de $1^{\circ}$ de novembro de 2017, instituiu a Secretaria Especial de Aquicultura e Pesca SEAP, novamente subordinada à presidência da república.

Em ocasião da transferência da Secretaria de Aquicultura e Pesca do MAPA para o MDIC foi divulgada uma carta aberta do Movimento dos pescadores e pescadoras artesanais expondo o contexto político no qual essa transferência de pasta foi realizada:

\begin{abstract}
A pesca continua sendo manipulada como uma mercadoria política em prol de interesses políticos eleitorais e financeiros, às custas da mesma sobrevivência da atividade e dos seus trabalhadores. Nós, dos Movimentos de Pescadores e Pescadoras, pesquisadores, ativistas, entidades e ONG's de apoio à pesca artesanal, denunciamos e repudiamos esta manobra cruel, irresponsável, eleitoreira e pró reforma da previdência do atual governo. Por toda a situação exposta e em defesa da pesca artesanal, dos pescadores e pescadoras artesanais e de suas comunidades, exigimos que a atividade pesqueira e seus protagonistas sejam respeitados e valorizados e deixem de ser moeda de troca política para interesses particulares, colocando a Secretaria da Pesca em um ministério que a assuma realmente, visando o seu desenvolvimento econômico, com justiça social e sustentabilidade ambiental $^{54}$.
\end{abstract}

\title{
3.8 Modernização e Pesca artesanal
}

Até o momento tem-se discutido a expressão das faces da modernização sobre os territórios tradicionais das comunidades de pescadores artesanais. Contudo, as dissertações e teses também evidenciam contextos em que a pesca artesanal promove impactos/disputas/conflitos. Desta forma, como as faces da modernização foram estabelecidas a partir das fontes do movimento social é evidente que a pesca artesanal não se evidencia como atividades que causa degradação no ambiente, sobre-exploração e restrição de acesso aos pesqueiros e expropriação dos territórios.

54 PELO TERRITÓRIO PESQUEIRO. Ministério da Indústria, Comércio Exterior e Serviços (MDIC) sob o comando do Partido Republicano Brasileiro (PRB)!!!!. Disponível em: <http://peloterritoriopesqueiro.blogspot.com.br/2017/03/carta-aberta-nao-secretaria-de-pesca-no.html>. Acesso em 17 mai 2017. 
Para finalizar, a reflexão segue na perspectiva de que em alguns contextos a expressão das faces da modernização modificaram a pesca artesanal. Isso quer dizer que de um lado os pescadores artesanais foram obrigados a modificar as artes de pesca, tornando-as mais predatórias, e de outro os vínculos comunitários foram sendo deteriorados. Dos 15 registros de impactos/conflitos/disputas intrínsecos a pesca artesanal, 8 estão relacionados a conflitos por território, 4 a impactos ambientais e 3 a disputas por recurso do ambiente no território. Somase a isso 7 contextos em que os conflitos se devem a representatividade dos pescadores, por meio das suas entidades formais, e que dizem respeitos a conflitos por território.

Entre os impactos relacionados à pesca artesanal destaca-se a sobre-pesca e a realização de pescarias em locais e períodos de piracema (SANTOS, 2012), isso chega ao ponto de prejudicar ecossistemas como os manguezais (SILVA, 2006B). Contudo, a utiliza de apetrechos de pesca predatórios resulta em disputas entre os comunitários (COSTA, 2010). De um lado estão esses pescadores que utilizam técnicas mais intensivas, de outro permanece o contexto de acordo e respeito ao ambiente que provem os recursos pesqueiros (TORRES, 2014).

Outro fator que gera disputas entre pescadores artesanais é a inserção de novos pescadores na atividade (CONTATO, 2012). Frequentemente, os pescadores novos têm uma lógica de apropriação dos recursos presentes no espaço mais voltada para o lucro, sem terem conhecimento sobre a dinâmica do ambiente e sua necessidade de renovação. Destaca-se que os conflitos por território se dão entre pescadores locais e de outras localidades - com a invasão de pesqueiros de uso comunitário - (CRUZ, 2006; LIMA, 2008; DE PAULA, 2013; FERREIRA, 2014), mas também no âmbito da própria comunidade - devido aos pescadores que transgrediram regras comunitárias- (GALVÃO, 2009; CRUZ, 2011). Contudo, a própria legislação ambiental não é compreendida da mesma forma por todos os pescadores, o que gera impasses e conflitos (SILVA, 2012A). Esses conflitos frequentemente resultam em violência e em morte de pescadores (SILVA, 2006A). A redução de tais conflitos tem sido alcançada por meio de acordos de pesca (SILVA, 2012A; PRADO, 2015).

A face da modernização que provoca a degradação do ambiente, resulta na mudança das características dos corpos d'água e redução na quantidade e qualidade do pescado. Para permanecer na atividade pesqueira, os pescadores acabam tendo que se deslocarem para locais mais distantes, o que exige um incremento na capacidade de navegação e maior esforço de pesca. Nesses locais o manejo do ambiente não é feito por meio de saberes aprendidos ao longo de anos em relação com a natureza e com normas de uso aprendidas em comunidade, o que acaba desvinculando os pescadores dos saberes tradicionais e intensificando a exploração dos 
recursos. Nesse contexto, disputam com os pescadores artesanais do local, que estão mais vinculados a aquele ambiente e resulta em conflitos. Assim, a face da modernização que causa degradação acaba transformando a pesca artesanal.

Em relação a face da modernização que provoca a sobre-exploração e restrições no acesso, também vai se observar que as consequências também afetam a pesca artesanal. Nesse contexto, a perda do pesqueiro tradicional acaba por resultar na erosão dos conhecimentos tradicionais e na dissolução de importantes vínculos comunitários. Os pescadores que não acabam desistindo da atividade têm que se deslocar para áreas mais distantes, o que incide em disputas e conflitos por territórios entre pescadores artesanais. Na disputa pela produtividade do pesqueiro são empregadas artes de pesca que são mais predatórias, o que resulta também em conflitos de uso entre pescadores. Na constituição desse novo território os vínculos comunitários ainda não estão firmados o que é um obstáculo para a resolução de conflitos.

A terceira face da modernização que gera a expropriação do território de moradia e vivência dos pescadores artesanais também provoca transformações na atividade pesqueira artesanal. Aqui ganha centralidade as relações fora do pesqueiro, que também sustentam a atividade pesqueira artesanal seja na constituição dos saberes tradicionais, seja no estabelecimento de vínculos que são fundamentais para a gestão do território pesqueiro. Nessa face da modernização, cabe destacar os conflitos relacionados às entidades que representam os interesses dos pescadores artesanais. Destaca-se as Colônias de Pescadores e Associações de Pescadores, que em conflito geram cisões nas comunidades e também prejudicam os vínculos necessários para a existência e defesa do território tradicional. 


\section{Capítulo IV}

\section{Geografias da Pesca Artesanal Brasileira}

Cerca nas águas: Derrubar!

O caminho percorrido pela tese partiu da Geografia (Capítulo I) para compreender as pesquisas sobre a pesca artesanal. Na sequência (Capítulo II) estabeleceu um horizonte de análise, que expõe um contínuo entre território da natureza e a natureza do território, propondo três possibilidades: impactos ambientais, disputas no território, e conflitos por território. A partir dessa leitura "Geográfica" é estabelecido o diálogo com o movimento social (Capítulo III), do qual é possível distinguir as três faces da modernização sobre o território das comunidades: degradação, sobre-exploração e limite ao acesso, e expropriação da terra.

Nesse momento, os três Capítulos são retomados para destacar as significações e ressignificações que foram geradas no âmbito da Geografia e no da pesca artesanal brasileira. Na primeira sessão será exposto o movimento "Da pesquisa do Geógrafo à Rede de Geógrafos: desafios para a construção de Geografias da Pesca”. Para isso o Capítulo I é retomado, e acrescenta-se análises que expõe relações entre conceitos, métodos, problemáticas e áreas de pesquisa. Pretende-se assim expor os limites e possibilidades, inclusive institucionais, para a Geografia atual. Assim, serão apresentadas tendências de diálogos, entre teorias e métodos, e com os sujeitos sociais. Também será problematizado o diálogo entre pesquisadores. Por fim a Rede de Geografias da Pesca é apresentada como possibilidade, tendo em vista que diante da diversidade de abordagens há necessidade de um horizonte ético comum, na perspectiva da Geográfica Crítica atual.

Na segunda sessão expõe-se o movimento "Da Territorialidade Tradicional ao Território de Luta das Comunidades Tradicionais de Pescadores Artesanais" Volta-se às apreensões do Capítulo II, discutindo a dimensão territorial, no campo teórico e na gestão da pesca artesanal. Discute-se o conceito de território tradicional, o que deve influenciar a compreensão dos geógrafos sobre pesca artesanal, pescadores artesanais, comunidades e conhecimentos tradicionais. Na sequência, problematiza-se que esses territórios são atravessados por territórios de outras instituições, com ênfase nas de Estado, que se impõem, o que se reflete na gestão. Assim, evidencia-se os limites e possibilidades da gestão ambiental da pesca artesanal. Por fim, com base na relação entre território e ambiente, que expõe impactos ambientais, disputas no 
território e conflitos por território, são abordados os territórios de luta. Tal luta é estabelecida no local, com outras atividades se apresentam no território tradicional, e na sequência, em âmbito nacional, onde o Movimento dos Pescadores e Pescadoras Artesanais propõem um projeto de lei de iniciativa popular que busca a salvaguarda dos territórios tradicionais das comunidades tradicionais de pescadores artesanais.

$\mathrm{Na}$ última sessão pretende-se o movimento "Das Geografias das Ausências, às Geografia das Emergências da Pesca Artesanal Brasileira”. A partir do Capítulo III, retoma-se a modernização do território como mote de discussão do pensamento Geográfico atual. Compreende-se que há na Geografia brasileira e produção de ausências, que, no caso da pesca artesanal, resultam nas faces da modernização. Contudo, na medida em que os geógrafos expõem as faces da modernização, em suas pesquisas, a Geografia promove emergências:

Para essa discussão foi necessário apresentar acréscimos teóricos que proporcionem a promoção dos diálogos de saberes, onde destacou-se a tradução intercultural de saberes e práticas. Ainda se discutiu os movimentos sociais no contexto latino-americano, destacando a política como campo de disputa. E contemporaneamente buscou-se compreender novos movimentos sociais e suas lutas em defesa de subjetividades e de direitos.

Os princípios metodológicos seguem na perspectiva do pensamento complexo (MORIN, 1990, 1996, 2008), e retomou-se alguns resultados dos Capítulos anteriores, bem como complementou-se as análises, por meio de técnicas de análise de conteúdo, elaboração de gráficos e construção de mapas temáticos de fluxo.

Desta forma esse Capítulo se dispõe a: Avaliar o estágio atual da Geografia da pesca do Brasil, reconhecendo perspectivas e lacunas; destacar possíveis articulações entre os geógrafos que pesquisam a pesca artesanal, e a possibilidade do trabalho em rede; a pontar potencialidades e desafios na gestão da pesca artesanal brasileira a partir da pesquisa geográficas sobre a pesca artesanal; reconhecer a importância das comunidades tradicionais, especialmente a pesqueira artesanal, para pensar a Geografia brasileira. 


\subsection{Pressupostos Teóricos: Diálogos de Saberes e Movimentos Sociais}

$\mathrm{Na}$ discussão teórica e epistemológica presente nesse Capítulo é fundamental destacar a perspectiva de ciência que se pretende seguir e os sujeitos da pesquisa com quem se dialoga. Nesse sentido, em um primeiro momento será situada a conformação de uma racionalidade ambiental. Isto provoca pensar os conceitos de saber ambiental, complexidade ambiental, e diálogos de saberes, na perspectiva de Leff (2004, 2006, 2007, 2009, 2010). Leff (2006) apresenta possibilidades de interpretação de diálogos de saberes através de propostas de Habermas e Santos. Neste Capítulo será enfatiza a abordagem desse último autor que propõe a tradução intercultural de saberes e práticas (SANTOS, 2002, 2011). Tendo em vista que tal diálogo se estabelece com o movimento social, esse conceito será abordado no contex to colonial e de democratização na América Latina, com base em Tapia (2008) e contemporaneamente, com base em Santos (2001) serão abordados os novos movimentos sociais.

\section{Racionalidade Ambiental: diálogos de saberes e tradução intercultural}

Com o objetivo de situar a tese dentro da perspectiva de Racionalidade Ambiental, proposta por Enrique Leff $(2004,2006,2007,2009,2010)$ e em diálogo com Carlos Walter Porto-Gonçalves $(2002,2010)$ serão apresentados os conceitos de saber ambiental, complexidade ambiental e diálogo de saberes. Esse último terá destaque para enfatizar a dialógica estabelecida entre conhecimentos tradicionais e científicos, onde será enfatizado o trabalho de tradução intercultural proposto por Boaventura de Souza Santos (2002, 2011)

Porto-Gonçalves (2010, p.52) enaltece que no período atual da moderno-colonialidade são negados, além dos saberes nativos, selvagens e orientais, todos os que não se submetem à racionalidade hegemônica. Desta forma, privilegiou-se a instituição do conhecimento sobre, ou seja, o qual viabiliza a dominação; e se negou o "saber com", aquele elaborado conjuntamente e materialmente por meio do tato, do contato, dos sabores, etc. Então, todo o saber ancestral acumulado por sociedades tradicionais foi sistematicamente desqualificado pelas ciências e tiveram suas práticas estigmatizadas como arcaicas, rústicas ou atrasadas.

A crise ambiental vigente expõe as consequências da racionalidade moderna, bem como os limites do conhecimento científico instituído. Por isso, a academia tem sido sugestionada a repensar e respeitar, considerando os saberes provenientes de outras matrizes de racionalidade (que não separam sociedade/cultura da natureza), assim como instituições de pesquisa de ponta têm paulatinamente demonstrado interesse sobre os conhecimentos dos "peritos" das sociedades tradicionais (PORTO-GONÇALVES, 2002, p. 221). 
Esses atores, em reação a moderno-colonialidade que se instalou em seus territórios e impôs padrões cognitivos, que põem em pauta questões e relações forjadas em situações assimétricas de poder. Como enfatiza Milton Santos (2006, p. 8), no campo e nas cidades, o aprendizado e a crítica da racionalidade hegemônica se fazem através do uso da técnica e da experiência da escassez:

O fato de que a produção limitada de racionalidade é associada a uma produção ampla de escassez conduz os atores que estão fora do círculo da racionalidade hegemônica à descoberta de sua exclusão e à busca de formas alternativas de racionalidade, indispensáveis à sua sobrevivência. A racionalidade dominante e cega acaba por produzir os seus próprios limites (p.211)

Porto-Gonçalves (2002) destaca que os paradigmas são instituídos por atores situados em sociedade, tempo e espaço, logo, a crise paradigmática é, também, a crise da sociedade e dos sujeitos que a instituíram. Retomando Latour (1994) para ultrapassar os limites do conhecimento tem-se de romper com a epistemologia moderna. Portanto, a emergência de novos paradigmas é acompanhada pela visibilidade de atores não modernos (LATOUR, 1994) que reivindicam um lugar no mundo. Esses não se anulam, mas resistem às diretrizes da moderno-colonialidade e se reinventam continuamente na diferença. Nesse processo, mais do que a resistência observamos a R-Existência, uma vez que a resposta à ação alheia se dá com base em algo que preexiste. Assim, a partir da existência que se R-existe: "Existo, logo resisto. R-Existo" (PORTO-GONÇALVES, 2010, p. 51).

Quando esses atores sociais se inserem na geração do conhecimento científico, as ciências passam a integrar e expor os saberes tradicionais e supera-se, pelo menos em parte, a colonialidade do saber e do poder. Esse conhecimento ambiental se reafirma o ser no tempo e o reconhece na história, estabelece novas identidades e territórios de vida reconhecendo o poder do saber e a vontade de poder como um querer saber (LEFF, 2009, p. 18).

As consequências da crise ambiental planetária têm resultado na incorporação de bases ecológicas, princípios jurídicos e sociais para a gestão democrática dos recursos naturais e aumentam a necessidade de elaborar estratégias conceituais que apoiem práticas orientadas a construir uma racionalidade ambiental. Nesse contexto, o saber ambiental é elaborado no encontro de saberes diferenciados por matrizes diversas, que correspondem a estratégias de poder pela apropriação do mundo e da natureza (LEFF, 2010).

No tempo presente se evidenciam fraturas sociais, difusão de necessidades insatisfeitas, manipulações de sustentos cultuais da reprodução cultural, desrespeito com compromissos 
criados em períodos anteriores, sem que sejam garantidas formas mais plurais de cooperação e convívio. Também é no tempo presente que se manifestam outras formas de germinação, iniciativas orientadas pela autogestão, economia solidária e valorização de identidades culturais, desconsideradas pela classe dominante. Assim confrontam a ideia de que a tecnologia é epicentro de projetos que visam a modernização e desconsideram o debate ético e moral do desenvolvimento econômico e da experiência urbana (RIBEIRO, 2012, 96-97).

A crise ambiental evidencia os limites da racionalidade econômica e a crise do Estado, ou seja, é uma crise da legitimidade das instâncias de representação, que tem mobilizado a sociedade em busca de outro paradigma civilizatório. Nesse contexto, buscam-se rever os paradigmas econômicos, as análises clássicas de Estado e as concepções de democracia, na busca por sustentabilidade, solidariedade, participação, autogestão dos processos produtivos e políticos (LEFF, 2010, p. 149).

O estabelecimento de uma racionalidade ambiental, para a gestão ambiental, envolve valores, interesses e fins, que não são originados pela racionalidade científica. Evidentemente "a administração científica da natureza é insuficiente para resolver os conflitos ecológicos e a crise ambiental" (LEFF, 2010, p.179). Logo, necessita-se da confluência de saberes que ultrapassam o campo científico convencional. Nesse processo se constitui a complexidade científica que é a "presença do não científico no científico que não anula o científico, mas pelo contrário lhe permite exprimir-se" (MORIN, 1990, p. 153).

O saber ambiental está baseado na diversidade cultural, em que o conhecimento da realidade é permeado pela apropriação de conhecimentos e saberes de diferentes ordens culturais e identidades étnicas. Nessa forma de saber, as identidades dos povos são reconhecidas e dá-se ênfase às cosmologias e aos saberes tradicionais, como integrantes das formas de apropriação do patrimônio de recursos naturais (LEFF, 2010, p. 169).

Entende-se, então, a crise ambiental como a crise do mundo real resultante do desconhecimento do conhecimento, ou seja, da concepção de mundo e do domínio da natureza que resultam em falsas certezas quanto aos limites do crescimento econômico e quanto à eficiência da racionalidade instrumental e tecnológica. Assim, Leff compreende que "o real sempre foi complexo; as estruturas dissipativas sempre existiram e são mais naturais que os processos reversíveis e em equilíbrio" (LEFF, 2010, p.206). No entanto, a complexidade é efetivamente o tecido de acontecimentos, ações, interações, retroações, determinações, acasos, que constituem o mundo fenomenal (MORIN, 1990, p. 20). 
$\mathrm{Na}$ complexidade ambiental as identidades se manifestam a partir do posicionamento do indivíduo e de um povo no mundo. Ou seja, no processo de construção de um saber que orienta estratégias de apropriação da natureza e da construção de mundos de vida diversos. Nesta configuração, o princípio da identidade ganha sentido, enquanto processo de construção social no saber. Em síntese, a partir da identidade que se coloca o diálogo de saberes, "a partir do ser constituído por sua história até o inédito, o impensado, até uma utopia enraizada no ser e no real, construída com base nos potenciais da natureza e nos sentidos da cultura" (LEFF, 2010, p.212).

O diálogo de saberes na perspectiva da racionalidade ambiental se abre à outridade, busca a compreensão do outro, negocia e encontra acordos com o outro, sem englobar as diferenças culturais em um saber de fundo universal ou traduzir o outro em termos do mesmo. A relação estabelecida com o outro, na ordem do ser e do saber, é um relação de diferença e respeito. Estabelece-se uma relação de "justiça que não se dissolve nem se resolve em um campo unitário de direitos humanos, mas no direito de ter direitos

Leff (2006) apresenta possibilidades de compreensão de diálogos de saberes a partir de Jurgen Habermas e Boaventura Santos. Na dissertação de mestrado a "Gestão compartilhada dos territórios da pesca artesanal: Fórum Delta do Jacuí (RS)” (DE PAULA, 2013) foi enfatizada a abordagem de Habermas, contudo nesse momento como pretende-se dar ênfase ao trabalho de tradução intercultural proposto por Santos $(2002,2011)$.

Boaventura de Sousa Santos et. al.- (2006) ressaltam a importância de recuperar e reconstruir as "outras versões da história e da ciência, para que "deixe de ser a história da emergência e expansão da ciência ocidental moderna e passe a abrir novos caminhos para histórias globais e multiculturais do conhecimento, superando assim o que tem sido designado por colonialidade do saber" (p.15).

Os autores atentam para a posição binária que tem sido estabelecida entre saber local/tradicional:

Na era moderna, a oposição binária entre saber local/tradicional e saber moderno/global tem sido elaborada de diferentes formas, das quais destacamos: a ciência do concreto/a ciência pura (Lévi-Strauss, 1962); o conhecimento tácito/conhecimento científico (Polanyi, 1966); o saber popular/saber universal (Hunn, 1982); o conhecimento indígena/conhecimento ocidental (Posey, 1983, 1999; Warren et al, 1995); e o conhecimento tradicional/conhecimento moderno (Huber e Pedersen, 1997). (SANTOS E MENESES, 2006, p. 26). 
Santos (2002) atenta que prevalece nessas dicotomias a concepção de que o conhecimento local é "prático, colectivo e fortemente implantado no local, refletindo as experiências exóticas". Agarwal e Nygren apud Santos (2002), aponta também para o entendimento de que o saber local consiste em um sistema "monolítico e culturalmente delimitado". Contudo, essa concepção do saber local vem sendo questionada, "ao afirmar que o saber é uma construção híbrida, exigindo uma abordagem diferente dos saberes, numa perspectiva situacional". Logo, a lógica binária inerente ao modo científico de refletir expõe uma construção do mundo que "estrutura profundamente as representações do conhecimento nos contextos onde este é produzido" (p.244). Para Santos (2002) se insere na estrutura colonial de dominação:

Nesta perspectiva, todos os conhecimentos são socialmente construídos - isto é, eles são o resultado de práticas socialmente organizadas envolvendo a mobilização de recursos materiais e intelectuais de diferentes tipos, vinculadas a contextos e situações específicos. Como consequência, o enfoque da análise deve estar centrado nos processos que legitimam a hierarquização do saber e do poder entre o conhecimento local-tradicional e o conhecimento globalcientífico. Porque o conhecimento científico tem sido definido como o paradigma do conhecimento, e o único epistemologicamente adequado, a produção do saber local consumou-se como não-saber, ou como um saber subalterno. A violência continua, pois, tão forte no hoje como no passado. Se antes era física e directa, hoje é-o muitas vezes de forma mais dramática, porque apostada na destruição e aniquilamento cultural, no epistemicídio, mesmo dentro das realidades pós-coloniais (p.244).

Tratando da dicotomia moderno/saber tradicional Santos et. al. (2006) atentam que a hierarquia deve ser questionada, pois se assumir, como faz a epistemologia crítica, que todo o conhecimento é situado, é mais adequado comparar todos os conhecimentos, inclusive o científico, em função das suas capacidades para a realização de determinadas tarefas em contextos sociais delineados por lógicas (p.43).

Ao longo dos séculos, as constelações de saberes foram desenvolvendo formas de articulação entre si e hoje, mais do que nunca, importa construir um diálogo modo verdadeiramente dialógico de engajamento permanente, articulando as estruturas do saber moderno/científico/ocidental às formações nativas/locais/tradicionais de conhecimento. O desafio é, pois, de luta contra uma monocultura do saber, não apenas na teoria, mas como uma prática constante do processo de estudo, de pesquisa-acção. Como Nandy (1999) refere, o futuro não está no retorno a velhas tradições, pois nenhuma tecnologia é neutra: cada tecnologia carrega consigo o peso do modo de ver e estar com a natureza e com os outros. O futuro encontra-se, assim, na encruzilhada dos saberes e das tecnologias (p.44). 
Boaventura Santos $(2002,2011)$ enaltece que as "concepções de desenvolvimento capitalista têm sido reproduzidas pela ciência econômica convencional e pela razão metonímica e a razão proléptica que lhe subjazem. Essas concepções assentam na ideia de crescimento infinito obtido através da sujeição progressiva das práticas e saberes à lógica mercantil” (2002, p.263). Como superação da razão metonímica (que se reivindica como única forma de racionalidade e, por isso não se propõe a descobrir outras formas de racionalidades) e a razão proléptica (que não se dispõe a pensar o futuro, porque que sabe tudo a respeito e concebe como uma superação linear, automática e definitiva do presente) propõe o exercício da Tradução Intercultural.

\begin{abstract}
A tradução é o procedimento que permite criar inteligibilidade recíproca entre as experiências do mundo, tanto as disponíveis como as possíveis, reveladas pela sociologia das ausências e a sociologia das emergências. Trata-se de um procedimento que não atribui a nenhum conjunto de experiências nem o estatuto de totalidade exclusiva nem o estatuto de parte homogénea. As experiências do mundo são vistas em momentos diferentes do trabalho de tradução como totalidades ou partes e como realidades que se não esgotam nessas totalidades ou partes. Por exemplo, ver o subalterno tanto dentro como fora da relação de subalternidade (SANTOS, 2002, p.262).
\end{abstract}

Entende-se que o trabalho da tradução incide tanto sobre saberes quanto as práticas e seus agentes. A tradução entre saberes se expressa como "hermenêutica diapótica, que consiste no esforço de interpretação entre duas ou mais culturas, com objetivo de identificar questões isomórficas entre elas e as diferentes respostas que cada cultura apresenta. $\mathrm{O}$ autor explica a hermenêutica diapótica:

\begin{abstract}
A hermenêutica diatópica parte da ideia de que todas as culturas são incompletas e, portanto, podem ser enriquecidas pelo diálogo e pelo confronto com outras culturas. Admitir a relatividade das culturas não implica adoptar sem mais o relativismo como atitude filosófica. Implica, sim, conceber o universalismo como uma particularidade ocidental cuja supremacia como ideia não reside em si mesma, mas antes na supremacia dos interesses que a sustentam. A crítica do universalismo decorre da crítica da possibilidade da teoria geral. A hermenêutica diatópica pressupõe, pelo contrário, o que designo por universalismo negativo, a ideia da impossibilidade da completude cultural. No período de transição que atravessamos, ainda dominado pela razão metonímica e pela razão proléptica, a melhor formulação para o universalismo negativo talvez seja designá-lo como uma teoria geral residual: uma teoria geral sobre a impossibilidade de uma teoria geral (p.264).
\end{abstract}

O autor destaca que esse trabalho de tradução pode ocorrer entre saberes hegemônicos e saberes não-hegemônicos, e entre diferentes saberes não-hegemônicos. "A importância deste último trabalho de tradução reside em que só através da inteligibilidade recíproca e consequente 
possibilidade de agregação entre saberes não-hegemónicos é possível construir a contrahegemonia" (SANTOS, 2002, p.265).

Já o segundo tipo de trabalho de tradução "tem lugar entre práticas sociais e seus agentes”. Como já foi destacado todas as práticas sociais envolvem conhecimentos, logo são também práticas de saber. Nesse contexto o trabalho de tradução propõe criar inteligibilidade recíproca entre formas de organização e entre objetivos de ação. Desta forma, o trabalho de tradução acontece sobre os saberes aplicados, transformados em práticas e materialidades. Esse trabalho de tradução se evidencia em situações em que os saberes que baseiam diferentes práticas são menos distintos do que as práticas em si mesmas. “É, sobretudo, o que acontece quando as práticas ocorrem no interior do mesmo universo cultural, como quando se tenta traduzir as formas de organização e os objectivos de acção de dois movimentos sociais” (p.265).

\section{Movimentos sociais}

Para estabelecer um horizonte de compreensão dos movimentos sociais, tal discussão será tomada em dois momentos. Luís Tapia (2008) discute, com base na obra "Política Salvage", as consequências sociais decorrentes do colonialismo e os limites da democracia, que resultaram na proeminência de movimento sociais na América Latina. Já Boaventura Santos (2001) faz uma análise crítica e aponta tendências dos novos movimentos sociais.

Tapia (2008) estabelece a sua leitura, a partir do Modo de Produção Capitalista, compreende os movimentos sociais no contexto latino-americano a partir do processo colonizador e da instituição das democracias. Para ele, as culturas que viveram e vivem em formas comunais de produção e governo, destinam boa parte dos seus excedentes (ele chama de a parte maldita) para relações de reciprocidade, o que forja um peculiar sistema de poder e prestígio.

En elmomento de la fiesta se juntan y articulan prácticas y necesidades de reproducción ritual del orden social y de la comunidad, el gasto improductivo y la reproducción de relaciones de prestigio, autoridad y poder en su seno. El gasto de la partemaldita sirve para la producción de la dimensión sagrada de las sociedades. La parte maldita da lugar a la dimensión de lo trascendente, aquella en la que los bienes y las personas dejan de ser cosas, simples medios para la producción y la reproducción, y pasan a ser elementos integrantes del fundamento y del fin, que desconocemos y reconocemos a la vez. La parte maldita financia el misterio de las sociedades y lo escenifica en los momentos de gasto colectivo improductivo. La partemaldita está destinada a la destrucción, en el sentido económico, y a veces en todo sentido, como en la guerra. En este consumo destructivo de excedente se suelen producir y reproducir lazos y relaciones sociales (p.26). 
Por outro lado, o excedente também constitui a base em que se instituiu a dominação, pela exclusão dos trabalhadores do usufruto do mesmo. Pode-se dizer que há soberania da comunidade quando o tempo e o consumo do excedente correspondem ao da produção. Existe soberania sobre a comunidade quando a participação no tempo e as formas de gasto do excedente são desiguais e os sujeitos de consumo não são os mesmos que os da produção. A política é considerada como o campo privilegiado da soberania porque decide a direção do consumo e os graus de inclusão ou exclusão nos momentos e formas de gastos. Para relacionar a consideração do destino da "parte amaldiçoada", no contexto boliviano, o autor apresenta o entendimento da exploração-exclusão-dominação.

A exploração-exclusão-dominação de caráter colonial, que consiste no desconhecimento e na negação da igualdade entre os princípios organizadores e de governo entre sociedades diferentes, e assim estabelecem relações de dominação entre si, a partir de pretensões de superioridade de umas sobre as outras. Soma-se a isso a "derrota político-militar, por el otro, que con el tiempo acaba volviéndose derrota cultural, esto es, introyección de la sumisión y la desvalorización del dominado". As desigualdades são então instituídas pelo poder político dominante, onde umas sociedades trabalham para as outras (p.27).

El orden colonial se apropia del excedente de las sociedades dominadas. No sólo del excedente, sino también de parte de lo destinado a la reproducción simple. De esta forma da lugar al deterioro y la contracción de estas sociedades, que se ven en el apremio de reformular los márgenes históricos y sociales de la supervivência y la reproducción. El colonialismo no sólo se apropia del excedente de los conquistados, sino que también provoca una recomposición del tiempo de trabajo y de losmárgenes de reproducción simple de las sociedades colonizada (p.27).

Para Tapia (2008) existem poderes e processos históricos que instituem desigualdades entre as sociedades que, por sua vez, reproduzem formas internas de desigualdade. $\mathrm{O}$ colonialismo implica na exclusão dos membros das sociedades dominadas de processos de governo político. O colonialismo é a instituição explícita da desigualdade, onde a exclusão política é exercida com base na suposição de desigualdade cultural, que resulta na exclusão dos processos, momentos e formas de consumo do excedente.

$\mathrm{O}$ autor entende a história da democracia para além do reconhecimento de direitos políticos e de representação, mas trata de processos de disputa pelo excedente e pela reorganização das instituições políticas e sociais para o acesso ao consumo legítimo de uma proporção do mesmo (TAPIA, 2008). 
Las democratizaciones han sido procesos de restauración —en algunos casos de institución por primera vez- de formas colectivas de gasto del excedente. Si no hay un acceso ampliado al consumo del excedente se puede sospechar que en rigor no hay democratización. La institucionalización de la representación y separación de poderes, por ejemplo, puede ser parte significativa en el desarrollo de un estado de derecho pero no son necesariamente democratizaciones si no hay un consumo más colectivizado del excedente. La historia de las democratizaciones consiste en luchas por conquistar márgenes más amplios de igualdad política, que a la vez se proyecta para atacar las desigualdades socioeconómicas. La condición imaginaria de la igualdad política permite presionar por la redistribución del excedente económico y modificar algunos patrones de consumo del excedente y de reproducción social, expresados en la vida de cada individuo. (p.29).

Frente a manutenção desse contexto de exploração-exclusão-dominação, na democracia, Tapia (2008) destaca o papel de reivindicação assumido pelos movimentos sociais. O movimento social expõe o campo do conflito social, que é um lugar não-político (partidário), uma vez que não é um espaço delimitado, nem possui instituições regulares para seu tratamento. Aparece em diferentes lugares, mas começa a se mover através da sociedade e de outros espaços políticos. Na medida em que o sistema do partido não é o lugar da representação, da deliberação e da solução dos principais problemas e demandas do país, há quase permanentemente um espaço político paralelo, mutável e descontínuo, que é constituído e reconstituído de acordo com os conflitos e as lutas sociais que surgem e na função dos assuntos sociais e políticos que se constituem como demandantes e reformadores (p.66).

Este espaço que forma movimentos sociais é um campo de forças mais que um lugar da política institucional. Embora haja mobilização de forças, demandas e projetos, lugares ocupados e recorre-se diversas ações, eles tendem a não se estabilizar e se identificar com um lugar de política delimitado e institucionalizado.

En este sentido, el campo de fuerzas configurado por los movimientos sociales es un no lugar político; es una zona de tránsito del conflicto social, es también como el viento que pasa y puede arrancar algunas cosas de raíz y mover otras de su lugar. Los movimientos sociales instauran la fluidez de la sociedad civil y la problematización del orden político. Es la parte de la sociedad que hace las preguntas y hace la crítica de la irracionalidad de algunas formas y principios de organización social y de distribución. Los movimientos sociales son la forma y sujeto de reflexión conflictiva de las sociedades sobre sí mismas (p.67).

Dalton e Kuechler apud Boaventura Santos (2001) parte da definição genérica de novos movimentos sociais com um setor significativo da população que desenvolve e define interesses incompatíveis com a atual ordem política e social e que prossegue através de meios não institucionalizados, invocando o uso da força física ou coerção. Destaca que na América Latina 
os movimentos populares ou novos "movimentos populares" (para diferenciar sua base social característica dos movimentos nos países centrais - a nova classe média) são muito heterogêneos (p.177).

O autor apresenta alguns dos novos fatores que os movimentos sociais introduziram na relação entre regulação/emancipação e subjetividade/cidadania, frisando que tais fatores não são comuns a todos os novos movimentos sociais, em todas as regiões do globo.

La novedad más grande de los NMSs reside en que constituyen tanto una crítica de la regulación social capitalista, como una crítica de la emancipación social socialista tal como fue definida por el marxismo. Al identificar nuevas formas de opresión que sobrepasan las relaciones de producción, y ni siquiera son específicas de ellas, como son la guerra, la polución, el machismo, el racismo o el productivismo; y al abogar por un nuevo paradigma social, menos basado en la riqueza y en el bienestar material del que, en la cultura y en la calidad de vida, denuncian los NMSs, con una radicalidad sin precedentes, los excesos de regulación de la modernidad. Tales excesos alcanzan no sólo el modo como se trabaja y produce, sino también el modo como se descansa y vive; la pobreza y las asimetrías de las relaciones sociales son la otra fase de la alienación y del desequilibrio interior de los individuos; y finalmente, esas formas de opresión no alcanzan específicamente a una clase social y sí a grupos sociales transclasistas o incluso a la sociedad en su todo temente también rural, el movimiento feminista, el movimiento ecológico, el movimiento pacifista en etapa de org anización, sectores de movimientos de jóvenes y otros" (1987: 4 l) (p.178).

Neste momento destaca-se a denúncia às novas formas de opressão, que implica na crítica às teorias e movimentos emancipatórios que as omitiram ou negligenciaram. Assim, estabelece crítica ao marxismo e ao movimento tradicional dos trabalhadores, bem como a crítica ao chamado "socialismo real" O que é visto por estes como um fator de emancipação (bem-estar material, desenvolvimento tecnológico das forças produtivas) é transformado nos NMSs em um fator de regulação. "Por otro lado, porque las nuevas formas de opresión se revelan discursivamente en los procesos sociales donde se forja la identidad de las víctimas, no hay una preconstitución estructural de los grupos y movimientos de emancipación, por lo que el movimiento obrero y la clase obrera no tienen una posición privilegiada en los procesos sociales de emancipació”" (SANTOS, 2001, p.178).

Santos (2001) entende como inegável que sem a experiência histórica de dominação na esfera da produção, hoje não seria social e culturalmente possível pensar sobre a reprodução social em termos de relações de dominação. Isso se evidencia quando se observa que países com NMS fortes tendem a ser países onde os movimentos sociais antigos eram, e talvez ainda sejam fortes. Nesse sentido a América Latina se destaca de forma proeminente. 
Santos (2001) entende que a globalização no campo da regulação também é um processo de localização. Logo as formas de intersubjetividade, as relações sociais de reprodução e as relações sociais na produção são muito mais concretas e imediatas do que admitir somente as relações sociais de produção. Para isso tem que se considerar que além da produção em si, também se evidenciam experiências de relações entre pessoas, entre grupos, entre pessoas ou grupos e o ar, rios, florestas ou animais, entre a vida e a morte (p. 179).

Ressalta que a emancipação pela qual eles lutam é sobretudo, pessoal, social e cultural. Essas lutas são traduzidas por formas organizacionais (democracia participativa), de forma distinção às que precederam as lutas pela cidadania (democracia representativa). Ao contrário do que ocorreu com a "dupla marshalliana cidadania-classe social", no período do capitalismo organizado, os protagonistas das lutas dos novos movimentos sociais não são as classes sociais, são grupos sociais, com contornos mais ou menos definidos em termos de interesses coletivos, às vezes muito localizados, mas potencialmente universalizados (p.180).

Las formas de opresión y de exclusión contra las cuales luchan no pueden, en general, ser abolidas con la mera concesión de derechos, como es típico de la ciudadanía; exigen una reconversión global de los procesos de socialización y de inculcación cultural y de los modelos de desarrollo, o exigen transformaciones concretas, inmediatas y locales (por ejemplo, el cierre de una central nuclear, la construcción de una guardería infantil o de una escuela, la prohibición de publicidad violenta en la televisión), exigencias que, en ambos casos, van más allá de la mera concesión de derechos abstractos y universales.

Para Santos (2001) as principais críticas aos novos movimentos sociais decorrem da afirmação da subjetividade sobre a cidadania. Para esses autores os temas pautados já eram tratados pelos antigos movimentos sociais. Ainda entendem que o impacto pretendido pelos NMSs é, em última análise, político e sua lógica prolonga a cidadania, que orientou os movimentos sociais do passado. Também apontam que a distância entre NMSs e o Estado é mais aparente do que real, uma vez que na relação global-local há o intermédio do Estado. “Además, la prueba de eso mismo es que no es raro que los NMSs jueguen el juego de la democracia representativa, aunque sea por el lobbyingy por la vía extraparlamentaria; y entran en alianzas más o menos oficiales con sindicatos y partidos, cuando ellos mismos no se transforman en partidos" (p.180).

Santos retoma Fernando Calderón e Elizabeth Jelin quando diz que na América Latina não há movimentos sociais puros ou claramente definidos, dada a multidimensionalidade, não só das relações sociais, mas também dos próprios sentidos da ação coletiva. Así, los movimientos sociales se nutren con innumerables energías que incluyen, en su constitución, 
desde formas orgánicas de acción social por el control del sistema político y cultural hasta modos de transformación y participación cotidiana de auto-reproducción societaria (en Ponte, 1990: 281) (p.180)

Para Santos (2001) a novidade dos NMS não está na rejeição da política, mas, pelo contrário, no alargamento da política além do quadro liberal da distinção entre Estado e sociedade civil. Os NMS partem do pressuposto de que as contradições e oscilações periódicas entre o princípio do Estado e o princípio de mercado são mais evidentes do que reais, na medida em que o trânsito histórico do capitalismo é feito de uma interpenetração cada vez maior entre os dois princípios. Santos (2001) aponta assim a tendência de formação de uma nova cultura política:

La idea de la obligación política horizontal entre ciudadanos y la idea de la participación y de la solidaridad concretas en la formulación de la voluntad general, son las únicas susceptibles de fundar una nueva cultura política y, en última instancia, una nueva calidad de vida personal y colectiva basadas en la autonomía y en el autogobierno, en la descentralización y en la democracia participativa, en el cooperativismo y en la producción socialmente útil. La politización de lo social, de lo cultural, e incluso de lo personal, abre un inmenso campo para el ejercicio de la ciudadanía y revela, al mismo tiempo, las limitaciones de la ciudadanía de extracción liberal, incluso de la ciudadanía social, circunscrita al marco del estado y de lo político por él constituído (p.181).

Em violação da racionalidade burocrática de Max Weber ou da "lei de ferro da oligarquia" de Robert Michels, Santos (2001) identifica a preferência dos NMSs por estruturas descentralizadas, não hierárquicas e fluida. Daí também a preferência pela ação política nãoinstitucional, fora do compromisso neocorporativista, direcionado à opinião pública, com uso vigoroso de meios de comunicação social, quase sempre envolvendo atividades de protesto e confiando na mobilização dos recursos que eles fornecem. Dialeticamente, essa novidade nas estruturas organizacionais e no estilo de ação política é a ligação entre os NMS e os velhos movimentos sociais, que mantém e aprofundam a luta pela cidadania. Desta forma Santos (2001) não considera correto presumir o desinteresse nas questões da cidadania (p.182).

Por fim, Santos (2001) ressalta que devido à grande diversidade dos NMSs, é impossível falar de um padrão único de relações entre a democracia representativa (quando isso existe, porque na América Latina a luta dos NMS tem ocorrido frequentemente para alcançar a referida democracia) e a democracia participativa. 
No me parece en sí mismo negativo el hecho de que esas relaciones, cualesquiera que sean, siempre se hayan caracterizado por la tensión y por la difícil convivência entre las dos formas de democracia, toda vez que es de esa tensión que se han liberado muchas veces las energías emancipatorias necesarias para la ampliación y la redefinición del campo político. Hay que agregar que, incluso cuando las formas de institucionalización son más tenues, la discontinuidad de los NMSs puede ser más aparente que real, pues, como afirma Paulo Krischke, es necesario tener en cuenta las contribuciones positivas de los movimientos "tanto para la memoria colectiva de la sociedad, como para la reforma de las instituciones" (1987: 287 (pp. 181-182).

\subsection{Caminho Metodológico}

Compreendendo que na complexidade não há uma totalidade, mas conformação de quase-totalidades (MORIN, 1990), esse Capítulo constitui a quase totalidade da pesquisa. Assim, busca-se articular diferentes compreensões e promover ressignificações. Nesse sentido o processo dialógico se dá entre conceitos e métodos, e destes com apreensões do movimento social. A recursividade se expressa, pois na medida em que as compreensões são geradas, o processo vai sendo dirigido. Desta forma, o próprio caminho da pesquisa constitui resultado da busca pelas Geografias da Pesca. Nesse sentido, as compreensões aqui apresentadas se devem ao caminho adotado pelo pesquisador, a partir das questões que o nortearam, mas também de novas inquietações que foram se evidenciando como relevantes. Esse Capítulo expõe um movimento de ir e vir, da parte para o todo e do todo para a parte, o que evidencia o principio hologramático. Desta forma, a partir das análises realizadas em outros Capítulos que permitiram compreender a expressão da parte, dirige-se ao todo, mas sempre reconhecendo as partes que o integram. Desta forma a discussão sobre a Geografia e a pesca artesanal brasileira, é substantivada por diversos contextos de pesquisa em Geografia, e de diversas experiências vividas pelas comunidades de pescadores. Da mesma forma entende-se que o todo deve voltar a parte seja expondo tendências à Geografia brasileira, seja provocando sobre os limites e possibilidades da gestão da pesca.

\section{Elaboração de Gráficos}

\section{Dissertações e Teses}

Com base na análise das dissertações e teses, apresentada no Capítulo I (figura 3) elaborou-se gráficos de composição (linhas e colunas), para evidenciar a relação entre: teorias e problemáticas, e métodos e problemáticas. 


\section{Questionários respondidos pelos geógrafos}

Retomou-se os questionários respondidos pelos geógrafos, cujo procedimento de análise está expresso no Capítulo I (figura 1) para destacar as respostas referentes ao interesse dos pesquisadores de integrarem a Rede de Geografias da Pesca, e atividades que propõem para a referida rede. Os resultados foram representados por meio de gráficos de setor.

\section{Análise de Conteúdo}

\section{Análise de Documentos}

As análises de conteúdo realizadas para este Capítulo foram estabelecidas sobre os seguintes documentos:

- Diretrizes para a regulamentação de Acordos de Pesca: Instrução Normativa IBAMA $\mathrm{N}^{\circ} 29,31$ de dezembro de 2002 (BRASIL, 2002).

- Sistema de Gestão Compartilhada do Uso Sustentável dos Recursos Pesqueiros: Portaria Interministerial MPA/MMA N² 2, de 13 de novembro de 2009 (BRASIL, 2009A) e Portaria Interministerial MPA/MMA n ${ }^{\circ}$ 5, de $1^{\circ}$ de setembro de 2015 (BRASIL, 2015D).

- Sistema Nacional de Unidades de Conservação (SNUC): Lei No 9.985, de 18 de julho de 2000 (BRASIL, 2000).

- Termo de Autorização de Uso Sustentável: Portaria No 89, de 15 de abril de 2010 (BRASIL, 2010A).

- Projeto de Lei de Iniciativa Popular "Regularização do Território das Tradicionais Pesqueiras" (MPP, 2012).

A exploração material foi realizada por meio do software Nvivo®, onde verificou-se a frequência de determinados termos e construiu-se nuvens de palavras. Buscou-se evidenciar a concepção de ambiente e de território presente em tais documentos.

\section{Dissertações e Teses}

O processo analítico está expresso no Capítulo II (figura 46), onde identificou-se nas dissertações e teses a ocorrência Impactos Ambientais, Disputas no Território e Conflitos por Território. A partir destas propostas serão discutidos conceitos associados aos territórios tradicionais das comunidades de pescadores. 


\section{Denúncias do Movimento Social}

Resgatou-se o processo de análise expresso do Capítulo III (figura 57), o qual expos as faces da modernização sobre os territórios das comunidades de pescadores: degradação, sobreexploração e restrição do acesso, e expropriação da terra. Assim, se estabelece o diálogo entre Geografia (dissertações e teses) e movimento social, para destacar as visibilidades geradas pelas Geografias das Emergências.

\section{Representações cartográficas}

Sistematização e georreferenciamento dos resultados:

- Relação entre layers das áreas de estudo e dos programas de pós-graduação

No Banco de Dados de dissertações e teses foram identificados os programas de pósgraduação (PPGs), onde os trabalhos foram realizados. Todos os programas foram Georreferenciados e a camada (layer) foi ligada à tabela do banco de dados formando o shapefile de trabalhos a partir do PPG. Também no Banco de Dados de dissertações e teses foram identificadas as áreas de estudo. Essas foram Georreferenciadas e o layer foi ligado à tabela do banco de dados formando o shapefile de trabalhos a partir da área de estudo.

- Relação entre layers de áreas de estudo e de instituições em que os geógrafos estão vinculados

No Banco de Dados de dissertações e teses foram identificados os geógrafos, que pesquisam a pesca artesanal, os quais foram citados em cada trabalho. Essa informação, que está na tabela, integrou o shapefile de trabalhos a partir da área de estudo. Já no Banco de Dados dos questionários respondidos pelos geógrafos que pesquisam a pesca artesanal foi identificada a instituição a que estão atualmente vinculados. Essas foram Georreferenciadas e o layer foi ligado à tabela do banco de dados originando o shapefile da instituição que geógrafo está vinculado.

Para a compreensão da relação regional, a generalização cartográfica foi baseada no shapefile do IBGE - limites regionais.

\section{Construção de mapas temáticos}

No mapa que expõe o fluxo do programa de pós-graduação para as áreas de estudo, a simbologia (setas) parte dos pontos do layer dos de PPGs para os pontos do layer da área de estudo. Para fins didáticos a generalização foi realizada na escala regional. Destaca-se que 
também se apresenta a distinção na simbologia quanto ao período em que as pesquisas foram realizadas.

Quanto ao mapa que expõe o fluxo das áreas de estudo para a instituição a que o pesquisador está atualmente vinculado, a simbologia (setas) parte dos pontos do layer da área de estudo para os pontos do layer das instituições dos geógrafos. Didaticamente, também, utilizou-se a generalização em escala regional.

\subsection{Da pesquisa do Geógrafo à Rede de Geógrafos: desafios para a construção de Geografias da Pesca}

Retomando o Capítulo I, onde identificou-se as principais abordagens sobre a pesca artesanal na Geografia brasileira, analisando e representando por meio de mapas temáticos o conteúdo das discussões intrínsecas às dissertações e teses, e apresentou-se os principais envolvidos (geógrafos, grupos de pesquisa e programas de pós-graduação), nesse momento serão discutidas algumas lacunas e perspectivas presentes no estágio atual das Geografias da Pesca Artesanal Brasileira, onde estarão destacadas possíveis articulações entre geógrafos que pesquisam a pesca e possibilidade de trabalho em rede.

A reflexão em um primeiro momento avalia limites e possibilidades inerentes ao estágio atual da Geografia brasileira, onde se evidencia a institucionalização da pós-graduação. Esse processo na tese evidencia a abertura para a pesquisa, incluindo novos sujeitos sociais (no caso pescadores e pesquisadores), que se refletiu na diversidade de abordagens. Além disso, será enfatizado o processo de (re)construção do pensamento geográfico crítico, que reflete o momento histórico atual. Isso se relaciona com o procedimento "necessário" de abertura da Geografia para outros saberes e da complexificação da análise para corresponder à complexidade do real (contexto de crise ambiental e territorial), por isso a discussão integra noções de saber ambiental (e territorial) e complexidade ambiental.

A análise dos trabalhos evidenciou convergências dos pontos de vista teóricos e metodológicos. Isso proporcionou, inclusive, propor um processo analítico que expõe a relação entre território e ambiente. Contudo, ainda se considera fundamental compreender dentro da diversidade apresentada, quais os rumos que vem tomando essas Geografias da Pesca. Ressaltase que prevalece a compreensão que frente a diversidade de possibilidades há uma postura ética comum, que insere esses trabalhos no pensamento geográfico crítico. Contudo, dentro dessa diversidade serão apontadas tendências de relação entre problemáticas e conceitos, 
problemáticas e métodos, conceitos e métodos. Ainda se evidenciará a tendência e necessidade de abertura teórica e metodológica para sujeitos sociais que até então não recebiam destaque, como as comunidades tradicionais de pescadores, reconhecendo os seus saberes. Assim, a Geografia abre o campo de discussão para as relações assimétricas de poder e contribui na construção de um cosmopolitismo subalterno.

Chega-se então à avaliação dos sujeitos com quem a Geografia brasileira dialoga. Para isso destaca-se a importância e as possibilidades relativas aos diálogos de saberes, principalmente no âmbito das comunidades. Contudo, a proposta da tese também evidencia a lacuna de diálogo com movimentos sociais (de âmbito nacional), que apresentam importantes questões à Geografia brasileira. Desta forma, destaca-se a importância do diálogo com os pescadores e seus grupos institucionalizados ou não. Evidenciar tais sujeitos na pesquisa geográfica, constitui em ação dos geógrafos na superação de ausências e promoção de emergências.

Na sequência destaca-se elementos distinguem e unem as dissertações e teses analisadas entre si, e com as demais abordagens da Geografia brasileira. Isso permite inferir possibilidades de diálogo no âmbito das Geografias da Pesca, da Geografia (como um todo), e das Ciências Humanas. Para enfatizar limites e possibilidades no âmbito das Geografias da Pesca, destacouse a relação entre trabalhos, no que diz respeito às citações. Quando ao diálogo na Geografia, destaca-se contextos comuns entre perspectivas de pesquisa como: análise crítica, visibilidade dos sujeitos, diálogos de saberes, relações de poder e abertura para movimentos sociais. No campo das humanidades os encontros se dão na busca por respostas às problemáticas do tempo presente, e na constituição de uma Racionalidade contra-hegemônica, que pode estar vinculada à Racionalidade Ambiental e às Epistemologias do Sul.

\subsubsection{Limites e possibilidades para a Geografia, no tempo presente}

Andrade (1999) enaltece que a Geografia brasileira não está efetivamente construída e que o seu processo de construção implica na permanente reconstrução na medida em que novos problemas se evidenciam com a transformação da sociedade. Assim, essa leitura sobre a Geografia no tempo presente está intrinsecamente relacionada com as formas de fazer Geografia (epistemológica e metodologicamente) e com o movimento da sociedade.

Quanto as formas de fazer Geografia destaca-se a diversidade de teorias e métodos (SPÓSITO, et. al., 2016). Contudo, deve-se considerar as consequências da fragmentação, e em certa medida a perda da "ligação" fundadora da Geografia, que é a relação sociedade/natureza 
(SUERTEGARAY, 2017). No âmbito das Geografias da Pesca, foi possível observar que há pluralidade de abordagens, mas que há um eixo comum, que relaciona questões ambientais e territoriais. Nem sempre essa discussão é o cerne das pesquisas, frequentemente o foco está em contextos mais específicos, mas situam a Geografia que se faz.

Diante das inúmeras compreensões sobre o pensamento Geográfico Brasileiro, ainda entende-se, que no âmbito das pesquisas analisadas, predomina a leitura crítica. Como enfatiza Moraes (2005) existem diversas possibilidades nessa perspectiva, que não se resumem ao emprego do "marxismo". Contudo, trata-se de uma Geografia que enaltece os sujeitos sociais "pescadores e pescadoras artesanais", seus grupos "comunidades, colônias, associações, movimento social" em situação de tensão (impactos, disputas e conflitos). Nesse sentido, é fundamental pensar o culturana na perspectiva crítica, pois ela constitui o argumento fundamental na luta pelo direito de permanecer no território, entre outros.

Nesse sentido, as Geografias da Pesca Artesanal Brasileira expõem possibilidades de elaborações para a explicação do processo de apropriação do Espaço Geográfico pelos sujeitos sociais. Isso expõe a significação que os grupos, através da cultura, atribuem ao espaço, bem como usos que permitem que tal grupo se reproduza socialmente. As tensões ocorrem quando o espaço passa a interessar a outros atores, que suprimem a fase das significações e só o veem como possibilidade de uso e dominação. Esses atores, muitas vezes, estão inseridos em lógicas de produção e informação que não correspondem a dinâmica do local, e encontram frequentemente no Estado apoio para se impor. Desta forma, os impactos conflitos e disputas se evidenciam e deixam marcas no território. Esse movimento nem sempre é pesquisado em sua globalidade, mas os autores abordam determinado parte desse processo de luta dos sujeitos sociais. Contudo, entende-se que mesmo os trabalhos que estão interessados nos modos de viver das comunidades - ou cultura -, são realizados na perpectiva da ameaça eminente de ruptura deste frente ao avanço de outras lógicas de uso, que geram exploração, exclusão e dominação.

Andrade (1999) também ressalta que o processo de institucionalização da Geografia brasileira e os rumos dos pensamento geográfico estão muito vinculados aos momentos históricos. Mas o que o momento histórico atual apresenta à Geografia Brasileira? Do ponto de vista institucional, entende-se que trata-se do período de expansão e consolidação da pósgraduação em Geografia. Destaca-se que a intensificação desse processo se deve a políticas de Estado, especificamente a partir do ano de 2005. Ressalta-se que esse contexto foi mais intenso no período em que o Partido dos Trabalhadores (PT) assume a Presidência da República (20032016). 
O processo de expansão da pós-graduação em Geografia é de grande importância na compreensão da pesquisa em Geografia no tempo presente. Esse suporte histórico/institucional possibilita compreender os contextos em que são estabelecidas Geografias da pesca artesanal brasileira. Pois se de um lado inserem-se atores e condições sociais que estavam invisibilizados nas análises, de outro lado a expansão da pós-graduação abre a possibilidade para outros sujeitos se inserirem como pesquisadores e, assim, apresentarem o Brasil a partir da análise de processos em que estão implicados.

Com base no mapa (figura 65) será apresentada a relação entre programas de pósgraduação, onde as pesquisas foram realizadas e áreas de estudo, por região e período.

\section{GEOGRAFIAS DA PESCA ARTESANAL BRASILEIRA:}

Relação entre Regiões dos PPGs e Áreas de Pesquisa (1982-2015)

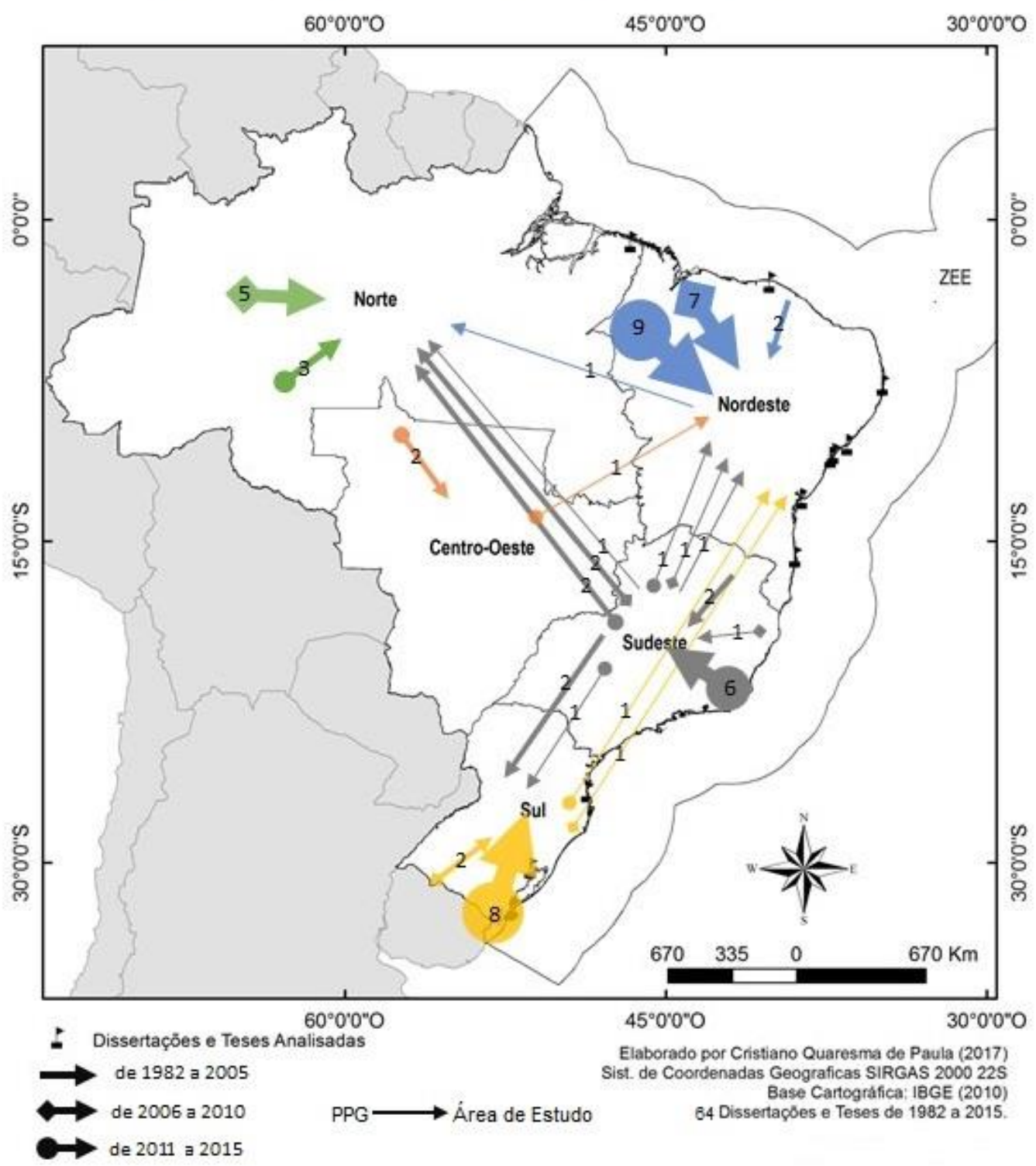


Figura 65: Mapa de Relação entre Programas de Pós-Graduação e Áreas de Estudo, por Região e Período.

Fonte: Elaborado por De Paula (2018).

Em um primeiro momento (até 2005) se observa que poucos programas de pósgraduação (4) realizam tais pesquisas e que os mesmos estão situados prioritariamente na região Sudeste, onde destaca-se o Programa de Pós-Graduação em Geografia Humana da USP. Contudo, se forem analisadas as áreas de pesquisa, se observa que as setas do Sudestes se direcionam para Sudeste, Nordeste, Norte e Sul; e do Nordeste para Nordeste e Norte. Sendo assim, se observa que a área de estudo não está vinculada ao local do curso de pós-graduação.

Em um segundo momento (de 2006 a 2010) são 14 programas de pós-graduação envolvidos nessas pesquisas, em quantas regiões brasileiras (a região Centro-Oeste ainda não está contemplada). Nesse período vai se observar um salto em pesquisas que abordam áreas de estudos das regiões Nordeste e Norte, a sendo a maioria realizada por programas da própria região. Ressalta-se que esses programas, do Norte e Nordeste, não realizam pesquisas em outras regiões. Um comportamento distinto se observa nos programas do Sudeste e Sul. A região Sudeste neste período tem áreas de estudos mais fora do que na própria região (setas voltadas para Norte e Nordeste).

Em um terceiro momento (de 2010-2015) são 24 programas de pós-graduação da Geografia envolvidos e o comportamento das regiões Norte e Nordeste se mantêm, onde as pesquisas em pesca são realizadas em áreas de estudo no âmbito da própria região. Na região Sudeste, contudo, além de continuarem pesquisando em outras regiões, há aumento de áreas de estudo na própria região. Na região Sul, a dinâmica é intermediária com o aumento significativo de pesquisas nos programas em áreas de estudo da região, e mantém, mesmo que em número reduzido, pesquisa com área de estudo no Nordeste. Nesse período iniciam as pesquisas realizadas na região Centro-Oeste, que são realizadas pelos programas da própria região, contudo há caso de área de estudo na região Nordeste.

Nesse contexto é fundamental destacar:

Aumento significativo de pesquisas na Geografia sobre pesca artesanal nas regiões Nordeste e Norte, realizadas por programas da própria região. Isso está muito relacionado aos Planos Nacionais de Pós-Graduação (2005-2010/2011-2020) que permitiu o avanço da pósgraduação e, desta forma, a visibilidade de áreas e situações de pesquisa até então não visibilizadas. Observa-se também um maior envolvimento entre pesquisadores e contextos de pesquisa. 
Destaca-se a particularidade das pesquisas em pós-graduação na região Sudeste, que abordam a pesca em áreas de estudo de outras regiões (Nordeste e Norte), respectivamente. Em um primeiro momento as pesquisas nesses programas acontecem, prioritariamente, fora da região Sudeste, mas atualmente cresceram dentro da região e se mantém ocorrendo em outras regiões. Nesse contexto, mais do que pesquisadores externos ao contexto de pesquisa, se observa o deslocamento de pesquisadores de outras regiões para o Sudeste, que até os anos 1990/2000 concentrava os cursos, (MENDONÇA, 2005; SUERTEGARAY, 2007), mas que mantém a área de estudo da região de origem.

Em todas as regiões crescem o número de pesquisas desenvolvidas por programas de pós-graduação da região, sobre áreas de estudo da própria região. Para pensar na possibilidade de trabalhos em rede, é fundamental atentar para o potencial de diálogo dentro das próprias regiões, a partir de problemáticas comuns.

Cabe ainda destacar a influência do momento histórico sobre as problemáticas e abordagens promovidas pela Geografia. Se a Revolução de 1930 favoreceu a Geografia Tradicional, a Ditadura Militar promoveu a Geografia Quantitativa e a Abertura Democrática favoreceu a Geografia Crítica (ANDRADE, 1999), compreende-se que esse ciclo de governo de esquerda também provocou mudanças no pensamento Geográfico brasileiro. Isso se deve tanto a distribuição geográfica dos programas de pós-graduação, quanto a pluralidade de problemáticas e abordagens.

Nesse período foram sansionadas leis que sucitaram importantes debates na Geografia como a Lei Maria da Penha (2006) e o Estatuto de Igualdade Racial (2010). No âmbito da pesca destaca-se a Lei de Consessão de Seguro-Defeso aos Pescadores Artesanais (2003). Por outro lado, dentro do contexto político neoliberal, foram instituidas leis que também provoracam debates e críticas no meio acadêmico como o Novo Código Florestal (2012).

Cabe enaltecer a emergência de novos movimentos sociais (SANTOS, 2001), muitos deles relacionados a antigos movimentos sociais, nesse período, que também trazem a tona problemáticas de grupos até então excluídos e insivilizados, Destaca-se a criação do Movimento dos Pescadores e Pescadoras Artesanais em 2009, muito relacionado com Conselho Pastoral da Pesca, Comissão Pastoral da Terra, Liga Campesina e Movimento dos Trabalhadores Rurais Sem Terra - MST. Na pesca outros movimentos em escala local e regional são criados.

Além disso há, por parte de políticas do próprio Estado, a promoção de Associações e Cooperativas de Pescadores Artesanais - fomentadas no Governo Luis Inácio Lula da Silva a partir da criação do Ministério da Pesca e Aquicultura - MPA, em 2003. 
Nesse sentido, se entende que o próprio contexto político incitou à Geografia. Diante das questões apresentadas pela sociedade, em movimento, esse campo do conhecimento elaborou meios teóricos e metodógicos para estabeler respostas. Assim, a Geografia brasileira abre espaço para a inserção de novos sujeitos sociais, como pescadores artesanais que até então estavam invisibilizados na pesquisa Geográfica.

A visibilidade desses novos sujeitos acompanha também um movimento de renovação que vai para além da Geografia brasileira. Este decorre da eminencia de uma crise ambiental planetária, que aponta para os limites do conhecimento ciêntífico. Nesse sentido, a visibilidade desses sujeitos, entendidos como comunidades tradicionais, assim como a dos povos originários, também decorre de um movimento de contestação que tem sido promovido no âmbito das ciências humanas.

Nessa perspectiva a visibilidade dos pescadores artesanais, enquanto comunidades tradicionais também se deve a compreensão de que os mesmos detém saberes ambientais fundamentais na manutenção dos ecossistemas (LEFF, 2010). Tal abertura epistemológica tem provocado a ciência para a sua complexificação, reconhecendo que o conhecimento ciêntíficos é cercado por incertezas, logo deve-se partir do pressuposto do desconhecimento do conhecimento (MORIN, 1990).

Frente aos limites do conhecimento científico, principalmente daqueles produzidos dentro de lógicas assimétricas de poder e dominação, tem sido pomovidas iniciativas como a constituição de epistemologias contra-hegemônicas (SANTOS, 2007), e discussões a respeito da colonialidade do saber (QUIJANO, 2005). Assim, discute-se a promoção de outras racionalidades (LEFF, 2006). Percebe-se que essas discussões que são contemporâneas também tem influênciado as abordagens das Geografias da Pesca.

\subsubsection{Tendências de diálogos entre teorias e métodos}

Dentro da diversidade de problemáticas e abordagens, na perspectiva crítica da Geografia, como enaltece Moraes (2005), há a unidade no que se refere à postura combativa frente a realidades espaciais contraditórias e injustas. Isso perpassa a visão de ciência, bem como da práxis, o que se evidencia em um discurso geográfico evidentemente político. Silva (2017) destaca a necessidade de pensar o fazer geográfico no tempo presente, identificando novas possibilidades teóricas, metodológicas e epistemológicas e repensando teorias sobre os sujeitos sociais e suas geograficidades. 
Esse discurso geográfico, no âmbito das Geografias da Pesca, apresenta possibilidades na perspectiva teórica e metodológica adotada. Com base no gráfico 8, serão discutidas tendências quanto à relação entre as principais problemáticas e principais abordagens teóricas. A espacialização de tais teorias e problemáticas foi apresentada no Capítulo I, onde se evidenciou que os principais conceitos adotados são "território", "espaço" e "ambiente" e as principais problemáticas são "resistência das comunidades à modernização", "gestão da pesca" e "modo de viver".

Gráfico 8: Relação entre principais problemáticas e principais abordagens conceituais

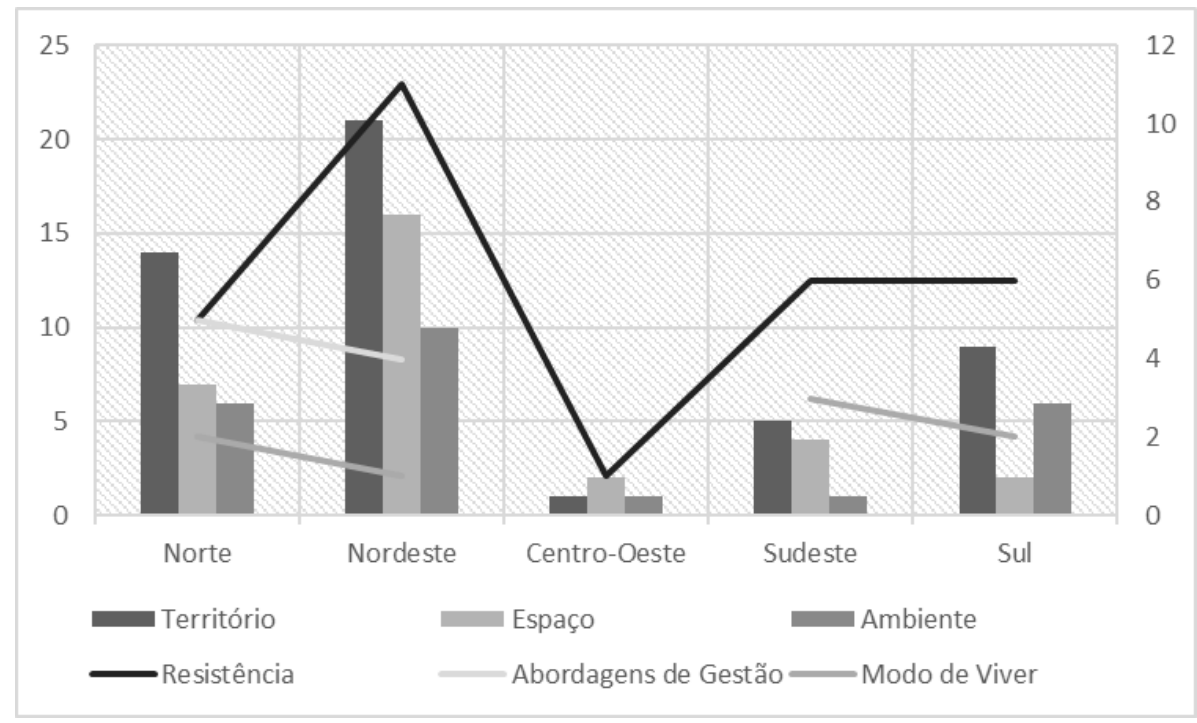

Fonte: Elaborado por De Paula (2018)

É importante destacar que tais problemáticas não estão isoladas, mas buscou-se distingui-las para compreendê-las melhor. Contudo, pressupõe-se que elas estão em relação na complexidade do real. Sendo assim, os contextos de resistências muitas vezes são influenciados pela gestão, bem como encontram sustentação no modo de viver tradicional. Da mesma forma a gestão, frequentemente, é questionada diante de contextos de resistência, bem como provoca a apresentar alternativas, assim como deve considerar as particularidades dos modos de viver. Os modos de viver também se evidenciam em situações de resistência e contrastam com encaminhamentos da gestão. Destacaram-se essas entre as inúmeras possibilidades de relação entre tais problemáticas.

Contudo, diante do processo recente de institucionalização da Geografia, por meio da expansão e consolidação da pós-graduação, é interessante compreender a relação entre problemáticas e abordagens conceituais, entre regiões brasileiras. Destaca-se que em todas as 
regiões há predominância das abordagens sobre a resistência das comunidades, assim como há destaque no emprego do conceito de território, em suas diversas abordagens. Sendo assim, há uma forte tendência de compreender nas Geografias da Pesca os processos de resistência enfrentados pelos pescadores artesanais, frente à modernização que avança sobre seu território tradicional.

Em relação às abordagens sobre problemáticas relativas à gestão ambiental, destaca-se que as mesmas também se relacionam com a questão territorial. Tais problemáticas se evidenciam na região Norte, onde alguns trabalhos abordam os Acordos de Pesca como possibilidade de gestão do ambiente com base no território e na região Nordeste onde nessa mesma perspectiva se apresenta contextos de gestão com base em Reservas Extrativistas (RESEX). Ambas as abordagens têm a dimensão territorial acentuada e relacionada com a questão ambiental. Nessas regiões também há evidência de problemáticas relativas ao modo de viver, assim como nas regiões Sudeste e Sul, que são tratadas tanto na perspectiva do território, quando sobre relações ambientais. Isso tem provocado a pensar a cultura de forma associada à natureza, em abordagens mais híbridas, como propõe Latour (1994).

Como foi frisado no Capítulo I, as abordagens de espaço também são recorrentes nas regiões, mas apresentam maior diversidade de concepções. Frequentemente, são abordados na perspectiva do espaço geográfico, mas também servem para discussões em campos mais específicos como a produção do espaço urbano e agrário. É comum a discussão sobre o espaço geográfico preceder uma abordagem de território. Sendo assim, se compreende o espaço geográfico como plano de fundo das discussões, onde é operacionalizado por meio dos conceitos de território e ambiente.

Nessa perspectiva de análise é importante destacar que as resistências das comunidades expõem situações de tensão, onde os sujeitos sociais enfrentam o avanço do capital sobre seus territórios. Esse campo conflitivo situa tais pesquisas na perspectiva crítica, na medida em que se contrapõe ao discurso dominante que rotula tais comunidades como obstáculos para a realização do desenvolvimento econômico. Tal disputa também se dá no âmbito acadêmico, uma vez que o reconhecimento de que tais comunidades se apropriam de territórios, vem rompendo com interpretações clássicas do território e da política, que se restringem ao Estado. Assim, também no âmbito científico há disputas, muitas vezes com a desqualificação do discurso do outro. Entende-se que ambas as contribuições são importantes (o território do Estado e o território das comunidades), contudo, a concepção uniescalar de território, nas 
pesquisas sobre comunidades tradicionais, tem promovido invisibilidades de diversos sujeitos sociais.

Se observa que, cada vez mais, as abordagens de território que são empregadas nos trabalhos que adotam a perspectiva relacional, como propõe Raffestin (1993, 1986B). Assim, interessa tratar a resistência das comunidades frente às relações assimétricas de dessimétricas de poder. Isto porque em determinados contextos as comunidades resistem por meio de estratégias para permanecer no território e entram em tensão com o poder dominante, mas em outras as relações dessimétricas de poder se impõem de modo contundente, impedindo qualquer possibilidade de contestação. A dessimetria do poder evidencia o território como prisão.

Além disso, a perspectiva relacional supõe conceber a territorialidade humana por meio de relações com territórios concretos e abstratos. Isso é fundamental para compreender o território na perspectiva do modo de viver, pois se constitui por meio das relações com a sociedade, com o ambiente, que suscita regras reconhecidas pelo grupo. Essas territorialidades são fundamentais para a gestão do ambiente a partir das comunidades (RAFFESTIN, 1986C).

Tendo destacado a relação entre conceitos e problemáticas, cabe enfatizar a relação entre tais problemáticas e os métodos empregados. Como destaca Moraes (2005), a perspectiva crítica apresenta um mosaico diversificado de orientações metodológicas, que sustentam como traço comum o discurso contestador. Interessa, então, compreender dentro do discurso crítico destacado nas principais problemáticas analisadas, a expressão das principais abordagens metodológicas: Composição, Materialismo Histórico e Dialético, Sistêmico e Fenomenologia.

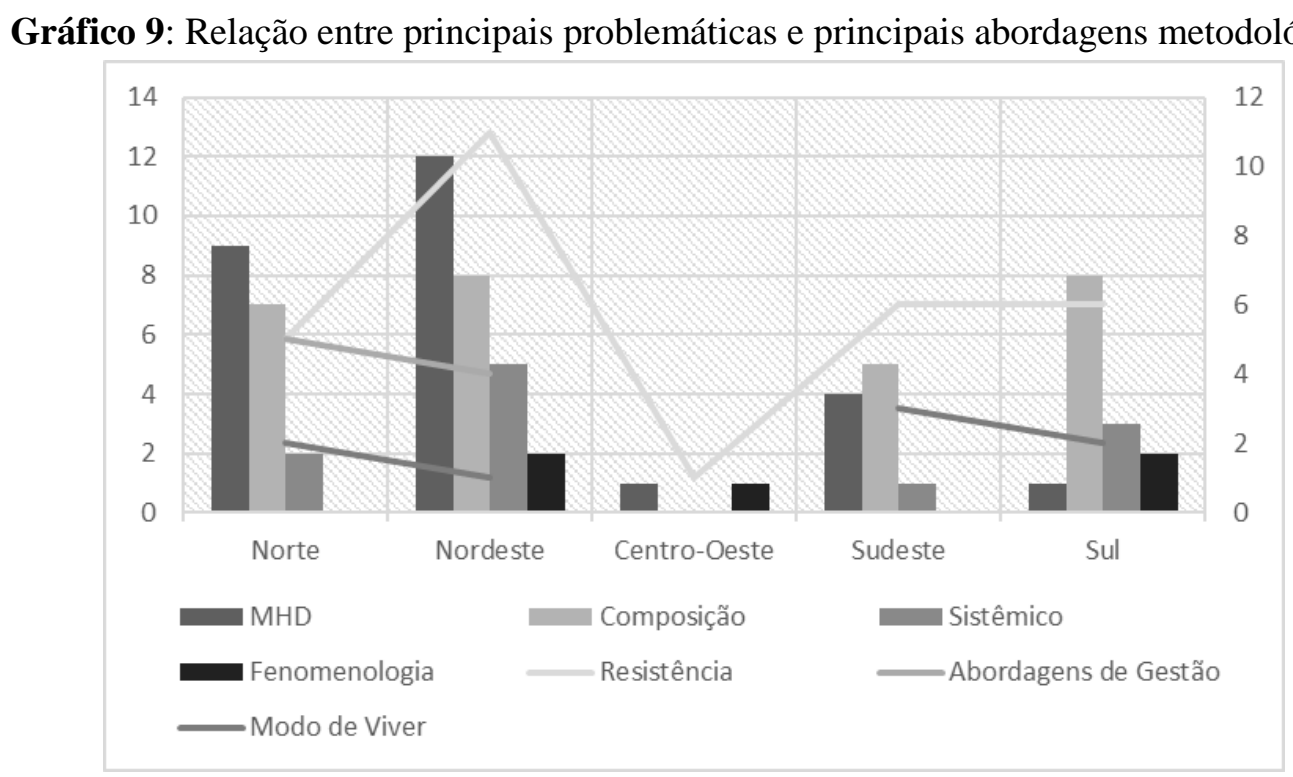

Fonte: Elaborado por De Paula (2018) 
Considera-se relevante enfatizar a presença do Materialismo Histórico e Dialético como método de pesquisa na Geografia brasileira. Essa presença é apontada pelos autores dos trabalhos e influenciam o tratamento das problemáticas. Observa-se a importância desse método nos trabalhos das Regiões Norte e Nordeste. No caso da região Norte destaca-se a compreensão dos pescadores/ribeirinhos como partícipes da estrutura de classe camponesa. Nessa região, gestão e resistência são abordadas com destaque. Logo, o método permite expor a expropriação capitalista do trabalho, que resulta em resistência. Também apresenta o contraponto da gestão a partir dos camponeses, e suas tensões com outras formas de gestão.

Quanto à categoria "composição" como já foi dito, integra trabalhos cujo método não é explicitado pelo autor. Nestes é possível verificar a mesclagem de procedimentos metodológicos, mas seria audacioso apontar a predominância de um método. Muitos deles compõem a discussão com o Materialismo Histórico e Dialético, o que se verifica a partir de categorias utilizadas. Esse "ecletismo" se observa de forma proeminente nas regiões Sul e Sudeste, onde as principais problemáticas estão relacionadas à resistência e modo de viver. Esses trabalhos se caracterizam na busca por respostas relacionadas às problemáticas da pesquisa de forma centrada em múltiplos procedimentos metodológicos. Geralmente, conclusões são apresentadas e evidenciam situações de tensão. Contudo, acredita-se que a discussão sobre o método de pesquisa contribui para compreender a Geografia do presente. Sendo assim, são pesquisas que permitem, que debatem determinada problemática, mas dentro de um limite que não permite ter claro a forma como o pesquisador se posiciona. $\mathrm{O}$ risco que se observa em certas pesquisas que não delimitam o campo metodológico é a reprodução da Geografia Tradicional.

Também se evidencia trabalhos que utilizam o método sistêmico. Esse, costuma utilizar procedimentos relacionados às geotecnologias para responderem as problemáticas de pesquisa. Esta perspectiva metodológica está bastante associada aos trabalhos que discutem a gestão, e estabelece propostas nesse sentido. Cabe também enfatizar que não é dispensado o trabalho de campo e diálogo com as comunidades, sendo assim se afasta das propostas da Geografia quantitativa.

Outra provocação que se faz necessária, é a presença da fenomenologia enquanto método. Como se considerou somente o método explicitado pelo pesquisador, a fenomenologia é menos presente, mesmo que se identifique a utilização de procedimentos relacionados a esse método, principalmente quando se trata dos modos de viver e da cultura das comunidades. Contudo, a discussão sobre o método é pouco frequente. 
Em relação aos métodos de pesquisa, se observou que cada um dentro do seu limite responde as principais discussões de problemáticas apresentadas. Contudo, enquanto se observa que o debate teórico tem sido profícuo, a discussão de método não tem sido tão evidenciada, em detrimento da descrição de técnicas de pesquisa. Acredita-se que superar esse limite é necessário para pensar articulações e ações em conjunto, no âmbito de Geografias da pesca.

Ainda sobre as metodologias de pesquisa é fundamental enfatizar a presença de trabalhos de campo, e as diversas abordagens de cartografia social. Isso é fundamental para pensar a Geografia do tempo presente, pois a pratica do geografo está muito associada à sua presença, participação e ação nos contextos de pesquisa. Assim cabe entender o geógrafo da pesca, como promotor de uma Geografia do diálogo horizontal, que conhece a comunidade e busca, em certa medida, corresponder as suas expectativas. Como enaltece Suertegaray (pesquisa de campo) cada método implica em determinada abordagem de campo. Sendo assim, as possibilidades de diálogos de saberes no âmbito das comunidades tradicionais estão intrinsecamente relacionadas com o método da pesquisa.

Quanto à cartografia social, em suas diversas abordagens: cartografia participativas, cartografia comunitária, mapeamentos comunitários, etc., é importante enaltecer essa expertise do geógrafo, que vem sendo aprimorada nos últimos anos. Nessa perspectiva, não se trata somente do procedimento técnico do mapeamento, mas de uma série de conhecimento que permitem o diálogo com base nas espacialidades dos sujeitos, grupos e comunidades.

A informação resulta da tradução intercultural de saberes e práticas a partir do diálogo e deverá expressar a simbologia do mapa. Do ponto de vista do território das comunidades, essa proposta metodológica é fundamental, pois permite a exposição de conflitos, bem como pensar a gestão do território. Para que o mapa comunitário seja um instrumento de gestão e luta, é fundamental a potencialização da participação em todos os processos relacionados à cartografia, para que corresponda aos objetivos do grupo (nova cartografia social).

Entende-se que o debate teórico e metodológico presente nos trabalhos analisados, contribui com a realização de uma racionalidade cosmopolita, que ao contrário da dominante, busca contrair o presente e expandir o futuro, criando um espaço de visibilidade para a experiência social que se manifesta no tempo presente (SANTOS, 2002). Trata-se, sobretudo, de reconhecer as experiências e solidariedades que se expressam no local, como propõe Milton Santos (2006) quanto ao enfrentamento das consequências da globalização.

Tais problemáticas, na perspectiva de Sousa Santos (2007) constituem a globalização contra-hegemonia, a qual estabelece a luta contra a exclusão (social, econômica, política e 
cultural) promovida pela globalização neoliberal, questionando as relações desiguais de poder, e de distribuição, com base nos princípios da igualdade e diferença, dos recursos (materiais, sociais, políticos, culturais e simbólicos).

\subsubsection{O diálogo com os sujeitos sociais}

Considera-se também relevante destacar o diálogo estabelecido entre pesquisadores e sujeitos sociais, bem como entre pesquisadores (no âmbito da Geografia e das Ciências Humanas). Para tanto, serão enfatizados tais sujeitos (organizações de pescadores e pesquisadores) e na sequencia algumas possibilidades de diálogo expressas no material analisado.

Como foi destacado no Capítulo I, na maior parte dos trabalhos o diálogo se dá no âmbito das comunidades. Contudo, também são frequentes sobre colônias e associações de pescadores. Em cada um desses contextos se observa limites e possibilidades, que valem ser brevemente discutidos.

Entende-se essa possibilidade de diálogo com os sujeitos sociais a partir de Leff (2006) que propõe os diálogos de saberes. No campo científico, isso permite recuperar e reconstruir outras versões da história e da ciência, abrindo novos caminhos para histórias globais e multiculturais do conhecimento, superando a colonialidade do saber (SANTOS, et. al. 2006).

O diálogo com as comunidades tem permitido conhecer a pesca artesanal brasileira e a relação entre território água e território terra (de moradia e vivência). Expressam os modos de viver e os enfrentamentos que as comunidades estabelecem frente a diversos contextos. Expõem a vida no lugar e no cotidiano, bem como as estratégias para a subsistência e a resistência. Tais abordagens trazem a dimensão política, por meio de debates, acordos comunitários e defesa do território. Contudo, a dimensão política não se apresenta no campo institucional.

O diálogo institucional com as comunidades tem se manifestado no âmbito das associações e cooperativas de pescadores. Essas entidades têm aberto espaços para a discussão democrática sobre as problemáticas da pesca e sociais dos pescadores artesanais, bem como contestado, a representação das colônias de pescadores. Além disso, costumam envolver os pesquisadores no seu processo de constituição favorecendo o debate político institucional, cujos encaminhamentos têm sido analisados nas pesquisas sobre a pesca artesanal brasileira.

Tomando por base essas instituições cabe enfatizar os limites do diálogo, sobretudo, entre associações e colônias de pescadores. Isto porque muitas vezes as associações são criadas frente aos descontentamentos dos pescadores com as colônias. Sendo assim, se estabelece um 
contexto de disputas, por qual entidade tem o direito de representar os pescadores artesanais. Estas situações conflituosas acabam por dividir as comunidades de pescadores em grupos políticos e existem implicações nos territórios tradicionais, como será discutido mais adiante.

Em relação à frequência do diálogo estabelecido entre pesquisadores e Colônias de Pescadores é importante enfatizar que, frequentemente, decorre do reconhecimento social que essas instituições possuem, como organização da pesca artesanal. Sendo assim, fornecem informações, documentos, proporcionam reuniões, e, em certa medida, preservam a história da pesca da região. Contudo, não costumam proporcionar o debate político mais amplo e horizontal, limitando a análise das tensões que ocorrem no território.

Ainda é importante atentar para a presença cada vez maior das organizações de pescadores, na perspectiva dos novos movimentos sociais (SANTOS, 2001). Identifica-se uma série de grupos organizados, que representam interesses coletivos localizados, mas possivelmente universalizados. Nesse sentido, cabe enfatizar os Fóruns de Pescadores (ex. Fórum Delta do Jacuí, Fórum da Lagoa dos Patos, Fórum de Pescadores em defesa da Baía de Sepetiba) Artesanais, Movimento dos Pescadores Artesanais do Litoral do Paraná - MOPEAR, Articulação Nacional de Pescadoras. Em escala nacional se destaca a ação do Movimento dos Pescadores e Pescadoras Artesanais - MPP. Ressalta-se que o diálogo com os movimentos sociais apresenta diferenças, pois se pressupõem que o trabalho do pesquisador corresponda às expectativas do grupo, logo, não é o pesquisador que estabelece a agenda de pesquisa, mas a mesma deve ser dialogada e construída conjuntamente.

Ainda em relação aos diálogos entre pescadores e geógrafos, é fundamental a superação da hierarquia estabelecida pela ciência moderna, entre conhecimento científico e tradicional. Ainda é importante reconhecer nos saberes tradicionais, a possibilidade de ligação entre conhecimento e prática, entre saber e pensar (SANTOS et a., 2006). Nesse sentido os caminhos apresentados por Leff (2006), na perspectiva da racionalidade ambiental, devem ser amplamente empregados nas pesquisas, pois relaciona conhecimentos tradicionais e científicos, distingue sem separar (MORIN, 1990). Dessa maneira, é fundamental conhecer a ação comunicativa proposta por Habermas (2012A, 2012B) e a tradução intercultura de Santos (2002). O primeiro expõe a dialógica a partir dos mundos da vida em que estão situadas as compreensões, o segundo, propõe reconhecer o que tem em comum entre compreensões de diferentes culturas.

Santos et al. (2006) destaca a importância de, na perspectiva da epistemologia crítica, compreender que todo o conhecimento é situado, logo corresponde a capacidades de realização 
em determinados contextos e lógicas. Assim, não só o conhecimento tradicional deve ser colocado em questão, mas também o conhecimento científico.

\subsubsection{Possibilidades de diálogos na Geografia e com as Ciências Humanas}

Tendo destacado o diálogo entre geógrafos e pescadores, cabe agora apresentar o diálogo entre pesquisadores. Para isso serão destacados limites e possibilidades a partir do diálogo expresso nas dissertações e teses (por meio de citações). Na sequência transpõe-se esses diálogos para o âmbito das ciências humanas e sociais, apontando potenciais para a dialógica.

Para verificar o diálogo, ou tendência de diálogo entre pesquisas (dissertações e teses) a análise das dissertações identificou 71 referências à 22 pesquisadores (que responderam os questionários) em 36 trabalhos (Dissertações e Teses) (figura 66). 


\section{GEOGRAFIAS DA PESCA ARTESANAL BRASILEIRA:}

\section{Expressão Regional das Referências nos Trabalhos aos Pesquisadores}

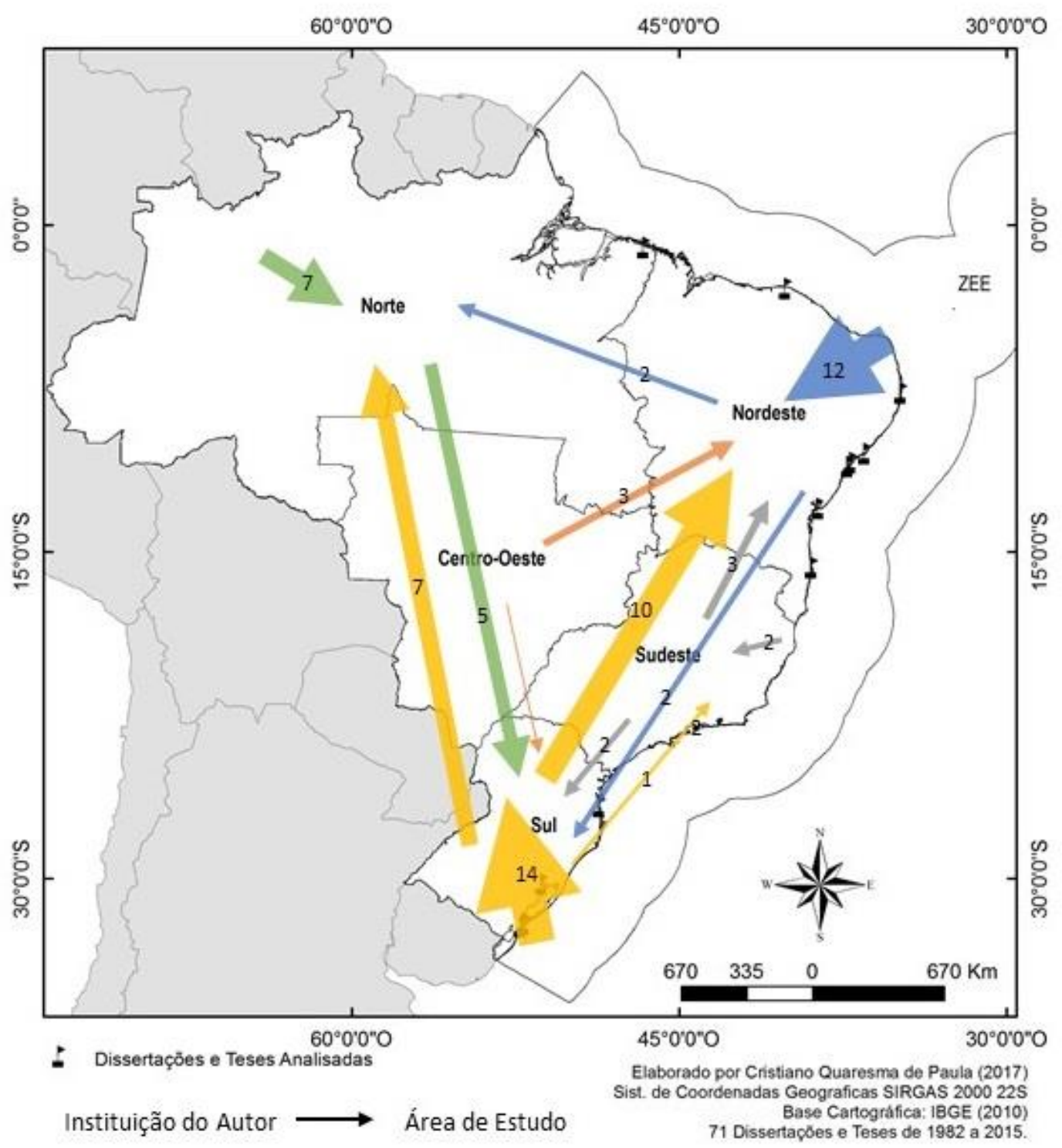

Figura 66: Mapa da Expressão Regional das Referências nos Trabalhos aos Pesquisadores que Responderam os Questionários

Fonte: Elaborado por De Paula (2018).

A primeira questão que deve ser destacada é que dos 71 trabalhos analisados, entre dissertações e teses, a partir da área de estudo, 35 não fazem nenhuma referência aos autores geógrafos, que foram identificados como pesquisadores da pesca artesanal. Essa ausência se manifesta mesmo em trabalhos que ocorrem na mesma área de estudo e com abordagens teóricas semelhantes. Sendo assim, o desconhecimento sobre a pesquisa em pesca artesanal na Geografia brasileira se apresenta como uma lacuna importante dentro dos trabalhos e limita o diálogo/debate direto entre os mesmos. Esse aspecto em contraposição a opinião de alguns 
pesquisadores, que responderam o questionário, de que ainda são poucas as referências, indica que devem ser produzidas estratégias para a melhor divulgação do que tem sido produzido na Geografia brasileira sobre a pesca artesanal.

Outro fator a destacar nas pesquisas realizadas em áreas de estudo das regiões Sul, Nordeste e Norte, respectivamente, é que o maior número de citações identificadas é de autores lotados institucionalmente na região. Ressalta-se que nessas regiões se observou a relação entre áreas e programas de pós-graduação. Logo, há relação entre os trabalhos, cuja área de pesquisa é a mesma, o que no contexto da pós-graduação propicia o diálogo entre as pesquisas no âmbito regional. Isso permitirá inferir que a área de estudo é o principal fator de diálogo entre tais pesquisas. Contudo, especialmente o impacto dos autores da região Sul, sobre as demais regiões leva a compreender que essa relação não é uma regra.

O professor Eduardo Cardoso, lotado na UFSM é mencionado em 23 trabalhos, o que resulta na densidade das setas que saem da região Sul. Ressalta-se que o autor é muito referenciado a partir da tese "Pescadores artesanais: natureza, território, movimento social" de 2001, que aborda os territórios dos pescadores artesanais em escala nacional. Diante disso se evidencia a importância dessa referência em pesquisas realizadas em outras regiões, principalmente Nordeste e Norte.

Outro ponto a destacar é que são reduzidas as citações de autores vinculados atualmente a instituições da região Sudeste, em trabalhos realizados em outras regiões. Esse é um comportamento contrário ao esperado, pois como se evidenciou os programas de pós-graduação da região Sudeste promovem pesquisas sobre a pesca artesanal em diversas regiões. Contudo, o que se observa é que ao concluírem a pós-graduação os pesquisadores frequentemente retornam a região de origem. A própria tese de Cardoso (2001) foi realizada no Programa de Geografia Humana da USP, mas o autor retornou ao Rio Grande do Sul, assim como Cruz (2007) que realizou no mesmo programa e retornou ao estado do Amazonas, onde está vinculado atualmente à UFAM. Desta forma, se conclui que os egressos da região Sudeste são citados, mas isso se expressa na região onde têm o vínculo atual.

Um comportamento contrário se observa na seta que sai da região Centro-Oeste para a região Nordeste. Nesse caso a autora, Ednizia Khun é citada na Bahia, pois realizou a pesquisa na UFBA, contudo, atualmente está vinculada à instituição no Distrito Federal. Logo, a citação se deve ao vínculo da pesquisa com a área de estudo situada em São Francisco do Paraguaçu, Bahia. 
Também cabe destacar características regionais e locais da pesca que motivam a interlocução entre pesquisas. Na seta que sai da região Norte, para a região Sul, por exemplo, as citações estão relacionadas às territorialidades típicas da Amazônia e aos Acordos de Pesca.

Cabe ressaltar que a questão das citações não se limita a questão quantitativa, mas à socialização do conhecimento. Supõe-se que o diálogo entre os autores é fundamental no movimento das compreensões construídas. Muitas vezes as pesquisas se voltam a um início que já foi superado por outros trabalhos. Nesse sentido, considera-se importante conhecer para debater, dialogar e responder à - e com a -sociedade a partir do conhecimento produzido na Geografia.

Em relação ao diálogo entre pesquisadores também é significativo ressaltar a importância dos eventos acadêmicos promovidos no âmbito da Geografia brasileira. Nesse sentido destacam-se os Encontros Nacionais de Geógrafos - ENGs e Encontros da Associação Nacional de Pós-Graduação e Pesquisa em Geografia - ENANPEs, nos quais os pesquisadores estabelecem diálogos, sobretudo em Espaços de Diálogos e Grupos de Trabalho. Cabe destacar que se tem criado a "cultura" de encontro dos pesquisadores da pesca nesses eventos, com o objetivo de aproximar tais sujeitos e, assim, potencializar o diálogo em rede.

Em relação ao diálogo com outras áreas do conhecimento é importante destacar as convergências no âmbito das ciências humanas e sociais na perspectiva do momento histórico e institucional.

Do ponto de vista histórico e institucional, as ciências humanas, onde se encontra a Geografia, estão em um processo semelhante de expansão e consolidação da pós-graduação. O tratamento dado no campo das humanidades, pelos PNPG (2005-2010, 2011-2020) não apresenta grandes distinções. Da mesma forma, como já destacado, as pesquisas, sobretudo, nas ciências sociais e história, têm dado atenção a diversos atores e problemáticas. Sendo assim, do ponto de vista institucional as ciências humanas e sociais se encontram sujeitas a contextos semelhantes, quanto ao estágio epistemológico e metodológico, esta pesquisa não tem condições de expressar compreensões.

As Geografias da Pesca estão muito influenciadas por outras áreas das ciências humanas e sociais, como foi apresentado, no Capítulo I, os trabalhos fazem referências a diversos autores, sobretudo das ciências sociais, como ciência política, sociologia e antropologia. Também há discussão com base em autores da história e filosofia. Geralmente essas referências dizem respeito a teorias e paradigmas de compreensão da sociedade, de uma forma mais ampla, não tratando especificamente da realidade brasileira. 
Os autores brasileiros, via de regra, são referenciados para permitir interpretações a respeito da sociedade brasileira diante de determinados contextos. Quanto à pesca artesanal, é unanime a referência aos trabalhos do antropólogo Antônio Carlos Diegues. Este autor tem influenciado os geógrafos com conceitos de pescador, pesca artesanal, comunidade tradicional, entre muitos outros. Sua referência também se refere a estudos realizados em diversas partes do território nacional, apresentando os caiçaras, açorianos, ribeirinhos, etc.

Entende-se que a Geografia tem capacidade de dialogar no campo das ciências humanas, pois compartilham de problemáticas e implicações institucionais e históricas semelhantes. Contudo, como ensina Milton Santos (2006) é fundamental que a Geografia se aprofunde na discussão epistemológica para o diálogo com outras áreas do conhecimento. Nesse sentido, parece necessário avançar para que, no diálogo com outras áreas do conhecimento, a Geografia não esvaneça. Por conseguinte, o diálogo, mesmo no campo científico, deve permitir o novo sem suprimir a contribuição de cada ciência. Entende-se que a contribuição da Geografia está na dimensão espacial, portanto deve enaltecer isso no diálogo interdisciplinar.

Ainda se compreende que o encontro, entre Geografia e demais ciências humanas e sociais, pode ser potencializado a partir de contextos de pesquisa implicados na construção de: Pensamento Complexo, Racionalidade Ambiental, e Cosmopolitismo Subalterno.

Na perspectiva do pensamento complexo, o encontro entre Geografia e outras ciências se dá no campo da interdisciplinaridade. Essa surge na medida em que se concebe os limites de cada área do conhecimento, bem como as suas insuficiências para responder às incertezas inerentes à complexidade do real. Reconhecendo o desconhecimento do conhecimento, o diálogo é estabelecido como possibilidade de construir o novo. Destaca-se que esse diálogo não se limita ao campo científico, mas deve paulatinamente transcender as ciências, sendo transdisciplinar, com o diálogo de saberes para além das ciências (MORIN, 1990).

$\mathrm{Na}$ perspectiva da racionalidade ambiental as ciências humanas e sociais devem estar comprometidas na construção de estratégias conceituais que permitam reagir às consequências da crise ambiental planetária, por meio da gestão democrática dos recursos do ambiente. Nesse sentido, deve abrir-se ao saber ambiental, se inserir na compreensão da complexidade ambiental, para entender o diálogo de saberes, no sentido da interpretação do outro (LEFF, 2010).

A perspectiva do cosmopolitismo subalterno, ou a construção de epistemologias do Sul, se encontra com outras perspectivas que buscam a superação da primazia da racionalidade ocidental (europeia) sobre os outros saberes e racionalidades (SANTOS, 2007). Desta forma, 
busca-se o reconhecimento e valorização das diversas cultural e a construção de conhecimentos a partir dos próprios sujeitos implicados nos processos sociais em estudo. Tais estratégias contribuem na superação da colonialidade do poder e do saber (QUIJANO, 2005).

\subsubsection{A rede como possibilidade}

Quanto à relação entre pesquisadores, principalmente no âmbito da Geografia brasileira, uma iniciativa que vem sendo tomada e a constituição de uma rede de pesquisas chamada de Rede de Geografias da Pesca. Esse processo de construção de um trabalho em rede tem sido lento, mas muito frutífero, na medida em que tem aproximado pesquisadores. Ressalta-se que a pesquisa da presente tese se deu nesse processo de articulação em rede. Sendo assim, será apresentado brevemente o contexto em que se concebe a ideia da constituição da rede. $\mathrm{Na}$ sequência serão apresentadas algumas possibilidades para o avanço desse trabalho. E por fim, será discutida a ética inerente a essa rede, a partir de diálogos que foram estabelecidos com os pesquisadores e em contraponto com Morin.

No XVII Encontro Nacional de Geógrafos, em Belo Horizonte, cerca de 30 pesquisadores se encontraram no Espaço de Diálogos e Práticas: Comunidades tradicionais: pescadores, ribeirinhos e caiçaras. Nessa oportunidade houve intenso debate e reflexão sobre a pesquisa sobre pesca artesanal na Geografia. Havia um entendimento comum que poucos geógrafos pesquisavam a pesca, o que tornava a pesquisa muito solitária. A professora Dirce Suertegaray, que participa do EDP em sua intervenção apontou que só naquele evento havia uma sala repleta de geógrafos que pesquisavam nessa perspectiva, e que, no âmbito da Associação de Geógrafos Brasileiros - AGB, esse grupo deveria promover a articulação para a superação desse estado de isolamento. A professora Catia Antonia da Silva estava presente e estimulou o grupo a promover tal articulação. Foi então que surgiu a ideia de construir uma rede de pesquisadores, que integrasse diversas formas de fazer Geografia, as quais se dessem em contextos de diálogos com comunidades de pescadores artesanais.

Criou-se então a Rede de Geografias da Pesca, que inicialmente se organizou por meio de lista de endereços eletrônicos e por meio de um grupo na rede social (facebook). Também se decidiu que até que a rede pudesse construir eventos próprios, o caminho seria incentivar o encontro nos eventos nacionais da Geografia. No V Congresso Brasileiro de Geógrafos Vitória, ES (2014) e no XVIII Encontro Nacional de Geógrafos - São Luís, MA (2016) os participantes da rede propuseram Espaços de Socialização de Coletivos. Como resultado do ESC de 2014, foi lançado em 2016 o Livro "Brasil e Moçambique: diálogos geográficos sobre 
a pesca artesanal" (SILVA e DE PAULA, 2016). Também houve encontros da rede em Grupos de Trabalho dos XI e XII Encontros Nacionais da ANPEGE (2015 e 2017).

É importante destacar que a rede social foi também importante para o estabelecimento de diálogos entre pesquisadores. Nesse caso tem agregado Geógrafos e outros pesquisadores, sobretudo, das ciências humanas e sociais, que divulgam trabalhos, eventos, e denunciam contextos de luta das comunidades. Ainda tem agregado pescadores de diversas partes do Brasil, muitos envolvidos com o Movimento de Pescadores e Pescadoras Artesanais - MPP, que utilizam a rede social para ter acesso informações sobre a pesca e expor suas denúncias, ações e lutas.

Dentro do que vem sendo discutindo, entre os geógrafos, a rede persegue dois pressupostos. O primeiro é do respeito a pluralidade de pesquisas, sobretudo no que diz respeito às abordagens teóricas e metodológicas. Sendo assim não constitui um objetivo construir uma Geografia da Pesca, mas reconhecer as diversas Geografias e colocá-las em diálogo. O segundo trata da relação entre pesquisadores e pescadores, onde a rede se entende como acadêmica e social, logo se dispõe ao diálogo com as comunidades e movimentos sociais, e provoca debates na Geografia para a constituição de respostas às problemáticas apresentadas pelos grupos.

Ainda em relação à rede, em 2015 para esta tese, foi realizado um questionário que serve como diagnóstico de algumas possibilidades de intercâmbios. Além da presença de pesquisas sobre pesca, cabe enaltecer a disposição desses pesquisadores para integrarem a pesquisa em rede, bem como os contextos institucionais em que estão inseridos, que expõem o potencial para a rede.

Com base no gráfico 10, apresenta-se o interesse dos pesquisadores em integrar a Rede de Geografias da Pesca. Ressalta-se que 61\% respondem que sim, e 33,3\% desejam mais informações. Somente 5,55\% não tem interesse em integrar a rede. Nesse sentido, entre os que responderam os questionários, observa-se a disposição para a construção da rede de Geografias da Pesca. 
Gráfico 10: Desejo dos pesquisadores de participarem da Rede de Geografias da Pesca

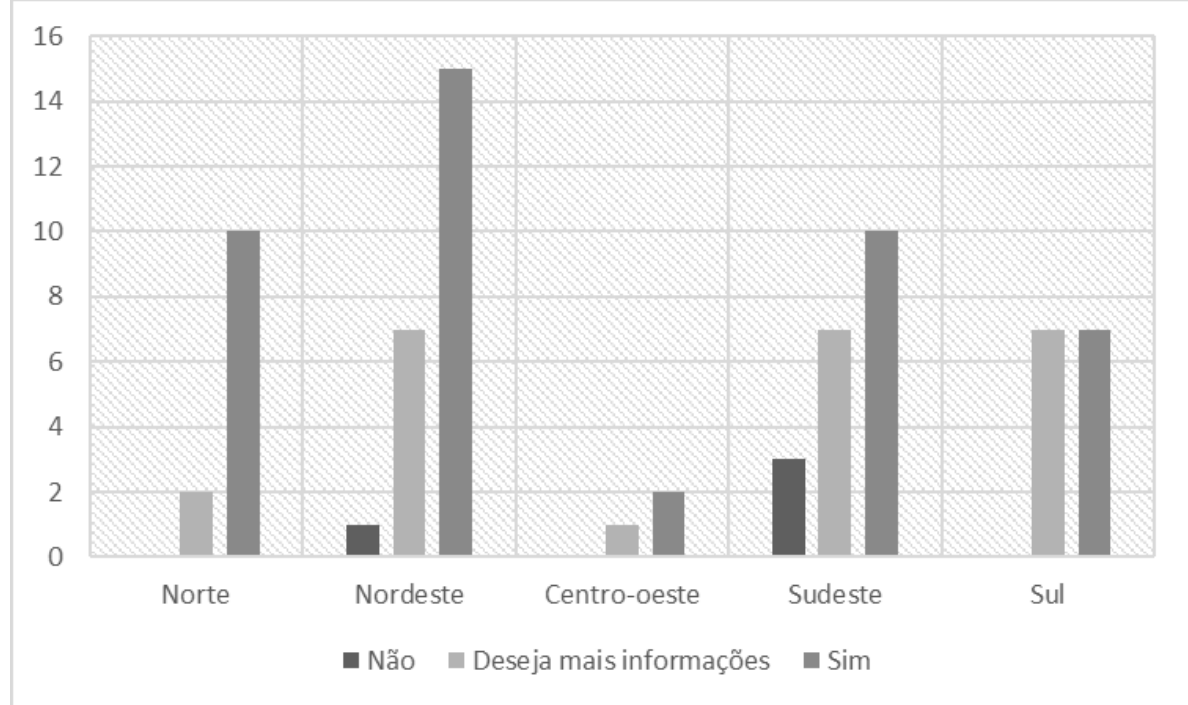

Fonte: Elaborado por De Paula (2018).

É importante retomar que esses pesquisadores desenvolvem pesquisas em instituições de todas as regiões do Brasil, como aponta o Capítulo 1. Além disso, integram grupos de pesquisa que vem elaborando importantes contribuições na compreensão da pesca artesanal em nível regional, principalmente. Também é importante frisar a presença de professor universitários, devido a possibilidade de abordarem a pesca artesanal no ensino, pesquisa e extensão.

Em relação aos pesquisadores que já são professores universitários na atualidade, eles atuam como elos, ou nós da rede. Pois a participação em bancas de defesa de, principalmente de dissertações e teses, tem promovido importantes diálogos entre pesquisadores. Muitos desses professores não abordaram a pesca em suas pesquisas de mestrado e doutorado, mas foram paulatinamente inserindo em suas pesquisas as problemáticas dos pescadores artesanais.

Questionou-se aos pesquisadores quais as atividades que a rede deveria promover. As principais indicações foram a construção de um evento (seminário, simpósio, workshop, oficinas) em escala nacional. Também foi sugerida a construção de publicações que expressem a discussão da pesca artesanal na Geografia, sendo indicado, livro e/ou revista. Também é apontada a necessidade de um meio de divulgação dos trabalhos, e atividades junto ao movimento social.

Ressalta-se que a Rede de Geografias da Pesca vem se constituindo em um ritmo lento, mas vai ganhando corpo na medida em que o diálogo entre os pesquisadores vai sendo potencializado, e os intercâmbios de conhecimentos vão sendo gerados. Sendo assim, a promoção da pesquisa em pesca artesanal em diversas partes do Brasil, tende a fortalecer a rede. 
Antes de finalizar essa sessão, considera-se relevante uma breve reflexão sobre a ética na pesquisa. Pretende-se tratar dessa questão de forma mais aprofundada em trabalhos futuros, a partir do diálogo em rede. Contudo, como não se trata de uma discussão elaborada coletivamente, não expressa um conjunto ético da Rede de Geografias da Pesca, mas a visão do pesquisador sobre uma possível abordagem ética.

Edgar Morin (2005) compreende a ética a partir da tríade "indivíduo-sociedadeespécie". Nesse sentido o ato moral expressa a religação do indivíduo com a sociedade e da sociedade com a espécie humana, o que pode resultar na regeneração nas ações humanas. Entre as implicações dessa visão de ética, o autor propõe o "pensar bem", tendo em vista que o pensamento nutre a capacidade de julgamento ético dos sujeitos.

Implicada na teoria do pensamento complexo, a ética apresenta por Morin (2005) expõe aspectos relacionados ao "pensar bem", que serão concebidos como algumas diretrizes epistemológicas (formas de pensar), metodológicas (formas de fazer) e da relação com os sujeitos, nas pesquisas sobre pesca artesanal (SILVA, 2016).

Na perspectiva do "pensar bem" as pesquisas abrem para a possibilidade de descobrir outros conhecimentos, e com eles (re)aprender conceitos que foram disjuntos no contexto moderno da ciência. Assim, contribui em superar pontos de vista mutilados, e mutiladores, o que favorece o diálogo entre as ciências e destas com a sociedade. Desta forma abre-se para outras racionalidades, e envolve-se pesquisadores e sujeitos sociais na busca por caminhos que permitam no presente arquitetar um futuro. Contudo, deve-se ter presente as incertezas e as contradições inerentes a complexidade do real. Também é fundamental nunca perder de vista a dialógica entre local e global, suas mutuas implicações, reações e resistências (MORIN, 2000).

Assim, a pesquisa em pesca artesanal teria a oportunidade de se abrir para o novo. A relação passado-presente-futuro, inerente ao conhecimento tradicional se apresenta como possibilidade de religar, não só os conceitos de território e ambiente, mas religar a Geografia (SUERTEGARAY,2017). Nesse sentido se constrói um pensamento contra-hegemônico, construído conjuntamente por meio de diálogos de saberes entre pesquisadores e pescadores, como possibilidades para estratégias de futuro, que não nega as incertezas e contradições. No local, se conforma uma globalização contra-hegemônica, enfrentando a exclusão social, econômica, política e cultural (SANTOS, 2007).

"Pensar bem" está articulada às formas de fazer (metodologia), a partir de princípios que permitem distinguir e religar. Desta maneira, o enfrentamento se dá diante da ciência moderna e da lógica clássica que promoveu a disjunção do conhecimento. Para esse 
enfrentamento a dialógica se coloca como princípio norteador para unir, sem suprimir as diferenças, reconhecendo na multiplicidade a unidade. Daí advém a expressão hologramática, pois se supera o reducionismo que só vê as partes e o holismo que só concebe o todo, para compreender o todo na parte e parte no todo. Relação circular, presente-passado-futuro, expõe a importância do processo e expressa o princípio recursivo. O processo ganha notoriedade em detrimento do produto, que nunca é acabado. Sendo assim, a busca da conjunção nunca se esgota (MORIN, 1990).

Nesse sentido, o "pensar bem" de Morin (2005) se expressa na relação entre saberes e fazeres. A primeira religação, que se faz necessária, é do pensar e do fazer. Tal separação que funda a ciência moderna não se manifesta no conhecimento tradicional dos pescadores artesanais, dessa forma mais do que estudar ou evidenciar tais saberes, é necessário aprender com eles. Acredita-se que a renovação se dá a partir do diálogo, que não suprime a importância da ciência em determinadas condições, mas que a problematiza. Para tal renovação a ciência deve estar aberta ao novo, que resulta da dialógica entre saberes. Assim, cada contexto de pesquisa passa a dialogar com contextos mais amplos, os quais põem em questão os limites do saber e racionalidade científica moderna. Da mesma forma se concebe que a problemática estudada, na pesquisa sobre pesca artesanal, deve ser entendida dentro e interação com problemáticas maiores. Desta forma a produção de um novo saber científico - Geografias da Pesca -, implica na associação de diversos saberes e fazeres, e vai se evidenciando nas novas respostas as questões que se apresentam no processo.

Finalmente, o pensar bem destaca os sujeitos sociais (MORIN, 2005), concebendo a autonomia do indivíduo, a noção de sujeito e a consciência humana. Assim como os elementos do todo são solidários, entende-se que deve estar presente a consciência de responsabilidade a partir da noção do sujeito. Para isso também é necessário reconhecer e enfrentar a cegueira da mente humana, que estabelece demarcações na memória, esquecimentos seletivos e autojustificação.

"Pensar bem" envolve então "enxergar os sujeitos" e compreender as consequências do conhecimento sobre os contextos em que estão inseridos. Exige, então, responsabilidade diante das decisões tomadas no processo de construção do conhecimento. No caso da pesca é fundamental que o pesquisador avalie as implicações de suas pesquisas nos contextos espaciais desiguais a que estão submetidas às comunidades. Contudo, assim como aponta-se as consequências do conhecimento, cabe destacar as consequências do desconhecimento gerado a partir da invisibilidade a que são submetidas as comunidades em análises de processos a que 
estão estritamente relacionadas. Essa cegueira, que invisibiliza os sujeitos sociais, produz ausências e no âmbito das Geografias da Pesca deve ser superada na promoção de emergências.

\subsection{Da Territorialidade Tradicional ao Território de Luta das Comunidades Tradicionais de Pescadores Artesanais.}

Retomando o Capítulo II, a Geografia brasileira expõe, em certa medida, proposições às problemáticas relativas aos territórios da pesca artesanal. A proposta analítica apresentada permite compreender o contínuo ou abordagem híbrida de território e ambiente, que se evidencia nas dissertações e teses, por meio de diálogos de saberes estabelecidos entre geógrafos e pescadores. Diante disso, nesse momento volta-se o olhar para compreensões relacionadas à gestão da pesca artesanal brasileira, para expor potencialidades e desafios a partir da pesquisa geográfica.

Existem concepções mais ou menos bem definidas que orientam discussões sobre pesca artesanal, pescadores e comunidades pesqueiras tradicionais, conhecimentos tradicionais, e organizações sociais de pescadores. Contudo, a partir do acúmulo da tese, considera-se relevante apresentar algumas ressignificações a partir da Geografia. Nesse momento, as compreensões geradas a partir da tradução, põe em evidencia saberes e práticas. Além disso cabe discutir a constituição do poder no âmbito comunitário e intercomunitário, bem como a relação com a natureza. Com base no entendimento do território tradicional, pretende-se expor a compreensão de pescadores artesanal como comunidades tradicionais territoriais, a dimensão territorial dos saberes, e o vínculo das organizações sociais ao território.

Contudo, cabe destacar a influência dos territórios das instituições, que atravessam os territórios das comunidades. No caso do Brasil, o Estado tem a prerrogativa da gestão. A gestão da pesca se dá por meio das instituições ambientais, e frequentemente não reconhecem ou não dialogam com os territórios comunitários. Assim, será problematizada a gestão, comunitária, compartilhada e centralizada dos territórios da pesca artesanal. Para tanto, serão percorridas algumas políticas relacionadas com a pesca artesanal, destacando a presença ou ausência da dimensão territorial nas mesmas. A gestão comunitária será pensada a partir dos acordos de pesca, a gestão compartilhada apresentará dois contextos: os Comitês Permanentes de Gestão e as Reservas Extrativistas.

Tendo compreendido os territórios comunitários, e os territórios das instituições que os atravessam, chega o momento de compreender o território de luta. Esse diz respeito ao processo 
de constituição e/ou afirmação do território frente a outras atividades econômicas que buscam o domínio do espaço. O território de luta decorre de impactos ambientais, disputas no território e conflitos por território. Ressalta-se e eminencia de um contexto de crise, que expõe a fragilidade da sociedade moderna, onde a regulação funcional foi priorizada em detrimento da regulatória. Diante disso, as comunidades resistem às Geografias fabricadas, e a TDR (Territorialização, Desterritorialização, Reterritorialização) submete o território ao ciclo do produto, onde a informação tem papel primordial ao desqualificar o território tradicional. $\mathrm{O}$ quadro exposto evidencia um contexto de Fascismo Territorial.

Frente a esse contexto, a luta pelo território se dá no campo da política a partir da mobilização dos pescadores em movimento social, onde buscam o direito de permanecer nos territórios tradicionais. Assim será apresentada a Campanha pela Regularização dos Territórios das Comunidades Tradicionais de Pescadores Artesanais promovida pelo Movimento dos Pescadores e Pescadoras Artesanais. Este último será compreendido no âmbito dos novos movimentos sociais, que tencionam regulação/emancipação, subjetividade/cidadania. O território tradicional das comunidades, defendido na campanha, pode ser entendido por meio das invariantes territoriais, onde, na atualidade, as redes globais se impõem e reduzem a autonomia. No campo da política o direito de permanecer no território (que nesse caso é água e terra) se traduz na busca dos novos movimentos sociais pela democracia participativa. No caso das comunidades tradicionais, esse processo possibilita a gestão do território por meio de saberes ambientais/territoriais.

\subsubsection{Territórios e Territorialidades na Pesca Artesanal}

No Capítulo II foram apresentados diversos contextos, a partir de dissertações e teses, em que os territórios tradicionais das comunidades de pescadores estão ameaçados pelo avanço de outras atividades, o Capítulo III corrobora a partir das denúncias do movimento social. Contudo, até o presente momento não se discutiu a noção de território e territorialidade tradicional das comunidades de pescadores. Antes de apresentar tais territórios e territorialidades considera-se importante discutir as noções de pesca artesanal, pescador artesanal, comunidade tradicional e conhecimento tradicional. Entende-se que esses conceitos são fundamentais para compreender territórios e territorialidades na pesca artesanal. 


\section{Pesca e pescadores artesanais}

Para a discussão sobre pesca artesanal e pescador artesanal, em um primeiro momento será destacado o contraste do entendimento do Estado e do Movimento Social. Na sequência dialoga-se com a definição de Diegues (2004). Por fim se estabelece uma compreensão a partir da Geografia.

A Lei N 11.959 de 2009 (BRASIL, 2009A), que estabelece a Política Nacional de Desenvolvimento Sustentável da Aquicultura e Pesca, define a pesca como "toda operação, ação ou ato tendente a extrair, colher, apanhar, apreender ou capturar recursos pesqueiros" (Capítulo II, Art. $2^{\circ}$ ). Da natureza de pesca comercial, apresenta a pesca artesanal "quando praticada diretamente por pescador profissional, de forma autônoma ou em regime de economia familiar, com meios de produção próprios ou mediante contrato de parceria, desembarcado, podendo utilizar embarcações de pequeno porte” (Seção I, Artigo $8^{\circ}$ ).

De uma forma mais ampla, compreende que a atividade pesqueira "compreende todos os processos de pesca, explotação e exploração, cultivo, conservação, processamento, transporte, comercialização e pesquisa dos recursos pesqueiros". Mais especificamente sobre a atividade pesqueira artesanal "Consideram-se atividade pesqueira artesanal, para os efeitos desta Lei, os trabalhos de confecção e de reparos de artes e petrechos de pesca, os reparos realizados em embarcações de pequeno porte e o processamento do produto da pesca artesanal" (Seção II, Artigo $4^{\circ}$ ).

Para a concessão do Seguro Defeso de Pesca Artesanal o Decreto 8424 de 2015 (BRASIL, 2015A, 2015B) compreende que essa deve ser uma atividade exclusiva e ininterrupta “Considera-se ininterrupta a atividade exercida durante o período compreendido entre o término do defeso anterior e o início do defeso em curso ou nos doze meses imediatamente anteriores ao início do defeso em curso, o que for menor" (Artigo $1^{\circ}$ ).

A Lei $\mathrm{N}^{\mathrm{o}} 11.959$ de 2009 define como pescador profissional "a pessoa física, brasileira ou estrangeira residente no País que, licenciada pelo órgão público competente, exerce a pesca com fins comerciais, atendidos os critérios estabelecidos em legislação específica" (Capítulo II, Artigo $2^{\circ}$ ).

No Decreto 8425 de 2015 (BRASIL, 2015B), que apresenta normas para a concessão do Registro Geral de Pesca, o artigo $2^{\circ}$ insere categorias de pescadores. Entre elas apresenta "pescador e pescadora profissional artesanal" como "pessoa física, brasileira ou estrangeira, residente no País, que exerce a pesca com fins comerciais de forma autônoma ou em regime de economia familiar, com meios de produção próprios ou mediante contrato de parceria, podendo 
atuar de forma desembarcada ou utilizar embarcação de pesca com arqueação bruta menor ou igual a vinte". Este decreto insere a categoria de "trabalhador e trabalhadora de apoio à pesca artesanal" definidos como "trabalhador e trabalhadora de apoio à pesca artesanal - pessoa física que, de forma autônoma ou em regime de economia familiar, com meios de produção próprios ou mediante contrato de parceria, exerce trabalhos de confecção e de reparos de artes e petrechos de pesca, de reparos em embarcações de pesca de pequeno porte ou atua no processamento do produto da pesca artesanal”. Esta última definição foi revogada no Decreto no 8.967, de 2017 (BRASIL, 2017).

Ressalta-se que a legislação distingue pesca de atividade pesqueira. A pesca artesanal é entendida como comercial e sua definição se restringe à captura, relação de trabalho, posse dos meios de produção e porte da embarcação. Já a atividade pesqueira artesanal integra reparo de apetrechos e embarcações, e processamento de pescado (BRASIL, 2009A). Já os Decretos 8424 de 2015 e 8467 de 2017 caracterizam essa atividade como exclusiva e ininterrupta.

Uma das consequências de separar a definição de pesca da de atividade pesqueira é a separação de categorias de pescador, como se observa no Decreto 8425 de 2015 que aparta o pescador artesanal profissional do trabalhador de apoio à pesca. Por consequência, permite restringir o acesso às políticas públicas como o seguro defeso, a quem está envolvido somente com a captura. Como apresenta o Decreto 8424 de 2015 "A concessão do benefício não será extensível aos trabalhadores de apoio à pesca artesanal, assim definidos em legislação específica, e nem aos componentes do grupo familiar do pescador profissional artesanal que não satisfaçam, individualmente, os requisitos e as condições estabelecidos neste Decreto" (Artigo $1^{\circ}$, Inciso $6^{\circ}$ ).

Os pescadores artesanais, por meio do Movimento dos Pescadores e Pescadoras Artesanais - MPP reagem a essas definições, as quais entendem que não correspondem à diversidade presente na pesca artesanal brasileira ${ }^{55}$.

Compreendem que a pesca artesanal na "maioria das vezes, é uma atividade familiar indivisível, diversificada, interdependente e inseparável. E a lógica das comunidades tradicionais pesqueiras é de famílias extensas e o trabalho por vezes ultrapassa a lógica familiar e se dá no âmbito comunitário, que se embasa principalmente em relações de solidariedade e reciprocidade".

${ }^{55}$ PELO TERRITÓRIO PESQUEIRO. Governo Brasileiro Rasga Direito de Autoidentificação das Comunidades Tradicionais Pesqueiras e Tira Direitos Trabalhistas das Mulheres Pescadoras. Disponível em: http://peloterritoriopesqueiro.blogspot.com.br/2015/06/governo-brasileiro-rasga-direito-de.html. Acesso em 01 out 2016. 
Sobre considerar a pesca artesanal uma atividade exclusiva e ininterrupta rebatem que:

O decreto faz uma classificação dos pescadores e das pescadoras, criando a categoria de pescador exclusivo, objetivando que o pescador para ter acesso a defeso não possa ter outra fonte de renda. O que destoa da realidade concreta dos pescadores que desenvolvem, na maioria dos casos, atividades complementares de agricultura de subsistência, artesanato, turismo de base comunitária, o extrativismo florestal e a criação de pequenos animais entre outras. Estas atividades individualmente são incapazes de prover a subsistência familiar, mas no seu conjunto são fundamentais para a garantia da segurança alimentar e da reprodução física e cultural destas comunidades. Inclusive, o exercício destas atividades é acolhido pela legislação previdenciária, caracterizando-se como elementos constitutivos da definição de segurado especial. Portanto, não é aceitável que o pescador seja constrangido a deixar de exercer as demais atividades que caracterizam a sua tradicionalidade.

Além disso há a negação de direitos aos pescadores que não estão inseridos na lógica de produção comercial:

O decreto impede que os pescadores que pescam para subsistência, para comer ou que fazem troca ou escambo tenham acesso ao RGP - Registro Geral da Pesca, documento que garante acesso a políticas públicas e sociais, principalmente direitos previdenciários e aposentadoria. Desta forma, deixará estas pessoas entregues à própria sorte e engrossará o número de beneficiários das ajudas assistenciais.

Segundo o movimento social o decreto nega a identidade dos pescadores artesanais para limitar o acesso a direitos:

Cria a categoria "trabalhador e trabalhadora de apoio à pesca artesanal". Desta forma, ele divide o grupo familiar classificando uns como pescador artesanal e outros não. Nega a identidade de pescador e pescadora artesanal a inúmeros trabalhadores que atuam na cadeia da pesca artesanal em regime de economia familiar e na forma tradicional de produzir. Limita o entendimento de que pescador ou pescadora artesanal são somente aqueles e aquelas que exercem a captura do pescado e comercializam. Desta forma, nega direitos trabalhistas, previdenciários e a identidade de pescadora artesanal a centenas de milhares mulheres pescadoras.

Assim, o MPP entende que se fere os direitos de autodeterminação das comunidades e povos tradicionais, promovendo o racismo institucional:

Esse decreto não condiz com a diversidade, peculiaridades e realidade da pesca artesanal no Brasil. Tenta homogeneizar os pescadores numa lógica urbana e capitalista. Interfere no direito de autodeterminação dos povos e comunidades tradicionais e fere um direito internacional de interferência do Estado na divisão da categoria, coisa que o Estado é proibido de fazer.

Este decreto faz parte de uma engrenagem de Racismo institucional que objetiva invisibilizar e eliminar os pescadores e as pescadoras artesanais, pois estes são entraves para o desenvolvimentismo degradador, excludente e 
concentrador ao estar perto e viver em íntima relação com a natureza tão cobiçada pelo capital e que conta com a anuência e conivência do Estado.

Em Política Pública e Território, Silva (2015) expõe a postura do Estado frente a pesca artesanal. Destaca-se que não há uma linearidade, mesclando períodos de avanços, no sentido do reconhecimento da importância da pesca artesanal, e retrocessos, desprestigiando a pesca artesanal em detrimento de outras atividades do setor pesqueiro e negando aos pescadores o acesso a políticas públicas. Contudo, é fundamental enfatizar, as contradições que se apresentam no tempo presente, com base na visão do Estado e do movimento Social.

Enquanto o Estado separa pesca de atividade pesqueira, o movimento social concebe a atividade pesqueira como um todo, e amplia essa definição destacando aspectos da tradicionalidade, na constituição da cultura e suas potencialidades no manejo do ambiente. $\mathrm{O}$ Estado restringe a figura do pescador artesanal à posse do "Registro Geral de Pesca" e realizar a captura. Para o movimento social os pescadores são sujeitos individuais e coletivos, que estão envolvidos com diversas atividades relacionadas à pesca, dentro de relações comunitárias, e por meio de saberes construídos a partir da relação com o ambiente, ao longo de gerações.

Ainda para o Estado a pesca artesanal se difere das demais modalidades de pesca pelas relações de trabalho, posse dos meios de produção e porte da embarcação. Para o movimento social a pesca artesanal se distingue no setor pesqueiro pela lógica de produção artesanal, que não visa a exploração da natureza e dos trabalhadores para a geração cega de lucro. Logo, expressa a capacidade de manejo dos ambientes por meio de técnicas que não provocam a degradação, pois decorrem do conhecimento da natureza, seus ciclos e limites. Muito além da produção pesqueira, promove relações comunitárias de respeito e reciprocidade, que se expressam na cultura. Assim, se apresenta como atividade econômica, de suma importância para a soberania alimentar brasileira, mas não se limita a isso.

O Estado ainda concebe a pesca "comercial" artesanal dentro do setor pesqueiro, logo está em disputa por políticas públicas e de fomento com a pesca industrial e aquicultura, principalmente. A sua visão sobre o pescador artesanal muda ao longo do tempo, deste a negação de direitos, até a instituição de políticas que visam reverter a situação de marginalidade social em que se encontram (LOBO, 2007). Para o movimento social a pesca artesanal se apresenta como uma atividade ambiental, social, cultural, econômica e política. Destaca-se que cada vez mais é política, pois se insere em um campo de disputas, que se dão na esfera local, frente ao avanço de outras atividades econômicas, em esfera nacional, frente às políticas de Estado, e esfera Global, questionando os efeitos da globalização sobre as comunidades e ecossistemas. Na perspectiva do MPP, o centro da luta política é o território tradicional. 
Maldonado (1986) caracteriza a pesca artesanal pela modesta tecnologia empregada na captura e pelo baixo custo da produção, que se dá através do trabalho realizado por meio de relações de parentesco e compadrio, sem vínculo empregatício entre pescadores. Entende que parte da produção é consumida pela própria família, onde a pesca é a principal fonte de renda, embora utilizem fontes complementares (pedreiro, jardineiro, caseiro, empregada doméstica, etc.). A autora ainda enaltece que apesar da utilização de algumas tecnologias, em comparação com a pesca industrial, a pesca artesanal não se destaca como atividade predatória.

Diegues (2004) distingue a transição entre pescadores-lavradores e pescadores artesanais (profissionais). Os pescadores artesanais são entendidos como trabalhadores da pequena produção mercantil ampliada. Nesse sentido destaca-se mudanças como: o grupo doméstico não constitui mais a base das unidades de produção e cooperação. A atividade pesqueira passa a ser a principal fonte de renda, e os padrões de distribuição entre a tripulação passam a ser menos igualitários. É necessário o conhecimento cada vez mais especifico sobre os ambientes lacustres, costeiros e marinhos. A posse dos instrumentos de trabalho definem o papel do pescador na organização produtiva. São introduzidas novas técnologias de navegação, captura e armazenagem. E as relações de comercialização vão sendo alteradas com a inserção de firmas.

Ressalta-se que Diegues (2004) apresenta o pescador, na perspectiva profissional. Essas transformações do pescador-lavrador (1983) da pequena produção mercantil, para o pescador profissional da pequena produção mercantil ampliada (2004) se dá em decorrência da expulsão dos pescadores de suas terras e progressiva urbanização, que foi afastando os pescadores da possibilidade de outras atividades de subsistência como a agricultura, que permitiam o sustento dos pescadores quando não podiam ir ao mar.

Assim, o autor compreende que cada vez mais a atividade se desenvolve como comercial:

Desta forma o pescador passa a se reproduzir e reproduzir suas condições de existência na pesca, voltada fundamentalmente para o comércio, o mercado é o objetivo de sua atividade, ainda que o "balaio" ou cesto de peixe para autoconsumo separado antes da partilha, constitua uma das bases da sua sobrevivência e de sua família (DIEGUES, 2004, p.137).

Contudo, o autor também expõe permanências:

No entando o excedente reduzido e irregular, a baixa capacidade de acumulação, a dependêmcia total vis- $a$-vis do intermediário, a propriedade dos meios de produção o domínio de um saber pescar baseado na experiência (e que constitui sua profissão) são elementos que caracterizam ainda a "pequena pesca mercantil" (DIEGUES, 2004, p.137). 
Quando a relação entre concepções do Estado, do movimento social e da academia, se observa consensos e discensos. Ressalta-se a enfase dada à pesca artesanal dada no processo de captura, tanto por Diegues, quanto por Maldonado. Contudo Diegues, abordando a categoria "trabalho" estabelece a compreensão de pesca e pescadores na perspectiva profissional e tendência comercial. Nesse sentido, dialoga com a lei, que concebe a pesca a partir das relações de produção e comerciais.

Destaca-se que a obra de Diegues é ampla, e não se limita a essa análise, contudo, é importante enaltecer que a perspectiva apresentada não condiz com a abordagem do movimento social. No entanto, é fundamental enfatizar que Diegues apresenta uma transição do pescadorlavrador para o pescador artesanal profissional. Nesse sentido se observa, a partir do movimento social, a pluralidade de possibilidades de ser pescador entre esse dois momentos. Além disso, Diegues dialoga com o movimento social, quando associa as tranformações na pesca às expropriações de terras das comunidades e avanço do urbano. Sendo assim, para a permanência da pesca artesanal nos moldes apresentados pelo movimento social, é fundamental a presença do território, para a promoção de outras atividades de subsistência, reprodução social e cultural das comunidades. Desta forma, pesca artesanal, comunidade e território são concepções que devem ser consideradas em mutua relação.

A pesca artesanal é compreendida como uma atividade extrativista, artesanal e territorial, para fins de subsistência e comercialização, que se constitui a partir de saberes e fazeres tradicionais. Isso implica no conhecimento e respeito aos ciclos e limites da natureza, e no uso de apetrechos de baixo impacto ambiental. É composta por diversos, interdependentes e inseparáveis fazeres, como a captura, construção e manutenção de apetrechos de pesca e embarcações, manuseio, beneficiamento e venda do pescado, ensino das artes de pesca, etc. Devido a piracema, escassez de pescado, ou condições ambientais, eventualmente a pescaria é interrompida, e os pescadores incluem outras atividades para a subsistência das comunidades. As embarcações de pequeno porte e a pesca desembarcada, incluindo a mariscagem, resultam na maior dependência dos pescadores aos recursos locais, o que, conjuntamente com outros aspectos concretos e abstratos, resulta na territorialização das comunidades. Promove a produção de alimentos, que contribui com a segurança alimentar das comunidades e sociedade geral, e importantes serviços ambientais, por meio do manejo dos ecossistemas que integram o território tradicional. 
Os pescadores artesanais são sujeitos de direitos individuais e coletivos. Estão inseridos de forma nas diversas atividades que compõem a pesca artesanal, por meio de relações e vínculos familiares e comunitários de produção, interdependência econômica, ambientais e culturais, entre outros, que se estabelecem no território tradicional. Têm na pesca principal atividade profissional e constituição do modo de viver, inseparavelmente, cuja noção de autonomia e liberdade são características. Sendo assim, não se definem a partir de critérios da legislação ou pela posse de documentos específicos, mas por saberes e fazeres aprendidos no âmbito comunitário, na relação com o ambiente. Por isso, podem se autodeterminar como membros de comunidades tradicionais, reivindicando direitos de reconhecimento, participação, e uso do território tradicional. Bem como políticas públicas próprias, principalmente trabalhistas e previdenciárias, a partir das características das atividades integram a pesca artesanal.

\section{Comunidades e saberes tradicionais}

A pesca artesanal, na perspectiva exposta na tese, depende da presença da comunidade tradicional no território tradicional. Para avançar nessa discussão serão destacadas concepções de comunidade tradicionais, a partir do Estado, do movimento social e da academia. Então serão discutidos os saberes tradicionais. Ressalta-se que algumas das proposições presentes nessa discussão tiveram origem na dissertação de mestrado "Gestão Compartilhada dos Territórios da Pesca Artesanal: fórum Delta do Jacuí".

O Brasil enquanto signatário da Convenção 169 da Organização Internacional do Trabalho (OIT, 2011) compreende: "povos tribais em países independentes cujas condições sociais, culturais e econômicas os distingam de outros segmentos da comunidade nacional e cuja situação seja regida, total ou parcialmente, por seus próprios costumes ou tradições ou por uma legislação ou regulações especiais". Ainda propõe que "A autoidentificação como indígena ou tribal deverá ser considerada um critério fundamental para a definição dos grupos aos quais se aplicam as disposições da presente Convenção".

$\mathrm{Na}$ legislação federal a concepção de povos tribais foi ampliada para povos e comunidade tradicionais a partir do Decreto No 6.040 de 2007 (BRASIL, 2007A), que institui a Política Nacional de Desenvolvimento Sustentável dos Povos e Comunidades Tradicionais. Nestas Comunidades tradicionais constituem:

Grupos culturalmente diferenciados e que se reconhecem como tais, que possuem formas próprias de organização social, que ocupam e usam territórios e recursos naturais como condição para sua reprodução cultural, social, 
religiosa, ancestral e econômica, utilizando conhecimentos, inovações e práticas gerados e transmitidos pela tradição.

O Movimento dos Pescadores e Pescadoras Artesanais compreende como comunidades tradicionais pesqueiras (MPP, 2012):

Os grupos sociais, segundo critérios de autoidentificação, que tem na pesca artesanal elemento preponderante do seu modo de vida, dotados de relações territoriais específicas referidas à atividade pesqueira, bem como a outras atividades comunitárias e familiares, com base em conhecimentos tradicionais próprios e no acesso e usufruto de recursos naturais compartilhados.

Ressalta-se que em linhas gerais há congruências entre as compreensões da OIT 169, Governo Federal e movimento social. Contudo, o Decreto $N^{\circ} 6.040$ de 2007 limita o reconhecimento dos territórios tradicionais aos povos indígenas e quilombolas. Já o MPP associa o conceito de comunidade tradicional às relações territoriais específicas.

Diegues distingue algumas características das comunidades tradicionais pesqueiras: intensas relações simbólicas com a terra e o mar; ligação com o território em que o grupo se reproduz socialmente; relevância das atividades de subsistência; acumulação reduzida de capital; papel da unidade familiar e das relações sociais de parentesco; tecnologias artesanais e menos impactantes; fraco poder político e dependência política e econômica das cidades; saberes, símbolos e mitos da pesca transmitidos oralmente, modos de viver expressos na identidade social e cultural; pela visão de mundo e linguagem distinta da urbano-industrial (DIEGUES, 2004, p. 197).

Entende-se que, as comunidades tradicionais pesqueiras garantem a sua reprodução social por meio do manejo ou gerenciamento pesqueiro que, para a apropriação social dos ambientes aquáticos, podem ser entendidos como um conjunto de práticas culturais, de intervenção na natureza, na manipulação de componentes orgânicos e inorgânicos. Nesse processo, enquanto grupo social, eles podem, racionalmente ou não, regulamentar o acesso aos recursos, controlando artes de pesca, ou impedindo a entrada de pescadores de outras áreas (DIEGUES, 2004, p. 203-204).

Prost (2007, p. 146) frisa que os modos de viver dessas comunidades tradicionais não devem ser considerados como fenômenos cristalizados no tempo, pois integram traços de modernidade. Desta forma, como enfatiza Santos (2002) pode-se compreender a relação tradicional/moderno, por meio da tradução intercultural, sendo possível conceber a presença do moderno no tradicional sem reduzi-lo ao moderno. Mudanças e permanências se evidenciam no processo de apropriação social do mar que, nesse contexto, não é somente um espaço físico, 
mas, também, o resultado de práticas culturais, onde os grupos de pescadores artesanais se reproduzem material e simbolicamente (DIEGUES, 2004, p. 205). Tal relação com o ambiente se dá a partir de saberes tradicionais.

No âmbito das comunidades tradicionais é fundamental retomar a discussão dos saberes/conhecimentos tradicionais. Os saberes tradicionais das comunidades pesqueiras se substantificam em um conjunto de conceitos e imagens, produzidos e usados pelos pescadores artesanais, que são transmitidos oralmente (DIEGUES, 2004, p. 196). Logo, são repassados através de gerações por transmissão cultural ficando mais evidente quando há continuidade de uso de recursos em um determinado ambiente (BERKES, et al 2006, p. 55). Por mais que, geralmente, não seja um saber escrito, está inscrito nos modos de viver e nas práticas tradicionais, podendo muitas vezes resultar em instituições informais que influenciam a dinâmica social.

A elaboração, o acúmulo e a dinâmica transformadora dos saberes tradicionais, na pesca, implicam em processos que ocorrem por meio da adaptação (BERKES, et al., 2006, p. 55) e da relação entre os indivíduos, sociedades, entre si, e com o ambiente (lacustre, fluvial e marinho). Assim, expressam práticas cognitivas e culturais, habilidades práticas e saber-fazer (DIEGUES, 2004, p. 196). Entende-se que essas práticas se diferenciam das demais quanto ao conteúdo subjetivo inerente ao processo de autoidentificação dos indivíduos, do grupo e da relação de simbiose que estabelecem com a natureza.

Essa relação mais harmônica com a natureza, por vezes, implica no entendimento preconceituoso de que as sociedades tradicionais são destituídas de intencionalidades quando estabelecem relações ambientais. Contudo o próprio entendimento de saber tradicional pressupõe o objetivo de uso de determinado recurso ambiental (BERKES, et al., 2006, p. 55). Esta dimensão objetiva, nas sociedades extrativistas, proporciona a reprodução do modo tradicional de viver (DIEGUES, 2004, p. 196). Assim, entende-se que o saber tradicional, no âmbito da pesca, é concebido como as estratégias de uso dos recursos ambientais, em um regime de apropriação que garantam os modos de viver das sociedades tradicionais e, por isso, a perenidade dos mesmos.

Em De Paula (2013) ressaltou-se a importância de distinguir saberes tradicionais de conhecimentos tradicionais, para destacar que a ciência não consegue expor o saber tradicional na complexidade em que é tramado. Já o conhecimento tradicional é possível de ser apreendido, por meio do trabalho da tradução intercultural (SANTOS, 2002). Nesse processo se constrói 
inteligibilidade reciproca sobre saberes e práticas entre o "científico" e o tradicional, reconhecendo ambos como incompletos e possíveis de serem enriquecidos por meio do diálogo.

É fundamental enaltecer que não há um modelo de comunidade tradicional dentro da perspectiva que vem sendo apresentada. Nesse sentido utiliza-se a concepções de sociedade e comunidade tradicional pesqueira. Assim é possível distinguir, sem separar as comunidades de pescadores, dentro da sociedade pesqueira geral. Nos espaços, onde os pescadores dialogam com instituições governamentais e com outros atores sociais, prevalece a noção de sociedade tradicional pesqueira, uma vez que as comunidades se juntam para alcançar seus objetivos frente a esses outros atores. Já no diálogo comunitário, que se refere aos saberes e fazeres intrínsecos a comunidade, ou intercomunitário, sobre o manejo de territórios de uso comum, compreende-se que prevalece a noção de comunidade tradicional pesqueira. Já em discussões mais amplas como a crise ambiental planetária, em que se busca estabelecer um contraponto à sociedade capitalista, sugere-se a compreensão plural de sociedades tradicionais uma vez que o contexto deve integrar pescadores, indígenas, remanescentes de quilombolas, extrativistas, camponeses, etc. Essa relação entre sociedade e comunidades tradicionais de pescadores expõe a complexidade inerente à relação entre as partes e o todo.

Ressalta-se que a compreensão dos saberes tradicionais e dos saberes ambientais propostos por Leff $(2006,2007)$ dialogam. Contudo pretende-se enfatizar que os saberes tradicionais são construções comuntiárias e que também expressam estratégias de apropriação dos recursos do ambiente, que resultam em territorialidades das comunidades tradicionais, podendo, inclusive resultar na constituição de territórios a partir de situações de disputas e conflitos entre pescadores artesanais, e deles com outras atividades econômicas.

Nesse sentido, o saber está intrinsecamente relacionado ao uso e apropriação, como entende Raffestin (1996) e sua efetivação se dá por meio da técnica, que é elaborada a dentro de um "sistema cultural". Como destacam Diegues (2004) e Berkes et al. (2006) na pesca os saberes tradicionais são elaborados a partir da experiência, com uma determinada intencionalidade, e são transmitidos ao longo de gerações.

Assim, compreende-se o conhecimento tradicional como um conceito híbrido que integra dimensões ambientais e territoriais. Essa abordagem expõe o dinamismo de transformação dos saberes, que no passado eram reelaborados na medida em que ocorriam mudanças no ambiente e de acordo com o tempo da natureza, e que na contemporaneidade, com a aceleração da transfiguração da natureza (SUERTEGARAY, 2001, 2002), foram sendo erodidos, mas se reinventam em um quadro de conflitos e disputas territoriais. 
Os saberes tradicionais dos pescadores artesanais superam a dicotomia entre saberes e fazeres, e expõe o movimento de transformações da sociedade/comunidade e do ambiente/território. São transmitidos pela oralidade, ao longo de gerações, por meio da cultura, se inscrevem nos modos de viver das comunidades e expressam técnicas próprias. A partir da tradução intercultural, pode-se compreender a transformação desses conhecimentos a partir do avanço da modernização. Entende-se que intervenções na natureza, tem convertido os saberes ambientais em saberes territoriais. Isto, por que integram, em vez de adaptações ao ambiente, intencionalidades e estratégias de apropriação e resistência para se manter no território tradicional. Nesse sentido, o saber constitui um poder. Além da expressão local, esse poder se projeta na ciência, quando expõem os limites da racionalidade científica moderna (ocidental), e se insere o conhecimento tradicional "territorial" na construção de epistemologias contrahegemônicas.

É difícil estabelecer uma definição de comunidades pesqueiras, pois com o direito de autoidentificação, são as próprias que se apresentam, enquanto povos e comunidades tradicionais. Contudo, apresentam-se alguns elementos, que são mais ou menos, evidentes em tais comunidades. Esses aspectos são organização social, tradicionalidade e vínculo com o território. Constituem grupos sociais diferenciados pela cultura (costumes e tradições), cujos a pesca se apresenta como elemento preponderante no modo de viver. Por meio de saberes tradicionais, apropriam-se dos recursos do ambiente e constituem territorialidades e territórios. Estabelecem governança própria, por meio de acordos e pactos criados em relações sociais e de parentesco. O território comunal, de usufruto dos recursos, é estabelecido a partir de relações simbólicas e concretas com a terra e o mar, inesperadamente, e constitui condição para a reprodução social, cultural, religiosa, ancestral e econômica destas comunidades.

\section{Territorialidades e territórios tradicionais}

Como vem sendo apresentado na tese, a busca pelo entendimento dos territórios e territorialidades das comunidades tradicionais de pescadores artesanais tem orientado trabalhos de diversos geógrafos brasileiros. Nesse momento, a compreensão será estabelecida a partir da ecogênese territorial proposta por Raffestin (1986), onde a delimitação, a centralização e a

comunicação são o cerne do processo de territorialização, desterritorialização e reterritorialização. Retomando as invariantes territoriais é relevante compreender a dinâmica, neste momento interna de criação e regulamentação das "reservas", pelas comunidades tradicionais de pescadores, por meio de nós, malhas e rede (RAFFESTIN, 1986C). 
Parte-se de um quadro de natureza (MOSCOVICI, 1968) em que não se expressa o território. Neste os pescadores artesanais fazem uso dos recursos do ambiente, por meio do saber ambiental que por sua vez incita no manejo, mas sem concorrências entre eles. Esse estágio zero da ecogênese territorial, corresponde a primazia das relações com a natureza, sobre as relações sociais de uso do ambiente, o que Suertegaray (2002) chama de "território da natureza". Nesse estágio, as territorialidades se expressam a partir do conhecimento que se estabelece sobre o espaço para o acesso aos recursos. Assim, se relaciona condições ambientais, com artes de pesca (técnicas e apetrechos). A estratégia de apropriação que se manifesta é o saber, que é compartilhado na comunidade.

Neste momento o território tradicional não se expressa como uma malha delimitada, as redes ligam os nós das áreas de pesca com os das áreas de moradia de forma fluída, muito influenciada pela dinâmica da natureza (onde está o peixe). Contudo a proximidade entre área de moradia e de pesca constitui uma característica, pois condições de navegação são limitadas.

No segundo estágio que se visualiza, devido a condições naturais ou de uso, os recursos ambientais não estão tão acessíveis. Isso incita em uma busca maior por recursos ambientais e o saber da sua localização e técnica de obtenção constitui-se em poder. Contudo no âmbito da comunidade o poder não implica em domínio, mas o saber é compartilhado, mediante acordos verbais de uso. Sob a perspectiva relacional esse poder é fluxo, um processo de comunicação bem-sucedida, a partir de objetivos comuns (RAFFESTIN, BARAMPAMA, 1998, p. 64). Nesse momento os pesqueiros se constituem territorialidades. Corresponde a um estágio em que as informações funcionais e regulatórias se combinam (RAFFESTIN, 1996). Entende-se que há soberania da comunidade, pois mantém-se o tempo da produção corresponde ao tempo do consumo (TAPIA, 2008).

Nesse momento a área que constitui arranjo territorial já pode ser melhor identificada. Os nós que constituem os pesqueiros tradicionais são ligados por redes (conhecidas no âmbito comunitário), e estão relacionados com o nó do espaço de moradia. Nesse sentido é importante destacar a importância da rede como resultado de um saber, que incita regras de uso.

O terceiro estágio corresponde ao contexto em que devido à redução dos recursos pesqueiros e/ou a pressão pelo aumento da produção perspectiva, os saberes que proporcionavam o uso comum, convertem-se em estratégias de apropriação e domínio. Nesse cenário são estabelecidas disputas por recursos, que podem resultar em impactos e conflitos no âmbito da comunidade ou intercomunitário. O poder se apresenta como atributo, adquirido, mantido e perdido através de atores (RAFFESTIN, BARAMPAMA, 1998). Realiza-se o que 
Suertegaray (2002) entende como "a natureza do território", pois as relações de poder se impõem sobre os saberes e relações sociais. No âmbito da comunidade as tensões são decorrentes do desrespeito às regras estabelecidas, evidenciando fissuras e erosão do conhecimento tradicional. Entre comunidades, frequentemente há a reivindicação do direito de uso exclusivo do território, estabelecendo limites, bem como estratégias de manutenção desses limites. No âmbito da sociedade pesqueira há cisões entre comunidades, que comprometem a articulação entre as mesmas a partir de objetivos comuns.

Nesse estágio, as disputas intensas pelos nós (pesqueiros), faz com que os mesmos sejam mais raros. Igualmente o saber sobre sua localização constitui um poder que nem sempre é partilhado, mesmo no âmbito comunitário. Em alguns contextos são estabelecidas estratégias para dificultar o acesso a esses nós. Frente as disputas entre comunidades, a malha que corresponde ao território comunitário é cada vez mais definida, estabelecendo distinções ao acesso de quem está dentro e fora.

Destaca-se que na pesca artesanal brasileira coexistem esses estágios dependendo das condições ambientais dos corpos d'água, da presença de recursos pesqueiros, do número de pescadores, da coesão social, etc. Observa-se no estágio atual a tentativa de retorno ao segundo estágio apresentado, contudo para além das tensões territoriais existentes na pesca acrescentase a influência dos territórios das instituições e o avanço de atividade econômicas sobre a o território tradicional.

As territorialidades da pesca artesanal são evidentes no âmbito das comunidades e integram áreas de pesca e de recursos que são utilizados nas pescarias. Logo, abrangem pesqueiros, matas, manguezais, ranchos de pesca, locais de beneficiamento, etc. O poder se expressa no saber, que é compartilhado entre os comunitários por meio de conhecimentos tradicionais, que suscita práticas de uso. A informação inerente a esse saber é funcional e regulatória, logo ocorre o manejo, por meio de acordos que são elaborados na pesca e no cotidiano. Essas territorialidades são fluidas, conectadas por trajetos, canais, varadouros. Mudam de acordo com a dinâmica da natureza e movimento dos cardumes. No arranjo territorial as áreas terrestres, de trabalho, moradias e vivência também compõem territorialidades, e ocupam o papel de centralidade. Nesta ocorre a comunicação, e se evidencia a gestão comunitária.

Ressalta-se que na perspectiva das territorialidades, pode ocorrer sobreposição de arranjos territoriais de diferentes comunidades sem incidir em conflitos, na medida em que está estabelecido um processo de comunicação (funcional e regulatória) substantivada na troca de 
conhecimentos, bem como no respeito a certas normas, formais e informais. Esse processo de comunicação ocorre no âmbito da sociedade tradicional, onde os diferentes grupos compartilham elementos da tradição, embora com suas distinções. Nessa condição ocorre a multiterritorialidade sem conflitos e disputas.

O território comunitário é substantivado pelas territorialidades tradicionais, terra e água, área da comunidade e pesqueiros. E se caracteriza pelo estabelecimento de relações simétricas de poder (prestígio). A sustentação desse território se dá por meio de um processo comunicacional, que mobiliza todos os atores, que dependem em certo grau dos recursos locais (da reserva), para a manutenção dos mesmos. Assim, a partir da coesão social se estabelecem acordos, normas, processos de monitoramento e sansões construídos no âmbito comunitário e intercomunitário, em processos democráticos participativos (informação funcional e regulatória). Assim, o território expressa as relações comunitárias e com a natureza, sendo fundamental na reprodução social, cultural e econômica das comunidades.

Contudo, na medida em que a reserva (recursos locais) é ameaçada e os acordos passam a ser descumpridos, o território tradicional se transforma. Nesse sentido, os saberes tradicionais, que permitem identificar áreas mais piscosas (informações funcionais) não são mais compartilhados, frente ao declínio do respeito as normas de uso (informações regulatórias), que resultaram em sobre-exploração. O poder, expresso nos conhecimentos sobre a localização e uso dos pesqueiros (reserva), passa a ser domínio de determinadas comunidades ou grupos, que também estabelecem estratégias para a sua manutenção. Ressalta-se que a centralidade se mantém nas áreas de moradia e vivência das comunidades.

Quando as cisões se dão no âmbito comunitário, em contextos de gestão comunitária, a comunicação pode ser reestabelecida. Novos acordos de uso são estabelecidos, na perspectiva da restauração das relações sociais. Assim, internamente, o território volta a ser fluido (não necessariamente em sua totalidade). Geralmente isso se restringe a comunidade que reestabeleceu a comunicação, que tem área de moradia e vivência situada nas proximidades dos pesqueiros. Em De Paula (2013) destacou-se que esses territórios são amplamente reconhecidos no âmbito intercomunitário.

Contudo, compreende-se que há possibilidade de compartilhar territórios, quando é reestabelecido o diálogo entre comunidades. Desta maneira, é necessário um espaço onde a comunicação ocorra, e busquem-se soluções para enfrentar impactos, disputas e conflitos, a partir de objetivos comuns. Isso se realiza no âmbito da gestão compartilhada. 
Ressalta-se que no âmbito comunitário e intercomunitário, na pesca artesanal, prevalece a concepção de território de uso comum, substantivado por diversas territorialidades fluidas. Há uma propensão ao estabelecimento do território, que se realiza quando há contextos de impactos ambientais, disputas no território ou conflitos por território, frente à pesca predatória ou avanço de outras atividades econômicas.

\section{Gestão comunitária e compartilhada}

No âmbito da pesca artesanal o retorno ao segundo estágio tem se dado por meio de resgate da Gestão Comunitária e por iniciativas de Gestão Compartilhada. Em ambos os casos se evidencia a questão territorial como primordial nesses processos de gerenciamento da pesca a partir das comunidades.

Como destacam Berkes et al. (2006, p. 245), a bibliografia disponível contém inúmeros estudos de caso comprovando que as comunidades pesqueiras são capazes de criar suas próprias regras de apropriação e uso dos recursos de que dependem. Entendidas pelo autor como “instituições”, tais normas levam em conta os códigos de conduta que as próprias comunidades definiram. Cordell (2001), por exemplo, apresenta, na Bahia, a gestão comunitária baseada em um código primordial "o respeito".

Na perspectiva do manejo participativo dos recursos naturais, Begossi (2004) destaca o manejo comunitário, como possibilidade de envolver as comunidades de pescadores no manejo da pesca, e reduzir conflitos, por meio de regras sociais e estratégicas de pesca que favorecem a conservação dos recursos pesqueiros, com base em territorialidades (pp. 188-189).

$\mathrm{Na}$ pesca artesanal, existem muitos exemplos que apontam medidas de manejo comunitário que proporcionam a reprodução social dos pescadores artesanais sem depredar o ambiente. Entretanto, o que se observa é que na medida em que o Estado centralizou a gestão do recurso pesqueiro, houve o gradativo afastamento das comunidades de pescadores dos momentos de tomada de decisão (CORDELL, 2001). Em reação às consequências da gestão centralizada (CARDOSO, 2001) têm surgido iniciativas de manejo comunitário, sendo algumas delas reconhecidas pelo próprio Estado em espaços de gestão compartilhada.

Berkes et al. (2006, p. 279) definem gestão compartilhada da pesca como a parceria na qual o governo, a comunidade e os usuários locais do recurso (pescadores), os agentes externos (organizações não governamentais, acadêmicas e instituições de pesquisa) e outros atores relacionados com a pesca e os recursos costeiros (proprietários de embarcações, comerciantes 
de peixes, bancos que concedem empréstimos, estabelecimentos turísticos, etc.) compartilham a responsabilidade e a autoridade por tomar decisões sobre a gestão da pescaria.

A gestão compartilhada implica em relações institucionais multiescalares que possuam diferentes níveis de tomada de decisão, o que proporcionam meios de lidar efetivamente com os aspectos complexos e adaptativos característicos do gerenciamento pesqueiro. Essas relações têm capacidade de acelerar os processos de aprendizagem e comunicação, tendo em vista que aumentam a capacidade dos envolvidos suportarem, de adaptarem-se e de aprenderem com as mudanças. Esses arranjos participativos, no Brasil, têm proporcionado a manutenção de sociedades tradicionais (KALIKOSKI, SEIXAS e ALMUDI, 2009, p. 151). Entretanto, ressalta-se que o sucesso da gestão compartilhada depende do êxito da gestão comunitária, e quanto menor o papel comunidades, maior será o do Estado.

Do ponto de vista da gestão comunitária e/ou compartilhada destaca-se o exemplo dos Acordos de Pesca. Esses tem promovido a gestão da pesca a partir das comunidades e, em alguns casos, com reconhecimento do Estado. A Instrução Normativa IBAMA No 29 de 2002 (BRASIL, 2002) apresenta critérios para a regulamentação dos acordos de pesca. A nuvem de palavras (figura 67) apresenta o conteúdo da referida legislação.

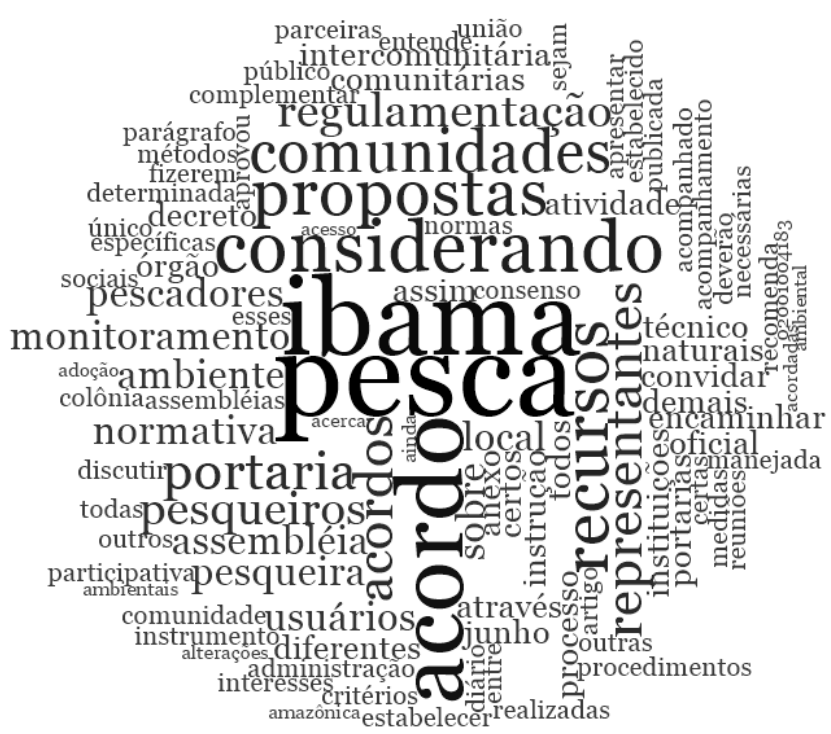

Figura 67: Nuvem de Palavras - IN IBAMA 29 de 2002.

Fonte: Elaborada por De Paula (2018)

A IN IBAMA 29 de 2002 está baseada no manejo comunitário “mostram-se importantes como estratégias de administração pesqueira, os quais reúnem um número significativo de comunidades de pescadores e definem normas específicas, regulando assim a pesca de acordo com os interesses da população local e com a preservação dos estoques pesqueiros”. Destaca a 
construções de regras que "geralmente, limitam o acesso a certos corpos d'água, para certos petrechos, para certas épocas do ano, para certos métodos de pesca e para certas espécies, contribuindo assim para a diminuição da pressão sobre o uso dos recursos pesqueiros em nível local". Ainda que favoreça a "redução de conflitos sociais no curso das pescarias", destaca a "existência de várias Portarias que regulamentam Acordos de Pesca na região amazônica". Assim, a instrução normativa estabelece critérios claros que permitam regulamentar esses Acordos de Pesca, para manter a credibilidade do processo de gestão participativa, ora em desenvolvimento, "como um instrumento complementar de ordenamento pesqueiro e como forma de prevenir danos ambientais e sociais".

Segundo Bocarde e Lima (2008) os Acordos de pesca são instrumentos de ordenamento pesqueiro, elaborados pelos principais utilizadores do recurso pesqueiro, através de reuniões comunitárias e, se aprovados, reconhecidos pelo Estado, através da publicação de Instrução Normativa. Para o autor, tal reconhecimento não implica em apoio legal, mas antes em apoio moral do acordo perante a comunidade. Trata-se dos comunitários respeitarem e fazerem respeitar suas próprias normas (MCGRATH, 1996).

No Artigo $1^{\circ}$ da IN IBAMA 29 de 2002 são apresentados os critérios adotados para a regulamentação de acordos de pesca, definidos no âmbito comunitário:

I) que sejam representativos dos interesses coletivos atuantes sobre os recursos pesqueiros; (pescadores comerciais, de subsistência, ribeirinhos, etc.), na área acerca da qual se refere o Acordo, desde que não comprometam o meio ambiente enquanto patrimônio público a ser assegurado e protegido;

II) que mantenham a exploração sustentável dos recursos pesqueiros, com vistas à valorização da pesca e do pescador;

III) que não estabeleçam privilégios de um grupo sobre outros, ou seja, as restrições de apetrechos, tamanho de embarcação, áreas protegidas, etc., deverão ser aplicáveis a todos os interessados no uso dos recursos;

IV) que tenham viabilidade operacional, principalmente em termos de fiscalização;

V) que não incluam elementos cuja regulamentação seja atribuição exclusiva do poder público, prevista em lei (penalidades, multas, taxas, etc.);

VI) que sejam regulamentados através de Portarias Normativas Complementares às Portarias de normas gerais que disciplinam o exercício da atividade pesqueira em cada bacia hidrográfica.

Diante disso, o objetivo do acordo é estabilizar ou reduzir a pressão sobre os recursos pesqueiros locais. Para tanto, a comunidade cria restrições aos apetrechos de pesca e à capacidade de armazenamento, em vez de delimitar diretamente o tamanho da captura. Além de regular a atividade pesqueira, acordos de pesca, frequentemente, incluem medidas que pretendem conservar habitats considerados importantes para a reprodução das espécies. As 
regras de uso são baseadas no conhecimento tradicional, bem como na viabilidade de monitoramento do acordo (MCGRATH, 1996).

Apesar da instrução normativa que regulamenta os acordos de pesca não fazerem referência direta ao conceito de território, diversos geógrafos têm abordado esse instrumento de gestão comunitária e/ou compartilhada na perspectiva territorial. Entre eles destaca-se Silva (2006), Lima (2008), Guedes (2009), Silva (2009), Cruz (2011), Queiroz (2012) e Rodrigues (2014).

Cruz (2011) apresenta o contexto que levou as comunidades ribeirinhas amazônidas a construírem acordos de pesca:

As áreas de várzeas, os rios, lagos e igarapés da Amazônia tornaram-se objetos de diversas formas de apropriação econômica, a partir da década de 1960, com o processo de modernização conservadora a que a região foi submetida. Essas apropriações vão desde a intensificação da pesca de caráter comercial, e muitas vezes de natureza predatória, até a construção de hidrelétricas, sem falar na apropriação para pecuária e agricultura comercial. Essas novas formas atingiram profundamente a vida daquelas comunidades que historicamente ocuparam essas áreas e, em muitos casos, os modos de vida dessas comunidades foram drasticamente afetados a ponto de ficar comprometida a própria sobrevivência desses grupos. Como forma de resistência e na busca por alternativas a essa nova situação, as comunidades ribeirinhas criam diversas formas de operações, mecanismos, táticas e estratégias de controle e reapropriação dos seus territórios, dentre os quais vale destacar os chamados Acordos Comunitários de Pesca (p.262-263).

Silva (2012) destaca que frente a conflitos relacionados ao uso dos recursos pesqueiros, bem como à falta de gerenciamento desses recursos, na região amazônica foram propostos pelos pescadores regulamentos e normatizações, que posteriormente foram corroborados por instituições públicas que fazem a gestão da pesca. Assim, foram firmados acordos de pesca em diversas localidades da Amazônia.

Cruz (2011) acordos de pesca como estratégias territoriais de apropriação social da natureza. Constituem instrumentos de gestão comunitária dos recursos pesqueiros, por meio de regras de apropriação dos recursos, elaboradas em diálogo com os órgãos responsáveis pela gestão ambiental, através de um processo de cogestão dos recursos pesqueiros (gestão compartilhada). $\mathrm{O}$ autor entende que os acordos de pesca têm "garantindo o controle das comunidades sobre o seus recursos e territórios". "Dessa forma, os acordos de pesca são um mecanismo de democratização da gestão dos recursos pesqueiros” (p.263). 
Para Cruz (2011, p. 265) a "visão geográfica" permite conceber os acordos de pesca como estratégia territorial usada pelas comunidades para "garantir o controle sobre os recursos pesqueiros, sobre os rios, lagos e igarapés na Amazônia, especialmente, nas regiões de várzea.

Partindo dessa leitura - o acordo como estratégia - verificamos que os acordos de pesca buscam atingir um fim específico, que é a garantia do recurso pesqueiro através de uma racionalidade ambiental fundamentada em determinados critérios de sustentabilidade que garantam a reprodução dessas comunidades. Para atingir esse fim, o acordo, como uma estratégia, implica na construção de um repertório de ações para impedir que outros grupos sociais se apropriem dos recursos pesqueiros. Nesse processo, se instituem formas de controle, regras de uso, formas de fiscalização e de classificação social, que permitem o controle físico e simbólico de uma determinada comunidade sobre um determinado espaço considerado importante do ponto de vista estratégico para garantir os recursos. É a partir desse registro que iremos analisar os acordos de pesca como estratégia territorial de reapropriação social do rio, como processo de territorialização dos ribeirinhos e pescadores na constituição de territórios coletivos de autogestão (p. 266).

Silva (2012, p.119) também destaca os acordos de pesca no sentido da gestão do território. Entende que "a partir dos acordos de pesca, os pescadores são reconhecidos pelo Estado como corresponsáveis na gestão dos recursos pesqueiros que estão disponíveis no território juntamente com os órgãos responsáveis pela fiscalização e legalização da atividade nos territórios onde a pesca ocorre". Nesse processo de co-gestão, ou co-manejo como uma forma de evidenciar o conhecimento tradicional dos pescadores por meio do compartilhamento de responsabilidades, onde o Governo e as comunidades dividem o gerenciamento dos recursos naturais locais.

Já Silva (2009) destaca que tais acordos são inerentes ao manejo tradicional dos recursos pesqueiros presentes no território apropriado:

As formas coletivas organizadas criam esses instrumentos de manejo dos
recursos pesqueiros não somente nas áreas lacustres, mas também em trechos
de rios piscosos, que pressupõem o seu domínio no território, uma relação de
poder sob os recursos naturais. Estes instrumentos de gestão se baseiam na
apropriação histórica dos territórios de pesca em questão, tendo legitimidade
para o estabelecimento de normas e princípios para a regulação dos recursos.
É o pensamento de pertencimento de uma porção do espaço, cuidando deste
como sendo o proprietário coletivo (p.113).

Contudo, é importante enaltecer que a existência de tais acordos independe da sua regularização pelos órgãos oficiais. Guedes (2009) destaca que a partir de uma situação de crise na pesca os "pescadores cajuunenses e ceuenses, junto a Colônia de Pescadores de Soure Z1, criaram-se um acordo que não está escrito na forma da lei, mas é legitimado pelos pescadores". 
Entre as regras foi proibida a pesca com rede nesse território, e foi delimitado através de balizas "o território de pesca proibida e as áreas sujeitas à pesca com cacuris e tarrafas". O acordo apresentado também integra monitoramento e sanções:

\begin{abstract}
Nesse território de pesca proibida, todos os pescadores são responsáveis pela fiscalização dos possíveis contraventores do acordo da pesca no território proibido. Mesmo assim, desde o início da criação do acordo da pesca proibida têm sido constantes os casos em que alguns pescadores tentam infringir o acordo, desenvolvendo a pesca nesses territórios que pelos constantes conflitos já ocorridos, ao logo do tempo, as coletividades locais denominaram de "ponta da encrenca". São nesse espaço que há mais de cem anos são apreendidos os instrumentos de pesca dos contraventores e levados até a vila Cajuúna, onde são queimados, cortados e extraviados na presença do pescador que descumpriu o acordo de proibição (p.131).
\end{abstract}

Diante do exposto se observa os acordos de pesca como possibilidade da gestão comunitária e/ou compartilhada da pesca artesanal, com base nos territórios tradicionais. Assim, se reestabelece a relação entre autonomia e território (RAFFESTIN, 1986), que se expressa na incorporação das noções de limite, de centralidade no local de coleta (pesqueiro) e circulação na gestão da pesca.

Para enfatizar a apropriação social da natureza, destaca-se a gestão (inter)comunitária do território. Neste caso, amplia-se a ideia de recurso pesqueiro, na medida em que se entende, que a gestão não se restringe ao pescado, mas integra corpos d'água, manguezais, matas ciliares, etc. Envolve também artes de pesca, relações entre pescadores na pesca, e modo de viver comunitário. Logo, enfrenta as diversas causas de impactos ambientais, assim como os conflitos decorrentes das disputas pelo uso de tais recursos presentes no território tradicional. Nesta gestão democrática, a governança se estabelece a partir das comunidades, que têm condições de elaborar instituições (acordos, regras, monitoramento, sanções), que proporcionam a gestão ambiental, bem como a resolução de conflitos no território tradicional. A comunicação baseada nos conhecimentos tradicionais "territoriais", associa objetivos comuns, que são fundamentais na elaboração de estratégias, congruentes com a realidade do território, e respeito as mesmas.

Já a gestão compartilhada só é possível se a gestão comunitária é bem-sucedida e incentivada. Esta integra diversos territórios e territorialidades de comunidades tradicionais. Nesse contexto, diversas comunidades discutem a gestão do território comum. Tal união se dá principalmente para o enfrentamento de problemáticas multiescalares e acessar outros níveis de tomada de decisão. As comunidades se reúnem para fortalecer as reivindicações, e, com base no conhecimento tradicional "territorial" dialogam com agentes públicos e outros atores envolvidos com tais problemáticas. A gestão compartilhada dos "territórios" da pesca artesanal 
é mais efetiva e democrática na medida em que amplia a participação das comunidades nos processos de tomadas de decisão, bem como proporciona às comunidades a possibilidade de apropriação e gestão do território tradicional.

\subsubsection{Territórios das Instituições}

Destacou-se a constituição e dinâmica das territorialidades e territórios das comunidades tradicionais pesqueiras. Contudo, é importante enfatizar que esses territórios são sobrepostos por outros territórios. Nesse momento, enfatiza-se os territórios das Instituições do Estado e também se retoma a expressão territorial das entidades que representam os pescadores artesanais.

Ressalta-se que além dos indivíduos, deve ser compreendido o papel das instituições no âmbito nas relações de conflitos no âmbito da abordagem territorial. Heidrich (2009) enfatiza o processo de redefinição de uso sobre as áreas anteriormente ocupadas pelas comunidades. Assim, é fundamental compreende os conflitos territoriais, que envolvem o entrechoque de poderes políticos e sociais (2010).

A Constituição Federal de 1988 no Artigo 24 atribui à União, aos Estados e Distrito Federal legislar sobre a pesca. Com base na Política Nacional de Desenvolvimento Sustentável da Aquicultura e da Pesca - Lei No 11.959 de 2009 - foi criado o Decreto No 6.981 de 2009 (BRASIL, 2009A) que "regulamenta a competência conjunta dos Ministérios da Pesca e Aquicultura e do Meio Ambiente para, sob a coordenação do primeiro, com base nos melhores dados científicos e existentes, fixar as normas, critérios, padrões e medidas de ordenamento do uso sustentável dos recursos pesqueiros". Na atualidade com a extinção do Ministério da Pesca e Aquicultura, suas funções estão sujeitas a Secretaria Especial de Aquicultura e Pesca - SEAP, vinculada à Presidência da República.

Em decorrência desta lei, também foi estabelecida a Portaria Interministerial MPA/MMA nº 5 de 2015 (BRASIL, 2015D), que regulamenta o "Sistema de Gestão Compartilhada do uso sustentável dos recursos pesqueiros" (Artigo $1^{\circ}$ ).

Na perspectiva da Gestão Ambiental da Pesca pelos estados é importante ressaltar a Lei Complementar No 140 de 2011 (BRASIL, 2011B) que estabelece no Artigo $1^{\circ}$ a "cooperação entre a União, os Estados, o Distrito Federal e os Municípios nas ações administrativas decorrentes do exercício da competência comum relativas à proteção das paisagens naturais notáveis, à proteção do meio ambiente, ao combate à poluição em qualquer de suas formas e à preservação das florestas, da fauna e da flora". No Artigo $8^{\circ}$ é apresentada como ação 
administrativa dos estados "XX - exercer o controle ambiental da pesca em âmbito estadual". Ressalta-se que a ação do ente da federação, nos termos da lei, pode ser supletiva, quando "substitui ao ente federativo originariamente detentor das atribuições" ou subsidiária, quando "visa a auxiliar no desempenho das atribuições decorrentes das competências comuns, quando solicitado pelo ente federativo originariamente detentor das atribuições" (Artigo $2^{\circ}$ ).

Ressalta-se que as atividades pesqueiras estão sujeitas, como atividade que utiliza recursos naturais, além das instituições que promovem a gestão da pesca, às instituições e leis que promovem a gestão ambiental. Sendo assim, a pesca está sujeita aos órgãos nacionais, estaduais e municipais que compõem o Sistema Nacional do Meio Ambiente (SISNAMA), instituído pela Lei N ${ }^{\circ} 6.938$ de 1981 (BRASIL, 1981). Entre as leis destaca-se a Lei de Crimes Ambientais - Lei No 9.605, de 1998 (BRASIL, 1998), e o Sistema Nacional de Unidade de Conservação - SNUC (BRASIL, 2000).

Ainda por utilizar corpos d'água para a realização de suas atividades, a pesca artesanal, é submetida aos órgãos nacionais, estaduais e municipais de gestão do Sistema Nacional de Gerenciamento de Recursos Hídricos - SINGREH -, instituído pela Lei No 9.433 de 1997 (BRASIL, 1997). Destaca-se que nessa lei a "bacia hidrográfica é a unidade territorial para implementação da Política Nacional de Recursos Hídricos e atuação do Sistema Nacional de Gerenciamento de Recursos Hídricos" (Título I, Capítulo I, Artigo I).

Com base nesses exemplos, mas que poderia agregar muitos outros, observa-se a sobreposição de políticas, leis e instituições sobre os territórios da pesca artesanal. Acrescentase que há a competência conjunta entre gestão da pesca e do ambiente, com o Decreto $\mathrm{N}^{\circ} 6.981$ de 2009. Contudo, se observa que as Política Nacional de Desenvolvimento Sustentável da Aquicultura e da Pesca, Política Nacional do Meio Ambiente e Política Nacional de Recursos Hídricos, frequentemente se sobrepõem e não dialogam, e separadamente não estão conseguindo impedir o avanço de impactos ambientais, disputas no território e conflitos por território.

Entende-se que a maioria das causas de impacto ambiental, apontados nas dissertações e teses, dependem mais da gestão ambiental e dos recursos hídricos, do que de normatizações específicas para a pesca. Contudo, esses impactos se refletem principalmente sobre as comunidades pesqueiras, que dependem dos recursos locais. Sendo assim, a falta de efetividade das Políticas Nacionais do Meio Ambiente e dos Recursos Hídricos tem levado à extinção de territórios tradicionais pesqueiros. Além disso, os órgãos colegiados propostos por tais políticas, como os Comitês de Bacias Hidrográficas, frequentemente são dominados por agentes 
promotores de outras atividades econômicas, e o discurso técnico não favorece o diálogo com os saberes tradicionais dos pescadores, que são desprestigiados.

Do ponto de vista das disputas no território, cabe destacar que muitas vezes as atividades que disputam recursos com os pescadores artesanais são licenciadas pelos órgãos responsáveis, que não mensuram o impacto desses usos sobre a pesca artesanal. Quando ocorrem de forma ilegal, essas atividades, não apresentam resistência frente as multas impostas pelos órgãos ambientais, que muitas vezes são contestadas no âmbito administrativo e reduzidas ou revogadas. A gestão da pesca, por si, não é capaz de impedir as disputas nos territórios com atividades permitidas e licenciadas pelos órgãos dos SISNAMA e SINGREH.

Os conflitos por território, também envolvem empreendimentos que geralmente foram submetidos aos processos de licenciamento por órgãos ambientais. Contudo, muitas vezes por pressão política, esses empreendimentos são aprovados a partir de proposição de uma série de medidas compensatórias. Entretanto, tais medidas não são capazes de preservar a pesca e os modos de viver das comunidades. Nesses conflitos as comunidades se mobilizam, e em alguns casos os licenciamentos são questionados e suspensos pelo Ministério Público.

Ressalta-se que muitas dessas políticas implicam em normativas que se tivessem efetividade proporcionariam uma melhor sanidade ambiental, que repercutiria positivamente sobre a pesca artesanal. Contudo, frequentemente, encontram limites na execução. Por outro lado, tais políticas influenciam os modos de viver das comunidades de pescadores, impondo normas incompatíveis com a realidade local e que frequentemente não dialogam com seus saberes tradicionais "territoriais", e que resultam na impossibilidade da realização da atividade pesqueira. Pelas limitadas infraestruturas dos pescadores artesanais, sobre eles a fiscalização dessas normas é mais ostensiva, o que resulta na criminalização dos pescadores artesanais.

Na sequência, serão destacados os Sistemas de Gestão Compartilhada do uso sustentável dos recursos pesqueiros e o Sistema Nacional de Unidades de Conservação (UCs), para destacar limites e possibilidades da gestão da pesca e ambiental, respectivamente, e suas consequências sobre os territórios tradicionais das comunidades pesqueiras.

\section{Sistema de Gestão Compartilhada do uso sustentável dos recursos pesqueiros}

Sistema de Gestão Compartilhada para o uso sustentável dos recursos pesqueiros está previsto no Decreto $n^{\circ} 6.981$ de 2009 (BRASIL, 2009B), e tem como objetivo é "subsidiar a elaboração e implementação das normas, critérios, padrões e medidas de ordenamento do uso sustentável dos recursos pesqueiros" (Artigo $3^{\circ}$ ). A Portaria MPA/MMA No 5 de 2015 
(BRASIL, 2015D) regulamenta esse sistema, que é composto pelos seguintes órgãos consultivos: Comitês Permanentes de Gestão para o Uso Sustentável de Recursos Pesqueiros (CPG), Câmaras Técnicas e Grupos de Trabalho, sendo a Comissão Técnica da Gestão Compartilhada dos Recursos Pesqueiros (CTPG) o órgão consultivo e coordenador das atividades do Sistema (Artigo $5^{\circ}$ ). A figura 68 apresenta a nuvem de palavras que expressa à referida portaria:

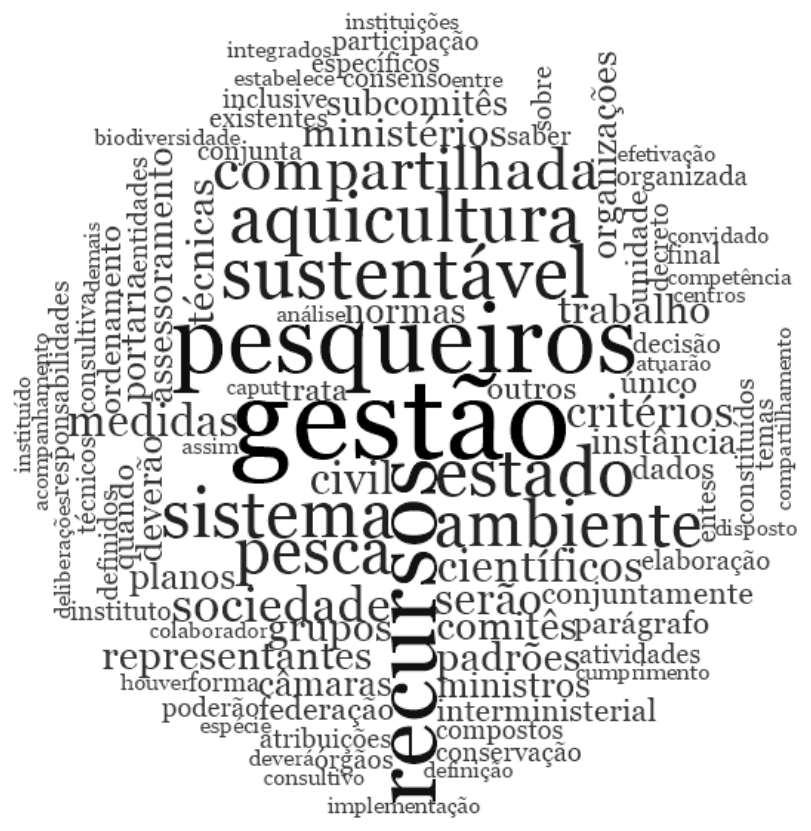

Figura 68: Nuvem de palavras - Portaria MPA MMA No 5 de 2015

Fonte: Elaborada por De Paula (2018).

Como foi apresentado existem diversos níveis de gestão compartilhada, desde processos de consulta, até contextos em que o governo compartilha com as comunidades o poder de tomar decisões sobre a gestão. Contudo, como se observa o sistema é composto por órgãos consultivos. Logo, o governo não compartilha efetivamente o poder de deliberação, mas proporciona possibilidades de consulta. Isso se evidencia nas seguintes definições (Artigo $2^{\circ}$ ):

I - gestão compartilhada: o processo de compartilhamento de responsabilidades e atribuições entre representantes do Estado e da sociedade civil organizada visando subsidiar a elaboração e implementação de normas, critérios, padrões e medidas para o uso sustentável dos recursos pesqueiros; II - sistema de gestão compartilhada: sistema de compartilhamento de responsabilidades e atribuições entre representantes do Estado e da sociedade civil organizada, formado por comitês, câmaras técnicas e grupos de trabalho de caráter consultivo e de assessoramento, constituídos por órgãos do governo de gestão de recursos pesqueiros e pela sociedade formalmente organizada; 
Um outro ponto a destacar é o peso das informações científica para basear as ações do sistema. Das fontes apresentadas, uma delas faz referência aos conhecimentos tradicionais. Trata-se dos dados gerados pelo "pelo saber acumulado por populações tradicionais ou de usuários dos recursos pesqueiros" (Artigo $2^{\circ}$ ). Nesse sentido é importante enaltecer a inserção dos conhecimentos tradicionais, contudo se evidencia primazia das informações científicas.

A organização dos Comitês Permanentes de Gestão para o Uso Sustentável de Recursos Pesqueiros (CPGs) tomou por base espécies e/ou regiões, e grandes bacias hidrográficas. Foram instituído nove CPGs, segundo a nominata que segue: CPG Lagosta (BRASIL, 2010B); CPG de Atuns e Afins (BRASIL, 2011A); CPG Camarões (BRASIL, 2012); CPG Demersais Sudeste e Sul (BRASIL, 2013); CPG Pelágicos Sudeste e Sul (BRASIL;2015E), CPG Centro-Sul (BRASIL, 2015F); CPG Norte (BRASIL, 2015G); CPG Nordeste (BRASIL, 2015, H), CPG Demersais e Pelágicos Norte e Nordeste (BRASIL, 2015I).

Quanto à participação dos pescadores nesse comitê é importante destacar:

Os CPGs deverão ser compostos por representantes de Estado, inclusive, de outros entes da federação e da sociedade civil, de forma paritária, e definidos conjuntamente pelos Ministérios da Pesca e Aquicultura e do Meio Ambiente. $\S 2^{\circ}$ A sociedade civil será representada por:

I - até dez organizações do setor pesqueiro, incluindo até cinco organizações, entidades ou associações de atuação dos pescadores artesanais, com participação majoritária de entidades membros do Conselho Nacional de Aquicultura e Pesca do MPA;

II - duas organizações ambientalistas.

Observa-se, assim, que a representação nacional dos pescadores artesanais é resumida a (até) cinco organizações. Essa composição varia, observa-se, por exemplo, a composição do CPG Pelágicos Sudeste e Sul:

II - representantes da Sociedade Civil Organizada - Setor Produtivo:

a) quatro de Organizações da pesca artesanal, dois de cada região;

b) dois de Organizações dos Armadores de Pesca, um de cada região;

c) dois representantes dos pescadores profissionais, trabalhadores e aquaviários, um de cada região;

d) um de Organizações do setor de comercialização/exportação; e

e) um de Organização das Indústrias de beneficiamento ou conserva.

Ressalta-se a reduzida representação dos pescadores artesanais, dois por região, bem como a predominância de organizações relacionadas ao setor pesqueiro empresarial. Nesse "modelo" a gestão compartilhada consiste na abertura de espaço para a representação da sociedade civil organizada, limitada a consulta. A representação proposta não condiz com a participação inerente aos espaços de gestão comunitária e compartilhada criados pelos 
pescadores, como os Fóruns de Pesca. Assim se estabelece uma democracia representativa, em detrimento da possibilidade da democracia participativa.

Em relação aos subcomitês científicos, que oferecem assessoramento aos CPGs serão integrados "por pesquisadores, técnicos e profissionais com notório saber na área afim e atuarão como instâncias de assessoramento sobre as medidas de ordenamento e uso sustentável dos recursos pesqueiros, com base nos melhores dados técnicos e científicos existentes, assim como no conhecimento tradicional" (Artigo $7^{\circ}$ ).

O sistema também contém "câmaras técnicas serão compostas por representantes de Estado, inclusive, de outros entes da federação e da sociedade civil e integradas por especialistas de notório saber, para análise e proposições sobre temas específicos" (Artigo $8^{\circ}$ ) e Grupos de Trabalho "compostos por representantes de Estado, inclusive, de outros entes da federação e da sociedade civil, podendo ser constituídos por Unidade da Federação ou para análise e proposições sobre temas específicos" (Artigo $9^{\circ}$ ).

Ainda os Planos de Gestão para o Uso Sustentável dos Recursos Pesqueiros "serão, preferencialmente, elaborados, apresentados e aprovados pelo subcomitê científico, diretamente ou sob sua coordenação, devendo ser submetidos aos respectivos CPGs, que os avaliarão e encaminharão para validação na CTGP”. Ressalta-se que estes planos devem, sempre que possível adotar o enfoque ecossistêmico (Artigo 10). Quanto à unidade de gestão o sistema entende "compreende a espécie ou grupo de espécies, o ecossistema, a área geográfica, a bacia hidrográfica, o sistema de produção ou pescaria" (Artigo $2^{\circ}$ ).

Ressalta-se que há indicação de que os Planos de Gestão sejam elaborados pelos subcomitês científicos. Essa medida é bastante centralizadora, e não estimula a construção de planos pelas organizações sociais de pescadores artesanais. Além disso, o enfoque ecossistêmico proposto pelos técnicos, não corresponde ao enfoque territorial característico da gestão comunitária.

\section{Sistema Nacional de Unidades de Conservação -SNUC}

Como já foi apresentado diversos geógrafos tem analisado as tensões geradas devido a instalação de unidades de conservação sobre territórios das comunidades tradicionais pesqueiras (CHAMAS, 2008; FARIAS, 2009; GIANNELLA, 2009; DUMITH, 2012; PÉREZ, 2012, DE PAULA, 2013; SCHEIBEL, 2013; RODRIGUES, 2014; BARBOSA, 2014). Nesse momento, serão enfatizados a sobreposição de unidades de conservação de proteção integral 
sobre os territórios das comunidades pesqueiras, e as possibilidades que se apresentam no âmbito das unidades de uso sustentável, como as Reservas Extrativistas.

A criação e implementação de unidades de conservação, no Brasil, segue as diretrizes da Lei N 9985 de 2000 (BRASIL, 2000) que institui o Sistema Nacional de Unidades de Conservação (figura 69).

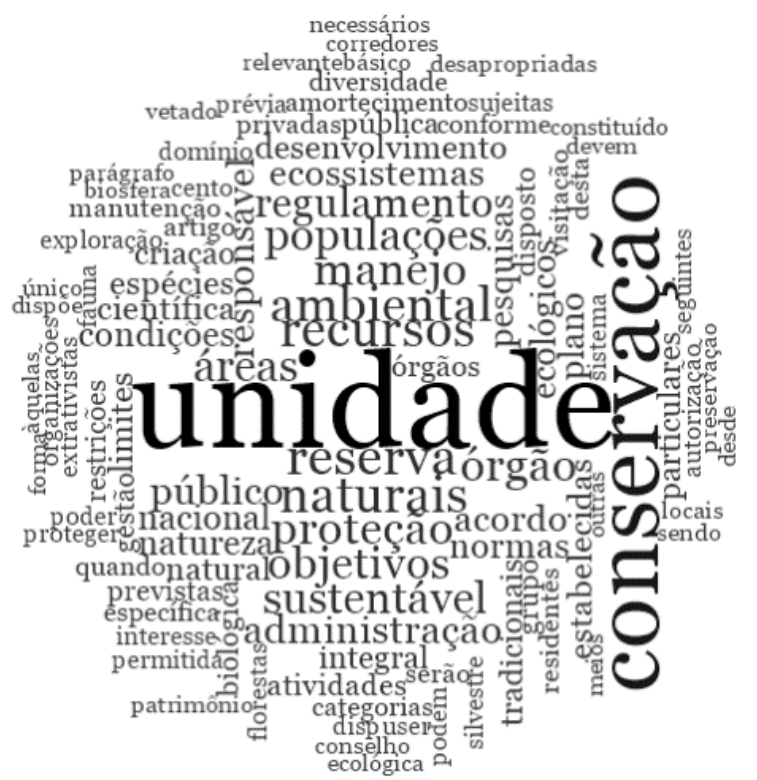

Figura 69: Nuvem de Palavras - Sistema Nacional de Unidades de Conservação (SNUC) Fonte: Elaborado por De Paula (2018)

Nesta lei se entende como unidade de conservação:

I - unidade de conservação: espaço territorial e seus recursos ambientais, incluindo as águas jurisdicionais, com características naturais relevantes, legalmente instituído pelo Poder Público, com objetivos de conservação e limites definidos, sob regime especial de administração, ao qual se aplicam garantias adequadas de proteção $\left(\right.$ Artigo $\left.2^{\circ}\right)$;

O SNUC (Artigo $7^{\circ}$ ) apresenta dois grupos de unidades de conservação. As unidades de proteção integral, cujo objetivo "é preservar a natureza, sendo admitido apenas o uso indireto dos seus recursos naturais, com exceção dos casos previstos nesta Lei”. E as unidades de uso sustentável que visam "compatibilizar a conservação da natureza com o uso sustentável de parcela dos seus recursos naturais".

O grupo de unidades de proteção integral é composto por Estação Ecológica, Reserva Biológica, Parque Nacional, Monumento Natural e Refúgio da Vida Silvestre. Esse tipo de unidade segue a perspectiva da proteção em detrimento da conservação, ou seja, exclui a presença e uso das sociedades (DIEGUES, 2001). Nessa perspectiva é importante enfatizar os 
parques nacionais, onde se evidencia diversos conflitos com comunidades tradicionais de pescadores.

Segundo o SNUC (Artigo $11^{\circ}$ ) os Parques Nacionais (podem ser também Estaduais e Municipais): "tem como objetivo básico a preservação de ecossistemas naturais de grande relevância ecológica e beleza cênica, possibilitando a realização de pesquisas científicas e o desenvolvimento de atividades de educação e interpretação ambiental, de recreação em contato com a natureza e de turismo ecológico".

Um dos principais conflitos que decorrem a instalação de Parques Nacional sobre territórios tradicionais é a prerrogativa da desapropriação, que promove conflitos fundiários. Segundo a referida lei, "O Parque Nacional é de posse e domínio públicos, sendo que as áreas particulares incluídas em seus limites serão desapropriadas, de acordo com o que dispõe a lei (Artigo $11^{\circ}$ ).

Os conflitos com Parques Nacionais por território com os Parques Nacionais são frequentes, como evidenciam De Paula (2013) no Parque Estadual do Delta do Jacuí, Rio Grande do Sul; Farias e Barbosa no Parque Nacional Superagui, Paraná; Costa (2015) no Parque Nacional dos Lençóis Maranhenses, Maranhão; Scheibel (2013) no Parque Nacional dos Campos Gerais, Paraná. Nesses contextos as comunidades resistem e reivindicam o direito de permanecer no território e realizar as atividades tradicionais, por meio de saberes e regras acordadas no âmbito comunitário. Contudo, emergem conflitos devido a regularização fundiário e pelo uso, que muitas vezes resultam na oposição entre gestores e comunitários.

Dentro da malha territorial, das comunidades tradicionais pesqueiras, observa-se mudanças significativas devido a instalação de unidades de conservação. Quando a lei é imposta, essas comunidades deixam de ter acesso aos nós que compõem áreas da pesca e da moradia. As redes estabelecidas a partir do conhecimento tradicional não podem mais ser acessadas. Nesse caso as informações regulatórias, do território da unidade, que se apresentam como restrição e proibição, não dialogam com as informações funcionais e regulatórias das comunidades. Do ponto de vista do uso dos recursos as consequências ao ambiente também se evidenciam, pois, as informações funcionais e regulatórias das comunidades incidiam no manejo dos ecossistemas. Já a imposição de proibições ao mesmo tempo que, desgasta as regras comunitárias, abrem o espaço para o avanço de outros atores que não se comprometem em obedecer tais regras e degradam o território. Ressalta-se que o afastamento dos comunitários da gestão, que ocorre nas unidades de proteção integral, estabelecem um território de exclusão, que encontra resistência nas comunidades que tradicionalmente se apropriariam do território. 
Em outro contexto de unidades de conservação estão as de uso sustentável, que integra Área de Proteção Ambiental; Área de Relevante Interesse Ecológico; Floresta Nacional; Reserva Extrativista; Reserva de Fauna; Reserva de Desenvolvimento Sustentável; e Reserva Particular do Patrimônio Natural. Os geógrafos estão dando uma atenção especial às Reservas Extrativistas - RESEX, entre os diversos trabalhos que abordam essas unidades destaca-se: Dumith (2012) e Figueiredo (2013) na RESEX de Canavieiras, Bahia; Rosário (2009) e Khun (2009) na Reserva Extrativista Baía do Iguape - Bahia; e Barbosa (2014) onde apresenta demanda de criação da RESEX Marinha em Guaraqueçaba-PR.

\begin{abstract}
A Reserva Extrativista é uma área utilizada por populações extrativistas tradicionais, cuja subsistência baseia-se no extrativismo e, complementarmente, na agricultura de subsistência e na criação de animais de pequeno porte, e tem como objetivos básicos proteger os meios de vida e a cultura dessas populações, e assegurar o uso sustentável dos recursos naturais da unidade (Artigo $18^{\circ}$ ).
\end{abstract}

Quando os ecossistemas a serem preservados são lagos, rios e parte da costa, essas são adjetivadas de Reservas Extrativistas Marinhas. A dimensão da gestão territorial se evidencia na pesquisa geográfica sobre essas RESEX. Figueiredo (2013, p.41) entende que são "espaços de uso sustentável cujo objetivo é o ordenamento territorial em comunidades pesqueiras a fim de contribuir com a gestão e a extração dos recursos marítimos pelas populações tradicionais de pescadores e pescadoras artesanais". Dumith (2012) destaca que as Áreas Marinhas Protegidas (AMPs) "vêm permitindo a possibilidade de consolidação de territórios sustentáveis de pesca artesanal. No entanto, nem sempre as AMPs representam um instrumento adequado para o manejo dos sistemas socioecológicos da pesca artesanal, podendo levar a muitos conflitos em seu interior" (p.66).

Barbosa (2014) destaca a dimensão territorial das RESEX, por meio da configuração fundiária:

O modelo da RESEX foi muitas vezes designado pelos próprios sujeitos envolvidos, como a "Reforma Agrária dos Seringueiros". Uma vez que a criação de uma RESEX interfere na questão fundiária da área, assim como os assentamentos de Reforma Agrária, pois desapropria qualquer propriedade particular que por ventura haja na área em questão e legitima toda a área da UC como território tradicional extrativista (p.91).

Ressalta-se que ao priorizar o uso dos recursos pelas comunidades tradicionais, o modelo de RESEX tem permitido a manutenção do ambiente e dos modos de viver. Rosário (2009) exemplifica a conservação dos manguezais "Em contrapartida, o meio ambiente da 
Resex Baía do Iguape encontra-se em bom estado, incluindo ecossistemas aquáticos e florestais, dentre eles, destacando-se o ecossistema de manguezal nas margens da Baía do Iguape que sofre constante influência das marés" (p.26).

A luta pelas Resex Marinhas tem se intensificado nos últimos anos, devido ao avanço de outras atividades econômicas sobre os territórios pesqueiros tradicionais, causando impactos ambientais, disputas no território e conflitos por território. Para fortalecer esse processo foi criada a "Comissão Nacional para o Fortalecimento das Reservas Extrativistas e dos Povos Extrativistas Costeiros e Marinhos - COMFREM" em 2014, cuja missão é: “desenvolver, articular e implementar estratégias visando o reconhecimento e a garantia dos territórios extrativistas tradicionais costeiros e marinhos na dimensão social, cultural, ambiental e econômica, garantindo os seus meios de vida e produção sustentável”. São objetivos da CONFREM:

Lutar pelo reconhecimento e andamento dos processos de solicitação de novas Resex marinhas;

Assegurar o direito a produção do espaço próprio dos extrativistas; Promover o contato entre as 22 Resex espalhadas de norte a sul do país; Garantir a manutenção dos saberes das populações tradicionais pesqueiras; Garantir a conservação dos rios, mares, manguezais e fauna marinha e costeira $^{56}$.

Outra distinção das unidades de uso sustentável, onde se encontram as RESEX é a presença de existência de Conselho Deliberativo, em vez de consultivo. Este, é "presidido pelo órgão responsável por sua administração e constituído por representantes de órgãos públicos, de organizações da sociedade civil e das populações tradicionais residentes na área, conforme se dispuser em regulamento e no ato de criação da unidade". Esse espaço tem sido apontado como potencial para a gestão compartilhada do território, sendo que o sucesso tem dependido da postura dos gestores (respeito e reconhecimento as comunidades e saberes tradicionais) e da interação com outros atores que desejam fazer uso do território. Nesse contexto Dumith (2012) enaltece:

Embora as relações oriundas de uma gestão compartilhada em uma RESEX, teoricamente, enriqueçam o processo de formulação de ideias e fortaleçam a legitimação das decisões deliberadas, é primordial que todos os atores envolvidos na gestão tenham o devido esclarecimento, no mínimo, do que vem a ser "população extrativista tradicional" e de que uma RESEX deve atender aos interesses dessa população. Percebe-se que, na RESEX Canavieiras, ainda há atores, os quais fazem parte do corpo gestor, que, além de não abrirem mão

\footnotetext{
${ }^{56}$ https://confrem.wordpress.com/
} 
de seus interesses econômicos, não compreendem o significado de "extrativista" e, consequentemente, de "RESEX" (DUMITH, 2012, p.158).

O principal instrumento de Gestão das RESEXs são os Planos de Manejo, os pais são aprovados pelo Conselho Deliberativo da unidade. Contudo também são importantes os Acordos de Gestão, que integram as normas propostas pelas comunidades em diálogo com os gestores. Ressalta-se que essa proposta, quando bem executada, permite o sucesso da gestão comunitária do território, por meio do acordo de gestão, que substantifica a gestão compartilhada no Plano de Manejo e Conselho Deliberativo. Diante disso, uma das prioridades apontadas pela CONFREM diz respeito aos instrumentos de gestão: "Fortalecer e acelerar processos de elaboração dos Acordos de Gestão e Plano de Manejo nas RESEX, respeitando o tempo das comunidades" e "Definir regras claras e valorizar as regras internas das comunidades nos Acordos de Gestão e Plano de Manejo nas RESEX" $"$.

Analisando as invariantes territoriais das comunidades tradicionais pesqueiras no caso das RESEXs, se percebe que a delimitação da unidade é um fator que preserva o arranjo territorial das comunidades. Diante da estabilidade das informações funcionais e regulatórias, os nós e redes se mantêm mais constantes, proporcionando a autonomia das comunidades. O processo de construção de regras (Acordos de Gestão e Plano de Manejo) também potencializa a dimensão comunitária na Gestão Compartilhada. Isso implica em uma comunicação bemsucedida, que resulta na redução de conflitos no território.

É importante destacar o território que se constitui no processo de luta que envolve tanto questões fundiárias, quanto ambientais (BARBOSA, 2014). Porto-Gonçalves enaltece a luta dos seringueiros da Amazônia nos anos 1980 que vão resultar na criação das RESEX (2003). $\mathrm{Na}$ atualidade os pescadores artesanais lutam, através da CONFREM e outros movimentos sociais, pela constituição de RESEX, incluindo RESEX Marinhas, frente aos impactos ambientais, disputas no território e conflitos por território que se evidenciam na (e sobre a) pesca artesanal brasileira.

\subsubsection{Território de Luta}

Até o presente momento deu-se ênfase à dinâmica interna nos territórios tradicionais das comunidades pesqueiras. Buscou-se ressaltar a relação entre autonomia e território. Logo, internamente se observa que há coerência entre a sociedade e a semiosfera, que expõe a lógica

57 CONFREM. Carta de Belém: Assembleia Nacional dos Extrativistas Costeiros e Marinhos e da CONFREM - 14 a 18 de outubro de 2014. 
entre território e territorialidades. Ressalta-se que no caso das comunidades pesqueiras as territorialidades são fluidas. E o processo de Territorialização-DesterritorializaçãoReterritorialização é contínuo e bastante influenciado pela dinâmica da natureza e necessidades das comunidades.

Contudo, quando se estabelece um território sobre essas territorialidades, a partir de uma regulação que é externa à comunidade não há mais coerência entre território e territorialidades e se estabelecem impactos ambientais, disputas no território e conflitos por território. Nesse sentido, a ecogênese do território de luta se inicia quando surge a necessidade de delimitar o território, como condição para a permanência do arranjo territorial da comunidade tradicional.

Assim, chega o momento de compreender a mudanças no território provocadas por atores que não fazem parte da dinâmica territorial tradicional. Esses atores estabelecem processos que são alheios ao território, pois estão ligados em redes informacionais com centros de decisão distantes do local. Desta forma, o território de luta é o território da resistência e da (re)existência, onde as comunidades de pescadores se reinventam para reivindicar as políticas dos povos e comunidades tradicionais. Essas estratégias e contextos de luta se evidenciam em todo o Brasil, e inclusive é observável nos trabalhos dos geógrafos sobre a pesca artesanal.

Como vem sendo apresentado a permanência no território tradicional tem se dado por meio da luta para o acesso de políticas específicas. Em diversos casos, onde as comunidades pesqueiras também são remanescentes quilombolas a reivindicação tem sido por meio do Decreto No 4887 de 2003 (território quilombola) (BRASIL, 2003). Em outros casos onde os conflitos se resumem à pesca, tem sido buscado a constituição de Acordos de Pesca - IN MMA No 29 de 2002. Já no caso em que se busca defender o território extrativista, onde se inclui a pesca, o pleito se dá pela constituição de RESEX -Lei 9985 de 2000 (BRASIL, 2000). Ressaltase que em nenhum desses casos o direito de uso do território é dado sem a luta e mobilização das comunidades e movimento social.

Destaca-se que enquanto o território pesqueiro se substantifica em um processo de constituição de territorialidades e comunicação intra e intercomunitária, o território de luta é uma reação a impactos ambientais, disputas no território, e conflitos por território prioritariamente promovidos por atores que são externos às comunidades (muitas vezes ligados em redes globais). Enquanto o território tradicional se estabelece em condições simétricas de poder, o território de luta se evidencia nas relações assimétricas e dessimétricas de poder, expondo um contexto de fascismo territorial. 
Entende-se que outras atividades econômicas também causam influências sobre a pesca e os pescadores, inclusive a erosão de saberes tradicionais e rompimento de vínculos comunitários. O território de luta tende a reestabelecer esses vínculos, pois a união para a luta exige um processo comunicacional que se estabelece com base em objetivos comuns, que nesse caso viabiliza a manutenção da pesca e do modo de viver. Por isso tende a conformar instituições fortes, que irão influenciar a gestão comunitária e compartilhada do território. Assim, o território pesqueiro é cada vez mais político, no sentido em que promove espaços para estabelecer a governança. No processo de (re)existência em que se deu a luta, diversas práticas culturais das comunidades são resgatadas, isso também contribui com a coesão comunitária e estabelecimento de vínculos com o território/ambiente conquistado. Desta forma o território de luta pode ser o caminho para o reestabelecimento do território pesqueiro tradicional.

$\mathrm{Na}$ sequência serão expostos dois instrumentos que podem garantir a presença dos pescadores nos territórios pesqueiros. O primeiro, o Termo de Autorização de Uso Sustentável (TAUS), foi estabelecido pela Portaria No 89 de 2010 (BRASIL, 2010A). Esse instrumento tem sido arrogado por grupos comunitários junto à Secretaria de Patrimônio da União - SPU e garantido a presença das comunidades no território, bem como a continuidade da atividade tradicional. O segundo é o Projeto de Lei de Inciativa Popular promovido pelo Movimento dos Pescadores e Pescadoras Artesanais que busca o reconhecimento, proteção e garantia do direito ao território de comunidades tradicionais pesqueiras. Para esse projeto, foi estabelecida a Campanha Nacional pela Regularização do Território das Comunidades Tradicionais de Pesqueiras. O processo de acesso a esses instrumentos é compreendido no âmbito dos territórios de luta.

\section{Termo de Autorização de Uso Sustentável (TAUS)}

Em diversos casos no Brasil a garantia de permanência no território tradicional tem se dado por meio dos Temos de Autorização e Uso Sustentável (TAUS) (BRASIL, 2010A). No II Encontro da Articulação Sudeste-Sul do Movimento dos Pescadores e Pescadoras Artesanais MPP foi destacado o processo de construção de TAUS que permitiu a manutenção de ranchos de pesca no estado de Santa Catarina. Esse instrumento é atribuído pela Secretaria de Patrimônio da União (SPU). A figura 70 apresenta a nuvem de palavras construída a partir da Portaria $N^{o} 89$ de 2010 que regulamenta o TAUS. 


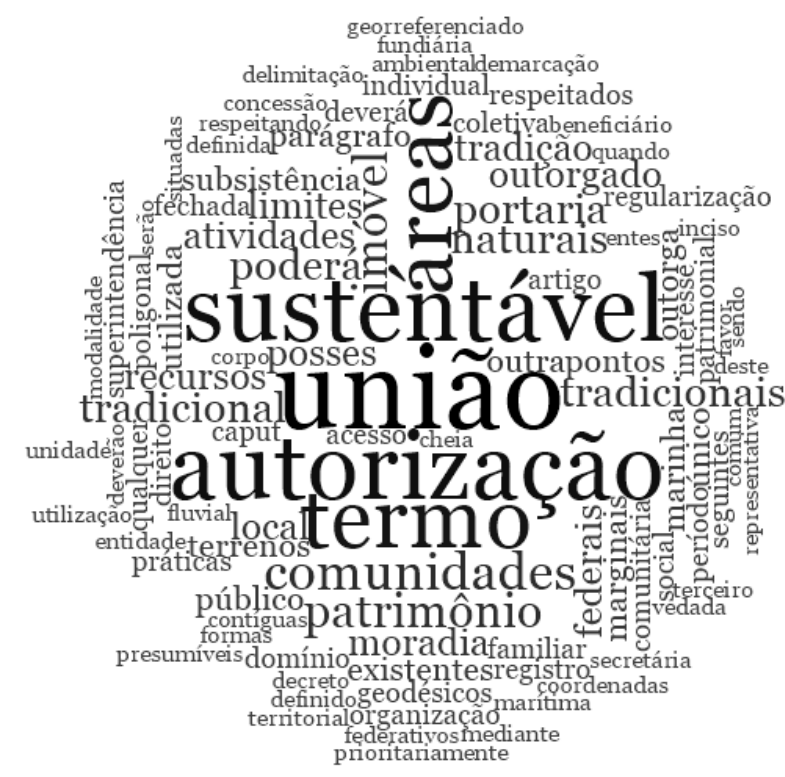

Figura 70: Nuvem de Palavras - Lei No 89 de 2010

Fonte: Elaborada por De Paula (2018).

Segundo a Portaria No 89 de 2010, os Temos de Autorização e Uso Sustentável visam:

Disciplinar a utilização e o aproveitamento dos imóveis da União em favor das comunidades tradicionais, com o objetivo de possibilitar a ordenação do uso racional e sustentável dos recursos naturais disponíveis na orla marítima e fluvial, voltados à subsistência dessa população, mediante a outorga de Termo de Autorização de Uso Sustentável - TAUS, a ser conferida em caráter transitório e precário pelos Superintendentes do Patrimônio da União (Artigo $\left.1^{\circ}\right)$.

Observa-se que é uma política voltada para as comunidades tradicionais, que concede o direito de uso dos recursos naturais da orla marítima e fluvial. Contudo, tal uso é relacionado à concessão do direito de permanecer no território. Pressupõe que para o uso, racional e sustentável é necessário estabelecer. Outro ponto que deve ser destacado na portaria é que essa autorização "poderá compreender as áreas utilizadas tradicionalmente para fins de moradia e uso sustentável dos recursos naturais, contíguas ou não" (Artigo 1). Logo, reconhece a continuidade entre território de moradia e território onde estão os pesqueiros, que pode ser concebida a partir de pontos (pesqueiros, moradias, praias), conectados por redes (caminhos). Essa norma abrangem as seguintes áreas da União:

I - áreas de várzeas e mangues enquanto leito de corpos de água federais;

II - mar territorial,

III - áreas de praia marítima ou fluvial federais;

IV - ilhas situadas em faixa de fronteira;

$\mathrm{V}$ - acrescidos de marinha e marginais de rio federais;

VI - terrenos de marinha e marginais presumidos (Artigo $2^{\circ}$ ). 
A Portaria destaca que o Termo de Autorização de Uso Sustentável - TAUS das áreas citada acima serão outorgados exclusivamente "a grupos culturalmente diferenciados e que se reconhecem como tais, que possuem formas próprias de organização social, que utilizam áreas da União e seus recursos naturais como condição para sua reprodução cultural, social, econômica, ambiental e religiosa utilizando conhecimentos, inovações e práticas gerados e transmitidos pela tradição". Portanto, é vetada essa outorga para "atividades extensivas de agricultura, pecuária ou outras formas de exploração ou ocupação indireta de áreas da União". Assim a obtenção da autorização de uso, individual ou coletiva só será dada mediante comprovação "a posse tradicional da área da União e a utilização sustentável dos recursos naturais, por qualquer meio de prova admitida em direito" (Artigo $4^{\circ}$ ).

Nesse sentido a portaria apresenta melhorias no que se refere à adoção do critério de autoidentificação das comunidades tradicionais. Além disso, reconhece o direito do uso tradicional do território, logo não se aplica às atividades agrícolas e pecuárias extensivas. Ainda, sobre a possibilidade de posse individual e coletiva, está previsto o uso coletivo, prioritariamente, e individual para unidade familiar (em nome da mulher), sendo transferíveis somente por sucessão (Artigo $5^{\circ}$ ). Ressalta-se que a portaria prevê o uso individual e coletivo, contudo no âmbito das comunidades tradicionais pesqueiras compreende-se que o uso deve ser sempre coletivo. Nesse sentido a lógica de apropriação do território concebida pelas comunidades tradicionais se difere da proposta. Cabe enfatizar que muitos dos conflitos presentes na pesca artesanal brasileira se devem à defesa da propriedade privada em detrimentos do uso coletivo e das posses tradicionais.

Ainda a delimitação da área da União para a outorga deverá respeitar "os limites de tradição das posses existentes no local, a ser definido com a participação das comunidades diretamente beneficiadas, respeitando as peculiaridades locais dos ciclos naturais e organização comunitária territorial das práticas produtivas" (Artigo $6^{\circ}$ ). Nesse sentido é preservado o território na perspectiva da cultura em que foi concebido.

A cartografia social do território pode constituir um importante instrumento de luta, uma vez que as comunidades podem utilizar esse documento para reivindicar junto aos órgãos públicos responsáveis o direito de uso do território tradicional. Ressalta-se que a luta deve ser sempre para que seja garantida a ampla participação das comunidades nesse processo de demarcação, para que a delimitação permita a permanência do arranjo territorial tradicional.

Quanto às áreas que não são contíguas, o TAUS será concedido nas seguintes situações: 
I - 01 (uma) das áreas destinada à moradia e outra à atividade tradicional de subsistência;

II - 01 (uma) área utilizada para moradia ou para atividade tradicional de subsistência no período de cheia e outra no período de vazante (Artigo $7^{\circ}$ ).

De um lado se observa avanços no sentido da portaria inserir tanto a área de moradia trabalho e vivências como os pesqueiros, contudo essa limitação de áreas constitui um obstáculo em diversas situações, onde devido a sazonalidade da pesca os pescadores se deslocam entre pesqueiro, que por vezes não são contíguos. Desta forma não deveriam ser estabelecidas uma, mas diversas poligonais, segundo as características tradicionais e da pesca comunitária.

O TAUS inicia o processo de regularização fundiária, podendo ser convertido em Concessão de Direito Real de Uso - CDRU. Contudo, esse documento deve "conter cláusula expressa de que o corpo d'água, no período de cheia, das áreas de que trata esta Portaria, se mantém sob o uso comum do povo para navegação, prática de atividades pesqueiras e acesso público, sendo vedado restringir ou dificultar seu acesso, por qualquer meio" (Artigo $11^{\circ}$ ). Isso constitui uma limitação na portaria, pois se acredita que o direito de uso deve estar associado ao manejo comunitário. A abertura, livre acesso, a outras atividades pode comprometer os recursos e a permanência do território tradicional. Existindo a necessidade de diversos usos, estes devem ser discutidos em espaços de gestão compartilhada, e com base em cartografia social e estabelecendo um zoneamento para o exercício das diversas atividades, sempre priorizando as práticas tradicionais. Ressalta-se como um contraponto, a IN N ${ }^{\circ} 1$ de 2007 (BRASIL, 2007B), que estabelece os procedimentos para o uso de espaços físicos em águas de domínio da União para fins de aquicultura, a qual não prevê essa abertura para outras atividades.

Por fim, cabe enfatizar que pode haver cancelamento do TAUS se "constatada a ocorrência de infração ambiental" (Artigo $12^{\circ}$ ). Nesse sentido é importante compreende o vínculo do TAUS com a manutenção do ambiente em situação de equilíbrio. Entretanto entende-se que o contexto gerado pelo TAUS deve suscitar a construção participativa de acordos de gestão comunitária do território delimitado. Logo, não se trata apenas de fazer valer leis, que muitas vezes estão desatualizas e incongruentes com as características do ambiente.

Entende-se que esse instrumento é de suma importância para as comunidades de pescadores artesanais do Brasil. Destaca-se que garante a manutenção do arranjo territorial ao garantir às comunidades a permanência dos nós (pesqueiros e outras áreas de moradia e convívio). Contudo como prevê a utilização de áreas não contiguas devem garantir o acesso dos pescadores às redes, que continuem os trajetos entre os nós. Ainda é importante frisar que é importante que esse arranjo territorial seja mantido por meio da gestão comunitária. Logo, o 
direito de uso do território, deve ser acompanhado do direito de realizar a gestão comunitária do mesmo.

Ressalta-se que esse território não será alcançado sem a luta das comunidades pelo seu reconhecimento. Nesse sentido encontrará obstáculos nas burocracias e vagarosidade dos órgãos públicos. Ainda encontrará resistência de atores políticos e econômicos que têm interesse de dominação do território. Contudo a sua conquista tende a resultar na redução de impactos ambientais, disputas no território e conflitos por território.

\section{Campanha Nacional pela Regularização do Território das Comunidades Tradicionais}

\section{de Pesqueiras}

Para compreende a constituição do território de luta, a partir dos pescadores artesanais brasileiros, será apresentado o "movimento social em movimento" para apontar o contexto que levou à elevação do território ao centro da luta dos pescadores artesanais. Então, será discutida, na perspectiva do território de luta, a Campanha Nacional pela Regularização do Território das Comunidades Tradicionais de Pesqueiras.

Segundo Fox e Callou (2013) já no período imperial os pescadores integravam movimentos abolicionistas. No século XX as relações de poder entre o governo e as colônias de pesca sempre foram o estopim para a insurgência de movimentos sociais de pescadores. Destaca-se que a partir dos anos 1970, com apoio do Conselho Pastoral dos Pescadores (CPP), "os pescadores passaram a reivindicar direitos previdenciários específicos, a lutar contra a expulsão das praias, pela direção de órgãos de representação (colônias, federações e confederação), contra o alto preço dos insumos e o baixo preço do pescado pago pelos intermediários. Também demandavam linhas de crédito para o setor pesqueiro artesanal” (p.3)

A organização de diversos conselhos pastorais e a convocação da Confederação Nacional dos Pescadores para que as federações estaduais defendessem os interesses da categoria resultaram no surgimento do Movimento Constituinte da Pesca, em 1988 (CARDOSO, 2001).

Esse movimento lutava pela autonomia política e sindical da categoria e incentivava a campanha de elaboração da Constituição Federal Brasileira. Sua grande conquista se deu no âmbito da liberdade organizativa e autonomia dos pescadores artesanais, equiparando-os aos sindicatos e às próprias colônias de pesca, pelo artigo $8^{\circ}$ da Constituição, que trata sobre a livre associação profissional ou sindical (Potiguar Júnior, 2000; Ramalho, 1999; Silva, 2004) (FOX, CALLOU, 2013, p. 4). 
Tendo conquistado direitos, os pescadores entenderam que necessitavam de uma representação nacional para dar continuidade as suas lutas, e assim a Constituinte da Pesca se converteu em Movimento Nacional dos Pescadores (Monape), criado em abril de 1988, no Recife, Pernambuco. O principal objetivo do movimento era organizar a categoria para "ocupar espaços de representação nas colônias, federações e confederação e buscar melhores condições de vida e trabalho para os pescadores. "Para tanto, encaminhava à legislação pesqueira e ambiental propostas que contemplassem o seu modo de vida" (FOX, CALLOU, 2013, p. 9).

Em 1999 o Monape se torna Associação Movimento Nacional dos Pescadores (Amonape), uma sociedade civil sem fins lucrativos, de caráter filantrópico, de âmbito nacional, que passou, a priorizar a captação, o gerenciamento e a fiscalização de recursos para projetos no setor artesanal. "As atividades de luta e resistência, dos anos 1980 e início dos 1990, tinham definitivamente cedido lugar à gestão institucional” (FOX, CALLOU, 2013, p.20). Nos anos 2000, o movimento acumulava diversas conquistas, dentre elas:

1) garantia do pescador artesanal como segurado especial da previdência, inclusive seguro-desemprego e outros benefícios sociais;

2) crédito específico do Fundo Constitucional de Financiamento do Nordeste e Fundo Constitucional de Financiamento do Norte; e

3) reconhecimento e habilitação das pescadoras (FOX, CALLOU, 2013, p.20).

Contudo, a ausência de intervenções sistemáticas, em conflitos e lutas resultou no seu afastamento dos pescadores artesanais. Em reação ao descontentamento dos pescadores com a desorganização da categoria, os rumos tomados pelo movimento e, com a postura da Secretaria Especial da Pesca - SEAP, em 2005 foi criada a Articulação Nacional dos Pescadores e Pescadoras Artesanais, cuja luta principal "centrava-se em questões ambientais, combatendo o hidronegócio e a Transposição do Rio São Francisco (FOX, CALLOU, 2013, p.24)

Em 2009 foi realizada a $3^{\text {a }}$ Conferência Nacional de Aquicultura e Pesca, organizada pelo recentemente criado MPA. Em paralelo a Articulação Nacional dos Pescadores organizou a I Conferência Nacional da Pesca Artesanal, para pressionar o Governo federal por políticas públicas adequadas para a categoria. Neste evento buscou-se "construir e apresentar propostas de investimento e garantia dos direitos sociais dos pescadores; identidade e território; direitos específicos das pescadoras; sustentabilidade ambiental, além de desenvolvimento do setor pesqueiro artesanal e sua legislação" (FOX, CALLOU, 2013, p.27).

Fox e Callou (2013) entendem que 
Até 2009, pescadores, assessores e mediadores não sabiam ao certo o rumo do Monape. Algumas lideranças do Nordeste defendiam que o movimento ainda representava os interesses e objetivos dos pescadores. Outras romperam de vez com ele, inclusive lançaram um novo movimento social da categoria (Carta do Movimento de Pescadores e Pescadoras, 2010) (FOX, CALLOU, 2013, p.27).

Na perspectiva do movimento social, se observa que as lutas presentes nos anos $1980 \mathrm{e}$ início dos anos 1990, com constituinte da pesca e criação do Monape, dava-se em reação à exploração-exclusão-dominação sofrida pelos pescadores artesanais brasileiros, em situações de desigualdade instituídas pelo poder político dominante (TAPIA, 2008). Contudo, na medida em que o Monape se institucionaliza chegando a constituir em Amonape e se relaciona estreitamente com o Estado, vai perdendo a característica de movimento social. Já a Articulação Nacional dos Pescadores, já se insere em um outro contexto, apresentado pautas que vão além de direitos. Nesse sentido se entende que os pescadores passam a se organizar como "novos movimentos sociais". Entre os debates introduzidos pela articulação ganha ênfase a questão ambiental. Além da produção ganham destaque experiências de relações entre pessoas, entre grupos, entre pessoas ou com o ambiente (SANTOS, 2001). Essa perspectiva tem continuidade na I Conferência Nacional da Pesca Artesanal, onde destaca-se a presença do território no âmbito da identidade.

Assim, entende a constituição do Movimento dos Pescadores e Pescadoras Artesanais (MPP) em 2009 na perspectiva dos "novos movimentos sociais", pois resultada da necessidade de ação política não-institucional, fora do compromisso neocorporativista, buscando envolver a opinião pública, através de meios de comunicação social, e envolvendo atividades de protesto (SANTOS, 2001).

Ressalta-se que enquanto o Monape visava a ocupação das Colônias de Pescadores, o MPP propõe a expansão do debate político para as comunidades e grupos de pescadores, inclusive questionando a centralidade das colônias. Além disso, enaltece os pescadores enquanto comunidades tradicionais, o papel destes na sustentabilidade ambiental e destaca a necessidade do território. Isso pode ser observado nas bandeiras de luta estabelecidas na II Assembleia Nacional do MPP, realizada em Aquiraz - CE em 2016 ${ }^{58}$ :

- Luta pela defesa e garantia dos territórios Pesqueiros (Campanha pelo território Pesqueiro, RESEX, Quilombos, TAUS, RDS, etc.)

- Lutar por política de Ordenamento Pesqueiro com participação efetiva da Pesca artesanal e a partir do saber das comunidades pesqueiras;

${ }^{58}$ Carta da II Assembleia Nacional do Movimento dos Pescadores e Pescadoras Artesanais do Brasil MPP. 
- Lutar por uma legislação específica para pesca artesanal

- Defesa dos direitos conquistados e luta por novos direitos (Nenhum direito a menos); previdenciários, sociais, trabalhistas, ambientais; RGP, etc.

- Combater a criminalização e violência institucional.

- Lutar por Políticas e Investimentos para a Pesca Artesanal (garantia de condições adequadas para produção, processamento e comercialização)

- Lutar por uma educação específica e contextualizada para a Pesca Artesanal (alfabetização, escolas das águas, técnica, etc.)

- Enfrentamento aos Grandes Projetos que causam impacto nos territórios e meios de vida dos pescadores: (Barragens, mineração, eólicas, imobiliários, portos, petróleo, etc.)

- Atuar junto as ações contra as causas e efeitos das Mudanças climáticas (Carta da II Assembleia do MPP) [grifos do autor].

Destaca-se que a principal bandeira de luta do MPP é o território pesqueiro. Na busca por uma lei específica, foi lançada em junho de 2012 a campanha cujo lema é "Território pesqueiro: Biodiversidade, Cultura e Soberania Alimentar do Povo Brasileiro" (MPP, 2012B). A Campanha apresenta como objetivos/metas

- Dois mil pescadores e pescadoras por estado com conhecimento dos seus direitos sociais e afirmam sua identidade pesqueira artesanal;

- Comunidades pesqueiras afirmando-se em sua identidade específica, com o propósito de se empoderar em defesa do seu território, enquanto comunidade articulada e reconhecida frente à sociedade;

- As comunidades pesqueiras artesanais debatendo e demonstrando a viabilidade de sua economia da pesca, a qual garante a sua sobrevivência e reprodução social, com qualidade de vida superior ao modelo do capital;

- A sociedade encampa a campanha de regularização dos territórios pesqueiros;

- As comunidades tradicionais pesqueiras conhecem e fazem valer as leis para garantir os territórios pesqueiros tradicionais;

- Comunidades pesqueiras conquistam instrumento jurídico que reconheça e regularize os territórios tradicionais pesqueiros (MPP, 2012B, pp. 19-20) [grifos do autor].

Para além do resultado, que ainda não foi alcançado, destaca-se o processo da campanha que realizou lançamentos, seminários e caravanas (nacionais e federais) entre outras atividades. Entende-se que a luta promovida nos estados brasileiros, nas ações da campanha, que tem levado os pescadores artesanais, cada vez mais a reclamarem seus direitos como comunidades tradicionais, e desejarem o reconhecimento dos seus territórios e territorialidades.

O instrumento jurídico proposto pela campanha é uma "Lei de iniciativa popular", a qual regulamente os direitos territoriais das comunidades pesqueiras. Para isso, nas atividades promovidas pela campanha também são recolhidas assinaturas para um abaixo-assinado (deve alcançar $1 \%$ do eleitorado brasileiro), para que o projeto seja levado ao congresso nacional. A figura 71 expõe a nuvem de palavras constituída a partir do referido projeto de lei: 


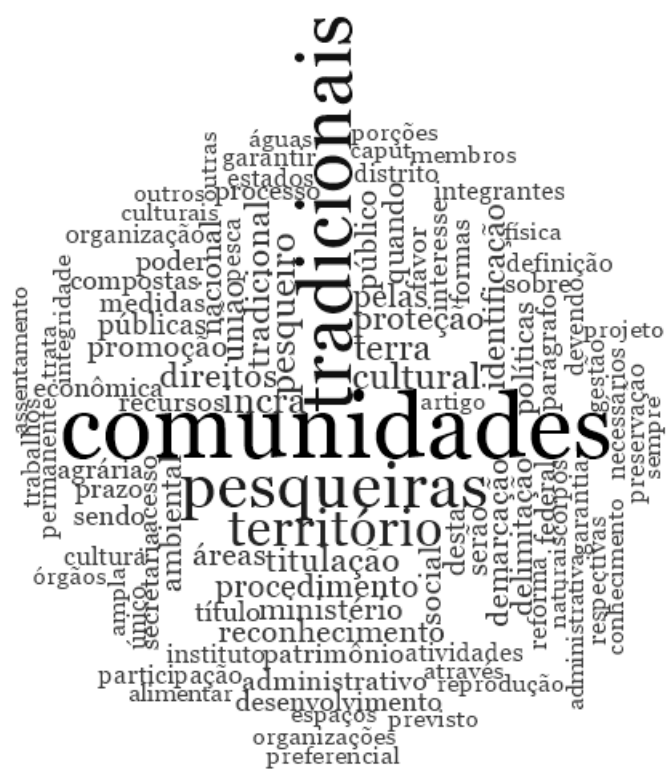

Figura 71: Nuvem de Palavras - Projeto de Lei de Iniciativa Popular Fonte: Elaborado por De Paula (2018).

O Projeto de Lei de Iniciativa Popular (MPP, 2012A) propõe:

o reconhecimento e mecanismos de garantia e proteção do direito ao território de comunidades tradicionais pesqueiras e o procedimento para a sua identificação, demarcação, delimitação e titulação, destinado a garantir a essas comunidades e seus membros a concretização e efetivação de seus direitos individuais, coletivos e difusos de natureza econômica, social, cultural e ambiental, compreendendo a salvaguarda, proteção e promoção de seus modos de criar, fazer e viver (Artigo $1^{\circ}$ )

É importante ressaltar que o projeto de lei, sintetiza as bandeiras de luta do MPP, uma vez que o território é apresentado como condição para a realização de outros direitos. As necessidades de identificação, demarcação, delimitação e titulação se apresentam devido ao avanço de outras atividades econômicas, que provocam impactos ambientais, disputas no território e conflitos por território. Como enfrentamento a isso, se constitui o território de luta, que se realiza nas resistências das comunidades, que passam a reivindicar o direito de permanência e uso, e na mobilização dos pescadores em escala nacional reclamando políticas públicas, que lhes permitam permanecer no território e a reprodução dos seus modos de viver.

Na compreensão do projeto de lei, constituem territórios tradicionais pesqueiros:

as extensões, em superfícies de terra ou corpos d'água, utilizadas pelas comunidades tradicionais pesqueiras para a sua habitação, desenvolvimento de atividades produtivas, preservação, abrigo e reprodução das espécies e de outros recursos necessários à garantia do seu modo de vida, bem como à sua reprodução física, social, econômica e cultural, de acordo com suas relações 
sociais, costumes e tradições, inclusive os espaços que abrigam sítios de valor simbólico, religioso, cosmológico ou histórico (Artigo $1^{\circ}$ ).

É importante destacar que na constituição do território tradicional pesqueiro há presença de áreas em terra e nos corpos d'água, mas que no arranjo territorial estão conectadas em rede. Nesse sentido é fundamental a presença das comunidades nas proximidades dos principais pesqueiros. Além disso, além dos pesqueiros, os pescadores estabelecem outras territorialidades, como as áreas de reprodução e maturação das espécies, que ensejam normas que são reconhecidas no âmbito das comunidades. Essa dinâmica interna nos territórios já foi apresentada, contudo cabe frisar que na perspectiva do território de luta, trata-se de estabelecer o direito ao território para de um lado favorecer que as comunidades façam a gestão do território (intrínseco), e de outro impedir o avanço de outras atividades que desejam dominar o território (extrínseco).

Além disso, o direito ao território se desdobra em garantir às comunidades o acesso preferencial aos "recursos naturais e seu usufruto permanente, bem como a consulta prévia e informada quanto aos planos e decisões que afetem de alguma forma o seu modo de vida e a gestão do território tradicional pesqueiro" (Artigo $2^{\circ}$ ). Outro ponto fundamental presente nesse projeto de lei, é que "a caracterização das comunidades tradicionais pesqueiras será atestada mediante autodefinição das próprias comunidades" (Artigo $3^{\circ}$ ). Nesse sentido se observa a observância à OIT 169 ao Decreto 6040 de 2007 que estabelecem os direitos dos povos e comunidades tradicionais.

Como foi apresentado no Capítulo II, a principal causa de conflito por território decorre de questões fundiárias. Segundo o projeto de lei "As porções de terras compostas por áreas de terras particulares ou bens públicos disponíveis, terão o domínio e a propriedade coletiva definitiva titularizados em favor das comunidades tradicionais pesqueiras de acordo com as suas territorialidades, através de ações de regularização fundiária, cabendo, ao Poder Público, sempre que necessário, desapropriar, por interesse social, os imóveis urbanos e rurais que abrangem o território" (Artigo $4^{\circ}$ ). Entretanto o projeto de lei prevê a regularização de áreas de terra e de água:

II - As porções de terras compostas por bens públicos que sejam constitucionalmente vedadas a transferência de domínio, serão titularizadas em favor das comunidades tradicionais pesqueiras, através de cessão de uso e, quando cabível, de concessão de direito real de uso, sendo garantida a fruição em caráter permanente e preferencial pelas referidas comunidades, devendo constar, obrigatoriamente, no instrumento de titulação, prazo indeterminado e cláusula de afetação da área para os fins desta Lei. 
III - As porções compostas por correntes de água fluviais, lacustres ou marítimas, bem como os depósitos decorrentes de obras públicas, açudes, reservatórios e canais, integrantes do território tradicional pesqueiro, serão objeto de cessão de uso de águas públicas, sendo garantida a fruição em caráter permanente e preferencial desses espaços e dos recursos pesqueiros pelas referidas comunidades, devendo constar, obrigatoriamente, no instrumento de titulação, prazo indeterminado e cláusula de afetação da área para os fins desta Lei.

No processo de regularização fundiária há previsão de desapropriação por interesse social e reassentamentos. "Incidindo nos territórios das comunidades tradicionais pesqueiras título de domínio particular não invalidado por nulidade, prescrição ou comisso, e nem tornado ineficaz por outros fundamentos, será realizada vistoria e avaliação do imóvel, objetivando a adoção dos atos necessários à sua desapropriação por interesse social, quando couber" (Artigo $16^{\circ}$ ). Também quando "Verificada a presença de ocupantes que não fazem parte da comunidade tradicional pesqueira, o INCRA, observando o interesse da comunidade, procederá à desintrusão, acionando os dispositivos administrativos e legais para o reassentamento das famílias de agricultores pertencentes à clientela da reforma agrária ou a indenização das benfeitorias de boa-fé, quando couber" (Artigo 19²).

Ainda para bloquear o avanço de outras atividades econômicas, o projeto de lei prevê dispositivos para que seja garantida a integridade do território, proibindo a implantação de empreendimentos, enquanto ocorre o processo de identificação, reconhecimento, delimitação, demarcação e titulação dos territórios tradicionais pesqueiros (Artigo $8^{\circ}$ ). Nesse processo também deve ser garantida a ampla participação das comunidades tradicionais pesqueiras em todas as fases (Artigo $9^{\circ}$ ).

Em relação ao título, na perspectiva desse projeto de lei deve ser coletivo e pro-indiviso (várias pessoas possuem o mesmo bem), o artigo $12^{\circ}$ do projeto de lei dialoga com as propostas do TAUS, mas o artigo $13^{\circ}$ o supera, dando titularidade sobre os corpos d'água.

A União, através do INCRA e da Secretaria do Patrimônio da União, tomará as medidas cabíveis para a demarcação e expedição do título coletivo e proindiviso em favor da organização representativa da comunidade, correspondente à porção de terra inclusa do território tradicional pesqueiro que configure terrenos de marinha e acrescidos, terrenos marginais de rios, ilhas e lagos (Artigo $12^{\circ}$ ).

A União, através do INCRA e da Secretaria do Patrimônio da União, com a colaboração do Ministério do Meio Ambiente, da Autoridade Marítima e da Agência Nacional de Águas, no âmbito de suas respectivas competências, tomará as medidas cabíveis para assegurar a demarcação e expedição do título coletivo e pro-indiviso em favor da organização representativa da comunidade correspondente às áreas formada por corpos d'água integrantes do território (Artigo $13^{\circ}$ ). 
Logo, na perspectiva do movimento social o território pesqueiro é sempre coletivo, relacionado à comunidade tradicional. Sendo assim, ao contrário do TAUS não se prevê a titularidade individual. Além disso, considerando as ameaças do avanço de atividades como a pesca industrial e a aquicultura sobre os pesqueiros tradicionais torna-se fundamental a demarcação dos corpos d'água.

Frente aos conflitos com unidades de conservação, o projeto de lei também traz proposições, assim como a sobreposição com outros territórios (terra indígena, território quilombola, assentamentos de reforma agrária, etc.):

Quando houver sobreposição entre o território das comunidades tradicionais pesqueiras e unidades de conservação constituídas, áreas de segurança nacional, faixa de fronteira, projetos de assentamento da Reforma Agrária, terras indígenas, terras ocupadas pelas comunidades remanescentes de quilombos e outros povos e comunidades tradicionais, o INCRA, o IBAMA, a Secretaria-Executiva do Conselho de Defesa Nacional, a FUNAI e a Fundação Cultural Palmares tomarão medidas visando garantir a sustentabilidade das comunidades envolvidas, revisando, quando cabível, atos administrativos e legais pretéritos e devendo, sempre, consultar as comunidades tradicionais interessadas, observando a efetiva participação das mesmas na tomada de decisões que possam afetar os seus modos de vida (Artigo $\left.14^{\circ}\right)$.

No caso das unidades de conservação essa lei e o SNUC seriam compatibilizados, garantindo o uso pelas comunidades tradicionais, assim como a conservação dos recursos do ambiente. Já em relação a presença de outras sociedades tradicionais, destaca-se a abertura de processos de diálogo para estabelecer os limites da co-presença no território. Acredita-se que no âmbito das sociedades tradicionais é viável a multiterritorialidade, respeitando os limites de cada cultura. Esse entendimento se estende especialmente "as áreas compostas por corpos d’água, poderá ser compartilhada por povos e comunidades originárias ou tradicionais que pratiquem a pesca artesanal" (Artigo $17^{\circ}$ ). Contudo destaca-se que isso requer espaços de gestão compartilhada do território.

Outra inovação presente no projeto de lei é a apresentação das "Diretrizes das Políticas de Desenvolvimento Social, Econômico e Ambiental das Comunidades Tradicionais Pesqueiras" (Capítulo III).

Cabe a União, Estados, Distrito Federal e Municípios, com a coparticipação das comunidades, formular políticas públicas destinadas a garantir o desenvolvimento sustentável das comunidades tradicionais pesqueiras e desdobrá-las em planos de ação dotados de estratégias e metas definidas, com ênfase no reconhecimento, promoção, fortalecimento, proteção e garantia dos 
direitos territoriais, sociais, ambientais, econômicos e culturais e com respeito e valorização da identidade, formas de organização e instituições destas comunidades (Artigo 24\% ) [grifo do autor].

Nessa perspectiva o projeto lei não se restringe ao reconhecimento e demarcação dos territórios das comunidades pesqueiras, mas estabelece a partir do movimento social 18 Diretrizes das Políticas de Desenvolvimento Social, Econômico e Ambiental das Comunidades Tradicionais Pesqueiras. Ressalta-se que está expresso o entendimento de que além de garantir o território se faz necessário promover políticas públicas que permitam a sustentabilidade das comunidades no seu território. Nesse sentido, destaca-se entre as diretrizes (Artigo $25^{\circ}$ ) quatro eixos que são fundamentais: o reconhecimento das comunidades tradicionais; a garantia da participação nos processos de tomada de decisão; a gestão ambiental com envolvimento das comunidades e, o acesso a políticas sociais.

Em suma compreende-se que a Campanha Nacional pela Regularização do Território das Comunidades Tradicionais de Pesqueiras, e o respectivo projeto de iniciativa popular expressam as estratégias do Movimento dos Pescadores e Pescadoras Artesanais (MPP), para a mobilização social das comunidades tradicionais pesqueiras em torno de um objetivo comum, o território pesqueiro. O instrumento jurídico proposto dialoga com algumas ideias presentes nos Termos de Uso Sustentável, mas avança por assumir a luta pelos territórios presentes no meio aquático, e por incluir uma política de desenvolvimento das comunidades (social, econômico e ambiental). Destaca-se que nesse instrumento as comunidades têm papel central, e nesse sentido o empenho deve prosseguir para garantir a gestão comunitária do território.

\subsection{Das Geografias das Ausências, às Geografias das Emergências da Pesca Artesanal Brasileira.}

Nesta última sessão a discussão retoma o Capítulo III, para analisar a modernização que avança sobre os territórios tradicionais, bem como a reação das comunidades tradicionais frente a esses processos. Neste momento, a argumentação busca estabelecer compreensões no âmbito das comunidades tradicionais, especialmente a pesqueira artesanal, para pensar a própria Geografia brasileira.

Como a tese apresenta, desde o início, nesse recorte da Geografia brasileira que se refere aos estudos relativos à pesca artesanal, há significativos avanços principalmente a partir da primeira década do século XXI. Tem-se proporcionado a abertura para a multiculturalidade e a exposição de campos de disputas e conflitos, onde o poder é multidimensional. Assim, tem interessado as leituras dos processos de TDR, onde a influência das redes informacionais é 
significativa na transformação dos territórios, mas encontra resistência nas comunidades organizadas em movimentos sociais de escala local e nacional.

Contudo, frente à dimensão da Geografia brasileira as presenças ainda são limitadas frente às ausências. Pensando, por exemplo, no âmbito da cartografia, é importante refletir o "porquê" de na imensa quantidade de mapas produzidos sobre bacias hidrográficas raramente haver presença de comunidades de pescadores. O porquê de frequentemente os mapas do urbano situarem o território das comunidades de pescadores como áreas verdes. Esses são dois de inúmeros exemplos que poderiam ser citados, onde a Geografia é produtora de ausências. No caso dos mapas, as ausências produzidas servem para a promoção de outras atividades, que buscam o domínio do território, como a construção de complexos portuários e instalação de loteamentos, retomando os dois exemplos.

Sem querer finalizar a discussão, mas abrir esse debate será dado ênfase à produção de ausências na Geografia brasileira, a partir do diálogo com Boaventura Santos. Tais ausências na Geografia têm expressão no espaço geográfico concebido e produzido. Assim, entende-se a produção de ausências no território que viabilizam o avanço da modernização, por meio dos paradigmas do saber único, tempo sincrônico, inferioridade dos grupos e territórios, escala global, e produtivismo. As consequências disso se apresentam no Capítulo II como impactos ambientais, disputas no território e conflitos por território.

Para destacar as Geografias das Emergências retoma-se as faces da modernização, apresentadas nos trabalhos analisados e nas denúncias do movimento social, como expressão das expectativas e estratégias sociais, frente ao avanço da modernização, para a recuperação da autonomia dos territórios tradicionais. Assim, expõem a autonomia do território a partir da promoção dos saberes, das multitemporalidades, dos reconhecimentos das diferenças, da escala do local e da produção tradicional. Essas seriam possibilidades de enfrentamento a modernização que apresenta como faces: degradação, sobre-exploração e limite do acesso, e expropriação, do território tradicional dos pescadores artesanais.

De tal modo, acredita-se que a Geografia, por meio do diálogo com as comunidades tradicionais, tem um papel importante na superação da moderno-colonialidade.

\subsubsection{A expressão do/no Território das Ausências e Emergências}

A compreensão de ausências e emergências no âmbito da Geografia provoca a pensar as mesmas na dimensão espacial. Isso tem sido assumido por diversos geógrafos que tem tratado as "invisibilidades", cujas abordagens têm em comum a compreensão de que 
determinados sujeitos, por meio de processos sociais, são invisibilizados no espaço. Assim, as abordagens que enaltecem os "até então invisíveis", expõem a expressão deles no espaço (lugar, território, paisagem, etc.).

Contudo, como ensina Santos (2006), as ausências são amplamente produzidas, inclusive no meio científico. Desta forma, cabe compreender que tais "invisibilidades" sociais decorrem também da ausência desses sujeitos nos estudos dos geógrafos. Compreende-se a impossibilidade de tratar de todas as dimensões em determinada pesquisa, contudo, questionase o porquê da predileção destas por determinada classe ou grupo (dependendo do método). Destacou-se as ausências no âmbito da cartografia, mas entende-se que elas são produzidas amplamente na Geografia e decorrem da promoção do discurso sempre a partir do dominante, no privilégio a alguma cultura, e na promoção de determinada racionalidade.

Nesse sentido é significativo retomar a relação entre território e modernidade na produção de ausências na Geografia. Ressalta-se que a separação entre sociedade e natureza na Geografia, se deu no âmbito da ciência moderna ocidental (SUERTEGARAY, 2017). Nesse contexto também se separou as inúmeras possibilidades de compreensão da sociedade e da natureza. Assim, a Geografia moderna expõe em seus estudos fragmentos da sociedade/natureza no espaço. Se os elementos da análise são fragmentados, quanto aos sujeitos, os geógrafos são levados a expor aqueles que estão mais visíveis no contexto social. Sendo assim, fica à margem da pesquisa geográfica aqueles que se encontram em invisibilidade social e que não se explicam por elementos isolados na análise.

A professora Catia Antonia da Silva, frequentemente toma o exemplo dos "vazios demográficos", como promoção de invisibilidades pelos geógrafos. Entende-se que os vazios demográficos correspondem a compreensão do espaço a partir da lógica dominante, no caso a industrialização e a urbanização, expondo um discurso comprometido com o desenvolvimento econômico (SANTOS, 2002), por meio da modernização. Tal compreensão exclui das análises todos os sujeitos que não estão inseridos nesse processo de desenvolvimento e não correspondem ao projeto de modernização proposto. Além disso, são sujeitos que muitas vezes não se explicam por meio da razão da ciência geográfica moderna, por não separarem sociedade de natureza e por estabelecerem outras lógicas de relações sociais. Por isso, quando identificados (não analisados) são apresentados como arcaicos, estagnados, miseráveis, e obstáculos para o progresso da sociedade, uma vez que o ponto de vista se estabelece a partir do moderno. 
Contudo, deve-se questionar sobre a modernização que provoca invisibilidades dos sujeitos sociais e ausências nas análises geográficas do espaço. Nesse sentido é fundamental retomar a noção de "colonialidade do poder" que se efetiva por meio de dispositivos, no âmbito dos Estados, de criação de identidades homogêneas através de políticas de subjetivação, bem como na manutenção da governabilidade a partir das potencias hegemônicas do sistema-mundo moderno/colonial (GÓMEZ, 2005). Isso se dá em contextos que Santos (2007) chama de "regresso colonizador", na ressurgência de formas de governo colonial tanto nas cidades metropolitanas, quanto naquelas anteriormente sujeitas ao colonialismo europeu.

Esse contexto, no âmbito científico, provoca ausências, que intencionalmente, reafirmam as invisibilidades sociais. Desta forma são inseparáveis os movimentos das ciências e da sociedade, a ponto de Quijano (2005) considerar a colonialidade do poder e do saber. Nesse sentido, Santos et. al. (2006) destaca a necessidade de construir outras versões da história e da ciência, para evidenciar histórias globais e multiculturais do conhecimento e superar a colonialidade do saber. Nessa perspectiva entende-se a necessidade de evidenciar outas Geografias do vivido, para renovar a ciência geográfica, abrindo-a para outros sujeitos e problemáticas que não correspondem, e contestam, a racionalidade dominante moderna/ocidental. Assim, deve-se superar no âmbito da Geografia os efeitos da razão metonímica e proléptica, de que fala Santos (2002).

Desta forma a Geografia deve abrir-se para as inúmeras racionalidades de uso e apropriação do espaço. Isso significa reconhecer saberes e práticas, bem como vínculos singulares que determinados grupos estabelecem com o espaço geográfico. Tais racionalidades promovem na Geografia o novo, apresentando soluções para problemáticas que não foram resolvidas pelo pensamento científico, antes criadas por este, e que promovem reflexões epistemológicas na própria Geografia. De outro lado, a Geografia deve pensar o futuro para além do que se evidencia, reconhecendo possibilidades de conversão e rompimento com a linearidade do presente. Esse futuro se expõe no diálogo com outras perspectivas de mundo.

Para isso, Santos (2007) propõe criar um espaço-tempo para o conhecimento e valorização da experiência social, que se manifesta no presente. $O$ autor entende que é necessário expandir o presente e contrair o futuro. Na leitura geográfica que se apresenta entende-se que o movimento analítico deve enaltecer a experiência local, para reduzir a influência do global. Assim se estabelece o contraponto entre presente/local e futuro/global, na compreensão das Geografias das Ausências e Geografias das Emergências, respectivamente. 
$\mathrm{Na}$ perspectiva da tese o encontro entre presente e futuro, local e global, se dá no território, por isso é fundamental compreender as diversas temporalidades específicas que que dão significado às relações de poder. Logo a análise é multidimensional, integrando atores, energia e informação, códigos, objetivos, estratégias, contexto espaço-temporal e o canal de relacionamento ou comunicação (RAFFESTIN, BARAMPAMA, 1998). Ainda, Raffestin (1986C) destaca que a territorialidade humana se apresenta em um ciclo duplo - territorial (territorialização-desterritorialização-reterritorialização - TDR) e informacional (inovaçãodifusão-obsolescência - IDO), dinâmico, e constituído de continuidade e descontinuidade, que associa grande e pequena escala. Assim se entende que as relações com a externalidade e com a alteridade são condicionadas por mudanças que ocorrem também nos sistemas informacionais.

Portanto, a Geografia das Ausências é amplamente promovida quando não se considera as consequências da imposição da lógica global sobre o local. Desta forma, não se tenciona a submissão das dinâmicas territoriais locais (TDR) ao ciclo do produto (IDEO), vinculado ao global, que é concebido como promotor da modernização e associado a um projeto de futuro que visa a transformação do território. Também o território construído na dinâmica do local é desqualificado, e o presente desvalorizado em detrimento de um futuro apresentado promissor. Para enfrentar a Geografia das Ausências faz-se necessário expandir o presente e enaltecer o local. Assim, deve-se contestar os processos de TDR, os quais estão em curso no local, e a imposição de uma lógica externa ao território, por meio de processos informacionais (IDO), que sujeita a dinâmica territorial ao ciclo do produto e cujas consequências se evidenciam impactos ambientais, disputas no território e conflitos por território.

$\mathrm{Na}$ pesca artesanal a Geografia das Ausências se expõe quando os geógrafos não reconhecem ou desqualificam as comunidades tradicionais, em processos de instalação de empreendimentos sobre os seus territórios. O uso do território comunitário é considerado como superado, e se propõe novos usos que são entendidos como inovadores, a partir de um padrão global. Essa proposta encontra apoio no Estado, interessado no desenvolvimento econômico, e é fomentado no âmbito dos meios de comunicação. Assim, as comunidades são apresentadas como um entrave para o estabelecimento de projetos, que são benéficos para a sociedade geral. Enfrentar a Geografia das Ausências, é descortinar essa falácia. Para isso é necessário abrir espaço nas pesquisas para evidenciar as comunidades tradicionais, no tempo presente, na produção de cultura, nos serviços ambientais, produção de alimentos (entre muitos outros). Bem como destacar os processos de desterritorialização a que são submetidas, muitas vezes sofrendo 
violências física, psicológica e institucional. E acima de tudo evidenciar os impactos ambientais, disputas nos território e conflitos por território sofridos no local, a partir de processos estabelecidos por atores externos, ligados em redes globais e comprometidos somente com a geração de lucro.

Para promover a Geografia das Emergências o empenho está em contrair o futuro e reduzir a influência do global. Então parte-se da exposição das faces da modernização no território, suas consequências ambientais e sociais, bem como as estratégias adotadas no local para enfrentar os processos de TDR promovidos por atores externos, inseridos lógicas globais (IDO). Desta forma, as emergências expõem resistências no território à imposição de ideias de futuro e projetos de desenvolvimento que são alheios ao local. No território de luta, a Geografia das Emergências evidencia e valoriza a inesgotável experiência social que está em curso no mundo de hoje, as quais se apresentam como possibilidades para o enfrentamento da modernização, que expõe suas faces no território.

Na pesca artesanal as Geografia das Emergências se evidenciam quando se abre espaço para as comunidades, reconhecendo seus saberes e fazeres como alternativas para a superação da crise ambiental e promoção de outras formas de desenvolvimento e gestão do território. Essas constituem possibilidade de enfrentamento ao avanço da modernização, que são consequências das ações do global sobre o local, por meio de processos informacionais, e resultam na degradação ambiental, sobre-exploração e limite de acesso aos pesqueiros, e expropriação da terra. Frente a esses processos devem ser expostas as resistências das comunidades, pela adesão ao projeto de comunidades e povos tradicionais, mobilização em movimento social, e constituição de um território de luta. Desta forma, o trabalho do geógrafo, oferece instrumentos de luta evidenciando as faces da modernização no território tradicional.

Nesse contexto o enfrentamento às Geografias das Ausências e promoção das Geografias das Emergências, se constituem em processos de ensino, pesquisa, extensão e atuação profissional, nos quais os geógrafos questionam os limites do projeto de futuro apresentado pela modernização, e expõem como contraponto as experiências e resistências no território (local), em enfrentamento às relações assimétricas de poder, que resultam no fascismo territorial.

\subsubsection{Geografias das Ausências}

Partindo da obra de Boaventura Santos $(2002,2011)$ propõe-se a compreensão das Geografias das Ausências, as quais se expressam na busca por "expandir o presente", 
enaltecendo o local. Na perspectiva que se apresenta o local será compreendido no âmbito do território (tradicional). Assim, o cosmopolitismo subalterno se expressa na luta contra a exclusão social, econômica, política e cultural decorrente do capitalismo global, que se manifesta no território (SANTOS, 2007).

A compreensão territorial das ausências parte de Raffestin (2012), o qual destaca o papel da memória e do esquecimento na dinâmica territorial a partir dos eixos de compreensão paradigmático e sintagmático. Isso permite compreender a produção de território sobre territórios, por meio da criação e recriação de valores econômicos, culturais, sociais e políticos. Sendo assim, o novo território decorre do estabelecimento de um novo paradigma é acompanhado pela instalação de sintagmas que o evidencia. Em outras palavras, as promessas da modernização são acompanhadas da instalação de elementos no espaço que remetem ao moderno, que darão sustentação ao novo território. Nesses contextos, territórios são construídos, desconstruídos e reconstruídos, funcionalizados, desfuncionalizados e refuncionalizados.

Santos (2011), apresenta cinco lógicas que produzem ausências no âmbito da Sociologia. Contudo, buscando compreender essas abordagens no âmbito da Geografia das Ausências serão estas serão destacadas como paradigmas que permitem o avanço e territorialização da modernização, por meio do estabelecimento de ausências no território tradicional com a elaboração do ignorante, atrasado, inferior, local ou particular e o improdutivo ou estéril.

\section{Paradigma do saber único (da monocultura do saber)}

No território o paradigma do saber único, pode ser compreendido por meio da colonialidade do saber e do poder (QUIJANO, 2005). Nesse sentido, o poder se estabelece a partir do desconhecimento ou da negação dos saberes de outras culturas. A eleição da ciência moderna ocidental como racionalidade superior, mantém as estruturas de dominação e subalternização (SANTOS, 2002) de grupos sociais, detentores de outras racionalidades e conhecimentos.

A ideia de que o conhecimento científico é uma verdade absoluta constitui um paradigma que o elege como base para a gestão do ambiente/território. As estruturas de poder estabelecidas a partir do saber se mantem com a submissão dos sujeitos, e do território, aos ditames provenientes da ciência moderna. Assim, as atividades promotoras da modernização, com base nos conhecimentos científicos, propõem a construção de outros territórios associados 
a outros usos, estabelecendo valores culturais, sociais e políticos, que indicam que tais atividades superam o uso tradicional. Na medida em que os empreendimentos se instalam, as presenças de suas infraestruturas expressam sintagmas que caracterizam o novo território. Esse território, da modernização, põe em choque os paradigmas da ciência moderna e do conhecimento tradicional. Desse processo se evidenciam marcas no território (SUERTEGARAY, 2002), ao ponto de configurar em uma problemática ambiental.

Outro ponto a destacar é a administração científica da natureza. Como se sabe a crise ambiental e territorial foi amplamente gestada no âmbito do conhecimento científico, com a promoção de tecnologias de extração de recursos, industrialização, etc. Contudo, diante do desconhecimento do conhecimento (MORIN,1996) a própria ciência apresenta soluções, para a superação da crise que ela mesma criou. Essas soluções se expressam em normas restritivas de uso do território, que excluem sujeitos que não estão inseridos nesta racionalidade. Ressaltase que por esses sujeitos não separarem seus saberes de fazeres (MORIN, 2005) fazem uso do território sob uma racionalidade (Ambiental) (LEFF, 2006) que não promoveu tal crise. Assim, mais uma vez se impõe os paradigmas da ciência moderna sobre os do conhecimento tradicional. Os sintagmas na gestão do território, vão se expressar em um quadro normativo que associa a estruturas de fiscalização e de controle.

\section{Paradigma do tempo sincrônico (da monocultura do tempo linear)}

Milton Santos (2006) entende que no espaço coexistem diversos tempos (diacrônico). Contudo o paradigma da unicidade do tempo (sincrônico) e da história é largamente produzido, gerando ausências no/do território. A temporalidade pautada na ideia de "progresso, revolução, modernização, desenvolvimento, crescimento, globalização" (SANTOS, 2011) não dialoga e nega as temporalidades que se expressam no território, no presente. Na perspectiva do território destaca-se que as relações de poder não se desenvolvem em um tempo único e uniforme, mas é significada por temporalidades específicas para os atores em questão (RAFFESTIN, BARAMPAMA, 1998).

Entende-se que diversos tempos e histórias são negados resultando em ausências. Quanto às comunidades tradicionais, deve ser destacada a negação do tempo da ancestralidade na constituição dos saberes e fazeres, do tempo da natureza no uso dos recursos e do tempo histórico na apropriação do território (poderiam ser citados outros vários)

Destaca-se que há uma temporalidade estimável, mas incomensurável do ponto de vista da constituição dos modos de viver no território. Essa temporalidade se manifesta no presente 
como o tradicional, contudo está sempre em movimento. Logo expõe saberes e práticas nos processos em curso, mas que foram constituídos a partir de gerações, transmitidos principalmente por meio da oralidade. Esse tempo se expressa no uso do território tradicional, e se expõe nos sintagmas que evidenciam a conservação do mesmo.

Contudo, esse tempo é negado quando tais saberes e práticas são confrontados com paradigmas científicos, cujos dados não os corroboram. Nesse sentido, o desconhecimento da complexidade temporal/histórica de constituição dos saberes, que se manifestam no presente, é a principal causa do seu desprestígio. A ancestralidade é concebida como resquícios de um passado, quando concebida por métodos científicos modernos, que só concebem a história como uma reta normal linear. Contudo, a ancestralidade nos saberes e fazeres, retoma o passado, ressignifica o presente onde se expõe, sempre considerando as possibilidades de futuro do território tradicional. Sem essa compreensão o paradigma do progresso da modernização tende a negar tal temporalidade.

A segunda temporalidade que é negada diz respeito à congruência entre tempo da natureza e tempo da comunidade. Isso contrasta com o paradigma da modernização, cujo tempo de uso da natureza está cada vez mais subordinado ao da sociedade, e entende a permanência de sujeitos sociais cujas temporalidades estão associadas à dinâmica do ambiente como atrasados. Ressalta-se que esse tempo não diz respeito somente à produção, mas está relacionado com toda a dinâmica social das comunidades, que Milton Santos (2006) denomina de "tempo lento", e se expressa no território. No entanto, na medida em que essas temporalidades são desqualificadas, os argumentos colaboram para imposição no território de processo, cujo tempo está associado ao tempo da máquina. Os sintagmas que marcam o território da modernização, nesse caso, se expõem como oposição ao natural.

A terceira temporalidade que deve ser enfatiza diz respeito ao tempo histórico de apropriação do território. Esse tem constituído um dos principais argumentos que garantem a presença das comunidades nos territórios tradicionais. Contudo costumeiramente é desconsiderado nos contextos em que a modernização ou outros projetos do Estado avançam sobre os territórios tradicionais. A produção de ausências está associada ao discurso que defende o paradigma da promoção do progresso, com a instalação de estruturas (sintagmas) que expõem a modernização do território. Disso resulta na destruição do ambiente e/ou uso do território ocupado historicamente pelas comunidades em condições de sustentabilidade. Nesse sentido a ocupação histórica do território, no presente é tratada como um vínculo indesejado com o passado e uma barreira para avanços futuros. 


\section{Paradigma da inferioridade de grupos e territórios (da monocultura da naturalização}

\section{das diferenças)}

O paradigma da inferioridade de grupos consiste na produção hierarquias e expressam no território. Assim é importante frisar que no âmbito das Geografias das Ausências, a naturalização das diferenças, sustenta a noção de inferioridade dos grupos sociais e seus territórios, o que está por trás do racismo ambiental ${ }^{59}$.

Da hierarquia das classes e grupos sociais, vê-se derivar a constituição da hierarquia do acesso ao território. Essa encontra no argumento econômico um dos principais fatores, que é bem aceito no campo político. Além disso, a ideia de modernização dos territórios das comunidades tradicionais, muitas vezes produzidas em campanhas publicitárias, parece agradar os seguimentos da sociedade que aspiram o acesso a tais recursos acrescidos de infraestruturas modernas, sem considerar o contexto de fascismo territorial a que as comunidades locais são submetidas.

Entende-se que os processos de construção, desconstrução e reconstrução, funcionalização, desfuncionalização e refuncionalização dos territórios são seletivos. Esses não ocorrem nos territórios dominados por sujeitos sociais detentores poder econômico e político. Mas ocorrem sobre territórios apropriados por grupos sociais considerados vulneráveis socialmente. Sendo assim, a instalação de empreendimentos não leva em conta somente o aspecto locacional, mas a população que será afetada (população negra, comunidades tradicionais, etc.), cuja falta de acesso a direitos básicos podem viabilizar remoções arbitrárias, pagamentos de indenizações irrisórias, e pouca reclamação (judiciária) frente a possíveis impactos.

Assim, o território tradicional se apresenta como vulnerável à modernização, e instalação dos seus sintagmas que viabilizam a sua territorialização. Diante disso as comunidades tradicionais veem o avanço da modernização, cujos empreendimentos fazem uso dos recursos acima da possibilidade de renovação dos mesmos ou que causam outros impactos como poluições e contaminações dos corpos d'água, solo, ar. Além disso, inserem atores que não reconhecem a dinâmica social, provocando tensões nas comunidades. Esses empreendimentos são permitidos, pois não se considera seus impactos sobre as comunidades locais e seus modos de viver. Logo se realizam presumindo a superioridade dos atores detentores do capital sobre as comunidades locais, com apoio do Estado.

${ }^{59}$ PELO TERRITÓRIO PESQUEIRO. Manifesto do MPP sobre explosão de navio no Porto de Aratu Salvador/BA. Disponível em: < http://denunciapeloterritorio.blogspot.com.br/2013/12/manifesto-do-mpp-sobreexplosao-de.html>. Acesso em: 01 out 2016. 
Destaca-se que o paradigma de uso do território pelas comunidades tradicionais permitiu a manutenção das condições ambientais relativamente em equilíbrio. Contudo, esses espaços com paisagens de beleza natural na atualidade são cada vez mais raros. Assim, a modernização avança sobre os mesmos propondo a refuncionalização, com instalação de infraestruturas que interessam às elites econômicas e políticas. Já os comunitários são paulatinamente desterritorializados, por não terem acesso a tais infraestruturas e serviços, e terem suas atividades normadas a partir de lógicas que são externas ao território tradicional. Em muitos casos, para viabilizar a modernização, o Estado viabiliza a remoção dessas comunidades de seus territórios ancestrais, com argumentos de que os mesmos são áreas degradadas, de insegurança ambiental, etc.

\section{Paradigma da superioridade do global (da monocultura da escala dominante)}

O paradigma da superioridade do global, no âmbito da modernização, também é responsável pela produção de ausências no território. Com a modernização o global foi eleito como escala dominante, que orienta a relevância das demais escalas. Disto a importância da escala local, onde se encontram os territórios tradicionais é minimizada frente aos interesses do global. Para Santos (2011) isso se apresenta como universalismo, ou seja, na predominância de escalas independentemente de contextos específicos.

Nesse sentido a dinâmica territorial está cada vez mais sujeita à escala global. Isso se evidencia na influência das redes globais de tomadas de decisões que promovem a modernização sobre territórios tradicionais. Assim, as comunidades se veem sujeitas às dinâmicas, processos e tecnologias que são alheias ao local, e que não correspondem à realidade ambiental e social presente nos territórios tradicionais. A modernização como expressão do paradigma do global expõe seus sintagmas no local onde estabelece um novo território, sobre os territórios preexistentes.

Contudo é fundamental que a decisão locacional de instalar essas atividades promotoras da modernização sobre territórios tradicionais, devem-se ao interesse dos países centrais de transferirem seus impactos e conflitos para países periféricos. Ressalta-se que o Estado é a entidade que viabiliza a promoção da lógica global sobre o local, por meio da modernização. Ainda oferece os meios necessários para a instalação dos sintagmas da modernização, que estabelecem o novo território, mesmo reconhecendo o custo ambiental e social desse avanço. Nesse processo que se apresenta como um regresso colonizador, as comunidades são desassistidas pelo Estado, que não reconhece o uso tradicional do território. 
Diante disso o local é compreendido como incapaz de apresentar alternativas viáveis às propostas do global. Os arranjos territoriais das comunidades tradicionais não são reconhecidos, nem suas práticas de gestão comunitária do território. Frente ao global, o local é apresentado como impossibilidade de futuro.

\section{Paradigma do produtivismo (da monocultura dos padrões de produção)}

O paradigma do produtivismo expõe os critérios de produtividade capitalista e constitui elemento fundamental para a compreensão da produção de ausências pela modernização nos territórios tradicionais. Este pressupõe que o crescimento/desenvolvimento econômico constituem o objetivo inquestionável, o que viabiliza a promoção dos territórios da modernização. Logo, nega-se que o território é multidimensional, integrando dimensões culturais, sociais, econômicas, políticas, ambientais e muitas outras.

Ressalta-se que os critérios de produtividade dizem respeito tanto à natureza quanto ao trabalho humano (SANTOS, 2002). Em relação à natureza, o meio encontrado é a potencialização dos seus processos por meio do emprego de ciência e tecnologia. Quanto ao trabalho isso se expressa na submissão dos trabalhadores aos ritmos de produção cada vez mais associados ao funcionamento das máquinas e às demandas do consumo. Isso tem resultado em desprestígios às atividades, sujeitos, grupos e territórios associados ao setor primário, especialmente aqueles que estão mais vinculados aos tempos da natureza.

Outra problemática que vai se expressar nos territórios tradicionais é a relação entre trabalho urbano e trabalho rural. Cada vez mais os trabalhadores rurais vão ser estimulados a intensificarem seus processos para atender as demandas da sociedade urbana. Esta última já está sujeita aos processos de produtividade da modernização, então vão cobrar maior produção do trabalho rural. Os trabalhadores rurais que não se submetem a esses contextos, assim como seus territórios, serão considerados improdutivos. Desta forma a própria lógica de produção e consumo do urbano se impõem sobre as comunidades que estabelecem outras relações com o território.

Desta forma o estimulo à intensificação da produção será uma demanda da sociedade geral, interessada no consumo e do Estado que deseja o desenvolvimento econômico. Outras vezes o Estado vai fomentar a substituição da atividade tradicional por outras atividades econômicas que promovam a modernização do território, cujos padrões de produtividade são superiores. Isso vai implicar na constituição de um território completamente adverso ao tradicional, e as múltiplas dimensões se resumem à econômica. Nesse sentido o paradigma do 
produtivismo, acompanha elementos ou sintagmas que funcionam como próteses no território para o estabelecimento de processos que visam a maior produção possível.

\subsubsection{Geografias das Emergências}

Para Santos (2002) enquanto a Sociologia das Ausências evidencia o que é ativamente produzido como não existente, na Sociologia das Emergências a ausência exprime possibilidades futuras, ainda por identificar e uma capacidade ainda não plenamente formada para ser executada.

Na leitura geográfica que se faz das Sociologias das Emergências de Santos (2002, 2011) propõem-se destacar possibilidades e estratégias para a recuperação da autonomia das comunidades no território tradicional. Nesse caso, as Geografias das Emergências contraem o futuro e reduzem a influência do global. Logo, expõem disputas de futuro com base nas expectativas sociais, que visam o enfrentamento do avanço da modernização sobre o território, e a recuperação da autonomia. Assim, as ausências são convertidas em instrumentos de luta, resistência e reivindicação, como possibilidades de futuro. Ressalta-se a importância da reserva, para a autonomia, logo o território de luta pretende também a conservação dos recursos ambientais.

Seguindo a perspectiva de Raffestin (1986) a autonomia é fundamental na territorialidade humana. Para o autor os extrativistas apresentam uma estreita relação entre autonomia e território. Logo, a ecogênese territorial integra as noções de limite, centralidade no local da coleta e circulação. O território delimitado constitui a reserva, fundamental para autonomia, e se mantém por meio da comunicação, que representa o cerne dos processos de TDR. Desta forma a permanência do grupo depende da manutenção dessa autonomia.

Nesse contexto a Geografia das Emergências expõe as realidades que estavam silenciadas, suprimidas e marginalizadas na produção de ausências no território, produzidos pela imposição da lógica global. Nessa linha de análise, compreende-se como Santos (2002, p.253) para a necessidade de "imaginação epistemológica e democrática". Assim, a imaginação epistemológica proporciona a diversificação dos saberes, perspectivas e escalas de identificação, análise e avaliação das práticas. Já a imaginação democrática favorece o reconhecimento das diferentes práticas e atores sociais. Assim, a Geografia deve abrir seu horizonte analítico para as práticas e estratégias sociais de enfrentamento da modernização que avança sobre os territórios. Bem como ampliar o diálogo nos espaços democráticos de luta e reivindicação do território tradicional. 
Para a "ampliação simbólica" (excesso de atenção que deve ser dado a aquilo que foi negligenciado), Santos (2002) propõe dois procedimentos: tornar menos parcial o conhecimento das condições do possível para conhecer melhor as realidades investigadas -, e tornar menos parciais as condições do possível para fortalecer as pistas e sinais. Logo, devem ser evidenciados os sinais, pistas e tendências latentes, que mesmo dispersas, embrionárias e fragmentadas expõem a "constelação de sentidos" sobre a compreensão e transformação do mundo (SANTOS, 2007). Esses contextos frente a globalização, Milton Santos (2006) compreende como solidariedades estabelecidas a partir do local.

No Capítulo III estabelecendo o diálogo entre abordagens da Geografia e denúncias do movimento social, apresentou-se as faces da modernização que se expõem no território. Essas são expostas nos contextos de luta, como argumento e estratégia de recuperação da autonomia do território tradicional. As faces da modernização correspondem a uma estratégia de análise, das muitas possíveis, de enfrentamento às ausências geradas na modernização, para expor um "futuro simultaneamente utópico e realista". Assim, parte de "realidades concretas", e ampliando o presente agrega o "real amplo", ou seja, as possibilidades e esperanças de futuro que ele comporta (SANTOS, 2002). Os enfretamentos e contrapostos à modernização que evidencia suas faces no território, constituem estratégias para a recuperação da autonomia no território, e se evidenciam nas Geografias das Emergências.

Santos (2002, 2011), apresenta como contraponto às monoculturas nas ausências as ecologias nas emergências. Na leitura geográfica que se apresenta, o contraponto é estabelecido entre os paradigmas dos territórios da modernização, em contraste com a promoção de autonomia dos territórios tradicionais. A promoção da autonomia se dá no âmbito dos saberes, das multitemporalidades, dos reconhecimentos das diferenças, da escala do local e da produção tradicional.

\section{Autonomia nos saberes (da ecologia dos saberes)}

Para enfrentar o paradigma do saber único na constituição dos territórios da modernização, propõem-se a promoção da autonomia do território tradicional com a valorização dos diversos saberes, especialmente os tradicionais. Isso significa reconhecer e credibilizar os saberes tradicionais "territoriais" na gestão ambiental e territorial, bem como promover diálogos de saberes.

Nesse sentido valoriza-se a constituição dos saberes na escala local, bem como a viabilidade destes para pensar a gestão do território no presente. Entende-se que quanto mais 
os saberes tradicionais forem a base da gestão do território tradicional, maior será a autonomia deste último. Assim, enfrenta-se os desígnios do global sobre o local, bem como embate-se os processos de tomada de decisão baseados unicamente no conhecimento científico moderno.

Nestes diálogos e disputas epistemológicas (SANTOS, 2002, 2007), onde cada saber contribui com o diálogo e com a superação da ignorância. Contudo, é fundamental reconhecer a pluralidade de conhecimentos heterogêneos, e que a interação entre eles não deve comprometer a autonomia de cada um, assim o conhecimento é interconhecimento (SANTOS, 2007).

Logo, não se trata de reproduzir a unicidade do conhecimento, no saber tradicional, mas de superar a situação de subalternidade destes. Neste sentido o diálogo deve ser consciente de o que está sendo aprendido, e o que é desaprendido, pois no interconhecimento se aprende com os outros sem esquecer os próprios saberes. Os conhecimentos científicos devem ser apropriados então numa perspectiva contra-hegemônica. Nesse diálogo deve também ser enfatizado que o conhecimento científico se apresenta repleto de incertezas, que quando não reconhecidas em perspectivas complexas, promove usos e aplicações de tecnologias, concebidas no global, que apresentam consequências irreversíveis (SANTOS, 2006) principalmente sobre o local.

Ao enfatizar os saberes das comunidades locais na gestão do território tradicional a Geografia contribui na promoção de “contraepistemologias" (SANTOS, 2007). Logo expõe diversas alternativas plurais, para o enfrentamento do capitalismo global, que através da modernização avança sobre os territórios tradicionais.

\section{Autonomia nas multitemporalidades (da ecologia das temporalidades)}

Para resistir ao paradigma do tempo sincrônico, que impõe a modernização sobre o território, propõe-se a de autonomia do território por meio da promoção das multitemporalidades. Entende-se que o tempo linear é o tempo da modernidade, que submete as demais temporalidades ao tempo do global (SANTOS, 2007). Nos territórios tradicionais se expressam diversas temporalidades, como da ancestralidade, da relação com a natureza, da ocupação histórica.

Ressalta-se que a superação das hierarquias, a partir da temporalidade dominante do global, reduzem a influência do poder do global sobre o local. Assim, o território passa a expressar diversas temporalidades (tempos das ancestralidades, da relação com a natureza, da ocupação histórica do território), que estão vinculadas ao local. Logo o reconhecimento das 
temporalidades faz com que as práticas sociais deixem de ser consideradas como resíduos, ganhando forma para o desenvolvimento autônomo (SANTOS, 2002) do território.

Uma evidencia disso são as práticas sociais vinculadas aos tempos da natureza, que sendo reconhecidas na dinâmica do território proporcionam a gestão dos recursos sem comprometer a sustentabilidade. Ressalta-se que no local as temporalidades da natureza além do manejo dos ecossistemas têm grande influência sobre os modos de viver. Essas sociedades "de tempo lento" exprimem o contraponto à sociedade global, e evidenciam vínculos de solidariedade que expressam alternativas do local à modernização que se impõe no território.

Também cabe destacar a compreensão da simultaneidade de tempos, como aponta Milton Santos (2006). Desta forma, a ancestralidade não é concebida como um resquício do passado, mas corresponde a uma forma de viver no presente. Esta, assim como a temporalidade de ocupação e uso do território, passa então a ser consideradas na argumentação e disputa política (SANTOS, 2002).

Santos (2007) enaltece que a compreensão da moldura temporal para além da duração da ação do Estado, tem evidenciado em experiencias subalternas do Sul, respostas às necessidades imediatas à sobrevivência e de longa duração frente ao capitalismo e colonialismo. Assim, o reconhecimento das inúmeras temporalidades que se expressam no território tradicional, expõe emergências na medida em que apresenta propostas que a temporalidade da globalização não é capaz de proporcionar. Ainda permite compreender as raízes profundas do colonialismo nos contextos de dominação a que os territórios estão sujeitos.

\section{Autonomia na diferença (da ecologia dos reconhecimentos)}

Para a autonomia do território tradicional, superando o paradigma da inferioridade de grupos e territórios, propõe-se a promoção do reconhecimento das diferenças. Para isso tem-se que superar a colonialidade do poder que entende diferença como desigualdade, bem como se entende com a prerrogativa de apontar os diferentes. Desta forma se faz necessário articular os princípios da igualdade e da diferença. Assim, quando desaparecem as hierarquias, permanecem as diferenças que a hierarquia necessita para se manter (SANTOS, 2002).

$\mathrm{Na}$ leitura das Geografias das Emergências se entende que devem ser enfrentadas as desqualificações dos sujeitos, práticas, saberes e territórios. Isto por que as hierarquias constituídas no global se impõem no local, e expressam desigualdades no território. Isso também faz com que determinados territórios sejam preferidos para a instalação de 
empreendimentos da modernização que são potencialmente causadores de danos ambientais e sociais.

Para enfrentar essas diferenças propõem-se a que a hierarquia entre sujeitos e territórios seja convertida em reconhecimentos. Nesse sentido, em contraponto a homogeneidade que o global propõe, propõe-se a valorização da heterogeneidade dos territórios, cujas diferenças se expressam nos saberes e fazeres, modos de viver, cultura. Além disso, o devido reconhecimento tente a reservar tais territórios para esses usos tradicionais, significando um obstáculo para o avanço da modernização.

Na promoção dos territórios da diferença, que se apresenta como território de direitos específicos, é fundamental a garantia da manutenção dos modos de viver, que se reinventa no processo de luta por territórios. Por isso, deve ser promovida ampla participação, desde o reconhecimento, que deve ser baseado na autoidentificação das comunidades tradicionais, até os usos que devem estar pautados na gestão comunitária do território.

A autonomia do território tradicional se manifesta quando externamente o território deixa de ser visto como inferior, passando a ser compreendido como prioritário no que tange a determinadas políticas. E quando internamente as diferenças hierárquicas são suprimidas, por meio de processos participativos e democráticos de gestão, que viabilizam a promoção dos modos de viver tradicional. Ressalta-se que esses modos de viver não devem ser tomados como estáticos, mas em processo continuo de transformação, cuja essência se expressa nos vínculos comunitários, com o ambiente e território.

\section{Autonomia na escala local (da ecologia das trans-escalas)}

Entende-se que para a autonomia dos territórios tradicionais é fundamental afrontar o paradigma da superioridade do global, por meio da valorização da escala local (território). Para isso Santos $(2002,2007)$ entende que deve ser identificado no local o que não foi integrado na globalização hegemônica, bem como proporcionar a (des)globalização do local.

Para a autonomia do território tradicional, é fundamental reconhecer os efeitos da globalização internos e externos ao mesmo. Internamente o empenho deve estar em garantir a manutenção e resgate de saberes e práticas que não estão vinculadas ao global. Também é fundamental proporcionar a gestão do território a partir da dinâmica do local, reconhecendo as práticas de governança. Ainda deve-se identificar o que já está associado ao global e ressignificá-lo a partir do local, servindo de contraponto ao global. 
A autonomia frente aos efeitos externos da globalização, nesse caso depende do reconhecimento e salvaguarda do território tradicional, para inibir o avanço das atividades da modernização. Além disso, por meio de políticas públicas, deve-se promover a sustentabilidade do território tradicional. Assim, o território tradicional corresponde ao outro da globalização, que pode expor questionamentos e alternativas para a sociedade geral quanto os efeitos nocivos da globalização.

É também fundamental compreender a necessidade de conversão do papel do Estado como mediador entre global e local. Se a crítica estabelecida é de que o estado viabiliza a expressão do paradigma da globalização no território, entende-se que o mesmo pode promover o local no território, como uma outra globalização (M. SANTOS, 2006). Nesse sentido, reconhece as multiterritorialidades no âmbito do território nacional, bem como suas singularidades e alternativas ao global. Isto, fomentado por políticas públicas tende a promover, no presente, a ressurgência de grupos sociais que estavam em situação de invisibilidade.

Ressalta-se a escala do local como a possibilidade de um contraponto à globalização, que se realiza na constituição de territórios tradicionais, que não aderem ao projeto global, e ressignificam os elementos do global no local, promovendo uma outra globalização. Esta visibiliza sujeitos sociais e territórios, que não eram possíveis no contexto de homogeneização promovido pelo global.

\section{Autonomia na produção tradicional (da ecologia da produtividade)}

Finalmente entende-se que para a autonomia do território tradicional é necessário enfrentar o paradigma produtivismo e promover formas tradicionais de produção. Entende-se que essas formas tradicionais de produção foram mantidas no capitalismo global, contudo de forma desqualificada para a manutenção da relação de subalternidade.

Assim, para a recuperação da autonomia do território tradicional se faz necessário pensar a produção a partir do local, valorizando as atividades tradicionais, bem como relações e sistemas de produção alternativos. Ainda, deve-se questionar os limites do desenvolvimento econômico, sobretudo evidenciando suas consequências na escala do local.

Ressalta-se que no caso das comunidades extrativistas constitui um equívoco considerar que não há produção, mas somente extração. No mínimo é excessivamente simplificadora essa compreensão, que limita a produção à coleta ou captura. Entende-se que a produção nas atividades extrativistas corresponde a uma complexa cadeia, que integra múltiplos atores, bem como saberes e fazeres constituídos no âmbito comunitário ao longo de gerações. Sendo assim, 
para a autonomia do território é fundamental que sejam garantidas as diversas territorialidades que integram a produção tradicional.

Além disso, é fundamental reconhecer a pluriatividade das comunidades tradicionais, para garantir que os processos produtivos estejam de acordo com os ritmos e ciclos da natureza. Como já foi apresentado, a falta de garantia do território para a realização de diversas atividades que correspondem a produção nos modos de viver tradicional, resulta na deterioração desses últimos e emprego de técnicas que provocam danos no ambiente. Sendo assim, o território constitui elemento indispensável na produção tradicional. Dialeticamente o mesmo território só se mantém, especialmente em condições ambientais, se a produção se manter em tais condições.

A relação entre uso do território e condição de sustentabilidade da natureza, além de valorizada, deve constituir argumento para garantir e salvaguarda de tais territórios tradicionais. Sendo assim, em vez de depreciada a lógica de produção artesanal, em consonância com a dinâmica ambiental deve ser valorizada e concebida como alternativa local para o enfrentamento da crise ambiental concebida no global e que se expressa no território.

A promoção da produção tradicional no território também valoriza as comunidades, enquanto promotoras de alimento para a sociedade geral. Contudo essas comunidades não devem perder a autonomia do território tendo a produção condicionada à dinâmica do consumo dos centros urbanos ligados à lógica global, que promete o acesso de todos a qualquer produto em qualquer lugar. Isso promove para além do território a discussão sobre os padrões de consumo, onde a valorização das condições da natureza tende a se expressar em variedades segundo sazonalidades, estimulando a produção e consumo segundo suas safras, bem como conscientizando quanto ao desperdício e necessidade de racionamento em determinados períodos. Essa lógica é amplamente vivenciada nos territórios tradicionais, cujo consumo expressa seus modos de viver, e tende a contribuir para o questionamento à lógica global, cujo único compromisso é com a acumulação do capital. 


\section{CONCLUSÕES}

A Geografia brasileira evidencia a relação complexa entre ambiente e território na pesca artesanal. Desta forma estabelece diálogos com grupos e movimentos sociais de pescadores artesanais onde emergem discussões sobre os territórios tradicionais. Tal diálogo, ao mesmo tempo que, permite discutir a gestão ambiental e territorial da pesca artesanal brasileira, promove discussões teóricas e metodológicas na Geografia.

Para expor as compreensões da Geografia brasileira sobre a pesca artesanal, esta tese analisou dissertações e teses defendidas entre 1982 e 2015, que abordam a pesca problemáticas relativas às comunidades pesqueiras. Também foram analisados questionários respondidos por geógrafos que abordam a pesca artesanal na Geografia brasileira.

Esse processo permitiu compreender a pesca artesanal na pesquisa geográfica, enaltecendo áreas de estudo e instituições envolvidas (programas de pós-graduação em que as pesquisas foram realizadas, e instituições a que os geógrafos estão vinculados atualmente). Quanto às dissertações e teses é importante destacar que as instituições que realizaram as pesquisas estão situadas prioritariamente no Sudeste, Sul e Nordeste, e em contraste as áreas de pesquisa se referem aos Nordeste, Sul, Sudeste e Norte. Destaca-se também a expansão dessas pesquisas a partir de 2006.

Esse crescimento foi contrastado com as informações sobre a expansão da pósgraduação em Geografia no Brasil, se observou certa proporcionalidade. Contudo, a análise evidencia também que além da expansão no território nacional (regional e mesoregional), a introdução da pesca artesanal entre as problemáticas dos geógrafos são abordadas na perspectiva crítica, que se distingue das propostas dos anos 1980, e que ajuda a pensar a Geografia brasileira no século XXI. Nesse sentido destaca-se que as Geografias da Pesca, dentro das diversas abordagens apresentam em comum um discurso crítico, e em certo grau político, que expõe grupos e sujeitos sociais em situação de conflito.

Em relação à expansão da pós-graduação, destaca-se que decorreu de políticas de Estado, estabelecidas principalmente a partir de 2005. Os reflexos destas nas pesquisas sobre a pesca artesanal se evidenciam na superação da concentração das instituições de pesquisa no Sudeste. Enquanto havia essa concentração os programas do Sudeste realizavam pesquisas nas diversas regiões do Brasil. Contudo, o movimento que se observa é que na medida em que a pós-graduação expande regional e mesorregionalmente as pesquisas passam a ser realizadas em 
áreas de estudo até então não abordadas, e por pesquisadores vinculados a programas da própria região.

A presença dos pesquisadores próximo da área de estudo também parece que tem favorecido o diálogo de saberes, entre geógrafos e comunidades de pescadores. Nesses processos a Geografia tem sido tensionada a responder as dinâmicas vividas pelas comunidades e estabelecer abordagens teóricas e metodológicas que correspondam à complexidade do real. Isso tem promovido transformações no pensamento geográfico crítico do século XXI, em um movimento que acompanha as Ciências Humanas e Sociais, que buscam promover outras epistemologias, para a superação da colonialidade do saber.

Ressalta-se que em vez de classes sociais, os geógrafos têm adotados diversos arranjos de grupos sociais, que expõem a importância da cultura e modo de viver nas suas lutas. Esses grupos, da escala local à nacional ganham forma como novos movimentos sociais e desenvolvem processos de reivindicação e resistência que passam a compor os trabalhos dos geógrafos. Nesse sentido, acredita-se que o pensamento geográfico crítico deve ser contemporanizado, pois as análises, dentro do que foi pesquisado, não tratam da cultura pela cultura, mas da cultura como perspectiva de luta.

Em relação ao diálogo também é importante destacar a relação entre pesquisadores. No âmbito da Geografia, avaliou-se o diálogo entre pesquisas, por meio das citações aos autores que pesquisam a pesca artesanal. Nesse sentido, percebe-se que, embora as pesquisas tenham crescido em número, há pouca visibilidade entre os geógrafos. Ainda que frequentemente pesquisas que tratam de problemáticas similares e mesma área de estudo parecem não se conhecer. Entretanto, também se observa que o diálogo nas citações tem sido principalmente no âmbito regional sobre contextos específicos das áreas de pesquisa. O diálogo inter-regional se dá sobre abordagens teóricas e metodológicas. Ressalta-se a importância do diálogo regional para o estabelecimento de propostas conjuntas e superação do isolamento característico das instituições científicas.

Nesse contexto também se propõe o avanço das pesquisas em rede. Destaca-se a proposta de Rede de Geografias da Pesca, para promover o diálogo no âmbito da Geografia brasileira. Observa-se que há disposição de geógrafos de diversas regiões para compor a citada rede, contudo aponta-se que é necessário ter em mente a garantia da pluralidade de abordagens, mas dentro de um horizonte ético comum. Esse horizonte ético nas ciências foi apresentado na perspectiva do "pensar bem". 
Deste modo, se observa que a conformação das Geografias da Pesca se dá em consonância com os rumos do pensamento geográfico crítico do século XXI, onde questões institucionais, políticas e o movimento de renovação das ciências tem colocado em evidência atores e problemáticas que até então não estavam visibilizados pelo conhecimento geográfico. Esses não se configuram como objetos de pesquisa, mas sujeitos em diálogo com os pesquisadores a partir de problemáticas vivenciadas no real.

As dissertações e teses também apontam que a principal problemática discutida permeia a resistência das comunidades de pescadores frente ao avanço de determinada atividade econômicas sobre seus pesqueiros e áreas de uso tradicional (moradia, trabalho, religião, etc.). Entre as possibilidades teóricas apresentadas, os geógrafos fazem uso principalmente dos conceitos de território, espaço e ambiente, sendo que se expressa a relação entre território e ambiente frente as problemáticas analisadas. Também se observou a tendência ao uso de "composições metodológicas" e do Materialismo Histórico e Dialético como métodos de pesquisa.

Assim, compreende-se que a análise dos geógrafos sobre as dinâmicas dos territórios tradicionais das comunidades de pescadores artesanais, é estabelecia a partir dos diálogos de saberes que ocorrem no âmbito das pesquisas. Esse processo democratiza a pesquisa geográfica que passa a ocorrer em áreas até então invisibilizadas, e expor conhecimentos tradicionais e problemáticas enfrentadas pelos sujeitos nos territórios tradicionais.

Ressalta-se que essas análises permitiram compreender a posição da Geografia brasileira sobre os processos de desterritorialização das comunidades pesqueiras. Diante disso, foi estabelecido um horizonte analítico, que relaciona território e ambiente a partir de três perspectivas: impactos ambientais, disputas no território e conflitos por território. Apesar de essas perspectivas apresentarem certas interconexões, a generalização de todas como impactos ou conflitos reduz a complexidade da análise. Assim, é possível distinguir os processos de territorialização e desterritorialização das comunidades de pescadores.

$\mathrm{Na}$ leitura geográfica destaca-se que os impactos ambientais além de afetar os ecossistemas repercutem sobre as comunidades que dependem do ambiente e seus recursos. Desta forma, impactos no ambiente frequentemente levam ao fim da territorialidade, pois a "reserva" é fundamental na constituição das territorialidades das sociedades extrativista, e na permanência de suas territorialidades tradicionais. Logo, a transformação ou transfiguração das condições naturais implica em consequências nos processos de territorialização e 
desterritorialização. Os impactos ambientais decorrem principalmente da industrialização, urbanização, agricultura e pesca industrial e são mais frequentes nas regiões Nordeste e Sul.

As disputas no território expõem a relação território e ambiente, na medida em que a presença (ou redução) de recursos ambientais promove disputas, que por consequência tendem a comprometer tais recursos. Desta forma as disputas no território tendem em resultar tanto em impactos ambientais como em conflitos por território. Além das disputas por recursos, entram em choque visões de natureza e lógicas de apropriação, tais dissensos impedem a perenidade dos recursos no território. O contexto de disputas também pressupõe o reconhecimento de territórios e territorialidades, e nem sempre resulta em desterritorialização, podendo ocorrer a multiterritorialidade. As disputas no território, com a pesca artesanal, ocorrem principalmente nas regiões Nordeste e Norte, e são promovidas com a Aquicultura, Pesca Industrial, Pesca Comercial e Geração de Energia.

Os conflitos por território se evidenciam na perda de autonomia em uma situação de desequilíbrio, que é resultado do não reconhecimento dos territórios tradicionais, que pode levar ao desaparecimento de determinado grupo. Os conflitos resultam prioritariamente do exercício do poder, que nesse caso é assimétrico ou dissimétrico, pois é exercido pelas atividades detentoras do capital e encontram suporte no Estado e suas instituições. Se destaca a rede informacional, tendo em vista que essas atividades econômicas estão em uma lógica de relações externa ao lugar. Na pesca esses conflitos além de incidirem sobre os pesqueiros tradicionais, expulsa as comunidades dos seus territórios tradicionais de moraria e vivência. Logo, esses conflitos por território envolvem questões Fundiárias, do Turismo, Unidades de Conservação, Especulação Imobiliária e Comercialização de Pescado.

Ressalta-se que esses contextos de impactos, disputas e conflito promovem alterações nas invariantes territoriais e podem resultar na desterritorialização das comunidades pesqueiras.

A compreensão da evidente dinâmica territorial das comunidades de pescadores permitiu repensar os conceitos de pesca artesanal, pescadores artesanais, conhecimentos tradicionais e comunidades tradicionais considerando concepções do Estado, do movimento social e da academia, a luz da abordagem territorial/ambiental.

A pesca artesanal é compreendida como uma atividade extrativista, artesanal e territorial, para fins de subsistência e comercialização, que se constitui a partir de saberes e fazeres tradicionais. Isso implica no conhecimento e respeito aos ciclos e limites da natureza, e no uso de apetrechos de baixo impacto ambiental. É composta por diversos, interdependentes e inseparáveis fazeres, como a captura, construção e manutenção de apetrechos de pesca e 
embarcações, manuseio, beneficiamento e venda do pescado, ensino das artes de pesca, etc. Devido a piracema, escassez de pescado, ou condições ambientais, eventualmente a pescaria é interrompida, e os pescadores incluem outras atividades para a subsistência das comunidades. As embarcações de pequeno porte e a pesca desembarcada, incluindo a mariscagem, resultam na maior dependência dos pescadores aos recursos locais, o que, conjuntamente com outros aspectos concretos e abstratos, resulta na territorialização das comunidades. Promove a produção de alimentos, que contribui com a segurança alimentar das comunidades e sociedade geral, e importantes serviços ambientais, por meio do manejo dos ecossistemas que integram o território tradicional.

Os pescadores artesanais são sujeitos de direitos individuais e coletivos. Estão inseridos nas diversas atividades que compõem a pesca artesanal, por meio de relações e vínculos familiares e comunitários de produção, interdependência econômica, ambientais e culturais, entre outros, que se estabelecem no território tradicional. Têm na pesca principal atividade profissional e constituição do modo de viver, inseparavelmente, cuja noção de autonomia e liberdade são características. Sendo assim, não se definem a partir de critérios da legislação ou pela posse de documentos específicos, mas por saberes e fazeres aprendidos no âmbito comunitário, na relação com o ambiente. Por isso, podem se autodeterminar como membros de comunidades tradicionais, reivindicando direitos de reconhecimento, participação, e uso do território tradicional. Bem como políticas públicas próprias, principalmente trabalhistas e previdenciárias, a partir das características das atividades integram a pesca artesanal.

O conhecimento tradicional é entendido como um conceito híbrido que integra dimensões ambientais e territoriais. Essa abordagem expõe o dinamismo de transformação dos saberes, que no passado eram reelaborados na medida em que ocorriam mudanças no ambiente e de acordo com o tempo da natureza, e que na contemporaneidade, com a aceleração da transfiguração da natureza, foram sendo erodidos, mas se reinventam em um quadro de conflitos e disputas territoriais. Nesse sentido é cada vez mais necessário compreender os saberes tradicionais territoriais.

Entende-se que as comunidades pesqueiras têm o direito de autoidentificação, então em vez de apresentar uma definição serão expostos alguns elementos, que são mais ou menos, evidentes em tais comunidades. Esses aspectos são organização social, tradicionalidade e vínculo com o território. Constituem grupos sociais diferenciados pela cultura (costumes e tradições), cujos a pesca se apresenta como elemento preponderante no modo de viver. Por meio de saberes tradicionais, apropriam-se dos recursos do ambiente e constituem 
territorialidades e territórios. Estabelecem governança própria, por meio de acordos e pactos criados em relações sociais e de parentesco. O território comunal, de usufruto dos recursos, é estabelecido a partir de relações simbólicas e concretas com a terra e o mar, inseparadamente, e constitui condição para a reprodução social, cultural, religiosa, ancestral e econômica destas comunidades.

Ressalta-se que também se discutiu a expressão das invariantes territoriais sobre os territórios tradicionais. Concomitante abordou-se a gestão comunitária e compartilhada da pesca, em diálogo com instrumentos de governo e proposições dos movimentos sociais. Isso permitiu estabelecer compreensões sobre território e territorialidade comunitário (pesqueiro) e o território de luta.

As territorialidades da pesca artesanal são evidentes no âmbito das comunidades e integram áreas de pesca e de recursos que são utilizados nas pescarias. Logo, abrangem pesqueiros, matas, manguezais, ranchos de pesca, locais de beneficiamento, etc. O poder se expressa no saber, que é compartilhado entre os comunitários por meio de conhecimentos tradicionais, que suscita práticas de uso. A informação inerente a esse saber é funcional e regulatória, logo ocorre o manejo, por meio de acordos que são elaborados na pesca e no cotidiano. Essas territorialidades são fluidas, conectadas por trajetos, canais, varadouros. Mudam de acordo com a dinâmica da natureza e movimento dos cardumes. No arranjo territorial as áreas terrestres, de trabalho, moradias e vivência também compõem territorialidades, e ocupam o papel de centralidade. Nesta ocorre a comunicação, e se evidencia a gestão comunitária.

O território comunitário é substantivado pelas territorialidades tradicionais, terra e água, área da comunidade e pesqueiros. E se caracteriza pelo estabelecimento de relações simétricas de poder (prestígio). A sustentação desse território se dá por meio de um processo comunicacional, que mobiliza todos os atores, que dependem em certo grau dos recursos locais (da reserva), para a manutenção dos mesmos. Assim, a partir da coesão social se estabelecem acordos, normas, processos de monitoramento e sansões construídas no âmbito comunitário e intercomunitário, em processos democráticos participativos (informação funcional e regulatória). Assim, o território expressa as relações comunitárias e com a natureza, sendo fundamental na reprodução social, cultural e econômica das comunidades.

O território de luta se apresenta, quando outras atividades buscam estabelecer território sobre os territórios e territorialidades das comunidades, a partir de uma regulação que é externa à comunidade, logo não há mais coerência entre território e territorialidades e se estabelecem 
impactos ambientais, disputas no território e conflitos no território. Nesse sentido, a ecogênese do território de luta se inicia quando surge a necessidade de delimitar o território, como condição para a permanência do arranjo territorial da comunidade tradicional. Desta forma, o território de luta é o território da resistência e da (re)existência, onde as comunidades de pescadores se reinventam para reivindicar as políticas dos povos e comunidades tradicionais. Essas estratégias e contextos de luta se evidenciam em todo o Brasil, e inclusive é observável nos trabalhos dos geógrafos sobre a pesca artesanal.

Destaca-se que a análise dos trabalhos (dissertações e teses) evidenciam diálogos de saberes, contudo buscou-se ampliar esse diálogo contrastando as perspectivas supracitadas com denúncias do movimento social, especialmente do Movimento dos Pescadores e Pescadoras Artesanais (MPP). Nesse processo, a análise das denúncias expõe que a modernização constitui a principal opositora ao território de luta. Tais denúncias enfatizam as três faces da modernização: degradação, sobre-exploração e limite ao acesso, e expropriação da terra. Nesse sentido as perspectivas apresentadas de relação entre território e ambiente, torna inteligíveis, no saber geográfico, as faces da modernização que se expõe nos territórios das comunidades tradicionais.

A face da degradação resulta do avanço da modernização sobre os corpos d'água, e ecossistemas associados (mangues, marismas, matas de várzea, etc.) e suas marcas se evidenciam na intensa transformação da natureza, alteração dos seus processos, e por isso redução na quantidade e na qualidade do pescado. Desta forma cabe compreender os contextos de Industrialização, Urbanização, Agroindústria e Mineração enquanto projetos de Estado. Essa face da modernização enfatiza a degradação ambiental que extingue territórios dos pescadores artesanais, logo, dialoga principalmente com a perspectiva de análise de impactos ambientais.

A face da modernização da sobre-exploração e restrição do acesso aos pesqueiros atinge principalmente o pesqueiro tradicional, seja pela sobre-exploração do pescado, seja pela proibição do acesso dos pescadores ao mesmo. Nessa perspectiva da modernização foram identificadas como principais atividades o Hidronegócio (Aquicultura, Barragens de Usinas Hidrelétricas, Porto e Industria Naval, Plataforma e Industria do Petróleo) e Pesca (Industrial, Comercial e Amadora). Essa face dialoga principalmente com a perspectiva das disputas no território.

A face da modernização da desapropriação da terra, diz respeito ao avanço das atividades econômicas sobre o espaço das comunidades tradicionais de pescadores. As comunidades de pescadores artesanais têm essa distinção do território ser ao mesmo tempo 
aquático e terrestre. Contudo, as áreas de moradias das comunidades despertam o interesse dos agentes da modernização que as consideram um espaço que não é devidamente explorado pelo capital. Assim, se instalam sobre as comunidades e provocam a expulsão dos pescadores, ou nas proximidades submetendo as comunidades a outras logicas de relação social. Os conflitos Fundiários são decorrentes dessa face da modernização, bem como o Turismo Predatório e a Especulação Imobiliária. Assim, trata-se da modernização que disputa com as comunidades a posse da terra, que até então é de uso comunitário (valor de uso), mas passa a ser vista como mercadoria (valor de troca). Essa face dialoga com a perspectiva de conflitos por território.

Destaca-se que apesar de haver certa correspondência entre as perspectivas de análise de território e ambiente, e as faces da modernização, o que pressupõe certo diálogo, enquanto as perspectivas correspondem a possibilidades teóricas da Geografia, as faces da modernização às problematiza em contexto de luta por território no movimento social. De um lado a Geografia fala sobre a pesca artesanal, de outro a Geografia fala com a pesca artesanal. Entende-se que nenhum desses processos se excluem, mas que permitem compreensões distintas. Em suma as perspectivas de análise apresentadas correspondem às possibilidades de tratamento, presentes nos trabalhos analisados, das faces da modernização.

Ainda sobre as faces da modernização destacou-se o papel do Estado, enquanto promotor, gerando principalmente conflitos por território, por meio de Unidades de Conservação, Normatizações, Fiscalização e Discriminação Institucional. Ao contrário a pesca artesanal é apresentada prioritariamente como promotora de conflitos por território, mas esses decorrem pela expressão das faces da modernização sobre as comunidades, que provoca consequências na coesão social e nas práticas tradicionais de uso do território.

A discussão sobre o avanço da modernização sobre os territórios tradicionais, e do papel da Geografia nesse processo, resultou na proposição de estratégias teóricas para enfrentar as ausências e promover as emergências. Contudo, nessa proposição geográfica, destaca-se a dinâmica territorial. Assim propõem-se compreender as Geografias das Ausências, por meio da produção territorial dos empreendimentos da modernização, e as Geografias da Emergências na luta das comunidades para a recuperação da autonomia do território.

As Geografias das Ausências se expõem quando os geógrafos não reconhecem ou desqualificam as comunidades tradicionais, em processos de instalação de empreendimentos sobre os seus territórios. O uso do território comunitário é considerado como superado, e se propõe novos usos que são entendidos como inovadores, a partir de um padrão global. Essa proposta encontra apoio no Estado, interessado no desenvolvimento econômico, e é fomentado 
no âmbito dos meios de comunicação. Assim, as comunidades são apresentadas como um entrave para o estabelecimento de projetos, que são benéficos para a sociedade geral. Entendese que as Geografias das Ausências resultam em impactos ambientais, disputas no território e conflitos por território.

Para superar as Geografias das Ausências propõem-se enfrentar os paradigmas que possibilitam a produção do território da modernização: paradigmas do saber único, do tempo sincrônico, da inferioridade dos grupos e territórios, da escala global, e do produtivismo.

As Geografias das Emergências propõem destacar possibilidades e estratégias para a recuperação da autonomia das comunidades no território tradicional. Nesse caso, as Geografias das Emergências contraem o futuro e reduzem a influência do global. Logo, expõem disputas de futuro com base nas expectativas sociais, que visam o enfrentamento do avanço da modernização sobre o território, e a recuperação da autonomia. Assim, as ausências são convertidas em instrumentos de luta, resistência e reivindicação, como possibilidades de futuro. Ressalta-se a importância da reserva, para a autonomia, logo o território de luta pretende também a conservação dos recursos ambientais. Os contextos em que os movimentos sociais e geógrafos expõe a degradação, sobre-exploração e limitação ao acesso, e expropriação da terra, expõem as Geografias das Emergências.

Na proposição das Geografias das Emergências, o território tradicional é reestabelecido na medida em que se promove autonomia nos saberes, nas multitemporalidades, nos conhecimentos das diferenças, na escala do local e na produção tradicional.

Desta forma compreende-se que influenciada por aspectos históricos, institucionais e perspectivas científicas do presente, a Geografia brasileira vem superando as ausências na pesca artesanal brasileira, com abordagens que expõem a relação complexa entre os conceitos de ambiente e território, como impactos ambientais, disputas no território e conflitos por território. Em diálogos com os grupos e movimentos sociais de pescadores artesanais expõem emergências, no território comunitário e de luta, frente às faces da modernização: degradação, sobre-exploração e restrição ao acesso, e expropriação da terra. Desse processo observa-se transformações no pensamento geográfico crítico no século XXI, assim como possibilidades quanto à gestão comunitária e compartilhada da pesca artesanal brasileira. 


\section{REFERÊNCIAS}

ABREU, Georgete Cabral de. Território da pesca: o uso do espaço aquático no baixo rio Solimões município de Manacapuru-AM. 106p. Programa de Pós-Graduação em da Universidade Federal do Amazonas, Manaus, 2011.

ACSELRAD, Henri. Justiça ambiental e construção social do risco. Revista Desenvolvimento e Meio Ambiente. $\mathrm{N}^{\mathrm{o}}$ 5. Curitiba: UFPR, jan./jun. 2002. Disponível em: <http://ojs.c3sl.ufpr.br/ojs2/index.php/made/article/viewFile/22116/14480>. Acesso em 3 abr 2010.

ALVES, Taíse dos Santos. A pesca artesanal no Baiacu - Vera Cruz (BA): identidades, contradições e produção do espaço. 152p. Dissertação (Mestrado em Geografia). Programa de Pós-Graduação em Geografia da Universidade Federal da Bahia, Salvador, 2015.

ANDRADE, José Vicente de. Turismo: fundamentos e dimensões. 8. ed. Ática, 2004.

ANDRADE, Manoel Correia de Andrade. A construção da Geografia brasileira. RA'EGA. Espaço Geográfico em análise. v. 3, 1999. Pp.19-34

ARAÚJO, Glauco Rivelino Ferreira de. Migração, Territorialização e pesca em Augusto Correa - PA (1990-2010).158p. Dissertação (Mestrado em Geografia). Programa de PósGraduação em Geografia da Universidade Federal do Pará. 2012.

BARBOSA, Aline Miranda. Povos e Comunidades Tradicionais em Luta Pelo Território: Interseções e Tensões entre a Questão Agrária e a Questão Ambiental. 170p. Dissertação (Mestrado em Geografia). Programa de Pós-Graduação em Geografia da Universidade Federal Fluminense, Niterói, 2014.

BARDIN, Laurence. Análise de Conteúdo. Lisboa, 2007.

BEGOSSI, Alpina. Áreas, pontos de pesca, pesqueiros e territórios na pesca artesanal. In. BEGOSSI, Alpina (Org.) LEME, Andrea (et al.). Ecologia de pescadores da Mata Atlântica e da Amazônia. São Paulo: Hucitec: Nepam/ Unicamp: Nupaub/USP; FAPESP, 2004, pp.223-253.

BERKES, F. et al. Gestão de pesca de pequena escala: diretrizes e métodos alternativos. Rio Grande: FURG, 2006.

BERTRAND, Georges., BERTRAND, Claude. Uma Geografia transversal e de travessias: o meio ambiente através do território e das temporalidades. Maringá. Massoni. 2007

BOCARDE, Flávio; LIMA, Natália. Construindo Acordos de Pesca: experiências de gestão participativa em Parintins, Amazonas. Projeto Manejo dos Recursos Naturais da Várzea PROVÁRZEA/IBAMA, Brasília: Ibama, 2008.

BONNEMAISON, Joel. Viagem em torno do território. In. Corrêa, Roberto. Lobato, Rosendahl, Zenni (orgs). Geografia Cultural: um século (3). Rio de Janeiro: UERJ, 2002. 
BRACONARO, Fernando. A Geografia da pesca: modo de vida e lazer na bacia do Rio Araguari-MG. 204p. Dissertação (Mestrado em Geografia). Programa de Pós-Graduação em Geografia da Universidade Federal de Uberlândia, 2011.

BRASIL. Coordenação de Aperfeiçoamento de Pessoal de Nível Superior. Documento da Área. Área 36 Geografia. / Coordenação de Pessoal de Nível Superior. - Brasília, DF: CAPES, 2016. 42p.

CALVÃO NETO, João. O território das novas economias e suas implicações socioambientais na comunidade pesqueira de Barra do Cunhaú. 141p. Dissertação (Mestrado em Geografia). Programa de Pós-Graduação em Geografia da Universidade Federal do Rio Grande do Norte, Natal, 2009.

CAMARGO, Cézar Pardo Mêo Pompêo de. Territorialidades caiçaras do tempo de antigamente ao tempo de hoje em dia em Paraty, RJ (Vila Oratório, Praia do Sono, Ponta Negra e Martim de Sá). 239p. Dissertação (Mestrado em Geografia). Programa de Pós-Graduação em Geografia da Universidade Estadual de Campinas, Campinas, 2013.

CARDOSO, E. S. Pescadores artesanais: natureza, território, movimento social. Tese (Doutorado em Geografia Física) - Faculdade de Filosofia, Letras e Ciências Humanas, Universidade de São Paulo. São Paulo: 2001. Disponível em: www.teses.usp.br. Acesso em: 24 ago 2012.

CARDOSO, Eduardo Schiavone, Thomaz Junior, Antonio. Ilhéus do Litoral Norte Paulista Espaço, Pesca e Trabalho. Revista do Departamento de Geografia - USP, Volume 25. 2013, p. 164-182.

CARDOSO, Eduardo Schiavone. Vitoreiros e Monteiros: Ilhéus do Litoral Norte Paulista. 78p. Dissertação (Mestrado em Geografia). Programa de Pós-Graduação em Geografia Humana da Universidade de São Paulo, São Paulo, 1996.

CARLOS, Ana Fani Alessandri. Crise Urbana. São Paulo: Editora CONTEXTO, 2015. 192p.

CARLOS, Ana Fani Alessandri. O Espaço Urbano: Novos Escritos sobre a Cidade. São Paulo: FFLCH, 2007, 123p.

CASTELLS, Manuel. Paraísos comunais: identidade e significado na sociedade em rede. In: CASTELLS, Manuel. O poder da identidade. Tradução Klauss Brandini Gerhardt. 2.ed. São Paulo: Paz e Terra, 2000.

CASTILHO, Cláudio. Entrevista feita com o Geógrafo Claude Raffestin, em Janeiro do ano 2012. In. Revista Movimentos Sociais e Dinâmicas Espaciais. V. 2, N. 1, 2013. Acessível em:< https://periodicos.ufpe.br/revistas/revistamseu/issue/view/2227. Acesso em jan 2016.

CAVALCANTE, Eider Olivindo. Modernização seletiva do litoral: conflitos, mudanças e permanências da localidade de Cumbuco (CE). 138p. Dissertação (Mestrado em Geografia). Programa de Pós-Graduação em Geografia da Universidade Federal do Ceará, Fortaleza, 2012. 
CHAMAS, Cintia Aparecida Pereira Costa. A Gestão de um Patrimônio Arqueológico e Paisagístico: Ilha do Campeche/ SC. 263p. Dissertação (Mestrado em Geografia). Programa de Pós-Graduação em Geografia da Universidade Federal de Santa Catarina, Florianópolis, 2008.

CHAVES, Carla Ramôa. Mapeamento Participativo da Pesca Artesanal da Baía de Guanabara, 158p. Dissertação (Mestrado em Geografia). Programa de Pós-Graduação em Geografia da Universidade Federal do Rio de Janeiro, Rio de Janeiro, 2011.

CLAVAL, Paul [1996]. O Território na Transição da Pós-Modernidade. In: GEOgraphia, Revista da Pós-Graduação em Geografia da UFF. Niterói: UFF, Ano 1 - n 2, 1999. p. 726.

CONFREM. Carta de Belém: Assembleia Nacional dos Extrativistas Costeiros e Marinhos e da CONFREM - 14 a 18 de outubro de 2014.

CONTATO, Maria Carolina Dollo. O Período de Defeso na Manutenção dos Meios de Vida e na Gestão da Pesca Artesanal no Município de Rio Grande - RS. 81p. Dissertação (Mestrado em Geografia). Programa de Pós-Graduação em Geografia da Universidade Federal do Rio Grande, Rio Grande, 2012.

CORDELL, John. Marginalidade social e apropriação territorial marítima na Bahia. In: DIEGUES, Antonio Carlos; MOREIRA, André de Castro. Espaço e Recursos Naturais de Uso Comum. São Paulo: NUPAUB/USP, 2001. p. 139-159.

CORIOLANO, Luzia Neide. Do local ao global: o turismo litorâneo cearense. 3 Ed. Campinas, SP: Papirus, 2002.

CORTES, Soraia. Técnicas de coleta e análise qualitativa de dados. Revista Cadernos de Sociologia, Porto Alegre, v. 9, p. 11-47, 1998.

COSTA, Carlos Rerissom Rocha da. O Litoral do Maranhão, entre Segredos e Descobertas: a fronteira de expansão do turismo litorâneo na periferia do Brasil. 266p. Tese (Doutorado em Geografia). Programa de Pós-Graduação em Geografia da Universidade de São Paulo, São Paulo, 2015.

COSTA, Carlos Rerisson Rocha da. Turismo, produção e consumo do espaço nas comunidades de Redonda e Tremembé, Icapuí - Ceará. Dissertação (Mestrado Acadêmico em Geografia). Programa de Pós-Graduação em Geografia da Universidade Estadual do Ceará, Fortaleza, 2010.

CRUZ, Manoel de Jesus Masulo da. Territorialização Camponesa na Várzea Amazônica. Tese (Doutorado em Geografia). Programa de Pós-Graduação em Geografia Humana da Universidade de São Paulo, 2007.

CRUZ, Rita de Cassia Ariza da. Introdução à Geografia do Turismo. 2 Ed. São Paulo: Roca, 2003.

CRUZ, Valter Carmo. Lutas Sociais, Reconfigurações Identitárias e Estratégias de Reapropriação Social do Território na Amazônia. 368p. Tese (Doutorado em 
Geografia). Programa de Pós-Graduação em Geografia da Universidade Federal Fluminense, Niterói, 2011.

CRUZ, Valter Carmo. Pela Outra Margem da Fronteira: Território, Identidade e Lutas Sociais na Amazônia. 201p. Dissertação (Mestrado em Geografia). Programa de Pós-Graduação em Geografia da Universidade Federal Fluminense, Niterói, 2006.

CUNHA, Alessandra Sampaio. Fragmento de território de pesca na Amazônia [manuscrito]: Comunidade Segredinho/Capanema-Pa. 141p. Dissertação (Mestrado em Gestão dos Recursos Naturais e Desenvolvimento Local na Amazônia). Programa de Pós-Graduação em Gestão dos Recursos Naturais e Desenvolvimento Local na Amazônia da Universidade Federal do Pará, Belém, 2011.

CUNHA, Cleidinilson de Jesus. Regularização da vazão e sustentabilidade de agroecossistemas no estuário do rio São Francisco. 232p. Dissertação (Mestrado em Geografia) Programa de Pós-Graduação em Geografia da Universidade Estadual da Ceará, Fortaleza, 2015.

CUSTÓDIO, Jonas Simas. Caminhos da Produção Familiar Artesanal em Governador Celso Ramos/SC: Da Pesca Maricultura. 155p. Dissertação (Mestrado em Geografia) Programa de Pós-Graduação em Geografia da Universidade da Universidade de Santa Catarina, Florianópolis, 2006.

DE PAULA, C. Q. Gestão compartilhada dos territórios da pesca artesanal: Fórum Delta do Jacuí. 2013. 129p. Dissertação ( Mestrado em Geografia). Programa de Pós-Graduação em Geografia da Universidade Federal do Rio Grande do Sul, Porto Alegre, 2013.

DE PAULA, Cristiano Quaresma de. Tecendo uma Rede de Geografias da Pesca. In. SILVA, C. A.; DE PAULA, C. Q. (orgs) Brasil e Moçambique: diálogos geográficos sobre a pesca artesanal. Rio de Janeiro: Ed. Consequência, 2016, pp.33-52.

DE PAULA, Cristiano Quaresma. Territórios e Territorialidades na Pesca Artesanal do Estuário da Lagoa dos Patos: Contribuições para iniciativas de Ecodesenvolvimento. Monografia (Trabalho de Conclusão de Curso) Curso de Geografia da Universidade Federal do Rio Grande, 2010.

DI MÉO, Guy. Les Territoires de L'action. In. Bulletin de la Société géographique de Liège, Liège, v. 48, p. 7-17, 2006. Disponível em: http://www.bsglg.be/ Acesso em: 23 ago 2011.

DIEGUES, Antonio Carlos (org) Enciclopédia Caiçara vol. 1: O Olhar do Pesquisador. São Paulo: NUPAUB-CEC/HUCITEC, 2004B.

DIEGUES, Antonio Carlos. Pescadores, camponeses e trabalhadores do mar. São Paulo: Ática, 1983.

DIEGUES, Antonio Carlos. A pesca Construindo Sociedades. São Paulo: NUPAUB/USP, 2004A.

DIEGUES, Antonio Carlos. O mito moderno da natureza intocada. 3. ed. São Paulo: Hucitec, 2001. 
DIEGUES, ANTONIO CARLOS. O mito moderno da natureza intocada. $3^{a}$ Ed. São Paulo: Editora HUCITEC, 2001. 169p.

DUMITH, Raquel Carvalho. Dinâmicas do Sistema de Gestão na Reserva Extrativista de Canavieiras (BA): análise da robustez institucional e de possibilidades para o ecodesenvolvimento. Dissertação (Mestrado em Geografia) Programa de Pós-Graduação em Geografia da Universidade Federal do Rio Grande, Rio Grande, 2012.

EAGLETON, Terry. La idea da Cultura. Barcelona: Paidós, 2001.

ELLIOT, T. S. Notas para a Definição da Cultura. Tradução Geraldo Gerson de Souza. São Paulo: Editora Perspectiva, S.A., 1988.

ELLIS, Frank. Rural Livelihoods and Diversity in Developing Countries. Oxford: Oxford University Press. 2000.

ESCOBAR, Arturo. O lugar da natureza e a natureza do lugar: globalização ou pósdesenvolvimento? In. LANDER, Edgardo. A colonialidade do saber: eurocentrismo e ciências sociais Perspectivas latino-americanas. Títulos del Programa Sur-Sur: CLACSO, 2005. Pp. 63-80.

FARIAS, Ariadne Sílvia de. A educação ambiental chega de barco na vila de pescadores da Barra do Superagui. Dissertação (Mestrado em Geografia). Programa de PósGraduação em Geografia da Universidade do Oeste do Paraná, Francisco, Beltrão, 2009.

FERREIRA, Graziele. Comunidade de pescadores artesanais no Lago Itaipu - conflitos territoriais na Colônia Z11 de São Miguel do Iguaçu/PR. 207p. Dissertação (Mestrado em Geografia). Programa de Pós-Graduação em Geografia da Universidade Federal do Oeste do Paraná, Francisco Beltrão, 2014.

FERREIRA, Jamylle de Almeida . Controle do território, identidade e existência: a histórica relação de poder sobre a Colônia de Pescadores Almirante Gomes Pereira- Ilha do Governador- RJ. Dissertação (Mestrado em História Social). Programa de Pós-Graduação em História Social da Universidade do Estado do Rio de Janeiro, 2013.

FIGUEIREDO, Marina Morenna Alves de. Trabalho e participação político-social das pescadoras na RESEX Canavieiras - BA. 116p. Dissertação (Mestrado em Geografia). Programa de Pós-Graduação em Geografia da Universidade Federal da Bahia. Salvador, 2013.

FOX, Veronica; CALLOU, Ângelo Brás Fernandes. Estratégias de comunicação do movimento nacional dos pescadores no Brasil. Razón y Palabra, v. 84, p. 1-1, 2013.

FRANÇA, Ary. A Ilha de São Sebastião: estudo de Geografia humana. São Paulo: Departamento de Geografia da Universidade de São Paulo, 1954. 194p.

FREIRE, Paulo. Pedagogia da autonomia: saberes necessários a pratica educativa. São Paulo: Paz e Terra, 1996.

GIANNELLA, Letícia de Carvalho. Entre o mar e a metrópole: desenvolvimento, território e identidade da comunidade de pescadores de Copacabana, Rio de Janeiro, RJ. 161p. 
Dissertação (Mestrado em Geografia). Programa de Pós-Graduação em Geografia da Pontifícia Universidade Católica do Rio de Janeiro, Rio de Janeiro, 2009.

GIDDENS, A. As consequências da modernidade. São Paulo: Editora UNESP, 1991. 177p.

GOMES, Renan da Silva. A ILHA, o MAR e a "CIDADE DEBAIXO D'ÁGUA": paisagens e mudanças ambientais em Atafona - RJ. 117p. Programa de Pós-Graduação em Geografia da Universidade Federal do Rio de Janeiro. Rio de Janeiro, 2012.

GÓMEZ, Santiago Castro. Ciências sociais, violência epistêmica e o problema da "invenção do outroIn. LANDER, Edgardo. A colonialidade do saber: eurocentrismo e ciências sociais Perspectivas latino-americanas. Títulos del Programa Sur-Sur: CLACSO, 2005. Pp. 80-88.

GUEDES, Eneias Barbosa. Território e Territorialidade de Pescadores nas Localidades Céu e Cajuuna Soure-Pa. 161p. Dissertação (Mestrado em Geografia). Programa de PósGraduação em Geografia da Universidade Federal do Pará, Belém, 2009.

GUILHERME, Cássio Augusto. DE DILMA A TEMER: da crise do lulismo ao golpe do pemedebismo. Anais do XXIX Simpósio Nacional de História.Contra os preconceitos: história e democracia. 2017. Disponível em <http://www.snh2017.anpuh.org/resources/anais/54/1502040383_ARQUIVO_Artigoco mpleto-Anpuh2017-deDilmaaTemer.pdf>. Acesso em 12 out 2017.

HABERMAS, Jurgüen. Teoria do Agir Comunicativo - Racionalidade da Ação e Racionalização do Social. São Paulo: Martins Fontes, v. 1, 2012A.

HABERMAS, Jurgüen. Teoria do Agir Comunicativo - Sobre a Crítica da Razão Funcionalista. São Paulo: Martins Fontes, v. 2, 2012B.

HAESBAERT, Rogério. O mito da desterritorialização: do "fim dos territórios" à multiterritorialidade. 3.ed. Rio de Janeiro: Bertrand Brasil, 2007.

HAESBAERT, Rogério. Territórios Alternativos. 2 Ed. São Paulo: Contexto, 2006.

HALL, Stuart. Quem precisa de identidade? In: SILVA, Tomaz Tadeu (Org.). Identidade e Diferença: a perspectiva dos estudos culturais. 12. ed. Petrópolis, RJ: Vozes, 2012.

HARVEY, David. Espaços de Esperança. São Paulo: Edições Loyola, 2004.

HEIDRICH, Álvaro Luís. Espaço e multiterritorialidade entre territórios: reflexões sobre a abordagem territorial. In. PEREIRA, Sélvia; COSTA, Benhur. Teorias e práticas territoriais: análises espaço temporais. São Paulo: Expressão Popular, 2010. pp.25-36.

HOBSBAWN, E. Introdução: a invenção das tradições. In: HOBSBAWN, E.; RANGER, T. (Orgs.). A invenção das tradições. $2^{a}$ ed. Rio de Janeiro: Paz e Terra, 2006.

KALIKOSKI, Daniela; SEIXAS, Cristiana.; ALMUDI, Tiago. Gestão compartilhada ecomunitária da pesca no Brasil: avanços e desafios. Ambiente \& Sociedade, Campinas, v. XIII, jan-jun 2009. Disponível em: www.scielo.br Acesso em 11 nov 2010. 
KUHN, Ednizia Ribeiro Araújo. Terra e água: Territórios dos pescadores artesanais de São Francisco do Paraguaçu-Bahia. 173p. Dissertação (Mestrado em Geografia). Programa de Pós-Graduação em Geografia da Universidade Federal da Bahia, Salvador, 2009.

LARAIA, Roque de Barros. Cultura: um conceito antropológico. 5. ed. Rio de Janeiro: Zahar, 1989. 116p.

LATOUR, Bruno. Jamais Fomos Modernos: ensaio de antropologia simétrica. Rio de Janeiro: Ed. 34, 2009.

LATOUR, Bruno. Jamais Fomos Modernos: ensaio de antropologia simétrica. Tradução de Carlos Irineu da Costa. Rio de Janeiro: Editora 34, v. $1^{\circ}$ Ed., 1994.

LEFEBVRE, Henri. Espaço e Política. Belo Horizonte: Editora UFMG, 2008.

LEFF, Enrique. Epistemologia Ambiental. 4. ed. São Paulo: Cortez, 2007.

LEFF, Enrique. Racionalidad ambiental - la reapropriación social de la naturaleza. México: 2004

LEFF, Enrique. Racionalidade Ambiental: a reapropriação social da natureza. Tradução de Luís Carlos Cabral. Rio de Janeiro: Civilização Brasileira, 2006.

LEFF. Enrique. Complexidade, Racionalidade Ambiental e Diálogo de Saberes. Revista Educação \& Realidade, Porto Alegre, v. 34, n. 3, 2009. Disponível em: seer.ufrgs.br Acesso: 10 jan 2011.

LEFF. Enrique. Epistemologia Ambiental. Tradução de Sandra Valenzuela. São Paulo: Cortez, 2010 .

LIMA, Maria do Céu. Comunidades pesqueiras marítimas no Ceará território, costumes e conflitos. 220p. Tese (Doutorado em Geografia). Programa de Pós-Graduação em Geografia da Universidade de São Paulo, São Paulo, 2002.

LIMA, Marta. Mobilidade geográfica como estratégia de sobrevivência de pescadores artesanais na Amazônia: o caso de Cubatão em Icoaraci, Pará. 120p. Dissertação (Mestrado em Geografia). Programa de Pós-Graduação em Geografia da Universidade Federal do Pará, Belém, 2008.

LIMA. Dário de Araújo. O Lugar Marambaia. 672p. Tese (Doutorado em Geografia). Programa de Pós-Graduação em Geografia da Universidade Estadual Paulista, Presidente Prudente. 2003.

LOBO, Adriane. (Org). Nas redes da pesca artesanal. Brasília: IBAMA, 2007.

LUKÁCS, Gyorgy. O Trabalho. Em: Perl' Ontologia Dell’ Essere Sociale. Roma: Riuniti Tradução: Tonet, Ivo. 1981.

MACHADO, Cristina Buratto Gross. O território da pesca artesanal da Colônia Z4, Barra Velha, SC: o paradoxo entre a tradição e a modernidade. 117p. Dissertação (Mestrado em Geografia. Programa de Pós-Graduação em Geografia da Universidade Estadual do Centro-Oeste, Guarapuava, 2013. 
MACHADO, Ricardo Augusto Souza. O meio natural na organização produtiva da população pesqueira tradicional do município de Canavieiras. 159p.Dissertação (Mestrado em Geografia). Programa de Pós-Graduação em Geografia da Universidade Federal da Bahia, Salvador, 2007.

MAIER, Eder Leandro Bayer. A pesca do siri como adaptação das comunidades pesqueiras artesanais do Estuário da Lagoa dos Patos - RS. Rio Grande: Programa de Pósgraduação em Geografia. (Dissertação de Mestrado): Universidade Federal do Rio Grande, 2009.

MALDONADO, Simone Carneiro. Pescadores do mar. Editora Ática. São Paulo. 1986.

MALVEZZI, Roberto. Hidronegócio. In: CALDART, Roseli Salete, PEREIRA, Isabel Brasil, FIRGOTTO, Gaudêncio. Dicionário de Educação do Campo. Rio de Janeiro - São Paulo: Expressão Popular, 2012, p. 397-404

MARCHKE, M. Livelihood in context: learning with Cambodian fishers. Dissertation for Natural Research Institute. University of Manitoba, Winnipeg, Manitoba, Canada. 2005.

MARTINS, César Augusto de Ávila. Nas águas da Lagoa há reprodução da vida: pesca artesanal no estuário da lagoa dos Patos- Rio Grande/RS. In. Scripta Nova Volume VI, Número 119 (47). Universidade de Barcelona, 2002. Disponível em: www.ub.edu/geocrit/sn/sn119-47.htm Acesso em 24 ago 2015.

MARX, Karl. Processo de Trabalho e Processo de Produzir Mais Valia. In: O Capital - livro primeiro. $6^{\circ}$ ed. Rio de Janeiro. Editora: Civilização Brasileira, V. I, 1980.

MASSEY, Doreen B. Pelo Espaço: uma nova política de espacialidade. Tadução de Maciel, Hilda P. e Haesbaert, Rogério. Rio de Janeiro: Bertrand Brasil, 2008.

MCGRATH, David et al. Manejo Comunitário de Lagos de Várzea e o Desenvolvimento Sustentável ea Pesca na Amazônia. PEPERS DO NAEA, Belém, 58, 1996. Disponível em: periodicos.ufpa.br Acesso em: 21 jan 2012.

MCGRATH, David et al. Varzeiros, geleiros e o manejo dos recursos naturais na várzea do baixo Amazonas. In. Cadernos do NAEA, nº.11, novembro, 1993.

MENDONÇA, Francisco. Temas, Tendências e Desafios da Geografia na Pós-Graduação Brasileira. Revista da ANPEGE V. 2, N. 02, 2005. Pp.

MERLEAU-PONTY, Maurice. Fenomenologia da Percepção. 2. Edição. São Paulo: Martins Fontes, 1999.

MORAES, Antonio Carlos Robert. Geografia Pequena História Crítica. 20. ed., São Paulo: Annablume, 2005. 152p.

MORAES, Lúcia de Fátima Saboia de. Para onde sopram os ventos de Cumbuco? Impactos do turismo no litoral de Caucaia, Ceará. Dissertação (Mestrado em Geografia). Programa de Pós-Graduação em Geografia da Universidade Estadual do Ceará, Fortaleza, 2010.

MORAES, Tiago Rossi de. Pesca Artesanal no Rio Vacacaí, RS: Influências da Orizicultura Irrigada e os Potenciais Territórios de Conflito. 141p. Dissertação (Mestrado em 
Geografia). Programa de Pós-Graduação em Geografia da Universidade Federal de Santa Maria, 2015.

MORIN, Edgar. Ciência com consciência. Tradução de Maria Alexandre e Maria Alice Sam. Rio de Janeiro: Bertrand Brasil, 1996.

MORIN, Edgar. Introdução ao Pensamento Complexo. Lisboa: Instituto Piaget, 1990.

MORIN, Edgar. O método 1: a natureza da natureza. Tradução de Ilana Heineberg. 2a . ed. Porto Alegre: Sulina, 2008.

MORIN, Edgar. O Método 6: ética. Porto Alegre: Sulina, 2005. 222 p.

MORIN, Edgar. Saberes globais e saberes locais: o olhar transdisciplinar. Rio de Janeiro: Garamond, 2000.

MOSCOVICI, Serge. Essai sur l'Histoire Humaine de la Nature. Paris: Flammarion, 1968.

MPP, ATA do I Encontro da Articulação Sudeste-Sul do Movimento dos Pescadores e Pescadoras Artesanais, 2016.

MPP, ATA do II Encontro da Articulação Sudeste-Sul do Movimento dos Pescadores e Pescadoras Artesanais, 2017

MPP, ATA. Resultado da II Assembleia Geral do Movimento dos Pescadores e Pescadoras Artesanais, 2016.

MPP, Carta de Jaguaruna. Resultado do II Encontro da Articulação Sudeste-Sul do Movimento dos Pescadores e Pescadoras Artesanais, 2017.

MPP, Cartilha para Trabalho de Base da Campanha pelo Território Pesqueiro. 2012B, disponível em: https://geografar.ufba.br/sites/geografar.ufba.br/files/cartilhaterritoriopesqueiro.pdf. Acesso em 17 maio 2014.

MPP. Cartilha para Trabalho de Base da Campanha pelo Território Pesqueiro. Brasil: [s.n.], 2012.

MPP. Projeto de Lei de Iniciativa Popular para o reconhecimento, proteção e garantia do território das comunidades tradicionais pesqueiras, 2012A. Disponível em: http://documentospeloterritorio.blogspot.com.br/. Acesso $10 \mathrm{dez} 2013$.

NUNES, Shauane Itainhara Freire. A Pesca Artesanal como Mediação da Relação Homem Natureza: Permanência e Resistência dos Pescadores nas Comunidades Pesqueiras do Povoado Mosqueiro/Aracaju-SE. Dissertação (Mestrado em Geografia). Programa de Pós-Graduação em Geografia da Universidade Federal da Paraíba, João Pessoa, 2011.

OLIVEIRA, Ariovaldo Umbelino. Espaço e Tempo: Compreensão Materialista Dialética. In: Milton Almeida dos Santos. (Org.). Novos Rumos da Geografia Brasileira. São Paulo: Hucitec, 1982. 
OLIVEIRA, Ariovaldo Umbelino. Modo de Produção Capitalista, Agricultura e Reforma Agrária. São Paulo: Labur Edições, 2007, 184p.

OSTROM, Eleonor. Governing the commons: the evolution of institutions for collective action. Cambridge: Cambridge University Press, 1990.

PASQUOTTO, V. F. Comercialização, políticas públicas e reprodução social na pesca artesanal. In. LOBO, A. C. (Org). Nas redes da pesca artesanal. Brasília: IBAMA, 2007 p.225239.

PAULA, Edson de. Vilegiatura marítima na Região Metropolitana de Fortaleza: análise de impactos socioambientais. 147p. Dissertação (Mestrado em Geografia). Programa de PósGraduação em Geografia da Universidade Federal do Ceará, Fortaleza, 2012.

PÉREZ, Mercedes Solá. Comunidade tradicional de pescadores e pescadoras artesanais da vila do Superaguii-PR na disputa pela vida: conflitos e resistências territoriais frente à implantação de políticas públicas de desenvolvimento.150p. Dissertação (Mestrado em Geografia). Programa de Pós-Graduação em Geografia da Universidade Federal do Paraná, Curitiba, 2012.

PORTO-GONÇALVES, Carlos Walter. A GEOGRAFIA ESTÁ EM CRISE. VIVA A GEOGRAFIA! (Comunicação apresentada no $3^{\circ}$ Encontro Nacional de Geógrafos). Boletim Paulista de Geografia. N.5, 1978.

PORTO-GONÇALVES, Carlos Walter. Da Geografia às geo-grafias: um mundo em busca de novas territorialidades. La Guerra Infinita: Hegemonía y terror mundial, Buenos Aires, p. 217-256, 2002. Disponível em: biblioteca.clacso.edu.ar Acesso 2011-01-05.

PORTO-GONÇALVES, Carlos Walter. De saberes e de territórios: diversidade e emancipação a partir da experiência Latino-Americano. GEOgraphia, 8 Fev 2010. Disponível em: www.uff.br. Acesso em: 23 jan 2012.

PORTO-GONÇALVES, Carlos Walter. Os (des) caminhos do Meio Ambiente. 14Ed. São Paulo: Contexto, 2006.

PRADO, Zenildo Crisostomo do. Uso Comum da Terra e do Rio: Conflitos e Resistência do Camponês Ribeirinho no Município de Santo Antônio de Leverger-MT. 226p. Dissertação (Mestrado em Geografia). Programa de Pós-Graduação em Geografia da Universidade Federal do Mato Grosso, Cuiaba, 2015.

PROST, Catherine. Ecodesenvolvimento da pesca artesanal em região costeira: estudos de caso no Norte e Nordeste do Brasil. GeoTextos, Salvador, v. 3, p. 139-169, 2007.

QUEIROZ, Greiziene Araujo, $O$ circuito inferior da economia urbana: a pesca no município de Ilhéus - BA. 118p. Dissertação (Mestrado em Geografia). Programa de PósGraduação em Geografia da Universidade Estadual de Campinas, Campinas, 2011.

QUEIROZ, Sebastião Sampaio. A pesca e a comercialização dos bagres no médio rio Solimões -Tefé (AM). 130p. Dissertação (Mestrado em Geografia). Programa de PósGraduação em Geografia da Universidade Federal do Amazonas, Manaus, 2012. 
QUIJANO, Aníbal. Colonialidade do poder, eurocentrismo e América Latina. In. LANDER, Edgardo. A colonialidade do saber: eurocentrismo e ciências sociais Perspectivas latino-americanas. Títulos del Programa Sur-Sur: CLACSO, 2005. Pp. 107-130.

RAFFESTIN, Claude, BARAMPAMA, Angelo. Espace et pouvoir. In: BAILLY Antoine. Les concepts de la géographie humaine. Paris : Armand Colin, 1998. p. 63-71

RAFFESTIN, Claude. De la nature aux images de la nature. In. Espaces et Sociétés, 1996, no.8283, p. $37-52$

RAFFESTIN, Claude. Ecogenèse territoriale et territorialité. In: AURIAC F. BRUNET R. Espaces, jeux et enjeux. Paris : Fayard \& Fondation Diderot, 1986. p. 175-185

RAFFESTIN, Claude. Les territorialités alpines ou les paradoxes du dialogue nature-culture. In: Economie et Ecologie dans le contexte de l'arc alpin. Berne: Sonderdruck Haupt, 1989.p. 37-50

RAFFESTIN, Claude. Por uma Geografia do poder. São Paulo: Ática, 1993.

RAFFESTIN, Claude. Pour une géographie du pouvoir. Paris: Éd. LITEC, 1980, 250p.

RAFFESTIN, Claude. Punti di riferimento per una teoria della territorialita' umana. In: COPETA Clara. Esistere e abitare. Prospettive umanistiche nella Geografia francofona. Milano : Franco Ageli, 1986C. p. 75-89

RAFFESTIN, Claude. Territorialité: concept ou paradigme de la géographie sociale? In. Geographica Helvetica, 1986B, no. 2, p. 91-96

RAFFESTIN, Claude; BRESSO, Mercedes "Tradition, modernité, territorialité." In. Cahiers de géographie du Québec 2668, 1982, pp.185-198.

RAFFESTIN. Claude. Space, territory, and territoriality. Environment and Planning D. In. Society and Space, V.30, 2012, pp. 121-141.

RAINHA, Felippe Andrade. Morar e Trabalhar: a pesca artesanal e o seu elo com o espaço da metrópole do Rio de Janeiro. Dissertação (Mestrado em Geografia) Programa de PósGraduação em Geografia da Universidade do Estado do Rio de Janeiro, 2015.

RATZEL, Friedrich. Antropogeografia. In: MORAES, A. C. R.; FERNANDES, F. Ratzel. São Paulo: Ática, 1990.

REIGOTA, Marcos. O que é educação ambiental. São Paulo: Brasiliense, 1994.

RELPH, Edward. As bases fenomenológicas da Geografia. Geografia, v.4, n.7, AGETEO, Rio Claro, São Paulo, 1979.

RESENDE, A. A origem da institucionalidade das Colônias de Pescadores. In. SILVA, C. A. (org.) Pesca Artesanal e Produção do Espaço: Desafios para a Reflexão Geográfica. Rio de Janeiro: Consequência, 2014. 
RIBEIRO, Ana Clara Torres. Territórios da sociedade: por uma cartografia da ação. In SILVA, Catia Antonia da (org.). Território e ação social: sentidos da apropriação urbana. Rio de Janeiro: Editora Lamparina, 2011.

RIBEIRO, Ana. Clara Torres. Metrópole: sentidos de fragmentação. In. SILVA, C. A.; OLIVEIRA, Andrelino.; RIBEIRO, Ana Clara. (orgs). Metrópoles: entre o local e as experiências cotidianas. Rio de Janeiro: EdUERJ, 2012.

RIOS, Francisco Ther; BRAVO, Jaime Valderrama. Dinámicas territoriales em assentamientos de pescadores artesanales economías, experiencias y conflitos. El caso de Guabúm y Puñihuil em la comuna de Ancud, Chiloé. CUHSO, CULTURA - HOMBRESOCIETAD, V.22, N.1, jul/2012, pp.61-64.

RIOS, Kássia Aguiar Norberto. Da produção do espaço a construção dos territórios pesqueiros: pescadores artesanais e carcinicultores no Distrito de Acupe - Santo Amaro (BA). 262p. Dissertação (Mestrado em Geografia) Programa de Pós-Graduação em Geografia da Universidade Federal da Bahia, Salvador, 2012.

RODRIGUES, Francisco Gleison de Souza. O Agronegócio da Carcinicultura Marinha e os Conflitos Sociais e Ambientais de Uso e Ocupação do Estuário do Rio Jaguaribe no Município de Aracati-CE. 122p. Dissertação (Mestrado em Geografia). Programa de Pós-Graduação em Geografia da Universidade Federal do Ceará, Fortaleza, 2005.

RODRIGUES, Fúlvia Maria Gomes. Unidades de Conservação, pesca e modo de vida: contradições. 123p. Dissertação (Mestrado em Geografia). Programa de Pós-Graduação em Geografia da Universidade Federal do Amazonas, 2014.

ROSÁRIO, Jeruza Jesus do. Marisqueiras e pescadoras: o cotidiano na reserva extrativista baía do Iguape-BA. 127p. Dissertação (Mestrado em Cultura Memória e Desenvolvimento Regional). Programa de Pós-graduação em Cultura Memória e Desenvolvimento Regional da Universidade do Estado da Bahia, 2009.

SACK, Robert. Human Territoriality: Its Theory and History. Cambridge: Cambridge University Press, 1986.

SANTANA, Gisele de Maria. A cultura da pesca artesanal de Bote na comunidade da Barra em Rio Grande/RS. 170p. Dissertação (Mestrado em Geografia) Programa de PósGraduação em Geografia da Universidade Federal do Rio Grande, Rio Grande, 2013.

SANTOS, Boaventura de Sousa. Epistemologías del Sur. In. Utopía y Praxis Latinoamericana, Año 16, $\mathrm{N}^{\circ}$ 54, 2011. Pp. 17-39.

SANTOS, Boaventura de Sousa. Los nuevos movimientos sociales. Revista del Observatorio Social de América Latina/OSAL, 5, 2001. Pp.177-188.

SANTOS, Boaventura de Sousa. Para além do Pensamento Abissal: Das linhas globais a uma ecologia de saberes. Revista Novos Estudos Cebrap, N. 79, 2007, pp. 71-94.

SANTOS, Boaventura de Sousa. Para uma sociologia das ausências e uma sociologia das emergências. In. Revista Crítica de Ciências Sociais, N. 63, 2002. Pp. 237-280. 
SANTOS, Boaventura de Sousa; MENESES, Maria Paula G.; NUNES, João Arriscado. Conhecimento e Transformação Social: por uma ecologia de saberes. In. Hiléia - Revista de Direito Ambiental da Amazônia, N. 6; 2006. Pp.11-104.

SANTOS, Eline Almeida. (Re)produção social e dinâmica ambiental no espaço da pesca reconstruindo a territorialidade das marisqueiras em Taiçosa de Fora-Nossa Senhora do Socorro/SE. 163p. Dissertação (Mestrado em Geografia). Programa de PósGraduação em Geografia da Universidade Federal do Sergipe, São Cristóvão, 2012.

SANTOS, Ingrid Regina da Silva; JESUZ, Cleberson Ribeiro de. A aplicação do discurso do sujeito coletivo, na análise da percepção da qualidade da água do rio Cuiabá nos municípios de Santo Antonio do Leverger, Várzea Grande e Cuiabá. Revista Matogrossense de Geografia. v. 17, n. 1, 2014. Pp. 117 138. Disponível em: http://periodicoscientificos.ufmt.br/

SANTOS, Maria Auxiliadora Ferreira dos. Análise do processo de internalização de propostas de educação ambiental em escolas de Ensino Médio no município de Acaraú-CE. 111p. Dissertação (Mestrado em Geografia). Programa de Pós-Graduação e Pesquisa em Geografia. Da Universidade Federal do Rio Grande do Norte, Natal, 2008.

SANTOS, Maria Auxiliadora Ferreira dos. Outra Banda. Lugar de Quem? Tese (Doutorado em Geografia). 118p. Programa de Pós-Graduação em Geografia da Universidade Estadual Paulista, UNESP, Rio Claro, 2013.

SANTOS, Milton. A Natureza do Espaço: Técnica e Tempo, Razão e Emoção. 4. ed. 2. reimpr. São Paulo: EDUSP, 2006.

SANTOS, Milton. Por uma Geografia Nova: Da crítica da Geografia a uma Geografia crítica. São Paulo: Edusp, 2004.

SANTOS, Milton.; SILVEIRA, Maria Laura. O Brasil: território e sociedade no início do século XXI. Rio de Janeiro: Record, 2004.

SAQUET, Marco Aurélio. Abordagens e concepções de território. $2^{\text {a }}$. ed. São Paulo: Expressão popula, 2010.

SCHEIBEL, Carlos Roberto. Práticas, técnicas e geossímbolos da cultura da pesca vernácula na paisagem fluvial de Pitangui-Juntuva - Região de Campos Gerais (PR). 120p. Dissertação (Mestrado em Geografia) Programa de Pós-Graduação em Geografia da Universidade Estadual de Ponta Grossa, 2013.

SCHNEIDER, Sérgio. Agricultura familiar e industrialização: Pluriatividade e descentralização industrial no Rio Grande do Sul. Ed. Universidade/UFRGS. Porto Alegre, 1999.

SHANIN, Theodor. A definição de Camponês: Conceituações e Desconceituações. Estudos SEBRAP, N26, Editora Vozes, 1980.

SILVA, Catia Antonia da Silva e DE PAULA, Cristiano Quaresma. Brasil e Moçambique Diálogos geográficos sobre a pesca artesanal. Rio de Janeiro: Ed. Consequência, 2016. 200p. 
SILVA, Catia Antonia da Silva. Sobre as Geografias das existências. SILVA, Catia Antonia da Silva e DE PAULA, Cristiano Quaresma. Brasil e Moçambique - Diálogos geográficos sobre a pesca artesanal. Rio de Janeiro: Ed. Consequência, 2016. Pp.17-32.

SILVA, Catia Antonia da. Modernização, Conflitos Territoriais e Sujeitos Sociais de Culturas Tradicionais: contribuições da Geografia na leitura da produção da totalidade do espaço brasileiro no século XXI. In. SUERTEGARAY, Dirce Maria Antunes; SILVA, Charlei Aparecido Da; PIRES, Cláudia Luísa Zeferino; DE PAULA, Cristiano Quaresma de. Geografia e Conjuntura Brasileira. Rio de Janeiro; Consequência, 2017. Pp.249-274.

SILVA, Christian Nunes da. Geotecnologias Aplicadas no Ordenamento Pesqueiro. 190p. Tese (Doutorado em Geografia) Programa de Pós-Graduação em Ecologia Aquática e Pesca da Universidade Federal do Pará, Belém, 2012A.

SILVA, Christian Nunes da. Territorialidades e modo de vida de pescadores do rio Ituquara, Breves - PA. Dissertação (Mestrado em Geografia) Programa de Pós-Graduação em Geografia da Universidade Federal do Pará, Belém, 2006A.

SILVA, Crisanto Damião da. Pesca: classes sociais, territorialidades e trabalho em ManacapuruAM. 145p. Dissertação (Mestrado em Geografia). Programa de Pós-Graduação em Geografia da Universidade Federal do Amazonas, Manaus,2009.

SILVA, Janaina Barbosa da. Territorialidade da pesca no estuário de Itapessoca - PE: técnicas, apetrechos, espécies e impactos ambientais. 83p. Dissertação (Mestrado em Geografia). Programa de Pós-Graduação em Geografia da Universidade Federal de Pernambuco, Recife, 2006B.

SILVA, José Borzacchiello da. DANTAS, Eustógio Wanderley Correia. A pós-graduação em Geografia no Brasil: uma contribuição à política de avaliação. Revista da ANPEGE. $n$. 2, 2005. Pp.

SILVA, Suana Medeiros da. Pesca artesanal: a história, a cultura e os (des) caminhos em Lucena/PB. 122p. Dissertação (Mestrado em Geografia). Programa de Pós-Graduação em Geografia da Universidade Federal da Paraíba, João Pessoa, 2012B.

SILVA, Tomás Rech da. Geograficidade, percepção e saberes ambientais dos pescadores do lago Guaíba, Porto Alegre, RS. 157p. Dissertação (Mestrado em Geografia). Programa de Pós-Graduação em Geografia da Universidade Federal do Rio Grande do Sul, 2007.

SIVA, Catia Antonia da. Política Pública e Território: passado e presente da efetivação de direitos dos pescadores artesanais no Brasil. $2^{\mathrm{a}} \mathrm{Ed}$. Rio de Janeiro: Consequência, 2015. 130 p.

SOJA, Edward W. Geografias pós-modernas: a reafirmação do espaço na teoria social crítica. Rio de janeiro: Jorge Zahar, 1993.

SOUZA, Marcelo Lopes de. A prisão e a ágora: reflexões em torno da democratização do planejamento e da gestão das cidades. Rio de Janeiro: Bertrand Brasil, 2006. 632p.

SPÓSITO, Eliseu Sevério. A pós-graduação em Geografia no Brasil: Avaliação e tendências. In. SPÓSITO, Eliseu Sevério; SILVA, Charlei Aparecido da, SANT’ANNA NETO, João 
Lima; MELAZZO, Everaldo Santos. A diversidade da Geografia Brasileira. Escalas e Dimensões da Análise e da Ação. Rio de Janeiro; Consequência, 2016. Pp.523-543.

SUERTEGARAY, Dirce Maria Antunes Espaço Geográfico Uno e Múltiplo. In. Scripta Nova, Barcelona, N.93, jul 2001. Disponível em www.ub.edu Acesso em 2010-06-12.

SUERTEGARAY, Dirce Maria Antunes. A expansão da pós-graduação em Geografia e a ANPEGE. Revista da ANPEGE. v. 1, n. 01, 2003. Pp.

SUERTEGARAY, Dirce Maria Antunes. Pesquisa de Campo e Geografia. In.GEOgraphia, Niterói, 2009.

SUERTEGARAY, Dirce Maria Antunes. Religar a Geografia: natureza e sociedade. Porto Alegre: Compasso Lugar-Cultura, 2017, 179p.

SUERTEGARAY, Dirce Maria Antunes. Rumos e Rumores da Pós-graduação e da Pesquisa em Geografia no Brasil. Revista da ANPEGE. v. 3, 2007. pp.11-19

SUERTEGARAY, Dirce Maria Antunes. Tempos Longos. Tempos Curtos. Na Análise da Natureza. In. Geografares, Vitória, jun 2002. 159-164.

SUERTEGARAY, Dirce Maria Antunes; OLIVEIRA, Mateus Gleiser; DELFINO, Elisa da Silveira. Ribeirinhos da FLONA de Tefé - AM: cartografia social na compreensão do modo de vida. In. HEIDRICH, Álvaro Luiz; PIRES, Cláudia Luísa Zeferino (Orgs.). Abordagens e práticas de pesquisa qualitativa em Geografia e saberes sobre espaço e cultura. Porto Alegre, Letra 1, 2016. Pp. 103-128.

TAPIA, Luis Mealla. Política Salvaje. Consejo Latinoamericano de Ciencias Sociales CLACSO: La Paz, 2008. 122p.

THOMAZ JUNIOR, Antonio. Dinâmica Geográfica do Trabalho no Século XXI (Limites explicativos, Autocrítica e Desafios Teóricos). Presidente Prudente: Tese Livre Docência - FCT - UNESP, v. 1, 2009.

TOMÁZ, Alzení de Freitas \& SANTOS, Gilmar. (Orgs.) Conflitos Socioambientais e Violações de Direitos Humanos em Comunidades Tradicionais Pesqueiras no Brasil. - Brasilia/DF: Conselho Pastoral dos Pescadores. 2016. 104p.

TORRES, Ronilse Pereira de Aquino. O sentido de ser pescador: signos e marcas no povoado Pedreiras - São Cristóvão/SE. 140p. Dissertação (Mestrado em Geografia). Programa de Pós-Graduação em Geografia da Universidade Federal de Sergipe. São Cristóvão, 2014.

TUAN, Yi-Fu. Topofilia: um estudo da percepção, atitudes e valores do meio ambiente. São Paulo: Difel, 1980.

VALLADARES, Licia. Os dez mandamentos da observação participante. Revista brasileira de Ciências Sociais.[online]. Vol. 22, N.63, 2007, pp.153-155.

VIEIRA, Paulo Freire. Rumo ao desenvolvimento territorial sustentável: esboço de roteiro metodológico participativo, In. Eisforia. Florianópolis, v. IV, p. 249-310, 2006. 
VINHAS, Antonio Lopes Ferreira. Pescadores artesanais de Pedra de Guaratiba, Rio de Janeiro (RJ): os diferentes conflitos pela identidade. 177p. Dissertação (Mestrado em Geografia) Programa de Pós-Graduação em Geografia da Pontifícia Universidade Católica do Rio de Janeiro, 2011.

WHYTE, William Foote. Sociedade de esquina: a estrutura social de uma área urbana pobre e degradada.Tradução de Maria Lucia de Oliveira. Rio de Janeiro, Jorge Zahar, 2005. 390p.

ZAOUAL, Hassan. Do turismo de massa ao turismo situado: quais as transições?. Caderno Virtual de Turismo. V. 8, N.2, 2008. Disponível em <http://www.redalyc.org/articulo.oa?id=115415175001>, Acesso $10 \mathrm{dez} 2017$.

\section{Legislações}

BRASIL, Decreto $\mathbf{N}^{\mathbf{0}} \mathbf{4 . 8 8 7}$, de 20 de novembro de 2003. Regulamenta o procedimento para identificação, reconhecimento, delimitação, demarcação e titulação das terras ocupadas por remanescentes das comunidades dos quilombos. Disponível em: http://www.planalto.gov.br/ccivil_03/decreto/2003/D4887.htm. Acesso em 12 out 2017.

BRASIL, Decreto No 6.040, de 7 de fevereiro de 2007A. Institui Política Nacional de Desenvolvimento Sustentável dos Povos e Comunidades Tradicionais. Disponível em: http://www.planalto.gov.br/ccivil_03/_ato2007-2010/2007/decreto/d6040.htm. Acesso 17 mai 2015.

BRASIL, Decreto $\mathbf{N}^{\circ} \mathbf{6 . 9 8 1}$, de 13 de outubro de 2009B.Dispõe sobre a atuação conjunta dos Ministérios da Pesca e Aquicultura e do Meio Ambiente nos aspectos relacionados ao uso sustentável dos recursos pesqueiros. Disponível em http://www.planalto.gov.br/ccivil_03/_Ato2007-2010/2009/Decreto/D6981.htm. Acesso 16 jan 2012.

BRASIL, Decreto No 8.967, de 23 de janeiro de 2017. Dispõe sobre a concessão do benefício de seguro-desemprego, durante o período de defeso, ao pescador profissional artesanal que exerce sua atividade exclusiva e ininterruptamente, 2017. Disponível em: http://www.planalto.gov.br/ccivil_03/_ato2015-2018/2017/decreto/D8967.htm. Acesso em 17 jun. de 2017.

BRASIL, Instrução Normativa Ibama No 3, de 9 de fevereiro de 2004. Estabelece normas para a pesca artesanal no Estuário da Laguna dos Patos. Disponível em: www.ibama.gov.br. Acesso em 2016-10-12.

BRASIL, Instrução Normativa Interministerial No 1, de 10 de outubro de 2007. Estabelece os procedimentos operacionais entre a SEAP/PR e a SPU/MP para a autorização de uso dos espaços físicos em águas de domínio da União para fins de aquicultura. Disponível em http://www.planejamento.gov.br/assuntos/patrimonio-dauniao/legislacao/instrucoesnormativas/instrucoes-normativas-arquivos-pdf/ininterministerial-01-2007-aquicultura.pdf. Acesso $10 \mathrm{dez} 2017$

BRASIL, Lei Complementar $\mathbf{N}^{\mathbf{0}}$ 140, de 8 de dezembro de 2011B. Estabelece a cooperação entre a União, os Estados, o Distrito Federal e os Municípios nas ações administrativas 
decorrentes do exercício da competência comum relativas à proteção das paisagens naturais notáveis, à proteção do meio ambiente, ao combate à poluição em qualquer de suas formas e à preservação das florestas, da fauna e da flora. Disponível em: http://www.planalto.gov.br/ccivil_03/Leis/LCP/Lcp140.htm. Acesso 16 jan 2012.

BRASIL, Lei $\mathbf{N}^{\mathbf{0}}$ 11.959, DE 29 de junho de 2009A. Dispõe sobre a política nacional de desenvolvimento sustentável da aquicultura e da pesca. Disponível em: https://www.planalto.gov.br/ccivil_03/_ato2007-2010/2009/lei/111959.htm. Acesso 10 dez. 2017.

BRASIL, Lei $\mathbf{N}^{\mathbf{0}} \mathbf{6 . 9 3 8}$, de 31 de agosto de 1981. Dispõe sobre a Política Nacional do Meio Ambiente, seus fins e mecanismos de formulação e aplicação, e dá outras providências. Disponível em: http://www.mma.gov.br/port/conama//legiabre.cfm?codlegi=313. Acesso 24 ago 2017.

BRASIL, Lei No 9.433, de 8 de janeiro de 1997.Institui a Política Nacional de Recursos Hídricos, cria o Sistema Nacional de Gerenciamento de Recursos Hídricos. Disponível em http://www.planalto.gov.br/ccivil_03/Leis/L9433.htm. Acesso 24 ago 2017.

BRASIL, Lei $\mathbf{N}^{\mathbf{9}} \mathbf{9 . 6 0 5}$, de 12 de fevereiro de 1998. Dispõe sobre as sanções penais e administrativas derivadas de condutas e atividades lesivas ao meio ambiente, e dá outras providências. Disponível em: http://www.planalto.gov.br/CCivil_03/leis/L9605.htm. Acesso 24 ago 2017.

BRASIL, Lei $\mathbf{N}^{\mathbf{0}}$ 9.985, de 18 de julho de 2000. Institui o Sistema Nacional de Unidades de Conservação da Natureza e dá outras providências. Disponível em: http://www.planalto.gov.br/ccivil_03/Leis/L9985.htm. Acesso 24 ago 2016.

BRASIL, Portaria Interministerial MPA/MMA $\mathbf{N}^{\mathbf{5}} \mathbf{5}$, de $1^{\circ}$ de setembro de 2015D. Regulamenta o Sistema de Gestão Compartilhada do uso sustentável dos recursos pesqueiros. Disponível

em http://www.icmbio.gov.br/cepsul/images/stories/legislacao/Portaria/2015/p_mpa_mma_ 05_2015_sistema_gest\%C3\%A3o_pesca_compartilhada.pdf. Acesso 17 jun 2017.

BRASIL, Portaria $\mathbf{N}^{\circ}$ 03, de 14 de maio de 2015C. Estabelece Plano de Gestão para o Uso Sustentável da Tainha, Mugil liza, nas regiões Sudeste e Sul do Brasil. Disponível em: <www.icmbio.gov.br>. Acesso em $10 \mathrm{dez} 2016$.

BRASIL, Portaria No 89, de 15 de abril de 2010A. Disciplina a utilização e o aproveitamento dos imóveis da União em favor das comunidades tradicionais. Disponível em: file:///C:/Users/cqpge/Downloads/Portaria\%2089-2010\%20TAU.pdf. Acesso em 12 out 2017.

BRASIL. Decreto $\mathbf{N}^{\mathbf{0}} \mathbf{8 . 4 2 5}$, de 31 de março de 2015B. Regulamenta o parágrafo único do art. 24 e o art. 25 da Lei $n^{\circ} 11.959$, de 29 de junho de 2009, para dispor sobre os critérios para inscrição no Registro Geral da Atividade Pesqueira e para a concessão de autorização, permissão ou licença para o exercício da atividade pesqueira. Disponível em <http://www.planalto.gov.br/ccivil_03/_ato2015-2018/2015/decreto/d8425.htm>. Acesso em 24 ago 2016. 
BRASIL. Instrução Normativa Ibama $\mathbf{N}^{\circ}$ 29, 31 de dezembro de 2002. Estabelece critérios para regulamentação de acordos de pesca pelo IBAMA, 2002. Disponível em: http://www.ibama.gov.br/sophia/cnia/legislacao/IBAMA/IN0029-311202.PDF. Acesso $10 \mathrm{dez} 2013$.

BRASIL. Ministério da Educação. Coordenação de Aperfeiçoamento de Pessoal de Nível Superior. Plano Nacional de Pós-Graduação - PNPG 2011-2020 / Coordenação de Pessoal de Nível Superior. - Brasília, DF: CAPES, 2010. 309p.

BRASIL. Ministério da Educação. Coordenação de Aperfeiçoamento de Pessoal de Nível Superior. Plano. Nacional de Pós-Graduação - PNPG 2005-2010/ Coordenação de Pessoal de Nível Superior. - Brasília, DF: CAPES, 2010. 91p.

BRASIL. MMA. Portaria N$^{\circ}$ 445, de 17 de dezembro de 2014B. Institui Lista Nacional Oficial de Espécies da Fauna Ameaçadas de Extinção - Peixes e Invertebrados Aquáticos. Disponível em <http://www.icmbio.gov.br >. Acesso em 16 jan 2017.

BRASIL. MPA. Decreto No 8.424, de 31 de março de 2015A. Regulamenta a Lei $n^{\circ} 10.779$, de 25 de novembro de 2003, para dispor sobre a concessão do benefício de segurodesemprego, durante o período de defeso, ao pescador profissional artesanal que exerce sua atividade exclusiva e ininterruptamente. Disponível em < http://www.planalto.gov.br/ccivil_03/_ato2015-2018/2015/decreto/D8424.htm>. Acesso em 24 ago 2016.

BRASIL. Portaria Interministerial MPA/MMA Nº 1 , de 15 de abril de 2011A. Cria o Comitê Permanente de Gestão de Atuns e Afins - CPG de atuns e afins. Disponível em: http://www.lex.com.br/doc_20726311_PORTARIA_INTERMINISTERIAL_N_1_DE_ 15_DE_ABRIL_DE_2011.aspx. Acesso $04 \mathrm{dez} 2017$.

BRASIL. Portaria Interministerial MPA/MMA Nº 1, de 20 de abril de 2010B. Criar o Comitê de Gestão da Pesca da Lagosta - CGPL. Disponível em: http://www.icmbio.gov.br/cepsul/images/stories/legislacao/Portaria/2010/p_inter_mpa_ mma_01_2010_criarcomitegestaolagosta.pdf. Acesso 04 dez 2017.

BRASIL. Portaria Interministerial MPA/MMA $\mathbf{N}^{\mathbf{0}} \mathbf{1 0}$, de $1^{\circ}$ de outubro de 2015F. Cria o Comitê Permanente de Gestão e do Uso Sustentável dos Recursos Pesqueiros das Bacias Hidrográficas das Regiões Centro-Oeste, Sudeste e Sul - CPG Centro-Sul. Disponível em:

http://www.icmbio.gov.br/cepsul/images/stories/legislacao/Portaria/2015/p_mpa_mma_ 10_2015_CPG_centro_sul_recursos_pesqueiros_bacias_hidrograficas.pdf. Acesso 04 $\operatorname{dez} 2017$.

BRASIL. Portaria Interministerial MPA/MMA $\mathbf{N}^{\mathbf{0}} \mathbf{1 1}$, de $1^{\circ}$ de outubro de $2015 \mathrm{G}$. Cria o Comitê Permanente de Gestão e do Uso Sustentável dos Recursos Pesqueiros das Bacias Hidrográficas Amazônica, Tocantins/Araguaia - CPG Norte. Disponível em http://www.icmbio.gov.br/cepsul/images/stories/legislacao/Portaria/2015/p_mpa_mma_ 11_2015_CPG_norte_recursos_pesqueiros_bacias_hid_amazonica_tocantins_araguaia_ revoga_p_mpa_mma_7_2012.pdf. Acesso 04 dez 2017.

BRASIL. Portaria Interministerial MPA/MMA $\mathbf{N}^{\mathbf{0}} \mathbf{1 2}$, de $1^{\circ}$ de outubro de 2015F. Cria o Comitê Permanente de Gestão e do Uso Sustentável dos Recursos Demersais e Pelágicos 
Norte e Nordeste - CPG Demersais e Pelágicos N/NE. Disponível em: http://www.ibama.gov.br/sophia/cnia/legislacao/MPA/PI0008-01092015.pdf. Acesso 04 $\operatorname{dez} 2017$.

BRASIL. Portaria Interministerial MPA/MMA N 2 de 18 de março de 2013. Criar o Comitê Permanente de Gestão da Pesca e do Uso Sustentável de Recursos Demersais Sudeste e Sul - CPG Demersais Sudeste e Sul. Disponível em http://www.icmbio.gov.br/cepsul/images/stories/legislacao/Portaria/2013/p_ini_mpa_m ma_02_2013_cria_cpgdemersais_se_s.pdf. Acesso em $04 \mathrm{dez} 2017$.

BRASIL. Portaria Interministerial MPA/MMA No 5, de 11 de dezembro de 2012. Cria o Comitê Permanente de Gestão da Pesca e do Uso Sustentável dos Camarões - CPG Camarões.

Disponível em: http://www.editoramagister.com/legis_24057327_PORTARIA_INTERMINISTERIAL _N_5_DE_11_DE_DEZEMBRO_DE_2012.aspx. Acesso 04 dez 2017.

BRASIL. Portaria Interministerial MPA/MMA $\mathbf{N}^{\mathbf{0}}$ 7, de $1^{\circ}$ de setembro de 2015E. Criar o Comitê Permanente de Gestão e do Uso Sustentável dos Recursos Pelágicos - CPG Pelágicos Sudeste Sul. Disponível em: http://www.icmbio.gov.br/cepsul/images/stories/legislacao/Portaria/2015/p_mpa_mma_ 07_2015_cria_CPG_pel\%C3\%A1gicos_SE_Sul.pdf. Acessso 04 dez 2017.

BRASIL. Portaria Interministerial MPA/MMA $\mathbf{N}^{\mathbf{0}} \mathbf{8}$, de $1^{\mathbf{0}}$ de setembro de 2015I. Cria o Comitê Permanente de Gestão e do Uso Sustentável dos Recursos Pesqueiros das Bacias Hidrográficas do Nordeste - CPG Nordeste. Disponível em: http://www.icmbio.gov.br/cepsul/images/stories/legislacao/Portaria/2015/p_mpa_mma_ 12_2015_CPG_nordeste_recursos_pesqueiros_bacias_hid_nordeste_revoga_p_mpa_m ma_8_2012.pdf. Acesso 04 dez 2017.

BRASIL. RIO GRANDE DO SUL. Decreto N. ${ }^{\circ}$ 51.797, de 8 de setembro de 2014A. Declara as Espécies da Fauna Silvestre Ameaçadas de Extinção no Estado do Rio Grande do Sul. Disponível em: <http://www.al.rs.gov.br/filerepository/repLegis/arquivos/DEC\%2051.797.pdf>Acesso em 2016-01-16.

ORGANIZAÇÃO INTERNACIONAL DO TRABALHO - OIT. Convenção $\mathbf{n}^{\circ} \mathbf{1 6 9}$ sobre povos indígenas e tribais e Resolução referente à ação da OIT. Brasília: OIT, 2011. 48p. Disponível em: http://portal.iphan.gov.br/uploads/ckfinder/arquivos/Convencao_169_OIT.pdf. Acesso 17 mai 2015. 